


\section{REESE LIBRARY}

OF THE

UNIVERSITY OF CALIFORNIA.

Receivert

$A R R ; 0.00$ ?

- Accessions No.S506\% Class No. 



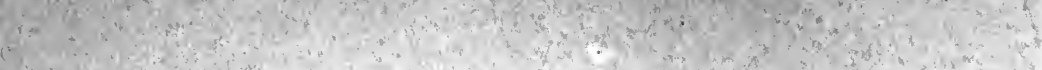

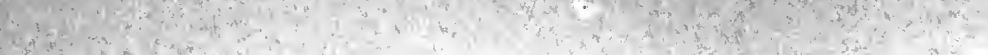
C. 


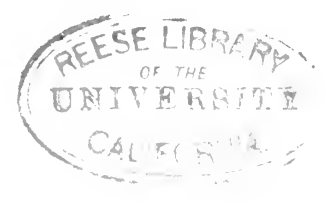

TEXT BOOK OF COMPARATIVE GEOLOGY 



\title{
TEXT BOOK
}

OF

\section{COMPARATIVE GEOLOGY

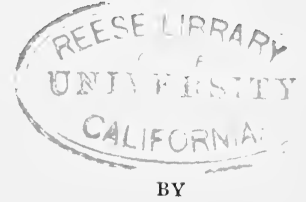

E. KAYSER, PH.D.

Professor of Geology in the University of Marburg

\author{
TRANSLATED AND EDITED \\ $\mathrm{BY}$ \\ PHILIP LAKE, M.A., F.G.S. \\ Late Harkness Scholar in the University of Cambridge
}

WITH 596 ILLUSTRATIONS (73 PLATES AND 70 FIGURES IN THE TEXT)

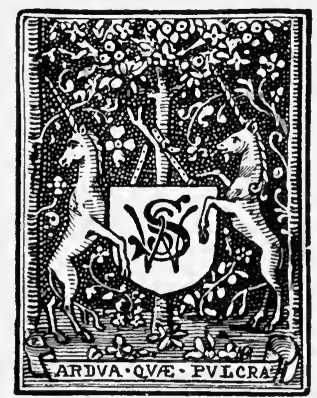

Zlandan

SIVAN SONNENSCHEIN \& CO.

NEW YORK: MACMILLAN \& CO.

I893 


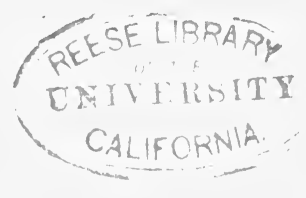

\section{P R E F A C E.}

A JUST conception of the science of geology is scarcely to be gained by the examination of any single country: the outlook must be broad and must, as far as possible, include the whole earth. It is to the use of the comparative method that we owe the striking generalisations of Neunayr and the philosophical views of Suess.

Even in the study of a particular district, comparison with other areas is invaluable; for the key to the geology will of tan be found in some far distant region. South Devonshire, for example, was very imperfectly understood until Mr. Ussher applied the knowledge which had been won in the Rhenish Mountains.

There is, however, no text book in the English language which affords sufficient help in such comparisons, for there is none which gives an adequate account even of the geology of Europe; and it is with the object of supplying this deficiency, in part at least, that the translation of Dr. Kayser's "Lehrbuch der geologischen Formationskunde" has been undertaken. Dr. Kayser's work was intended primarily for use in Germany; but the space devoted to other countries is much larger than in earlier text books.

In the present edition very considerable additions have been made to the portions descriptive of extra-German countries. These additions are most numerous in the first half of the work, while in the latter half the greatness of the subject and the limits of space have made themselves more severely felt. Extra-European rocks have necessarily received but brief notice. 
Besides these additions the chief alteration that has been made is that the Cambro-Silurian rocks have been divided into Cambrian, Ordovician and Silurian instead of into Cambrian and Silurian.

The illustrations with few exceptions are the same as in the German edition; and they will be found of the greatest value in imparting to the student a knowledge of characteristic and zone fossils.

In the preparation of the book my thanks are due to Prof. G. A. Lebour and Mr. J. E. Marr, F.R.S., for valuable advice and notes in certain portions of the work; and above all to Dr. Kayser himself, who has read through the whole of the proof sheets and has added some supplementary remarks. 


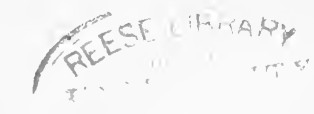

\section{CONTENT'S.}

INTRODUCTION

I. ARCHAEAN OR PRIMITIVE ROCKS . . . . . 13

General Character and Composition of . . . . . 13

Structure and Mode of Occurrence of . . . . . 17

Classification of .

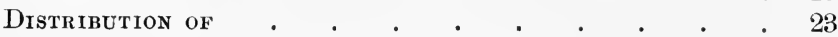

VIEWS on the Origin or. . . . . . . . . . $\quad . \quad 24$

II. PALEOZOIC OR PRIMARY GROUP . . . . . 27

Cambro-Silurian Rocks . . . . . . . . 28

Historical . . . . . . . . . . 28

General Remarks . . . . . . . . 30

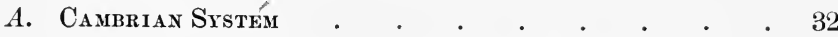

Palæontology of . . . . . . . . . . 45

B. Ordovician System . . . . . . . . . . . . 50

C. Silurian System . . . . . . . . . . . 64

Palæontology of Ordovician and Silurian Systems 73

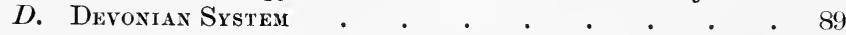

Historical . . . . . . . . . . . 39

Distribution and Development of . . . . . 91

Palæontology of . . . . . . . . . 113

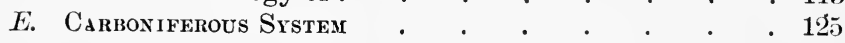

General and Historical . . . . . . 125

Distribution and Development of-

Central and Western Europe . . . . . 129

The Mediterranean Region ․ . . . 142

Russia . . . . . . . . . 144

Extra-European Areas . . . . . 146

On the Mode of Formation of Coal . . . . 148

Palæontology of . . . . . . . . 150

F. Phrmian System . . . . . . . . . . . 164

General and Historical $\quad . \quad$. . . . . 164

Distribution and Composition of-

German Facies . . . . . . . . 167

Russian Facies . . . . . . . . 178

The Permo-Carboniferous Glacial Epock . . . 183

Palæontology of .. . . . . . . . . 185

III. MESOZOIC OR SECONDARY GROUP . . . . . 193

A. Triassic System . . . . . . . . . . . . . 194

General and Historical $\quad . \quad$. . . . . . 194

The German Facies of the Trias. . . . 196

The Alpine Trias. $\quad . \quad$. $\quad . \quad$. . . . 217

Palæontology of . $. \quad . \quad . \quad . \quad . \quad . \quad .230$ 
B. Jurassic System . . . . . . . . 235

General and Historical . . . . . . 230

Distribution and Development of-

Jura of Central Europe . . . . . . 239

The Alpine Jura . . . . . . . . . 262

The Russian Jura . . . . . . . 269

Climatic Zones of . . . . . . . . . 270

Palæontology of . . . . . . . . . . 271

C. Cretaceous System . . . . . . . . . . 279

General and Historical . . . . . . . 279

Distribution and Development of-

Lower Cretaceous . . . . . . 284

Germany, N. France, and England . . 284

S. Europe . . . . . . . 296

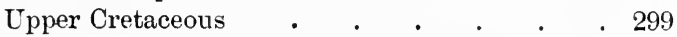

Germany, England, and N. France . . 299

S. Europe . . . . . . . . 315

Extra-European Cretaceous . . . . 318

Palæontology of . . . . . . . . . 319

IV. NEOZOIC GROUP. . . . . . . . . . . . 326

A. Tertiary System . . . . . . . . . . 327

General and Historical . . . . . . . 327

Older Tertiary or Palæogene . . . . . . . 332

1. Eocene . . . . . . . . . 332

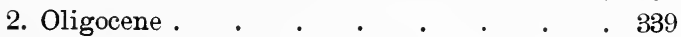

Palæontology of Older Tertiary . . . . 348

Newer Tertiary or Neogene . . . . . . 353

1. Miocene . . . . . . . . .

2. Pliocene . . . . . . . . . 362

Palæontology of Newer Tertiary . . . . 366

B. Quaternary System . . . . . . . . . 373

1. Drift or Diluvium . . . . . . . 374

General and Historical . . . . . 374

Distribution and Development of . . . 378

Mammalia of . . . . . . . 393

2. Alluvium . $. \quad . \quad . \quad . \quad . \quad . \quad 399$ 


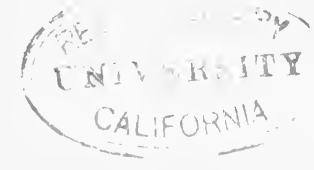

\section{LIST OF PLATES.}

PLATE

I. Cambrian Trilobites

II. " Fossils . . . . . . . . . . . 47

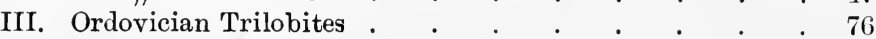

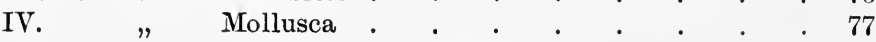

V. $"$ Brachiopods and Cystideans . . . . 78

VI. $" \quad$ and Silurian Coelenterates . . . . $\quad . \quad 79$

VII. Silurian Crustacea $\quad$. . . . . . . . . . $\quad .80$

VIII. " $"$ and Cephalopoda . . . . . $\quad .81$

IX. $"$ Molluses . . . . . . . . . . . 82

X. " Brachiopods and Corals . . . . . $\quad .83$

XI. " Colenterates . . . . . . . . 81

XII. Lower Devonian Fossils . . . . . . . 114

XIII. " $"$. . . . . . . . 115

XIV. Middle "

XV. " " Fossils . . . . . . . 117

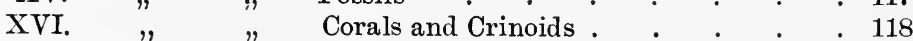

XVII. Upper " Fossils . . . . . . . 119

XVIII. Fossils from the Upper Devonian, etc. . . . . . 120

XIX. Hercynian Fossils . . . . . . . . 121

XX. Fossils of the Culm and Carboniferous Limestone . . 151

XXI. Cephalopods and Gasteropods of the Carboniferous Limestone . . 152

XXII. Brachiopods and Lamellibranchs of the Carboniferous Limestone . . . . . . . . 153

XXIII. Carboniferous Limestone Coelenterates . . . . $\quad$. 154

XXIV. Coal Measure Plants . . . . . . . . 155

XXV. " " $"$. . . . . . . . . . 156

XXVI. " " $"$. . . . . . . . 157

XXVII. Plant and Animal remains of the Coal Measures . 158

XXVIII. Fossils of the Marine Upper Carboniferous . . 159

XXIX. " " " Rothliegende . . . . . . . 187

XXX. " " " " . . . . . . . 188

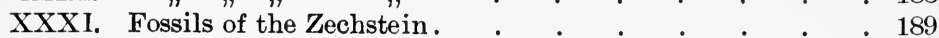

XXXII. Permian Fossils . . . . . . . . 190

XXXIII. Fossils of the Bunter Sandstone . . . . . . . 201

XXXIV. Muschelkalk Fossils . . . . . . . . 204

XXXV. $" \# \quad . \quad . \quad . \quad . \quad . \quad . \quad . \quad .205$

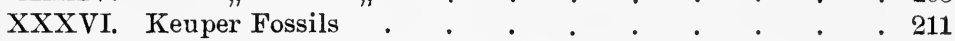

XXXVII. Fossils of the Keuper and of the Karoo Series . . . 212

XXXVIII. " " " Bunter Sandstone and the Muschelkalk of the Alps. 
PLATE

XXXIX. Fossils of the Norian Series of the Alps _ . . . 222

XL. " " " Carinthian and Rhætic Series of the Alps . '223

XLI. " " " $"$ Lower Lias . . . . . . 245

XLII. " " , Middle Lias . . . . . . . . 246

XLIII. $", \quad$, Upper Lias . . . . . . . . 247

XLIV. " " " Lower Oolite . . . . . . . . 254

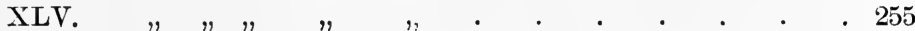

XLVI. " " " Great Oolite and of the Keliaways Rock . 256

XLVII. $" ~ ", ~ O x f o r d i a n$ and Corallian . . . . 263

XLVIII. $", "$ Kimeridgian . . . . . . . 264

XLIX. $", ", \quad "$ and Portlandian, also Titho-

LII. " " " Albian and Aptian . . . . . . . 294

LIII. " " " Alpine Lower Cretaceous . . . . 297

LIV. " " " Cenomanian . . . . . . . 301

LV. " " " $"$ and Turonian . . . . 302

LVI. " " " Turonian . . . . . . . . 303

LVII. " " " Senonian . • • • . . . . 305

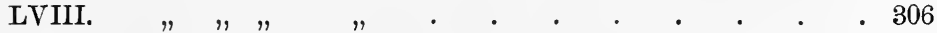

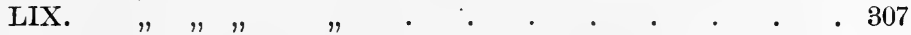

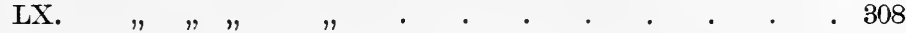

LXI. " " " Alpine Upper Cretaceous . . . . 317

LXII. Eocene Mollusca . . . . . . . . . 333

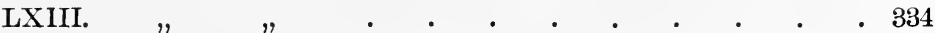

LXIV. Fossils of the Nummulitic Beds . $\quad$ • . . . . $\quad$ • 338

LXV. Oligocene Mollusca. . . . . . . . . . 343

LXVI. " Fossils . . . . . . . . . 344

LXVII. Miocene Gasteropoda . . . . . . . . . 357

LXVIII. $"$ Mollusca . . . . . . . . . 358

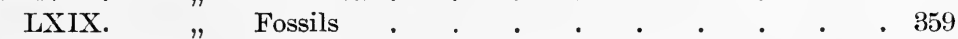

LXX. Pliocene Mollusca . . . . . . . . . . 364

LXXI. Mammals of the Drift . . . . . . . . . . 394

$\cdot \quad . \quad . \quad . \quad .395$

LXXIII. $\quad " \quad$ and Molluses of the Drift $\quad$ • . . . 396 


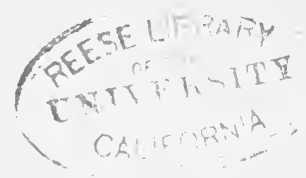

\section{LIS'T OF FIGURES.}

FIG.

1. Section near Wolmersdorf in Lower Austria (v. Hauer)

2. " through the Pfahl in Eastern Bavaria (Gümbel) . . 16

3. $" \quad$ in the King Mine in New Jersey (Würtz) . . . . 17

4. " $\quad$ through the Archæan at Grenville in Canada (Logan) . 18

5. " " $"$ a part of the Bavarian Hills (Gümbel) . 18

6. " " St. Gotthard and the Finsteraarhorn (A. Heim). 20

7. $" \quad$ Mont Pelvoux (Lory) . . . . . . 20

8. $" \quad$ Mont Blanc (A. Favre and Lory) . . . . . 21

$9 . \quad " \quad$ " the Simplon (Lory) . . . . . 21

10. $" \quad$ in the Menomonee area in Michigan (Credner) . . . 23

11. " of Kinekulle on Lake Wener . . . . . . . 35

12. Diagrammatic section through the Lower Palæozoic Rocks of Bohemia (Fr. Katzer) . . . . . . . . . 58

13. Section from Finland through the islands of Oesel, Gotland, and Oeland to Sweden (Fr. Schmidt). $\quad . \quad$. $\quad . \quad$. $\quad . \quad 70$

14. Section through a part of the Schiefergebirge of the Eifel (Baur)

15. Meganteris Archiaci, Vern, from the Lower Devonian of the Eifel (with the dorsal shell broken open to show the long internal loop)

16. Section on the West Coast of Arran (F. Zirkel) . . . .

17. $" \quad$ through the Coal Basin of Liège (Vancherpenzeel-Thim). (F. Holzapfel) . . . . . . . . . . 136

19. Section through the Coal Basin of Ruhr (H. Br. Geinitz) . 137

20. " " " Carboniferous and Rothliegende of the Saar and Nahe Area (Nasse)

21. Section through the Alleghany Mountains $\quad \cdot \quad \cdot \quad \cdot \quad \cdot \quad \cdot \quad \cdot 147$

22. Upright Trunks in the Carboniferous of St. Etienne . . . 150

23. Section through the Rothliegende and accompanying eruptive rocks on the left bank of the Nahe above Münster $(H$. Laspeyres) . . . . . . . . . . . 16

24. Section through the Erzgebirge Basin at Chemnitz (Siegert) . 171

25. " " " Salt beds of Stassfurt (Bischof) . . . 176

26. Glossopteris Browniana, Brngn. . . . . . . . . 184

27. Callipteris conferta, Brngn. . . . . . . . . . . 185

28. Section through the Mesozoic Rocks of Hanover (Heinr. Credner) 193

29. False-bedding in the Middle Bunter Sandstone near Marburg . 199

30. Section of the Trias in the neighbourhood of Mutzig and Sulzbad, on the Eastern border of the Vosges (Benecke). . . . 208

31. Section of the Trias in the neighbourhood of Oberheldrungen in Thuringia . . . . . . . . . . 208

32. The Dolomite Reefs of the Sett Sass in the Southern Tyrol . $\quad$. 226

33. Section through the Trias of Lunz in the Lower Austrian Alps (Bittner) 
FIG.

34. Section through the Triassic and Jurassic Beds of Swabia .

35. " " " Upper Jurassic of the Porta Westfalica (Heinr. Credner) . . . . . . . . . . 240

36. Lepidotus notopterus, Agass. . . . . . . . . . . . 274

37. Leptolepis sprattiformis, Agass. . . . . . . . . . . . . 274

38. Ichthyosaurus communis, Conyb. . . . . . . . . . . . 276

39. Plesiosaurus dolichodeirus, Conyb. . . . . . . . . . . 276

40. Pterodactylus spectabilis, H. v. Mey. . . . . . . . . . . 277

41. Restoration of Ramphorhynchus phyllurus, Marsh . . . . . 277

42. Archcoopteryx macrura, Owen . . . . . . . . 278

43. Hesperornis regalis, Marsh . . . . . . . . . 323

43A. Tooth of Hesperornis regalis, with germ of succeeding tooth . 323

44. Ichthyornis victor, Marsh . . . . . . . . . 324

45. Section of the Tertiary Beds of Brandenburg (G. Berendt) . $\quad$. 342

46. " " Oligocene Lignite deposits of the neighbourhood of Halle on the Saal (H. Laspeyres) .

47. Chamaerops helvetica, Heer. Lower Oligocene of Nachterstädt,

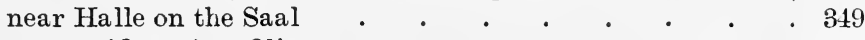

48. Lamna cuspidata, Ag., Oligocene . . . . . . . . . . 350

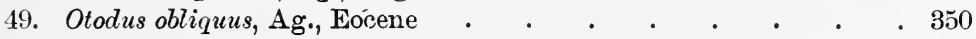

50. Palcotherium magnum, Cuvier. Oligocene, Montmartre, near Paris 351

51. Skull of Loxolophodon (Dinoceras) mirabilis, Marsh. Eocene of Wyoming . . . . . . . . . . . 352

52. Section through the Meissner, near Cassel (Fr. Moesta) . . 356

53. Diagrammatic Section through the Vienna Tertiary Basin (Karrer) . . . . . . . . . . . . . 361

54. Dinotherium giganteum, Kaup. Pliocene of Eppelsheim. . 366

55. Upper molar teeth of Dinotherium giganteum, Kaup. 366

56. Mastodon angustidens, Cuv. Miocene of Simorre, France 367

57. Last molar of the upper jaw of Mastodon angustidens, Cuv., seen

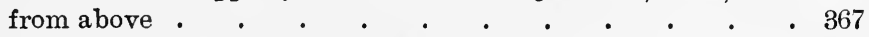

58. Last molar of the lower jaw of Mastodon turicensis, Schinz., seen from the side $. \quad . \quad . \quad . \quad . \quad . \quad . \quad . \quad .367$

59. Hippotherium gracile, Kaup. Pliocene of Pikermi . . . 368

60. Upper molars and hind feet of (a) Palcotherium; (b) Anchitherium; (c) Hippotherium; (d) Equus . . . . . . 368

61. Tooth of Anchitherium (A); Hippotherium (B) and Equus (C) $\quad . \quad 370$

62. Upper molar of Aceratherium incisivum . . . . . . 370

63. Rhinoceros (Aceratherium) incisivus, Cuv.. . . . . . . 370

64. Rhinoceros (Dihoplus) Schleiermacheri, Kaup. . . . . . 370

65. Antlers of: a. Cervus (Palcomeryx) elegans, Lartet =furcatus, Hens.; Miocene, Sansan. b. C. (Pal.) anocerus, Kaup.; Plioeene, Eppelsheim. c. C. Matheronis, Gaudr.; Pliocene, M. Luberon. d. C.martialis, Croiz. and Job. ; Pliocene, St. Martial.

66. Cervus Sedgwicki, Falc. Upper Miocene, Val d'Arno • • •

67. Machorodus meganthereon, Croiz. and Job. Pliocene of S. France.

68. Mylodon robustus, Owen. Argentine Pampas formation . .

69. Extent of the ice-sheet and glaciers during the Ice Age in Europe

70. Map of the ice-sheet and glaciers in North America . . . 


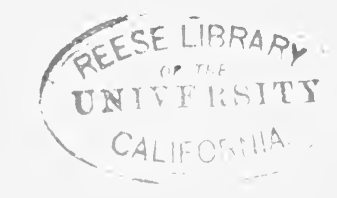

\section{IN'T'RODUC'TION.}

\section{GEVERAL REMARKS.}

Stratigraphy or Stratigraphical Geology is but a part of the great science of Geology, i.e. the science of the material (especially the mineralogical) constitution of the globe, its structure and the history of its formation.

In Geology, as in other sciences, we can distinguish various branches; such as Physical Geology, which is concerned with the form and size of the earth, its density and temperature, the general contour and relief of its surface and other similar matters; Dynamical or Mechanical Geology, which treats of the action of volcanoes, water, etc.; Tectonic Geology, which describes the arrangement of the rocks composing the crust of the earth; Petrographical Geology or Petrography, which teaches the chemical and mineralogical composition, and the mode of occurrence and distribution, of the various types of rocks; and lastly, Stratigraphical Geology. This undertakes the task of examining the composition, distribution, and organic inclusions of the geological formations, i.e. of the rock-structures which have arisen at different and successive periods of the earth's history. It thus gives us a kind of history of the development of the globe and of its inhabitants, both animals and plants, from the earliest times to the present. Hence the term Historical Geology is also used for this branch of the science; and when we compare the stratigraphy of various areas, we may well speak of CoMparative GEOLOGY.

If we take a general view of the rocks forming the solid crust of the earth we find that they fall into two chief classes, viz. (1) Eruptive Rocks, which like the lavas of to-day, rose hot and liquid from the inner parts of the earth, and on cooling became firm and solid; and (2) Sedimentary Rocks, which are either C. G. 
deposits of the solid matter mechanically carried by water, or deposits from mineral solutions. Besides these two great groups, there is a third, which is of but slight importance, viz. the Eolian or Subaerial Rocks-deposits of material borne by the wind and laid down on dry land, as for example, certain mountain loams, volcanic tuffs, and sand dunes.

The sedimentary are distinguished from the eruptive rocks chiefly by two peculiarities,- - their bedding and their fossil contents. Bedding or stratification is indeed not universal, but it is found in most sedimentary or "stratified rocks." A stratified deposit is one in which the whole mass is divided into parallel platy or tabular layers (beds or strata). Each bed is separated from those above and below it by a divisional plane and is to be considered as the result of an uninterrupted process of sedimentation, whilst each divisional plane signifies a pause, however small, in the deposition. If a number of successive beds are of similar constitution and structure, they form a "series," "group," "complex," or "system" of beds. As for the fossils, they also are not universal, but are nevertheless found in the greater number of sedimentary rocks. They are the remains imbedded in the rock, and more or less mineralized, ${ }^{1}$ of the animals and plants which lived at the time of the formation of the beds.

Our whole system of reckoning time geologically rests exclusively on the sedimentary rocks, because it is they alone that afford the means, in their stratification and fossil contents, of tracing their chronological equivalence over wide areas or over the whole earth. The eruptive rocks are of no value for this purpose, because they possess no marks which allow of any certain conclusions as to their age; and this can only be determined from that of the sedimentary rocks through which they have broken.

With respect to the bedding it has already been noticed that each single bed is to be considered as the representative of a particular, though it may be a relatively very short, period of time. Since each series of beds is composed of numerous beds lying on one another like the leaves of a book, and each system of a number of successive series, it is possible to determine the age of each bed relatively to any other of the same series, and also the age of each

1 A striking exception to this rule is formed by the corpses of mammoths and rhinoceros which are found in the frozen soil of Siberia with their hair and skin preserved. They are not mineralized, but must nevertheless be considered as "fossils." 
: series relatively to any other. Hence we get this most important rule:-That in normal circumstances, i.e. when the beds are undisturbed or but little disturbed, a higher bed is younger than a lower. According to this principle of stratification, even before there was a science of geology, men separated the older from the younger, or as the old miners expressed it, the " heading " (Liegende) from the "hanging" (Hangende).

Concerning the mutual relations of two series it is necessary, in the first place, to distinguish between conformable and unconformable sequence. In the first or normal case, both series possess a similar "lie," the strike and dip being the same. We may then conclude that there was no great interval of time between the deposition of the older and the newer beds. In an unconformable sequence, on the other hand, each of the series has its own peculiar lie differing from that of the other. In this case a certain time must have elapsed between the formation of the older and that of the newer beds, during which the older beds were mover from their original horizontal position and sometimes set on edge and folded.

A peculiar kind of lie, which is too important to be left unnoticed, is known as overlap or transgression. In this case a series lies quite conformably upon the preceding beds, but overlaps the area occupied by these in such a manner as to lie in part immediately on a third, still older series, usually unconformably. Thus, for example, the Rothliegende of the Saar area overlaps the underlying conformable Saarbrïck Coal Measures in such a manner that to the north of the latter it rests directly on the older steeply inclined Devonian beds of the Hunsriick.

Overlaps indicate that after the deposition of a system of rocks (in the above example, the Coal Measures) had been accomplished, an overflow of the sea beyond the borders of the basin of deposition took place, in consequence of which the newer series (in our case the Rothliegende) was laid down over a greater area than the older.

The possibility of the determination of the age of a rock from its fossils rests on this, that the earth in the course of its history has been peopled by a long succession of very various faunas and floras, and that accordingly the fossils of the several systems and parts of systems are very different from one another. Moreover. the labours of several generations of observers have now established the evolution of organic life in its principal features; and at the 
same time it has become possible, from the character of a given fossil fauna or flora, to determine its relative age, i.e. to determine whether it is older or younger than another. For since the fauna and flora of each geological epoch has been evolved from that of the preceding epoch, and the present life of the world represents only the latest stage of this development, it follows universally that, on the one hand, the younger a fossil fauna or flora is, the more like it must be to the present; and on the other hand, the older it is, the more unlike.

This position is indeed only valid in its main features. It cannot be doubted that in former geological ages, just as at the present day, the character of the animal and plant world was influenced by gecgraphical differences. With these there were also other local differences. The terrestrial animals were always unlike the aquatic, and among the latter the dwellers in salt water were different from those in fresh water. Lastly, the influence of height, humidity, soil, etc., must have been as great in all times as it is to-day. All these circumstances must have combined, from the oldest times, to bring about regional differences in the animals and plants inhabiting our earth during any single epoch. Nevertheless it is proved afresh every day, and is confirmed by continual experience, that, leaving out of consideration all local differences, the succession of faunas and floras of the several geological periods has been the same throughout the whole earth. Not only is the sequence of the great Palæozoic faunas the same from Cambrian to Permian, in the most distant parts of the earth; but even the various Ammonite faunas of the Jurassic, which correspond with relatively short periods of time, are repeated with the most wonderful agreement in the most widely separated parts of Europe and also in India and South America.

The determination of the age of beds by means of their fossils is practicable, not only when we deal with strata of one and the same region, but even when these are widely separated from each other, as, for example, when we compare European with American rocks. In that case we may consider that-

(1) Strata of the same age (equivalent, homotaxial) contain more or less similar faunas and floras.

(2) The resemblance of any fauna or flora to that of the present day is less as its antiquity is greater.

The varieties in character of the faunas of beds of the same age, due to local variations in the conditions of life, are known as 
palreontological facies. Thus it is not uncommon to find an Ammonite or Cephalopod facies in a certain area, and near to this another facies of the same age-of Brachiopods, Lamellibranchs, Corals, or other forms. Still more marked are the differences between a marine and an equivalent freshwater facies.

The differences in character of the rocks of the various systems and other subdivisions afford but very slender evidence for the aletermination of the age of the beds. There was indeed a time when it was thought that each great geological period was characterized by the formation of a perfectly definite type of rock. It was at this time that the expressions, Chalk Formation, Oolite, Grauwacke, Coal Formation, and many others originated. But this idea has been proved to be erroneous. We know now that, for example, Oolitic rocks and Coal occur in the most different systems; and on the other hand that the same period may be represented in different regions by entirely different rocks: in one area by sandstones and conglomerates, in another by slates, in a third by limestone, etc.

It could not indeed be otherwise ; for the deposition of sediment has in all times taken place in different and more or less separated areas, and not only in marine but also in freshwater basins. Since the character of the deposited material may be different not only in separate basins but even at different points in the same basin, the petrographical character of the beds formed in any one age must also be very various. The often observed change in petrographical character of a certain bed or series along its strike, the passage from schist into sandstone and conglomerate, from clay into marl and limestone, etc., is also very natural. Hence it follows directly that the petrographical character of a series of beds can be of very limited value in the determination of its age, and it is only locally that a petrographical peculiarity can be of any great service for the recognition of any bed or series of beds.

Nevertheless the change in petrographical facies is not altogether without importance either for scientific or practical purposes. Experience has shown that a change in character of the rock is almost always accompanied by a corresponding variation in the fossil contents; in other words, petrographical and palæontological facies correspond with one another to a large extent.

According to the lie, palæontological characters, and to a certain extent according to the nature of the rocks, the whole of the stratified rocks have been divided into a number of large divisions 
which in Germany, and sometimes also in England and N. America, are known as Formations, whilst in France the term Terrains is used as of similar signification. At the International Geological Congress at Bologna the word System was proposed for these large divisions, and this is the term employed here. ${ }^{1}$

Several Systems following upon, and intimately connected with, one another are united together to form a greater division, or Group; and on the other hand each System is subdivided into several Series (Abtheilung, Stockwerk, section), these again into Stages (Stufe, étage), and Substages (Unterstufe, sous-étage), and then into Zones, within which we can still separate single beds (Schichte, conches).

The Group corresponds with an Era of time, the Formation or System with a Period, the Series with an Epoch, and the Stage with an Age.

Usually the smallest geological unit is taken to be, not the bed, because these are usually of very limited extent and are therefore only of local importance, but the Zone. This is a collection of beds which is distinguished by a perfectly definite fauna, or by some, or it may be only one (but in that case especially important and most probably widely spread) fossil, a so-called characteristic form or zone-fossil (Leitform).

Up to the present a strict palæontological division into zones has been accomplished only in the case of a few of the Systems, especially the Jurassic and Cretaceous, but the endeavour of later geologists is to establish a similar classification for the remaining. Systems.

THE CLASSIFICATION OF THE SEDIMENTARY FORMATIONS.

The classification of the sedimentary rocks took its rise in Central Germany, in the region between the Harz and the Thuringerwald, especially about Mansfeld, where the largest copper mines. in Germany have been worked for centuries. Here men first perceived that the series which includes the ore-bearing seam remains nearly unaltered over a very large area. The composition of this series was determined with great exactness, and under the name of Flötzgebirge (Flötz=stratum, or bed), it was separated from the older mountain cores of the Harz and Thuringerwald-the Grundgebirge-which rise through it like islands.

1 Dr. Kayser prefers the term "Formation," and uses it throughout. 
In this region also arose the knowledge of the important fact, entirely unknown to the ancients, that the various rocks which form the crust of the earth are not thrown together without order, but are arranged in a regular series of beds lying one upon another. This idea was followed out and developed especially by the famous Abrah. Gottl. Werner, who at the mining-school of Freiberg in the Erzgebirge, in the latter half of last century, taught Mineralogy and Geology, or, as these sciences were then called, Oryctognosy and Geognosy, before large numbers of pupils gathered together from all parts of Europe. Werner distinguished four chief divisions; viz.:-1. Urgebirge (primitive rocks). 2. Uebergangs-gebirge (transition rocks). 3. Flötzgebirge (stratified rocks); and 4. Aufgeschwemmtes Gebirge (alluvial rocks). Thus lie divided the Grundgebirge into two formations (Ur- and Uebergangs-gebirge), and added another for the newest deposits, including those which are now forming. The Primitive Rocks include the crystalline unfossiliferous schists of the Saxon Erzgebirge. The Transition Rocks, as the name implies, form a sort of passage from the Primitive to the Stratified Rocks-in their partly crystalline structure they are like the former, while in the occasional presence of fossils they resemble the latter.

Werner's doctrines spread over the whole of Europe, but outside of Germany they were moulded and extended according to the geological relations of the countries in question. Thus for the, to them, inconvenient names Ur-, Uebergangs-, and Flötzgebirge, the French substituted the terms terrain primitif, terrain primaire (or terrain de trunsition), and terrain secondaire, and added. another newer division, the terrain tertiaire, which is well doveloped around Paris, and contains beautifully preserved fossils. In England, on the examination of the sedimentary rocks it became clear that certain formations were developed there very different. from any in Saxony and Thuringia. These were added to the geological scheme under the designations Oolite and Chalk groups, and the former was further subdivided into Lias and Oolite Proper, names which Humboldt and L. v. Buch tried to naturalise in Germany. This difference in lithological character showed that it was impossible to compare rocks of different areas by their mineral constitution alone; and William Smith was the first to lay the foundation of stratigraphical geology by showing that each series of rocks was characterised by certain fossils which enable the series to be identified wherever it occurs. 
In Germany the further development of stratigraphical nomenclature was greatly influenced by v. Dechen's translation of the Geological Manual of De la Beche. In this eight groups ${ }^{1}$ are distinguished; viz.-1. Grauwacke group (=Werner's Uebergangsgebirge or Transition Rocks). 2. Carboniferous group. 3. Red Sandstone group (=Thuringian Flötzgebirge). 4. Oolitic group. 5. Cretaceous group. 6. Supercretaceous group (=terrain tertiaire of the French). 7. Erratic Block group (=Drift). 8. Modern group (=Alluvium). This English influence is also seen in the important and learned Manual of Bronn, ${ }^{2}$ in which are distinguished:-1. Coal period (=the similarly named group of De la Beche, together with the Granwacke of that anthor). 2. Salt period (= the Thuringian Flötzgebirge). 3. Oolite period. 4. Chalk period; and 5. Molasse period (Tertiary and Drift).

Thus the subdivisions usual in England and Germany abont 1830 and their relations with those of Werner and those now generally adopted are as follows :-

werner.

Germany.

$\left.\begin{array}{c}\text { Aufgreschwemmtes } \\ \text { Gebirge. }\end{array}\right\} \begin{gathered}\text { Molasse } \\ \text { period. }\end{gathered}$

Flötzgebirge.

Chalk period. $\{$ Salt period.

Uebergangsgebirge. Coal period.

Urgebirge.

\section{England.} Modern Group. Boulder group. ( $\begin{gathered}\text { Supercretaceous } \\ \text { group. }\end{gathered}$ Tertiary.

\section{Chalk group. Cretaceous.}

Oolite group.

$\left\{\begin{array}{l}\text { Red Sandstone } \\ \text { group. }\end{array}\right\}$ Trias.

Present Grouping.

Alluvium I QuaterAlluvium ${ }^{\text {I Quater }}$
Drift j nary. $\left\{\begin{array}{c}\text { Coal group. } \\ \text { Grauwacke } \\ \text { group. }\end{array}\right.$ \} Palæozoic group. Archran.

The subdivision of Werner's Transition Rocks (Uebergangsgebirge), that thick complex of beds which is now known as the Palæozoic Group, was not attempted till about 1830-1840, when the knowledge of the younger deposits was already far advanced. This was due to the great difficulties which beset the study of the older deposits, and especially to their complicated structure and their poorness in fossils. Germany, where Cambrian and Silurian rocks are almost entirely absent, was an especially difficult area

1 De la Beche distinguished a "Lowest Fossiliferous group" below the Grauwacke.

2 Lethaea geognostica, 1833-38, and Handbuch der Geschichte der Natur, $1841-49$. 
for such an attempt; and France for this purpose was not much better. England, on the other hand, was far more favourably placed and thus it is in this country that the classification of the older deposits originated, and the Palæozoic systems are universally known by their English names. The present classification of these rocks, and the relations of the names now in use to the older terms, is shown in the following table:-

Older terms.

Present terms.

Lower part of the Red Sandstone Group.

Coal group of the English

Coal group of Bronn in part.

Permian System.

Carboniferous System.

Transition or Grauwacke group.

Devonian System.
Silurian System.

Ordovician System.

Cambrian System.

These six oldest systems of the stratified rocks are united to form the great Palæozoic Group; and in the same way the Trias, Jurassic, and Cretaceous form the Mesozoic; and the Tertiary and Quaternary Systems, the Neozoic ${ }^{1}$ or Kainozoic Group; while another great group is often distinguished as the Azoic or Archrean, to include the Primitive Rocks of Werner. Each of these great Groups represents a great Era of the Earth's History, while the Systems represent smaller divisions of time, or Periods.

The whole of the Sedimentary deposits are thus divided into the following Groups and Systems, and the latter are again subdivided into a number of Series:-

I. Nrozoic Grour.

1. Quaternary System. $\left\{\begin{array}{l}\text { Alluvium. } \\ \text { Drift. }\end{array}\right.$

2. Tertiary System.

Pliocene.

Miocene.

Oligocene.

Eocene.

II. Mesozorc Group.

1. Cretaceous System.

U Upper Cretaceous.

L Lower Cretaceous.

Upper Jurassic.

2. Jurassic System.

$\{$ Middle Jurassic.

Lower Jurassic (Lias).

3. Triassic System.

$\left\{\begin{array}{l}\text { Keuper. } \\ \text { Muschelkallk. } \\ \text { Bunter. }\end{array}\right.$

1 The term Neozoic is sometimes used to include both Mesozoic and Kainozoic.

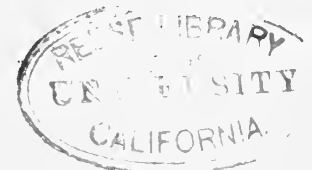


III. Palzozole Grour.
1. Permian System.
fZechstein.
¿ Rothliegende.
2. Carboniferous System.
(Upper Carboniferous (Coal Measures). $\left\{\begin{array}{l}\text { Lower Carboniferous (Culm and Carboni- } \\ \text { ferous Limestone). }\end{array}\right.$
3. Devonian System.
(Upper Devonian.
$\left\{\begin{array}{l}\text { Middle Devonian. } \\ \text { Lower Devonian. }\end{array}\right.$

4. Silurian System.

5. Ordovician System.

6. Cambrian System.

\section{Azoic or Archeny Group. \\ Primitive Rocks.}

\section{THE ORIGIN AND EARLY CONDITION OF THE EARTII.}

The Earth had the same origin as the planets of the solar system, and as the sun itself. Originally all these bodies formed a single mighty globe of gas. From this the planets separated out one after another (and from these their satellites separated in the same way), whilst the remainder of the mass formed the central body of the whole system, the sun.

This is, in a few words, the view of the evolution of our solar system which is known as the Kant-Laplace theory. In favour of this a large number of astronomical and physical facts are quoted, such as the agreement in the direction of motion of all the planets, and the (nearly complete) coincidence of the planes of their orbits; also the existence of the ring of Saturn and the gradual increase in density of the planets as we approach towards the sun, and also the increase in density of each from without inwards. ${ }^{1}$ For other still weightier evidence we have to thank the spectral analysis of our sun and of other heavenly bodies. This has shown that (1) certain of them, the so-called nebulæ, are huge masses consisting entirely of glowing gas: (2) others, the so-called suns (including our sun), are bodies in which, owing to the longcontinued loss of heat, and the consequent contraction of their mass, a fluid core has been formed-they consist of an inner glowing fluid part and an outer envelope of gas: lastly (3) a third kind, in consequence of still further cooling, have become solid and with this have lost their power of giving light. To this last kind of

1 This has been proved not only for the earth, but also for Jupiter. 
bodies belongs our earth, together with the other planets and their satellites, as well as certain dark stars of other systems.

Thus we now know that examples of all the chief stages which the theory of Laplace requires for the full development of a celestial body (namely, 1. the original gas ball; 2. the gas ball with liquid centre; 3 . the solidified mass), are now found, and this fact gives to the theory so high a degree of probability that we may consider it as certain.

If this was the mode of evolution of all celestial bodies, we are obliged to conclude that in a far distant time our earth also was a liquid, light-giving globe, which at a later period became covered with a solid crust; and this idea is in the most complete accord, not only with the old conclusion derived from purely geological facts, but also with the results of the latest observations of astronomical physics.

According to the above views, the idea of an original crust formed by solidification is absolutely necessary. Moreover, some such conclusion is unavoidable, since the oldest sediments require a foundation on which they may be laid, and the oldest eruptive rocks require a crust through which to break. Nor must we forget that the first sediments, whether of chemical or mechanical origin, necessarily presuppose an older already present rock from the chemical or mechanical destruction of which they might be formed; and this material can have been furnished only by the crust formed by the solidification of the glowing liquid mass of the earth.

Since the idea of a solidification crust, although it was once considered a mere picture of the fancy, is an absolute necessity, the question arises whether there are anywhere any rocks which may be pointed out with more or less probability as the remains of this crust. If such an origin may be admitted for any rock, there is none of which it is so likely to be true as gneiss, which-as will be shown-extends with wonderful regularity as the deepest. known rock on the whole earth. If this view cannot be accepted, it must yet be admitted that when we wish to form a picture of the constitution of the oldest rocks of the earth, we are forced to represent them to ourselves as more or less gneiss-like. For it may reasonably be considered that the material of the crust would not be very different from the oldest eruptive rocks; and these are of granite, which differs from gneiss only in structure. It has also been correctly remarked that if we could melt together 
all the rocks of the present crust of the earth, we should have a rock approximately like that which formed the original solidification crust; and that in that case we should have an acid silicate is beyond question, on account of the extraordinarily wide distribution of quartz. Moreover, since the eruptive rocks of later ages have risen from continually increasing depths, where probably a mixture more basic than at the surface is collected, they have thus become more and more basic; and such a smelting product would therefore be more basic than the original crust. If we consider the great density of the interior of the earth (which depends on the fact that when the earth was fluid, the materials composing it arranged themselves according to their specific gravity), it is clear that we can scarcely be far wrong if we suppose that the first crust would consist of those minerals the chemical constituents of which were the lightest. To these would belong (besides those combinations which remained in the state of vapour, such as carbonic acid, water, and several others) silica, alumina, the alkalies, and a part of the alkaline earths. But these are all constituents of those minerals which form gneiss (quartz, mica, felspar).

The condition of the earth after the formation of the crust can only be briefly indicated. With the progressive cooling, a gradual contraction of the earth must have gone hand in hand; and with this a constantly repeated tearing open, cracking, and dismembering of the first formed crust. From these rents and cracks the glowing interior pressed forth in huge masses to unite by their solidification as a cement the broken pieces of the crust.

It is clear that in those remote times, owing to the great heat of the air, no water could exist in a liquid state; and it was not till the temperature had fallen greatly that a covering of water could form around the solid centre. Moreover, this primitive sea, when first formed, lay under the pressure of an atmosphere much denser than the present, which still contained the whole of the carbonic acid and probably other matters alșo. It must therefore have possessed a very high temperature, far above the boiling point of water at ordinary pressures; so that it did not yet offer the necessary conditions for the development of organisms, and it was not till a still later period that the earth became cool enough for the first appearance of life. 


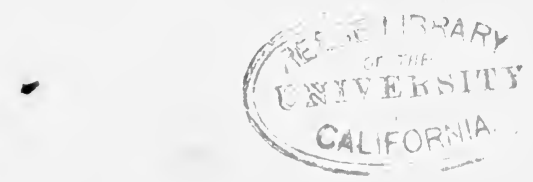

\title{
I. ARCH\&AN OR PRIMITIVE ROCKS.
}

\author{
GENERAL CHARACTERS ANI) ('OMPOSITION OF THE \\ ARCHLEAN ROC'K'S.
}

UNDER the head of Archæan we group together all those rocks which are older than the lowest beds of the Cambrian, and which extend from these as their upper limit to the deepest, so-called Laurentian, gneiss. The terms fundamental or Primitive (terrain primitif of the French) Azoic or Agnotozoic, and Pre-Cambrian have also been used with the same signification.

The Archæan are the oldest known rocks that reach the surface where the foundation of the oldest fossil-bearing beds has been laid bare by erosion, denudation or dislocations. They are the base on which have been laid the oldest as well as all the later sediments.

The Archæan rocks as a whole form an extremely large mass -one may well say the most important of all the rock-masses taking part in the formation of the earth's crust. Although it is very difficult, in consequence of the very disturbed condition of these primitive beds, to determine their thickness even approximately, yet there is no doubt that where they are fully developed they are many tens of thousands of feet thick. The total thickness of the Archran in N. America has been estimated at 50,000 feet, and in Bohemia at 100,000. The period of time occupied by the formation of these rocks must, in correspondence with their great thickness, have been of extraordinary length, probably so long that the beginning of the Cambrian period may be considered as comparatively a recent event.

The Archæan is not only the oldest and thickest, but also by far the most wide-spread of all the formations of the earth's crust. It is found in Bohemia and the Alps, in Scandinavia and Canada, in the Himalayas and Andes, in short in all continents and in all latitudes. In several regions, as in Arctic N. America 
and in Central Africa, it occupies thousands of square miles without any covering of later rocks. But even where the surface is occupied by younger beds one may take it for granted that the Archæan rocks are continued without interruption, so that any boring, if only it be made deep enough, would at length strike the Primitive rocks. The Primitive group is the only series which covers the whole earth like a shell, the only one which has justly been spoken of as ubiquitous; whilst on the other hand all the later normal sedimentary formations have a limited distribution and lie round the earth, as has been aptly remarked, like the leaves of a rose-bud.

The extraordinary thickness and universal extent of the Archæan rocks strongly distinguishes them from all the younger beds. But a much more important difference still is to be found in their crystalline character and the absence of fossils.

The first peculiarity is the one which gives to the rocks belonging to the series the name of "crystalline schists." We know indeed that even among the younger formations crystalline schists occur more or less like those of the Archæan; but the great mass of the crystalline schists belongs to the Archran, so that the two terms are usually of equal signification. The widest spread and at the same time most characteristic of the crystalline schists is Gneiss, which like granite is a crystalline mixture of quartz, felspar, and mica, but differs from it in being, not of a granular, but of a schistose structure. It is divided into two chief varieties, mica- and hornblende- gneiss, of which the first is again divisible into red (Muscovite) and grey (Biotite) gneiss. In close connection with these varieties come numerous allied rocks, such as Granulite, Protogine, Hälleflinta, etc. Another, very important and wide-spread type is Mica schist, consisting essentially of mica and quartz, with which numerous accessory minerals may be associated. Chlorite, Hornblende, Sericite, Talc, Quartzite, Hæmatite, and Graphite schists, and other allied schistose rocks are very common companions of mica schist. Lastly, the third chief type is Phyllite, which agrees in composition with mica schist but appears denser in structure, and has been aptly defined as a microscopic mica schist. All the various rocks ascribed to the Phyllites possess, on account of their high percentage of mica, a peculiar silky lustre. Along with these types of rocks, which are characterized without exception by a schistose structure, there occur a number of more massive crystalline rocks such as Gneissic- 
granite, Eklogite, Granite, etc., and especially crystalline limestone, which is of frequent occurrence in the form of lenticular interbedded masses in all Archaan regions.

That the parallel structure and foliation of the crystalline schists is, like all foliation, due to pressure, is universally agreed. But the explanation of the tabular and bed-like structure observed in almost all crystalline schists - a structure which is usually, but by no means always, parallel to the foliation - is very doubtful. On account of the fact that each layer usually possesses its own lithological character they have generally been regarded as true beds. But cases are known where the foliation of the gneiss little by little passes into tabular structure, and others where the different and successive layers of gneiss and mica schist have been cut through by a bedding which does not coincide with their foliation; and hence it appears that no single explanation is applicable in all cases; the platy structure, like the foliation, may in many cases be the result of pressure.

The Archæan rocks must be considered unfossiliferous, since it has been shown that the supposed fossils found towards the middle of the century in Canada and afterwards in Scotland, Scandinavia and Bohemia, are of inorganic origin. These supposed fossils occur in crystalline limestone in the gneiss and form nodular masses consisting chiefly of serpentinous material divided by numerous tubes swelling out into cells. They were described as giant Foraminifers under the name Eozoon, but have been shown, thanks especially to the minute microscopic researches of Möbius, to be inorganic. On account of this absence of fossils the name Azoic (first used by Murchison in 1845 for the old crystalline mass of Scandinavia) has been applied to these rocks. Some observers indeed have thought that the occurrence of limestone and graphite in the Archran is an indication of the existence of organic life ; and they have pointed to the great importance of organisms in the formation of limestone, and have looked upon graphite as the final product of change of the vegetable matter. Against this view, which has occasioned the use of the terms eozoic, agnotozoic, etc., it may be objected that limestone as well as graphite can certainly be formed inorganically; the latter, for example, separates out in the casting of pig-iron. The strongest evidence of the existence of organized life during the Archrean period, is to be found in the relatively high organization of the oldest known fauna, the Cambrian. The high development of this fauna indeed necessarily 
forces us to the conclusion that it was preceded by one or more, probably a whole series, of older faunas, the remains of which we may expect in time to find in the Archæan. So long, however, as such remains have not been found, it is advisable, instead of the as yet unwarranted term Eozoic, to keep to the expression Archæan introduced by Dana (1874).

With respect to the composition of the Archæan rocks it has already been mentioned that they are built up essentially of crystalline schists with the three chief varieties, Gneiss, Mica schist and Phyllite. But it must still be noticed that besides these there occur in the upper part of the series more or less clearly clastic rocks such as quartzite, sandstone, and hæmatite

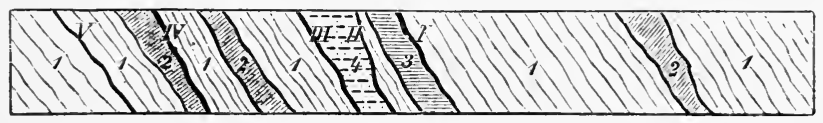

FIG. 1.-Section near Wolmersdorf in Lower Austria (v. Hauer).

1. Quartzite Schist. 2. Granular Limestone. 3. Hornblende Schist. 4. Mica Scbist. I.-IV. Beds of Graphite.

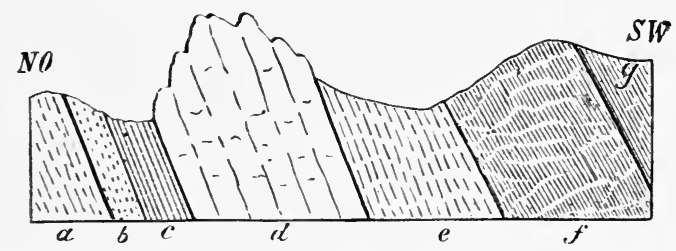

Fig. 2.- Section through the Pfahl in Eastern Bavaria (Gümbe).

a. Gneissic Granite. b. Hälleflinta. c. Schistose Hälleflinta. d. Quartz reef of the Pfahl. e. Augengneiss. f. Normal Gneiss. g. "Flaser" Gneiss.

(in N. America with ripple marks?) and even conglomerates (Scandinavia, North America.) Moreover, everywhere there occur old eruptive rocks, whether as widespread sheets or as large masses or smaller dykes. Of these, granite occupies the first place, then Syenite, Diorite, Gabbro, Olivenfels and Serpentine, Porphyry and other massive rocks. All these rocks are found along with crystalline limestone, dolomite, occasionally also in close connection with layers and masses of ore, and often occur in hundredfold alternations as in the accompanying sections.

Lastly in connection with the composition of the Archæan rocks it must be remarked that no other group is so rich in mineral ores. It has therefore been fitly called the true Ore or Vein-bearing group (Erz- or Ganggebirge.) This is especially true of the 
noble metals, gold, platinum, silver, as well as of the gems and gem-like stones such as the diamond, ruby, emerald, topaz, garnet, tourmaline, etc. Most of the gold and platinum, and also the gems, are indeed obtained from the so-called alluvium (Seifengebirge), but this has clearly been formed by the de- Frg. 3.-Section in the King Mine in New struction of the Archæan, which in this case is the original home of those minerals.

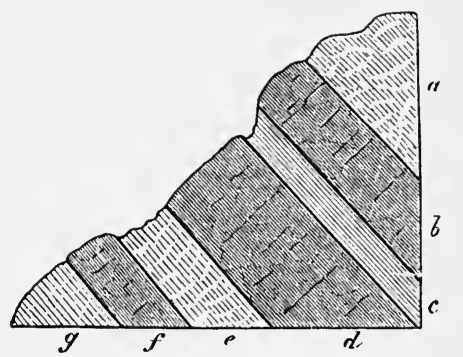

a. Flasor Gneiss, $b$ and $d$. Magnetic Iron-ore. c. Mica Schist. $f$. Mixture of Magnetite, Felspar, and Quartz. $e$ and $g$. Gneiss.

\section{STRUCTURE AND MODE OF OCCURRENCE OF THE ARCHAAN ROCKS.}

The Archæan rocks are never horizontal over any extent of country, but are always more or less steeply inclined, folded, overturned, torn and faulted, in short disturbed in the highest degree. This can scarcely cause surprise when we consider that the primitive rocks have not only shared in all the disturbances which affect the younger normal sediments, but have also been subject to the action of many earlier earth movements. On a small as well as a large scale these disturbances have rendered themselves visible in the numerous faults which run through the rock masses, in internal clefts and gliding planes, in the flattening out or breaking up of the minerals of the rock, in the often very pronounced minute faulting of the rock and its conversion into a kind of breccia, the fragments of which are kneaded into one another. Similar mechanical deformations may be seen in some of the later rocks, especially of the Palæozoic group; but they are never so abundant or so strongly marked as in the Archæan.

According to their mode of occurrence the Archæan rocks may be divided into two chief groups:--

1. They form extensive, more or less self-contained masses, the so-called massifs. These were either never covered by younger strata, or-as is usually more probably the case-all the overlying sediments have been carried off by extensive denudation and they have been left bare. In such massifs the Archæan rocks

C. G. 
usually form a succession of sharply compressed folds (Fig. 4); more seldom-e.g., according to Gumbel, in the Bavarian Hills-a series of beds dipping in regular succession (see section Fig. 5). Examples of this kind of occurrence are the Bohemian and Moravian mountains, the Central Plateau of France, the old crystalline masses of Scandinavia, Canada, Brazil, and others.

2. They form the central portion of old and young mountain chains. They appear here as long narrow zones which correspond with the most prominent of the folds and represent the geological axis of the range. In consequence of the strong compression, the direction of the schist planes in such central zones is usually
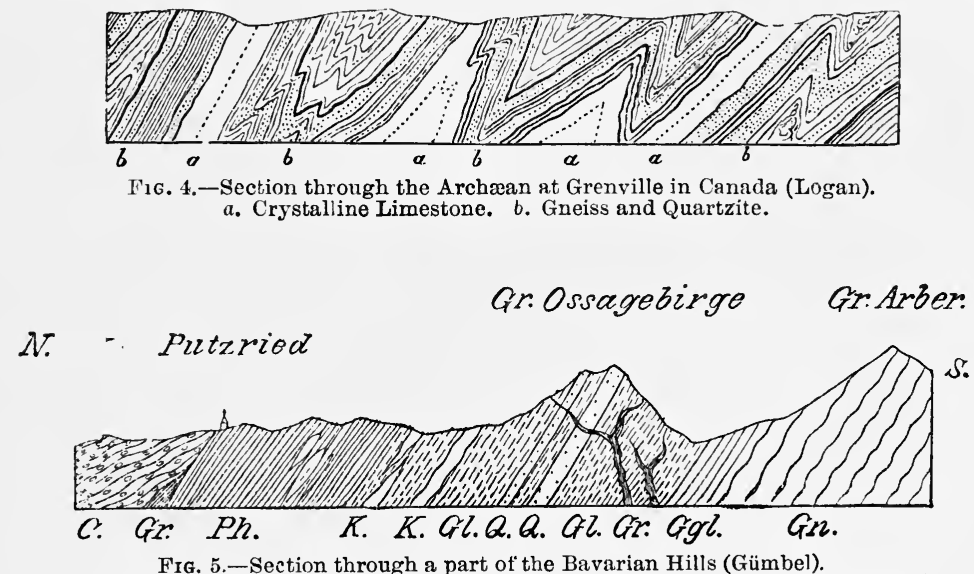

Gn. Gneiss. Ggl. Dyke of Greiss in Mica Schist. Gl. Mica Schist. Gr. Granite Dyke.

Q. Quartzite Schist. K. Granular Limestone. Ph. Phyllite. C. Cambrian.

very steep or vertical. Figs. $6-8$, which represent sections through the western and central Alps afford good examples. These sections show at a glance the peculiar fan-structure of the mountain masses of Mont Blanc and St. Gothard. This structure is common not only in the Alps but also in the Caucasus, Himalaya, etc., and can usually be explained on the view that each fan is the centre of a strong anticlinal fold compressed at the base and spreading out at the summit. But the dip of the gneiss, mica schist, and phyllites is not always so steep. Often, not only in the lower mountains (such as the Granulite mountains of Saxony), but even in the Alps (e.g. the Simplon, Fig. 9) there are cases where the folding has been much weaker and the beds form a flat arch or dome. 
Examples of these zones or belts of Archæan rocks are offered by the central chain of the Alps, the Atlas, Himalayas, Andes, Appalachians, and other ranges. Sometimes they are of considerable extent, as in the case, for example, of the crystalline schist zone that forms the backbone of the Appalachian Alps and reaches from Georgia to the mouth of the St. Lawrence, a distance of some 1,400 miles.

\section{CLASSIFICATION OF THE ARCHEAN ROCKS.}

A classification based on the palæontological characters, such as has been so successfully applied in the case of the normal sedimentary formations, is impossible for the Archæan rocks on account of the absence of fossils; and owing to their very complicated structure no attempt based on stratigraphical observations could lead to satisfactory or universally applicable results. But the division of the Archæan system is rendered possible by the fact that a perfectly definite succession is observable within it as a whole, which is repeated with extreme regularity in far separated regions and appears to be universally applicable.

As early as the middle of the last century the German geologists, to whom we owe the expressions Grund- and Urgebirge, distinguished between an older gneisslike and a newer mica-schistlike series. Werner indeed went a step further, and divided the latter into a lower mica schist and an upper slaty schist. A long while elapsed before this attempt at classification, which in the meantime had been almost forgotten, was again taken up. This was first done in the sixth decade of the present century by Logan and Sterry Hunt, who based their classification on the extensive and lengthened researches undertaken in Canada, and separated the rocks lying below the Cambrian into two great divisions which are unconformable to each other and to the Cambrian, viz.: the older Laurentian System, made up mainly of gneiss, and the newer Huronian, composed chiefly of mica schist and phyllitic rocks. ${ }^{1}$

About the same time were begun the comprehensive researches of Hochstetter, Jokéli and others in the mountains of the Archæan massif of Bohemia. Still more important were the detailed researches of Gümbel ${ }^{2}$ on the border mountains between Bavaria and Bohemia. Gümbel not only confirmed, like the earlier obser-

1 Logan, "Geology of Canada" (1863).

2 "Geognost. Beschreibung des ostbayer. Grenzgebirges" (1868). 

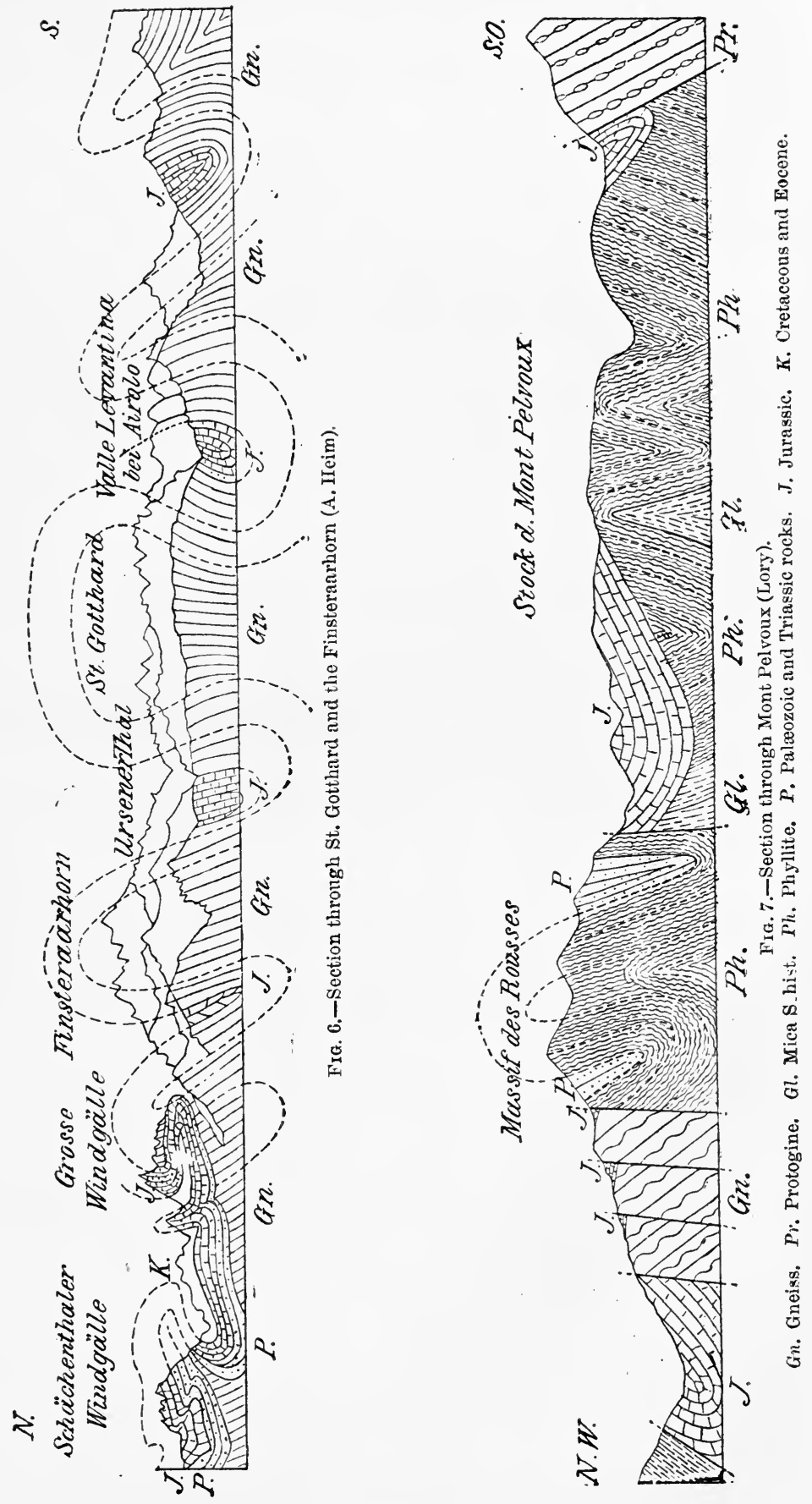

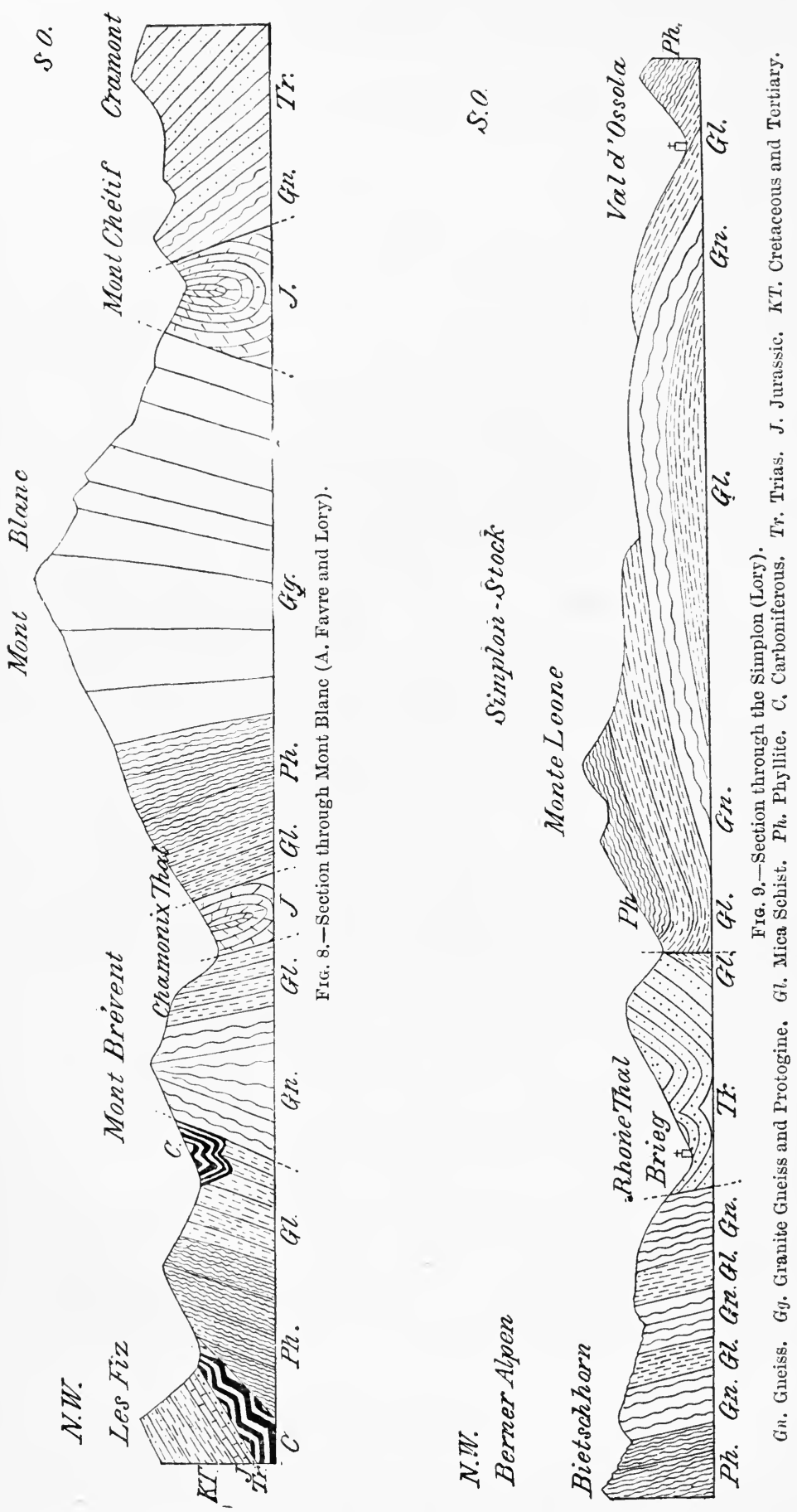
vers, the separation into three chief divisions, gneiss, mica schist, and phyllite, but also distinguished in the first an older Bojian Gneiss without limestone (called after an ancient Celtic race which dwelt in those regions), and a later Hercynian Gneiss containing limestone and graphite. In the Böhmerwald and the Fichtelgebirge, according to Gümbel, neither within the Archæan rocks themselves, nor at their junction with the Cambrian, is there any unconformity; but there is here so gradual a passage from Archæan to Cambrian that the determination of the boundary between the two is very difficult. The later researches of the Saxon geologists in the Erzgebirge and the Granulite mountains lead to similar results. Credner, ${ }^{1}$ like Gümbel, divides the whole series of the Archæan rocks into a lower or primitive gneiss formation and an upper or primitive schist formation, of which the former is likened to the N. American Laurentian, and the latter to the Huronian. ${ }^{2}$

Other attempts at the classification of the Archæan have been made in more recent times in England. Towards the middle of the century Murchison gave to the gneiss of Scotland, which is discordantly overlaid by Cambrian conglomerates, the name of Fundamental Gneiss, and compared it with the Laurentian Gneiss of North America. Since that time H. Hicks has sought to establish a classification of the Precambrian of Wales and Scotland into four series, Lewisian, Dimetian, Arvonian, and Pebidian. ${ }^{3}$ This division is based on differences in character of the rocks themselves, and on the evidence of several unconformities and horizons of conglomerate which are considered to be proofs of various great breaks in the process of formation of the Archæan. During these breaks the rocks already formed, were folded, raised above the sea and partly worn away so that their fragments afforded the material for the conglomerate at the base of the next younger series.

The divisions proposed by Hicks are by no means universally accepted; and the correlations which he proposes with the rocks of North America rest on very insufficient evidence. In the present state of our knowledge no such correlation of the Archæan rocks of distant areas is possible.

1 "Elemente der Geologie," 5th ed. (1883), p. 387.

2 Instead of the term Huronian, which has been used by various observers in very different senses, the North American geologists now employ the word "Algonkian."

3 Quar. Journ. Geol. Soc. (1877), p. 229, and (1884), p. 507. Geol. Mag. (1879), p. 433. 
In England as in North America the lower part of the gneissic system, which in Wales is composed almost exclusively of darkcoloured gneiss, is distinguished by the absence of carbonate of lime, while the upper part, on the other hand, which consists of light-coloured gneiss, and also of hornblende and chlorite schists, is characterized by an abundance of lime.

A still more detailed classification of the Archæan rocks of Canada has recently been proposed by Sterry Hunt. ${ }^{1}$ But this appears to rest on even more uncertain data, so that an enumeration of the many names given by him is unnecessary. Only this much seems clear, that the Archæan of North America is everywhere separated from the Cambrian sediments by a great unconformity-a fact which the observations of Credner (Fig. 10) confirmand that there is very probbably a similar unconformity between the Huronian and Laurentian. These are results which differ greatly

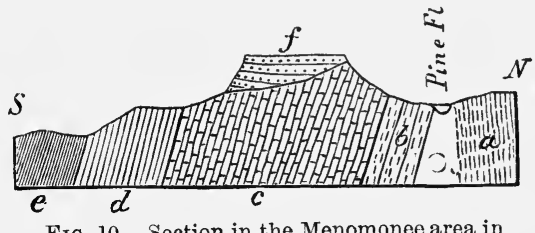

Fig. 10.-Section in the Menomonee area in Michigan (Credner).

a. Laurentian Gneiss. b. Huronian Quartzite. c. Limestone. d. Hæmatite. e. Chlorite Schist. f. Potsdam Sandstone (Cambrian). from those reached by Gümbel in the Fichtelgebirge and Böhmerwald.

\section{DISTRIBUTION OF THE ARCHEAN ROCKS.}

In Germany the Archæan is developed in the mountains of the great Moravo-Bohemian massif, the Böhmerwald, Fichtelgebirge, Erzgebirge, Lausitzer Gebirge, Riesengebirge, and Sudetengebirge; and also in the Thüringerwald and the Kyffhäuser, in the Black Forest, Odenwald and Spessart, on the Hardt and in the Vosges. In other parts of Central and Southern Europe the chief regions of Archæan rocks are the Central Plateau of France, Brittany, the Alps, Pyrenees, Balkans, Tatra, etc. But by far the largest area in Europe is that of the North-West, where the whole of Scandinavia, together with Finland and Lapland, forms a single continuous mass, with which probably the Archæan districts of Scotland and Ireland were formerly connected.

In Asia the primitive rocks take a large share in the formation of the Central mountain chains, the Himalayas, Kuenlun, Altai,

1 Amer. Journ. of Sci. (1830), p. 269. 
etc.; and they also play an important part in East India, Borneo, Sumatra, China, and Japan. Their extent is great in the interior of the African continent, and we also find them largely developed in the North and North-east of North America, in Brazil and the Andes. In Australia and the surrounding islands and in the Antarctic region they occupy a considerable area.

VIEWS ON THE ORIGIN OF THE ARCHEAN ROCKS.

The question of the mode of formation of the Archæan Rocks has long occupied geologists, and to-day forms the theme of ardent researches and burning discussions, without as yet any very satisfactory results. Any explanation must not only explain the crystalline condition of the primitive rocks and their mixed composition out of quartz, felspar, mica, chlorite, hornblende, augite, garnet, and other silicates-both characters in which they resemble the crystalline massive rocks; - but it must also explain their schistose structure, the absence of fossils, the apparently unquestionable alternation of crystalline with more or less clearly clastic rocks, their universal distribution and remarkable uniformity in the most distant parts of the earth, their resemblance to certain younger sediments altered by regional or contact metamorphism, the locally almost imperceptible passage in to the fossil-bearing beds of the Cambrian,-a series of facts which apparently contradict nne another.

Among the theories of the origin of the Archæan rocks there are three that require especial notice. The first, which has its chief exponent in J. Roth, considers that the whole of the crystalline rocks are to be looked upon as the remains of the original solidification crust of our earth. In the face of the bccurrence of clastic and conglomeratic rocks in the Archæan, this view can no longer be held, at least if it is to be extended to all the divisions of the Archæan ; and it has therefore but very few supporters.

According to a second view, which now numbers the most adherents, the Archæan formation is a complex of metamorphosed or altered rocks partly sedimentary, partly eruptive. The cause of the alteration has been sought by preference in the great movements of the earth's crust, which produced great heat and brought about the chemical and structural changes of the rocks in question. This theory of the dynamometamorphic origin of the primitive rocks has won much support from the discovery made in many places 
of mica schists or gneisslike schists which from the included fossils are undoubtedly post-Archæan. Among these the best examples are the trilobite and graptolite-bearing Silurian schists found by Hans Reusch not far from Bergen, the belemnite-bearing, probably Jurassic schists of Switzerland, and the Cretaceous rocks of the Californian coastal ranges. This hypothesis explains the crystalline structure of the Archæan rocks, their schistosity, composition out of silicates, and the occurrence of interbedded conglomeratic layers. On the other hand it can only with difficulty explain the gradual decrease of the crystalline structure which is represented by the universal succession from gneiss to mica schist and phyllite, and the locally quite imperceptible passage upwards into the normal sediments of the Cambrian, and it leaves quite unexplained the universal distribution and the uniformity in character of the Archæan. If we consider the Archæan to be metamorphosed, we are compelled to admit that this metamorphosis took place in Precambrian times. In many places the pebbles of gneiss and mica schist which are found in the basal conglomerate of the Cambrian are undistinguishable from the gneiss and mica schist of the large Archæan masses, and they thus afford an indubitable proof that these rocks must have already possessed their present characters before they were broken up and reformed into a conglomerate; for no one can well imagine that the rocks had been metamorphosed as pebbles in the same way as in the mass.

The third view (hypothesis of Diagenesis) occupies a position midway between these. It was proposed by Gümbel and has been adopted by Credner in his "Elemente der Geologie." According to this the Archæan rocks are true sediments which owe their peculiarities to the character of the original oceans. As has already been shown, those seas must have possessed a very high temperature and must have lain under a much denser atmosphere than that of the present. In consequence of the absorption of the various vaporised substances which this atmosphere then contained, the water would strongly attack all the rocks with which it came in contact. It would thus become laden with many matters in solution, and when the point of saturation was passed these would be laid down as true crystalline deposits. Moreover the débris of the continents on reaching the early sea must in these circumstances (as in Daubrée's well-known experiments, in which the action of superheated water and great pressure caused amorphous mineral substances to assume a crystalline form). soon have been 
brought into a crystalline state. Under these conditions gneiss especially would be formed. But because these conditions did not remain permanent, because the high temperature and pressure and the richness in dissolved substances gradually diminished, and the resemblance to present conditions increased, it follows that the conditions became continually more unfavourable for crystalline sedimentation, and that therefore mechanical deposition, which works almost alone in our present sea, gradually increased at the expense of the chemical, and finally completely overmastered it. Hence the succession, repeated everywhere with such regularity: Gneiss, mica schist, phyllite.

But however seductive this theory may appear at first sight, however well it may clear up several points left unexplained by the first two, nevertheless on closer observation it will be found that it does not solve by any means all the difficulties. Leaving out of consideration the fact that from its point of view the occurrence of crystalline schists in the Cretaceous and Tertiary formations is quite inexplicable, one needs no microscope, as Rosenbusch has recently pointed out, to recognise that the millionfold alternations of micaceous and quarzo-felspathic laminæ, such as constitute gneiss, cannot be explained by crystallisation from solution. Each glance at the texture and the constituents of the primitive rocks shows us that there is here no sequence of the constituent minerals according to their solubilities or other chemical relations.

As Rosenbusch endeavours to show, the great fault in all attempts hitherto made to explain the origin of the Archæan masses lies in the fact that these have always been considered uniform in substance as in structure, whilst in reality they represent a complex which is composed of elements different both in material and in origin. With Rosenbusch we may see in one part of the Archæan-the oldest gneiss-the more or less altered remains of the original crust of the earth. The stratigraphical position of these old gneisses, their universal occurrence, their remarkable uniformity and their close resemblance to the oldest of the eruptive rocks, granite, speak strongly in favour of such a view. Other portions of the Archæan allow us to recognise with more or less certainty their clastic origin, their derivation from clay-slates, grauwacke, conglomerates and limestone; while lastly a third part clearly shows by its structure under the microscope that it has been formed by the alteration by pressure of old eruptive rocks (granite, syenite, diorite, etc.) or their tuffs. 


\section{PALAOZOIC OR PRIMARY GROUP.}

The Palæozoic Group forms the oldest of the three great divisions into which the normal fossiliferous deposits have been divided. It is subdivided into six great systems or formations, namely, Cambrian, Ordovician, Silurian, Devonian, Carboniferous, and Permian. It is to be remarked, however, that the claims of the Cambrian and Ordovician; and of the Permian beds to be considered separate formations are not recognised by all geologists, that the first two are sometimes united with the Silurian, and the last with the Carboniferous.

The six Systems together form a succession of beds fully 100,000 feet thick. In Germany, the part which underlies the Carboniferous was formerly known as the Transition or Grauwacke group. The last name was adopted on the ground that the socalled Grauwacke-a fine to coarse-grained, quartzose, often felspathic sandstone containing small fragments of milkquartz, argillaceous and siliceous schists and other older rocks-occurred only in these beds. In fact, however, grauwacke, grauwacke sandstones and schists, are widely spread in all the older Palæozoic formations, while precisely similar rocks occur also in the Culm - such as the very typical grauwacke sandstone of the Upper Harz, which is now recognised as belonging to the Lower Carboniferous. For the upper half of the Palæozoic group, especially for the Carboniferous and in part for the Permian, coal is particularly characteristic.

Besides the already mentioned rocks, the Palæozoic formations consist especially of clay-slates (which along with roofing slates and phyllites are very widely distributed), numerous sandstones quartzites and conglomerates, siliceous schists, and various limestones and calcareous beds. With these occur eruptive rocks, such as granite, syenite, diorite, diabase, quartz-porphyry, porphyrite, melaphyre, and other less abundant massive rocks, and also the various tufaceous forms of these.

Palæontologically the Palæozoic Formations are characterized 
by containing the oldest known organic remains. In correspondence with the long duration of this era, the group in question contains a whole succession of different faunas and floras. In general it may be said that the rise of the Palæozoic life took place in the first four Systems, whilst the last two represent the age of its decline. The flora is characterized by the extraordinary predominance of cryptogams (gigantic ferns, Lycopodiaceæ and Equisetacex), which in the second half of the era are accompanied by conifers and cycads, whilst angiosperms or leaf-bearing trees are entirely absent. The fauna derives its peculiar stamp from the great development of crinoids, rugose and tabulate corals, an abundance of peculiarly organized brachiopods, nautili as well as Goniatites among the molluscs, trilobites and Eurypterids (limited to this age) among the crustaceans, placoderms and heterocerca, ganoids among fish, and in the second half of the period, Stegocephala among amphibians. To these may be added a few reptiles, which also appear for the first time in the last phase whilst birds are completely wanting.

With regard to the structure, it should be noticed that the Palæozoic beds in Central and Southern Europe, and also in most of the extra-European regions, are steeply inclined, folded, and cut through by numerous faults and dykes. In Northern and Northeastern Europe on the other hand, as also in Eastern North America and some other regions, they lie horizontally over very wide areas.

\section{CAMBRO-SILURIAN ROCKS.}

\section{HISTORICAL.}

THE term Cambrian, derived from Cambria, the ancient name of Wales, was proposed by Sedgwick in the year 1833, and was one of the results of the researches begun by him in 1831, on the oldest fossiliferous beds of North Wales. Two years after this, Murchison proposed the name Silurian (from the old South Wales tribe of Silures) for a series of rocks examined by him in South Wales and the adjoining parts of England.

After some years it became clear that the lower part of Murchison's Silurian was the equivalent of the upper part of Sedgwick's Cambrian. Murchison endeavoured to fix the boundary between the two below what he had described as Silurian; and, as he could 
there find no suitable base line, he gradually included in his Silurian more and more of the rocks below, until at length he reached the Lower Cambrian of Sedgwick. He relied on the great poverty of the Cambrian fauna in comparison with the Silurian, and on the absence of a natural base for his Silurian; while Sedgwick, in opposing him, emphasized the right of so thick and peculiarly developed a series as the Cambrian to be considered a distinct Formation, and pointed out the partial distinctness of the -at that time little known-Cambrian fauna.

In spite of the great influence which Murchison in time gained, his attempts to reduce the Cambrian merely to a basal group of the Silurian, had but limited success. Among the few geologists who follow him, Joachim Barrande claims the first place. In the fifth decade of the century he undertook the examination of the oldest beds of Bohemia ; and there he recognised not only Murchison's Upper and Lower Silurian, but also a third still older fauna consisting chiefly of trilobites, which were afterwards found in the Menevian of Wales. Unfortunately he called this the first or Primordial Fauna of the Silurian, becanse he applied this term to the whole of the pre-Devonian beds. This "Primordial Fauna" coincides essentially with the Lower Cambrian of Sedgwick.

A similar trilobite fauna, specially characterized by the genus Paradoxides, was immediately proved in Scandinavia and also in North America; and this circumstance caused the term Cambrian, in spite of the opposition of Murchison and Barrande, to grow more and more in favour. At the present time most of the German, English, Swedish, Russian, and North American geologists consider the Cambrian a distinct system, while their French comrades in part follow the example of Barrande and distinguish it as Primordial Silurian. In North America, Marcou and others have lately tried to introduce the term Taconic instead of Cambrian, a term proposed by Emmons in 1842, but with a very different meaning.

It is now almost universally admitted that the Cambro-Silurian rocks fall naturally into three great divisions, each characterized by its own peculiar fauna. Speaking broadly, Sedgwick applied the term Cambrian to the two lower; Murchison at first included in his Silurian the two upper divisions, but ultimately took in a large part of the lowest also. The greater number of geologists, perhaps, apply the term Cambrian to the lowest division and of Silurian to the two upper. 
In 1881 Prof. Lapworth proposed to give expression to the facts of the case by giving to each of the great divisions a different name. Then, since the term Cambrian is almost universally applied to the lowest group, and the term Silurian to the uppermost, he retains these names with those significations; and for the intermediate or second group of beds, which is the group in dispute, he proposes the term Ordovician (derived from the name of one of the old Welsh tribes).

The merits of this arrangement, not only as the fairest compromise possible between the conflicting parties, but also as the natural expression of the facts of the case, are now very generally recognised, and it is accordingly adopted in this work. ${ }^{l}$

The following table shows the different significations that have been given to the terms Cambrian and Silurian in England:-

\begin{tabular}{|c|c|c|c|c|c|}
\hline & Sedgwick. & Murchison. & $\begin{array}{l}\text { Geological } \\
\text { Survey. }\end{array}$ & Lyell. & Lapworth. \\
\hline $\begin{array}{l}\text { Downtonian } \\
\text { Salopian } \\
\text { Valentian }\end{array}$ & Silurian & $\begin{array}{l}\text { Upper } \\
\text { Silurian }\end{array}$ & $\begin{array}{l}\text { Upper } \\
\text { Silurian }\end{array}$ & $\begin{array}{l}\text { Upper } \\
\text { Silurian }\end{array}$ & Silurian \\
\hline $\begin{array}{l}\text { Bala Series } \\
\text { Llandeilo } \\
\text { Arenig and } \\
\text { Llanvirn }\end{array}$ & & $\begin{array}{l}\text { Lower } \\
\text { Silurian }\end{array}$ & $\begin{array}{l}\text { Lower } \\
\text { Silnrinn }\end{array}$ & $\begin{array}{l}\text { Lower } \\
\text { Silurian }\end{array}$ & Ordovician? \\
\hline \begin{tabular}{l} 
Tremadoc \\
\multicolumn{1}{c}{ Slates } \\
Lingula Flags \\
Menevian
\end{tabular} & Cambrian & $\begin{array}{l}\text { Primordial } \\
\text { Silurian }\end{array}$ & & Cambrian & Cambrian \\
\hline Harlech, etc. & & Cambrian & Cambrian & & \\
\hline
\end{tabular}

GENERAL REIARKS.

By far the most extensive of the Cambro-Silurian deposits of Europe are those of Russia. They seem to form a continuous sheet stretching from the Gulf of Finland and the White Sea to the south and east over the whole country. Throughout the greater part of its extent this sheet is covered and hidden by newer rocks; but its edge appears along the south coast of the Gulf of Finland and stretches thence north-eastward to the White Sea,

1 Dr. Kayser adopts the usual Continental arrangement, and unites the Ordovician with the Silurian.

2 The term Ordovician, as used in this work, includes the Tremadoc Slates. 
while in the south, the river Dniester has cut down through the later deposits and exposes the upper surface of the CambroSilurian sheet. Where exposed, the beds are nearly flat and undisturbed; to the east, however, the edge of the sheet is turned up along the western slope of the Urals, and it is here thrown into folds running from north to south.

Leaving this Russian sheet of deposits and passing towards the west, we find that at one time the undisturbed beds extended over the south of Scandinavia, where they are now represented by the outlying patches of Scania, etc. But in the western and central parts of Norway they are thrown into folds and much altered, just as they are along the eastern border of the sheet.

It is probably the same system of folds that brings up the Cambro-Silurian along the western border of Britain, in Wales, the Lake District, and the South of Scotland; and again in the North of Scotland. The first three areas appear to be the eastern portions of long elliptical domes running from about W.S.W.E.N.E., which are cut into by the Irish Sea; but the westerly continuations of which bring up the Cambro-Silurian as a fringe along the northern and southern border of the sheet of Carboniferous rocks which covers the greater part of Ireland. It is clear that no system of simple folds striking from W.S.W.-E.N.E. would have the effect of turning up these rocks only along the western border of Britain, and there must be a system running from S.S.W. to E.N.E. ; and the elliptical domes have been produced by the combination of the two systems.

Turning now to Central and Southern Europe, the chief areas of Cambro-Silurian rocks are those of Brittany, Spain, and Bohemia. Unfortunately, the structure of the first is very complex, and that of the second very imperfectly known. In the character of the deposits and fossils, however, they differ considerably from the Cambro-Silurian of Northern Europe; so that we recognise two more or less distinct facies of Cambro-Silurian in Europe, a Northern and a Southern. Thus, neither the Orthoceras limestone nor the Pentamerus beds, both of which are almost universal in the Northern facies, is found in the South. The Olenus beds also are unknown in Southern Europe; but this seems to be due to the fact that there was no deposition during the Olenus period.

But the most important difference between the two facies is to be found in the fauna. Many forms are characteristic in the one area and unknown in the other; while still more are abundant in 
the one and rare in the other. Considering the richness of both faunas, the number of species common to the two is strikingly small. This has usually been explained by supposing a ridge of land to have separated the two seas in Cambro-Silurian times; but it is probable that climate was at least one of the causes of the difference, and that we have here indications of climatic zones in those early periods. It should be remarked that in the appearance of Maclurea Logani and other N. American forms in the CambroSilurian of Scotland, we seem to have indications of a still more northerly zone.

\section{A.-CAMBRIAN SYSTEM.}

British Islands. - In England and Wales Cambrian rocks occur in North and South Wales, Shropshire, Warwickshire and the Malverns; while the lower part of the Skiddaw Slates in the Lake District may possibly also be of Cambrian age. In Scotland Cambrian rocks are known only in the North ; and in Ireland they are found in three areas, viz. Wicklow, Wexford, and perhaps Galway. In Britain, as throughout northern Europe, the lowest beds are characterized by the occurrence of the trilobite Olenellus. Above these come beds with the somewhat similar form Yaradoxides; while the upper part of the system contains Olenus in abundance. The whole system may be subdivided as follows:-

\section{Dictyograptus Shales.}

Olenus Beds $\left\{\begin{array}{l}\text { Lingula } \\ \text { Flags }\end{array}\left\{\begin{array}{l}\text { Dolgelly group. } \\ \text { Ffestiniog group. } \\ \text { Maentwrog group. }\end{array}\right.\right.$

Paradoxides Beds $\left\{\begin{array}{l}\text { Menevian. } \\ \text { Harlech grits (?), Llanberis Slates (?), Solra } \\ \text { group. }\end{array}\right.$

Olenellus Beds $\left\{\begin{array}{l}\text { Comley Sandstone (lower part), Fucoid beds } \\ \text { of Scotland, Caerfai group (?). }\end{array}\right.$

The Longmynd rocks, which were formerly supposed to be of Cambrian age, now appear to be Pre-Cambrian.

Our knowledge of the Olenellus fauna in England is yet in its infancy, and it is impossible to correlate with exactness the lowest Cambrian rocks throughout the British Isles. Olencllus was first found in England ${ }^{1}$ at the base of the Comley Sandstone on the

1 Lapworth, Geol. Mag., 1888, p. 484; 1891, p. 529. 
flanks of Caer Caradoc in Shropshire; and there the Olenellus beds consist of a basal quartzite followed by this sandstone. Besides Olenellus, these beds have yielded Kutorgina and Mickuitzia, the latter of which is characteristic of the Olcnellus zone of the Baltic Provinces. The upper part of the Comley Sandstone has yielded Paradoxides, and belongs therefore to the next division of the Cambrian.

In South Wales the oldest Cambrian rocks are divided by Dr. Hicks ${ }^{1}$ into two groups. The lower of these, called the Caerfai group, probably belongs to the Olenellus zone, and consists of conglomerates, sandstone and shales with few fossils (tracks of Annelids, Fucoids (?), Leperditia, and Lingula [Lingulella] primava). This is succeeded by the Solva group, which is made up of red and green schists and sandstones, and contains a comparatively rich fauna-various species of Paradoxides (P. IIarknessi, P. solvensis, $P$. aurora), Conocoryphe, Agnostus and other trilobites-and belongs to the Paradoxides fauna.

In North Wales the oldest of the Cambrian rocks are the Harlech grits and the Llanberis Slates. The Harlech series consists of more than 6,000 feet of sandstones with ripplemarks and suncracks, but without fossils; and the Llanberis Slates consist mainly of several thousand feet of purple slate-worked at Penrhyn in the largest slate quarries in the world-with some greenish grits and with a conglomerate of Archæan rocks at their base. Formerly nothing was known from these beds except some doubtful fucoids; but recently remains of trilobites, notably a fine Conocoryphe (C. viola), have been discovered in the slates at Penrhyn.?

These older beds are followed both in North and South Wales by the Menevian Series-a series of slates and sandstones only a few hundred feet thick, which contain two species of Paradoxides (P. Hicksii, P. Davidis), Conocoryphe, Arionellus, Agnostus and other trilobites, a Theca, an Orthis, Obolella, sponge spicules (Protospongia), and other fossils.

Next follows the most important division of the English Cambrian, the Lingula Flags, which are especially well developed in North Wales, and consist of 5,000 feet of dark, thick-bedded slates and shales with intercalated hard beds of grit and sandstone. They have been divided into three groups, and these

1 Quart. Journ. Geol. Soc., xxvii. 396.

2 Woodward, Quart. Journ. Geol. Soc., xliv. p. 74.

c. G. 
groups are again subdivided into zones which closely correspond with the zones in the Olenus Shales of Scandinavia, thus:-

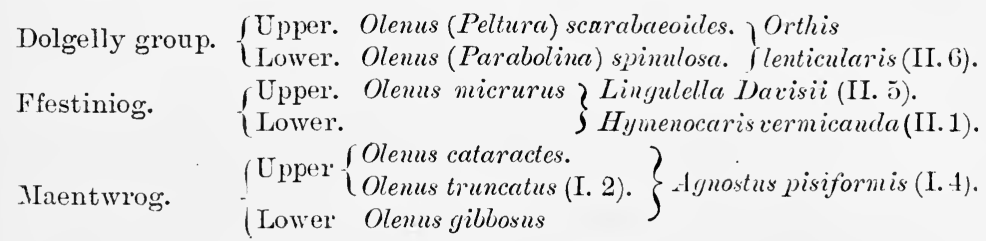

At the uppermost limit of the Lingula Flags, or (according to the terminology more usually accepted in England) at the base of the Tremadoc beds, there occurs a horizon of great importance owing to its occurrence throughout the whole of Northern Europe, namely, the Dictyograptus Shales with Dictyograptus (Dictyonema) flabelliformis = socialis (II. 2).

The uppermost division of the Cambrian, according to the usual English classification, is the Tremadoc group, consisting of bluish-gray shales and sandstones, which do indeed contain the Cambrian forms Olenus, Conocoryphe, Agnostus, and Dicellocephalus, but contain also a number of forms that are quite foreign to the Cambrian in general, and are in fact the forerunners of the Ordovician fauna. We find a somewhat similar mixture of forms in the Swedish Ceratopyge Limestone, the Russian Greensand, and the North American Calciferous Sandstone, which all lie in the same stratigraphical position, directly on the Cambrian. Since these are no longer referred to the Cambrian, but to the Silurian, the same must be the case with the Tremadoc Slates.

In the North of Scotrand ${ }^{1}$ Olenellus has recently been found in what are known as the Fucoid Beds, and also in the Serpulite Grit. As the group of beds of which these form a part lies unconformably upon the Torridon Sandstone, this, which was formerly considered to be Cambrian, must now be referred to the PreCambrian.

In IRELAND a series of red, purple, and green slates and grits occupies considerable areas in Wicklow and Wexford. No fossils have been found except Annelid tracks and the problematic Oldhamia, which was formerly supposed to be a plant, but is now sometimes supposed to be simply a wrinkle in the slate. These rocks, from their position, are correlated with the Harlech Series of Wales.

1 Peach and Horne, Quart. Journ. Geol. Soc., xlviii. 227. 
In Connemara quartzites and slates, with the Connemara marble, underlie beds with Llandeilo fossils; and have been doubtfully referred to the Upper Cambrian.

Sweden and Norway.--Our knowledge of the Cambrian Rocks of Scandinavia is due in part to the older work of Angelin ${ }^{1}$ in Sweden, and of Kjerulf 2 in Norway, and in part to that of later observers, especially Linnarsson, Brögger, Nathorst, Holm and Tullberg. ${ }^{3}$ Unlike the extraordinarily disturbed beds of England, the Lower Palieozoic rocks of Sweden, especially in the south of the country and on the Island of Oeland, lie undisturbed in their original horizontal position. This may be well seen in the greenstone-capped hills of Ostrogothia, such as Kinekulle, Hunneberg, Halleberg, etc. (Fig. 11).

At the base of the Swedish Cambrian and immediately on the sharply inclined Archæan rocks, lies a massive sandstone, the lower part of which is known as the Eophyton, and the upper as the Fucoid, Sandstone. Organic remains are rare. Along with

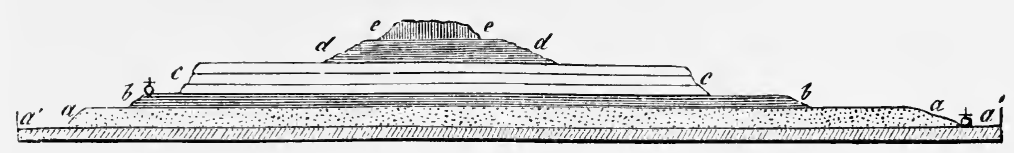

Frg. 11.-Section of Kinekulle on Lake Wener.

$a^{\prime}$. Gneiss. a. Oldest Cambrian Sandstone. b. Alum Shales. c. Ordovician Orthoceras Limestone. d. Graptolite Snales. e. Greenstone C'ap.

loubtful remains of plants (Cruziana), there have recently been found in the lower Sandstone a brachiopod like Obolus (Mickwitzic monilifera), remains of Medusæ, and at the upper limit of the upper bed, a species of the important genus of trilobites Olenellus (O. K.jerulfi, I. 6). These sandstone beds are succeeded by dark bituminous, somewhat calcareous, shales, which were formerly used at many places (at Andrarum in Scania, in Oeland, etc.) for the manufacture of alum, and are therefore known as Alum Shales. The lower division of these beds is characterized palæontologically by the appearance of the genus Paradoxides ( $P$. celandicus, P. Tessini, P. Forchhammeri); and the upper division by the genus Olenus (O. truncatus [I. 2], etc.). Linnarsson therefore separated the series into Paradoxides and Olenus

1 "Palæontologia Scandinavica," 1854.

2 "Geologie d. südl. Norwegen," 1858 and 1879.

2 " Sveriges Geol. Undersökn." (1882); Zeits. deutsch. Geol. Ges., xxxv. 223. 
Shales. At the upper limits of the latter, as in England, appears the genus Dictyograptus.

Thus the Swedish Cambrian is subdivided as follows (in descending order):-

Dictyograptus zone.

Olenus beds.

Paradoxides beds.

Olenellus beds.

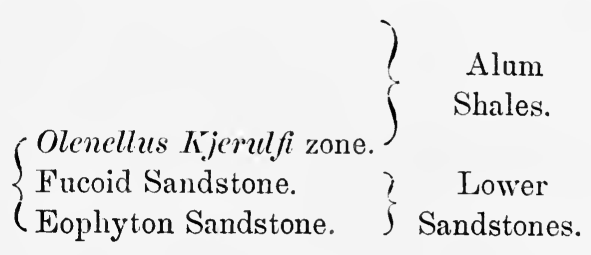

In Norway the development of the upper part of the series is quite like that in Sweden; but the oldest Swedish sandstone formation is represented by Kjerulf's Sparagmite, a thick, unfossiliferous series of conglomerate, felspathic sandstones, quartzites, schists, and limestone. The red Dala Sandstone (so widely spread in the form of fragments in the North German Drift) of Central Sweden (Dalecarlia), and certain arkoses of West Finland, occupy a position similar to that of the Sparagmite. ${ }^{1}$

The following zones have been established by Brögger in the Alum shales of the Christiania area :-

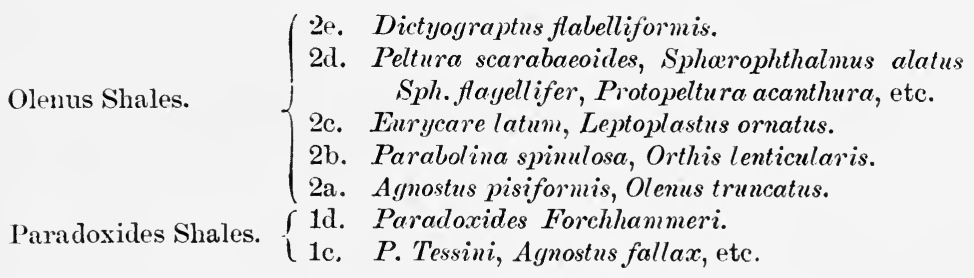

On the Island of Bornholm, similar Cambrian beds are also present, for the knowledge of which we are indebted chiefly to Johnstrup.

In Scania the zones have been nost minutely worked out by Tullberg, who distinguishes the following, in descending order:-G. Olenus Shales: (a1) Bryograptus Kjerulfi, (a2) Dictyograptus flabelliformis, (b) Acerocare ecorne, (c) Cyclognathus micropygus, (d) Peltura scarabaeoides, (e) Eurycave camuricorne, (f) Parabolina spinulosa and Orthis lenticularis, (g) Ceratopyge, (h) Olenns, (i) Leperditia, (k) Aynostus pisiformis, (l) Alum shales without fossils. H. Paradoxides Shales: (a) Agnostus lavigatus, (b) Paradoxides Forchhanmeri, (c) Agnostus Lundgreni, (d) Paradoxides Davidis, (e) Conocoryphe cequalis, (f) Agnostus rex, (g) A. intermedius, (b) Microdiscus scanicus,

1 It is probable that at least a portion of these is, like the Torridon Sandstone of Scotland, of Pre-Cambrian age. 
(i) Conocoryphe exsulans, (k) Aynostus atavus, (l) Limestone, (m) Black Alum Shale, (n) Olenellus Kjerulfi. The last three probably belong to the Olenellus zone.

Baltic Provinces.-The Cambrian of the Russian Baltic provinces and of the neighbourhnod of St. Petersburg las become known partly through the older work of Pander, de Vernenil, Count Keyserling, von Eichwald and others, and still more through the long continued researches of F. Schmidt. ${ }^{1}$ In this region, as in Southern Sweden, the beds lie nearly flat and have, moreover, in part-especially the so-called Blue Clay-preserved their original soft character.

The lowest part of the Cambrian, resting directly on Gneiss and Granite, is the Blue Clay, a plastic clay some 300 feet thick (as borings near St. Petersburg have shown), with interbedded sandy layers, which in the lower part form a somewhat thick bed of sandstone. The only organic remains hitherto found in the oldest beds are groups of glauconite grains which were shown by Ehrenberg to be casts of Foraminifera, and some doubtful remains of Algæ.

The Blue Clay passes upwards into a series of alternating clay and sandstone beds. From these the only fossils formerly known were the so-called Platysolenites and Volborthellas - the former probably fragments of the stalks and arms of Cystideans, and the later a very small Orthoceras. In later times, however, a number of other very important forms have been discovered. These include a species of Olenellus (O. Mickuitzi, the oldest known European trilobite), and two species of a Patella-like shell, called Scenella (which occurs also in the N. American Cambrian). They contain also Medusa and Mickuitzia monilifera, which have already been mentioned as occurring in the Eophyton Sandstone of Sweden; fossils like Obolella and Discina, as well as Cruziana, a plant-like form which is now usually supposed to be pseudo-organic.

Since the Medusa and Mickwitzia show that these beds are the equivalents of the Swedish Eophyton Sandstone, the succeeding 30-50 feet of unfossiliferous Sandstone must represent the unfossiliferous Fucoid Sandstone.

The next bed is the Ungulite Sandstone, a loose yellow sandstone, the upper layers of which are completely filled with

${ }^{1}$ Quart. Journ. Geol. Soc., xxxviii. 514. Mem. l'Acad. Imp. Sci. St. Petersburg, Ser. vii. xxxvi. No. 2. 
fragments of horny brachiopods, the most abundant being Obolus Apollinis. The resemblance of the muscle-impressions of this shell to the mark of a horse's hoof, has given to it the name of Ungulite. It is a point of very great importance, as observed by Schmidt, that there is a sharp boundary between the Ungulite Sandstone and the underlying Fucoid Sandstone, and also that at the base of the Ungulite Sandstone there are conglomerates which consist of pieces of Fucoid Sandstone. These facts indicate a gap at the boundary between the two formations-a gap which points to a change of level and an interruption of sedimentation, during which the older Fucoid Sandstone suffered some denudation.

Lastly, the uppermost beds of the Cambrian, as in Scandinavia and England, are the Dictyograptus shales,-dark-coloured, bituminous clays some 20 feet thick, which contain Dictyograptus flabelliformis, and also numerous true graptolites.

The following table shows the grouping of the Baltic Cambrian and its relations to that of Sweden and Norway :-

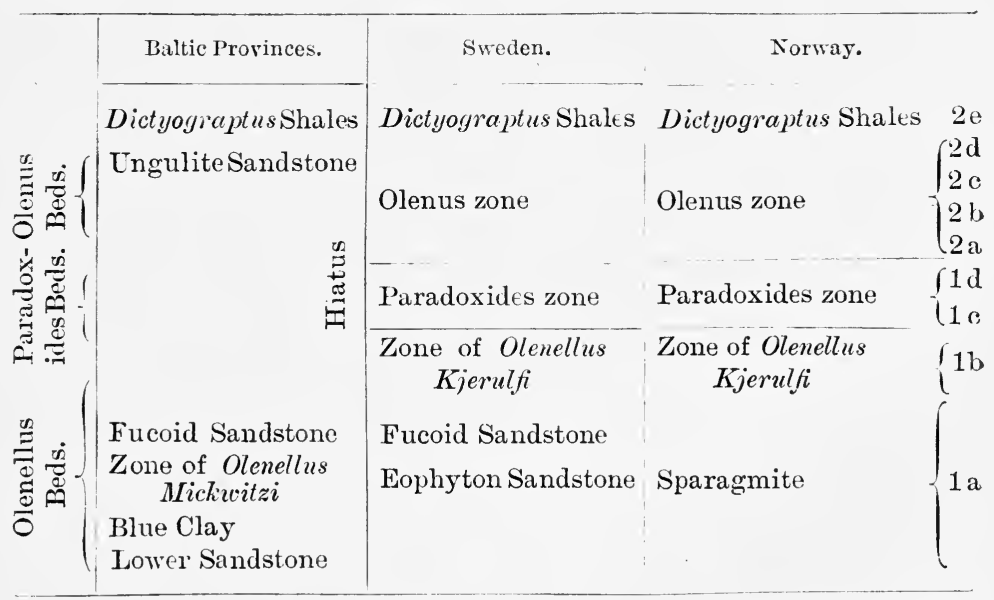

Bohemia.-In Central Europe Cambrian beds have been known longest in Bohemia. Our knowledge of them is due entirely to the remarkable observations, extending over more than forty years, of Joachim Barrande, on the oldest rocks of this region.

The first result of Barrande's observations was the appearance in 1846 of his "Notice préliminaire sur le Système Silurien de la Bohême."1 This was followed in 1847 by a work on the Brachi-

1 V. Haidinger's "Naturw. Abhandl.," i. and ii. 
opods; and afterwards, from 1852 onwards, by his great work, "The Silurian System of Bohemia," the most comprehensive Monograph of this kind that has yet appeared, treating of the different groups of animals in order.

The oldest beds of Bohemia form a basin, some $90 \mathrm{~m}$. long and 10 or $12 \mathrm{~m}$. broad, the principal axis running in an S.W. direction from Prague through Beraun to Pilsen. In consequence of this very regular structure the oldest beds occur at the boundary and the newest in the middle of the basin, whilst the floor of the trough is made of Archæan rocks and, above them, of unfossiliferous, phyllitic schists? ${ }_{2}^{\text {? }}$ called the Przibram schists by Lipold, which include locally conglomerate, sandstone and oolitic limestone.

Barrande has divided the whole series of beds of this basin into Stages, which he indicates by capital letters, whilst he marks the smaller sub-divisions by small letters and figures. His Stage A represents the Przibram schists, and is of Pre-Cambrian age. The succeeding unconformable Przibram Grauwacke of Lipoid, which begins with coarse conglomerates and is made up mainly of dark coloured sandstone below and lighter coloured above, was placed by Barrande as "Stage B" with the azoic rocks; but in later times they have been separated from these and classified as lowest Cambrian. ${ }^{1}$ Except Annelid tracks and a solitary Orthis, no fossils have yet been found in these rocks. Above these comes Stage C, Barrande's "Primordial beds," consisting of greenish, thick-bedded slates, some 300 feet thick, with a rich and wellpreserved fauna. Trilobites preponderate, and among them the genera Paradoxides (with both the chief species P. bohemicus [I. 1] and P. spinulosus), Conocoryphe (I. 3), Ellipsocephalus, Arionellus, Agnostus and others play the chief part. Besides these, there are only a few species of Hyolithes or Theca (II. 3), a few brachiopods (Orthis, Obolus), and a number of cystideans, in all some thirty species. These Paradoxides or Jinetz beds (so called from their chief locality, Jinetz, on the south border of the synclinal) are undoubtedly equivalent to the Swedish Paradoxides Shales and to the English Menevian. It is worthy of remark that they do not form a continuous zone round the whole basin, but are known only at Jinetz and near Skrej, at the

1 Marr, Quart. Journ. Geol. Soc., xxxvi.; Katzer, "Das ältere Palæozoicum in Mittelböhmen," Prague, 1888. "Geologie von Böhmen," Prague, 1892. 
northern border of the basin. According to Marr this is due to a slight unconformity (probably a normal overlap) between the Paradoxides beds and the succeeding, somewhat conglomeratic, basement beds of Barrande's Stage $\mathrm{D}$, and accordingly there must be a stratigraphical gap between them. This view would satisfactorily explain the absence of any equivalent of the English and Swedish Olenus beds in Bohemia. According to Katzer, however, the two deepest zones of Barrande's $D, d$, and $d 1 \beta$, which consist of sandy conglomeratic beds with diabases, diabase tuffs and ironstone, and contain as organic remains only Lingula and some species of Orthis, also belong to the Cambrian.

Germany.-In Germany Cambrian beds are but very slightly developed. The largest area is that of the Fichtelgebirge and the neighbouring Saxo-Thuringian Voigtland. They are here underlaid conformably and without any sharp boundary by Archæan phyllites, and consist of thick greenish grey, micaceous sandy, often very schist-like slates with interbedded quartzites. The only fossils found are usually badly preserved bivalves and, in the upper part of the series, lying on the surface of the beds, certain alga-like forms, the so-called Phycodes, the significance of which is still doubtful. It is only at Leimitz near Hof that a richer fauna has been found, consisting principally of trilobites and brachiopods. These have been worked out by Barrande, ${ }^{l}$ and described as a sort of passage-fauna between Cambrian and Ordovician. According to the notices of Gümbel ${ }^{2}$ on this interesting fauna, these beds must be considered of the same age as the English Tremadoc and the Swedish Ceratopyge Limestone, and thus would be classified as Lowest Ordovician.

Except in this area, Cambrian rocks are known in Germany only in the Hohe Venn, south of Aix la Chapelle. This is an old mountain core consisting of clay and roofing slates, quartzites and phyllites, surrounded by unconformable Devonian beds. A few fossils (Agnostus, Dictyograptus, Oldhamia) discovered in the neighbourhood of the well-known Baden Spa and elsewhere, render the Cambrian age of the rocks at least probable.

France.-In France the chief Cambrian areas are found in the Ardennes, in Brittany and Normandy, and on the borders of the Central Plateau and in the Pyrenees. As a rule fossils are very

1 "Faune silurienne des environs de Hof," Prague, 1868.

2 "Grandzüge der Geologie," p. 544. 
rare and the relations of the beds obscure. In the Ardennes they form several massifs of slates, quartzites, and phyllites, rising through later rocks; and Gosselet recognises two sub-divisions, Devillo-Revinien below and Salmien above. The former he correlates with the Longmynd and the latter with the Lingula Flags. Dictyograptus occurs in both.-Paradoxides has been found in the Montagne-Noire on the south of the Central Plateau.

Spain.-In the Provinces of Galicia and Asturias Cambrian rocks have been described by Barrois and divided by him as follows (in descending order) :-

Limestones and Slates of the Vega, with Paradoxides . 50-100 m.

Slates of Rivadeo . . . . . . . . . $3000 \mathrm{~m}$.

They rest quite conformably on the underlying rocks. Besides Paradoxides, the Vega beds contain Conocoryphe and Arionellus. No Olenus beds are known in this area; and this appears to be a feature common to most of the southern Cambrian areas.

Cambrian rocks lave also been found in Seville (with Archaocyathus [II. 7]), and Ciudad Real (Ellipsocephalus).

In Sardinia, in the region of the Canal Grande, and in the district of Iglesias, a series of schists, with limestones and sandstones, has been found, which contain forms of both the Olenellus and Paradoxides faunas; among them Paradoxides, Conoceplealites, Lingula and Archcocyathus.

Cambrian fossils are also known from China and the Argentine Republic. But among distant parts of the earth, there is none so important for a knowledge of the constitution and succession of the Cambrian Fauna as North America. Cambrian rocks have there been found at a number of different points and, in some places, of very considerable extent. They occur both in the east of the continent (Newfoundland, Nova Scotia, New Brunswick, Eastern Massachusetts, in the north of the States of Vermont and New York, and in Canada), at various localities in the Mississippi basin (Wisconsin, Minnesota, Missouri, Arkansas, and Texas), and further westward on the slopes of the Rocky Mountains (in the Dakota Territory, Utal, Nevada, Arizona, etc.). In some placesas in the New York States, Canada and the Western Territoriesthey rest directly on the Archæan rocks. These are, as is everywhere the case, steeply inclined and much folded; while the Cambrian and succeeding newer Palæozoic beds in the east are nearly horizontal over large areas, just as in the South of Sweden and the Russian Baltic Provinces. 
Our knowledge of the North American Cambrian rests on the work of many observers, among whom we mention here only $\mathrm{J}$. Hall, Emmons, Billings, Dawson, Meek, Hartt, Whitfield, White, Matthew, and Walcott, the last of whom has lately published some very important general treatises on the subject. ${ }^{1}$ It was for a long time the opinion of North American geologists that the Olenellus fauna was later than the Paradoxides, a view which was in part based on the greater richness and rariety of the formor. So strongly was this opinion held, that when Olencllus was found in Europe below the Paradoxides beds, the Americans were loth to admit the correctness of the determination. In 1888, however, Walcott succeeded in finding in Newfoundland a continuous series of the Cambrian, from the top of the Huronian up to the Paradoxides beds; and here he discovered, below the Paradoxides zone, Oienellus and other typical fossils of the Olenellus fauna. This discovery, showing that the so-called Middle Cambrian-the Olenellus zone-of N. America, really underlies the "Lower" Cambrian or Paradoxides zone, has necessarily thrown into confusion the classification of the $\mathrm{N}$. American rocks. But the following table gives, according to Walcott, the general succession of the Cambrian beds :- 2

$$
\text { Calciferous Sandstone. }(=\text { Undovicienv })
$$

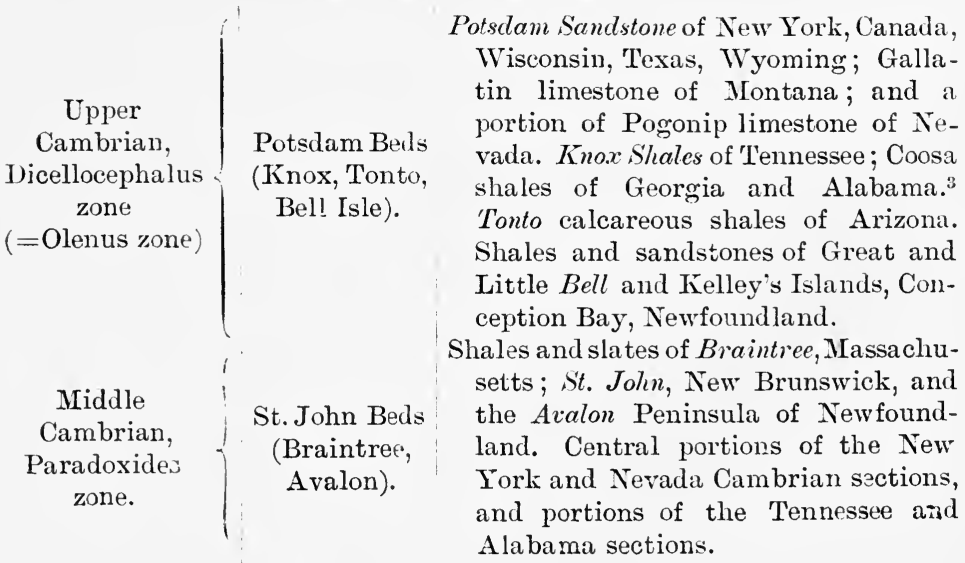

1 See especially Tenth Ann. Report I.S. Geol. Survey, "The Olenellis Fauna."

2 Walcott includes a part of the Calciferous Sandstone in his Cambrian.

3 The lower part of the Alabama section may be Middle Cambrian. 


\begin{tabular}{|c|c|c|}
\hline & Germoust & SANDSTONE-Continuet. \\
\hline $\begin{array}{l}\text { Lower } \\
\text { Cambrian, } \\
\text { Olenelius } \\
\text { zone. }\end{array}$ & $\begin{array}{l}\text { Georgia Beds } \\
\text { (Placentia, } \\
\text { Prospect } \\
\text { Mountain). }\end{array}$ & $\begin{array}{l}\text { Georgia shales and Granular quartz of } \\
\text { Yermont, Canada, New York and } \\
\text { Massachusetts; shales and quartzite } \\
\text { of Chilhowee Mountain, Tennessee. } \\
\text { Limestones, etc., of L'Anse au Loup, } \\
\text { Labrador; northwest coast and penin- } \\
\text { sula of Avalon, Newfoundland; basal } \\
\text { series of Hanford Brook, New Bruns- } \\
\text { wick; and shales and limestones of } \\
\text { North Attleborough, Mass. Lower } \\
\text { part of Cambrian section of Eureka, } \\
\text { and Highland Range, Nevada; Upper } \\
\text { arenaceous shales of Big Cottonwood } \\
\text { Cañon, Cambrian section of Utah. }\end{array}$ \\
\hline
\end{tabular}

The lowest sub-division, the Georgia group, consists, where typically developed, of several thousand feet of dolomitic limestone, sandstone, sandy marls, etc. They contain several species of the characteristic genus Olencllus, and also the trilobite genera, Olenoides, Ptychoparia, Bathynotus, Bathyuriscus, Microdiscus, Agnostus and others, a couple of other crustaceans (Protocaris, Leperditia), a series of gasteropods (Scenclla, Stenotheca, Platycercas) and pteropods (Iyolithes, Hyolithcllus and others), a lamellibranch (Fordilla), a number of brachiopods (Lingulella, Acrotreta, Lutorgina, Acrothele, Obolella, Orthisina, etc.), a doubtful cystidean, a few graptolites (Diplograptus and Climacograptus?), various sponges-among them especially Archcoocyathus-as well as traces of annelids and algæ.

The middle division, which includes some 2,000 feet of schists and sandstones, the St. John or Paradoxides beds, is distinguished especially by the occurrence of large species of Paradoxidles-among them P. Marlani, probably the largest known trilobite. With these are associated Conocoryphe, Ptychoparia, Arionellus, Agnostus, and other trilobites, a few ostracods, several species of the pteropod Hyolithes, a few gasteropods, species of Lingulella, Obolella, Kutorgina, Acrotreta, Orthis, and other genera of brachiopods, and lastly a few graptolites and sponges.

Lastly, the upper division of this formation, the most widespread and the longest known, the Potsd a m Sands tone, consists mainly of sandstones, which often become conglomeratic at the base. They not unfrequently show ripple-marks, tracks, sun-cracks, and other indications of a fresh-water origin, and in the valley of the St. 
Lawrence they reach a thickness of 6,000 feet. The most significant, and at the same time most widely-spread genus of the fauna is Dicellocephalus. Of the trilobites, Olenus, Arionellus, Ptychoparia, Agnostus, etc., may be mentioned, and various gasteropods. a number of brachiopods, etc. A true Olenus fauna has recently been discovered by Matthew in New Brunswick.

In all Walcott reckons the number of the known species of the N. American Cambrian at nearly 400, belonging to some 90 genera. In this calculation, it is to be remarked that he includes in the Cambrian the Calciferous Sandstone, which we, following most others, place, like its equivalents the English Tremadoc and the Swedish Ceratopyge Limestone, in the Ordovician.

A classification applicable to the whole of the Cambrian deposits, as described in the foregoing account, was proposed by Linnarsson, who was the first to separate the Paradoxides from the Olenus Beds. This classification is indeed valid, not only for Europe, but also for North America, where the occurrence of Paradoxides everywhere points to an older phase than that marked by the appearance of the genus Olenus-a circumstance which loses scarcely any of its significance, although, in America it is not Olenus, but Dicellocephalus, that plays the most important part in this phase, In more recent times Lapworth has added to Linnarsson's two groups a third division, which includes the lowest conglomeratic and sandy beds that are found in most of the European Cambrian areas at the base of the formation.

Since scarcely anything was formerly known from this oldest division except traces of annelids and algæ, Lapworth ${ }^{1}$ proposed for it the name Annelidian-considering it as a group of equal value with the Paradoxidian and Olenidian. But recently, not only in Scandinavia and Russia, but also in North America, there has been found in the Annelidian a comparatively rich fauna, in which the genus Olenellus is the most important form; and it therefore appears advisable to replace this name by the term Olenellidian or Olenellus beds. In this way we arrive at a tripartite grouping of the Cambrian, which appears in the following table :-

1 Geol. Mag. (1881), pp. 260 and 317. 


\begin{tabular}{|c|c|c|c|c|c|}
\hline & England. & Sweden. & $\begin{array}{c}\text { Baltic } \\
\text { Provinces. }\end{array}$ & Bohemia. & $\begin{array}{l}\text { North } \\
\text { America. }\end{array}$ \\
\hline $\begin{array}{c}\text { Upper Cambrian } \\
\text { or }\end{array}$ & \multicolumn{3}{|c|}{ Upper limit: Dictyonema Shales. } & & \\
\hline $\begin{array}{l}\text { Olenus (Dicello- } \\
\text { cephalus) zone. }\end{array}$ & $\begin{array}{l}\text { Lingula } \\
\text { Flags. }\end{array}$ & $\begin{array}{l}\text { Olenus } \\
\text { Shales. }\end{array}$ & $\begin{array}{c}\text { Ungulite } \\
\text { Sandstone. }\end{array}$ & $\begin{array}{l}D d 1 \alpha \text { and } \beta \\
\text { Barrande? }\end{array}$ & $\begin{array}{l}\text { Potsdam } \\
\text { Sandstone. }\end{array}$ \\
\hline $\begin{array}{l}\text { Middle Cambrian } \\
\text { or } \\
\text { Paradoxides zone. }\end{array}$ & $\begin{array}{c}\text { Menevian } \\
\text { (and Solva). }\end{array}$ & $\begin{array}{l}\text { Para- } \\
\text { doxides } \\
\text { Beds. }\end{array}$ & - & $\begin{array}{l}\text { Jinetz } \\
\text { Schists. }\end{array}$ & $\begin{array}{l}\text { St. John } \\
\text { or Acadia } \\
\text { group. }\end{array}$ \\
\hline $\begin{array}{l}\text { Lower Cambrian } \\
\text { or } \\
\text { Olenellus zone. }\end{array}$ & Caerfai. & $\begin{array}{l}\text { Fucoid and } \\
\text { Eophyton } \\
\text { Sandstone. }\end{array}$ & $\begin{array}{c}\text { Fucoid } \\
\text { Sandstone, } \\
\text { Blue Clay; } \\
\text { Sand. }\end{array}$ & $\begin{array}{l}\text { Przibram } \\
\text { Granwacke. }\end{array}$ & $\begin{array}{l}\text { Georgia } \\
\text { group. }\end{array}$ \\
\hline
\end{tabular}

\section{Paldentology of the Cambrian Sistem.}

As above remarked the Cambrian fauna of North America now amounts to some 400 species. The fauna of the same age in the various countries of Europe and other continents is much poorer and does not include so many species as that of America alone. Altogether one may conclude that the total number of the hitherto known Cambrian fauna amounts to 700 or at the most 800 species. This is very few compared with other Palæozoic systems, as for example the Silurian. We should not forget, however, that till a few decades ago, scarcely a tenth of the present species was known, and we may therefore hope that future observations will continue to add to the number of the Cambrian fauna. Especially we must remember that, as in recent times, it has been shown that the Paradoxides beds are not the oldest of the Cambrian, but that under them there is still another equally well characterised series, the Olenellus beds, in the same way the future may show us other and lower series, and with this the Cambrian System would become more nearly equal to other systems in the number of its fauna.

The most favourable prospect of an increase appears to be in China, where, according to $\mathrm{v}$. Richthofen, below the beds recognised as Cambrian by their fossils, there is a thick series largely made up of oolitic limestone, out of which however no fossils have yet been obtained.

The composition of the Cambrian fauna, where it has hitherto 


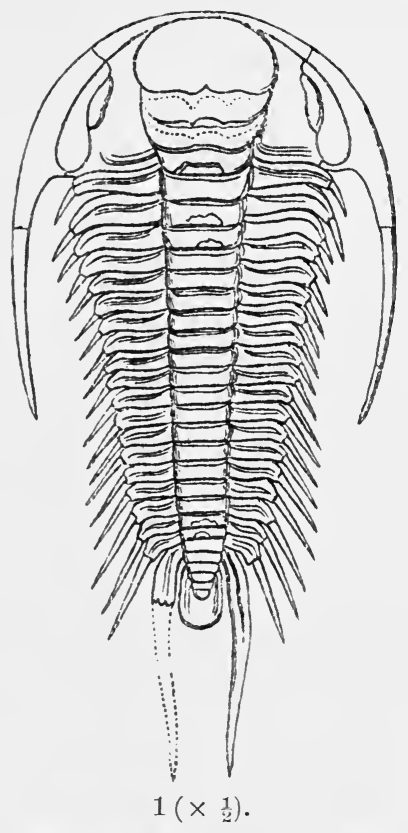

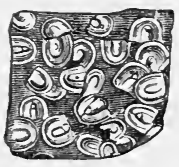

4
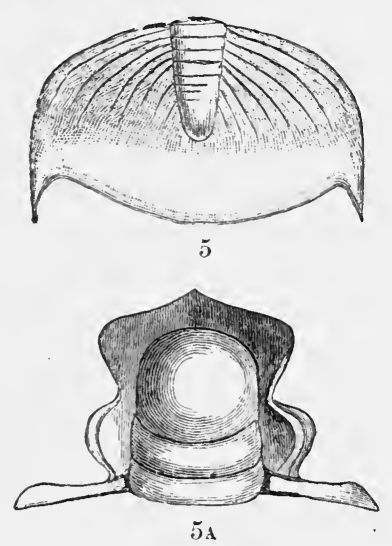

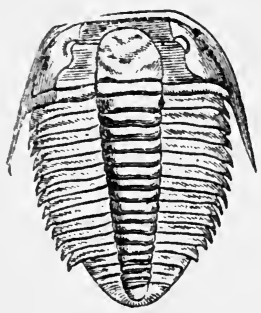

2 .

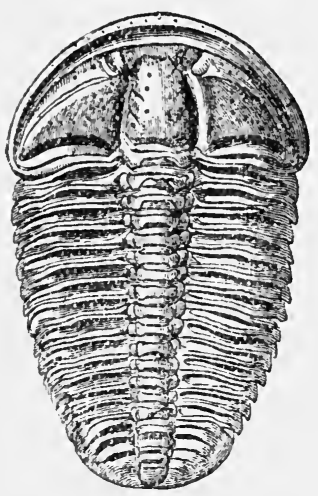

3.

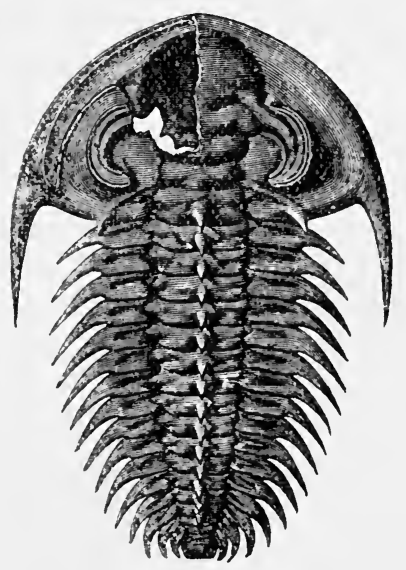

6.

Plate I.-Cambrian Trilobites.

1. Paradoxides bohemicus, Barr. 2. Olenus truncatus, Brünn. 3. Conocoryphe Sulzeri, Schloth. 4. Agnostus pisiformis, Lin. 4A. The same, enlarged. 5. Dicellocephalus minnesotensis, D. Owen, tail-shield. 5s. Central part of the head. 6. Olencllus Kjerulfi, Linars (glabella partly broken through to show the hypostome). 


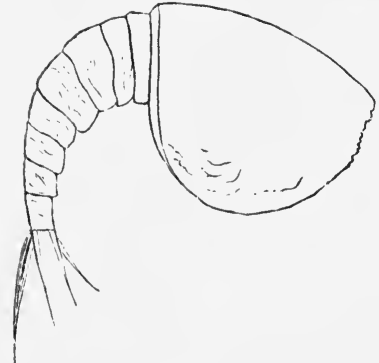

1

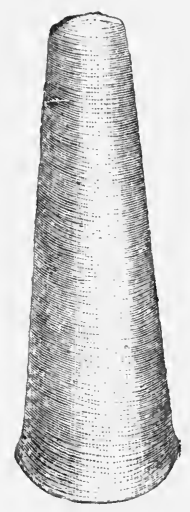

3

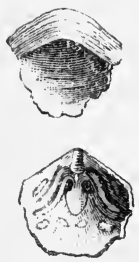

4
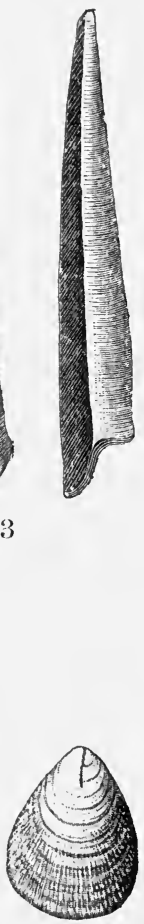

5

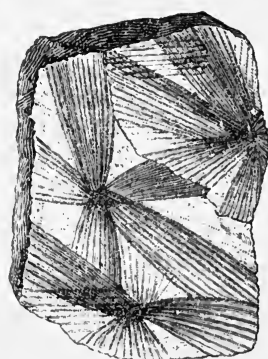

2

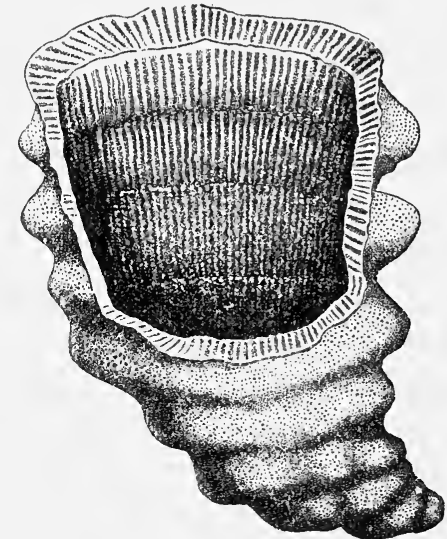

7

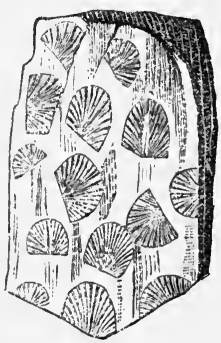

6

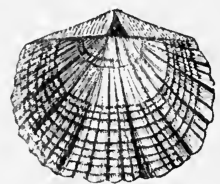

$6 \mathrm{~A}$

Puate II.-Cambrian Fossils.

1. Hymenocaiis vermicauda, Salt. 2. Dictyograptus flabelliformis, Eichw. 3. Hyolithes paiens, Barr (incomplete at the point), front and side views. 4. Obolus Apollinis, Eichw., external and internal view of an imperfect larger valve. 5. Lingulella Davisii, M'Coy. 6. Crthis lenticularis, Wahlenb. 6s. The same enlarged. 7. Archacocyathus minganensis, Btllings. 
been studied, is extremely homogeneous. Above all it consists essentially of Trilobites and Brachiopods; along with which only a few other Crustacea and Molluscs and representatives of still lower groups are usually found. The chief subdivisions now known from the Cambrian are:-Trilobites, Phyllocaridæ, Ostracoda, Gasteropoda, Pteropoda, Lamellibranchiata, Brachiopoda, Annelida (in the form of tracks known as "Nereites"), Cystidea, Medusæ, Graptolites, Sponges and Foraminifera. Among the animals the great rarity of Lamellibranchs (only a few genera of which are known) and the complete absence of Cephalopods and Corals are especially remarkable. Animals of higher type than Crustacea are, so far as is yet known, absent. No Vertebrates, even of the lowest division, the fishes, are known. Of plants only marine Algæ are found. A great number of the forms known as Eophyton, Cruziana, Oldhamia are of very doubtful significance.

Far the most important part is played by the Trilobites. They are distinguished from those of younger beds by several characters, viz.:-(1) by the extreme shortness of the tail, which is often reduced to a small appendage, or indeed, as in several species of Olcnellus, to a swollen spine at the end of the body; $(2)$ by the want of power to roll themselves up; (3) by the blindness of most. Hany indeed have still an eye-socket, but no trace of a lens.

As a typical example of the Cambrian Trilobites we may take the genus Paradoxides (I. 1), which is characterized by its considerable size $-P$. Harlan $i$ and $P$. regina reaching $1 \frac{1}{2}$ feet in length -crescentic head-shield produced posteriorly into long spines, very broad club-shaped glabella swollen in front, spiny thoracic rings and extraordinarily short tail. The genus Olenellus (I. 6) differs from Paradoxides in the absence of facial sutures and the possession of a long cylindrical glabella, with the anterior part of which the large eyes are confluent; while the grooves on the wings of the thoracic segments are flatter, broader, and not so deep as in Paradoxides. The smaller genus Olenus (I. 2) is characterized by a relatively short but broad oval glabella, small narrow eyes connected with the glabella by special ridges, etc. The genus Diccllocephalus (I. 5) is specially distinguished by an unusually large and broad tail-plate. The widely-spread genus Agnostus (I. 4), which extends upwards into the Silurian, is distinguished from all other Trilobites by the great similarity between the head and tail, the absence of eyes and the presence of only two thoracic rings. The genus Conocoryphe or Conoccphalites (I. 3), which also 
extends even into the Silurian, is of great importance. The head shield is semi-circular, with ridge-like thickened border, and the glabella separated by deep grooves from the cheeks. Eyes present or not; thorax and tail sharply separated.

Among the Brachiopods the principal part is played by the hingeless, horny-shelled Lingulidæ and Obolidæ, with Lingula, Lingulella (II. 5), Obolus (II. 4), Obolella, Acrotreta, Acrothele, Kutorgina, etc. Besides these there are a few only of the hinged forms, such as Orthis (II. 6).

Of the Molluses only the genus IIyolithes (Theca) (II.3), a threecornered, quiver-shaped operculate form, has a wide distribution.

Although the Cambrian fauna is in many respects of a low type, yet its constitution is not such as one would expect of the oldest fossil fauna. The Cambrian Trilobites and other Crustacea are of a relatively high organization, which, as Barrande, Matthew, .etc., have shown, must have been reached through a long individual metamorphosis. At the same time he who believes in the theory of evolution can see that it is improbable that organic life should originate in the earth with such highly organized forms, and consequently that it is improbable that the Cambrian fauna represents the primordial fauna of our planet. He will rather consider, with the greatest number of the geologists of the day, that the oldest yet known fauna has been preceded by a whole series of other faunas of which our Cambrian fauna is the descendant. But unfortunately these older faunas, which must lie far below the Olenellus beds, are still quite unknown.

Moreover other facts have been pointed out as proof of the relative newness of the Cambrian fauna. Thus, it is distinctly an impoverished fauna, for besides the two prominent and abundant groups of trilobites and brachiopods, it includes representatives of other groups of which there are 'only scattered and isolated forms; and this mixture of an abundant with other dying groups is what we find to-day in the deep sea, or in water basins which have lnst their former connection with the ocean. Moreover, E. Suess has drawn attention to the fact that almost all the Cambrian Trilobites are blind, whilst on the other hand among the Ordovician forms (such as Eglina) we find some with abnormally large eyes. These are characteristics that are found also among the deep-sea crabs of the present day, some of which are characterized by immensely large eyes, whilst others, though they still possess eyestalks or other remains of eyes, are blind. But just as the blind C. G. 
crustacea of the deep sea are the successors of an older seeing fauna, so also the blind Cambrian Trilobites were descendants of Trilobites with eyes, and thus it follows that our Cambrian fauna represents an impoverished deep-sea fauna which must have been preceded by another richer fauna.

\section{B. ORDOTICIAN SYSTEM.}

British Isles. - The Ordorician rocks cover a considerably larger area than the Cambrian. They occupy a large part of Wales and of the Lake District, and are found also in Shropshire, the Isle of Man, and in Cornwall. In Scotland they are found in the south, and also in the North-West Highlands; while in Ireland they occur in the south-east, in Ulster, in Galway and Mayo, and in Clare and Tipperary.

For the reasons already given the boundary between the Cambrian and Ordovician systems is drawn between the Upper and Lower divisions of the Tremadoc Slates, the Dictyograptus Shales. being included in the Cambrian. The boundary between the Ordorician and the overlying Silurian was placed by Murchison. between the Lower and Upper Llandovery; but Prof. Lapworth has. demonstrated the palæontological and stratigraphical unity of these two series; and since, if we consider the whole country, the Lower Llandovery lies with pronounced unconformity on the older beds, it is now universally allowed in England that the Silurian (Upper Silurian of Murchison's followers) commences with this series.

It is remarkable that in the Ordovician of England massive interbedded layers of eruptive rocks (especially andesites and felsites), accompanied by tuffs and other ejections, occur almost everywhere among the normal sediments, while the Silurian is free from such intercalations.

The Ordovician rocks in the typical area of WALES are divided as follows :-

Bala Series.

Llandeilo Series.

Llanvirn Series.

Arenig Series.

Tremadoc Series. 
The Tremadoc beds consist of slates and sandstones, which contain, together with a number of Cambrian types (such as Olenus, Agnostus, Dicellocephalus, etc.), a series of Silurian forms, such as Asaphus (Asaphellus) IIomfrayi, Ogygia scutatrix, and several other representatives of the important Ordovician family, Asaphidæ; also species of Cheimums, Orthoceras, Cyrtoceras, Orthisina, Porambonites, and others, so that from a purely palaontological point of view, the reference of these beds to the Ordovician seems to be justified.

The Arenig beds consist of some 2,500 feet of slates, sandstones and quartzites-to the last belong the so-called stiperstones of Shropshire-with numerous graptolites of the genera Didymograptus, Diplograptus, Dendrograptus, Tetragraptus, etc., which are accompanied by Asaphellus IIomfrayi, Aglina, Trinucleus, Ampyx and other trilobites, Lingula, etc.

The Llanvirn beds, consisting of dark slates and tuffs, also contain graptolites and numerous trilobites. Among the latter the genera Illanus, Dalmanites, and Acidaspis appear here for the first time, and Placoparia, a genus of wide distribution, both in and out of England, is confined to this horizon.

The Llandeilo series consists of some 3,000 to 4,000 feet of tuffs, slates and flags, the middle member in the South of Wales being more or less calcareous. In the South of Wales three: zones may be recognised :-

Upper Stage: Ogygia Buchii, Dicranograptus.

Middle " Asaphus tyrannus, Diplograptus foliaceus.

Lower " Didymograptus Murchisoni.

The Bala rocks include chiefly slates and grits, with various. beds of volcanic ash, and two important bands of limestone (the Bala and the Hirnant limestones). The series contains a rich fauna of trilobites and brachiopods (Asaphus Pouisii, Illanus Bowmanni, Trinucleus concentricus, etc., Orthis calligramma [V. 2], O. Actonia, Platystrophia lynx [=Orthis biforata, V. 3], Leptana. sericea, etc.).

No subdivisions of general value have yet been established; but at. Haverfordwest they have been grouped by Messrs. Marr and Roberts ${ }^{1}$ as. follows :-

Trinucleus seticornis Beds. Limestone and shales.

Trinucleus seticornis, Phacops Brongniarti, Stauroceplıalus globiceps.

1 Quart. Journ. Geol. Soc., xli. p. 476. 
Robeston Wathen Limestone (=Bala Limestone of North Wales). Halysites catenularia, Orthis elegantula.

Dicranograptus Shales. Zone of Orthis aryentea at summit. Dicranograptus ramosns, Climacograptus bicornis.

A peculiar and somewhat different facies of the Ordovician is found in the Lake District, where both Ordovician and Silurian are in part represented by graptolitic shales. Thus the Skiddaw Slates are, in part at least, the graptolitic equivalents of the Arenig and Llanvirn beds. The whole system may be divided as follows : -1

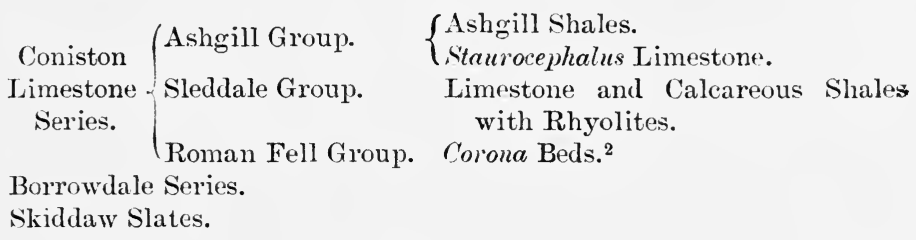

The Skiddaw Slates consist chiefly of shales and sandstones, usually much cleaved. The presence of Dichograptus, Didymograptus, and Phyllograptus shows that a part at least represents the Arenig of Wales.

The Borrowdale Series is made up almost entirely of volcanic rocks (Green slates and porphyries of Sedgwick), and contains no fossils.

The Corona beds, as found near Cross Fell, consist of calcareous ashes and limestone, and are characterized by the presence of Trematis corona. They are the equivalents of the Beyrichia Limestone of Scandinavia and the Trenton Limestone of North America.

The Sleddale Group, which includes most of what has been described as the Coniston Limestone proper, contains various corals and brachiopods (Orthis calligramma, etc.) and numerous trilobites, such as Trinucleus, Illanus, Cheimurus, Lichas, and especially Chasmops macrouvus, and C. conicophthatmus, two zone fossils of the Swedish and Russian Ordovician. The fossils are nearly the same as those of the Bala Limestone of Wales.

The Ashgill Group includes the thin Staurocephalus Limestone (about $5 \mathrm{ft}$.), which is a very constant horizon throughout

1 Marr, Geol. Mag. (1892), p. 97.

2 J. G. Goodchild states that there are two Corona beds separated by a considerable thickness of other deposits. Geol. Mag. (1892), p. 295. 
Britain and Scandinavia; and the Ashgill Shales with Trinucleus concentricus, etc.

In the South of Scotland there are two areas of Ordovician and Silurian rocks that have been described in detail, by Prof. Lapworth, viz., the neighbourhood of Girvan in Ayrshire and of Moffat in Dumfries. In the latter the whole of the Bala and part of the Llandeilo of Wales are represented by some 150 feet of graptolitic shales, while in the former the development is more normal.

In the Girran area, the Ordovician rocks are grouped by Professor Lapworth as follows :-

\section{Ardmillan Series. \\ Barr Series. \\ Ballantrae Rocks.}

The Ballantrae Rocks are partly igneous, partly sedimentary, and have not as yet been closely examined; but they contain black shales which yield Arenig graptolites, such as Didymograptus extensus, Phyllograptus typus, Tetragraptus bryonoides.

The Barr Series begins with a conglomerate of igneous rocks, but its most characteristic member is the Stinchar Limestone. This contains many of the common Llandeilo and Bala fossils; and a remarkable feature is that along with these it contains also Maclurea Logani and other forms which are found in the Trenton Limestone of Canada, but are unknown in any English rocks.

The succeeding Ardmillan Series consists of shales, flags and sandstones, divided into four groups, which contain fossils of Bala age and also graptolites of the Hartfell group of the Moffat area.

In the Moffat area the Ordovician, so far as known, is divided into a lower, or Glenkiln, group, which corresponds with the upper part of the Llandeilo; and an upper, or Hartfell, group, which represents the Bala beds of Wales; and the following graptolite zones are here recognised :-

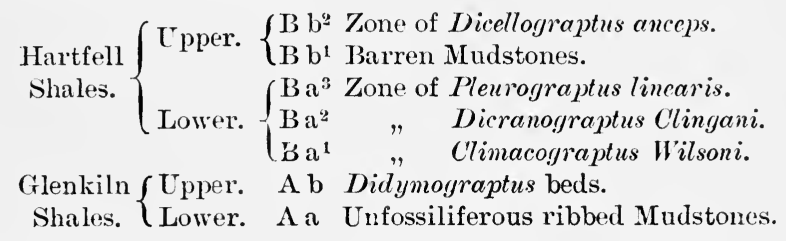

These correspond closely with those established by Tullberg in Scania. 
The following table shows the relations of the Ordovician rocks of the areas described to one another :-

\begin{tabular}{c|c|c|c}
\hline Girvan. & Moffat. & Lake District. & Wales. \\
\hline $\begin{array}{c}\text { Ardmillan } \\
\text { Series }\end{array}$ & Hartfell Shales & $\begin{array}{c}\text { Coniston } \\
\text { Limestone Series }\end{array}$ & $\begin{array}{c}\text { Upper } \\
\text { Lower }\end{array}$ \\
\cline { 1 - 3 } Barr Series & Glenkiln Shales & Borrowdale Series & $\begin{array}{c}\text { Upper } \\
\text { Lower }\end{array}$ \\
\hdashline $\begin{array}{c}\text { Ballantrae } \\
\text { Rocks }\end{array}$ & & Skidandeilo Slates & $\begin{array}{c}\text { Llanvirn } \\
\text { Upper } \\
\text { Lower }\end{array}$ \\
\hline
\end{tabular}

In the North of Scothand the examination of the beds is not yet completed; and some of the rocks which were formerly supposed to be Ordovician, such as the Serpulite Grit, have now been shown to belong to the Olenellus zone of the Cambrian. A remarkable group of limestones and dolomites found in Durness and Eriboll contains numerous Ordovician forms, many of which, like those of the Stinchar Limestone in the south, are well-known American forms, unknown in England.

In IRELAND no rocks of Arenig age have yet been recognised. The beds of Llandeilo age are known as the Dark Shale Series, and those of Bala age as the Ballymoney Series.

Scandinavia.-Here also Ordovician rocks occupy a considerable area; in Sweden, especially in Scania, Westrogothia and Ostrogothia, Dalecarlia and Jutland, Oeland and Bornholm; in Norway, especially in the south, in the neighbourhood of Christiania and Porsgrund, and further north in the region of the Mjösen See and in the Trondhjem Stift, where they are in part strongly metamorphosed. In Sweden the Ordovician and also the Silurian beds are everywhere very slightly disturbed; and over large tracts in the south they still lie almost horizontally. There also the whole succession is as complete as it is in England, but the various members are not in such close and immediate connection, and therefore the determination of the relation of the deposits of the various regions of Sweden is a matter of much greater difficulty. The works devoted to the Scandinavian Ordovician and Silurian formations reach back to the time of Linnæus. After him Wahlenberg, Dalman and Hisinger added to our know- 
ledge, and in later times Angelin, ${ }^{1} \mathrm{Kjerulf},{ }^{2}$ and recently especially Linnarsson," Brögger, ${ }^{4}$ Tullberg,, Johnstrup, Türnquist, and others.

According to Angelin, Linnarsson, and later writers the Ordovician rocks of Scandinavia may be classified as follows :-

Brachiopod sehists. Shaces

Trinucleus schists and Limestone.

see 1.56

Chasmops Limestone, Beyrichia Limestone, Cystidean Limestone, and Middle Graptolite shales.

Orthoceras Limestone and Lower Graptolite shales.

Ceratopyge Limestone.

The Ceratopyge Limestone is a thin series of beds which, like the English Tremadoc and the Russian Glauconite sand, contains a mixture of Cambrian (Diccllocephalus, Agnostus, Obolus, etc.) and predominant Silurian (Niobe, Symphysurus, Amphion, Cheirumes) forms.

The Lower Graptolite or Phyllograptus Shales of Westrogothia and South Norway are characterized by the presence of Phyllograptus (VI.4), Dichograptus, and Didymograptus, and according to Tullberg represent the English Skiddaw Slates. They are closely connected with the most important and constant division of the Scandinavian Lower Silurian, the Orthoceras Limestone, a grey or red, platy nodular limestone, which owes its name to the occurrence of numerous large Orthoceratitesespecially those with thick marginal syphon (sub-genus Endoceras [IV. 2]). In this limestone, along with varions species of Endoceras (E. commune, $\boldsymbol{E}$. duplex, $\boldsymbol{E}$. vaginatum), there occur the remarkable Ordovician genus Lituites (L. lituus [IV. 1], L. antiquissimus), some gasteropods (Pleurotomaria [Raphistoma] qualteriata [IV. 4]), as well as trilobites of the genera Asaphus (A. cxpansus [III. 1], A. platyurus) Illanus (I. crassicauda, I. chiron, I. oblongatus [III. 2]), and Megalaspis (M. limbata, M. planilimbata), whilst brachiopods are rare.

In Scania these beds are followed by the Middle Graptolite Shales (with Didymograptus [VI. 3], Diplograptus, Climaco-

1 "Palæontologia Scandinavica" (1851)._" Fragmenta Silurica (1880).

2 "Udsigt over" sydlige Norges Geologi" (1879).

$3 \mathrm{Om}$ Vestergötlands cambrisca och siluriska aflagringar. "Svenska Vetenskaps Akad.," viii., No. 2.

4 "Die Siluretagen 2 und 3 im Kristianiagebiete" (1882).

3 "Skånes Graptoliter" (1882).-Zeits. deutsch. geo!. Ges. (1883), p. 223. 
graptus), which were clearly formed in a deeper sea, and which, according to Tullberg, represent the English Llandeilo and. Caradoc. In Dalecarlia the Orthoceras Limestone is succeeded by the Cystidean or Echinosphaerites Limestone, so called from the numbers of the globular shells of Echinospharites aurantium (V. 7), and other Cystideans that are contained in it. Besides these, various brachiopods (especially Orthis calligramme [V. 2], Platystrophia lynx [V.3]], Porambonites [IV. 6], Orthisina [V. 1]), some trilobites and a few other fossils are found. In Westrogothia this position is occupied by the Beyrichia Limestone and in the Christiania area by the Chasmops Limestone. The latter is especially characterized by the genus Chasmops (III. 6) of the Phacopidæ (type species, C. macrourus and C. conicophthalmus).

Above these various limestones come the Trinucleus Shales, which are found throughout Scandinavia, and are characterized by the great development of the genus Trinucleus (III. 3) ( $T$. seticornis, etc.). In Westrogothia and Ostrogothia and also in Scania they are succeeded by the Lower Brachiopod, Shales, which are characterized by an abundant Trilobite farma (Trinucleus, Staurocephalus, Ampyx, Agnostus, Calymene Blumenbachi [?]).

The Ordovician rocks of Scania are divided by Tullberg into three stages, and each of these into a number of zones, as follows (in descending order):-

D. Upper Stage. Chiefly trilobite shales.

(a) Climacograptus scalaris, (b) Phacops mucronata, (c) Staurocephalus clavifrons, (d) Marl slate without fossils, (e) Niobe lata and Dicellograptus complanatus, $(f)$ Diplograptus pristis, $(g)$ Diplograptus quadrimucronatus, $(h)$ Shales with fragments of Trinucleus and Ampyx, (i) Calymene dilatata, (k) Shales without fossils.

E. Middle Stage. Middle Graptolite Shales of Linnarsson.

(a) Climacograptus rugosus, (b) Climacograptus styloideus, (c) Shales, (d) Trinucleus coscinorhinus, $(e)$ Dicranograptus Clingani, $(f)$ C'limacograptus Vasce, (g) Unfossiliferous Shales, (li) Coenograptus gracilis, (i) Phosphate Limestone, $(k)$ Diplograptus putillus, $(l)$ Glossograptus sp., $(m)$ GymnograptusLinnarssoni, (n) Glossograptus Hincksii, (o) Didymograptus Murchisoni.

F. Lower Stage.

(a) Phyllograptus typus, (b) Orthoceras Limestone, (c) Tetragraptus, (d) Ceratopyge Limestone.

Russia.-In no part of Europe do the Ordovician and Silurian rocks occupy so wide an area as in Russia, where they are developed on the coast of the Gulf of Finland, and also in the valley of the 
Dniester. ${ }^{1}$ In these two areas, the beds are still horizontal and of loose texture; and the latter character is correctly attributed to the fact that since their formation they have never been eovered by younger deposits, nor noticeably disturbed. ${ }^{2}$

In the Baltic Provinces the Ordovician beds form a broad belt stretching from the Ladoga Sea through the Government of St. Petersburg and the whole of Esthonia and Livonia to the Islands of Dagö and Oesel, where indeed they are to a great extent superficially covered by alluvium. The grouping and the fossil contents of these rocks, which in general are very like those of Scandinavia (especially of the Islands of Gotland and Oeland), have been known through the works of numerons older authors, such as v. Eichwald, Pander, v. Helmersen, v. Schrenk, Grewingk, and others ; bit still more through the researches of Fr. Schmidt."

Schmidt subdivides the Ordorician of the Baltic as follows :-

\begin{tabular}{|c|c|c|c|c|c|c|c|}
\hline \multirow[b]{2}{*}{ Borkholm beds } & & & \multirow[b]{2}{*}{$\cdots$} & & \multicolumn{3}{|c|}{ Schmidt's terms. } \\
\hline & & & & & $\begin{array}{l}\text { Jater. } \\
\mathrm{F}^{2}\end{array}$ & & $\begin{array}{l}\text { der. } \\
3\end{array}$ \\
\hline Lyckholm ," & ... & $\ldots$ & $\ldots$ & $\ldots$ & $\mathrm{F}^{1}$ & & $2 a$ \\
\hline Wesenberg :, & ... & $\ldots$ & $\ldots$ & ... & $\mathrm{E}$ & & 2 \\
\hline Jewe & $\ldots$ & $\ldots$ & $\ldots$ & $\ldots$ & I) & & 16 \\
\hline Itfer and Kück & & $\ldots$ & $\ldots$ & $\ldots$ & $\mathrm{C}^{3}$ and & & $1 a$ \\
\hline Echinosphærite & $\mathrm{Li}$ & stone & $\ldots$ & $\ldots$ & $\mathrm{C}^{1}$ & & 1 \\
\hline Vaginatus and & Alar & nite I & imes & ne & $\mathrm{B}^{3}$ and & & - \\
\hline Glauconite- (G1 & een- & and & $\ldots$ & $\ldots$ & $\mathrm{B}^{1}$ & & - \\
\hline
\end{tabular}

The lowest division, the Gla nconite Sand, which rests directly on the Cambrian, is only a few feet thick, and corresponds in position with the Swedish Ceratopyge Limestone (= English Tremadoc). But it contains few fossils (Lingulella ef. Davisii, Obolus, and the Annelid jaws, described by Pander as "Conodonts"). This is followed by the chief division of the Baltic Ordovician, the Vaginatus Limestone, which agrees in every way with the Scandinavian Orthoceras Limestone, and contains numerous. large Orthoceratites, of the group Endoceras (= Vaginati), many Asaphidæ, etc. The so-called Glauconite Limestone represents the lowest zone of the Swedish Orthoceras Limestone (recog-

1 Only Silurian rocks are found in the valley of the Dniester; the Ordovician is not exposed.

2 "The Geology of Russia and the Ural Mountains," by Murchison, de Verneuil and Count Keyserling (1845), is still very valuable for these rocks.

3 "Silur. Form. v. Ehstland, Nord-Livland u. Oesel" (1858). Quart. Journ. Geol. Soc., xxxviii. p. 514. "Revision der ostbaltischen SilurTrilobiten," Mem. Acad. St. Petersburg (1881, 1885, 1886, etc.). 
nised by Megalaspis planilimbata). So also the Echinosphaerites Limestone is simply a repetition of the equivalent Swedish rock, whilst the succeeding divisions of the Ordovician are characterized by the great development of the Phacopid genus Chasmops (C. Odini [III. (i)], very close to the Scandinavian C. conicophthalmus, C'. macrourus, C'. bucculentus. C. Wesenbergensis, etc.), numerous species of Lichas, Cheimurus, and other genera of trilobites, species of Orthis, Orthisina (V. 1), Porambonites (IV. 6), and other brachiopods, various gasteropods, cephalopods, etc.

The Ordovician rocks of all the areas so far described are essentially similar in development, and those of Scandinavia and Russia show a close and detailed agreement. As we pass from west to east the deposits become less sandy and shaly and more

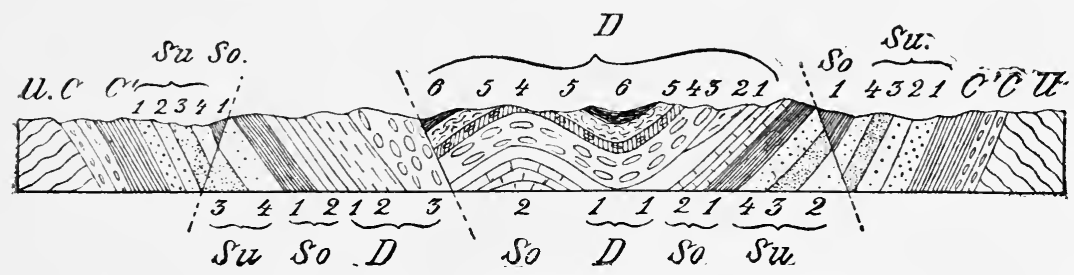

Fig. 12.-Diagrammatic section through the Lower Palæozoic Rocks of Bohemia

(Fr. Katzer).

U. Archæan. C. Przibram Grauwacke. C'. Paradoxides beds and overlying Cambrian. Su 1-4. Ordovician. So 1. Silurian graptolite shales. So 2. Silurian Limestone. D 1-6. Devonian (Hereynian=F. H. Barrande).

calcareous, showing that the sediment was derived from the west; but there is no alteration of type. When we pass into Central and Southern Europe, on the other hand, we find a very different facies of the Ordovician. Among the Ordovician areas of these parts that have come under observation, none of which are so extensive as those of Northern Europe, there is not one of such importance as Bohemia.

Bohemia.-In the account of the Bohemian Cambrian, the general arrangement of the Old Palæozoic beds of Central Bohemia has already been described; and the section in Fig. 12 borrowed from a recent work of $\mathrm{Fr}$. Katzer ${ }^{1}$ will help to make matters clearer.

In the same place the great work of Joachim Barrande has been mentioned and his classification described. His thick Stage D,

1 "Das ältere Palïozoicum Mittelbühmens" (1881). "Geologie von Böhmen" (1892). 
following on the Cambrian (Barrande's Stages B and C) is the Ordovician, Barrande's Second (Silurian) Fauna.

If, with Katzer, we separate the deepest layers of Stage D as Uppermost Cambrian, and leave out of consideration the greenstone and porphyry layers which are so abundant in the Ordovician, the Bohemian Ordovician may be classified as follows:-

$\mathrm{Dd}^{5}$. Sehists with beds of quartzite. Agnostus tardus, Eglina, Calymene Blumenbachi, Ampyx Portlocki, Cheirurus, Renopleurides, Diplograptus, Dicellograptus, etc.

$\mathrm{Dd}^{4}, \mathrm{Dd}^{3}$. Dark, micaceous sehists and sandstones. Trinucleus Goldfussi, T. ornatus, Aglina rediviva, Cheirurus claviger, etc., Dalmanites, Illcemus, Asaphus, Nucula, Orthis, Cystidea, etc.

Dd2. Quartzite Sandstone with Asaphus ingens, Dalmanites socialis, Acidaspis Buchii, Illcenus, Trinucleus, Placoparia, etc.

Dd $^{1}$ j. Black platy schists with $^{2}$ flint nodules, containing Placoparia Zippei, Ogygia, Illenus, Dalmanites, Eglina, Ribeiria, Orthis, Didymograptus.

The difference between the Ordovician of Bohemia and that of North Europe consists not only in the absence of the Orthoceras Limestone in Bohemia, but above all in the strikingly small number of species common with the northern part of Europe. The agreement of England and Scandinavia with the Baltic area, and even with North America, is in this respect much closer than that of Bohemia with any of these regions. Under these circumstances it is difficult to attempt any accurate correlation of the single subdivisions of the Bohemian Ordovician with those of North Europe and England. To the small number of the divisions with which this is possible belong the lower parts of $\mathrm{Dd}^{5}$, the KraluvDvur-Schists of Kreiči, the trilobites of which, according to Linnarsson, show a close connection with the Swedish Trinucleus Shales. ${ }^{1}$

The so-called Colonies of Barrande here require a short notice. Barrande understood by this term the sudden appearance, observed by him at several points, of a younger fauna in the midst of rocks of an older series, especially the appearance of the fauna of $\mathrm{E}$ (Silurian) between beds of $\mathrm{D}$. He explained this circumstance by supposing that whilst the beds of $\mathrm{D}$ were being formed, the $\mathrm{E}$ fauna, already developed in some other place, wandered for a time into the Bohemian Sea, and here lived locally with the D fauna,- - a view which he defended with the greatest perseverance against all opponents. The Colonies, however, may be very simply explained

1 Zeits. d. deutsch. geol. ('es. (1873), p. 684. 
by disturbances, by which later beds have locally been brought down to the level of older rocks. They have been let in by trough-like sinkings of the beds such as have long been familiar to German, Scandinavian, and English Geologists. The proof brought forward by Tullberg that in the Colonies the various. graptolite zones lie on one another in their regular succession and in the same kinds of rocks as in the neighbouring beds of $\mathrm{Ee}^{1}$, allow us to throw aside the last doubts as to the correctness of this interpretation.

It is remarkable that the Ordovician rocks as developed in the rest of Europe are more or less closely related to the Bohemian and not to the Northern facies.

Germany.-This may be seen in the only tolerably extensive area of Ordovician rocks known in Germany, in the district of Thuringia and the Fichtelgebirge. According to the observations. of R. Richter, Guimbel, and Liebe, the Ordovician of this area, which lies conformably on the Cambrian, may be divided as follows, in descending order :-

Unfossiliferous, somewhat caleareous slates, weathering yellow (Lederschiefer).

Thick, partly slaty, often splintery, schists (Griffelschiefer) with large species of Asaplus, Ogygia, etc. Interbedded with these occur local quartzites, and, near the base, oolitic ironstone, with Orthis, ef. Lindstroemi (the so-called Thuringit zone).

We must also refer to the Ordovician the trilobite beds, already mentioned, of Leimitz near Hof, with Olenus, Agnostus, Niobe, Symphysurus, Amphion, Cheirurus, Lichas, Lingula, Orthis, etc., which seem to be the equivalent of the Swedish Ceratopyge Limestone and the English Tremadoc.

In the Harz true Ordovician and Silurian are as little developed as in the Rhenish Mountains. In the mountains of South Germany they are absent; and generally speaking they occur elsewhere in Germany only at a few points in Saxony and Silesia, where, especially at Silberberg, Lauban, and Schönau, graptolite shales are found.

Belgium.-In Western Europe Ordovician rocks have been found in Belgium, both in Brabant (Grand-Manil near Gembloux), and in the so-called Condroz ridge, a long narrow belt of old rocks stretching past Huy, Namu and Charleroi on the south side of the Meuse and Sambre. They are divided by Gosselet into two groups, a lower, or Llandeilien, and an upper, or Caradocien. The 
former contains no fossils; while the latter contains a large number of Caradoc or Bala forms (Calymene, Trinucleus, Orthis cailigramma, O. Actonice graptolites, etc.).

France.-In France Ordovician rocks occur chiefly in the northwestern part of the country, in Normandy and Brittany, but are also found in tho south, at the southern border of the French Centralmassif and in the Pyrenees. The following arrangement specially referring to the neighbourhood of Brest, may be considered typical of the Ordovician in these regions:-

Limestone of Rosan with Orthis Actonice and O.testudinaria, etc.

Sandstone of May (unknown near Brest, but found in Calvados, etc.; with Trinucleus Goldfussi, Dalmanites Phillipsi, etc.

Slates of Angers, with Calymene Tristani, Illenus giganteus, Acidaspis

Buchii, Placoparia Tourneminei, Asaphus, Ogygia, etc. (=the English Llanvirn).

Armorican Grit, with worm holes, tracks, Lingula, Asaplus armoricanus, etc.

Spain.-A quartzite with bilobites is found in various places, especially in Ciudad Real; and this is succeeded by slates containing Calymene Tristani, Ogygia glabrata and other Ordovician forms. Below the quartzite there are in places graptolite siates corresponding with the English Skiddaw.

In Asturias the succession is very similar, and M. Barrois groups the Ordovician thus :-

(Calcareous slates of El Horno with Endoceras duplex.

Roofing slates of Luarca with Calymene Tristani.

Bed of iron ore.

$=$ Angers Slates of France.

S Sandstone of Cabo Busto with Scolithes and bilobites. =Armorican $\mathrm{s}$.

Variegated sandstones, conglomerates and slates.

Ordovician rocks are also found in Portugal and Sardinia, of essentially the same type as those of France and Spain. Everywhere in Southern Europe we find species identical with, or closely allied to, Bohemian forms; but very few species from the Ordovician of Northern Europe. This has been explained by supposing that the seas of the two regions were separated in Ordovician times by a ridge of dry land. In Sardinia the beds consist of sehists with black limestones containing Orthoccras; and these are followed by a white unfossiliferous limestone of uncertain age (calcaire metallifère).

The Ordovician, and also the Silurian, rocks which are as yet known out of Europe, are related not so 
much to those of Bohemia as to those of North Europe; for which reason the latter may be considered the normal facies, whilst the Bohemian rocks represent a relatively local development.

This is clearly brought out by an examination of the most important and best known of the extra-European Ordovician regions, namely, that of North America. Ordovician and Silurian rocks here occupy a large part of the extensive region between the Alleghany range and the Mississippi, and also extend in Canada far beyond the Arctic circle. They have been longest known and best studied in the State of New York, where, as on the coast of the Baltic Sea, they lie nearly horizontal, and rest conformably on the Cambrian Potsdam Sandstone. James Hall has done more than any other American geologist for our knowledge of the North American Ordovician and Silurian, in his "Palæontology of New York," a monograph surpassed in extent only by Barrande's wellknown work. This work was begun in 1847, but is not yet brought to a conclusion, and the first three volumes treat of the organic contents of the Cambro-Silurian beds. According to him and other observers the Ordovician rocks of the region in question may be classified as follows :-

Hudson River, or Cincinnati group, and Utica group.

Slates and sandstones with Graptolites ( $\mathrm{Di}$ cranograptus, Climacograptus), 'Trilobites, Brachiopods, etc.

Thick dark Limestone with large spacies of

Trenton Limestone, Bird's eye and Black

River group. Asaphus; Bathyurus, Illomus, Cheirurus Calymene, Chasmops, Trinucleus concentricus, Platystrophia lynx, Orthis testudinaria, Leptana, Strophomena, Gasteropoda, Cephalopoda, etc.

Chazy group.

f Limestones and sandstones with Bathyurus,

\{ Illcenus, etc., Brachiopoda, Gasteropoda, etc.

Calciferous Sandstone. $\left\{\begin{array}{l}\text { Dolomitic calcareous sandstone with Bathy/n- } \\ \text { rus, Dicelloceplaalus, and other Cambrian } \\ \text { types, which are, however, accompanied by } \\ \text { Orthisina, Conocardium, Maclurea, Orthoceras, } \\ \text { etc. }\end{array}\right.$

The Trenton Limestone has long been looked upon as the equivalent of the Scandinavian Orthoceras Limestone, and is represented in Scotland by the Durness Limestone of the north, and the Stinchar or Barr Limestone of the south. The Calciferous 
Sandstone, with its mixed fauna, is equivalent to the English Tremadoc Slates and the Scandinavian Ceratopyge Limestone.

In Eastern Canada, instead of the two lower groups, we find the so-called Quebec group, consisting of calcareous and slaty beds with a rich graptolite fauna, which has been worked out by J. Hall (with Didymograptus, Phyllograptus, etc.), and agrees with that of the English Arenig.

Ordovician rocks closely resembling those of North Etrope extend in the Northern Hemisphere to the immediate neighbourhood of the Pole; and are found also in the Southern Hemisphere in Australia.

The following comparative table shows the relations of the Ordovician rocks of the most important areas :-

Comparative Tabee of the Ordovichan System in various areas.

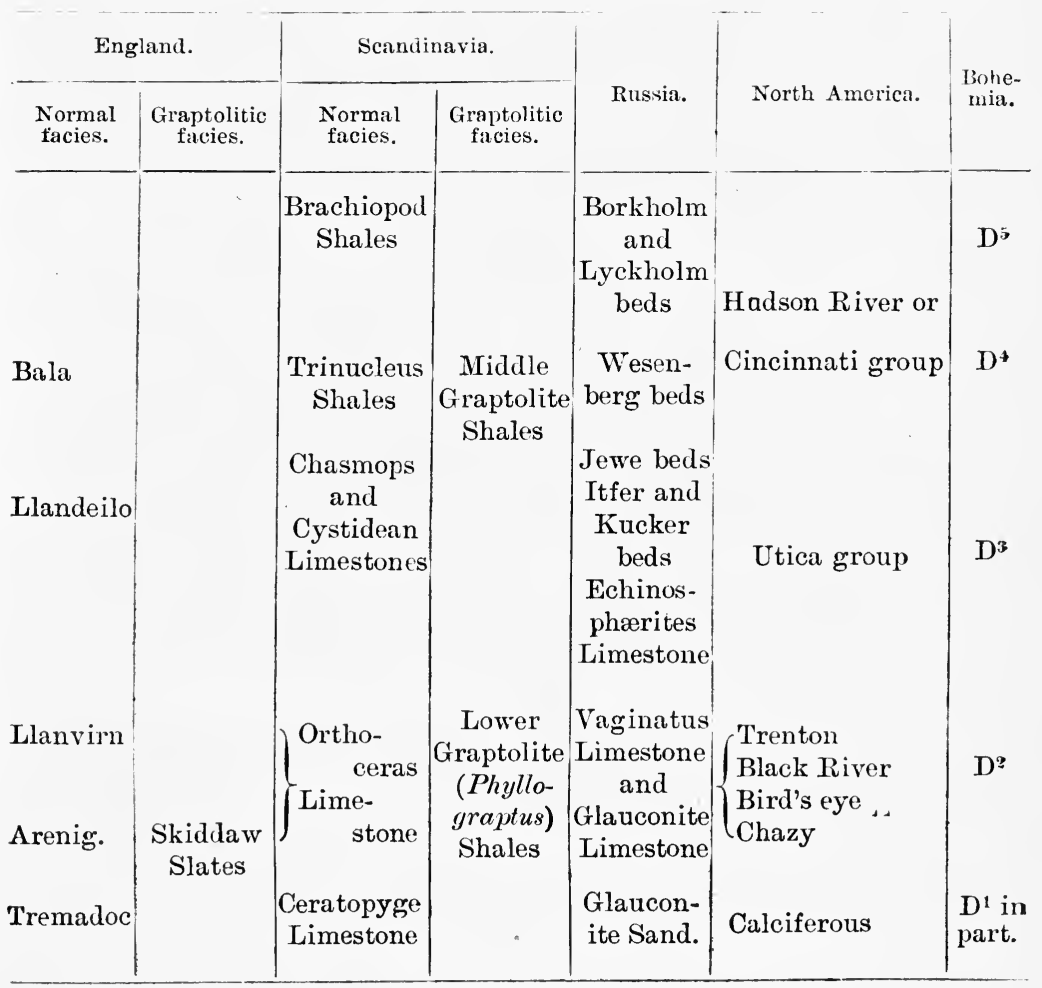




\section{SILURIAN SYSTEM.}

British Isles. - Silurian rocks are found over a large part of Wales, and in some of the neighbouring counties of England; and occupy a considerable area in the Lake District. In Scotland they are found chiefly in the South and in the Northern Highlands; while in Ireland they are known only in the extreme west, and in the countios of Down and Dublin.

In the typical area of WALEs they are divided as follows :-

\begin{tabular}{|c|c|}
\hline $\begin{array}{l}\text { Ludlow } \\
\text { or } \\
\text { Clunian } \\
\text { (Downtonian). }\end{array}$ & $\left\{\begin{array}{l}\text { Ledbury Shales. } \\
\text { Downton Sandstone. }\} \text { beds. } \\
\text { Upper Ludlow beds } \\
\text { including the Bone-bed. } \\
\text { Aymestry Limestone. }\end{array}\right.$ \\
\hline $\begin{array}{l}\text { Wenlock } \\
\text { or } \\
\text { Salopian. }\end{array}$ & $\left\{\begin{array}{l}\text { Lower Ludlow beds. } \\
\text { Wenlock Limestone. } \\
\text { Wenlock Shale and Woolhopa Limestone. }\end{array}\right.$ \\
\hline $\begin{array}{l}\text { Llandovery } \\
\text { or } \\
\text { Valentian. }\end{array}$ & $\left\{\begin{array}{l}\text { Tarannon Shales. } \\
\text { May Hill Sandstone }=\text { Upper Llandovery. } \\
\text { Lower Llandovery beds. }\end{array}\right.$ \\
\hline
\end{tabular}

The May Hill or Lland overy bed s consist of 1,000-2,000 feet of strong conglomerate, sandstone, and grauwacke, which are distinguished palæontologically by the occurrence (characteristic of this horizon in other areas also), of large species of Pentamerus (Pentamerus oblongus, P. [Stricklandinia] lens, etc.), and spiral-bearing brachiopods (Atrypa, with the type species A. reticularis [X. 4], Meristella). Moreover we find here for the first time many of the characteristic Silurian trilobites and corals, such as Encrimurus punctatus (VII. 5), Calymene Blumenbachi (VII. 3), Halysites catenularia (X.9), Heliolites interstincta, etc. Of especial interest also is the first appearance of the crustacean genus Eurypterus (VIII. 1). Closely united with these beds are the purple red and green Tarannon shales, reaching 1,500 feet in thickness, which contain especially graptolites, and anong them particularly the genera Rastrites and Monograptus.

The next series, the Wenlock or Salopian, the chief of the Silurian divisions, usually consists in its lowest parts of marl slates, and interbedded lenticular masses of carbonate of lime. At the base is a remarkably constant zone, characterized by Cyrtograptus Ifurchisoni. Towards the upper part of the series the limestone increases in amount, and locally massive accumulations of corals in the form of coral reefs, occur; whilst elsewhere in the 
marly intermerliate beds numerous well preserved trilobites, brachiopods, cephalopods, gasteropods, crinoids, etc., are imbedded which have made the Wenlock limestone at many places-among which Dudley may be especially mentioned-one of the chief hunting grounds for Silurian fossils. Among the especially characteristic species are Halysites catenularia (X.9), Heliolites interstincta, fiarosites gotlandica (X. 8), among the corals; Actinocrinus pulcher, Crotalocrinus rugosus, Cyathocrinus pyriformis, among the crinoids ; Encrinurus variolaris, Calymene Blumenbachi(VII. 3), Lichas anglicus, Acaste Douningia, Dalmanites caudatus, Proëtus Stolesii, Spharexochus mirus among the trilobites; Strophomena englypha, Leptena transversalis (IX. 6), Pentamerus galeatus, Orthis clegantula (IX. 4), Atrypa roticularis (X. 4), Meristella tumida (X. 5), Spirifer clevatus and S. plicatellus (X. T), Rhynchonella Wilsoni (IX. 3), R.borealis (X. 1), and Chonetes striatella (IX. 5), among the brachiopods; Orthoceras anmulatum (VIII. 3), and Phragmoceras ventricosum among the Cephalopoda. The genus Stromatopora, belonging to the Hydrocorallinæ, and built up of numerous thin, undulating, concentric layers of carbonate of lime, is abundant in the reefs.

The Lower Ludlow Shales, which succed the Wenlock Limestone, consist of greenish grey, micaceous sandy shale, and cannot be separated from the Wenlock Shale. They are therefore placed in the Salopian, and the line between this and the succeeding Clunian group is drawn at the base of Leintwardine Flags, which consist of thick earthy flagstones underlying the Aymestry Limestone. The Upper Ludlow Beds are formed at the base of micaceous argillaceous sandy beds, which include the so-called Bone Bed-a remarkable bed reaching a foot in thickness, made up almost entirely of fish and crustacea, especially scales and teeth.

This is followed by some 100 feet of reddish or yellowish Sandstone, known as the Downton Sandstone; and lastly above this comes over 300 feet of greyish or reddish marly sandy shales, the Ledbury Shales, which form the uppermost division of the Silurian and pass up quite gradualiy into the Old Red Sandstone. On account of this gradual passage the two uppermost divisions have been called Passage beds. Murchison employed for them the name Tilestone.

Palæontologically the Ludlow rocks on the whole are commonly very closely related to the Wenlock; most of the molluscs, many of the trilobites and other fossils are common to the two formations

c. 'G. 
and only a few forms such as Cardiola interrupta (IX. 2), Pentamerus Knighti (X. 3), are, if not entirely limited to the upper beds, at least chiefly found in them. A special pecularity of the Ludlow is the appearance, even in the lowest beds, of numerous Eurypterids (especially Eurypterus [VIII. 1], and Pterygotusforms which become very abundant in the Old Red Sandstone)-and the peculiar Cephalaspidæ (Cephalaspis, Scaphaspis, Pteraspis, etc.), the oldest of British fishes.

In the Lake District, the Silurian, like the Ordovician, rocks are the graptolitic equivalents of those of Wales, and may be classified as follows :-

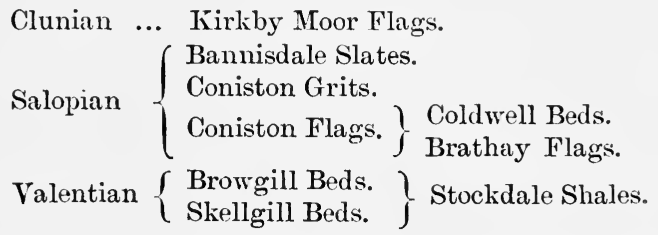

At the base there is usually a conglomerate with Meristella crassa. This is succeeded by the Stockdale Shales, which are chiefly graptolitic mudstones, and in which the following zones have been recognised :- -1

BROWGILL BEDS.

Upper ... Barren.

Lower $\} \begin{aligned} & \text { 2. Monograptus crispus. } \\ & \text { 1. Monograptus turriculatus. }\end{aligned}$

SKELGILL BEDS.

$\begin{aligned} & \text { Upper }\left\{\begin{array}{l}\text { 5. Rastrites maximus. } \\ \text { 4. Acidaspis erinaceus. } \\ \text { 3. Monograptus spinigerus. } \\ \text { 2. Ampyx alariensis. } \\ \text { 1. Monograptus Clingani. }\end{array}\right. \\ & \text { Middle }\left\{\begin{array}{l}\text { 5. Monograptus convolutus. } \\ \text { 4. Placops glaber. } \\ \text { 3. Monograptus argenteus. } \\ \text { 2. Encrinurus punctatus. } \\ \text { 1. Monograptus fimbriatus. }\end{array}\right\} \text { Monograptus } \\ & \text { gregarius }\end{aligned}$

Lower $\left\{\begin{array}{l}\text { 2. Dimorphograptus confertus. } \\ \text { 1. Diplograptus acuminatus. }\end{array}\right.$

The Salopian forms a series of flags and grits closely resembling the Denbighshire Grits and Flags of North Wales. At the

1 Marr \& Nicholson, Quart. Journ. Geol. Soc., xìv. p. 654. 
base are the Brathay Flags, which since they contain Cyrtograptus Murchisoni (also Monograptus priodon, etc.), clearly represent the Cyrtograptus zone of Wales, etc. These are followed by the Coldwell Flags and Grits, which contain the important Cardiola interrupta and many others. The Coniston Grits and the Bannisdale Slates are not very fossiliferous; but the latter has yielded Rhynchonella navicula, Acaste Downingia, etc.

Lastly the Clunian is represented by grey calcareous flags and grits, the Kirkby Moor Flags, which contain numerous fossils, of which the commonest are Holopella gregaria and II. conica.

The Silurian rocks of the South of Scotland have been examined in detail only near Girvan and Moffat.

In the Girvan area the group is divided by Prof. Lapworth into a lower, Newlands, and an upper, Dailly Series.

These are subdivided as follows :-

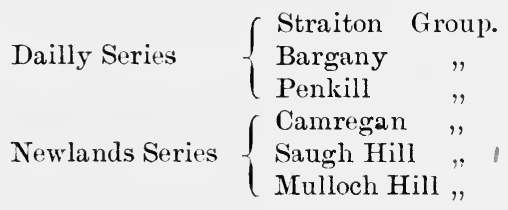

The whole commences with a conglomerate. The most important member of the Mulloch Hill group is a sandstone containing Meristella angustifrons. In the Saugh Hill group is the Woodland limestone with Stricklandinia lens, followed by shales and grits, with Monograptus Sedguickii in the upper part; while the Camregan group contains grits with Rhynchonella, limestone with Pentamerus oblongus, and shales with Rastrites maximus. All these are clearly Valentian.

The Penkill group consists of shales and grits with Monograptus. exiguus, M. priodon, and Cyrtograptus Graya, and represents the Tarannon Shales of Wales.

The succeeding Bargany and Straiton groups consist of flags, shales, and mudstones, with (upper part of the Straiton group) grits and conglomerates above. They contain Monograptus acus, M. vomerinus, Cardiola fibrosa and Beyrichia Kloedeni; and are of Salopian age.

In the Moffat area the Lower Valentian is represented by the 
Birkhill Shales of Lapworth, which contain the following zones of Graptolites :-

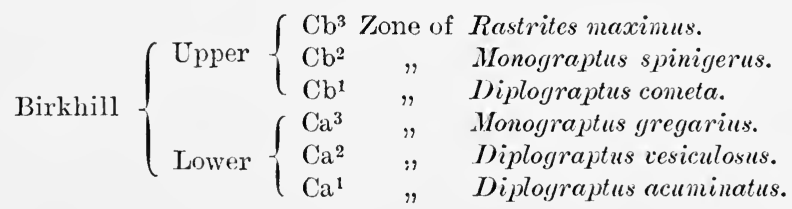

These are succeeded by a thick series of flags and shales with Monograptus priodon, M. Sedguickii, Cyrtograptus Graya, known as the Gala or Queensberry Beds, which correspond on the whole with the Penkill group of the Girvan area.

At Lesmahagow in Lanarkshire beds of Downtonian age have been found, which contain large crustacea, together with Platy schisma helicoides, Ceratiocaris, Tentaculites, etc.

In IRELAND the Silurian rocks have not yet been thoroughly examined and compared; but in the west at least, the whole series is represented. There they appear to be shore deposits, and they also differ from those of Britain in containing volcanic rocks.

Scandinavia.-The Silurian is represented in Sweden especially by the Gotland Limestone, a thick and fossiliferous series of limestones, marls and sandstones, the constitution and organic contents of which have been made known chiefly by the works of Fr. Schmidt ${ }^{1}$ and Lindström. ${ }^{2}$ The fauna, already numbering 1,000 species, is very varied, containing typical Silurian species of corals, crinoids, bryozoa, brachiopods, gasteropods, cephalopods, lamellibranchs and trilobites, which for the most part agree with those of the Wenlock Limestone of England. With regard to the sequence of individual subdivisions and their correlation with those of the English and Baltic Silurian, geologists are not yet quite unanimous. But this much appears certain, that the uppermost Limestone and Sandstone represent the English Ludlow, and the main mass of the series, underlying these, represents the Wenlock Limestone; whilst other calcareous marls (with Stricklandinia lens, etc.) dereloped near the town of Wisby, perhaps correspond with the May. Hill beds. Limestones of the same age rich in Pentamerus are also known at various places in Norway.

In Ost- and Westrogothia, Dalecarlia and Scania the Silurian is represented by the Upper Graptolite Shales (now divided

1 "Archiv für Naturkunde Liv.-, Ehst.- u. Kurlands (1859)."

". "Neues Jahrb., (1888)" I. "Silurian Gastropoda of Gotland (1884);" etc. 
into a lower or Rastrites, and an upper or Cyrtograptus, stage); and the succeeding Cardiola Shales with Cardiola interrupta, Monograptus and other Ludlow forms. The latter are locally replaced by certain light red sandstones with grey limestones and marl slates (Bjersjölagård-Öveds Beds) with Beyrichia Filecteni, Grammysia cingulata and other typical Upper Ludlow forms.

In Scania these rocks are divided by 'Tullberg into the following stages and zones:-

A. Upper Stage.

A1.-Bjersjölagi̊n-Öveds Beds (=Cardiola Shales in part.). (a) Öveds Sandstone, (b) Klinta Limestone and Shale, (c) Karrstorp Sandstone, (d) Bjersjülagird Limestone and Shales.

A2.-Cardiola Shales.

B. Middle Stage. Cyrtograptus Beds.

(a) Cyrtograptus Carruthersi, (b) C. rigidus, (c) Monograptus Riccartonensis (d) Cyrtograptus Murchisoni, (e) C'. Lapucorthi, $(f) C$. (?) spiralis, (g) C'. Graye.

C. Lower Stage. Rastrites Shales.

(a) Monograpius runcinatus, (b) Unfossiliferous (=Rastrites maximus zone), (c) Cepleaiograptus cometa, (d) Monograptus leptotheca, (e) M. gregarius, $(f)$ D1. cyghus, (g) Diplograptus acuminatus.

Sandstones similar to the Öveds Sandstone, but unfossiliferous, are developed in Norway in the uppermost Silurian.

The Leptœna Limestone of Dalecarlia is a peculiar formation and its position is still uncertain. By some it is considered to be approximately an equivalent of the May Hill Series; by others it is referred to the Ordovician.

Russia.-Silurian rocks occur in the Baltic Provinces, and in the valley of the Dniester.

In the Baltic, Provinces Schmidt classifies as follows :-

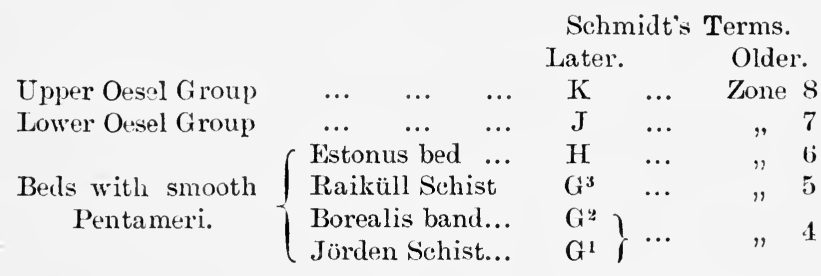

The Silurian begins, as in England, with a group of beds characterized by the abundance of large smooth Pentameri (P. borealis at the base, and then $P$. esthonus, very like, if not identical with, 
the English P.oblongus), with which appear at the same time spiralbearing brachiopods such as Spivifer plicatellus (X. 7), Atrypa reticularis (X. 4), and various corals, etc. The Lower Oesel Zone is partly made up of very thick coral beds and contains numerous trilobites (Calymene Blumenbachi [VII. 3], Encrinumes punctatus [VII. 5], Proëtus concinnus and brachiopods, and is compared by Schmidt with the Wenlock Limestone. The Upper Oesel Zone, with various brachiopods (Atrypa prunum, Spirifer elevatus, Rhynchonella nucula, Chonetes striatella [IX. 5], etc., Acephala (Pterinea retroflexa, etc.), Ostracoda (Beyrichia tuberculata [VII. 6], Tentaculites, etc., is compared with the Ludlow. One of the most important localities for this zone is Rootsiküll on the Island of Oesel. Here occur yellow platy dolomite beds which contain cephalaspid fishes (Thyestes, Tremataspis) and numerous

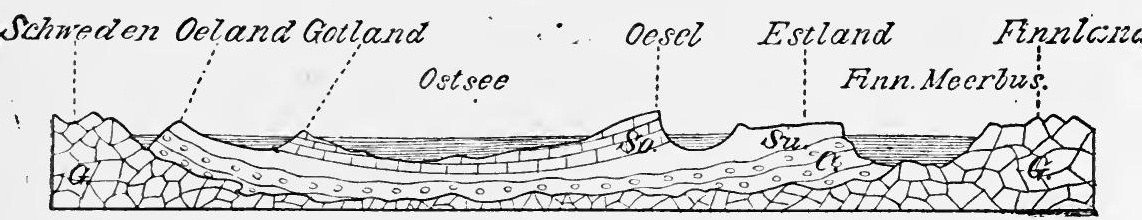

Fic. 13.-Section from Finland through the islandsl of Oesel, Gotland, and Oeland to Sweden (Fr. Schmidt). G. Granite. C. Cambrian. Su. Ordovician. So. Silurian.

large crustaceans (Eumypteme [VIII. 1], Pterygotus, etc.), which are very similar to those of the Waterlime group at the upper limit of the Silurian in North America. These Eurypterus beds are overlaid by a fish zone with the fauna of the English Passage beds (Onchus, Pachylepis, etc).

Finally, in the Dniester region, in Podolia and Galicia, the development according to Schmidt, F. Römer and others, is quite similar to that of the Baltic. Here also, at the top of the series, there are found beds with Eurypteridæ and Cephalaspidæ; with this difference, however, that they pass upwards quite gradually into the red Devonian sandstone (Old Red). The beds here are exclusively of the age of the English Ludlow.

It is worthy of note that the Pentamerus beds can be followed eastward over a considerable area as far as East Siberia (the region of the Lena).

Bohemia.-The Silurian rocks of Bohemia, like the Ordovician, are very different from those of Northern Europe. The Pentamerus beds which form so striking a feature at the base of tho 
Silurian in England and Scandinavia, are not found in Bohemia nor is it possible here to distinguish between the Wenlock and Ludlow series. In fact the rocks of England and Scandinavia aro much more like those of the Baltic Provinces, of Podolia and Galicia, and even of North America, than the Bohemian rocks are like those of any of these areas.

Following the usual view that Barrande's Stages, F, G, H, must be referred to the Devonian, the Silurian rocks of Bohemia may be divided as follows :-

E e 2.-Thin-bedded, grey, crystalline Limestone, in part schistose, filled with all sorts of Cephalopods, Gasteropods, Brachiopods, Trilobites, Corals, etc. (Calymene Blumenbachi [VII.3], Sphcerexochus mirus, Cheirurus insignis [VII. 1], Harpes [VII. 4], Acidaspis [VII. 2], Lichas, Phacops, Cardiola interrupta [IX. 2], Halysites catenularia [X. 9], Capulus, Orthoceras bohemicum, Cyrtoceras [VIII. 5], Gomphoceras [VIII. 6], Phragmoceras [IX. 1], etc.

$\mathrm{E} \mathrm{e}^{1}$.-Black graptolite schists with impure limestones and diabase tuffs. At the base Diplograptus still occurs along with Monograptus (VI. 6-9); further up, only the latter of these and Cyrtograptus, Rastrites (VI. 11), Retiolites (VI. 10), etc.

According to Marr and Tullberg the graptolite schists $\mathrm{E} \mathrm{e}^{1}$ may be divided into a number of zones (according to Marr in the following order, from below upwards :-(1) Rastrites peregrinus, (2) Monograptus turriculatus, (3) Cyrtograptus Murchisoni, (4) Monograptus colonus) which are repeated in precisely similar order in Scania and England.

Germany.-In the district of Thuringia and the Fichtelgebirge the Silurian rocks which overlie the Ordovician already described may be divided as follows:-

Upper Graptolite sehists with species of Monograptus (colonus, etc).

Ockerkalk; a light-coloured iron-bearing limestone, which weathers ochrey and contains Cardiola interrupta, Orthoceras, etc.

Alum and siliceous sehists with Monograptus Halli, Mr. Becki, etc., Retiolites Geinitzianus, Diplograptus.

Here the graptolitic alum schists at the base-which are correlated by Törnquist with the Swedish Rastrites beds, by Marr with the Stockdale shales of the English Lakes and the Cyrtograptus Murchisoni beds-are clearly the approximate equivalents of Barrande's Stage $\mathrm{E} \mathrm{e}^{1}$ though they contain lower beds than do the shales of Bohemia ; and the Ockerkalk of Stage Ee?.

In the Alps Cardiola interrupta, Dualina and other Silurian fossils have long been known from Dienten near Werfen in Salzburg. But a fuller and more complete development has lately 
been proved in the Southern Grauwacke zone of the Austrian Alps, in the Karawanken and Steiner Alps (Carinthia and Carniola), and especially in the Carinthian Alps, in the Osterniggebirge, at Kellerspitz, in the Wolayer District, etc. According to the valuable observations of G. Stache ${ }^{1}$ and others, Graptolite schists are everywhere clearly recognisable with Monograptus, Rastrites, Diplograptus, Climacograptus, etc., which may be considered as the approximate equivalents of the Scottish Birkhill Shales. These are succeeded by dark or light-coloured (in part red) Orthoceras Limestone with many Orthoceras, Cardiolacex and Trilobites-among the latter Arcthusina Haucri, Cheirum Quenstedti, Cromus Beaumonti, and other Bohemian species. Below the Graptolite Schists already mentioned, the Ordovician is represented by thick clay-, and grauwacke schists with quartzites, in which Strophomena cxpansa, Orthis calligramma, Porambonites, and a few other fossils are found. We may well conclude, with Stache, that a great part of the so-called Grauwacke zone which borders the central chain of the $\mathrm{Al}_{\mathrm{p} s}$, and consists partly of highly crystalline schists, partly also of the usual slates and grauwackes, sandstones, limestones, etc., is of Silurian age.

In France Silurian rocks occur chiefly in the North-west, in Brittany and Normandy. Near Brest, the Ordovician rocks already described are followed by Silurian, which may be grouped as follows:-

Slates with calcareous nodules, containing Cardiola interruptar Orthoceras, Dualina, Ceratiocaris.

Alum-bearing, bituminous shales (Schistes ampélitiques) with Graptolites (Monograptus priodon, M. colomus, etc.).

In Southern Europe also, in Spain, Portugal, and Sardinia, the Ordovician rocks with Asaphus, Calymene, etc., are succeeded by Graptolite selifists and dark nodular limestones with Cardiola interrupta, Orthoceras, etc.; and thus they are very closely related to the rocks of France, Germany and Bohemia, and quite different from those of Northern Europe.

The Silurian, like the Ordovician, rocks which are known out of Europe, are more nearly related to those of Northern Europe than to those of Bohemia.

1 Zeits. d. deutsch. geol. Ges. (1884), p. 277. Compare also Fr. Frech, ibid. (1887), p. 702 . 
In the region of Now York in the United States they may be grouped as follows:-

Waterlime and Onondaga salt group. An almost unfossiliferous: series, some 700 feet thick, of variegated marls and sandstones with gypsum and rock salt; succeeded by the Waterlime group, a calcareous formation which contains a host of Eurypterids, especially Eurypterus remipes, together with Leperditia and Tentaculites.

Niagara Limestone. A succession of fossiliferous limestones and marl slates of varıous thicknesses. The Corals (Favosites gotlandica, Heliolites interstincta, Halysites catemularia, etc.), Brachiopods (Orthis elegantula, Spirifer plicatellus, Rhynchonella cuneata, etc.), Trilobites (Illamus Barriensis, Calymene Blumenbachi, Encrinurus punctatus, etc.), agree in great part specifically with those of the English Wenlock Limestone.

Medina Sandstone. $\left\{\begin{array}{l}\text { The former composed of argillaceous slates and } \\ \text { sandstones, with Pentamerus oblongus, Illonus Bar- } \\ \text { viensis, Orthis elegantula, etc.; the latter of poorly } \\ \text { fossiliferous sandstones at the base of which in: } \\ \text { the New York State lies the Oneida Congl o- } \\ \text { merate. }\end{array}\right.$

The Niagara Limestone has long been considered to be the equivalent of the Wenlock Limestone; and the Clinton group. with Pentamerus oblongus is recognised without difficulty as the representative of the English May Hill or Valentian group and of the equivalent Russian Pentamerus beds.

The American geologists include in the Silurian both the Lower Helderberg beds which follow the Waterlime group, and the succeeding Oriskany Sandstone. On the grounds, however, which will be put forward in the account of the North American Devonian, it appears more correct to draw the boundary between Silurian and Devonian where Murchison did, as in the foregoing table.

In South America, Australia, Asia (China), and Africa. Silurian rocks have been found, and in all these areas they are more or less similar to those of Northern Europe.

\section{PALAEONTOLOGY OF THE ORDOITCIAN AND SILURIAN SYSTEMS.}

Compared with the Cambrian, the organic life of Ordovician and Silurian times shows a very great advance. Besides the two groups of animals which alone occur abundantly in the Cambrian, viz. the Trilobites and Brachiopods-both of which play an important part in the Ordovico-Silurian-we find the new and important division of the Cephalopoda; and among lower types. 


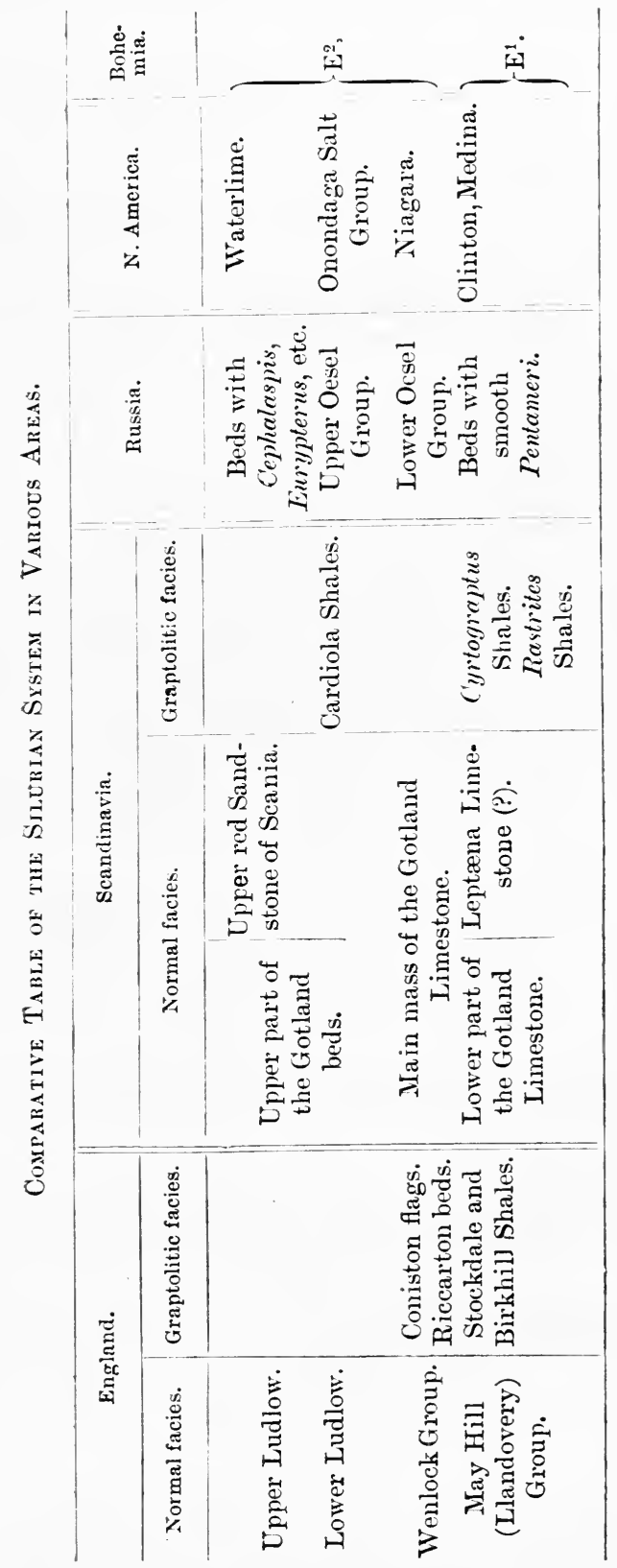


which are almost unrepresented in the Cambrian we get Corals, Crinoids, and Graptolites. The last phase of the Silurian period was especially marked by the first appearance of fishes in Europe, ${ }^{1}$ which are accompanied by a very remarkable race of large Crustacea, the Eurypterids. Lastly it is in these systems that we find the oldest Land-plants (Sigillaria, Lepidodendron, Sphenophyllum, in the Cincinnati group of North America), Insects (Palcoblattina in France), and Arachnoidea (Scorpions in the upper Silurian of Gotland and Scotland [Lesmahagow]).

As in the Cambrian, the most characteristic fossils are the Trilobites. Unlike those of the Cambrian, most of them possess well developed (facetted) eyes and a large tail; and they were able to roll themselves up (VII. 3). In the Ordovician the genera Asaphus (III. 1) and Illcmus (III. 2) are especially important and widespread, the former being exclusively Ordovician, whilst the latter extends into the Silurian. Asaphus has eight, Illanus ten thoracic rings; Asaphus diagonally furrowed, Illanus smooth, pleura; Asaphus a large tail, furnished with a long axis-and this is still more marked in the subgenus Megalaspis-Illanus a very indistinctly marked axis and glabella. Another very important somewhat younger genus is Trinucleus (III. 3), distinguished by its long horns and the sieve-like perforated border of the head shield, which is without sutures and eyes. Another, exclusively Ordovician, genus is Chasmops (III. 6) belonging to the Phacopidæ, with a distinctly granulated shell, glabella widened in front and large eyes, but distinguished from allied forms by the large triangular lobes on the sides of the glabella. Other genera limited to the Ordovician are Ogygia, Placoparia, Aglina (III. 4), Remopleurides, etc.

Among the most important genera common to both the Ordovician and Silurian, are: Dalmanitcs (III. 5 ; see also XVIII. 5),also a Phacopid, the glabella of which has three strong grooves on each side, and the headshield is produced into long spines and the tail usually into a point-; Calymene (VII. 3),-head with broad oval, much swollen glabella, clearly defined, and divided on each side into three globular lobes, small eyes, a raised border to the front of the head, etc.-; Iomalonotus,-large, indistinctly marked glabella, and very broad axis, otherwise like Calymene-; Cheiruvus (VII. 1),-long, narrow, with very broad head, small eyes,

1 Walcott has recently described fishes from supposed Ordovician rocks in North America. 

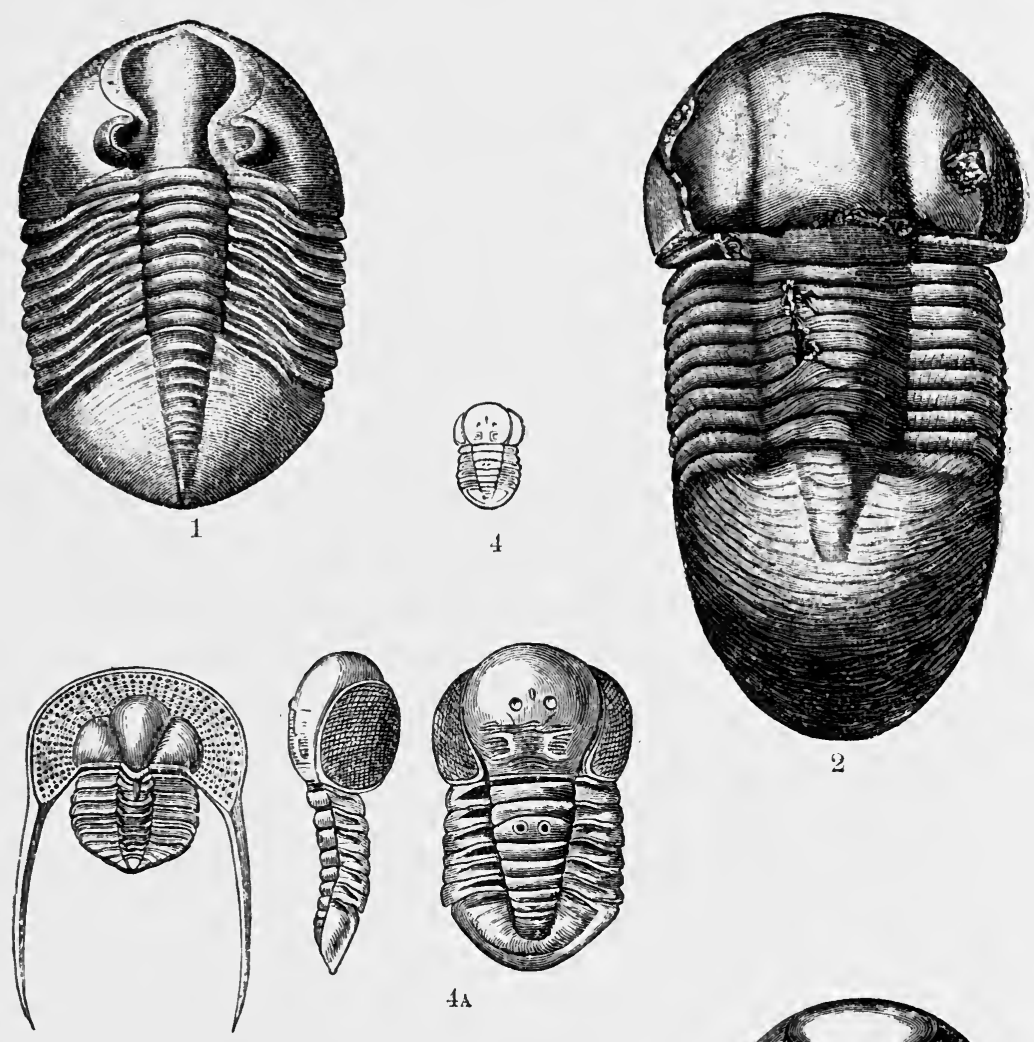

$4 \mathrm{~A}$

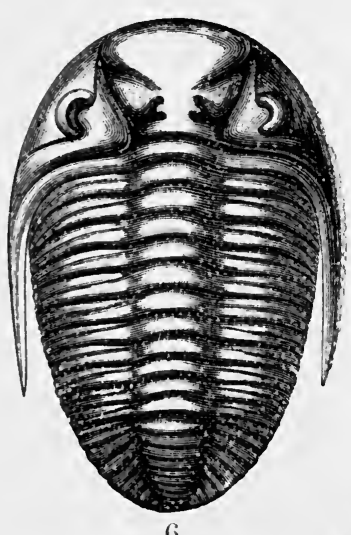

5

6

Plate III.-Ordovician Trilobites.

1. Aasphus expansus, Wahl. 2. Illonus oblongatus, Ang. 3. Trinucleus Goldfussi, Barr (somewhat reduced). 4. Aeglina prisca, Barr. 4A. The same, enlarged. 5. Dalmanites: socialis, Barr, head-shield. 6. Chasmops Odini, Eichw. 

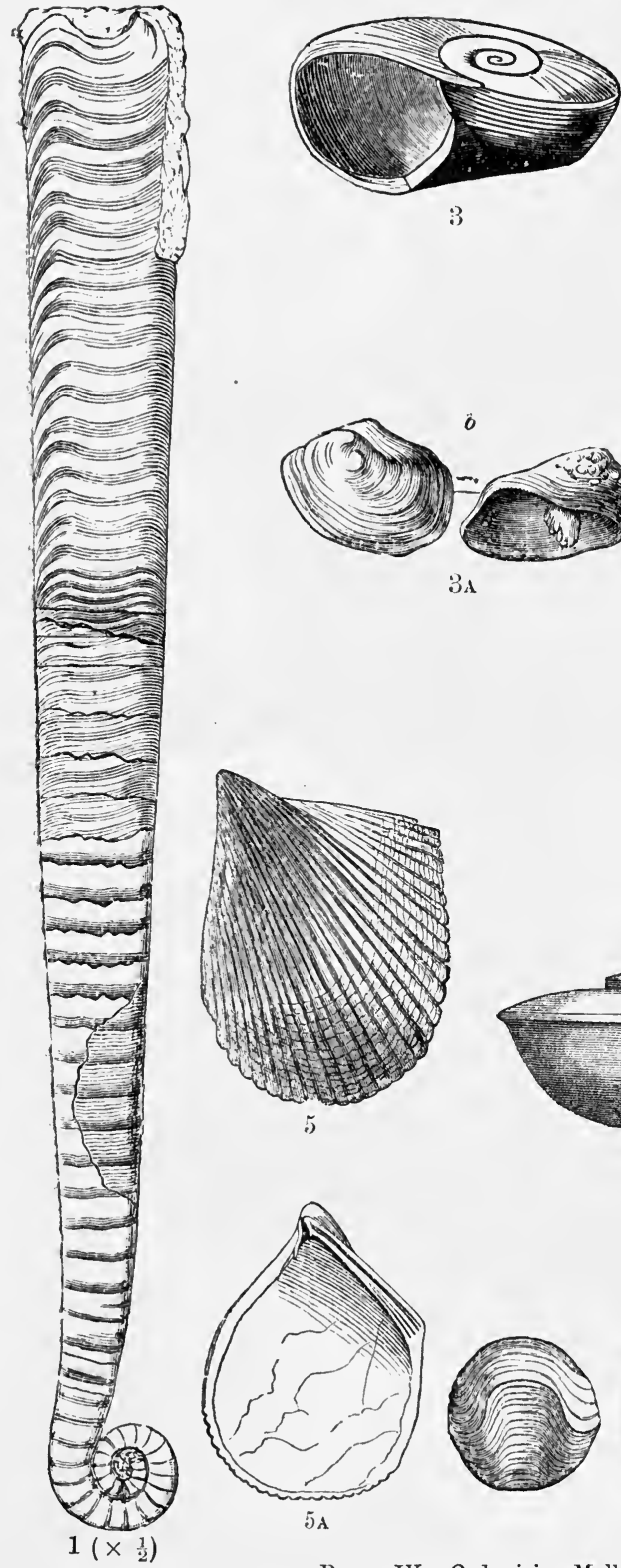

3

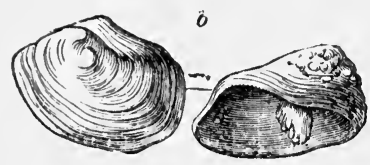

$3 \mathrm{~A}$
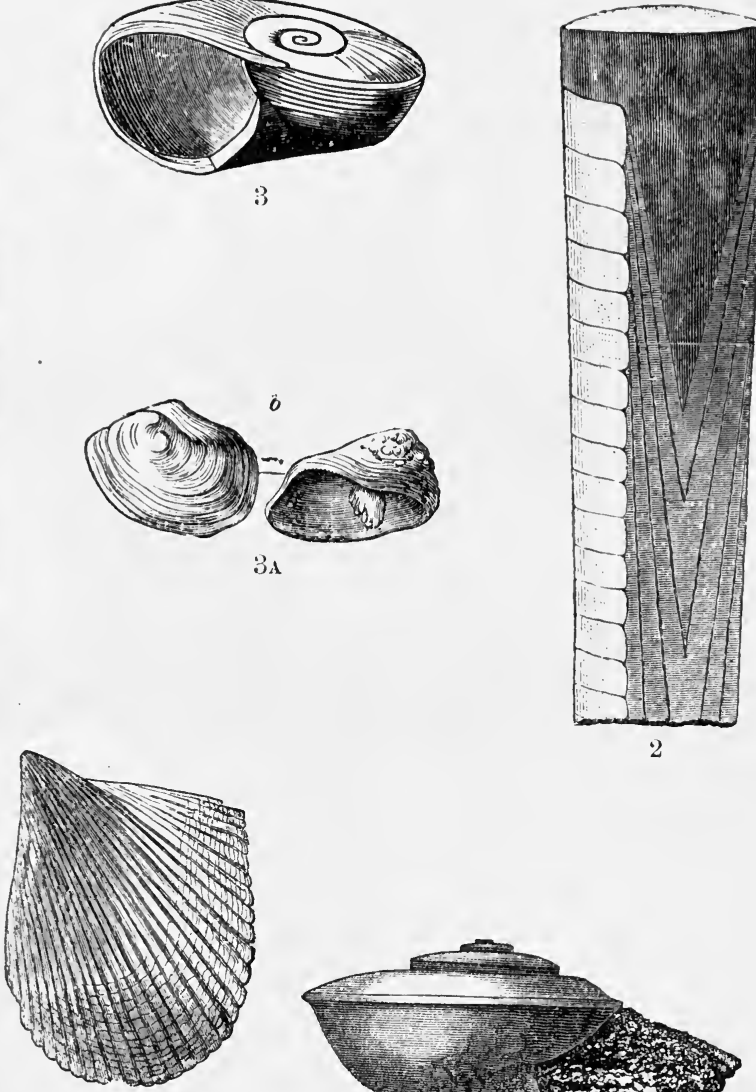

2
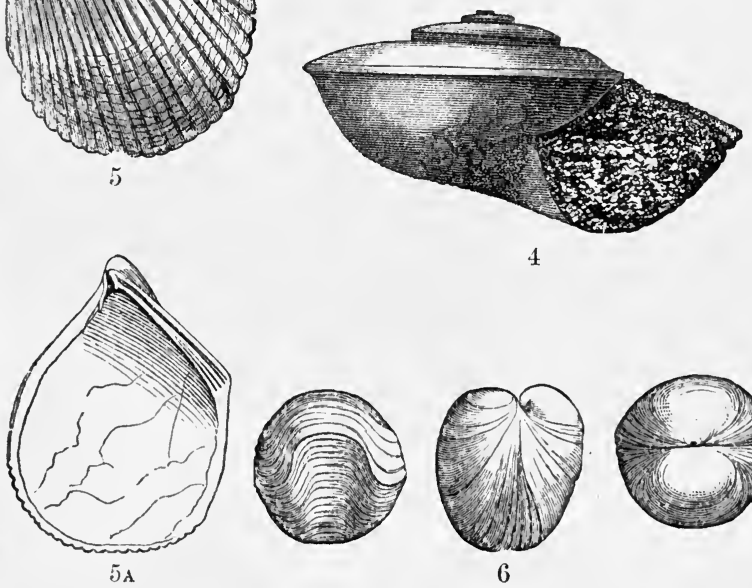

4
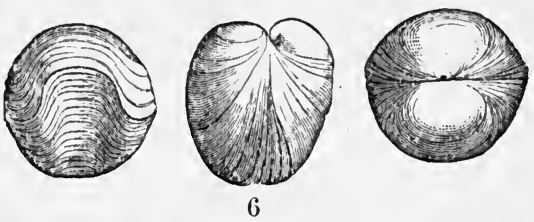

Plate IV.-Ordovician Mollusca.

1. Lituites lituus, Montf. 2. Endoceras longissimum, J. Hall (longitudinal section). 3. Maclurea Logani. Salt. 3А. Ditto, operculum. 4. Pleurotomaria (Raphistoma) qualteriata, Schloth. 5, Ambonychia bellistriata, J. Hall. 5A. Ditto. Internal view of right valve. 6. Porambonites a quirostris, Schlotb. 

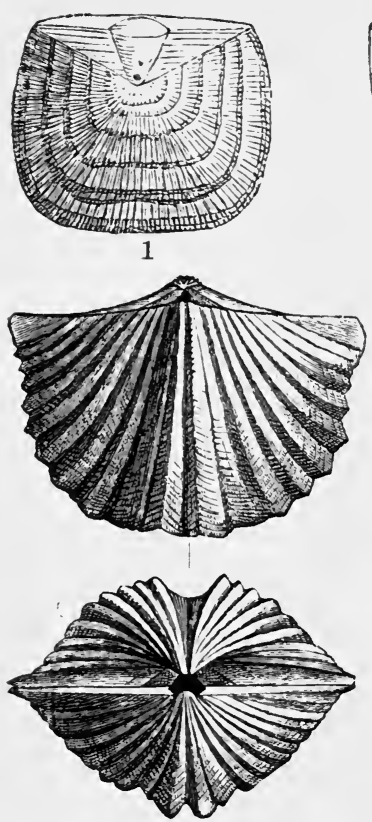

3

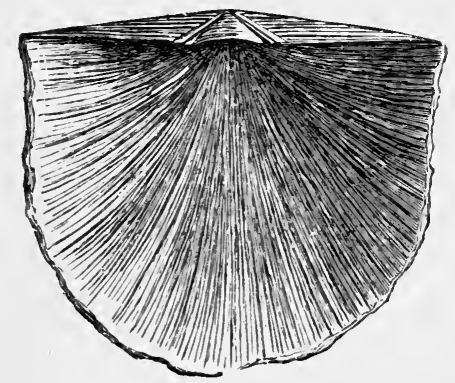

う
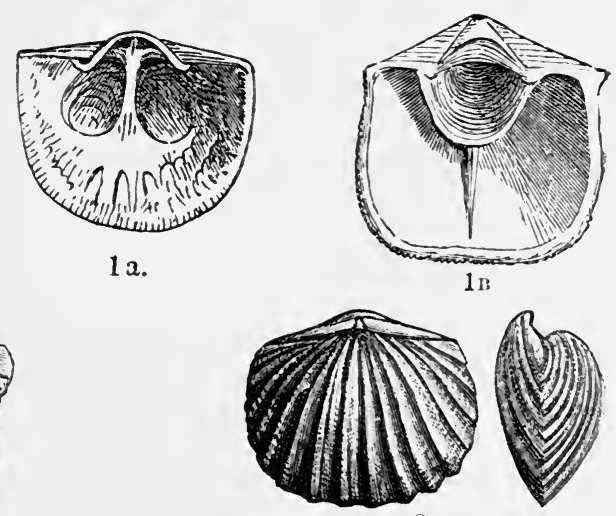

2

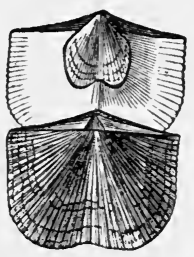

4

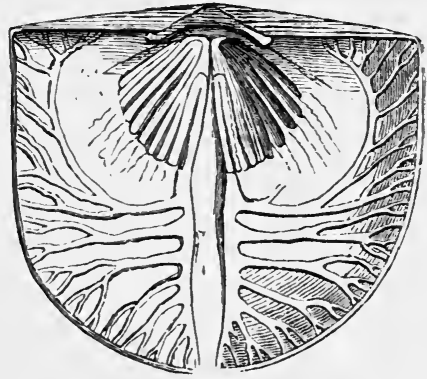

כ̇
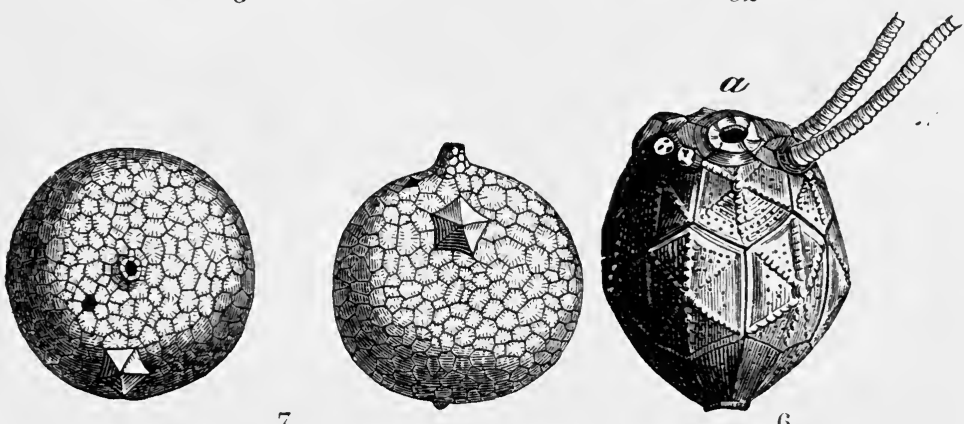

7

Platr V.-Ordovician Brachiopods and Cystideans.

1. Orthisina adscendens, Pand. 1A. Ditto. Internal view of small valve. 1в, Large valve of the same. 2. Orthis calligramma, Dalm. 3. Platystrophia lynx, Eichw. 4. Orthis vespertilio, Sow. 5. Strophomena alterrata, Conr. 5. Ditto. Internal view of large valve. 6. Caryocrinus ornatus, Say. 7. Echinospherites aurantium, Hising., from above and from the side. 


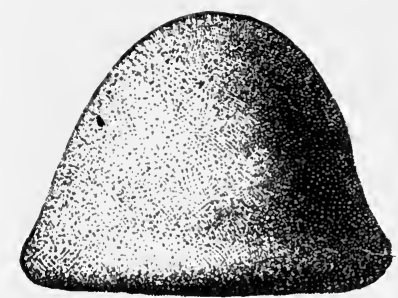

1

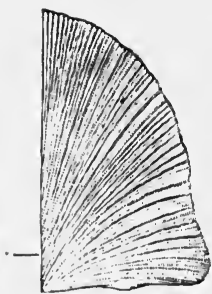

$1 \mathrm{~A}$
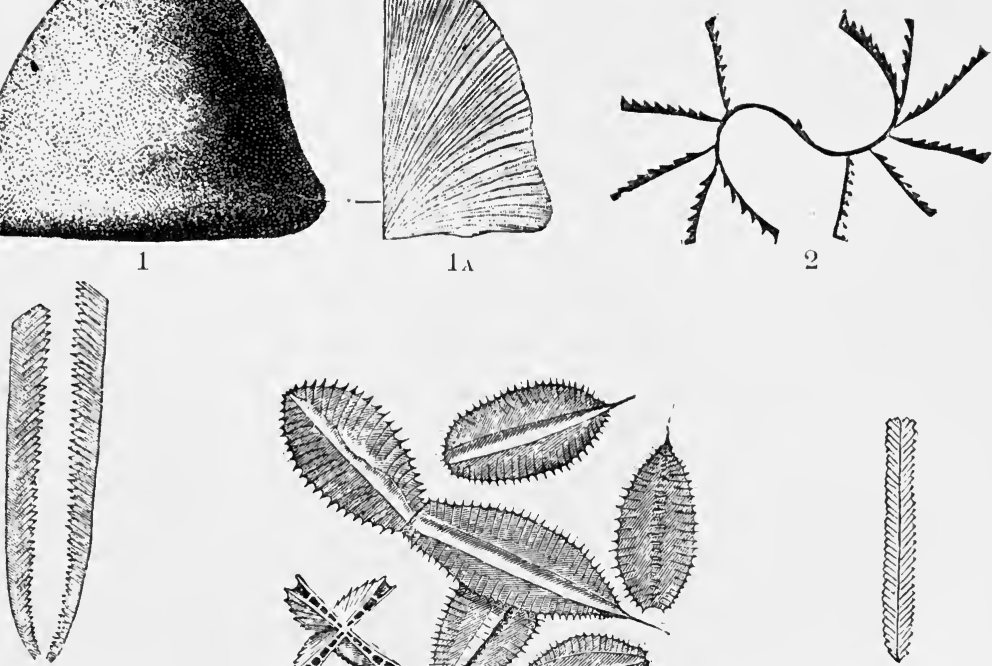

3
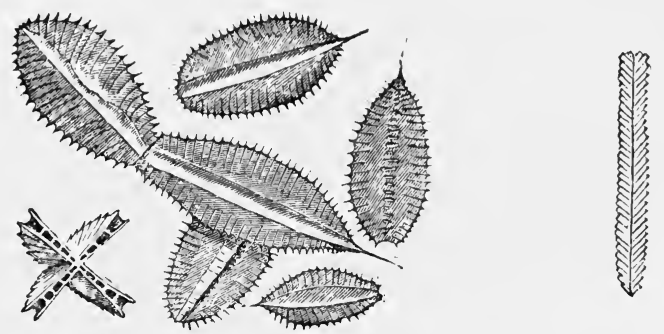

4
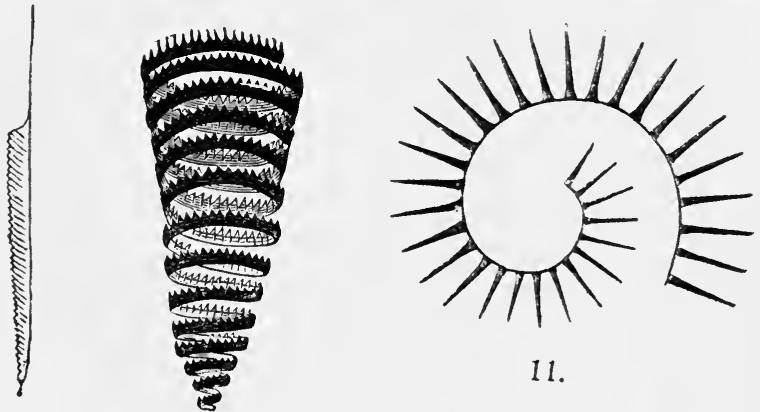

6 .

8.

9

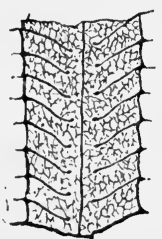

10
11.

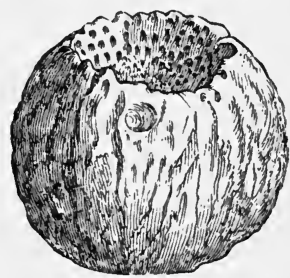

12

Plate VI.-Ordovician and Silurian Cœlenterates.

1. Monticulipora petropolitcna, Pand. 1A. Ditto, longitudinal section. 2. Cenograptus gracilis, Hall. 3. Didymograptus Murchisoni, Beck. 4. Phyllograptus typus, Hall. 5. Diplograptus palmeus, Barr. 6. Monograptus priodon, Bronn. 7. M. Nilssoni, Barr. 8. M. olonus, Barr, 9. M. turviculatus, Barr. 10. Retiolites Geinitrianus, Barr. 11. Rastrites Linnoei, Barr. 12. Astylospongia promgrsa, Goldf. 


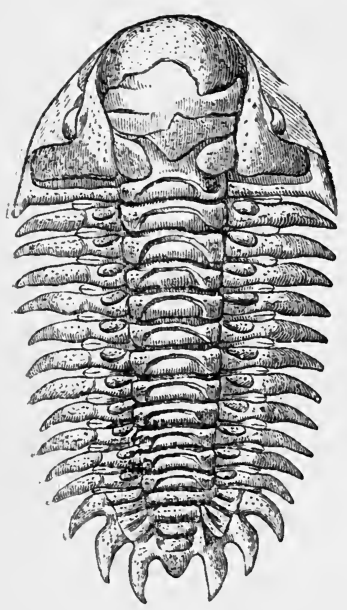

1
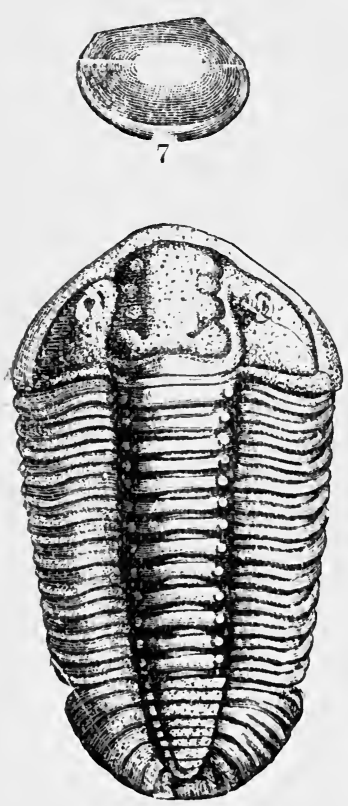

3
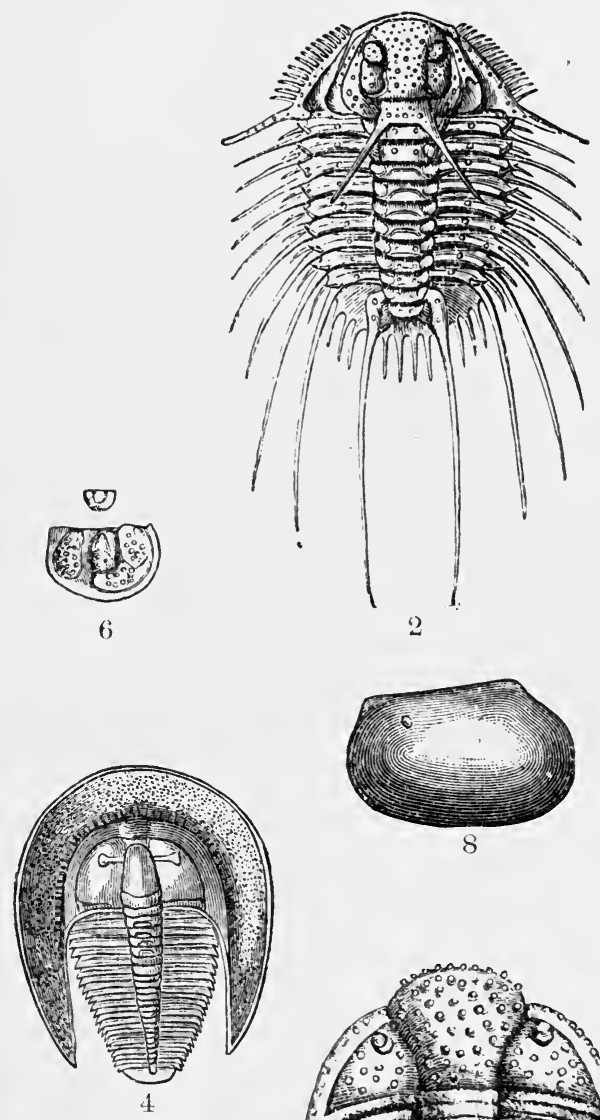

2

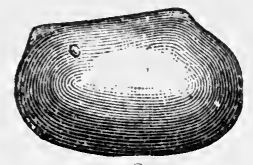

8

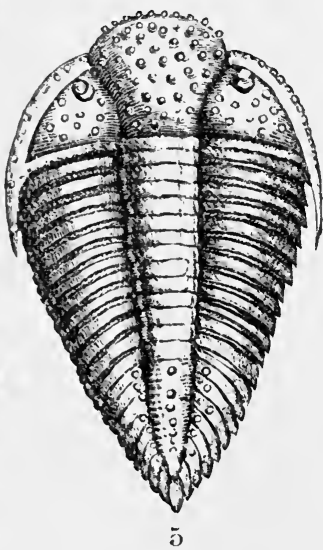

Plate VII.-Silurian Crustacea.

1. Cheirurus insignis, Beyr. 2. Acidaspis Dufrenoyi, Barr. 3. Calymene Blumenbacki, Brongn. 3. The same, rolled up. 4. Harpes ungula, Sternb. 5. Encrinurus punctatus, Emmr. 6. Beyrichia tuberculata, Klöd. 7 and 8. Leperditia Hisingeri, Schmidt. 


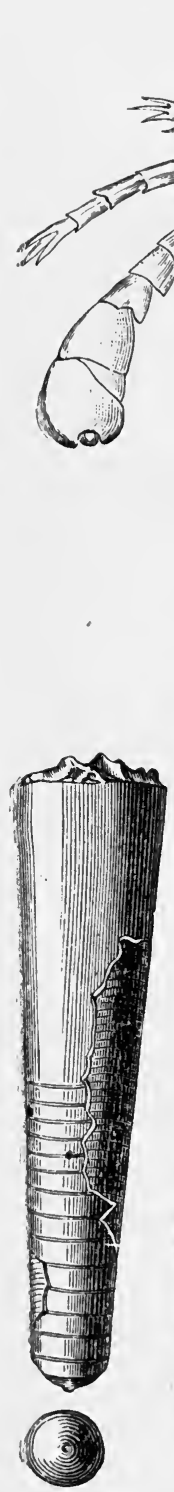

4
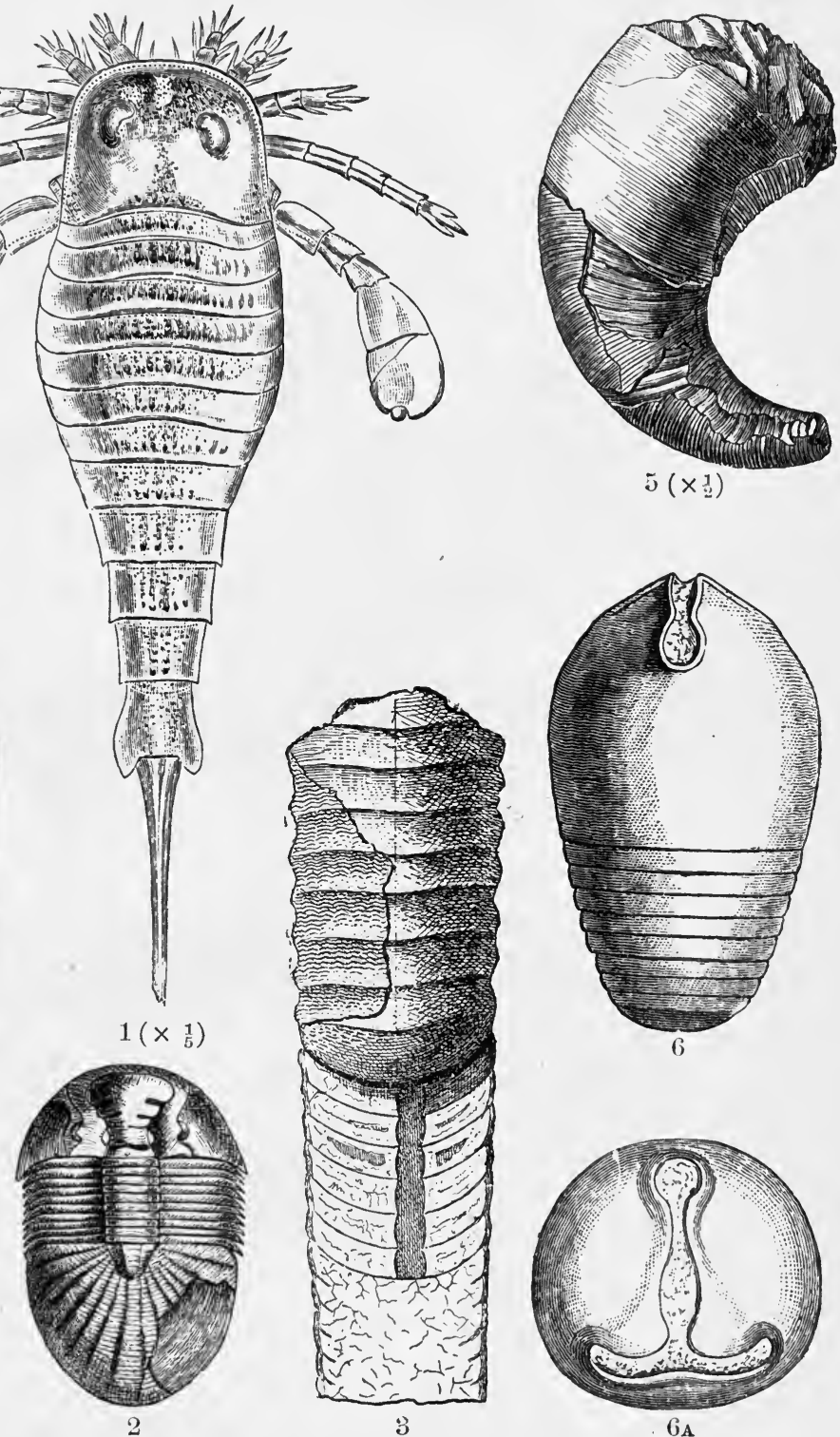

Plate VIII.-Silurian Crustacea and Cephalopoda.

1. Eurypterus Fischeri, Eichw. 2. Bronteus planus, Corda. 3. Orthoceras annulatum, Sow. 4. 0. timidum, Barr. 5. Cyrtoceras Murchisoni, Barr. 6. Gomphoceras bohemicum, Barr. 6A. Ditto, terminal chamber from above.

C. G. 


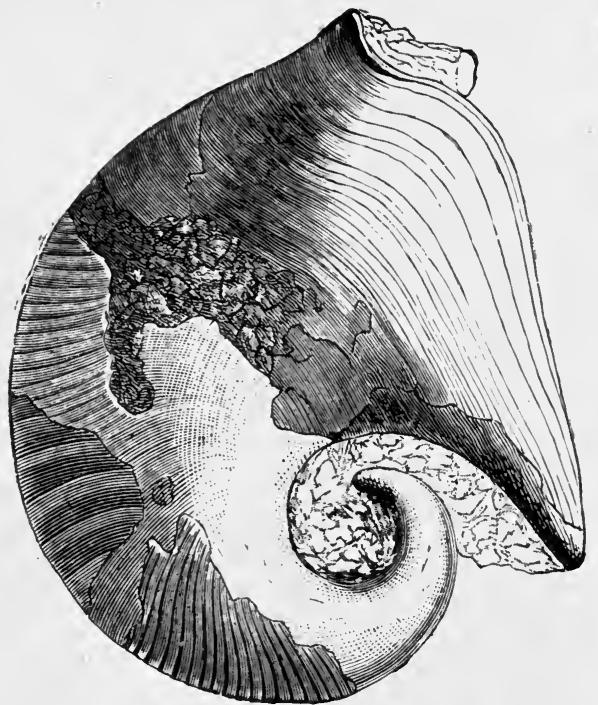

$1 \mathrm{~A}$
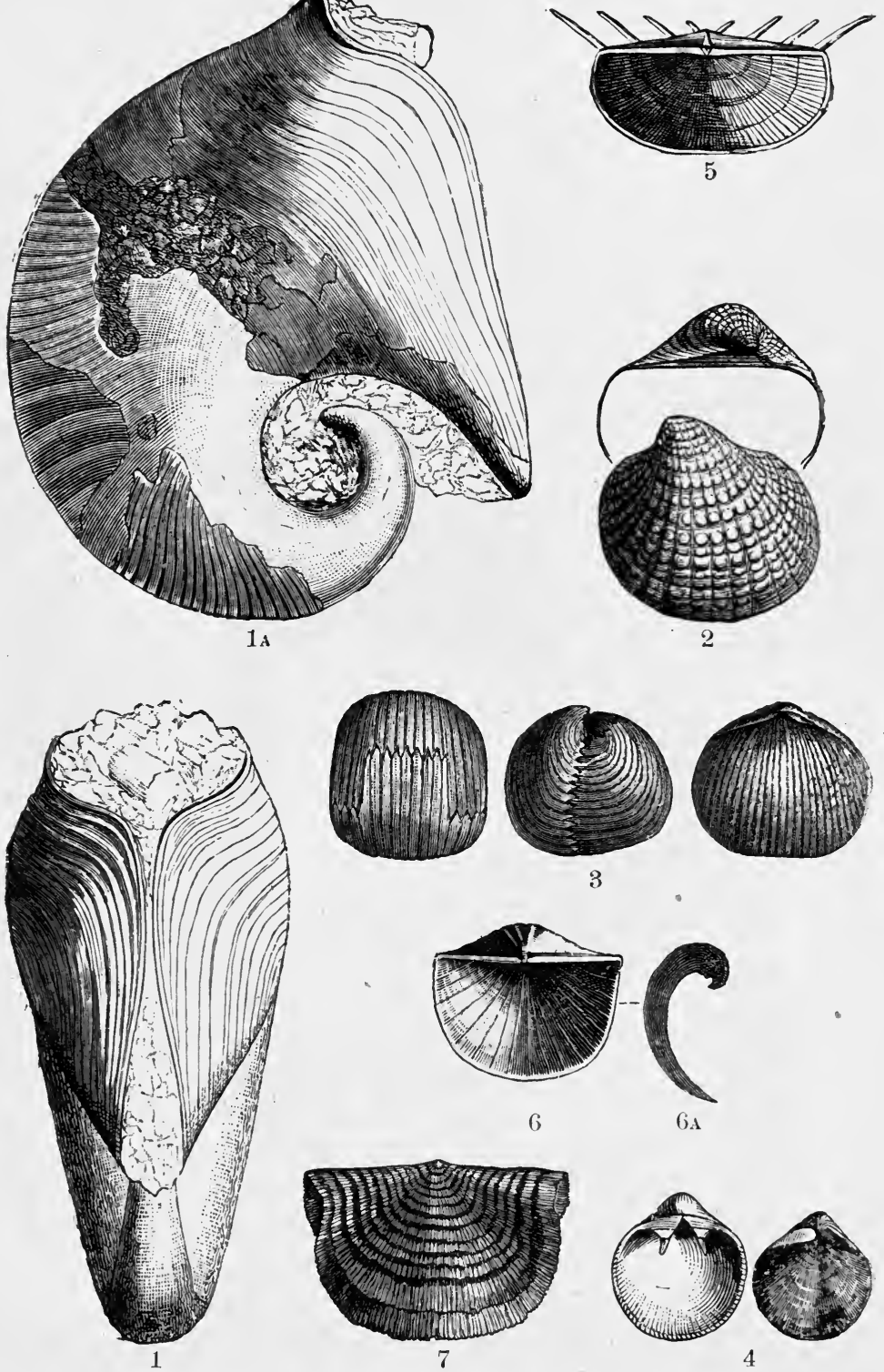

3

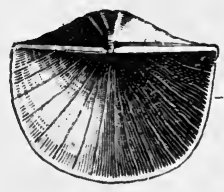

6

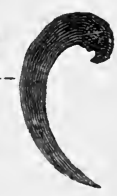

$6 \Lambda$

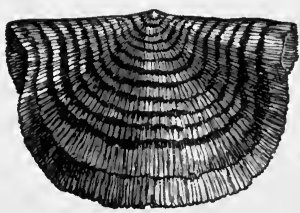

7

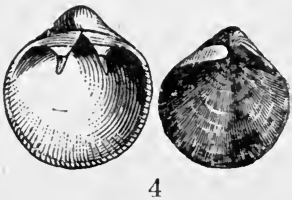

Plate IX.-Silurian Molluses.

1 and 1A. Phragmoceras Broderipi, Barr, from in front and from the side. 2. Cardiola interrupta, Sqw. 3. Rhynchonella Wilsoni, Sow. 4. Orthis elegantula, Dalm. 5. Chonetes striatella, Dalm. 6. Leptcena transversalis, Dalm. 6.. Ditto, transverse section. 7. Strophomena rhomboidalis, Wahl. 

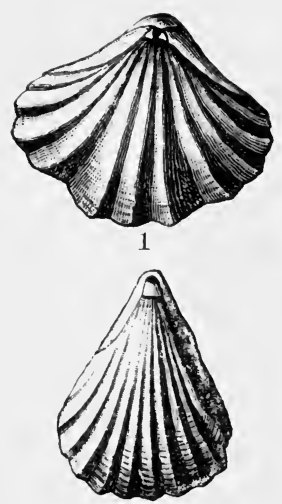

$\because$
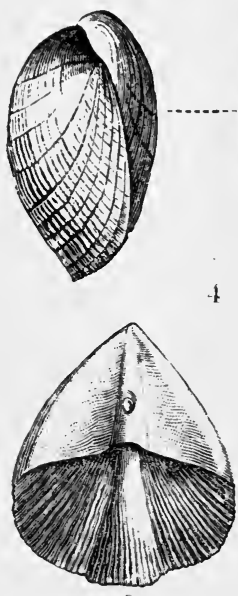

6

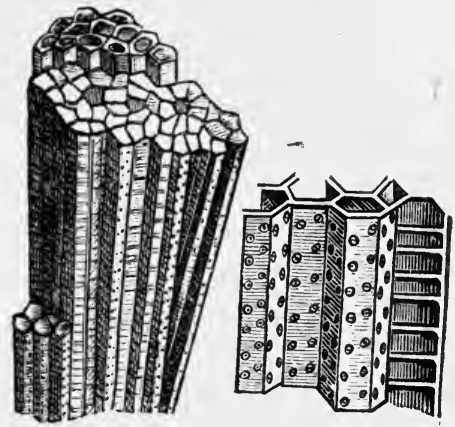

8

5 b.
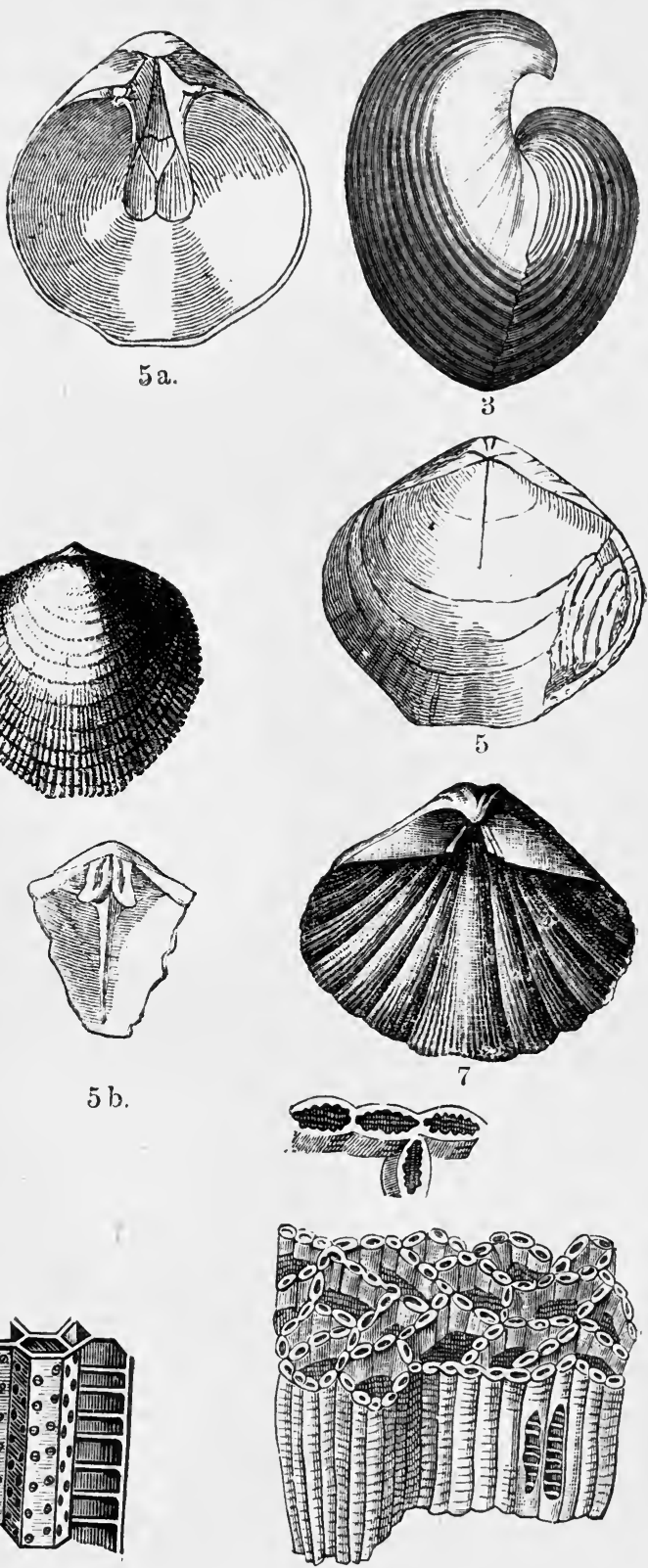

9

Plate X.-Silurian Brachiopods and Corals.

1. Rhynchonellaborealis, Schloth. 2. Rhynchonella cuneata, Dalm. 3. Pentamerus Knighti, Sow. 4. Atrypa reticularis, Lin. 5. Meristella tımida, Dalm. 5A. Ditto, interior of largevalve. 5в. Ditto, hinge area of small valve from within. 6. Spirifer (Cyrtia) exporrectus, Dalm. 7. Spirifer plicatellus, Lir. 8. Favosites gotlandica, Lin. 9. Halysites catcinularia Lin. 


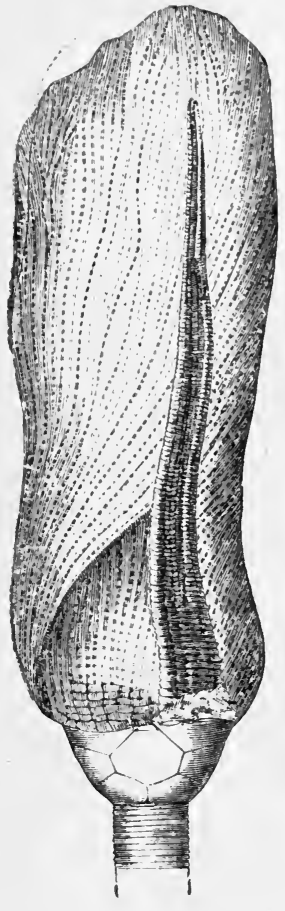

1

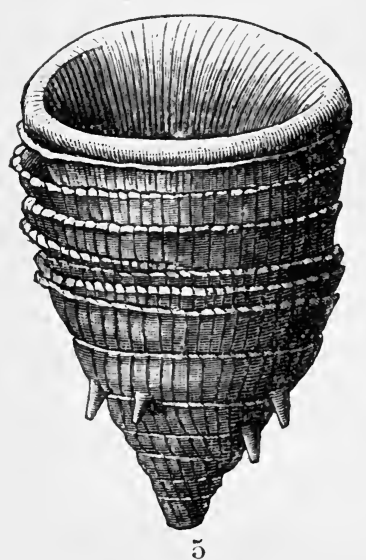

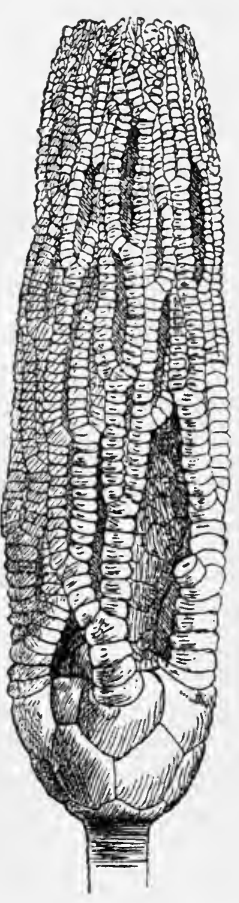

2.

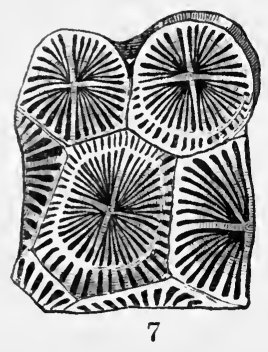

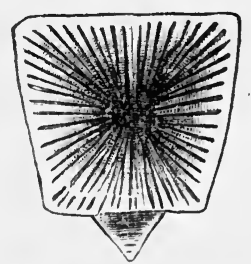

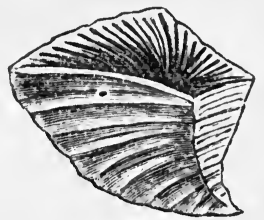

6

Plate XI.-Silurian Cœlenterates.

1. Crotalocrinus pulcher, His. 2. Cyathocrinus longimanus, Ang. 3. Palsocyclus porpita, Lin. 4. Acervularialuaviaus, Eichw. 5. Omphyma subturbinatum, d'Orb. 6. Goniophyllum .pyramidale, His. 7. Stauria astruformis, M. Edw. and H. 
short pygidium, and pleura ending in spines-; Acidaspis (VII. 2),-a very spiny form, glabella with two longitudinal grooves-; Lichas,-very broad, especially the axis, glabella with longitudinal grooves, pleura pointed-; IIarpes (VII. 4), -head-shield with broad perforated border, broad long side spines, oval glabella, and small but distinct eyes-; and Ampyx,-without eyes, the swollen glabella produced into a long point.

Along with these species we find in the Silurian a whole series of newer types which give to the Silurian fauna its own peculiar stamp. Here belong Phacops (cf. XV. 1, and XIX. 4), Proëtus, Encrinurus, Bronteus, Spharexochus, Cyphaspis, Arethusina, and others. Phacops is characterized by a club-shaped, slightlygrooved glabella, large crescentic eyes and small tail; Proëtus by an oval almost unfurrowed glabella and small eyes; Encrinurus (VII. 5) by a broad pear-shaped, strongiy granulated glabella, small eyes, triangular many-jointed tail, etc.; Bronteus (VIII. 2) by very much widened glabella, eyes far back and sickle-shaped, quite ungrooved pleura and especially by a large peculiarly shaped tail which possesses a very short axis and broad ribs arranged in fan-like fashion.

Among the non-trilobitic Crustacea of the Silurian formation the most important and interesting are the large Eurypteridx, which begin in the Silurian and reach to the Carboniferous. The numerous forms, some more than a yard in length, group themselves round the type genus Euryptcrus (VIII. 1). All are distinguished by a short broad head shield consisting of one piece, which bears small compound eyes; and six pairs of jointed limbs, some of them armed with pincers. The body, which is composed of twelve freely movable segments, and is produced into a tail spine, was corered with fine scales.

The families of the Limulidx (to which the living Limulus: polyphemus [King Crab] belongs) and Hemiaspidce have also been traced back as far as the Silurian. To the former belongs the genus Neolimulus, to the latter, Hemiaspis, etc.

Of other Crustacea there remain to be mentioned the Phyllocaridæ, with the genus Ceratiocaris and others, and the Cirripedia with Turrilepas, etc. More important than these are certain Ostracoda, small forms in which the soft parts of the animal are completely enclosed in two horny shells, hinged together at the back of the animal. The most widely spread genera are Leperditia (VII. 7, 8) and Beyrichia (VII. 6), the former essentially 
smooth, the latter bearing strong tubercules. Beyrichia shells are found in thousands in the Beyrichia Limestone of the Northern Ordovician areas.

The most highly organized animals of the Silurian period, the fishes, occur for the first time in Europe in the upper part of the system, and there but sparingly. They belong in part to the Selachii, in part to the Cephalaspidæ and Pteraspidæ. Of the first scarcely anything but fin-spines (Onchus, etc.) has been found; of the Cephalaspidæ (chief genus Cephalaspis), a peculiar order limited to the uppermost Silurian and the Devonian, parts of the head (which consisted of a single trilobite-like shield drawn out posteriorly into long spines) and the trunk are known; and lastly of the Pteraspidæ, the systematic position of which is uncertain, only the armour plates of the stomach and the back have been found. Fishes have recently been found in rocks thought to be of Ordovician age in North America. They occur in sandstone beds which pass upwards into limestone with a Trenton fauna.

Among the Mollusca the Cephalopoda are, from their number and variety, of great importance. They all belong to the one great division, the Nautiloidea (of which the genus Nautilus is the solitary living representative), whilst the other division, the Ammonoidea, is entirely absent. The genus Endoceras (IV. 2), a straight form like Orthoceras, but with very thick marginal siphuncle, is of great importance in the Ordovician; also the crozier-like genus Lituites (IV. 1), the proximal part of which is spirally coiled while the distal portion is straight. In the Silurian we find the staff-like genus Orthoceras (VIII. 3, 4), the very variable slightly-bowed genus Cyrtoceras (VIII. 5), also Gomphoceras (VIII. 6) and Phragmoceras (IX. 1)-formed like Orthoceras or Cyrtoceras but with the end chamber contracted above-also Nautilus (differing from the typical later forms in the fact that the whorls do not enclose one another), Trochoccras, the remarkable Ascoceras, etc.

Among the Gasteropoda must be mentioned Pleurotomaria (IV. 4), Murchisonia, Turbo, Bellerophon, Maclurea (IV. 3) (especially in the Ordovician), Capulus (Silurian); whilst of the Pteropoda the little conical transversely-ringed Tentaculites, with an opening at the top, were important in the Silurian.

Of the Lamellibranchs or bivalve shells, we meet with only the integripalliate genera, while the sinupalliate are still entirely wanting. The widest spread are forms which resemble Avicula, 
Arca, and Astarte, and also Cypricardinia. In the Silurian Cardiola interrupta (IX. 2) is a well known and characteristic fossil.

The Brachiopoda were of much greater importance. In them also we find considerable differences between the Ordovician and Silurian faunas. In the Ordovician, Orthis (V. 2, 4; IX. 4), Leptena (IX. (i) and strophomena (V. 5 ; IX. 7) play an important part; and with these occur the genera Porambonites (IV. 6), Orthisinc (V. 1), and Platystrophia (V. 3), which are confined entirely to these rocks. At the base of the Silurian, large smooth species of Pentamerus (P. oblongus, P. estonus, P. borealis) become important; whilst higher up we meet with $P$. galeatus and $P$. Knightii (X. 3). Later, forms with internal spirals, Spiriferaceæ, occur, such as Meristella (X. 5), Atrypa (X. 4), Spirifer (X. 6, 7), Retzia, etc.; and the genus Rhynchonella (IX. 3 ; X. 1, 2), which in the Ordovician is comparatively rare, becomes here very rich in species. Chonetes (IX. 5) and Terebratula also require notice as the youngest important genera.

Bryozoa are present in the Ordovician, but neither here nor in the Silurian are they of much importance.

Passing on to the Echinodermata we find Crinoids, Echinoids and Asteroids already developed. Both the last-named groups occur at first quite rarely (Botriocidaris, Protaster), but tho Crinoids are so much the more abundant. In the Ordovician the order Cystidea, distinguished by the poor development of the arms and the absence of a stalk, is important, especially the genera Echinospharites (V. 7) and Caryocrinus (V. 6), whilst the true Crinoids or Eucrinoids are still rare; but in the Silurian the latter reach a great development, whilst the former have diminished. The Silurian Encrinoidea belong, like all the Palæozoic forms, to the division of the Tesselata or Palæocrinoidea, among which the plates composing the calyx are fused together (not, as in the later forms, articulated). The genera Cyathocrinus (XI: 2), Taxocrinus, Crotalocrinus (XI. 1), Ichthyocrinus and others, which in part pass into the newer Palæozoic formations, are specially important.

Coelenterata also have in these rocks become very numerous. In the Ordovician Corals are still few in number (here belongs the tabulate genus Monticulipora [VI. 1]); but in the Silurian, they hold an important place and often form reefs. Of the Rugosa (Tetracoralla).we may mention Cyathophyllum, Stauria (XI. 7), 
Omphyma (XI.5), Palaocychus (XI. 3), Acervularia (XI. 4), Cystiphyllum, and the operculate Goniophyllum (XI. 6); of the Tabulata, Favosites (X. 8), Alveolites, IIalysites (X. 9), IIeliolites.

In the class Hydrozoa the Graptolites are the most important. They are most nearly allied to the living Plumularias and, as in these, the skeleton is chitinous. It is only in a very few cases that any forms pass beyond the upper limit of the Silurian formation. The Ordovician Graptolites are branched, e.g. Didymograptus (VI. 3), Conograptus (VI. 2), Tetragraptus, Dichograptus-or they are double, bearing cells on both sides of the axis, e.g. Diplograptus (VI. 5), and Phyllograptus (VI. 4). In the Silurian it is only in the lower horizons that any of the double forms occur, and branched forms are quite absent-whilst the greater number are simple, e.g. Monograptus (VI. 7-9), Rastrites (VI. 11), Cyrtograptus, etc. The double genus Retiolites (VI. 10) with its net-like surface occurs in the Ordovician as well as in the Silurian.

Another peculiar form, belonging to the Hydrocorallinæ, is Stromatopora. Its knob-like remains formed of numerous concentric layers of carbonate of lime take a considerable part in the formation of the Silurian coral reefs.

Of less importance than the Hydrozoa are the sponges. A number of forms, mostly built on the Lithistid plan, such as. Astylospongia (VI. 12), Aulocopium, are tolerably widely distributed.

To the Protozoa, and indeed to the group Foraminifera, belong, as already remarked, certain forms observed in the Russian Glauconite Sand as well as others found in England, North America, and still more in Siberia; whilst Radiolaria are known from the Silurian of Scotland, Saxony, etc.

If one glances back at the foregoing observations, it will be: seen that all the great divisions of the Animal Kingdom were already represented in the Silurian period and that the lower forms especially were richly developed. If we consider, moreover, that we already know far more than 10,000 species of OrdovicoSilurian animals, that even the small area of Bohemia alone has. yielded several thousand, it will be granted that it would be quite groundless to speak of the poverty of this fauna. It was certainly not poorer than that of any later period. It was only differently developed: of the most highly organized class, the vertebrates, only the lowest division, that of the fishes, was present, and the: various groups of the lower animals of the Silurian show a mutual 
relation in numbers which differs more or less considerably from that of later times.

\section{DEVONIAN SYSTEM.}

IIISTORICAL.

THE establishment of the Devonian System was, like that of the Cambrian and Silurian, a result of the researches carried on by Murchison and Sedgwick in Western England during the fourth decade of the century. The name was first proposed in 1839 by these two observers in a paper devoted to the older rocks of Devonshire and Cornwall, ${ }^{1}$ and was applied by them to a great succession of grauwacke slates and limestones, fossils of which had already been shown by Lonsdale to be intermediate between those of the Silurian and those of the Carboniferous Limestone. Mainly on account of this, although the rocks underlying it had nowhere been found, the Devonian was even then considered by Murchison and Sedgwick to be of the same age as the Old Red Sandstone, which is developed in Middle and Northern England between the Silurian and the Carboniferous Limestone. In the same year, De la Beche, in his geological map of Devonshire and Cornwall, accepted the name Devonian; and two years later (1841) John Phillips, in his "Figures and Descriptions of the Palæozoic Fossils of Cornwall, Devon and West Somerset," described a number of the most important fossils of the English Devonian. In this way the honour of being the cradle of the Devonian formation has fallen to England, although it is not nearly so well developed there as in many other countries of Europe.

Scarcely had the English division of the older Palæozoic beds. into Cambrian, Silurian, and Devonian become known ou the Continent, when search was everywhere made to find the equivalents of that formation there also; and Murchison and Sedgwick themselves took a prominent part in these attempts.

They first broke ground on the Continent in the Rhenish Schiefergebirge and their westerly extension, the Ardennes,-the largest and best developed Devonian area of Western Europe, which, even up to the present day, continues to add more to our knowledge of the Devonian than any other area. Already scat- 
tered attempts at classification had been made in these mountains, without, however, leading to results of general importance. This is true even of the most prominent of these researches, those of the Belgian Andre Dumont, whose work in the Ardennes had not the importance of the later researches of Murchison and Sedgwick simply because it was carried out in a too purely stratigraphical way.

The famous essay of the two English observers devoted to the Rhenish mountains, appeared in $1842,{ }^{1}$ and its value was enhanced by the palæontological appendix contributed by d'Archiac and de Verneuil. In this classical work, a part of the Taunus and Hunsrïck was considered as Cambrian; the chief mass of the Schiefergebirge as Silurian; a sinaller part, including the Eifel Limestone formation, as Devonian; whilst the Culm formation was described as the equivalent of the Carboniferous Limestone. The last was one of the chief services of the work; but the classification of the older beds has needed considerable alteration. The merit of undertaking this necessary revision is due to the "Rheinischen Uebergangs-gebirges" of Ferd. Römer, appearing in 1844, in which the author shows that the chief mass of the Schiefergebirge must, according to its fossils, be correlated not with the English Silurian, but with the Devonian. In this work the limestone of the Eifel is separated as a younger Devonian from the "oider (Lower Devonian) Rhenish grauwacke," but as yet the Upper Devonian was not recognised. The separation of this is due to the work of Von Dechen ${ }^{2}$ and of the brothers Sandberger, the latter of whom by their great Monograph, "Die Versteinerungen des rheinischen Schichtensystems in Nassau," 3 contributed much to the establishment of the !now universal three-fold division of the Devonian.

Among the more important of the later contributions to our knowledge of the Devonian are the researches of J. Gosselet in the Ardennes, ${ }^{4}$ which are closely connected with the older work of Dumont. These studies have made known, among other things, the wide extent of the Upper Devonian Iberg Limestone, first distinguished by Fried. Adolph Römer in the Harz.

1 "Trans. Geol. Soc." (2), vi. p. 222.

2 "Verh. naturh. Ver. Rheinl.-Westf." (1855).

3 Wiesbaden (1850-56).

4 "Mém.sur les terrains primaires de la Belgique" (1860). "L'Ardenne" (1887). 
The observations of E. Kayser ${ }^{1}$ on the Rhenish Devonian have been undertaken with a view to a detailed classification of the system based especially on the distribution of the fossils; while for the further development of our knowledge of the German Devonian the works of the Prussian Geological Survey are of the greatest importance. These have not only led to a subdivision of the Rhenish Lower Devonian and to the removal of the Wissenbach or Orthoceras beds from the Lower to the Middle; but have also, by the establishment of the oft-discussed Hercynian of the Harz, been the cause of a great and general change in the limitation of the Silurian and Devonian systems.

\section{DISTRIBUTION AND DEVELOPIENT OF THE DEVUNIAN FORILATION.}

Rhenish Area.-The extent of the Devonian in the Rhenish Schiefergebirge, the accuracy of the observations made upon it, the completeness and variety of the series, and its richness in fossils, make it important to begin the account of the system with a description of this area. This mountain region, which in general has the form of a plateau, stretches from the Eder and Diemel to beyond the Mense, and is formed of more or less strongly compressed beds, which, especially in the southern part of the district, present over a wide area a system of reversed folds dipping regularly to the S.E. All these folds consist of Devonian rocks, altogether probably at least 20,000 feet thick, which are accompanied locally by Lower Carboniferous beds. Beds of Silurian age do indeed occur between Namur and Liège, but are unknown in the interior of the mountains themselves. The occurrence of still older formations is limited to a few island-like Cambrian kernels rising up through the Devonian, such as the Hohe Venn, not far from Aixla-Chapelle; the so-called Massif of Rocroi below Mezières on the Meuse, which-as A. Dumont showed-is surrounded by unconformable Devonian beds; and some masses of sericite-gneiss, etc., in the Hunsrück and the Taunus, which are supposed to be of Archæan age.

Within the Devonian rocks themselves no unconformity has yet been found ; and the whole succession seems to have been deposited without any important check, and passes up without break into the overlying Culm.

1 Zeits. d. deutsch. geol. Ges. $(1870,1872$, etc.). 
Lower Devonian.- This consists of at least 10,000 feet of sandy and clayey beds, almost entirely free from lime. The fossils which occur in it are almost always mere stone-casts without the original calcareous shells. They are generally rare and are found only in isolated beds, which are often separated by many hundred feet of practically unfossiliferous rock. The fauna consists chiefly of Brachiopoda. The only other important forms are Lamellibranchs, Crinoids, and some Trilobites and Gasteropods, whilst Cephalopods and Corals are few in number. Some species, such as Chonetes sarcinulata, C. plebeja (XII. 5), Orthis hysterita (vulvaria [XII. 4]), Grammysia hamiltonensis (XIII. 3), Pterinea costata, Pleurodictyum problematicum (XII. 2), etc., go through the whole or almost the whole series of beds, whilst others have a more restricted range. In general the constitution of the famna points to a shallow sea, and the ripple-marks frequently met with at all horizons also speak in favour of this view. The classification of the Rhenish Lower Devonian is due mainly to the researches of the Prussian Geological Survey, especially those of C. Koch and E. Kayser. ${ }^{1}$

The lowest subdivision of the Lower Devonian, resting directly on the Cambrian Rocks, consists in the Ardennes and the Hohe Tenn of the Gedinnien. Beginning usually with a coarse conglomerate, it is made up of variegated, phyllitic schists, sandstones, and arkoses, which here and there have yielded a small fauna. Very probably the similar, but generally more strongly crystalline rocks of the southern border of the Taunus and Hunsrück (sericite gneiss, etc.), the base of which is unknown, are of the same age. A circumstance which tells most strongly in favour of this view,

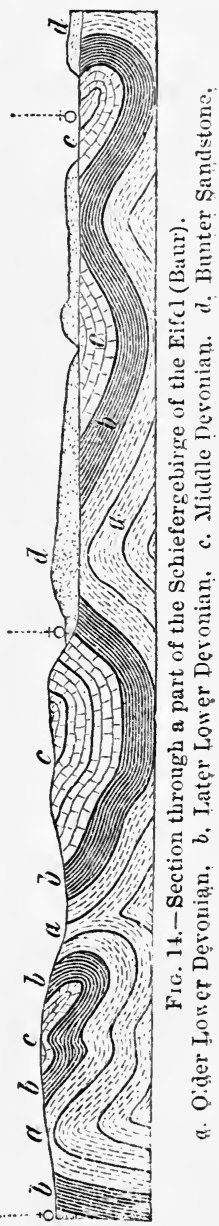
is that they, like the already mentioned Ardennes rocks, aro covered conformably by the next succeeding division of the Lower Devonian, the Taunus quartzite; but for the most part they have recently been referred by Gosselet to the Archæan.

1 "Jahrb. d. preuss. geol. L.-Anst." (1881), p. 190 ; ibid. (1884), p. LII. Se also Frech, Zeits. d. deutsch. geol. Ges. (1889), p. 175. 
The Taunus quartzite, consisting almost exclusively of white quartzite, forms the crest of the Taunus and Hunsrïck, but is also developed in the neighbourhood of the Venn, in Belgium, and probably also in the Altvatergebirge in Austrian Silesia. Fossils are very rare, the most characteristic being Spirifer primcevus (XIII. (j), S. hystericus (=microptems), Rensscaria crassicosta, R. striyiceps (XII. 3), and Kochia capuliformis. The Taunus quartzite is succeeded by the Hunsrück slates, a thick series of dark coloured clay slates, including numerous layers of roofing slate. 'They form the monotonous plateaux of Hunsrück and Taunus, but are also repeated in their characteristic form in the Vem and the Ardennes. In these areas, however, they are for the most part represented by the Grauwacke of Montigny. The famna of the Hunsrück schists (chief localities, Bundenbach and Gemünden in the Hunsrïck, Caub on the Rhine, Alles on the Semois) unlike that of the rest of the Lower Devonian, consists chiefly of trilobites (Phacops Ferdinandi, Homalonotus omatus, etc., Cryphaus, Dalmanites [Odontochile]), mailed fish, bivalves, cephalopods (Orthoceras, Goniatites), crinoids and beautifully preserved starfishes, whilst brachiopods are almost entirely wanting. In the Siegerland, in the valley of the Rhine below Andernach, in the valley of the Aar and a part of the Eifel, the Taunus quartzite and Hunsrück slates are not developed as such but are represented by the Siegen Grauwacke, a thick complex of grauwacke and slates. The fauna of these beds consists especially of brachiopods (Spirifer mimavus, Rensselaria crassicosta, etc.), but also contains bivalves, gasteropods, trilobites (Homalonotris ornatus), crinoids (Ctenocrimus typus [XII. 1]), etc., and agrees closely with that of the Taunus quartzite and Hunsrück slates.

The succeeding upper half of the Rhenish Lower Devonian is formed by the Coblenz beds of the Prussian Survey, the Spirifer Sandstone of the brothers Sandberger. In the Rhine area it may be divided into the three following groups: 1. Lower Coblenz beds, consisting mainly of rough grauwacke, which contain as characteristic fossils Strophomena laticosta (XIII. 5) Orthis circularis, Spirifer dunensis (XII. 6) IIomalonotus ornatus, H. crassicauda (XII. 7), etc. One of the chief fossil localities is Stadtfeld in the Eifel. 2. The Coblenz quartzite, a white platy quartzite, found especially in the neighbourhood of Coblenz, but also on the Lahn and Moselle, in the Westerwald, in the Eifel and Luxemburg. The Quartzite of. the Kellerwald, not far from Wildungen, 
is also of essentially the same age. The fauna of this subdivision is more nearly allied to that of the Upper than of the Lower Coblenz beds, but shows it to be distinct from both. In the Ardennes the place of the Quartzite is taken by red sandstones and schists, the so-called beds of Burnot, which, however, appear to represent not only the quartzite but also a part of the Lower Coblenz beds. 3. The Upper Coblenz beds consist of soft grauwacke slates, which in many places (Coblenz, Ems, Daleiden, etc.) contain a very rich fauna. Among the specially typical species are Spirifer auriculatus, S. curratus and S. paradoxus (=macropterus), Atrypa reticularis, Chonetes dilatata, Ctenocrinus decadactylus, Cryphaeus laciniatus (XIII. 1), Homalonotus lavicauda, etc. At their upper boundary these slates in many places (the old paper mill near Haiger, mouth of the Ruppach valley near Diez, etc.) pass up into slates, which though containing for the most part Lower Devonian species, also include a few Middle Devonian forms (Spirifer intermedius = speciosus [XIV.2], S. elegans, S. aculeatus, Orthis striatula [XIV. 8], etc.). On the left bank of the Rhine these uppermost Coblenz beds are represented by calcareous sandy rocks accompanied by oolitic red hæmatite, which directly underlie the Eifel Limestone, and harbour a similar mixture of Lower and Middle Devonian species (among the latter Calceola sandalina [XVI. 6]).

Middle Devonian.-The Middle Devonian of the Rhine is mainly composed of calcareous rocks, whilst sandy beds play quite a subordinate part, and it thus contrasts strongly with the Lower Devonian. In the ErfeL, ${ }^{1}$ the group occurs in a series of troughs in the Lower Devonian running from S.W. to N.E. ; and here, as also in BeLgiUm, the lower part of the series consists of marly limestones and slates; these are known as the Calceola beds, and contain those numerous finely preserved fossils, for which the Eife] has become so famous. Along with brachiopods-of which we can mention only Atrypa reticularis, Athyris concentrica (XIV. 4), Merista plebeja, Spirifer intermedius = speciosus (XIV. 2), S. curvatus, S. ostiolatus (XIV. 1), Cyrtina heteroclita (XIV. 5), Pentamerus galeatus (XIV. 6), Rhynchonella parallelopipeda, Orthis striatula (XIV. 8), and Streptorhynchus umbraculum (XIV. 9)corals (Calceola sandalina [XVI. 6]), Cyathophyllum ceratites, C. heliantoides, Cystiphyllum resiculosum (XVI. 4), Heliolites porosa

${ }^{1}$ E. Kayser. Zeits. d. deutsch. geol. Ges. (1871), p. 289. Frech, "Paläont. Abh. von Dames u. Kayser," III., pt. 3 (1886). 
(XVI. 7), Alveolites suborbicularis, several species of Favosites, etc., and Stromatopora, are especially abundant. A very common trilnbite of this horizon is Phacops Schlotheimi (XV.1). The lowest zone of the Calceola beds, the so-called Cultrijugatus zone, is specially characterized by the occurrence of the large Spirifer cultrijugatus - a younger variety of $S_{p}$. auriculatus,-Rhynchonella Orbignyana, and other species.

The upper division of the Middle Devonian consists in the EifeI and in Belgium, of a pure massive limestone and dolomite, the Stringocephalus Limestone, which contains numerous brachiopods, gasteropods and cephalopods. The typical fossils are Stringocephalus Burtini (XIV. 7), Uncites gryplius (XIV. 3), Macrochilus arculatum (XV. 5), Pleurotomaria delphinuloides (XV.3), Murchisonia bilineata (XV.4), and Megalodon cucullatum (XIV.10). The boundary between the Calceola and Stringocephalus beds is formed in the Eifel by the Crinoid beds, which are often almost exclusively made up of Crinoid stems, and yield all the beautiful crinoids of the Eifel Limestone (Cupressocrinus [XVI. 1], Poteriocrinus, Melocrinus, Rhodocrinus [XV. 6], etc.).Calcoola sandalina, however, passes up beyond this boundary.

In other parts of the Schiefergebirge, limestones of the same age are also developed, as at Paffrath not far froin Cologne (Paffrath Limestone), Elberfeld, Hagen, Brilon, etc. (Elberfeld Limestone), in the Lahn region at Wetzlar, Diez, etc. In the neighbourhood of Brilon the uppermost part of this limestone is changed in contact with diabase into red ironstone, which encloses a fauna in many ways very different (with Cardiola retrostriata [X VII. 8], and some other Upper Deronian species).

A very different facies of the Middle Devonian is met with in southern Westphalia, in the Lexve area. The Calceola beds and a part of the Stringocephalus beds are here represented by sandy, clayey rocks, which closely resemble the Spirifer sandstone, but, as was first shown by F. Römer, contain Middle Devonian fossils. V. Dechen called these beds the Lenne schists. Shars.

The Middle Devonian is developed in yet another way in the Dillenberg area, the Hessian Hinterland, in the region of Wildungen, as well as on the Moselle (at Olkenbach). In these places it takes on the form of dark clay and roofing slates with interbedded limestones and quartzites. These slates contain abundance of Tentaculites, which often cover the surfaces of the slates in thousands (hence Tentaculite-schists [R. Ludwig]); but otherwise the 
fauna is scanty, consisting chiefly of cephalopods and trilobites Often, especially at Wissenbach not far from Dillenburg and in the Ruppach valley at Diez, the fossils are silicified, and here the slates are usually known as the Wissenbach or Orthoceras Slates. As Kayser has shown, ${ }^{1}$ two different faunas may be distinguished in them: an older with Goniatites (Anarcestes) lateseptatus (XIX. 2), and subnautilinus, G. (Mimoceras) gracilis (= compressus), Hercoceras subtuberculatum (XIX. 1), Orthoceras triangulare, etc.; and a younger with Goniatites (Pinacites) Jugleri, G. (Aphyllites) occultus (XIX. 3) and Dannenbergi, Bactrites carinatus and Schlotheimi, etc. These two groups are also developed in calcareous form at Wildungen, at Günterod and Bicken (between Marburg and Herborn) and elsewhere; and these limestones, which are always of very restricted extent, are particularly remarkable on account of the appearance in them of a number of trilobites (Bronteus [Thysanopeltis] speciosus =thysanopeltis [XIX. 5], Phacops fecundus, etc.), and of the fossils which are characteristic of the Hercynian (to be described below) series of Bohemia, the Harz and other regions. Like the Hunsrück slates of the Lower Devonian, the Middle Devonian beds in question may be looked upon as deposits of a deeper and more open sea.

Lastly, it must be mentioned that in the LaHN and DILL areas, and also in some parts of the Sauerland and Waldeck, the Middle Devonian is, sometimes in part and sometimes entirely, represented by diabase (less often porphyry), and its tufaceous and brecciated form known as Schalstein, which is often fossiliferous.

Upper Devonian.-The Upper Devonian of the Rhine everywhere falls into an older and a newer division. The older Upper Devonian is very variously developed. In the country between Düsseldorf and Brilon it is represented by dark somewhat calcareous slates, v. Dechen's Flinz. At Aix-la-Chapelle, in the Eifel and in Belgium, on the other hand, at the same level, directly above the Stringocephalus Limestone, we find the Brachiopod Limestone. Rhynchonella cuboides (XVIII. 2), R. putgnus, R. acuminata, Spirifer Ternenili (XVIII. 1), Camarophoria formosa, Productus subaculeatus, along with a few Goniatites (G. [Gephyroceras] intumescens [XVII. 1]; G. [Tornoceras] simplex [XVII. 3]) and .corals, are the characteristic fossils.

At other places (Breitscheid near Dillenburg, etc.) corals-

1 "Jahrb. d. preuss. geol. L.-Anst." (1883), p."1. 
among which the genus Phillipsastrcea (XVII. 9) is especially important-are abundant enough to form more or less unbedded reefs of limestone, which may be called, after the longest known occurrence in Upper Harz, the Iberg Limestone. In these coral limestones also, Rhynchonella cuboides, Spirifer Verneuili, and species of Gephyroceras are very important. In Beigium these brachiopod and coral limestones are known as the Limestone of Frasue.

Another form of the older Upper Devonian is the Adorf Limestone, so called after its chief locality in Waldeck. This is met with in Nassan, Westphalia, and Waldeck, and consists of reddish or blackish limestone, almost everywhere nodular in structure, containing a rich cephalopod fauna. Here also Goniatites intumescens is the chief fossil; but besides this we find many other species of Gephyroceras, Gon. (Beloceras) multilobatus, d. (Tornoceras) simplex, and the elegant Cardiola retrostriata (XVII. 8). Certain marl-slates which, near Büdesheim in the Eifel, nverlie the marly limestone with Rhynchonella cuboides, contain similar Goniatites and Cardiola retrostriata, and evidently are only a slightly altered form of this limestone. It is on account of the important part played by Goniatites intumescens in the whole of the older Upper Devonian that Kayser has called it the Intumescens series.

The younger Upper Devonian is represented on the right wank of the Rhine chiefly by the Cypridina slates (Sandberger), which are soft light red or greenish slates with a small bivalved crustacean Entomis (Cypridina) serrato-striata (XVII. 6). Besides this form there are usually found only Avicula (Posidonia) venusta and Phacops cryptophthalmus (XVII. 7). Near the upper limit of these slates there are frequently more or less thick strata of nodular limestone (Nierenkalk), which at Enkeberg near Brilon, at Wildungen, in the Dillenburg area, etc., contain a peculiar Goniatite fauna, especially G. (Sporadoceras) Bronni, and also the grenus Clymenia - a genus which is entirely limited to this uppermost division of the Devonian (Clymenia levigata, C. undulata [XVII. 4], C. striata, etc.). These Clymenia Limestones represent the greater part of what v. Dechen has called the Kramenzel Limestone.

Somewhat lower than these lie the Goniatite slates of Nehden, not far from Brilon. At first associated by the brothers Sandberger with the Goniatite slates of Büdesheim, they were, after

C. G. 
Beyrich had perceived the close agreement of their fauna with that of the Clymenia Limestone, placed by Kayser as a special (Nehden) zone at the base of the Clymenia Series, including: under this term the whole of the younger Upper Devonian.

At many places on the right bank of the Rhine pale micaceous platy sandstones are interbedded with the Cypridina slates. When these sandstones, which include scarcely anything but indistinct plant remains, are more strongly developed, they have been called by a Westphalian local name, Pön sandstone.

In Belgium the younger Upper Devonian occurs in still another form, firstly as greenish brachiopod slates (with Spirifer. Terneuili, etc.), the slates of Famenne; and secondly as soft, brownish, micaceous sandstones, the Psammites du Condroz, which yield brachiopods (Spirifer Terneuili, etc.) and lamellibranchs. ("Cucullad" Irardingii, etc.), and are only a sandy facies of the Famenne slates. At their upper limit, directly below the Carboniferous Limestone, the so-called Limestones of Etroeungt occur locally. They contain a mixture of Devonian and Carboniferous brachiopods, and also the trilobite called Phacops latifrons. The sandstones and slates extend in an easterly direction as far as the neighbourhood of Aix-la-Chapelle-the sandstone indeed is. developed with a rich brachiopod fauna near Velbert, north-east of Dïsseldorf.

In the Upper Devonian of the Dilu and Lahn regions, as in the Lower Devonian of the same area, the normal sediments are in part replaced by schalstein and diabase. On account of the red ironstone beds connected with these occurrences and produced by the alteration of what were originally limestone beds, these: rocks are of great practical importance.-The table on the followingpage summarises the foregoing account.

The Harz. - The Harz, which, next to the Rhine area, is the most important of the German mountain ranges for a knowledge of the Devonian, was originally described by A. Römer : ${ }^{1}$ but it has recently been the subject of a detailed examination by the Prussian Survey, carried out with extraordinary expenditure of time and pains, especially by C. A. Lossen." If all the riddles of the geology of the Harz are not yet solved, this is due both to

1 "Verstein. d. Harzgebirges" (1843). "Buiträge z. Kenntniss d. nordwestl. Harzgeb. Paläontogr." (1850-1866).

2 See especially the "Geol. Uebersichtskarte des Harzgebirges" (1882). 
D. DEVONIAN SYSTEM.

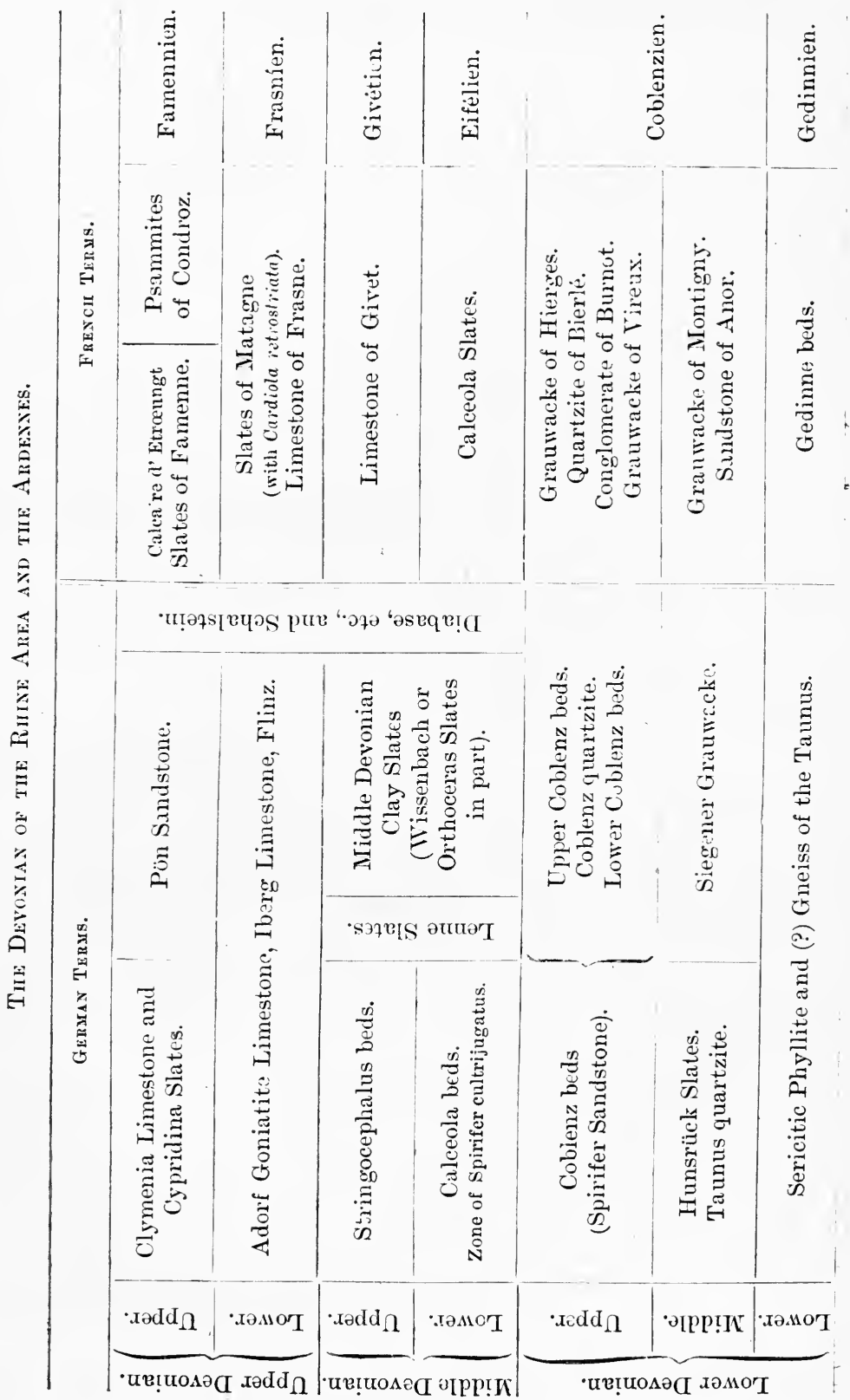


the unsatisfactory exposures and to the extremely complicated structure of the beds forming this little mountain island.

In the UPPER HARZ the succession of the Devonian beds represents in full the whole series of the Rhine. The oldest beds here rising to the surface, the Quartzite-sandstone of the Kahleberg and Rammelsberg between Goslar and Clausthal, are the equivalents of the Coblenz Quartzite and the Upper Coblenz beds; the Middle Devonian is represented by marly slates with Calceola sandalina, iron-stained limestone with Stringocephalus Burtini, and dark slates with silicified Wissenbach Goniatites (Goslar slates); and lastly the Upper Devonian is represented by the black limestone of Altenau with Goniatites intumescens and Cardiola retrostriata, the coral limestone of the Iberg (near Grund) with Rhynchonella cuboides, etc., Cypridina slates (near Lautenthal) and Clymenia Limestone (near Rhomker Halle).

In the Lower Harz also the Iberg Limestone and the Stringocephalus beds accompanied by Schalstein form a large basin in the neighbourhood of Elbingerode and Rübeland; but the whole of the remainder of the middle and eastern part of the mountains is occupied by a thick more ancient series of sandstones and slates with numerous sheets and dykes of eruptive rocks, which are classified from above downwards as follows:--

Elbingerode Grau wacke.

Zorge Slates.

Hauptkieselschiefer.

Upper Wieda Slates.

Hauptquartzit.

Hercynian. $\left\{\begin{array}{c}\text { Lower Wieda Slates with graptolites and the so-called } \\ \text { Hercynian Limestone. } \\ \text { Tanner Grauwacke (with Culm like flora). }\end{array}\right.$

Of these divisions the Hauptquartzit-a schist-zone with interbedded quartzites-contains the usual brachiopod fauna of the Rhenish Upper Coblenz berls (Spirifer auriculatus, Atrypa reticularis, etc.). The overlying beds must therefore belong to the Middle Devonian; and this is indeed proved to be the case by the scanty fauna (corresponding with that of the older Wissenbach slates) of the Zorge slates, with Goniatites (Mimoceras) gracilis, T'entaculites acuarius, etc. ${ }^{1}$ )

A very peculiar fauna on the other hand distinguishes the

1 Kayser. Fauna des Hauptquartzites und der Zorger Schiefer. "Abl.. a. preuss. geol. Landesanst." (1889). 
lowest beds, the Hercynian of Beyrich and Lossen, which conformably underlie the Hauptquartzit. The Lower Wieda Slates contain a most remarkable fauna of graptolites (always simple forms); whilst the deeper lenticular "Hercynian" limestone masses of Mügdesprung, Harzgerode, Hasselfeld, Wieda, Zorge, Ilsenburg, etc., contain a tolerably rich fauna consisting of trilobites (species of Dalmanites of the group of D. Hausmanni= Odontochile [XVIII. 5], Cryphaus, Phacops, Bronteus, Acidaspis, etc.), Orthoceratites (O. triangulare, etc.), numerous brachiopods (in great part the species of the Bohemian limestone of Konjeprus), lamellibranchs, gasteropods (including especially many Capulide [XIX. 6]) and corals (among them Pleurodictyum). First described by $H$. Römer and Giebel as Silurian, this Hercynian fauna of the Lower Harz has more recently been compared by E. Beyrich with the fauna of the Bohemian stages $\mathrm{F}, \mathrm{G}, \mathrm{H}$ of Barrande, and was afterwards described by Kayser, on the basis of a detailed examination, ${ }^{1}$ as Lower Devonian-an age which the same observer has also claimed for the Bohemian beds already mentioned, for some Rhenish, French and Ural limestones characterized by a similar fauna, and also for the American Lower Helderberg beds.

Bohemia.-The Devonian beds of Bohemia occupy a relatively small area, and are confined to the country between Prague and Beraun. They lie conformably on the Upper Silurian (Stage Ee* of Barrande), and may be classified according to this author as follows (from above downwards) :-

H. Black plant-bearing slates.

$\mathrm{Gg}^{3}$. Cephalopod-bearing nodular limestone of Hlubočep.

$\mathrm{Gg}^{2}$. Tentaculite slates.

Gg1. Nodular limestone with Cephalopoda, Pelecypoda, Trilobita.

Ff. Light coloured, crystalline Brachiopod and Trilobite Limestones of Konjeprus and Mnenian.

Ff ${ }^{1}$. Black Limestone.

The Limestone $\mathrm{Ff}^{1}$, which, if Novák is right, is only a facies of $\mathrm{Ff}^{2}$, contains but few fossils, the most important being the youngest Bohemian graptolites; but the succeeding division conceals a rich fauna, which is very like that of the Hercynian of the Harz, and consists of Goniatites (here also a series of Wissenbach species), trilobites (Odontochile [XVIII. 5], Phacops [especially fecundus], Thysanopeltis [speciosus, XIX. 5], Proëtus, Cheirumıs,

1 Fauna der ältesten Devanbildungen d. Harzes. "Abh. d. preuss. geol. Landesanstalt" (1878). 
Bronteus, Acidaspis, Harpes, Calymene, etc.), gasteropods (numerous Capulidæ), brachiopods (among them a species of Stringocephalus), lamellibranchs and corals. With these are also found the peculiar mailed fishes (Placoderms), which are represented in the Harz only by traces. The presence of these fishes and of numerous Goniatites (with the genera Anarcestes, Aphyllites, Mimoceras, Pinacites, etc.), both of which are unknown in the Silurian, but are very characteristic of the Devonian, has caused E. Kayser to refer these beds, hitherto commonly considered as Silurian, to the Devonian. While Kayser includes the whole of the Bohemian succession in the Lower Devonian, and attempts to explain their great palæontological difference from the Rhenish Lower Devonian on the supposition that the latter were deposited in a shallow, the former in a deeper, sea; we may, probably not incorrectly, correlate only the stages $\mathrm{F}^{1}-\mathrm{G}^{2}$ with the Lower Devonian, but place $\mathrm{G}^{3}$, with its fauna so like that of the Wissenbach beds, in the Middle Devonian, and $\mathrm{H}$ in the Upper Devonian. ${ }^{1}$

It still remains to be remarked that a few small occurrences of limestone have been discovered in later times at several places in the Rhine area-especially at Greifenstein, not far from Wetzlar-and that both petrographically and palæontologically these closely resemble the Limestones of Konjeprus and Mnenian. In these Rhenish limestones also, the Bohemian forms Phacops fecundus, P. cephalotes (XIX. 4), Thysanopeltis speciosus (XIX.5), Proëtus orbitatus, P. eremita and others, Lichas IIaueri, Tentaculites acuarius, Merista passer, II. securis, etc., are among the most abundant species. ${ }^{2}$ Moreover the Cephalopod and Trilobite Limestones of Wild ungen, already described, which belong to the upper Middle Devonian, include a not inconsiderable number of Hercynian species.

Thuringia.- We find a development of the Devonian in many ways like that of the Harz and Bohemia in the region of Thuringia and the Fichtelgebirge; and this has been made known especially by the researches of Gümbel and Liebe:- ${ }^{3}$

i Frech, Zeits. d. deutsch. geol. Ges. (1889), p. 175.

2. Mäurer, Der Kalk von Greifenstein, "N. Jahrb. f. Min.," Beilageband I. (1880). - Novák, Vergleichende Studien a. einig. Trilobiten aus dem Hercyn von Bicken, Wildungen, Greifenstein, und Böhmen, "Paläont. Abh." (1890).

"G. Gübel, "Geogn. Beschr. d. Fichtelgeb." (1879). Liebe, Der Schichtenaufbau Ostthuringens, "Abh. d. preuss. geol. Landesanst." (1S84). 
Upper Devonian : Clymenia Limestone (especially near Schübelhammer and Saalfeld), ${ }^{1}$ Cypridina slates, Adorf Goniatite Limestone.

Iriddle Devonian: Diabase tuffs and Schalstein (Planschwitz Tufl') with Corals and Brachiopods.

Lower Devouian: Tentaculites and Nereites beds, Tentaculite nodular' Limestone with a small Hereynian fauna (Odontochile, etc.).

Uneonformity.

Upper silurian.

Devonian beds of various ages are also known in Silesia Clymenia Limestone of Ebersdorf, Iberg Limestone of Oberkunzendorf), Moravia (Stringocephalus Limestone of Rittberg near Olmütz) and Poland (Upper Devonian of Kielce, Middle Devonian of Cracow, etc.). In South Germany undoubted Devonian rocks have quite recently been found for the first time in the Vosges (Stringocephalus Limestone near Schirmeck).

Alps. -Limestones with Clymenia have long been known in the Alps, in the region of Gratz in Steiermark. Lately the Austrian geologists, and also especially Frech, ${ }^{2}$ have recognised in the Carinthian Alps various other divisions of the Devonian, which there, as in Bohemia, appear to follow on the Silurian withont a break. According to these interesting discoveries the Devonian in this region is constituted as follows:-

Upper Devonian: Clymenia Limestone, Iberg Limestone.

Middle Devonian: Coral Limestone with Stringocephalus Burtini and Macrochilus arculatum.

Limestone Reef with brachiopods of the Konjeprus Limestone.

Lower Devonian: \{ Slates and nodular Limestone with brachiopods and Goniatites (Anarcestes lateseptatus, Tornoceras, etc.

France. - In France Devonian beds are found both in the NorthWest and in the South of the country. Near Ferques, not far from Boulogne-sur-Mer, fossiliferous limestones of the age of the Belgian Limestone of Frasne, have long been known. In Brittany, according to Charles Barrois, ${ }^{3}$ the Devonian is divided as follows :-

Upper Devonian: Slates of Rostellec.

:Middìe Devonian: Slates of Porsguen, with Wissenbach fauna.

Lower Devonian : $\left\{\begin{array}{c}\text { Slates and Limestone of Néhou, with Coblenz } \\ \text { fossils. } \\ \text { Quartzite of Gahard (=Taunus quartzite). } \\ \text { Quartzite of Plougastel (=Gedimnien). }\end{array}\right.$

1 Gümbel, Die Clymenier des Fichtelgebirges, "Pal:̈ontogr." (1863).

${ }_{2}^{2}$ Frech, Keits. d. deutsch. geol. Gés. (1887), p. 660.

3 Bull. Soc. Géol. de France, xiv. (1866), p. 655. 
Of especial interest is the occurrence near Erbray in the department of the Loire Inférieure of an undoubted Hercynian. Limestone with a rich fauna (numerous Bohemian brachiopods and gasteropods-here also especially Capulidae-Orthoceras triangulare, a species of Calymene, corals). Charles Barrois ${ }^{1}$ correlates. it with the Belgian Gedinnien; Oehlert, on the other hand, with the Coblenz beds.

In South France Devonian rocks are especially developed in the region of Cabrières, not far from Montpellier. In the Upper Deronian we find here also Nierenkalk (nodular limestone). with Clymenias, and lower down a similar rock with Goniatites. intumescens; in the Middle Deronian (?), marly limestone with. Calceola sandalina, and crystalline limestone, which contains in part species of the Konjeprus limestone.2 In the Pyrenees also variegated nodular limestones with Upper Deronian Goniatites (marbre griotte in part) are very widely spread. Near Catherveille a small Hercynian fauna (with Dalmanites, Thysanopeltis, Phacops fecundus, etc.) has been proved.

In Spain and Portugal Devonian rocks have been known for a long time. Dark slates, limestones and sandstones are the most widely spread rocks.

In Asturias they are classified by Barrois, ${ }^{3}$ as follows, in descending order:-

Sandstone of Cué.

Limestone of Candas with Sipirifer Vernenili.

Sundstone with Gosseletia.

Limestone of Moniello, with Caiceola sandalina.

Limstone of Arnao, with Sp. cultrijuyatus.

Limestone of Ferrones with Athyris.

Slates and limestones of Nieva with sp. hystericus.

Ferruginous sandstone of Furada.

The Gedinnien is unrepresented.
Famennien.

Frasnien.

Givétien.

jEifélien.

Coblenzien.

Taunusien.

British Isles. - In England the Devonian is developed in two. quite different and strongly marked facies, namely, 1. as a series. of slaty, sandy, and calcareous beds, which in all points resembles. that of the Continent; and 2. in the form of a thick red sandstone series, distinguished by a rich and peculiar fish fauna, the Old Red Sandstone.

1 Le Calcaire d'Erbray, "Mem. Soc. géol. du Nord." (1889).

" Frech, Zeits. d. deutsch. geol. Ges. (1887), p. 360 .

3 Terrains Anciens des Asturies et de la Galice. "Mém. Soc. géol. du. Nord" (1882). 
The first Facies, to which the name Devonian was originally applied, is limited to Devonshire and the neighbouring parts of Somerset and Cornwall, and consists of a thick series of grauwacke, slates, and limestones, with interbedded eruptive rocks and tuffs. It is everywhere strongly folded and cut through by numerous faults, so that the accurate determination of the relative age of the various subdivisions is possible only by means of the knowledge gained on the Continent concerning the stratigraphical meaning of the Devonian fossils. The agreement of the English Devonian with the Rhenish is very detailed. In the Lower Devonian, for example at Looe in Cornwall, we meet with typical Siegen grauwacke with Spirifer primavus, Rhynchonella Pengelliana, Streptorhynchus gigas, and other characteristic forms, whilst in the neighbourhood of Torquay both the Lower and the Upper Coblenz beds are recognisable (the former with Strophomena laticosta and IIomalonotus armatus, the latter with Spirifer auriculatus, etc.). The Middle Devonian is represented by Calceola slates and limestones and by the Stringocephalus Limestone with its type fossils: the Upper Devonian by Iberg Limestone, Adorf Goniatite limestone, and Büdesheim Goniatite slates, Cypridina slates, and Clymenia limestone (the last especially near Petherwin in Cornwall).

The general succession in South Devon, ${ }^{1}$ so far as it lias yet been determined, is as follows:-

$$
\begin{array}{ll}
\text { Upper. } & \left\{\begin{array}{l}
\text { Cypridina slates (Entomis slates). } \\
\text { Goniatite limestones and shales. } \\
\text { Massive limestones. }
\end{array}\right. \\
\text { Middle. } & \left\{\begin{array}{l}
\text { Middle Devonian limestones. } \\
\text { Ashprington volcanic series. } \\
\text { Eifelian slates and shaly limestones. }
\end{array}\right. \\
\text { Lower. } \quad \text { Grits and sandstones. }
\end{array}
$$

The boundary between the Lower and Middle Devonian can only be traced by means of the evidence of fossils; and that between the Middle and Upper is at present undeterminable.

The Lower Devonian includes the Lincombe and Warbury Hill grits, the Meadfoot beds (in part at least), and the Cockington grits. They have yielded Homalonotus, Pleurodictyum problematicum, etc.; but according to Ussher the beds near Torquay and Paignton are too much disturbed to admit of division into Lower and Upper Coblenzian.

The Middle Devonian commences with slates containing Streptorhynchus erenistria, Spirifer speciosus, etc., overlain by thin limestones with Calceola sandalina, etc. These represent the Eifelian or Calceola slates and limestones.-The limestone passes up without any line of demarcation into the

1 Ussher, Quart. Journ. Geol. Soc. (1890), p. 487. 
bedded Middle Devonian or Stringocephalus limestone, with the characteristic fossils.- In the Middle Devonian, there is in some parts of S. Deron a great series of tuffs, schalsteins and diabase masses, like those in the Lahn and Dill areas of the Rhine; and these appear to have been erupted at the time of the deposition of the later stages of the Calceola limestone and the lower part of the Stringocephalus limestone.

The Upper Devonian begins with massive limestones which have yielded Rhynchonella cuboides, Productus subaculeatus, and other fossils of the Cuboides beds of the Eifel (=Lower Frasnian of the Ardennes). These are followed by slates including limestone nodules, in which at Saltern Cove, isilver Cove, etc., Cardiola retrostriata, Goniatites, and Clymenia are found, Lastly we find clay slates with Posidonomya venusia and Entomis serratostriata, which clearly are equivalent to the Cypridina slates of the Eifel.

The whole series, as has been remarked by Champernowne, resembles that of the Ardemes and the Eifel more closely than it does that of N. Devon.

The succession in North Devon is as follows:-

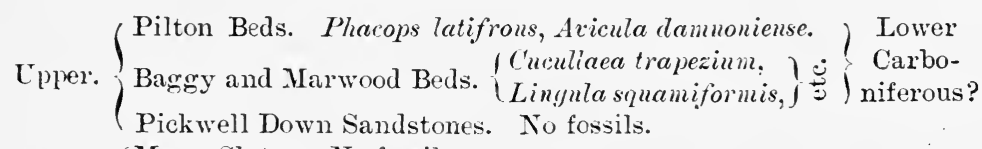

Viddle Morte Slates. No fossils.

Middle. IIfracombe Beds. Streptorlynchus, Stringocephalus Burtini.

Lower. $\left\{\begin{array}{l}\text { Hangman Grits. Myalina, Cucullaea. } \\ \text { Lynton Slates. Megalolon cucullatum, Orthis arcuata. } \\ \text { Foreland Sandstones. Plant remains. }\end{array}\right.$

The Hangman Grits may be the Foreland Sandstone repeated by a fault. The most distinctly marked horizon for comparison with other areas is that of the Ilfracombe Beds, which contain a Stringocephalus limestone like that of the Middle Devonian of the Eifel.

The second or Old Red Sandstone facies is made up of some 10,000 feet of massive red and greyish micaceous sandstone and marls, recalling the German Bunter sandstone, which have long. been known in South Wales and Herefordshire as forming a foundation for the Carboniferous system, and which are also widely spread in Scotland and the Orkney Islands. In their fauna, their general appearance, and their almost universally horizontal position, these red sandstones differ greatly from the normal Devonian. They contain none of the numerous trilobites, brachiopods, corals, or other common fossils of the latter, and indeed except a few land plants (Sphenopteris, Lepidodendron), there are scarcely any fossils except remains of large crustacea (Pterygotus anglicus, Eurypterus, etc.), and of fishes, among which the remarkable mailed fishes or Placoderms-Pterichthys [XVIII. 4], Coccosteus, etc., (first adequately described by $\mathrm{Agassiz}^{1}$ )-and other Ganoids are

1 "Monographie.des poissons du vieux gris rouge" (1814). 
especially abundant. In the Russian Baltic Provinces and in Podolia, and even in Spitzbergen and Greenland, the Old Red Sandstone facies of the Devonian is also developed.

Some English geologists, on account of the presence of land plants, and of a bivalve outwardly resembling Anodonta, and also on account of the fact that the Ganoids of the present day are limited to fresh water, consider this facies to be a freshwater formation. But the occurrence of the marine genus Conularia in the English Old Red is opposed to this view; and still more the frequently observed occurrence, in Germany and Russia, of mailed fishes along with brachiopods, crinoids, corals, etc.

In S. Wales and Hereford the Old Red Sandstone forms a massive series of red, brown and green shales, flags, conglomerates, sandstones and cornstones, in which no unconformity has yet been detected, though one has been suggested by the observations of De la Beche and J. B. Jukes. The lower part of the sries passes downwards quite gradually into the Upper Silurian, and contains fish and crustacea, and also Lingula; the middle beds, consisting chiefly of brown sandstone, have yielded only Lurypterns, and Cephalaspis; whilst the upper part, which graduates upwards into the Carboniferous, contains Holoptychius, Ptericlithys, and land plants (Sphenopteris, Knorria, etc.). In some of these higher beds Serpula and Conularia have been found, showing a return of marine conditions.

Throughout the rest of Britain the series falls into a Lower and an Epper division, separated by a strong unconformity :-

Upper. Yellow and red sandstones, conglomerates, marls, etc., passing up into the Carboniferous System. Holoptychius, Pterichthys major, etc.

Lower. Red sandstones, conglomerates, flagstones and associated igneous rocks, passing in some places conformably into Upper Silurian -Dipterus, Coccosteus, Cephalaspis, Pterygotus.

These, rocks are most completely developed in Scotland. According to Sir A. Geikie, they were there laid down in four great and separate lakes, which he calls:-Lake Caledonia (between the Highlands of the North and the Upland countries of the South; it also extended into the North of Ireland); Lake Orcadie (North of Scotland, Orkneys, perhaps stretching as far as Norway); Lake Cheviot (East of Berwickshire and North of Northumberland); Lake Lorne (flanks of South-west Highlands).

In Ireland the Lower Old Red Sandstone is represented by the Fin tona beils of Tyrone and the Glengariff grits of the South-west; and the Upper division by conglomerates or sandstones overlying them. The higher parts in the South-west are known as the Kiltorcan beds, and contain land plants and Anodon Jukesii.

Russia.--In Russia Devonian beds occupy an extraordinarily wide area, many thousands of square miles in extent. The large and famous work of Murchison, De Ternenil; and Count Keyser- 
ling, is the chief source of our knowledge of these rocks; whilst among the works of later observers, the most recent by Th. Tschernyschew ${ }^{1}$ is the most important. The following chief areas. of Devonian rocks may be distinguished in Russia: 1. The Northwest, which stretches from Kurland through Livonia and the Governments of Pskow, St. Petersburg, and Novgorod, to the White: Sea; 2. the Middle, lying in the country of Orel and Woronesch; 3. the Petchora area, in the basin of the river of that name; and lastly 4. the Ural area, on the western slopes of the Ural Mountains.

In the last mentioned area only are the beds disturbed, whilst elsewhere they lie horizontally. The Baltic region is interesting: because here, as in Scotland, the Devonian is represented chiefly by red sandstones with mailed ganoids, and in the uppermost part of the series these are found together with the ordinary Devonian brachiopods and marine mollusca, and thus afford a striking proof of the equivalence in age of the normal Devonian and the Old Red. In the Dniester area also the same red sandstones are known. But here they pass downwards quite gradually into the underlying Upper Silurian, whilst in the Baltic area they cover the latter unconformably. In harmony with this, the fishes of the lowest beds. of the Baltic. Sandstone agree, according to Lahusen, not with thoseof the Lower, but with those of the Middle Old Red of Scotland.

In the Central Russian and Petchora regions, as in the whole of North-western Russia, the Lower Devonian is entirely wanting. The Middle Devonian is represented chiefly by limestones with Spirifer Anossofi and corals, the Upper Devonian by limestones with Upper Devonian brachiopods (Spirifer Archiaci, S. Verneuili, Rhynchonella cuboides, and others) with which are associated on the Petchora dark bituminous slates with Goniatites (Gephyroccras intumescens, Ammon, etc.), the so-called Domanik Slates. In the Ural area also there are found limestones with Spirifer Anossofi and Stringocephalus Burtini, Iberg Limestone, Clymenia Limestone, and Cypridina Slates, with, however, Lower Devonian Rocks also. Among the latter the limestones on the upper Bjelaja River, and near Bogoslowsk, with Hercynian fauna (brachiopods of the Konjeprus limestone, Bohemian lamellibranchs [Dalila, Vlasta], gasteropods [Hercynella and numerous Capulidae], Orthoceras cf. triangulare, etc.), are especially noteworthy. Thus the development of the Devonian in European Russia may be shown in the following tabular view :-

${ }^{1}$ Ménr. du Comité géol. russe (1884-89): 
D.-DEVONIAN SYSTEM.

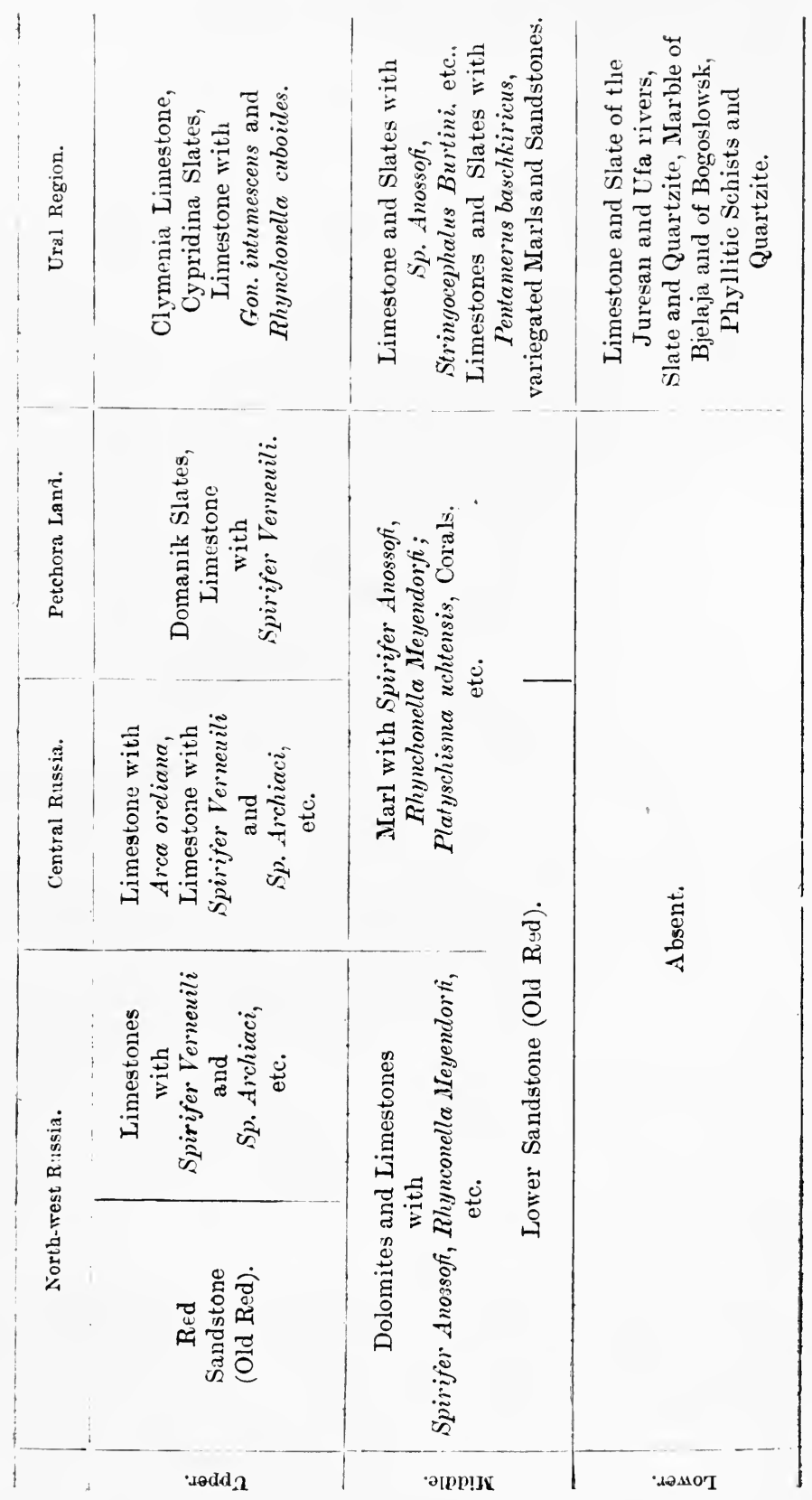


In Siberia also, in the Altai, and in China, Devonian beds are known, which in development and in fauna resemble those of Russia and Western Europe. Here, however, as also in Russia, some of the species show relations to the North American Devonian. In Asia Minor and the Turkish Bosporus, in North and South Africa, Deronian beds are found (at the Cape with species of IIomalonotus and Crypharus, and Lower Devonian brachiopods).

North America.-The Devonian of North America is more important than these, and occupies a larger area even than that of Europe. It forms: 1. in the East Coast Region (New Brunswick, Mnine, etc.), a sandy and conglomeratic series (Gaspé Sandstone) difficult to subdivide; 2 . in the Eastern Central Region (typically developed in New York, but found along the whole chain of the Appalachians to West Tirginia, and also in Ohio, West Canada and Michigan) sandstones, slates and limestones which contain a number of various, and in part very rich, faunas: 3 . in the In terior Central Region (Iowa, Missouri, Illinois, Indiana, etc.) a marly limestone series, which harbours a fauna that everywhere remains nearly the same, and represents the whole of tho faunas of the eastern Central Region; and 4. in the Western Central Region (Nevada); a calcareous slaty series, the fauna of which also shows no considerable changes.

The Daronian of the New York State, which has become classical through the works of J. Hall, will serve as an example of the constitution of the North American Devonian in general:-

1. Catskill group, red and green sandstones (like the Old Red) with fish remains (Holoptychius).

2. Chemung group, sandstones and slates with Spirifer Verneuili, Productus subaculeatus, etc., Goniatites, and many land plants.

3. Portage group, slates and sandstones. Near the base norlular limestone with ('́oniatites Patersoni (very close to, or identical with, G. intumescens), Carliola retrostriata (=-speciosa, Hull), etc. [Naples beds]. Recently a Clymenia ( $C$. neapolitana) has been found in this group.

4. Genessee Slates and Tully Limestone, black slates with poor fauna, and limestones with Rhynchonella venustula (=cuboides).

5. Hamilton beds, calcareous sandy slates with Phacops bufo, Homalonotus Dekayi, C'rypheces calliteles, many brachiopoda (among them the Russian :'sirifer Anossofi), corals, etc.

6. Marcellus beds, black slates with Goniatites expansus, etc., Nautilus, etc.

7. Corniferous Limestone, limestone with flint nodules, containing Dalmanites (in part Odontochile), Proëtus, Conocardium, Spirifer acuminatus. (like cultrijugatus), Sp. gregarius, etc.

8. Onondaga Limestone, Schohariegrit, Cauda galli grit. The 
first a limestone poor in fossils, the second a calcareous sandstone with a peculiar Alga (?), Fucoides cauda galli.

9. Oriskany Sandstone. Coarse-grained sandstone with Rensselaria ovoides, spirifer arenosns, etc.

10. Lower Helderberg group with Upper Pentanerus Limestone, Dethyris Limestone, Lower Pentamerus Limestone, and Stromatopora Limestone.

The whole series, which is many thousand foet in thicknoss, and is but slightly inclined, rests, like the Devonian of Bohemia and the Eastern Alps, conformably and without break on the Silurian, and is covered conformably by the Carboniferous. The divisions 4,5, 6 have been grouped together as the Hamilton group, 7 and 8 as the Upper Helderberg group. The Clymenia Limestone is absent in North America; yet the divisions 1-4 are recognised without difficulty as belonging to the Upper Devonian. The Hamilton and the Marcellus beds (the latter of which remind one of the Wissenbach schists), represent the Middle Devonian; and the lower beds correspond with the Lower Devonian. Most of the American geologists, indeed, refer the Oriskany Sandstone, and all refer the Lower Helderberg beds, to the Upper Silurian; but since the fauna of the sandstone has been observed in Canada interbedded with Upper Helderberg beds, the reference of this famn, at least, has become untenable. Tho Lower Helderberg beds must also be referred to the Inowar Devonian; for if, as appears inevitable, we consider the Upper. Helderberg beds and the Oriskany Sandstone as the approximate equivalents of the West European Coblenz beds, and of the Siegen Granwacke, there would be in North America no equivalent of the deepest beds of the Lower Devonian, the Gedinnien. That the Lower Helderberg group represents such an equivalent is shown by its fauna, which includes the Odontochile, Capulidxe, and broad-winged Spirifers of the Hercynian of Western Europe and of the Ural. Lastly, both in Maryland and New York (Beakraft's Mountain, near Hudson), Newberry, T. Clarke and others have recently discovered beds which contain a mixture of Lower Helderberg (Dalmanites, etc.), and Oriskany (Rensselceria, etc.) forms. 


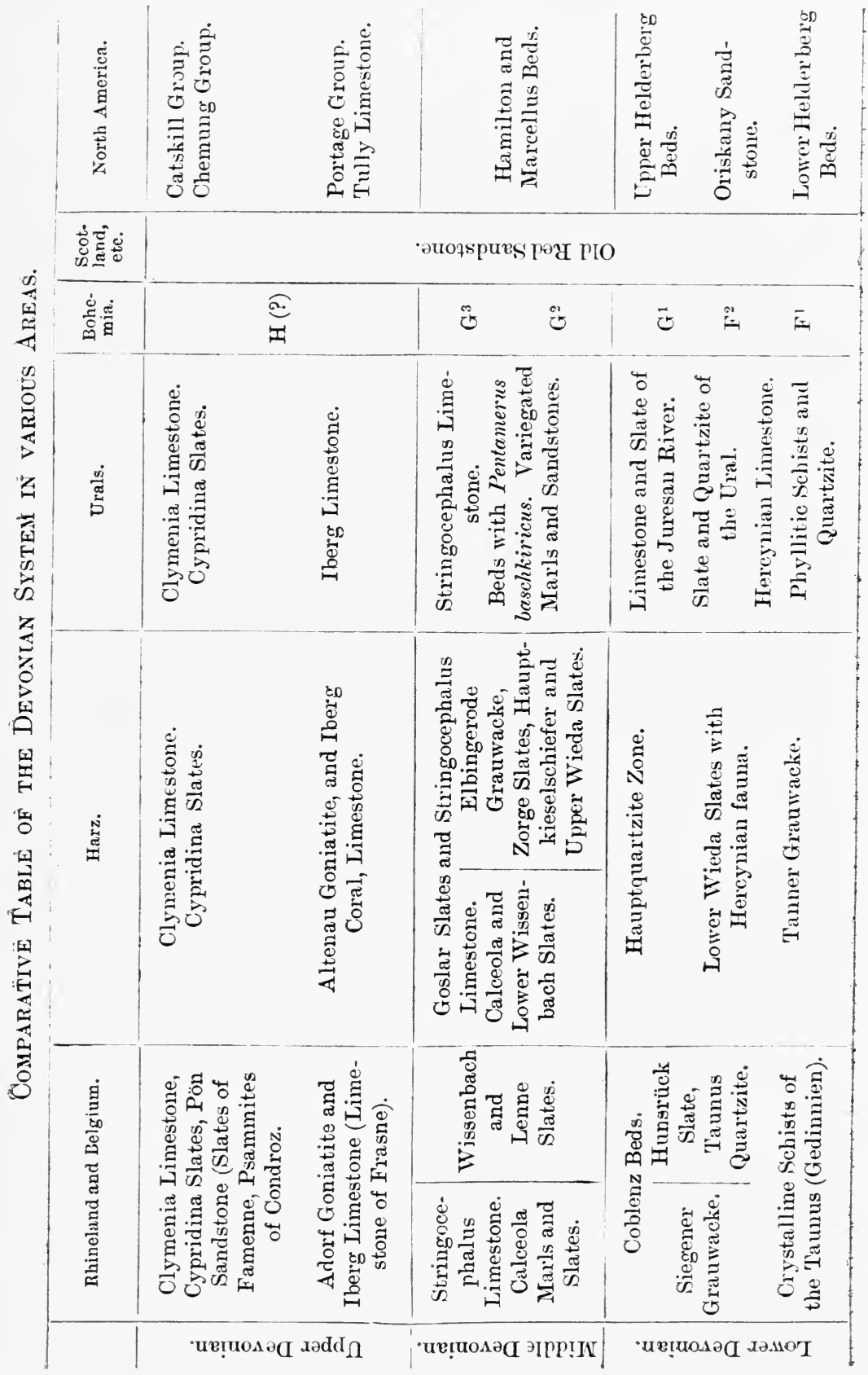




\section{PALAONTOLOGY OF THE DEVONIAN.}

The general palæontological character of the Devonian System is very similar to that of the Silurian. This is true especially of the chief constituents of the calcareous beds, the corals and brachiopods, which at first sight are so like those of the Silurian that the older palæontologists considered the faunas of the Upper Silurian Gotland Limestone and the Middle Devonian Eifel Limestone of the same age. A careful examination, however, soon shows that the points of resemblance are accompanied by many important differences.

The Devonian Corals, like the Silurian, belong chiefly to the groups of Rugosa and Tabulata. Among the former the most prominent in this formation also are the Cyathophyllidæ (with the chief genus Cyathophyllum [XVI. 2, 3]); among the latter the forms Favosites, Alveolites, Heliolites (XVI. 7), Cystiphyllum (XVI. 4) and others. But the genus IIalysites, so characteristic of the Silurian, is absent in the Devonian; whilst in the latter the operculate Calceola (chief species sandalina [XVI. 6]), the genus Pleurodictyum, so widely spread in the Rhenish Lower Devonian (chief species problematicum [XII. 2]), and Phillipsastraa [XVII. 9]-the most important reef builder in the Upper Devonian-are of great inipportance.

Amongst the Hydrozoa, the Graptolites, so important in Silurian beds, are already practically extinct. In the Lower Devonian of Bohemia, and the Harz, a few simple graptolites are found. A graptolite has also been found in supposed Lower Old Red Sandstone of Lanarkshire in the S. of Scotland, and at a similar horizon in North America a graptolithid (Dictyograptus).

Echinodermata are represented, as in the Silurian, chiefly by Crinoids. Among them the genera Ctenocrinus (XII. 1), peculiar to the Devonian, and Cupressocrinus (XVI. 1) (the latter with foursided stem, pierced by five canals), are especially important. The Cystidea, which play so important a part in the Silurian, have almost entirely dwindled away, whilst the Blastoidea, which are so richly developed in the succeeding Carboniferous epoch (especially the type Pentremites), are still rare.

The Brachiopoda exceed all the other groups in abundance and variety. Among them we miss altogether many Silurian forms such as Porambonites, Platystrophia, Orthisina, etc., whilst Strophomena and Orthis are much reduced. In place of these

C. G. 


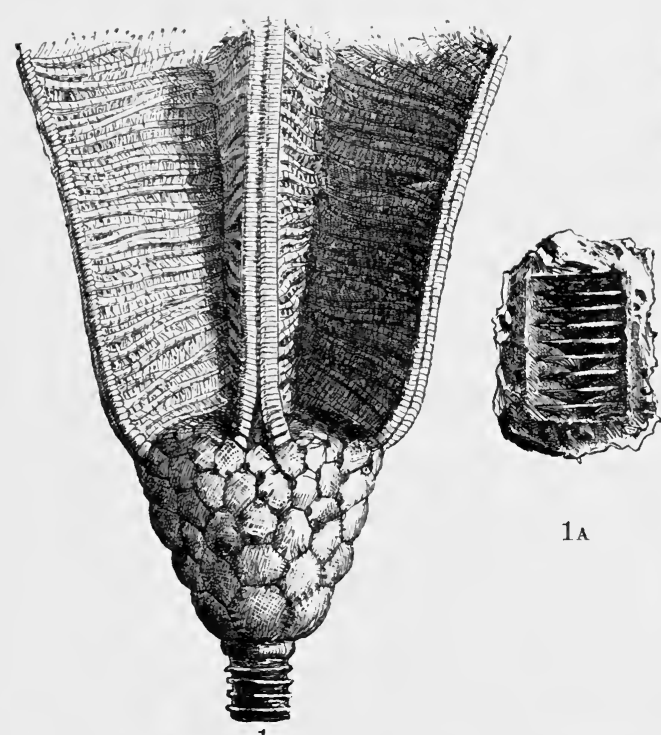

1
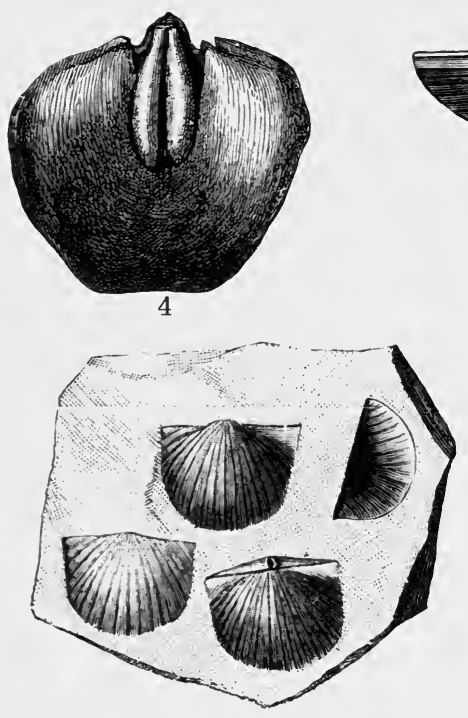

5

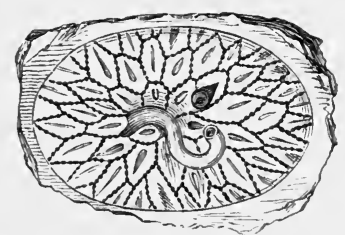

2

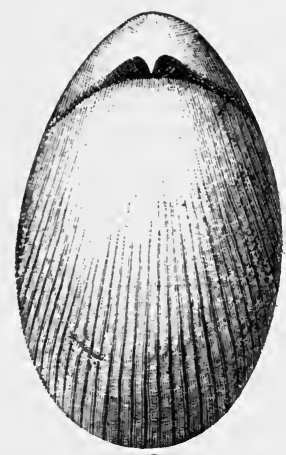

3
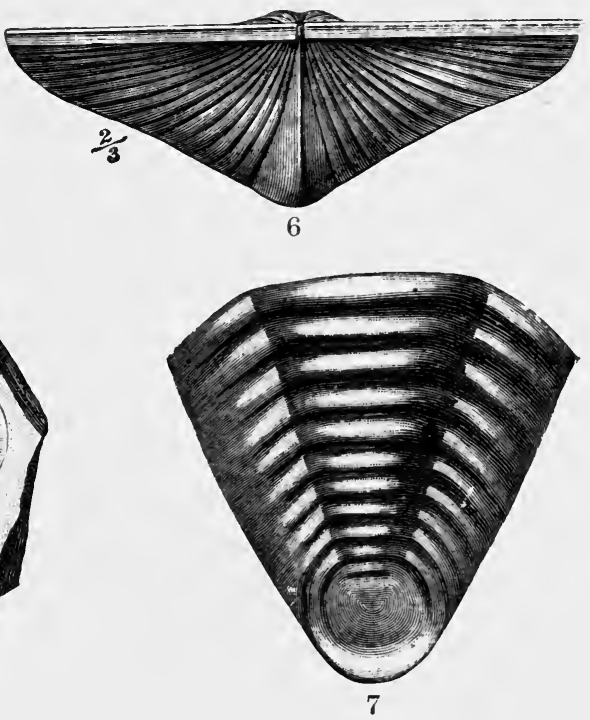

Pinte XIr.-Lower Devonian Fossil..

1. Ctenocrinus typus, Bronn, 1A, Do., stone-cast of a stem. 2. Pleurodictyum problematicum, Goldf. 3. Rensselaria strigiceps, F. Roem. 4. Orthis hysterita, Gmel, stone-cast of large valve. 5. Chonetes plebeja, Schnur. 6. Spirifer dunensis, Kays. 7. Homalonotus crassicauda, Sandb., tail-shield. 

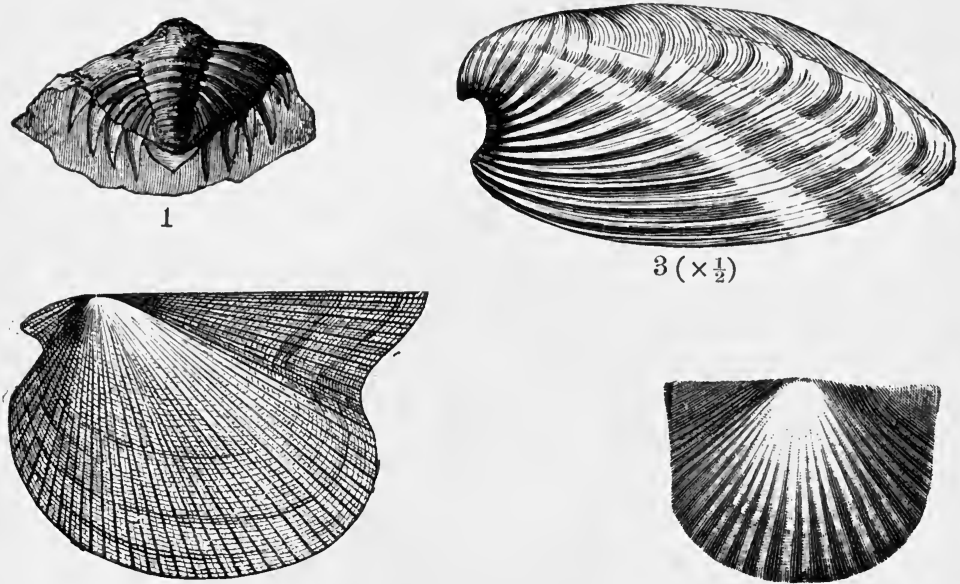

2

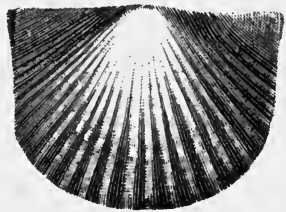

5

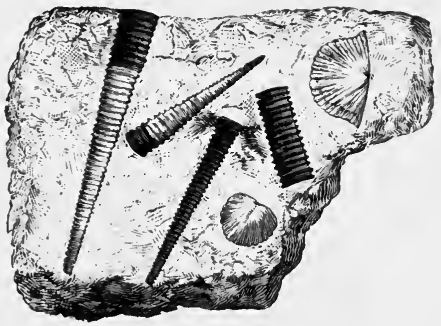

7
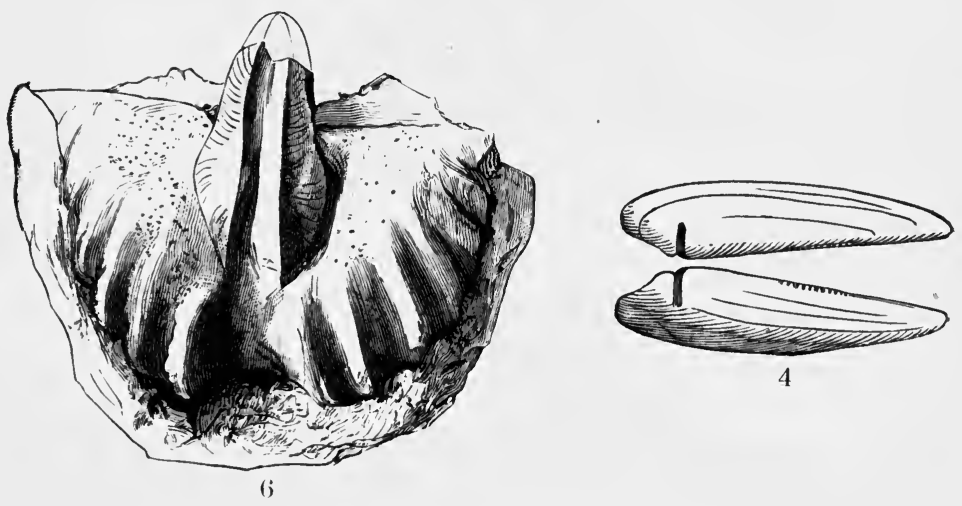

Plate XIII.-Lower Devonian Fossils.

1. Cryphous laciniatus, F. Roem, tail-shield. 2. Pterinea lineata, Goldf. 3. Granmysia hamiltonensis, Vern. 4. Cucullella solenoides, Goldf. 5. Strophomena laticosta, Conı. 6. Spirifer primoevus, Steining, cast of large valve. 7. Teutaculites scalaris, Schloth. 

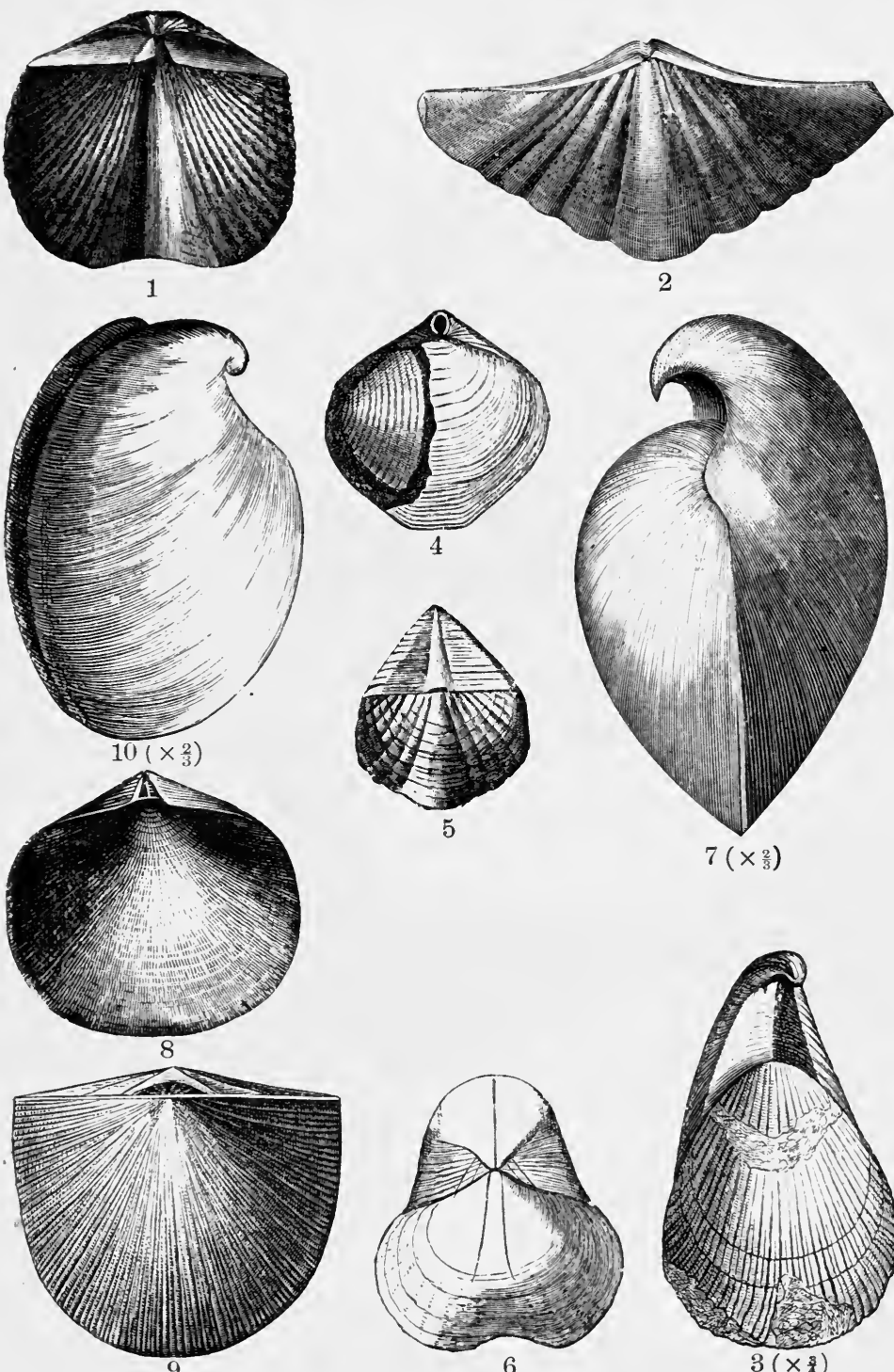

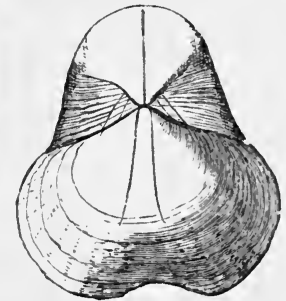

6

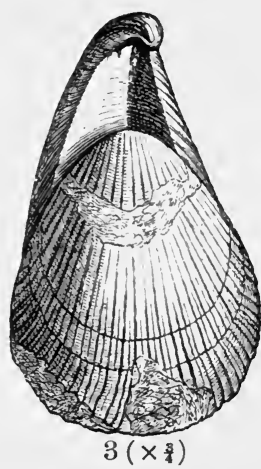

Puate XIV.-Middle Devonian Mollusca.

1. Spirifer ostiolatus, Schloth. 2. Spirifer intermedius, Schloth (=speciosus). 3. Uncites gryphus, Defr. 4. Athyris concentricn, v. Buch, with dorsal valve partly broken away. 5 . Cyrtina heteroclitu, Defr. 6. Pentamerus galeatus, Dalm. 7. Stringocephalus Buitini, Defr. 8. Orthis striatula, Schl. 9. Streptorhynchus umbraculum, Schl. 10. Megalodon cucullatum, Goldf. 


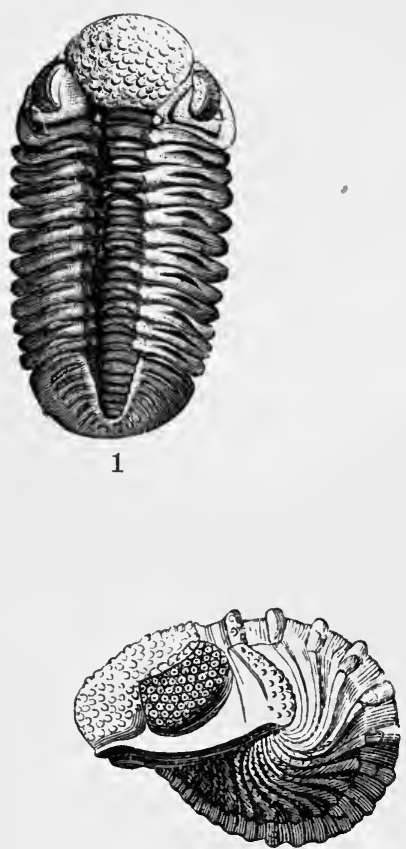

$1 \mathrm{~A}$

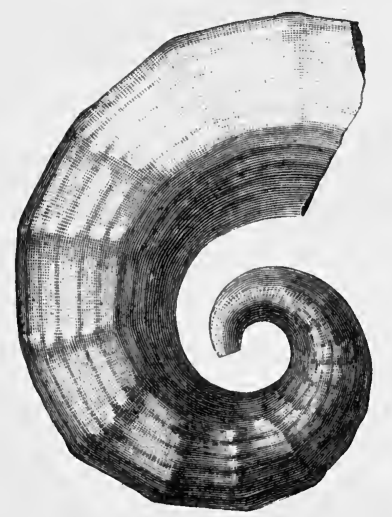

$2\left(\times \frac{1}{2}\right)$
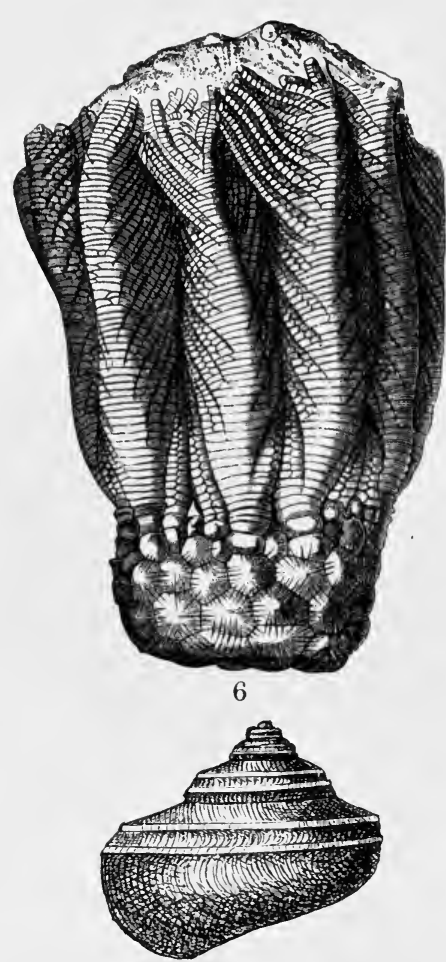

$3\left(x_{3}^{2}\right)$
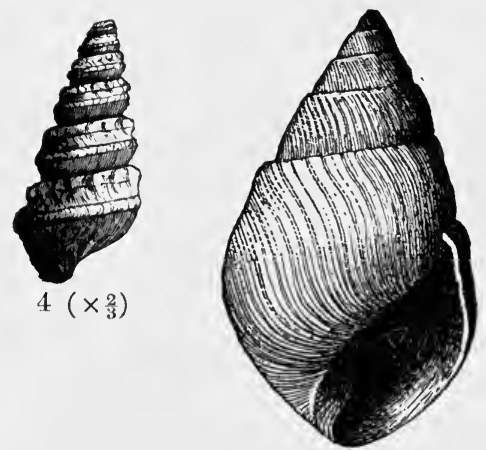

$5\left(\times \frac{2}{3}\right)$

Plate XV.-Middle Devonian Fossils.

1. Phacops Schlotheimi, Bronn. 1A. The same rolled up. 2. Gyroceras nodosum, Goldf. 3. Pleurotomaria delphinuloides, Goldf. 4. Murchisonia bilineata, Goldf. 5. Macrochilus arculatum, Schloth. 6. Rhodocrinus crenatus, Goldf. 

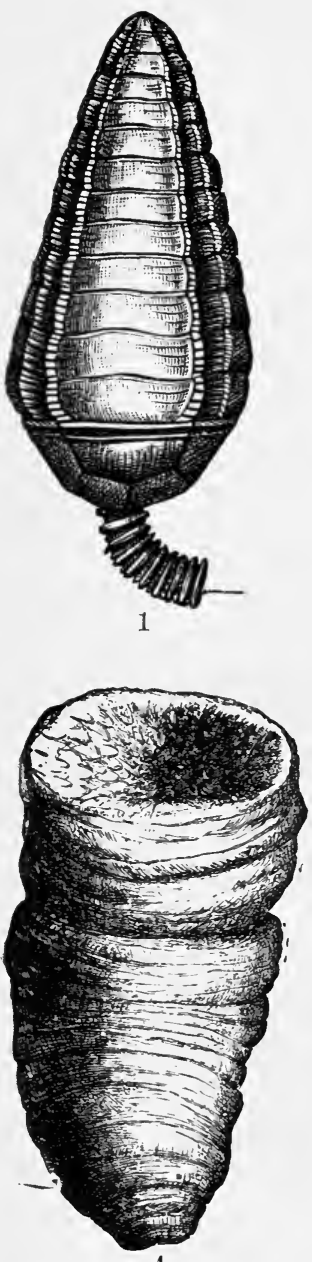

4

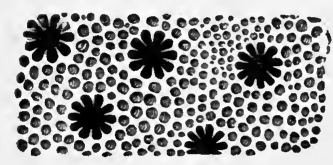

$7 \mathrm{~A}$
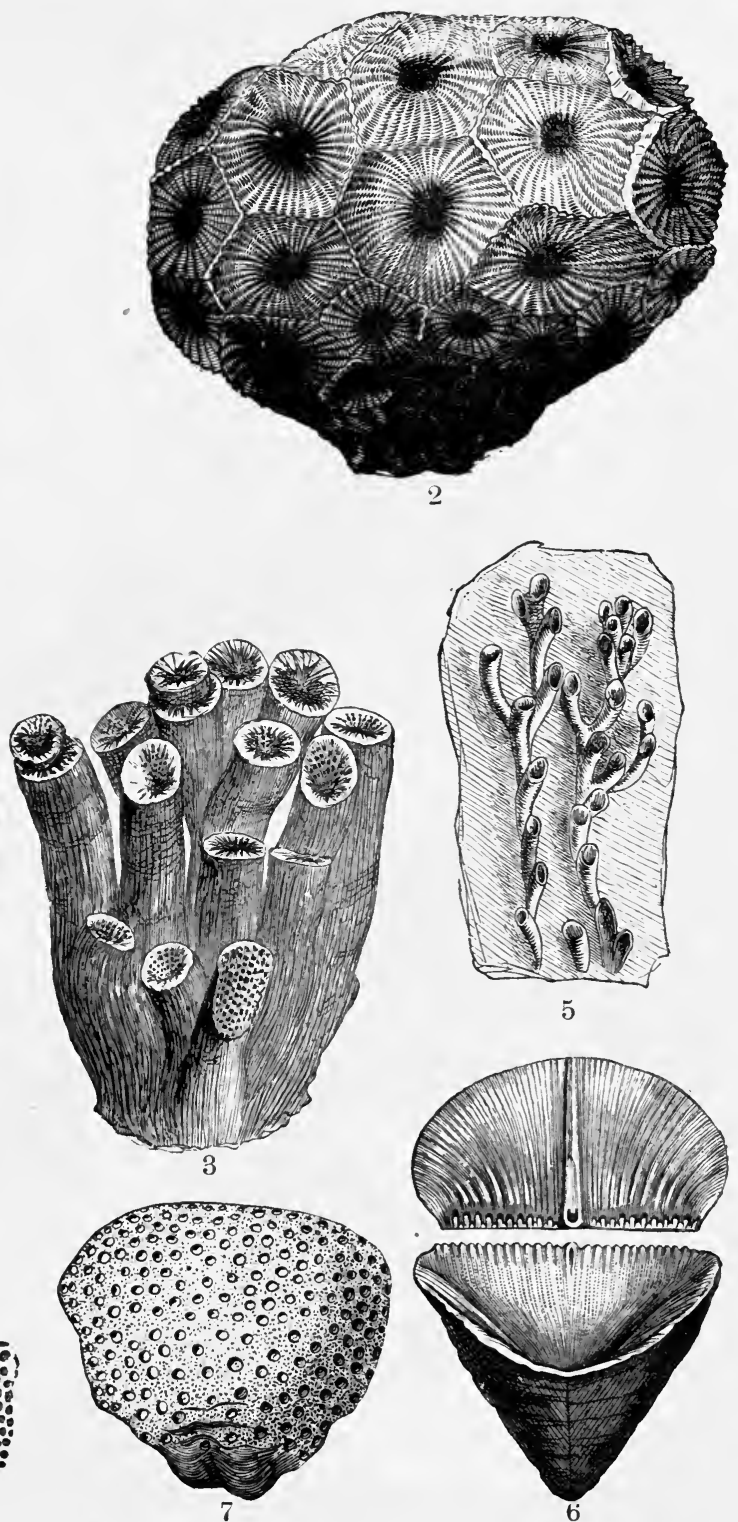

Plate XVI.-Middle Devonian Corals and Crinoids.

1. Cupressocrinus crassus, Goldf. 2. Cyathophyllum hexagonum, Goldf. 3. C. caespitosum, Goldf. 4. Cystiphyllum vesiculosum, Goldf. 5. Aulopora tabaeformis, Goldf. 6. Calceola sandalina, Lam. 7. Heliolites porosa, Goldf. 7^. Transverse section of same enlarged. 

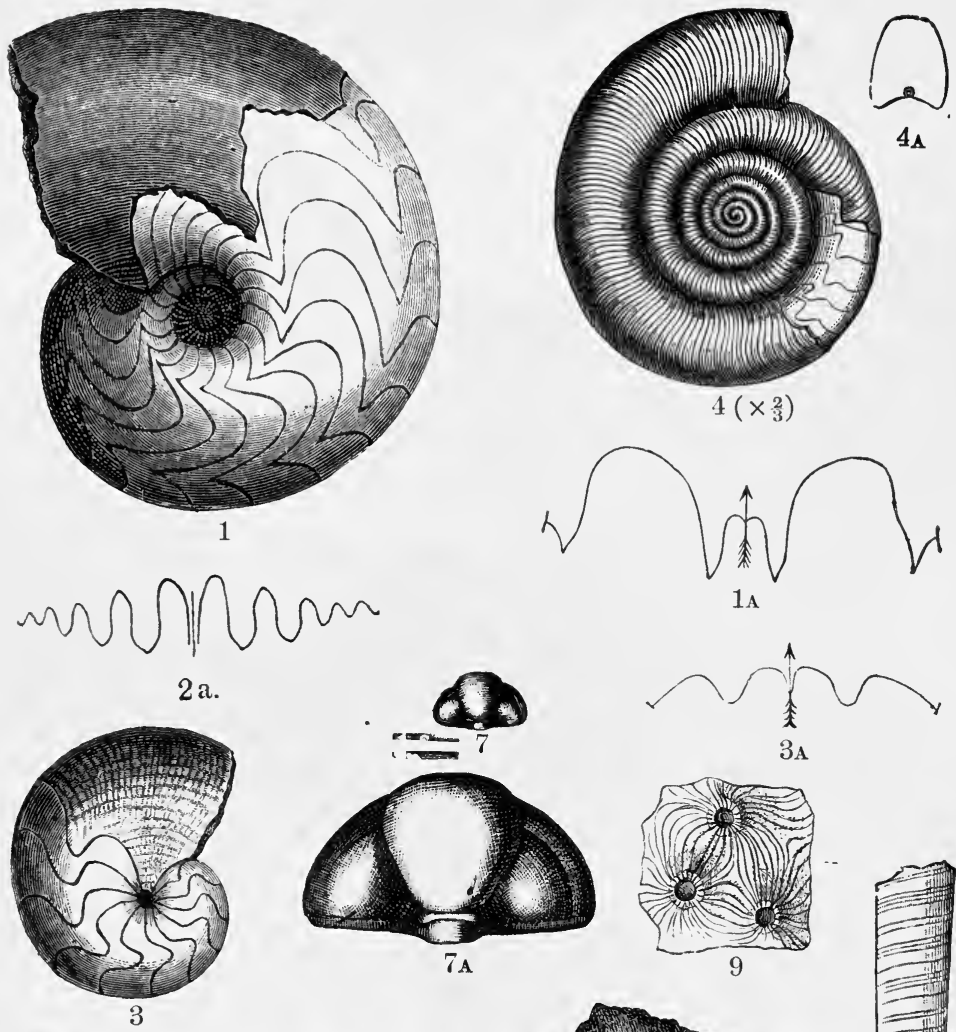

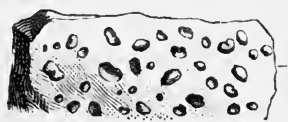

6

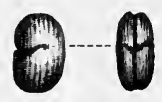

$6 A$

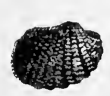

8

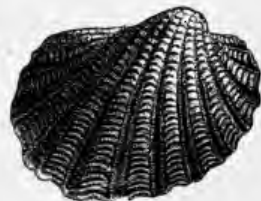

8 A

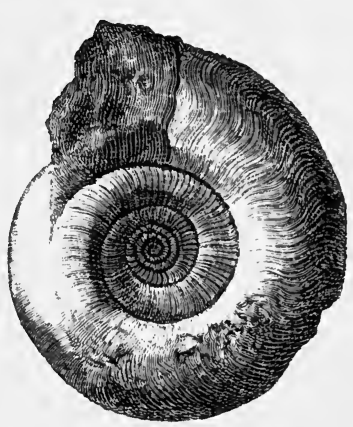

2
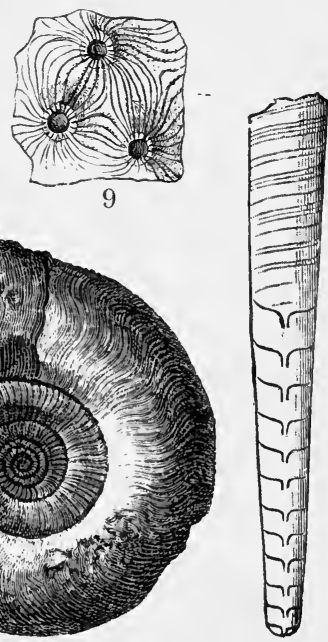

5

Plate XVII.-Upper Devonian Fossils.

1. Goniatites (Gephyroceias=Manticoccras) intumescens, Beyr. 1^. Suture of same. 2. Gon. (Prolecanites) lunulicosta, Sandb. 3. Gon. (Tornoceras) simplex, v. Buch. 4. Clymenia undulata, v. Münst. 4A. 'I'ransverse section of same. 5. Bactrites elegans, Sandb. 6. Entomis serratostriata, Sandb. 6⿳亠口冋. The same enlarged. 7. Phacops (Trimerocephalus) cryptophthalmus, Emmr. 7A. The same enlarged. 8. Cardiola retrostriata, v. Buch. 8A. The same enlarged. 9. Phillipsastroa Hennahi, Lonsd. 

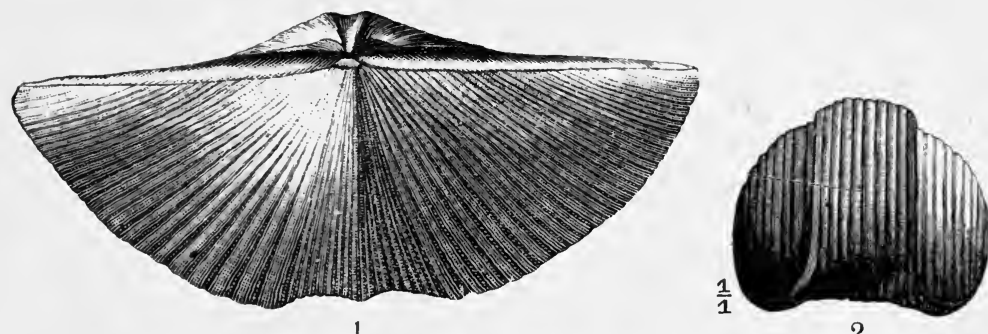

2

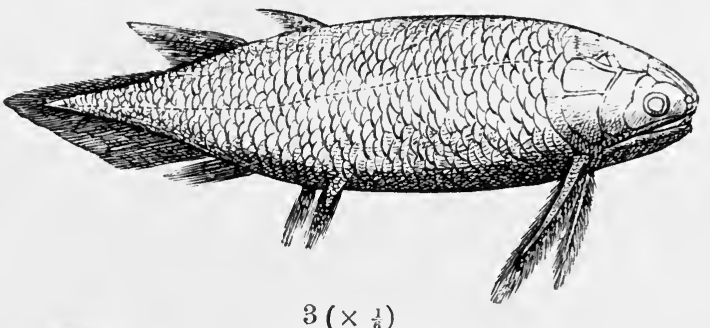

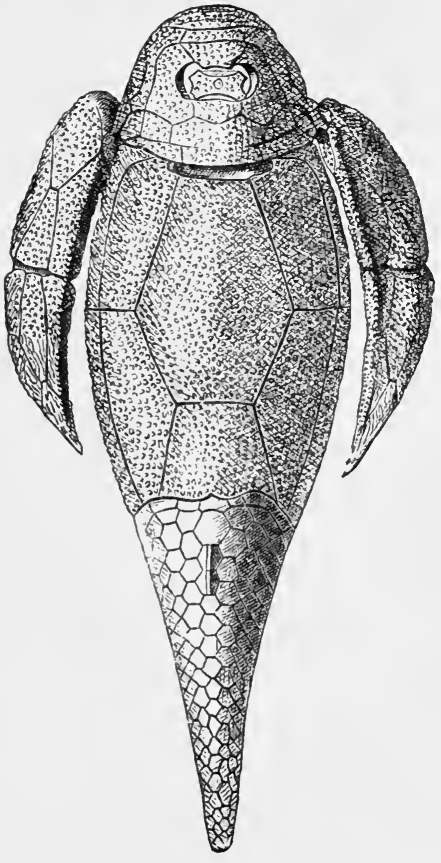

4

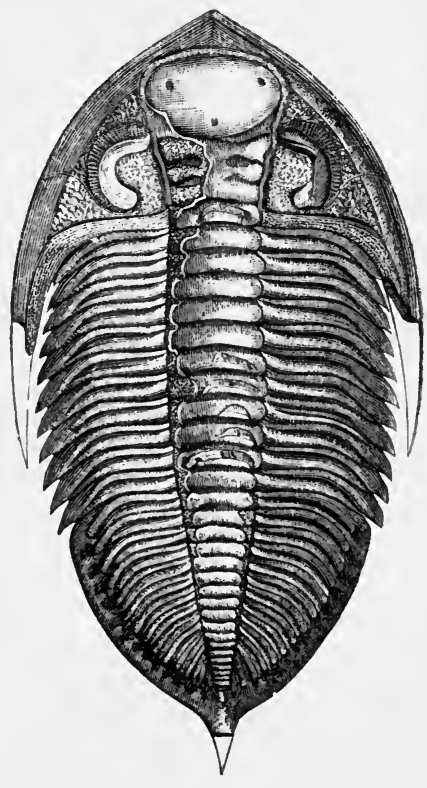

5

Plate XVIII.-Fossils from the Upper Devonian $(1,2)$, Old Red $(3,4)$ and Hercynian $(5)$.

1. Spirifer Verneuili, Murch. 2. Rhynchonella cuboides, Sow., from the front. 3. Holoptychius nobilissimus, Agass. 4. Pterichthys cornuta, Pand. 5. Dalmanites (Odontochile rugosa, Corda. 

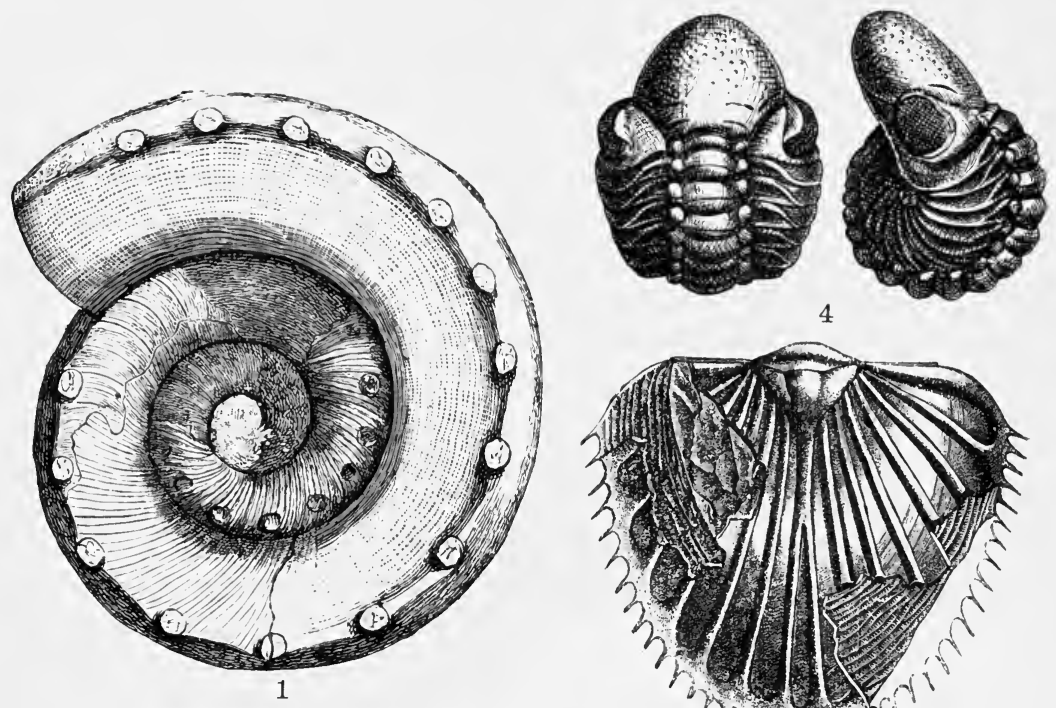

4
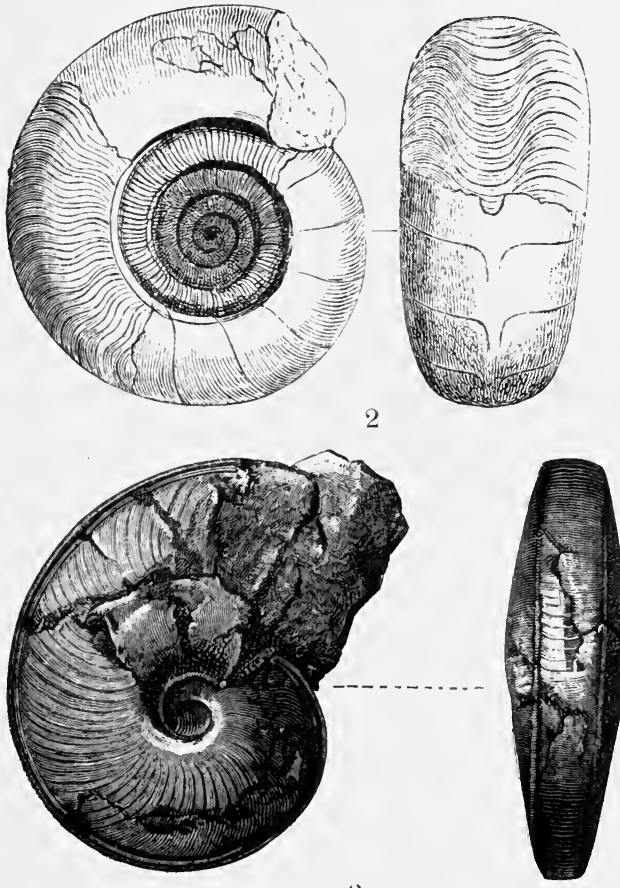

3

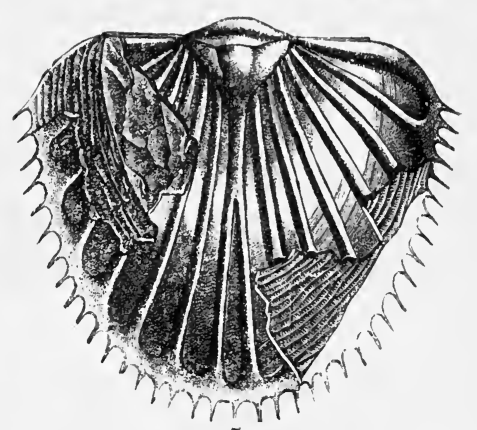

5

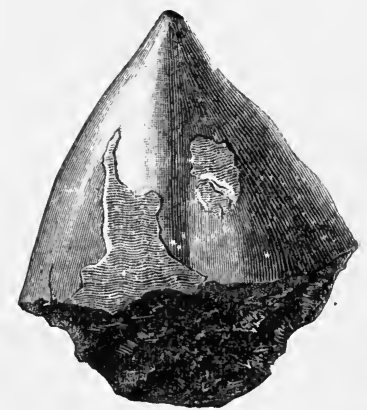

6
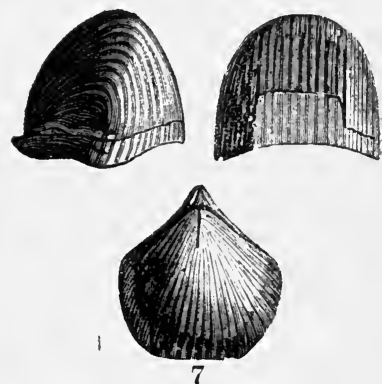

Plate XIX.-Hercynian Fossils.

1. Hercoceras subtuberculatum, Sandb. 2. Goniatites (Anarcestes) lateseptatus, Beyr. 3. Gon. (Aphyllites) occultus, Barr. 4. Phacops cephalotes, Barr. 5. Bronteus speciosus, Corda (=thysanopeltis, Barr), tail-shield. 6. Platyceras hercynicum, Kays., var, selcana, Giebel. 7. Rhynchonella Henrici, Barr. 
there appear as new forms, in part peculiar to the Devonian, certain genera of Terebratulidæ, Stringocephalus (XIV. 7), Rensselaria (XII. 3), Meganteris (Fig. 15), etc.; and the longbeaked Uncites (XIV. 3), the fixed Davidsonia, and the genera Productus and Strophalosia with their shells clothed with hollow spines, which reach their full development in Carboniferous and Permian rocks. The most widely spread forms are Spirifer (among them especially the broad-winged species [XII. 6], those with bifurcating ribs, and those in which not only the sides but also the middle part of the shell is plaited [XVIII. 1]), Rhynchonella (XVIII. 2, XIX. 7), Athyris (XIV. 4), Atrypa (Atrypa reticularis [X. 4] is an especially widely spread species, ranging from the

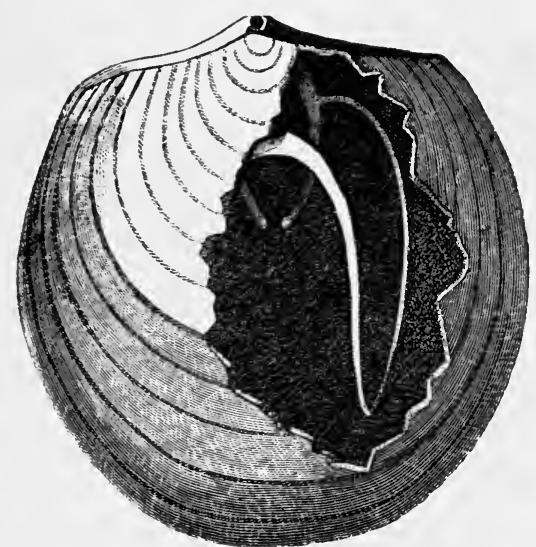

F'IG. 15.-Meganteris Aichiaci, Vern, from the Lower Devonian of the Eifel (with the dorsal shell broken open to show the long internal loop). upper Silurian right through the whole of the Devonian), and Orthis (XIV. 8).

Among the Lamellibranchs, Pterinea (XIII. 2), Grammysia (XIII. 3), Modiomorpha, Goniophora, Nucula, Leda, Cardiola (retrostriata [XVII. 8], in the Upper Devonian), Lucina and Megalodon (XIV. 10), must be mentioned as abundant; among the Gasteropoda, Pleurotomaria (XV., 3) Murchisonia (XV. 4), Platyceras (Capulus [XIX. 6]) and allied forms, Bellerophon and others; whilst among the Pteropoda the small Styliolinas (with smooth shells), and Tentaculites (with transversely ringed shells, pointed at one end, open at the other) are important on account of their abundance in certain beds.

The Cephalopoda include some of the genera which are found also in the Upper Silurian, such as Orthoceras, Cyrtoceras, Gomphoceras and Phragmoceras. Some of the Silurian genera however have already become extinct, like Ascoceras, while others, such as Gyroceras (XV. 2) and Hercoceras (subtuberculatum (XIX. 1), date their birth from the Wissenbach Slates and the Hercynian Limestones. Among the most important forms that are quite absent in the Silurian but are found in the Devonian are the 
Ammonitidæ. The chief of these are the Goniatites, characterized by simple undivided sutures. In the Lower and Middle Devonian, the genera Anarcestes (lateseptatus [XIX. 2]), Aphyllites (evexus etc. [XIX. 3]), Pinacites and Mimoceras (gracile) are especially abundant : and in the Upper Devonian Gephyroceras (intumescens [XVII. 1], etc.), Tornoceras (simplex [XVII. 3]), Beloceras, Prolecanites (Becheri and lunulicosta [XVII. 2]), Sporadoceras (Bronni). With these there occur in the Upper Devonian of Europe and the Ural region (but not in America ${ }^{1}$ ) the exclusively Upper Devonian form Clymenia (XVII. 4), which is distinguished chiefly by the position of the siphuncle on the internal side of the spiral, a character found in this alone among the Ammonitidæ. Lastly the peculiar genus Bactrites (XVII.5) resembling Orthoceras in its stafflike form but furnished with a siphonal lobe, should be mentioned.

Among the Articulated animals the Trilobites play the most important part in the Devonian, although they no longer occur in the same abundance and variety of form as in the Silurian. The Phacopidæ are especially important. Besides the type genus Phacops (in the Middle and Upper Devonian, especially $P h$. latifrons and Ph. Schlotheimi [XV. 1]; in the Hercynian Ph. fecundus and itsallies [XIX. 4]), Cryphaus and Dalmanites belong to this family. The latter genus scarcely passes beyond the Lower Devonian, and is richly represented in the Bohemian and Harz Hercynian, as well as in the American Helderberg beds, by large forms of the D. Hausmanni group (subgenus Odontochile [XVIII. 5]). The genus Cryphaus (XIII. 1) which reaches up to the Upper Devonian, is formed essentially like Dalmanites; but the tail is distinguished by its eleven ragged or thorn-like marginal appendages. From the Upper Silurian there pass up into the Devonian, Homalonotus, Proëtus, Harpes, Cheirurus, Acidaspis, Lichas and Bronteus, and also more seldom Arethusina and Calymene. Some of the Devonian species of Bronteus show several peculiarities : thus Br. speciosus=thysanopeltis (XIX. 5), which is very wide-spread in the Hercynian, is distinguished by spiny appendages to the border of the tail shield (subgenus Thysanopeltis). The Devonian species of Cheirurus also differ from the Silurian in the structure of the glabella (subgenus Crotalocephalus). The genus Dechenella, allied to Proëtus, is peculiar to the Devonian.

1 Clymenia neapolitana has recently been found in the Portage group of North America. 
Of the Crustacea, other than trilobites, the Eurypteridæ, already mentioned in the account of the Silurian rocks, are found also in the Devonian (especially in the Old Red Sandstone facies); and the small Entomis (Cypridina) serrato-striata (XVII. 6) is an abundant form in the European Cypridina slates.

Vertebrates are represented in the Devonian only by fishes; and these show such great peculiarities that the Devonian fauna receives its peculiar stamp chiefly from them. The most important place is taken by the Ganoids; to which group belong the remarkable families of the Cephalaspidæ and Pteraspidæ, which have already been found present in the uppermost Silurian. Along with these the peculiar family Crossopterygidæ, represented at the present time chiefly by Polypterus, is strongly developed. In this group the scaly pectoral and ventral fins are provided with a long axis, the tail fin is usually unsymmetrical (heterocercal), and the spine is continued to the point of the upper lobe. To this family belong the genera Holoptychius (XVIII. 3) and Glyptolepis with large rounded enamelled scales, and Osteolepis, etc., with rhombic enamelled scales. But the chief part among the Devonian fishes is taken by the mailed ganoids or Placoderms, the most remarkable fishes that have ever lived. All are distinguished by the fact that the head and anterior part of the body were protected by large, bony plates, generally sculptured in a radial fashion, whilst the hinder part of the body was covered with rhombic scales of enamel. To this group, which is most abundant in the Old Red but is not unknown in the normal Devonian, belongs the small, strange-looking genus Pterichthys (XVIII. 4), with its winglike scaly pectoral fins (so called Rudder-limbs), which on its first discovery was considered to be a link between fishes and birds. The large form Coccosteus, the gigantic Dinichthys and many others are also members of this group.

The remarkable group Dipnoi, which possesses both gills and lungs and is represented in the present world by the genus Ceratodus, was also present in the Devonian. To this group belongs for example Dipterus. Lastly, the Rays or Squalidæ, which begin to appear in the Silurian, are represented in the Devonian period by various families.

The Flora of the Devonian system is but little worthy of remark. To the seaweeds belong the Haliserites Dechenianus which is abundant in the Rhenish Lower Devonian, and probably also the peculiar, spirally curved Fucoides cauda galli. The few land 
plants hitherto known here and there, for example from the Tanner Grauwacke of the Harz, show a culm-like character. In the North American Devonian the genus Psilophyton, the position of which is still uncertain, is of some importance.

\section{E. CARBONIFEROUS SYSTEM.}

\section{GENERAL AND HISTORICAL.}

The name of Carboniferous or Coal-bearing System has been applied to a series of conglomerates, sandstones, grauwackes, clayslates, limestones, marls and coals, which in many places reaches a thickness of 10,000 feet and more, and has its normal position above the Devonian and below the Permian. In many areas, as, for example, in England, Belgium, Westphalia, and Russia, the Carboniferous beds lie conformably and without break on the newest Devonian ; and frequently, as in the Saar region, Bohemia, Russia, and Texas, they pass upwards without any sharp line of demarcation into the Permian. Elsewhere so close a connection between the Carboniferous and the under- and over-lying formations is by no means universal. On the contrary, after the deposition of the Lower Carboniferous, the sedimentation was in many places interrupted, so that there is a gap between the Upper and Lower Carboniferous, and-as throughout the eastern border of the Rhenish Schiefergebirge - the former follows unconformably on the folded beds of the older division. At other places, as near Pilsen, St. Etienne, etc., the whole of the lower half of the Carboniferous is entirely absent; as the result of an extension of the sea, commencing at the beginning of the Upper Carboniferous period, the Upper Carboniferous here rests immediately on old Palæozoic or Archæan rocks.

The name Carboniferous System (Conybeare) (terrain bituminifère [Omalius d'Halloy, 1808], houiller or carbonifère, Kohlenformation), originated at the time when it was still thought that each formation was distinguished by a special kind of rock peculiar to itself. Just as at that time oolite was considered characteristic of the deposits of the Jurassic period, grauwacke of the Palæozoic, so it was supposed that coal was essentially characteristic of the Carboniferous period. So far as concerns coal, we know that it occurs in various other formations such as the Kimeridgian, 
the Wealden, etc.; nevertheless it remains true that coal seams are present in no other formation, in such abundance, or of such great extent and thickness as in the Carboniferous, so that the name Coal formation even now seems not inappropriate.

Like the name itself, the attempts at classification of the Carboniferous reach back to the early part of our century. After the early essays of Omalius in Belgium, Conybeare and Phillips ${ }^{1}$ in 1822 divided the Carboniferous of the North of England into the groups still commonly recognised at the present day. They distinguished a lower calcareous division, the Mountain or Carboniferous Limestone; and an upper coal-bearing division, the Coal Measures (W. Smith, 1817) with the underlying Millstone Grit. It was very soon recognised that the equivalent beds of the Continent were of much the same constitution, and that here also, a lower calcareous series, the Carboniferous Limestone, and an upper sandy and slaty, coal-bearing series, could be separated. But it was not till the second half of the fourth decade that Murehison and Sedgwick recognised that the lower division is not everywhere represented by limestone; but that on the other hand-as was first shown in Devonshire and afterwards in the Rhine area-it often forms a sandy and slaty series, which is especially characterized by the abundance of the bivalve Posidonomya Becheri. To this facies they gave the English local name Culm-measures, ${ }^{2}$ and this name has since passed into common use.

The Carboniferous Limestone has usually been considered a deep-sea formation, while the Culm has been supposed to be a shore or shallow-water deposit. But Holzapfel has justly pointed out the improbability of these views. The numerous reefbuilding corals, thick-shelled gasteropods, and large brachiopods of the Carboniferous Limestone, the comparative rarity of cephalopods, certainly point rather to a shallow than a deep sea; whilst on the other hand the monotony and poverty of the Culm fauna, in which moreover cephalopods are much more numerous than in the Limestone, would prove it with much greater probability to be a deep-water formation. For the Cephalopod Knollenkalk (nodular limestone) so widely spread in the Culm, no other view seems admissible; and it is only the coarse conglomeratic

1 "Outlines of the Geology of England and Wales."

2 Prof. Lebour has shown that the "Culm "of Devonshire includes higher beds than the "Kulm" of Germany, though the two are approximately equivalent. 
grauwackes with numerous plant remains, that can well be considered as coast formations.

The division of the Carboniferous formation into two parts has proved generally applicable. For the Lower Carboniferous, the term Sub-Carboniferous has sometimes been employed, especially in America, whilst the Upper Carboniferous in Germany is often known as productive Carboniferous, a miner's term introduced by v. Dechen.

Throughout Germany, Belgium, North France and England, the Carboniferous Limestone contains a rich and varied marine fauna, while the Productive beds contain numerous land plants, but very scanty remains of marine animals. It had long been supposed that this was the case over the whole earth. But some fifteen years ago it gradually became clear that certain rocks which are widely spread in European Russia, and which were formerly compared with the Carboniferous Limestone of Western Europe, are probably equivalent, not with these beds, but with our Productive Carboniferous. ${ }^{1}$ This Upper Limestone, which contains a rich marine fauna, has been called (to distinguish it from the Lower Carboniferous Limestone) the Younger Carboniferous Limestone, or, from the remarkable abundance of Fusilina, the Fusulina Limestone. We know now that it is by no means limited to Russia, but is found, always with nearly the same fauna, over large areas in Southern and Eastern Asia and the western part of North America, and that it also occurs locally in Southern Europe. Thus there is a wide difference between Russia and parts of North America on the one hand, and Western Europe on the other, and we have two distinct facies of each of the great divisions of the Carboniferous System, as is shown in the following scheme :-

\begin{tabular}{|c|c|c|c|}
\hline & Littoral and Lacustrine facies. & \multicolumn{2}{|c|}{ Marine facies. } \\
\hline 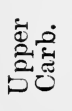 & $\begin{array}{c}\text { Upper Productive Carboniferous } \\
\text { (Western Europe). }\end{array}$ & \multicolumn{2}{|c|}{$\begin{array}{l}\text { Younger Carboniferous, or } \\
\text { Fusulina Limestone } \\
\text { (Russia, etc.). }\end{array}$} \\
\hline 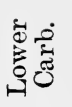 & $\begin{array}{l}\text { Lower Productive Carboniferous } \\
\text { (Russia, etc.). }\end{array}$ & $\begin{array}{c}\text { Lower } \\
\text { Carb. Limestone, } \\
\text { (Western Europe). }\end{array}$ & $\begin{array}{c}\text { Culm } \\
\text { (Germany). }\end{array}$ \\
\hline
\end{tabular}

Another advance, of recent times, concerns the classification of the Carboniferous System according to the character of its flora.

1 Cf. v. Möller, "Congrès internat. de Géologie de Paris (1880), p. 111. 
It had long been remarked that the flora of the Culm (especially characterized by the preponderance of Lepidodendron [Sagenaria] and Sphenopterids) was considerably different from that of the Productive Carboniferous. In the middle of the century, Geinitz, ${ }^{1}$ on the ground of his studies of the distribution of the plants of the Saxon Coal-formation, established, for the Productive part, four Plant zones, viz., in ascending order, the Sigillaria, Calamite, Annularia, and Fern zones. Instead of these he afterwards recognised only two subdivisions, viz., that of the Sigillarias, and that of the Calamites and Ferns. The three subdivisions, which we thus obtain for the whole Carboniferous formation, viz., the Sagenaria, the Sigillaria, and the Calamite and Fern zones, have now been proved applicable-as the observations of E. Weiss, Stur, Zeiller and others have shown-not only in Saxony, but also in Bohemia, Silesia, the Rhine area and France, and they have even been recognised in South Africa and China.

Geologists have also endeavoured to establish a further subdivision of the Carboniferous Limestone. This has been accomplished in Belgium by de Koninck, Dumont, Gosselet, and Dupont. But the results there reached seem to be of general validity only in one point, viz., in the limitation-repeated also in Russia, but not in England and elsewhere-of the important fossil Productus giganteus to the upper part of the Carboniferous Limestone.

The Carboniferous period was in Europe a time of great earth movement. The overiap of the Upper Carboniferous, already described, is a proof of this. The greatest disturbances took place at the close of the Culm epoch. Over a wide area the beds formed before that time, which often follow one another from the Silurian upwards without any considerable disturbance, were then upturned and folded. Side by side with these movements took place the eruption of large igneous masses, especially of porphyries and diabase-like rocks. Thus in Silesia, Saxony, and in the Saar region, we meet with numerous outbursts as well as interbedded sheets of such rocks in the sedimentary deposits of the Carboniferous formation. Moreover, many of the granite rocks of Germany, such as the granite and gabbro of the Harz, and probably the granite of the Fichtelgebirge, are of Upper Carboniferous age. In France and Britain also, similar eruptive rocks are not wanting. In the last named country, Scotland especially, during the Car-

1 "Geogn. Darstellung d. Steinkohlenform. in Sachsen" (1856). 
boniferous period, was the scene of vigorous eruptive action (Fig. 16) ; and in Derbyshire also we find in the Carboniferous Limestone contemporaneous masses of basalt, locally known as toadstones. In China again, according to Richthofen, the greatest eruptions of melaphyre, porphyrite, and quartz porphyry took place at the end of the Carboniferous period.

\section{DISTRIBUTION AND DEVELOPMENT OF THE CARBONIFEROUS.}

From the foregoing remarks it will be clear that there are two great facies of Carboniferous rocks in Europe. In the first of these, which we find in Western and Central Europe, the lower part of the system is marine, and the upper is littoral and lacustrine; while in the second, which is best known in Russia. the conditions

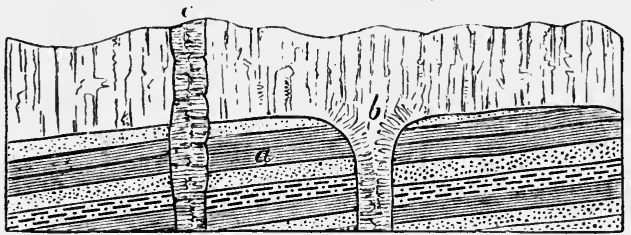

Fig. 16.-Section on the West Coast of Arran (F. Zirkel).

4. Lower Carboniferous slates and sandstones. b. Coarse-grained diabase dyke, spreading out above into a thick sheet. c. Dyke of very fine-grained diabase.

are reversed-the lower part is littoral, and the upper marine. 'The Carboniferous rocks of Southern Europe are of mixed character, and pass into the Russian facies towards the east; and it will be convenient to group the Carboniferous areas into those of (1) Central and Western Europe, (2) the Mediterannean, (3) Russia. In each case the changes which the beds show will be traced from west to east.

\section{Central and Western Europe.}

British Isles.--In no part of Europe does the Carboniferous system cover so wide an area as in the British Isles. It occurs both in England and Wales, and also in Scotland and in Ireland.

The Lower Carboniferous belongs mainly to the Limestone or calcareous facies of this division of the system, and it is only in Devonshire that we meet with the Culm facies. In the southwest of England (omitting Devonshire) it is represented by a series

C. G. 
of shales and limestones, which in the Bristol area may be grouped! as follows :-

Upper Limestone Shales.

Massive Limestone (some shales included).

Lower Limestone Shales.

Passing northwards, the limestone in the centre of England is. very much thicker (Derbyshire, $\mathrm{N}$. Wales, etc.), while the lower shales have almost disappeared. The Upper Limestone Shales. appear to be represented by limestones, shales, and sandstones, which form what is known as the Yoredale series, containing Goniatites Listeri, Posidonomya Becheri, (XX. 4), Aviculopecten papyraceus (XXVII. 4), etc.

Still further to the north the massive limestone becomes broken. up by beds of shale and sandstone, which increase in thickness at the expense of the limestone, until in Northumberland the whole group becomes a series of alternations of sandstones, shales and limestones, with beds of coal. They are divided by Prof. Lebour. into-

Bernician Series. Alternating beds of limestone, shale and sandstones, with workable seams of coal.

Tuedian Series. Yellow sandstones, shales, clays with cement-stones. Conglomerate at base.

The same rocks are somewhat differently grouped by Hugl Miller, as follows :-

Upper
Limestone
Series. $\begin{gathered}\text { Fell-top division. Sandstones and shales, some coal and } \\ \text { limestone. } \\ \text { Calcareous division. Sandstones and shales, with coal and } \\ \text { many beds of limestone. }\end{gathered}$

Carbonaceous division. Mainly carbonaceous; limestonesLower thin; coal.

Limestone Tuedian division. Mainly sandstones above; sandstones.

Series. $\begin{gathered}\text { and shales, with cement-stones below. } \\ \text { Conglomerate. }\end{gathered}$

Still going northward, the amount of limestone continues to decrease and the coal to increase, and in Scotland we have the following succession:-

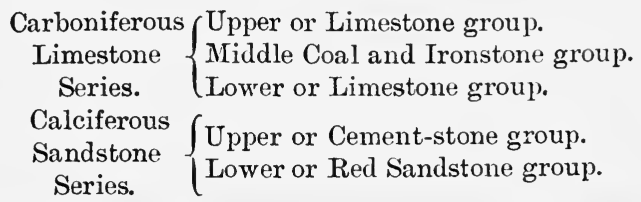

In the border counties the Calciferous Sandstone series has 
recently yielded an extraordinary number of phyllopods and scorpions, which have not as yet been fully described.

In Ireland the Carboniferous Limestone Series covers by far the greater part of the country. There is the same change of character as we go northward, that we get in England. In the southern counties we have a group of shales and slates ("Carbonif erous Slate") below the limestone, just as in the Bristol coalfield. In Clare, Tipperary and Queen's County, the series is formed by a massive limestone, more than 3,000 feet thick, which contains peculiar bands of chert; while as we go northwards the amount of limestone decreases, till in Antrim the succession closely resembles that in the South of Scotland.

The so-called Culm Measures of Devonshire consist in their lower parts of an alternation of clay-slates and sandstones, siliceous slates, and impure limestones, the latter of which contain as characteristic fossils Posidonomya Becheri, Goniatites (G. sphoricus: [XX.5], and G. mixolobus) and Orthoceras striolatum. The upper division, on the other hand, is composed exclusively of dark sandstones and clay-slates, and, near the lower boundary, of impure coal beds (Culm). These are often considered as the equivalent of the Millstone Grit.

The Upper Carboniferous begins almost everywhere in the British Isles with the Millstone Grit, a coarse sandstone locally reaching several thousands of feet in thickness, accompanied by conglomerates and shales. Besides remains of land plants it occasionally contains a few brachiopods, cephalopods, Posidonomya $r$ Phillipsia [XX. 8], etc.

It is followed by the Coal Measures, which consist of shales, sandstones, and coals, in many places reaching a thickness of 10,000 feet. They form a nnmber of basins which were originally continuous with one another, but have since been separated by two series of folds, running nearly N. to S. and E. to W. The result of these and of subsequent denudation has been to divide the Coal Measures of England into a number of distinct fields, of which the largest and most important are (1) Bristol and Somerset, (2) South Wales, (3) North Wales, (4) Staffordshire, (5) Yorkshire, Nottinghamshire and Derbyshire; (6) Northumberland and Durham. In the coal-fields of the south-west the Coal Measures are usually divided into-

Upper Series. Sandstones, shales and coals.

Middle " Chiefly Sandstone (Pennant Grit).

Lower " Sandstones, shales, and coal with ironstone in S. Wales. 
In the coal fields of the centre of England the Lower Series consists of shales and sandstones, with but little coal, and often contains marine fossils. The Middle Series yields the greater part of the coal, and at various horizons contains bands full of Anthracosia. (XXVII. 5), etc. Lastly, the Upper Series consists of clays and grits, with little or no coal, and is especially characterized by a bed of limestone with Spirorbis. The South Lancashire coal field may be looked upon as typical of this part of England, and there the beds are grouped as follows:-

Upper (Ardwick) Series. Shales, sandstones, and limestone with Spirorbis, Anthracosia, Anthracomya. Fish-remains. Thin coal-seams. $1680^{\prime}-2000^{\prime}$.

Middle Series. Sandstones, shales, clays, and thick coal-seams. Fish-remains. Anthracosia, Anthracomya, plants. $3000^{\prime}-4000^{\prime}$.

Lower (Ganister) Series. Flags, shales, and thin coals with Ganister floors and shale roofs. Goniatites Listeri, Aviculopecten papyraceus, and Spirorbis found at Billinge and Upholland.

$1400^{\prime}-2000^{\prime}$.

In the Northumberland and Durham coal field the succession is very similar; but the Upper Series is perhaps not fully represented, and the Spirorbis limestone is unknown though Spirorbis itself is common.

In Scotland the Millstone Grit is represented much as it is in England. The Coal Measures are divided into a Lower Series of sandstones, shales, coals, etc., with a flora resembling that of the Lower Coal Measures of the North of England, and an Upper Series of red sandstones and clays with a band of Spirorbis limestone. The Middle Coal Measures appear to be absent, and the Upper Series is slightly unconformable on the Lower.

The fossils of the Coal Measures of Britain are mostly land plants, but they include also remains of land and fresh-water animals (Crustacea, Insects, Spiders, Millipedes, Fish, Stegocephalous Amphibia). In the Lower Series a marine horizon with Goniatites, etc., of wide distribution is found at a little distance above the Millstone Grit; in the Middle Series there are a number of beds full of Anthracosia and Anthracomya, ${ }^{1}$ and in the Upper Series is found the marine Spirorbis limestone, with Spirorbis and other marine fossils.

Belgium and the Rhine.-The Carboniferous rocks of the Mendip Hills in England, striking nearly easterly; are covered by

1 Anthracosia and its allies are known to the Belgian geologists as Cardinia, and are regarded by them as purely marine forms; but they appear rather to be estuarine. 
the more recent deposits of the London Basin and the S.E. of England. Following the direction of their strike, however, they reappear in the Boulonnais and are found below the later deposits of Artois and Flanders. They again crop out on the surface in Hainault and form a long belt stretching away towards Liège and Aix-la-Chapelle. Here they are covered by Tertiary beds and the alluvium of the Rhine; but on the right bank of that river form the large basin of the Ruhr in Westphalia. Lastly a couple of small patches of coal-bearing Carboniferous rocks near Ibbenbüren, and at Piesberge near Osnabrück, to the north of the Ruhr basin, must be referred to this group of outcrops.

This belt of Carboniferous rocks is closely connected both in position and structure with the Schiefergebirge of the Lower Rhine; though only the lower part of the series enters into the formation of these mountains, whilst the productive Coal Measures do indeed rest against the old rocks of the mountain mass, but in the main occur beyond them. Throughout the northern border of the Schiefergebirge both divisions of the formation occur; both are conformable to each other and to the underlying Devonian beds, in all the foldings of which they share.

Throughout the part of this belt that lies to the WEST OF THE Rhine, the Lower Carboniferous consists exclusively of Carboniferous Limestone, a massive, semi-crystalline, dark or light coloured limestone (more rarely dolomite), which may reach more than 2,000 feet in thickness. The numerous fossils found in itfor which Tournai and Visé in Belgium have long been famoushave been worked out by de Koninck. ${ }^{1}$ He was the first to notice the palæontological difference between the limestones of these two localities; but did not connect this difference with difference of age. In more recent times Gosselet and Dupont have occupied themselves with the classification of the Belgian Carboniferous Limestone; and they recognise three chief divisions, in descending order :- ${ }^{2}$

Visé Stage. Large Producti (P. giganteus [XXII. 2], undatus, cora), and Chonetes comoides.

Waulsort Stage. Spirifer cuspidatus.

Tournai Stage. Spirifer einctus, Sp.tornacensis (erroneously described as Sp. mosquensis).

1 "Descriptions des animaux fossiles du terr. carb. de la Belgique" (184244, Supplement, 185̃1). "Faune du calcaire carbonifère de la Belgique" (1878-88).

2 Cf. Gosselet, "L'Ardenne" (1888), p. 615, et seq. 
Near Aix-la-Chapelle and in the neighbourhood of Düsseldorf(in this region Ratingen has long been known as a fossil locality)Carboniferous Limestone is still found; but through the rest of the belt that lies to the EAST OF THE RHINe, the Lower Carboniferous occurs not in the form of limestone, but of $\mathrm{Culm}$. It often consists of a series of beds several thousand feet thick; the lower half made of siliceous and alum slates, impure slaty limestones, and dark clay and grauwacke slates, alternating with beds of solid grauwacke; and the upper half of coarse to conglomeratic massive grauwackes. The former contains Goniatites (G. spharicus [XX. 3], G. mixolobus), Orthoceras (O. striolatum, O. scalare), Camarophoria papyracea, and the very important and widespread bivalve Posidonomya Becheri (XX. 4), which often covers the surfaces of the "Posidonia" shales" in hundreds. These are accompanied in some places (Herborn, Aprath near Elberfeld, etc.), ${ }^{2}$ by a few trilobites (Phillipsia), brachiopods (Chonetes, Productus), lamellibranchs and crinoids; which are in part such species as occur elsewhere in the Carboniferous Limestone, and thus afford a proof of the equivalence of the Culm and that rock. The upper division of the Culm contains only remains of land plants, especially Archaocalamites radiatus, Calamites transitionis (XX. 1), Lepidodendron Veltheimianum (XX. 3), and Knorria imbricata (XX. 2).

The Crinoidal Limestone which occurs in the Culm near Erdbach and Breitscheid near Dillenburg, contains a fauna rich in Goniatites and very different from the usual fauna of the Culm. ${ }^{3}$

On the LeFT BANK OF THE RHINe the Upper Carboniferous forms a zone on the north border of the Schiefergebirge which is indeed narrow, but stretches without any great break from the neighbourhood of Aix-la-Chapelle, past Liège, Namur and Mons, to Valenciennes, and, under cover of newer beds, as far as Boulogne. The following section shows the zigzag folds and numerous faults by which the coal-bearing rocks are affected in the Belgian area.

The lowest subdivision of the English Upper Carboniferous, the Millstone Grit, is not represented as such in Belgium or the North of France; but the coal-bearing beds, as at Aix-la-Chapelle, lie directly on the Carboniferous Limestone. In the Meuse area the

1 The generic name Posidonia is commonly used on the Continent instead of Posidononiya; but the latter has the priority.

2 V. Könen, "Neues Jahrbuch" (1879), p. 309. Kayser, "Jahrb. d. preuss. greol. Landesanst." (1881), p. 67.

${ }^{3}$ Holzapfel, "Paläont. A bhandl.," V. pt. 1. (1889). 
Carboniferous Limestone is succeeded by a series of alum and siliceous shales, which, especially at Chokier not far from Huy, contains a long known and interesting fauna-Goniatites diadema, etc., Posidonomya Becheri, Aviculopecten papyraceus, etc. Purves has correlated these shales with the English Yoredale beds, and the sandy beds with Productus carbonarius, which succeed them, with the Millstone Grit ; ${ }^{1}$ Gosselet, however, holds to the old view that they represent the base of the Productive group, which is inseparably connected with them. The latter (the Productive group) falls into a lower division consisting of sandstones with insignificant seams of coal, and an upper contrining numerous coal seams.

In the Aix-la-Chapelle region the Productive or coal-bearing Carboniferous beds form two distinct basins, the comparatively

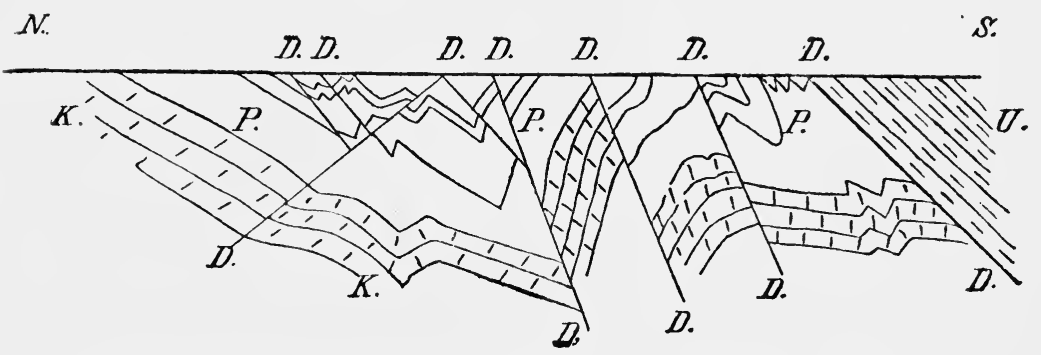

FIG. 17.-Section through the Coal Basin of Liège (Vanteherpenzecl-Thim).

d. Lower Devonian. K. Carboniferous Limestone. P. Productive Carboniferous. D. Faults.

simple Inde basin on the south, and the much-disturbed Worm basin (cf. Fig. 18) on the north. Here also, as in Belgium, a lower division poor in coal, and an upper rich in coal may be distinguished.

On the right bank of the Rhine we find the continuation of these Upper Carboniferous troughs represented by the BASIN OF THE RUHR. The lower part of the coal-bearing division here consists of "flötzleerer Sandstein" (sandstone free from coal seams), which rests directly on the Culm, and in its relations is like the English Millstone Grit. It consists of sandstones, conglomerates, and shales reaching 3,000 feet in thickness, but contains no coal seams and is unfossiliferous. According to v. Dechen the thick grauwackes of the Eder region, the Hessian Hinterland, etc., referred by other authors to the Upper Culm, should be reckoned with the

1 "Bull. de l'Acad. Roy. de Belgique," Ser. 3, II. (1881). 
Flötzleerer Sandstein. ${ }^{1}$ Directly above this sandstone come tho beds which have called into existence the important collieries of Bochum, Dortmund, and Essen. Here also may be distinguisher a lower subdivision containing little coal and reaching 3,000 feet in thickness, and an upper, rich in coal, 7,000 feet. According to $v$. Dechen the Ruhr basin contains in all ninety workable seams of coal with a united thickness of some 88 yards. It is remarkable that here, just as near Aix-la-Chapelle and in England, there are found at several horizons strata containing marine shells, among;

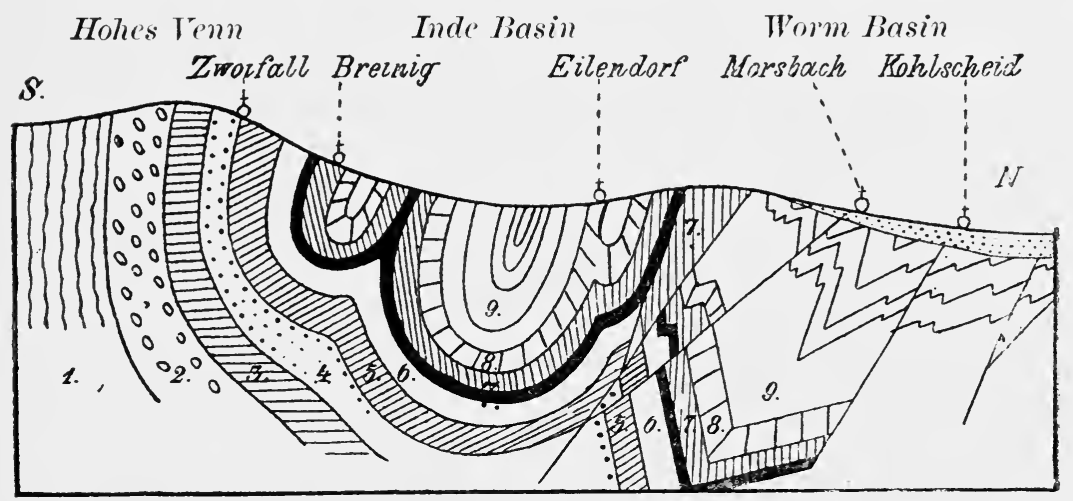

Fig. 18.-Section of the Carboniferous and Devonian near Aix-la-Chapelle (F. Holzapfel). 1, 2. Cambrian. 3. Gedinnien. 4. Taunus quartzite, etc. 5. Vichter beds. 6. Stringocephalus Limestone. 7. U. Devonian. 8. Carboniferous Limestone. 9. Coal Measures.

which are Anthracosia (often forming banks), Aviculopecten papyraceus (XXVII. 4), and Goniatites. The lie of the beds in the Ruhr basin is in general more regular than in Belgium, although even here dislocations are by no means wanting (cf. Fig. 19).

On the south side of the Rhenish Schiefergebirge, but not in actual contact with them, Productive Upper Carboniferous occurs only in the small, but, from the great thickness of its seams, very important BASIN OF THE SAAR. The immediate foundation orr which the coal-bearing beds lie is not known: but in the north, the Rothliegende, after overlapping the Devonian rocks, rests conformably on the Carboniferous beds. In the south the coal basin is cut through by a great fault, by which the Trias of the Palatinate is sunk down some 10,000 feet against the Carboniferous rocks (cf. Fig. 20). E. Weiss, who has studied the succession of the

1 "Erläuterungen z. geol. Karte der Rheinprov.," II. (1884), p. 223. 
E.-CARBoniferous SYSTEM.
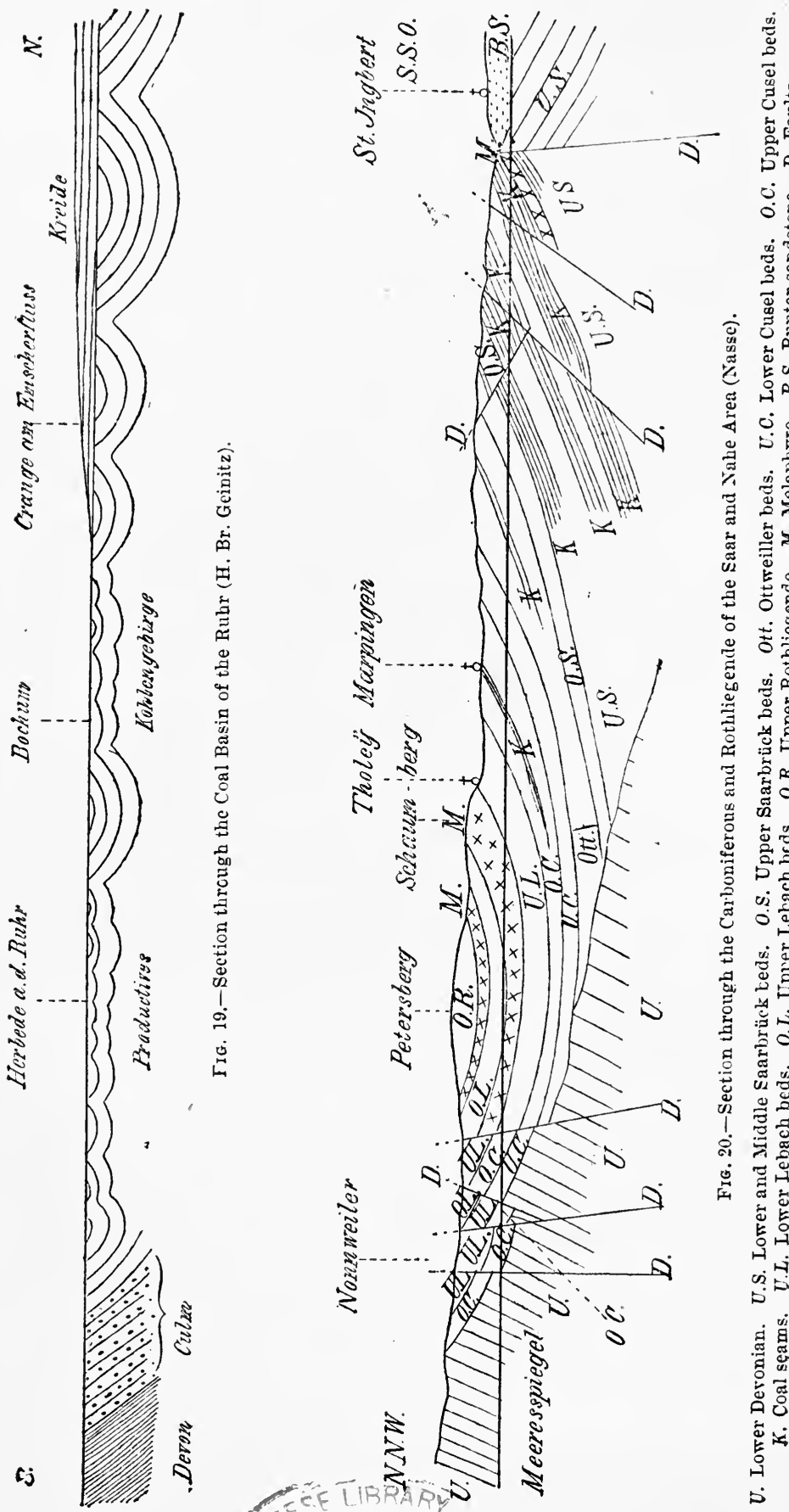

总

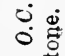

范范

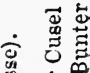

密

¿

ङ

ये 00

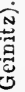

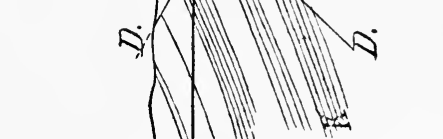

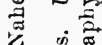

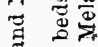

离 ذ

范

声范

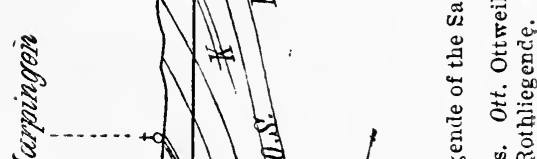

迥

$\Rightarrow \Rightarrow N$ Nat

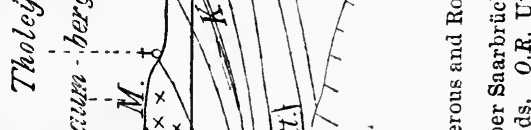

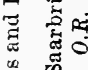

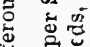

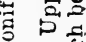

i vi

\& $0 \frac{0}{4}$

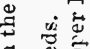

열

롤

表芯

1.

$\because$ 造

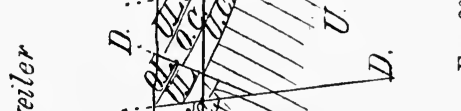

(

焉

담.

क्ञ

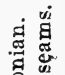

듕

离的 
Carboniferous and Rothliegende beds in detail, has divided the Carboniferous into a lower stage, the Sa arbr ück, and an upper, the $\mathrm{Ottweiler}$ beds. ${ }^{1}$ The former is rich in coal and corresponds with the chief part of the coal-bearing beds of the Ruhr and Inde basins; while the latter is poor in coal, and is considered younger than the youngest of the Carboniferous beds found on the north border of the Schiefergebirge. The two series together reach a thickness of 20,000 feet, and contain some three hundred and fifty seams with a united thickness of more than 150 yards.

Central Germany.-Passing now towards the east, we find that in Central Germany the Carboniferous Formation occupies a much more restricted area. In the Harz the Culm, which consists at the base of siliceous slates, limestones, and grauwacke slates, above this of grauwacke poor in conglomerate, and lastly at the top, of grauwacke rich in conglomerate, forms the greater part of the Oberharz plateau, and is the series in which the well-known silver-bearing lead veins of Clansthal occur. The upper Carboniferous, on the other hand, is limited to a few small patches which are composed of beds of Ottweiler age, and are found on the border of the mountains near Ilfeld, Ballenstedt, etc., lying unconformably on the Devonian.

In the neighbourhood of Wettin and Löbejün also, small patches of Productive Carboniferous beds occur. To the same group belong the thick red sandstones and conglomerates of Mansfeld and the north side of the Kyffhäuser, which have hitherto been referred to the Rothliegende, but are really unconformably overlaid by them.

In Eastern Thuringia and the Fichtelgebirge, as in the Harz, the greater part of the space occupied by Carboniferous beds is taken up by the Culm. This is divided into a lower part, which consists mainly of clay and roofing slates (Lehesten slates) with interbedded grauwacke, sandstones, limestones, etc., and an upper part which is chiefly made up of coarse grauwackes. The Productive Carboniferous occurs only in a few quite insignificant patches near Manebach, Crock, etc., close to the border of the mountains. Typical Carboniferous Limestone with large Producti is found only in small occurrences near Hof and other places.

The Carboniferous Formation occupies a larger area in the kingdom of Saxony. The Zwickau, Lugau-Oelsnitz, and Pot-

1 "Foss. Flora d. jüngst. Steinkohlenform. u. d. Rothlieg. im SaarRhein-gebiet" (1869-72). 
schappel coal basins are of Upper Carboniferous age. But the Chemnitz-Hainichen coal synclinal, as Geinitz and Sterzel ${ }^{1}$ have shown, and as is placed beyond doubt by the occurrence of such characteristic Culm fossils as Lepidodendron Veltheimianum, Stigmaria inaqualis, Archacocalamites radiatus, Sphenopteris slistans, etc., belongs not to the productive Carboniferous, but to the Culm.

Still further east we find large areas of Carboniferous rocks in Silesia; and we may here distinguish a Lower Silesian, or Waldenburg, and an Upper Silesian coal basin.

The first forms a trough striking from S.E. to N.W., which on the east rests on the cystalline schists of the Eulengebirge, and towards the west is continued into Bohemia (to Schatzlar). ${ }^{2}$ The middle of the basin is occupied by Rothliegende and Cretaceous rocks. The Productive beds include thirty-one workable seams, with a total thickness of more than 40 yards; and are often pierced by quartz porphyries, which have locally produced remarkable effects of contact metamorphism. Below the Productive Carboniferous lies the Lower Carboniferous, partly in the form of plant-bearing grauwackes of great extent, partly as Carboniferous Limestone (Hausdorf, Altwasser, etc.), and partly in the form of grey clay-slates, with an interesting mixture of characteristic Culm plants and Carboniferous Limestone brachiopods (especially near Rothwaltersdorf).

The Upper Silesian basin, on account of its extent and its wealth of coal, is much more important than the Lower Silesian. Both the subdivisions of the formation are developed here also. The Productive beds, which rise in detached spots like islands, through the covering of diluvium, occupy an area of some 2,000 square miles, and include more than a hundred seams with a united thickness of over 160 yards-the Xaveri seam alone is 17 yards thick! Here, as in England and the Lower Rhine area, there occur between the coal seams several strata with marine shells (Brachiopods, Goniatites, Trilobites, etc). ${ }^{3}$ The foundation of the coal-bearing beds is formed by a succession of several thousand feet of grauwacke, clay and roofing slates, which in many places contain characteristic culm fossils (Posidonomya Becheri, Goniatites sphcericus, G. mixcolobus, Archceocalamites radiatus, Lepidoden-

1 "9. Bericht d. naturf. Ges. zu Chemnitz" (1883-1884), p. 181.

2 Schütze, "Abh. d. geol. Landesanst.," III. pt. 4 (1882).

3 F. Rümer, "Geologie von Oberschlesien" (1880), p. 76, pl. 8. 
dron tetragonum, etc.). These beds resting on the west on the Devonian mass of Zuckmantel, which in its turn rests immediately on the crystalline schists of the Altvatergebirge, reach in a southwesterly direction far into Moravia (to the neighbourhood of Brünn), and form the largest known area of culm in Germany.

D. Stur, who has made the distribution of the fossil plants in the Upper Silesian basin the subject of detailed examination, distinguishes three stages, ${ }^{1}$ as follows, in descending order:-

3. Schadowitz and Radowenz beds; with numerous species of Pecopteris (P. arborescens, elegans, Serli, etc.), Annularia longifolia, etc.correlated with the Ottweiler beds of $\mathrm{E}$. Weiss.

2. Schatzlar beds; with numerous Sigillaria (S. oculata, S. alternans, etc.), Lepidodendra and Calamites (C. Cisti arenosus, etc.)-representing the Saarbrück beds of F. Weiss.

1. Waldenburg or Ostrau beds; with Archoocalamites radiatus, Lepidodendron Veltheimianum, Sphenophyllum tenerrimum, Sphenopteris Linki, ttc.-belonging, according to Stur, to the Upper Culm.

According to Weiss, however, the lowest or Waldenburg beds do not belung to the Culm, but form the lower part of the Upper Carboniferous ; ${ }^{2}$ and he correlates as follows:-

\begin{tabular}{|c|c|c|c|}
\hline & Saar Region. & Silesia, Boheuia, Saxony. & General Designation. \\
\hline$\stackrel{\dot{0}}{2}$ & Ottweiler beds. & Radowenz beds. & $\begin{array}{c}\text { Calamite and Fern } \\
\text { stage. }\end{array}$ \\
\hline$\underset{3}{\tilde{3}}$ & Saarbrück beds. & Schatzlar beds. & Sigillaria Stage. \\
\hline$\frac{\dot{2}}{2}$ & & $\begin{array}{c}\text { Waldenburg }=\text { Ostrau } \\
\text { beds. }\end{array}$ & \multirow{2}{*}{ Sagenaria Stage. } \\
\hline $\begin{array}{l}\text { Lower } \\
\text { Carboni- } \\
\text { ferous. }\end{array}$ & & Hainichen-Chemnitz. & \\
\hline
\end{tabular}

In Bohemia only the Upper Carboniferous is developed. It forms several coal-basins, among which that of Pilsen is the most inportant, and is especially remarkable because it was in the socalled Nyrschan Gas-coal belonging to this basin that the rich fauna of stegocephalous Amphibia, described by A. Fritsch, was. found. ${ }^{3}$

In Southern Germany the Carboniferous formation is restricted

1 "Die Culm Flora d. Ostrauer u. Waldenburger Schichten," Vienne. (1877).

2 The correctness of this view is supported by the unconformity discovered by Dathe between the Waldenburg beds and the Culm.

3 "Fauna der Gaskohle," etc., Prague, 1879 (still incomplete). 
to the Black Forest and the Vosges; and even in these areas the extent is but small. We find here the Culm grauwacke with typical plants, the Carboniferous Limestone (Oberburbach not far from Thann in the Vosges), and also the Upper Carboniferous- the latter only in small patches on the older rocks.

France.-The Belgian belt of Carboniferous rocks extends into the North of France; and in the south-east we have deposits which belong to the Mediterranean region. But besides these, Carboniferous rocks are found on the borders of and within the Armorican massif, and in the Central Plateau.

The most important and interesting are those of the Central Plateau, where the Carboniferous rocks occur in a number of small basins, especially in its eastern part. According to Julien ${ }^{1}$ the Lower Carboniferous rocks of these basins may be divided into two series:-

Upper. Sandstones and conglomerate (anthracifure), with contemporaneous porphyries and porphyry tuffs.

Lower. Marine quartzites, sandstones and arkoses,

In the Morvan, which is separated from the main part of the Plateau by the fault of Blanzy, the marine Lower Carboniferous belongs to the stage of Tournai; while in the Plateau proper only the Dinant assise of the stage of Visé is present. The sandstones and porphyries are not all of the same age. Those of the Morvan are of Waulsortian age; the upper sandstone of the Ardoisière belongs to the lower part of the Coal Measures (Millstone Grit, Namur Stage of Belgium); while the quartz-porphyries are of middle Coal Measure age.

Above these sandstones, etc., comes the productive part of the Coal Measures, which in the basin of St. Etienne commences with a breccia or conglomerate, and at the top is covered by a barren stage of red and green clays and sandstones, which forms a passage into the Permian. This passage upwards into the Permian is best seen in the basin of Autun.

The coal field of St. Etienne may be taken as the type of the basins of the Central Plateau. In it, according to Gruner, we have the following succession:--

Coal Measures $\int_{7}^{8}$. Coal-bearing stage of St. Etienne.

(Upper part) $\left\{\begin{array}{l}\text { 7. Unproductive beds; conglomerate of Grand' Croix. } \\ 6 . \text { Coal-bearing stage of Rive-de-Gier. }\end{array}\right.$

5. Flows of quartz-porphyry and interruption of sedimentation.

1 "Comptes Rendus," cx. p. 736. 


\author{
4. Grès anthracifère, with beds of porphyry. \\ Lower $\quad$ 3. Flows of granitoid porphyry. \\ Carboniferous $\{$ 2. Limestone and calcareous schists of Régny. \\ 1. Quartz-schists of the Roannais.
}

The series begins with the "grauwacke of the Roannais" ( 1 and 2 of the above table), the lower part of which is quartzose and the upper part calcareous; the fauna includes Productus giganteus, $P$. semireticulatus, and other Lower Carboniferous fossils. Above the grauwacke are flows of porphyry, and these are succeeded by a conglomerate, consisting of pebbles of porphyry, limestone and quartzite. The conglomerate is followed by sandstone, with anthracite, the grès anthracifère, which also is largely formed of small fragments of porphyry.

The Coal Measures commence with a thick breccia, nearly 500 feet thick, and this is succeeded by one or two thousand feet of conglomerates. This assise is usually unproductive, but below Rive-de-Gier includes workable seams of coal. It is followed by, the coal-bearing stage of St. Etienne with some thirty seams. Above all comes a barren series of clays and sandstones, which form a passage upwards in to the Permian.

\title{
The Mediterranean Region.
}

A considerably different development of the Carboniferous is met with in Southern Europe, on the south border of the Central Plateau of France, in Spain, and in the Alps. It is true that the Lower Carboniferous of these areas is not very different from that of Central Europe. Thus, in Spain, besides the peculiar marbre griotte, a variegated nodular limestone with Goniatites sphericus and other Cephalopods, ${ }^{1}$ we find both Culm-in part in the form of Posidonomya schists with the characteristic fossils-and Carboniferous Limestone. But the coal-bearing Upper Carboniferous rocks which overlie these contain near their base Fusulina ( $F$. cylindrica, etc.), ${ }^{2}$ and a few small outcrops of Fusulina limestone of the Russo-Asiatic facies have been found on the southern border of the Central Plateau.

In the Alps the Carboniferous beds are usually more or less. metamorphosed, the coal is changed into anthracite or a graphitelike substance, and the original plant fibres are not carbonised but silicified. Yet here also the Lower Carboniferous is quite like that of Central Europe, inasmuch as along with the plant-bearing Culm grauwacke, true Carboniferous Limestone occurs, as for example at Bleiberg in Carinthia. ${ }^{3}$ These Lower Carboniferous beds (Gail-

1 Barrois, "Le marbre griotte." Ann. Soc. Géol. du Nord, VI. (1879), p. 270.

2 Barrois, "Recherches sur les terrains anciens des Asturies et de la Galice" (1882), pp. 582, 592.

3 De Koninck, " Monogr. des fossils carbon. de Bleiberg," Brussels (1873). 
thal schists of the Austrian Alps) are overlaid in the Eastern Alps by schists, grauwacke sandstone and Fusulina Limestone, which are followed directly by Permian deposits. ${ }^{1}$

Pyrenees.-The "marbre griotte" is the most important member of the Carboniferous in the Pyrenees. It was referred by Leymerie to the Devonian; but in the Spanish province of Leon it has been shown to overlap schists with Cardium palmatum, and to be covered by limestone with Productus giganteus. From these circumstances and from the fossils it contains (Goniatites crenistria, ete., Orthoceras giganteum, Spirifer glaber), Barrois concludes that it is of Carboniferous age.

In the Rhune at the western end of the Pyrenees a limestone of this. sort is overlaid by grauwacke containing the flora of the upper part of the Coal Measures; and another outcrop of coal measures is to be seen at Sare near Ibantelli.

Spain.-In the north-west (Asturias and Leon) Barrois recognises the following groups :-

5. Conglomerates of Tineo with Pecopteris Pluckeneti (=Upper Coal Measures).

\section{Unconformity.}

4. Slates of Sama with Dictyopteris sub-Brongniarti (=Middle Coal Measures). Brackish facies contains Anthracosia, Bellerophon, etc.

3. Slates, conglomerates and limestones of Lena with Fusulinella sphceroidea (= Lower Coal Measures).

2. Limestone of the Cañons with Poteriocrinus.

1. Marbre griotte, with Goniatites crenistria.

The two upper assises form the coal-bearing portion of the system and contain the Middle and Upper Coal Measure floras of Grand' Eury and Zeiller. Of the others the Lena assise represents the Vise stage of the north of France; the Cañon limestone has not yielded enough fossils for its determination; while the exact position of the marbre griotte is still matter of discussion.

In Ciudad Real there is also a basin of Coal Measures in the midst of Silurian rocks. Calamites Suckovii, Walchia piniformis, ete., occur, showing. that the beds belong to the uppermost part of the coal.

Var.-In the Department of the Var there is a small basin of Carboniferous and Permian rocks, of which, however, the former is but feebly represented.

Alps.-In the Western Alps the Carboniferous is represented chiefly by conglomerates and a sandstone with anthracite (the grès à anthracite). This belongs to the Coal Measures; the flora in Switzerland pointing to the upper division, and that in Savoy to the third phase.

The grès à anthracite is overlaid by a red conglomerate of quartz pebbles, which is known as the Verrueano conglomerate, and is supposed to be of Permian age.

In the Eastern Alps the Lower Carboniferous is represented by the Gailthal Slates, best seen at Bleiberg in Carinthia. These are mostly dark slates with some sandstones and conglomerates, and they contain

1 Stache, Zeits. d. deutsch. geol. Gies. (1884), p. 375. 
an abundant fauna (Productus, Bellerophon, Nautilus, etc.), and also fossil plants characteristic of the Culm (Archococalamites radiatus). They are followed by a limestone with Fusulina ( $F$. robusta, carinthiaca), which represents the Upper Carboniferous.

Fusulina limestones are widely spread throughout the Upper Carboniferous of Carniola and the Southern Alps; and occur at several horizons in deposits of the more usual Western facies. The western type of Upper Carboniferous is found in the valley of Pressnitz in Styria, where Stur obtained from beds of graphite, the flora of the Schatzlar Beds of the Silesian basin.

Balkans.-Culm measures, consisting of sandstones and clay-slates, cover a large area in Turkey and yield the ordinary culm fossils.

\section{Russia.}

Quite unlike the sporadic appearances in Southern Europe, that facies of the Carboniferous System which is characterized by the occurrence of Fusulina limestones possesses an extraordinarily wide distribution in Russia. The Carboniferous formation in Russia, which still in great part lies horizontally, forms three great patches: a westerly, to which belongs the so-called Moscow basin; an easterly, which lies on the western slope of the Urals; and a southerly, which includes the coal fields of the Donetz. In all three areas the system, over 10,000 feet thick, is composed mainly of limestone, with which at the most different horizons are interbedded marls, shales, sandstones and other rocks; but in which the richer coal-seams are found only in the lower part. In all three regions an upper and a lower division may be distinguished. The Lower Division, the base of which is formed in the Moscow basin by the Limestones of MalewkaMurajewna with a mixed Devono-carboniferous fauna, consists partly of sands, sandstones and clays, with coal-seams (in which Lepidodendron Veltheimianum and other fossils occur), and partly of Carboniferous Limestone with Productus giganteus, Spirifer trigonalis, Sp. striatus, Orthoceras giganteum, and many other species of the Carboniferous Limestone of Western Europe. The upper division on the other hand is especially characterized by the abundance of Fusulina ( $F$. cylindrica [XXVIII. 6]) and other foraminifera. With these occur many species of the Carboniferous Limestone of Western Europe (especially brachiopods, such as Productus semireticulatus and $P$. cora, Streptorhynchus crenistria, Orthis resupinata, Spirifer lincatus); but also some that are absent in these beds but are found in beds of the same age in India, China, and North America, such as Productus timanicus 
P. tuberculatus, etc., Enteletes Lamarcki (XXVIII. 4), Streptorhynr.hus (Mcekella) eximius (XXVIII. 5), Marginifera (subgenus of Productus) sp., Euomphalus Whitneyi, Aviculopecten exoticus, Schizodus sp., Archceocidaris rossica, the remarkable and characteristic screw-shaped Bryozoan Archimedipora (XXVIII. 1), Chaetetes radians (XXVIII. 1), Phillipsia Griineualdti, the fishes Dactylodus, Edestus, etc. ${ }^{1}$

According to the most recent researches of Tschernyschew and Nikitin beds with Spirifer mosquensis (XXVIII. 3) lie at the base of the Russian Upper Carboniferous. They are typically developed at Mjatschkowa near Moscow, and have become well known through the monograph by Trautschold. It is directly above these beds that the true Upper Carboniferous (Gshelien) begins, and it here consists of three sub-stages :-

(3) Beds with Spirifer fasciger, Spiriferina Sarance, Marginifera, Agathioceras, Schwagerina.

(2) Beds with Productus cora, Marginifera uralica, Meekella eximia, C'amarophoria crumena, etc.

(1) Beds with Syringopora parallela, Omphalotrochus Whitneyi, Spirifer striatus, Productus semireticulatus.

These beds are followed by the so-called Artinsk stage with Permo-Carboniferous fauna (see Permian, p. 179). All three substages are developed in Central Russia, the Urals, and in Timan.

According to M. Nikitin ${ }^{2}$ the Carboniferous of the Moscow basin commences with sandstones and clays, with thin limestones and some beds of coal at the base. These have yielded Stigmaria and Lepidodendron Veltheimianum, etc. They are followed by limestones with Productus giganteus, and above this limestone and clays with Spirifer Kleini (sub-stage of Spirifer Kleini.) The upper part of the system consists of limestones with Spirifer nosquensis (étage moscovien) and dolomites with Chonetes uralica (Gshelien.) The latter occurs in the eastern part of the Moscow Government, where it is divided into the three sub-stages given above; and in Eastern Russia and the Urals it increases greatly in thickness and forms the well-known Fusulina Limestone. We thus get the following succession :-

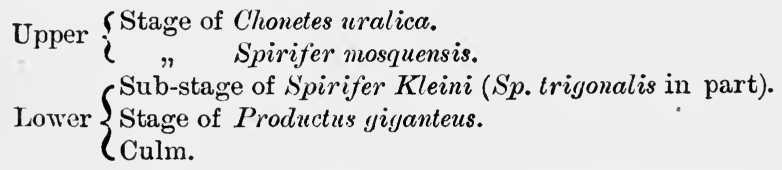

1 Von Möller, "Sur la composition, etc., du système carbonif." Congrès internat. de Géologie de Paris (1880). A. Struve, "Carbonabl. im. südl . 'Theile d. Moskauer Kohlenbechens." Mém. Acad. St. Pétersb. (1886). 'Trautschold, "Die Kalkbrüche von Mjatschkowa," Moscow (1874-79).

2 "Mém. Com. Géol. russe," v. no. 5.

C. G. 
In the Urals, according to the researches of M. Krasnopolski, ${ }^{1}$ the system begins with limestone with Productus mesolobus, sometimes partly or completely replaced by grits. This is succeeded by sandstones, clays and slates with seams of coal, which contain Lepidodendron glincanum, Sigillaria, Cordaites, Noeggerathia tenuistriata, Productus giganteus. These beds are followed by the "Lower Carboniferous Limestone," the lower stage of which is characterized by Productus giganteus and P. striatus, and the upper stage by Spirifermosquensis and Productus cora. Lastly the upper section of the whole system is represented by the Fusulina Limstone, which contains abundance of Fusulinas and Bryozoa, and numerous brachiopods, etc. (Chonetes uralica, etc.). The series is thus as follows:-

\section{Fusulina Limestone. \\ Stage of Spirifer mosquensis. \\ , Productus giganteus. \\ Coal-bearing stage. \\ Stage of Productus mesololus.}

Thus in general we have in Russia, in descending order:-

$$
\begin{aligned}
& \text { Upper }\left\{\begin{array}{l}
\text { Limestones with Fusulina. } \\
\text { (Stage of Spirifer mosquensis at base.) }
\end{array}\right. \\
& \text { Lower }\left\{\begin{array}{l}
\text { Limestones with Productus giganteus. } \\
\text { Coal-bearing stage. } \\
\text { (Stage of Productus mesolobus at base.) }
\end{array}\right.
\end{aligned}
$$

\section{Extra-European Areas.}

In Asia also we meet with this facies of the Carboniferous formation. Thus the lower part of the Productus Limestone of the Salt Range of India, which is chiefly Permian, and the fauna of which is being described by W. Waagen, $\stackrel{2}{ }$ is considered to be the equivalent of the Russian Fusulina Limestone. This is proved to be the case, moreover, with a limestone in $\mathrm{Ch}$ in a (near Lo-ping), which contains a marine fauna with Fusulina cylindrica, Enteletes Lamarcki, Productus semireticulatus, P. mexicanus, Orthis Pecosii, Schizodus Whecleri and other species of the Upper Carboniferous of America; and a similar but poorer fauna is known from Turkestan, and also from the islands of Timor and Sumatra. But along with these purely marine beds in these regions, the coal-bearing Upper Carboniferous is by no means absent. According to Richthofen, China is one of the richest countries of the world in coal. In the Province of Shansi alone the Productive coal measures occupy an area of some 35,000 square miles. The lower division of the formation is in Asia developed

1 "Mèm. Com. Géol. St. Petersbourg," xi., no. 1.

2 "Palæontologia Indica" (1879-88).

3 Kayser in Richthofen's "China," vol. iv. (1883). 
much as it is in Europe. Sandstones with a Culm flora are widely spread in Siberia; and in China and Japan Carboniferous Limestone occupies a large area.

Passing on to North America we again find the Carboniferous formation of extraordinary extent. In the eastern part of the United States the development is very nearly allied to that of Central Europe. An upper coal-bearing division with Millstone grit at its base may here be separated from a lower calcareous sandy division, which does indeed contain coal, but in its essential characters is the equivalent of our Lower Carboniferous. West of the Mississippi and in the Rocky Mountains, on the other hand, just as in Asia and Russia, the Upper Carboniferous is represented by limestones rich in Fusulina with an abundant marine fauna, which has been made known to us by the reports of the various American surveys. ${ }^{1}$ Here also, besides a predominance of species common to the Lower Carboniferous, there are found as especially

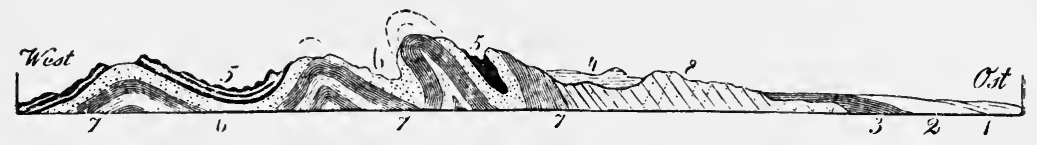

F1G. 21.-Section through the Alleghany Mountains.

1. Miocene. 2. Eocene. 3. Cretaceous. 4. Trias. 5. Carboniferous. 6. Devonian. 7. Silurian. 8. Crystalline schists.

characteristic forms, Enteletes, Mcekella, Marginifera, Archimedipora, Archarocidaris, Edestus, Dactylodus, and others. On the whole, in the region of the United States four chief coal-fields may be distinguished: (1) the great Appalachian or Pennsylvanian field with an area of some 50,000 square miles; (2) that of Michigan; (3) that of Illinois; (4) and lastly, the coal field of Missouri and Arkansas, which nearly equals the first in size. In the basin of Michigan a perfectly gradual passage may be observed in the "subcarboniferous" beds, from conglomerates and sandstones with land plants at the eastern border to limestone with marine fossils in the western part of the field. Not less interesting is the circumstance that in the western and central parts of the Pennsylvanian field, the coal seams, in correspondence with their almost undisturbed position, consist of bituminous coal ; whilst in the eastern patches, which are separated from the main area, in correspondence with the severe disturbance which they have there undergone, they consist of anthracite (Fig. 21).

1 "Final Report of Nebraska," 1872. 
The extraordinarily rich fauna of the North American Carboniferous Limestone has been made known to us in many geological reports, among which those of the Illinois, Missouri, and Iowa States must be specially mentioned.

In the Far North, in Novaja Semlja, Spitzbergen, the Barents Islands, etc., deposits of Carboniferous age are developed, chiefly in the form of Upper Carboniferous Limestone with a rich marine fauna. ${ }^{1}$

Finally, the formation occurs on the continents of the Southern Hemisphere. Carboniferous Limestone is known in Africa, in the Sahara ${ }^{2}$ in South America, in Peru and Bolivia ; in Australia, in New South Wales, ${ }^{3}$ with a rich fauna containing many European species, whilst coal-bearing Upper Carboniferous is found in the same district of Australia, and also in Tasmania and Brazil.

\section{(ON THE MODE OF FORMATION OF COAL.}

Although no doubt remains to-day as to the vegetable origin of coal, yet the views on the exact mode of its formation are still very various. All attempts to explain the formation of beds of coal must explain at the same time: (1) the alternation, often many times repeated, of coal, shale and sandstone; (2) the extraordinary extent of some of the seams-the Pittsburg seam in the Pennsylvanian field extends over thousands of square miles-as well as their great thickness and purity; (3) their derivation exclusively from land plants, and (4) the occurrence of marine fossils between the coal-bearing beds-an occurrence which is not rare, although it is always restricted to inconsiderable beds.

A. Brongniart, the father of fossil botany, was of opinion that coal was of a $t \circ 0 \mathrm{chthonous}$ origin; that is, it was formed of plants growing in situ. Of late, however, this opinion has given way to the view of an allochthonous origin, i.e. a formation from plants which have been floated together, like the great collections of driftwood which are found in the Mississippi delta and elsewhere. This view, according to which we consider the vegetable material to have been deposited sometimes in the sea, but more generally in large freshwater basins ("paralische" and "limnische" coal basins, Naumann), has received much approval, not only in Germany, but

1 Toula, "Sitzungsber. d. Wien. Acad." (1873-75).

2 G. Stache, "Denkschrift d. Wien. Acad." (1883).

${ }^{3}$ De Koninck, "Recherches sur les foss. paléoz. de la Nouvelles-Galles du Sud.," Brussels (1876-77). 
also in France ${ }^{1}$ and England, and it has derived strong support from the observations of Grand' Eury and Fayol. In fact, if we imagine the drifting together of plants to form a coal seam, and suppose this to be followed by a flood which deposited gravel, sand, or clay; and if we suppose a repeated alternation of these two processes, most of the peculiarities of the Coal Measures may be easily understood. The extraordinary extent of such seams as the Pittsburg, and still more their unvarying thickness and frecdom from earthy impurities over hundreds of square miles cannot, however, be explained by the drift theory. Moreover the circumstance brought forward in its favour, that in coal seams a stratified alternation of different varieties of coal can be recognised, the whole reminding one of bedding, has lost its value as evidence, since exactly the same appearance has been observed in many peat mosses at the present day. Gümbel, in a very remarkable recent work, ${ }^{2}$ has allowed the drift theory to drop, and has returned to Brongniart's old view, that by far the greater number of coal seams have been formed from remains of plants growing on the spot in the same way as are peat mosses.

In favour of this theory, which allows of the formation of almost uniformly thick coal seams practically free from foreign matters, may be mentioned the occurrence, observed in the most various coal basins, of tree stems, in places abundant, standing upright, and still with their roots attached (Fig. 22). ${ }^{3}$ We cannot well suppose these to have been floated hither, and we even find the remains of insects and amphibians in the hollows of the stems.

On the whole therefore, according to Gümbel, coal should be considered an inland deposit formed in wide flat depressions of continents, and also on low ground along the sea coast. Undisturbed growtl of marsh vegetation, which developed very quickly in the favourable climate of that time, alternated with floods, and thus allowed the formation of a succession of beds of coal, sandstone, and shale, which, during a long continued and gradual sinking of the basin, might reach' locally a thickness of several thousand yards. Occasionally; as is easily intelligible on this view,

1 Grand' Eury. "Mém. sur la flore carbonifère du dép. de la Loire." Paris (1887).

2 "Beiträge zur Kenntniss der Texturverhäit. d. Mineralkohlen. Sitzungsber. d. bayer. Akad" (1883).

3 Fayol, however, has shown that the upright position of trunks affords no proof that these are in situ. "Comptes Rendus," xciii., p. 160. 
inrushes of the sea brought in the marine shells which are now met with between the coal seams.

This attempted explanation does not, indeed, solve all the problems. There still remains the extraordinary constancy in character and thickness of the floor and roof of many seams, which is always very obvious, and which agrees but indifferently with what we observe in the detrital deposits found in the sea-basins of to-day.

\section{PALAEONTOLOGY OH THE CARBONIFEROLS SYSTEII.}

The Carboniferous system is the first in which plant remains become of great importance, and as has already been mentioned,

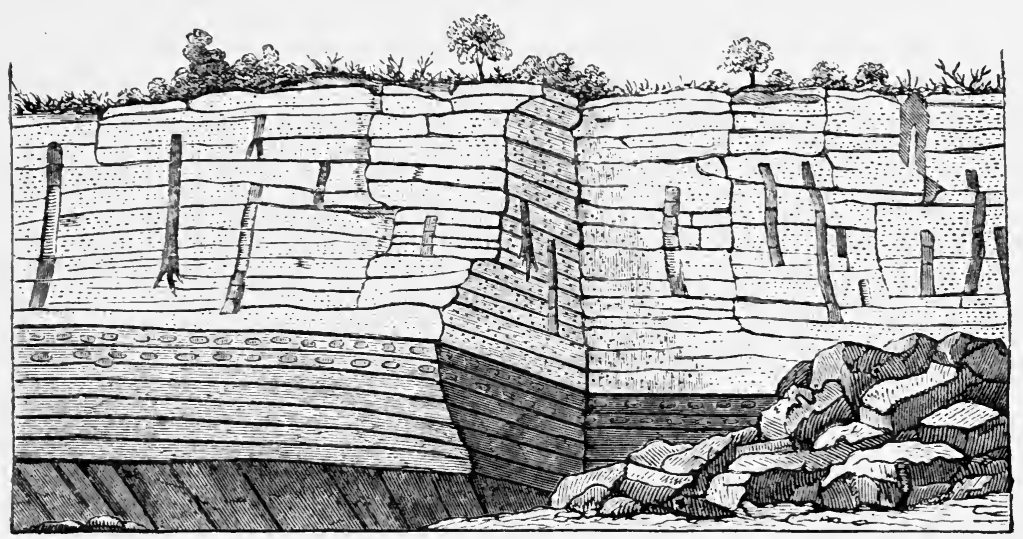

FrG. 22.-Upright Trunks in the Carboniferous of St. Etienne.

$\Delta t$ the base, a coal seam; above this, shale with nodules of sphærosiderite; at the top, sandstone with uprigint tree-trunks.

they are here exclusively terrestrial. Such plants appear for the first time in Silurian times; but the pre-Culm land floras are relatively of little importance, and the first really rich and extensive flora everywhere belongs to the Carboniferous. ${ }^{1}$

Our knowledge of the Carboniferous flora, like that of fossil botany in general, is due mainly to Adolphe Brongniart.2 In Germany, Count Sternberg (1820) was the first to occupy himself with the observation of fossil plants. Since then our knowledge has been increased by Göppert, Unger, Heer, Schimper, Geinitz

${ }^{1}$ It is remarkable-as has been shown by Weiss in the case of the Lower Devonian Tanner grauwacke of the Harz-that all the pre-Culm floras resemble the flora of the Culm.

2 "Prodrome d'une histoire des végétaux fossiles," Paris, 1828. 


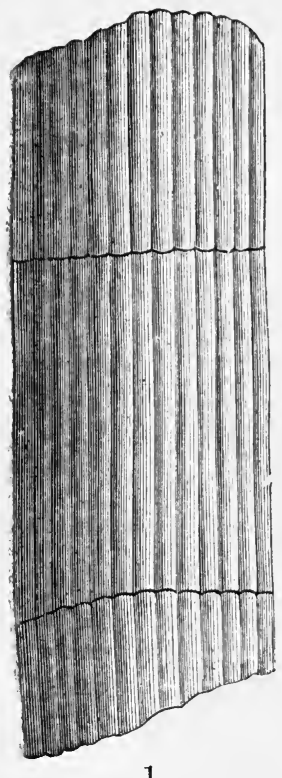

1

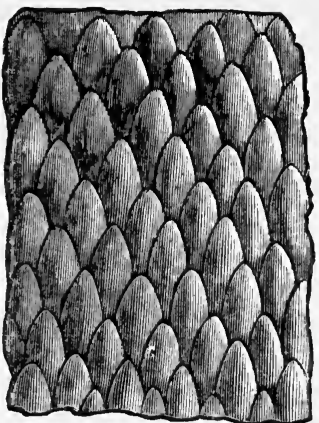

2

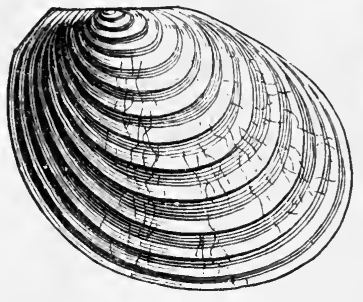

4

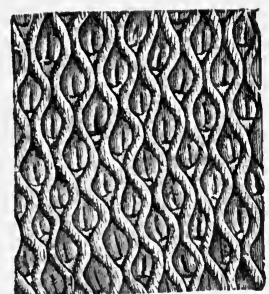

3

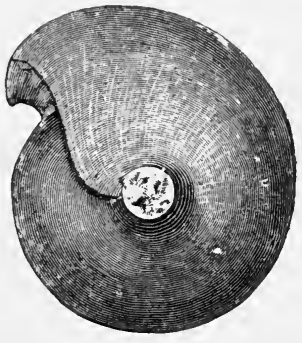

5
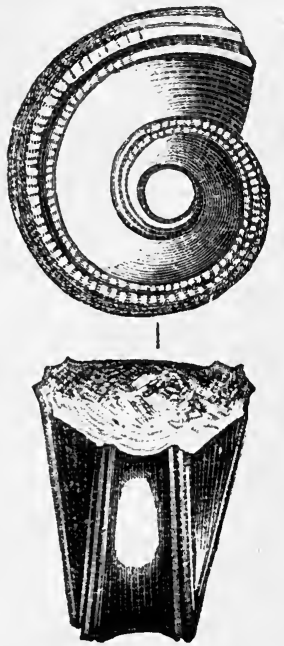

7

Puate XX.-Fossils of the Culm (above), and Carboniferous Limestone (below).

1. Archaocalamites radiatus, Brngn. 2. Knorria imbricata, Sternb. 3. Lepidodendron Veltheimianum, Sternb. 4. Posidonomya Becheri, Bronn. 5. Goniatites (Glyphioceras) sphoricus, Mart. 6. G. (Glyph) crenistria, Phill. 7. Nautilus bilobatus, Sow. 8..Phillipsia semmulifera, Phill. 

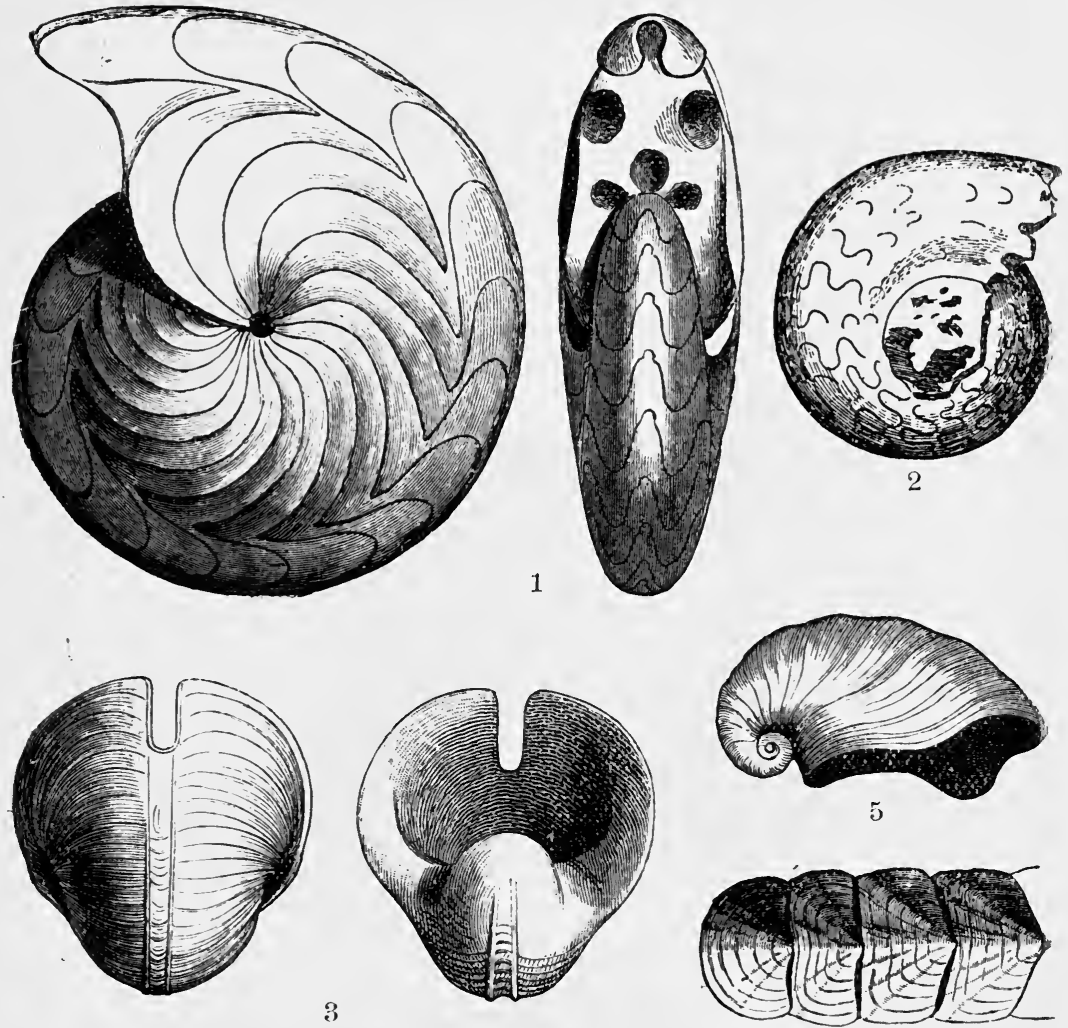

6
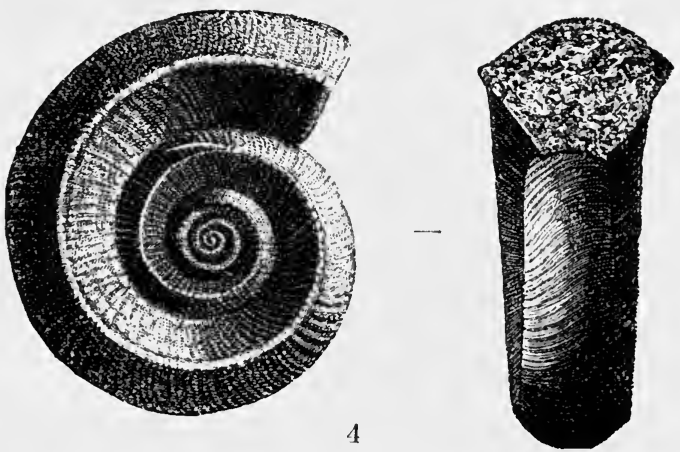

Plate XXI.-Cephalopods and Gasteropods of the Carboniferous Limestone.

1. Goniatites (Brancoceras) rotatorius, de Kon. 2. G. (Pronorites) cyclolobus, Phill. 3. Bellerophon bicaronus, Leveillé. 4. Euomphalus pentangulatus, Sow., from above, and from the side. 5. Acroculia neirtoides, Phill. 6. Chiton priscus, Münst. 

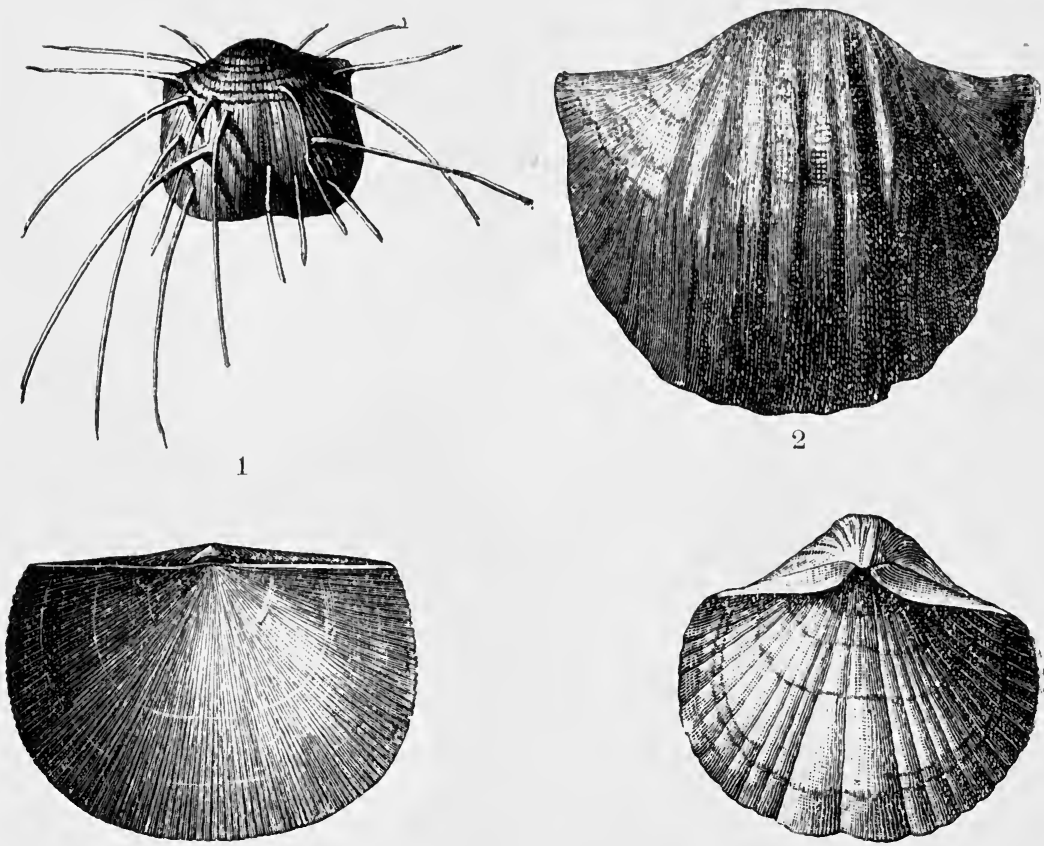

3

5

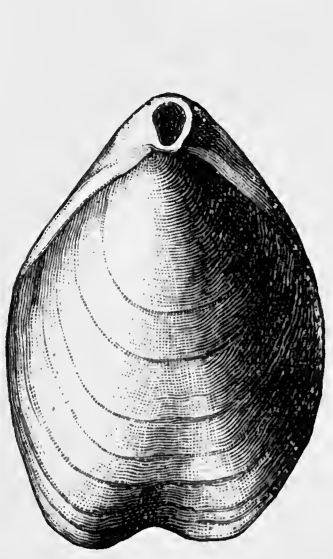

7
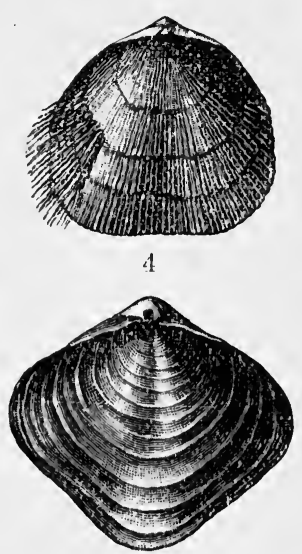

6

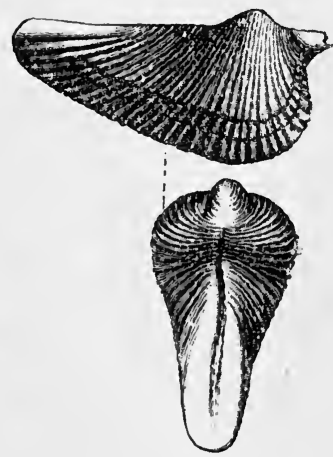

8

Plate XXII.-Brachiopods and Lamellibranchs of the Carboniferous Limestone.

1. Productus longispinus, Sow. 2. P. giganteus, Sow. 3. Streptorhynchus crenistria. Phill. 4. Orthis Michelini, Leveille, 5. Spirifer pinguis, Sow. 6. Athyris lamellosa, Lev. 7. Terebratula (Dielasma) hastata, Sow. 8. Conocardium aliforme, Sow. 


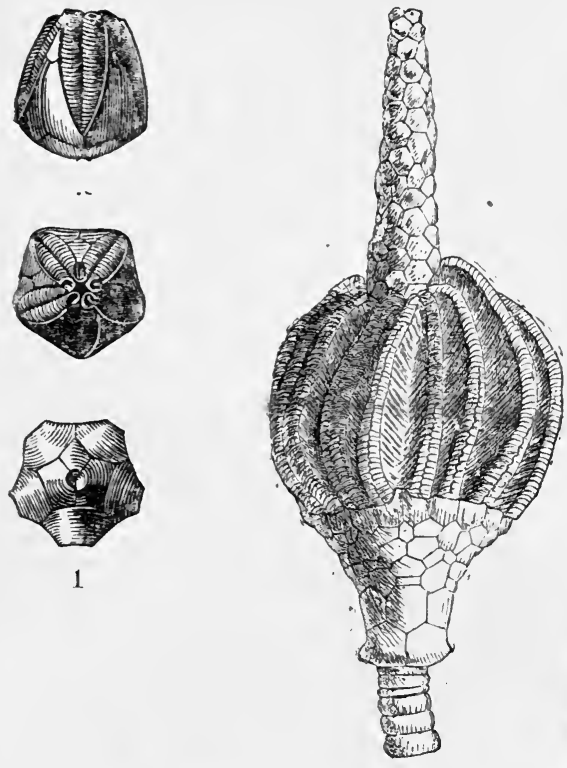

2
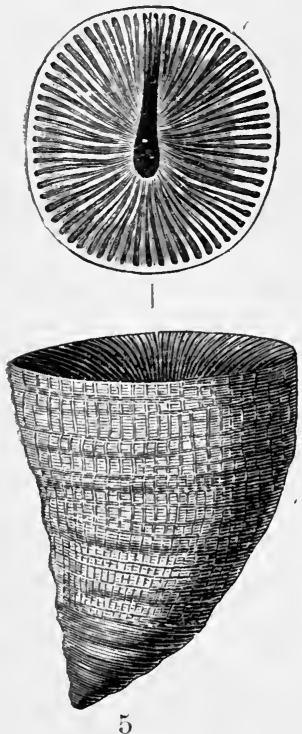

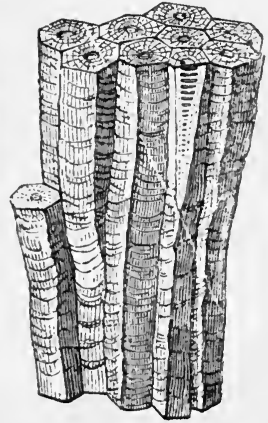

6
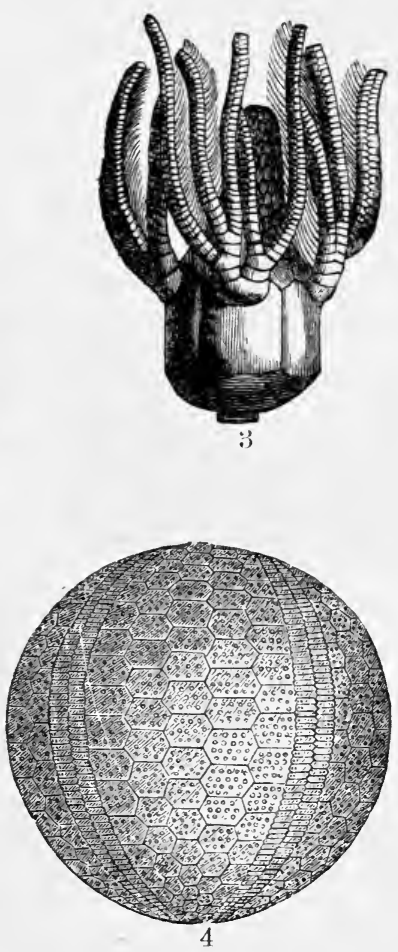

PLATE XXIII.-Carboniferons Limestone Colenterates.

1. Pentrcmites florealis, Say. 2. Actinocrinus pyriformis, Sow. 3. Platycrinus trigintialactylus, Anstin. 4. Palaechinus clegans, M'Coy. 5. Zaphrentis cornicula, Lesneur. 6. Lithostrotion basaltiforme, Phill. 7. Michelinia favosa, de Kon. 

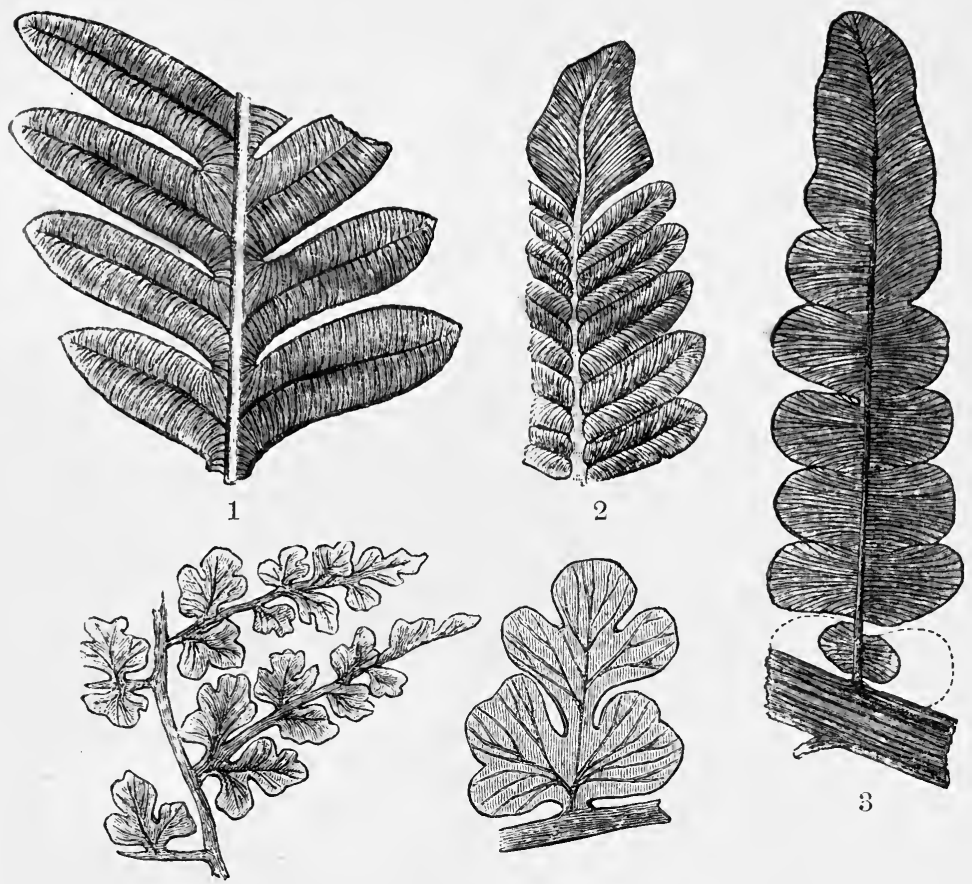

5

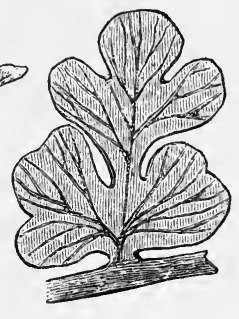

5 A
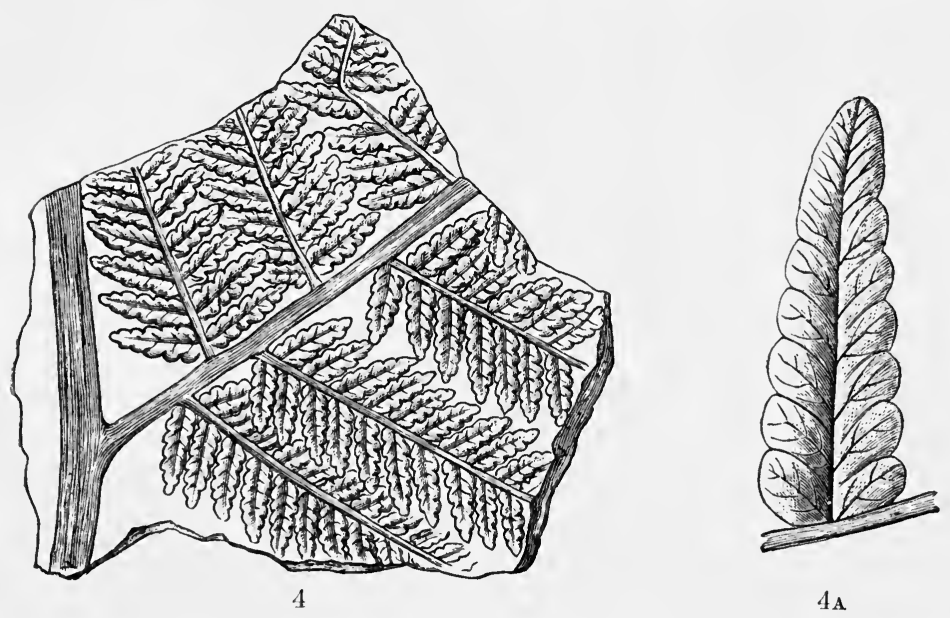

Plate XXIV.-Coal Measure Plants.

1. Alethopteris Serli, Brngn. 2. Neuropteris Jlexuosa, Brg. 3. Odontopteris obtusa, Brg. 4. Pecopteris dentata, Brg. 4A. Pinnule of same, enlarged. 5. Sphenopteris obtusiloba Brg. 5s. Pinnule, enlarged. 

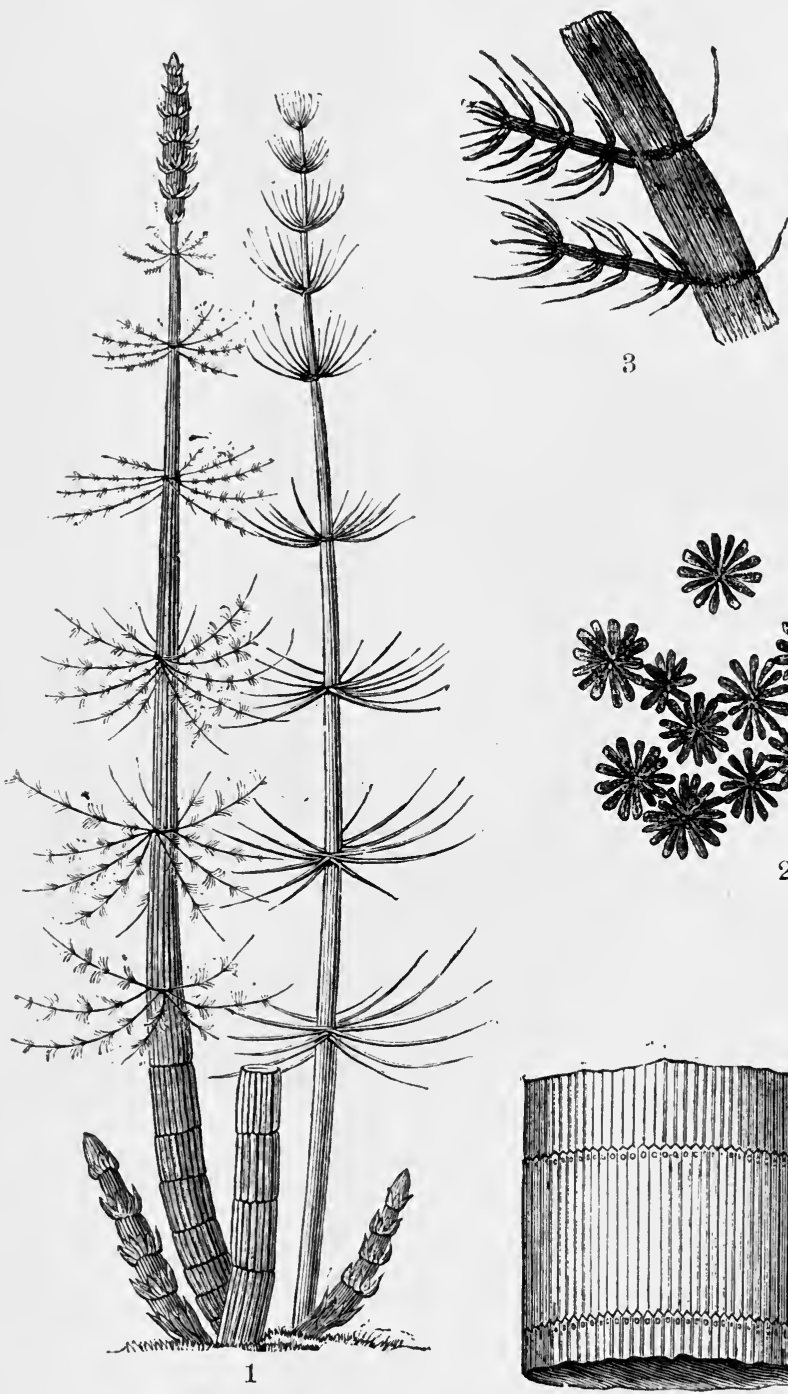

3
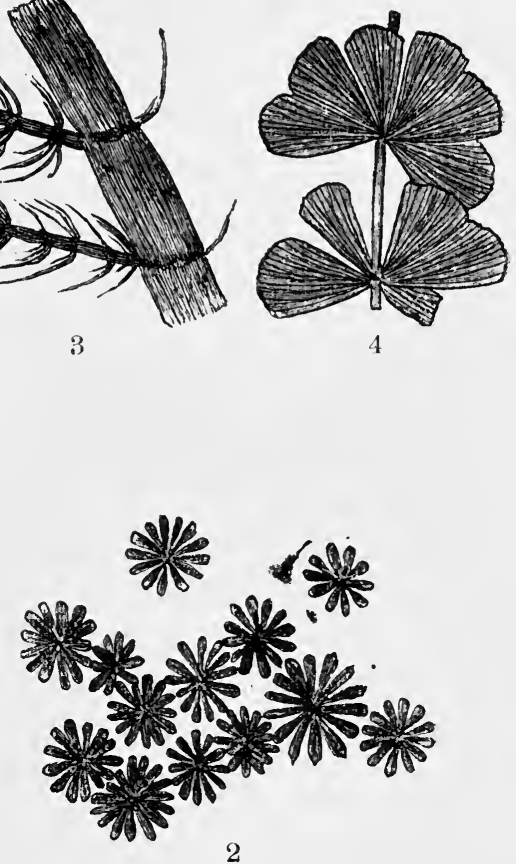

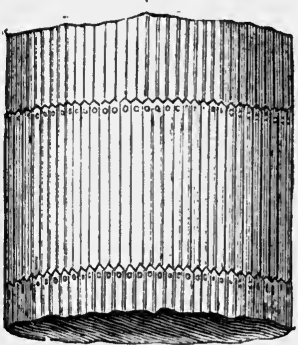

$1 \mathrm{~A}$

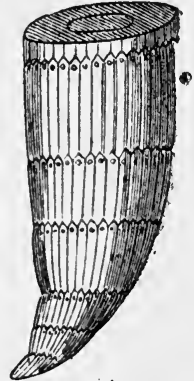

1s

Plats XXV.-Coal Measure Plants.

1. Calamites sp., restored (after Schenk), greatly reduced. 14. Portion of the stem. 1B. Lower end of the stem. 2. Annularia sphenophylloides, Zenk. 3. Asterophyllites equisetiformus, Schloth. 4. Sphenophyllum Schlotheimi, Brngn. 

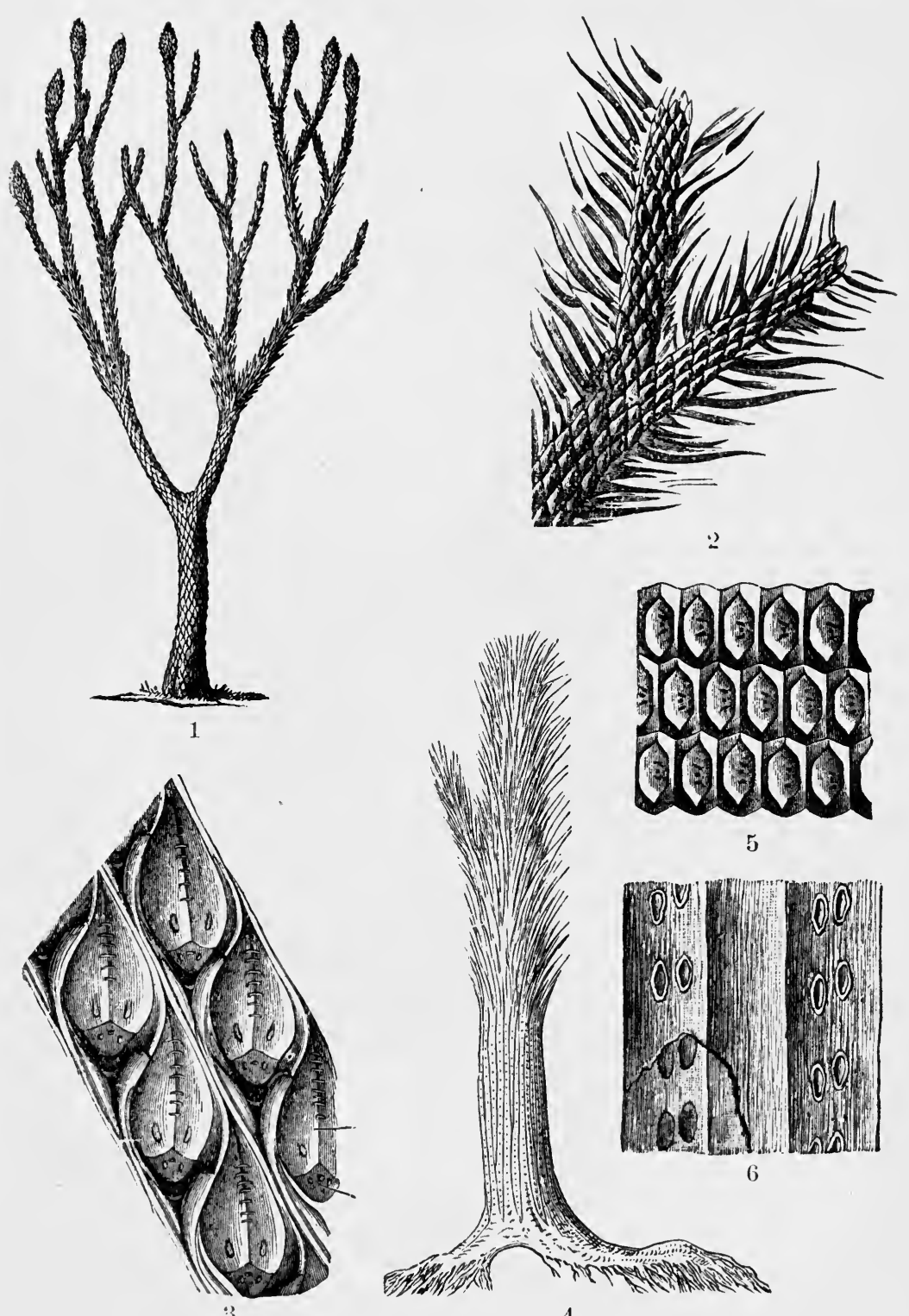

5

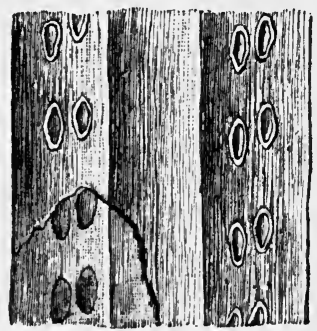

6

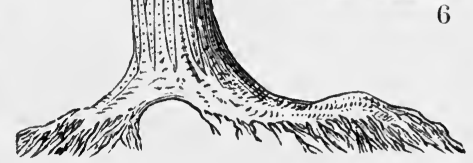

4

Plate XXVI.-Coal Measure Plants.

1. Lepidodendion sp., restored, greatly redueed, 2. Lépid. elegans Brngn. 3. Lepid. Aichotomum, Sternb., bark. 4. Sigillaria Browni, Daws., restored, greatly reduced. 5. S. hexagona, Brg., bark. 6. S. alternans, Lindl, and Hutt., reduced. 

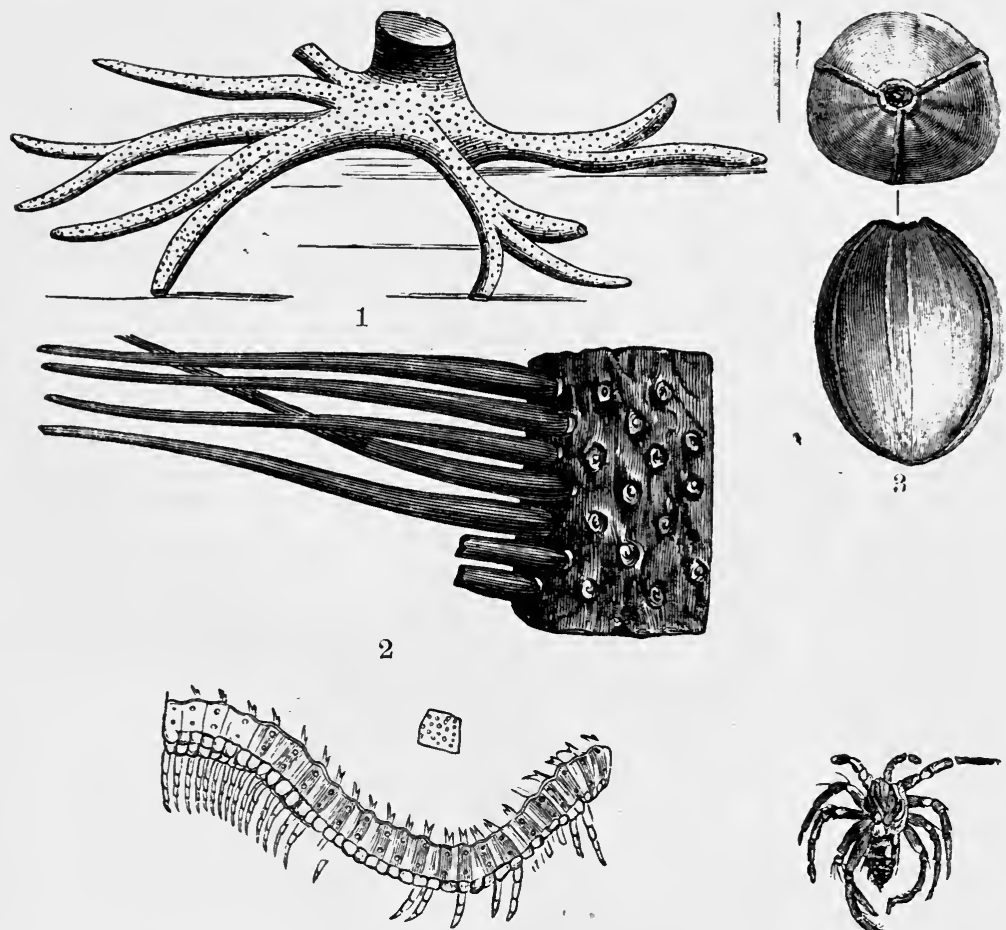

8
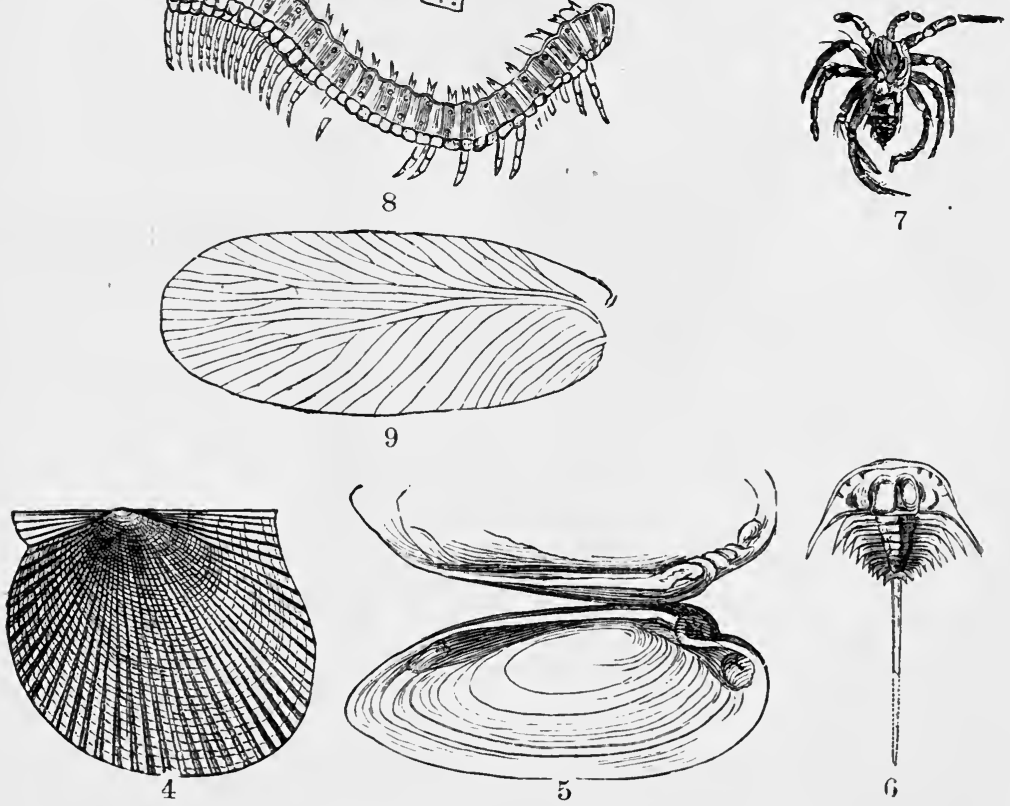

Plate XXVII.-Piant and Animal remains of the Coal Measures.

1. Stigmaria (root of Sigillaria), greatly reduced. 2. Stigm. ficoides, Brg. 3. Trigonocarpus Nöggerathi, Brg. 4. Aviculopecten papyraceus, Sow. . 5. Anthracosia Lottnori, Ludw. 6. Belinurus reginae, Baily. 7. Protoly.cosa anthracophila. F. Rüm. 8. Euphoberia armigera, Meek and Worthen. 9. Etoblattina manebachensis, Goldenb. 

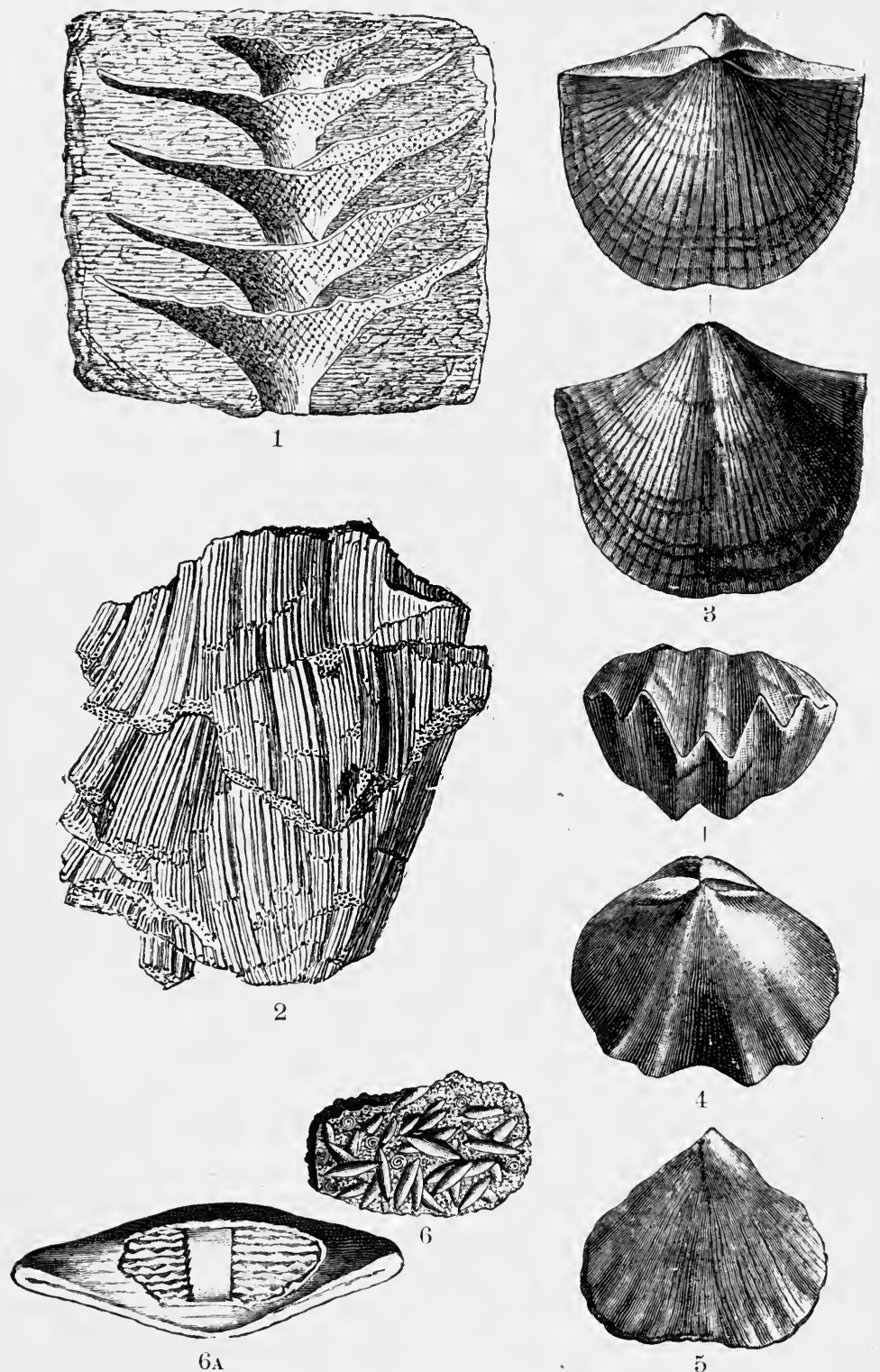

5

Plate XXVIII.-Fossils of the Marine Upper Carboniferous.

1. Archimedes (Archimedipora) Wortheni, Hall. 2. Chactetes radians, Fisch. 3. Spirifer mosquensis, Fisch. 4. Orthis (Enteles) Lamarcki, Fisch. 5. Orthis (Meeleella) eximia, Eichw. f. Fusulina cylindrica, Fisch. 6A. The same, enlarged. 
and others: and more recently E. Weiss ${ }^{1}$ and D. Stur in Germany, Grand' Eury, Renault aud Zeiller in France, Williamson in England, and Lesquereux in North America, have added to our knowledge of the Carboniferous flora in particular.

Brongniart distinguishes three great Vegetation periods (1) The age of Acrogens; (2) of Gymnosperms; (3) of Angiosperms. "The Palæozoic floras belong entirely to the age of Acrogens, which is distinguished by the predominance of acrogenous Crypto.. grams (Ferns, Lycopodiaceæ, Equisetaceæ), whilst Monocotyledons (grasses, palms, etc.) and Gymnosperms (Cycads and Conifers) are still rare, and Angiosperms are quite absent. In 1849 Brongniart reckoned in all some 500 Carboniferous plants with 346 Acrogens (250 ferns, 83 Lycopodiaceæ, 13 Equisetaceæ), and 135 Gymnosperms and plants of doubtful positions. Contrasting this with the number of species, more than 6,000, of Phanerogams alone, in the present flora of Europe, the poverty of the coal flora would appear remarkable, unless it could be explained by the absence of Angiosperms and the almost complete want of Monocotyledons.

Among the acrogenous Cryptogams we find ferns in great abundance and variety, but usually only the fronds or parts of the fronds are met with. Since the fructification (sori) on the under side of the leaf, which is so important for the classification of living ferns, is seldom distinctly seen in the Carboniferous ferns, Brongniart has based his classification on other characters, especially on the arrangement of the nerves. Among the most important Carboniferous types of ferns are Odontopteris (XXIV. 3without a strong median nerve, pinnules attached by the whole base), Neuropteris (XXIV. 2-median nerve not reaching to the point . of the leaf, pinnules short-stalked, cut in a heart-shaped fashion below), Pecopteris, especially rich in species, now divided into several subgenera (XXIV:4-median nerve reaching to the point of the leaf, pinnules notched or whole), Alethopteris (XXIV.1-strong median nerve, with the pinnules attached by the whole of the base), and Sphenopteris (XXIV. 5-pinnules deeply divided, with few, dichotomous nerves).

The Lycopodiaceæ, to which belongs the creeping Club moss of our hills (Lycopodium), were very greatly developed. The Carboniferous types of this group differed from the living ones and formed large thick-stemmed trees. The two most important forms

1 See his "Die Flora d. Steinkohlenf.," Berlin, 1881, etc. 
of that period were the Lepidodendra and the Sigillariæ. In both, the bark was covered with strict regularity with large peculiar leaf scars, and the leaves were of simple lancet-like shape. In Lepidodendron, the stems of which did not fork till a considerable height above the ground (XXVI. 1), the leaf scars were of rhombic form, and even in the youngest twigs were arranged in slanting rows on the stem (XXVI. 2,$3 ;$ XX. 3). ${ }^{1}$ At the ends of the twigs hung the long cylindrical fruit (Lepidostrobus). The stems of Sigillaria on the other hand did not divide into branches (XXVI. 4) and the shield-shaped scars stand in vertical rows one over the other (XXVI. 5,6). The long many branched cylindrical Stigmarias (XXVII. 1, 2), covered with circular scars, which are often found in thousands in the clays accompanying the coal seams, were the roots of the Sigillariæ and Lepidodendra.

The form next in importance as a coal builder to these two remarkable genera is that known as Calamites (XXV. 1), allied to the "horse-tails" of the present day. This also has a thick stem produced below to a cone (XXV. 1b) and both stem and branches are provided with transverse divisions and longitudinal grooves (XXV. 1a). The spike-like fructification has been described as Calamostachys, Macrostachya, etc. Nearly allied to Calamites, but differing in the fact that the longitudinal grooves at the articulations do not alternate but correspond with one another, is Archeocalamites, with the well known important Culm form, $A$. radiatus (Calamites transitionis [XX. 1]).

Asterophyllites and Annularia, like Calamites and Archrocalamites, belong to the family of Calamitidæ. Both possess jointed stems with long leaves arranged in whorls (XXV. 3 and 2). The systematic position of the genus Sphenophyllum (XXV. 4), characterized by wedge-shaped leaves, is on the other hand still uncertain.

The Gymnosperms possess a far more restricted distribution than the Acrogens already mentioned. Cordaites with its large simple leaves and parallel nerves, is referred to the Cycads or Sago-palm group. The numerous silicified stems called Araucarites or Araucarioxylon, on the other hand belong to the Coniferæ or pines. They first become rather commoner in the Upper Carboniferous.

As for the Fauna of the Carboniferous formation, it should be

1 The so-called genus Knorria (XX. 2) is the core of Lepidodendron deprived of its bark.

C. G. 
noticed that among the lowest animals Foraminifera for the first time occur of unusual size and in considerable numbers. This is true especially of the genus Fusulina (with the chief species cylindrica [XXVIII. 6]), which plays a part in the Upper Carboniferous like that of the Nummulites in the older Tertiary.

The Corals were represented in the Carboniferous, as in the Devonian and Silurian, chiefly by Tabulate and Rugose forms. Of the former, Chatetes (XXVIII. 2), Michelinia (XXIII. 7); and Syringopora should be mentioned as the important genera; of the latter Amplexus, Zaphrentis (XXIII. 5), Lithostrotion (XXIII.6).

The Echinodermata were, as in all the older formations, represented especially by Crinoids, which reach in the Carboniferous the highest point of their development. In North America especially they are found of great variety and beanty. The most widely spread are Actinocrinus (XXIII. 2), Platycrinus (XXIII.3), Rhodocrinus. Besides these true Crinoids the bud-like Blastoids with the genera Pentremites (XXIII. 1), Granatocrinus, etc., should be mentioned as characteristic types of the Carboniferous. Echinoids on the other hand were still rare. To this group belong Palachinus (XXIII. 4), the large genus Melonites, not uncommon in North America, and Archaocidaris, characteristic of the Upper Carboniferous. All these forms belong to the Palechinidæ, which are distinguished from the greater number of younger and recent Echinoids by the constitution of the test out of more than twenty rows of plates.

Brachiopods are still abundantly represented, although, in comparison with the Devonian, there is a decrease in the number and variety of the genera. Several of the older Palæozoic forms, such as Atrypa and Pentamerus are no longer present in the Carboniferous. Productus is by far the most important genus; first represented by a small species in the Middle Devonian, it develops in these rocks an extraordinary number of species, some of large size. Productus semireticulatus is almost worldwide in distribution, and $P r$.giganteus (XXII. 2), is the largest of all known brachiopods. Next to Productus, Chonetes, Spirifer, Rhynchonella, Orthis, Athyris, and Terebratula are the most abundant. The last named genus occurs here for the first time with large typical species, such as T. hastata (XXII. 7).

Among the Lamellibranchs Aviculopecten (XXVII. 4), Posidonomya (with the important typical Culm fossil P. Becheri [XX. 4]) Conocardium (XXII. 8), Cypricardinia, Anthracosia (XXVII. 5), 
Cardiomorpha, Edmondia, etc., are especially important; among the Gasteropods, Euomphalus (XXI. 4), Pleurotomaria, Loxonema, Macrocheilus, Acroculia (XXI. 5), Bellerophon (XXI. 3), Chiton (XXI. 6), etc. Lastly we must mention as a specially remarkable feature the first appearance of air-breathing Molluscs (Pupa, Zonites) which have been found principally in the coal-bearing beds of North America.

Of the Cephalopods, Orthoceras, Cyrtoceras, Nautilus and Goniatites are the most widely spread; neither of the first named genera, however, is so abundant as in the older formations. The Carboniferous Nautili are mostly distinguished by strong projecting spiral ribs and angles, and by knobs and tubercles; the shell is often not closed in the middle (XX. 7). In the Goniatites the structure of the chamber walls has become more complex than in the Devonian forms. Only a few genera, such as Prolecanites, are common to the Upper Devonian. Some, like Glyphioceras (XX. 5, 6), Brancoceras (XXI. 1) and Pericychus, recall, by their sutures, Devonian forms; whilst others, on the other hand, such as Pronorites (XXI. 2), with numerous, partly bifurcated, lobes, announce, as it were, the coming Ceratites type.

In correspondence with the great development of land plants in the Carboniferous period, Insects, Spiders, and Millipedes (XXVII. 7-9), become more numerous and more various. Among the Crustacea the trilobites, which even in the Devonian were much reduced, are now almost limited to two genera, Phillipsia (XX. 8), and Griffithides, which are peculiar to the Carboniferous. But with these occur various other Crustacea, such as Ostracods, Phyllopods, Limulids (Prestwichia, Belinurus [XXVII. 6]), Isopods, and even Decapods (Anthrapalamon, Crangopsis).

Lastly, among Vertebrates, as yet only fish and a few Amphibians are known in the Carboniferous. Of the former there are found fin-rays (Ichthyodorulites) and the grinding teeth of various Selachians, for which Agassiz has established the names Gyracanthus, Ctenacanthus, Psammodus, Orodus, Cochliodus, etc. Along with these there occur heterocercal Ganoids, with the genera Palaoniscus, Acrolepis, etc., and Dipnoi, with Ctenodus, a successor of the Devonian Dipterus.

The Amphibia are generally rare; and the forms found, such as Branchiosaurus, Keraterpeton, Dendrerpeton, etc., all belong to the group of Stegocephala, which does not reach its full development till Permian and Triassic times. 


\section{F. PERMIAN SYSTEM.}

\section{GENERAL AND HISTORICAL.}

The Permian, the youngest of the Palæozoic systems, consists chiefly of conglomerates, sandstones, shales, limestones, dolomite and gypsum. It is very different in different places, but is always situated stratigraphically above the Carboniferous beds and below the Trias.

The deposits of this period have been known longest in Centrai Germany, and especially about Mansfeld, where for centuries important mines have been worked in the Permian Kupferschiefer, and where also the old names Rothliegende and Zechstein, applied to the chief divisions of our Permian rocks, had their origin.

The name Permian System now in general use, was first proposed by Murchison in 1841 for a thick series of sandy and marly rocks which are very widely spread in the old kingdom of Perm, of which the present Russian "Government" Perm forms a part. Geinitz, who since the middle of the century has occupied himself diligently with the study of the deposits of this age, ${ }^{1}$ sought to naturalise, instead of the term Permian, that proposed by Marcou, viz., Dyas, a name alluding to the sharply marked division into two of the formation in Germany. This term, however, has not been able to supplant Murchison's older name.

In Germany the Permian beds everywhere group themselves very clearly into a lower conglomeratic sandy subdivision, the Rothliegende; and an upper calcareous clayey, the Zechstein. The first name is derived from the old expression, "rothes, todtes liegendes," by which the old Mansfeld miners designated the red, unmetalliferous sandstones which formed the foundation (Liegendes) on which the Kupferschiefer rests. The name Zechstein is connected with the mine-houses (Zechenhäuschen) of the numerous small pits which, serving for the winning of the Kupferschiefer, were usually placed on the Zechstein limestone; or with the tough (zähe) and solid character of the latter. In Germany the two groups behave quite independently of each other; the one indeed lies on the other, but often either one or the other is absent. This relation of the two groups, which is repeated also in England, is due to the fact that the Zechstein was everywhere deposited so as

1 Geinitz u. Gutbier "Die Verstein. d. Zechsteingebirges und des Rothliegenden in Sachsen" (1848-49). Geinitz, "Dyas." (1861-62. With appendices 1880 and 1882). 
to overlap older beds, and hence possesses an extent quite different from that of the Rothliegende. In other countries however, such as $\mathrm{N}$. America and Russia, no division in to two like that in Germany is recognisable, but there is present only a single series incapable of division.

In both the last named regions, the Permian System is so closely connected with the underlying Carboniferous and also with the overlying Trias, that its upper and lower limits can be determined only with the greatest difficulty, and are indeed to a certain extent arbitrary. In Germany also the Rothliegende is in some areas connected with the Carboniferous beds in a similarly close way, and the Zechstein usually passes upward quite gradually into the Bunter sandstone.

The fauna of the Permian deposits throughout the whole of Western Europe is very poor. In the Rothliegende, remains of animals are limited chiefly to the middle parts of the group. They consist of a few fish, amphibians, crustacea, insects, and shells, along with which a few land plants are present, but no undoubted marine shells. In the Zechstein are found brachiopods, lamellibranchs, gasteropods and cephalopods; but they are few in number and almost all are remarkably small, one may almost say stunted. Many have been inclined to explain these facts on the view that the animal kingdom of Palæozoic times, so rich in the Carboniferous Limestone, died away in Permian times; and in the second half of that period, during the deposition of the Zechstein, was already in great part extinct, while the later Mesozoic types were not yet developed in their place. In later times, however, an extremely rich and varied marine fauna of Permian age has been discovered in India, Armenia, and also Sicily, so that this explanation is no longer tenable. We must rather consider that the poverty of the West European Permian fauna was a consequence of peculiar unfavourable conditions of life. It is very possible that Th. Fuchs has hit the mark when he supposes that the Zechstein was deposited in an inland sea like the Black Sea of the present day. For the fauna of that brackish inland sea shows the same characteristics of uniformity and poverty compared with a normal marine fauna, as the Western Europe Zechstein compared with the Indian Permian fauna. If therefore one would learn to know the normal Permian fauna, one should seek for it not in England or Germany, but in S. Europe and Asia.

The great resemblance which the Permian marine fauna shows to 
that of the Carboniferous Limestone-a resemblance which is found not only in the German Zechstein but also in the rich Asiatic and American Permian limestone-has led several geologists to look upon the Permian as simply an appendix or younger phase of the Carboniferous. This has not only become almost universal in France, but Gümbel also, in his "Grundzüge der Geologie" distinguishes (1) Sub-Carboniferous, (2) Carboniferous proper, (3) Post-Carboniferous or Permian. On the other hand some have sought to unite the Permian with the Trias. Thus in the first decades of the century Conybeare and John Phillips united the English Permian formation with the overlying red Triassic sandstone, to form a younger sandstone formation, the New Red Sandstone or Poikilitic

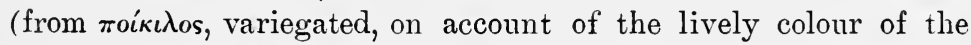
beds in question); and in more recent times geologists have several times returned (for example in Woodward's "Geology of England and Wales," 2nd ed., 1887) to this classification, which has also had its supporters at the International Geological Congress.

We cannot hold either the one or the other of the preceding views correct. The marked Palæozoic character of all the hitherto known Permian faunas tells against the union of the Permian with the Trias. Its incorporation with the Carboniferous is scarcely permissible on account of the overlap of the Rothliegende over the Carboniferous and its consequent very different distribution.

To these important facts, which speak for the individuality of the Permian Formation, may be added another not less important, namely, that with the commencement of the Permian period in Sonth Europe, India, and North America, the first appearance of true Ammonites and Reptiles began. Although the latter probably existed in Carboniferous times - which however is by no means certain as yet-they were then very rare, whilst with the commencement of the Permian epoch they reached a general and widespread development. These facts, as well as the close relationship of the flora of the Kupferschiefer not to the Carboniferous, but to the Triassic flora, seem to justify the separation of the Permian from the Carboniferous, whilst at the same time it is separated from the Trias also on palæontological grounds.

Lastly it should be noticed that the Permian period, like the second half of the Carboniferous, was throughout the whole of western Europe a time of intense and wide-spread earth movement, with which great eruptions went hand in hand. This is true especially of the epoch of the Rothliegende, in which throughout 
Germany, France and England, large masses of quartz-porphyry, porphyrite, melaphyre, and similar eruptive rocks reached the surface. These, in the form of sheets, beds, veins and dykes are in some places so abundant that the normal sediments are very much reduced. As in other formations, these massive rocks are here accompanied by tufaceous forms (claystones, etc.). It was with the commencement of the Zechstein that the oscillations and eruptions began to abate, and a quieter and more regular deposition of beds commenced.

\section{IDSTRIBUTION AND COMPOSITION OF THE PERMIAN.}

\section{German Factes.}

Germany.-On account of the sharp separation which exists throughout Germany between the Zechstein and the Rothliegende, it seems advisable to describe the two groups separately.

\section{The Rothliegende.}

In Germany this is a series, on an average some 2,000 feet thick, composed chiefly of conglomerates, sandstones and shales, very poor in lime or entirely free from it. The lively red colour of all the rocks, due to oxide of iron, is very conspicuous and characteristic. In the lower part of the series weak coal seams not unfrequently occur-a circumstance which, together with the great resemblance of these lowest beds, both petrographically and palæontologically, to the uppermost Coal Measures, renders the name "Kohlenrothliegende," used by E. Weiss and others, not inappropriate,

The classification of the German Rothliegende is in the main due to the work which has been carried out since 1860-70 for the construction of the Geological Map of Prussia. Up to that time there was no definite horizon for the comparison of the Rothliegende deposits of different regions; but such a horizon was fixed by these researches, among which those of E. Weiss ${ }^{1}$ in the region of the Saar and the Nahe were especially important.

The recognition of the fact that the fish and amphibians of the so-called Lebach beds of the Saar area are also found in company with plants in Lower Silesia and Bohemia, was of special importance. Since this is the only fauna and flora of our

1 "Verhandl. naturhistor.Ver. Rheinl.-Westf." (1868), p. 63. "Fossile Flora d. jüngst. Steinkohlenf. u. d. Rothliegend. im Saar-Rhein-Gebiet" (1869-72). 
Rothliegende which possesses a definite palæontological individuality, it was necessary to make it the Central Division of the whole series, whilst the under-and overlying parts were separated as the Lower and Upper Rothliegende. As E. Beyrich found in his detailed researches on the S. Harz Rothliegende, the Middle Rothliegende is distinguished, not only by its organic remains, but also by the fact that the chief eruptions of the massive crystalline rocks which occur in the Rothliegende of Germany, from the Saar nearly to Upper Silesia, took place during its deposition. Consequently the deepest beds of the Rothliegende, Beyrich's Unterrothliegende, are free from fragments of eruptive rocks, while on the other hand the conglomerates of the Upper Rothliegende are chiefly composed of fragments of Porphyry, Melaphyre, etc.

The threefold division of the German Rothliegende, thus resulting, into: (1) a Lower pre-eruptive (coal-bearing) group, (2) a Middle group with Lebach Flora and Fauna, and the chief mass of the porphyries, porphyrites, etc., and (3) an Upper post-eruptive group, with conglomerates of porphyry, etc., has, however, recently been given up by the Geological Survey in favour of a two-fold division. According to this grouping, the Upper Rothliegende remains of its original extent, while the Lower and Middle Rothliegende of earlier times are united as Lower Rothliegende. The reason for this change lies in the fact that the coal-bearing conglomerates, sandstones, and shales which Beyrich had originally included as Lower Rothliegende in S. Harz, and which were mapped as such in the first issue of the Prussian map, ${ }^{1}$ were afterwards recognised by Weiss, on account of their flora, as the equivalents of the Ottweiler beds of the Saar area, and were therefore included in the Upper Coal formation. ${ }^{2}$ Since in the same way in other areas, a part of the deposits hitherto classified as Kohlenrothliegende, seem to belong to the Carboniferous, and since the mutual relations of the Lower and Middle Rothliegende are always closer than those of the Lebach beds and the Upper Rothliegende-the latter of which proves itself distinct by its extensive overlap over the deeper beds-the new two-fold division of the Rothliegende in fact appears very natural.

Lastly, with reference to the general mode of lie of the Rothliegende, it is to be noticed that it occurs partly, as in the region of

1 Sheets Nordhausen, Benneckenstein, etc. (1870).

2 They are thus referred in the more recent (1882) geological map of the Harz (Lossen). 
the Saar and Nahe, in intimate connection with the Productive Coal Measures, and partly and more particularly quite independently of these. In the latter case it is especially spread around the outer border of many old mountain cores, such as the Rhenish Schiefergebirge, the Thüringerwald, the Harz, Erz- and Riesen-gebirge, Böhmerwald, Spessart, Odenwald, Black Forest and the Vosges. Everywhere, however, the lie of the Rothliegende is more or less horizontal.

By far the most extensive and important area of Rothliegende in Germany is that in the region of the $\mathrm{Saar}$ and $\mathrm{Nahe}$, south of the Hunsrück. The Rothliegende beds here occupy the large space between the Devonian Schiefergebirge on the north, and the Trias of the Palatinate on the south, and stretch beyond the plain of the Rhine, between the Taunus and Odenwald, into the Wetterau.

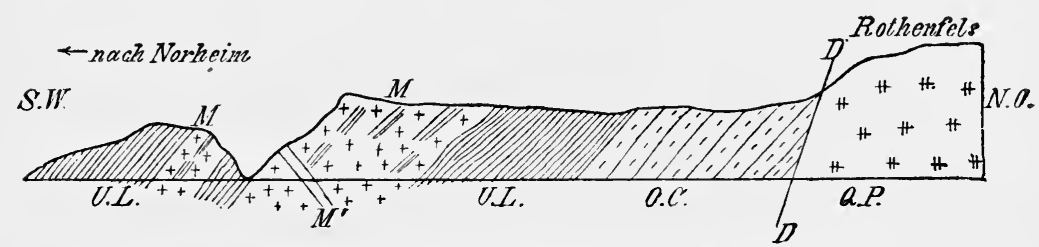

FIG. 23.-Section through the Rothliegende and accompanying eruptive rocks on the left bank of the Nahe above Münster (H. Laspeyres).

Q.P. Quartz porphyry. O.C. Upper Cusel beds. U.L. Lower Lebach beds. M. Melaphyre with beds of schist. $M^{\prime}$. Melaphyre dykés. D.D. Fault.

The lowest beds of the series lie quite conformably and without any sharp boundary on the Ottweiler beds of the Carboniferous. rocks, which rise up from below the Rothliegende in the form of a large anticlinal stretching north-easterly from the Saar. In these Rothliegende beds Weiss distinguishes three groups, namely, the Cusel beds, the Lebach beds, and the Upper Rothliegende. Fig. 20 shows clearly the basin-like arrangement of the strata and their overlap over the underlying Coal Measures on to the Devonian rocks. The Zechstein is absent here, as it is throughout the country west of the Rhine; and the Bunter sandstone follows the Rothliegende, with here and there a visible unconformity. Figs. 20 and 23 also show the numerous, sometimes very massive and extensive, sheets and beds of porphyritic eruptive rocks (especially Melaphyre), which are interbedded with the two lower groups, but especially with the Lebach beds, and which are so characteristic of this area. 
The petrological constitution and chief fossils of these beds are shown in the following table:-

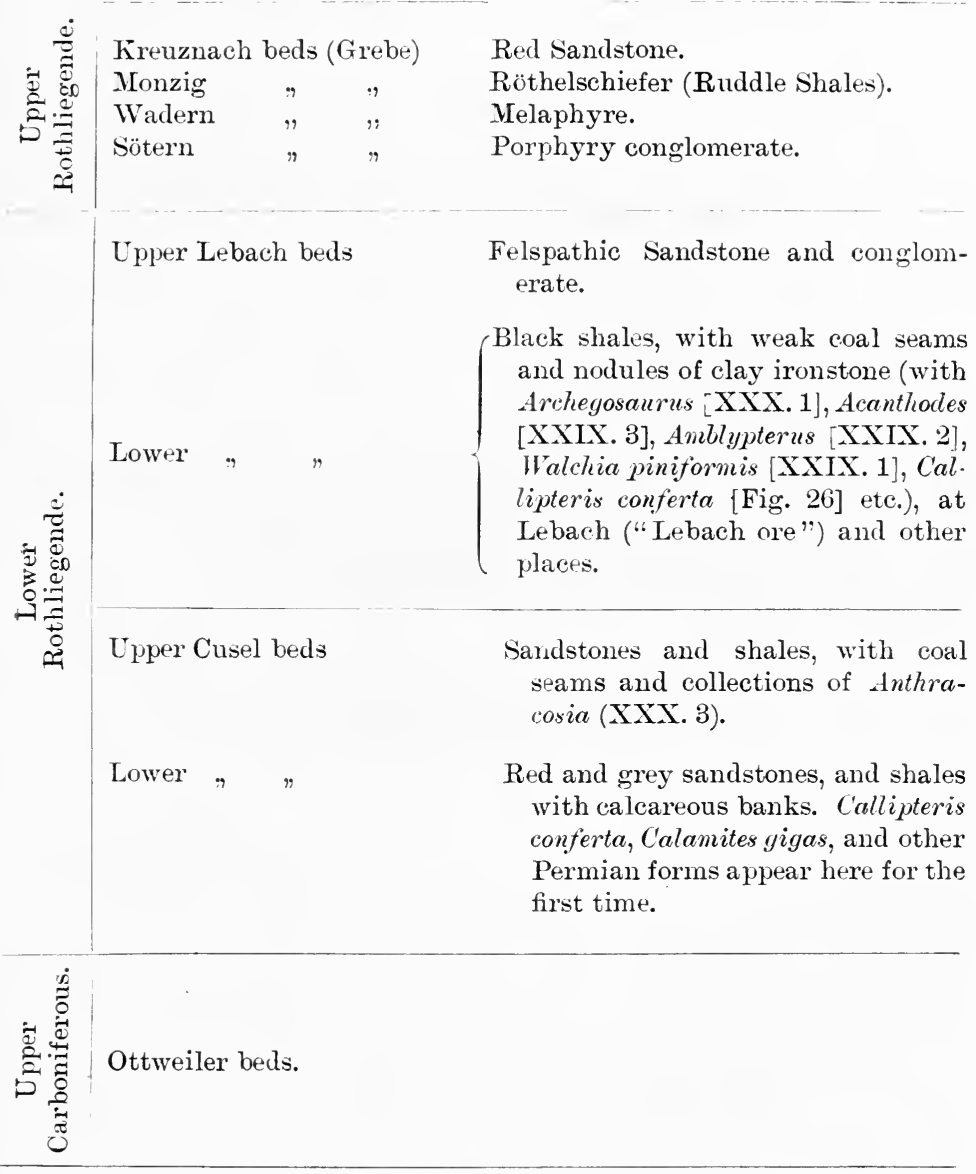

The two lower groups, which before Weiss' time were referred to the Carboniferous, are limited to the regions of the Nahe and of Darmstadt and the Wetterau, while the Upper Rothliegende stretches to the north-west, round the Hunsrück into the so-called Trier (Trèves) Bay, and on the eastern border of the Schiefergebirge of the Lower Rhine extends from the neighbourhood of Giessen to the region of the Eder. The Rothliegende here lies horizontally upon steeply inclined Devonian and Culm beds, which have afforded the chief material for its conglomerates. 
To the north of the Thüringer Wald, and again to the south of the Harz (Ilefeld), the Rothliegende is also developed in essentially the same fashion.

The sandstones and conglomerates which occur so widely in the Mansfeld area and the Kyffhäuser as the foundation of the Zechstein, have hitherto been looked upon as Permian, and have been coloured as such on the map of the Prussian Geological Survey. ${ }^{1}$ Later researches, however, not yet published in full, allow of no doubt that only the uppermost part of the series (the Porphyry conglomerate and overlying shales) belongs to the Rothliegende and indeed to its upper division; while the whole of the beds below, which are separated by an unconformity, belong to the Productive Coal Measures. These conclusions are based mainly on the results of a deep boring in the neighbourhood of Halle-onthe-Saale (near Schladebach). Another point that requires notice in this area is, that in the beds of Rothliegende immediately below the Zechstein, the colour is frequently washed out, and the beds

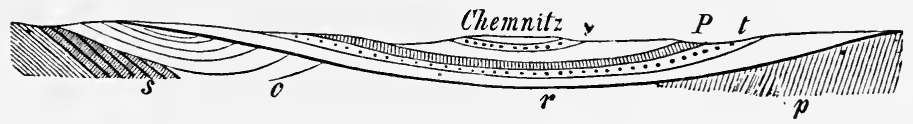

FIG. 24.-Section through the Erzgebirge basin at Chemnitz (Siegert).

p. Erzgebirge Phyllite. s. Silurian. c. Carboniferous. $\therefore$ Rothliegende. P. Quartz porphyry. t. Tuff.

are locally impregnated with copper ore from the Zechstein above. They are then known as the Weissliegende.

The Rothliegende also occupies a pretty considerable area in the kingdom of Saxony. Its chief development is in the so-called Erzgebirge Basin, near Chemnitz, Zwickau, etc. As in the West, we can here distinguish a lower coal-bearing division, including numerous eruptive beds, with Walchia piniformis, Callipteris conferta, Calamites gigas, and other type forms of the Lower Rothliegende; and an upper division composed chiefly of fragments of various eruptive rocks. Whilst the latter is undoubtedly the equivalent of the Upper Rothliegende, the former, according to the researches of Sterzel, ${ }^{2}$ corresponds with the Lebach beds. The deeper Cusel beds are absent in this area, and thus is brought about the unconformity visible in the accompanying section (Fig. 24) between the Rothliegende and the underlying Carboniferous.

1 Sheets Cönnern, Wettin, etc.

2 " Erläut. z. Blatt Stollberg-Lugauy der geol. Specialkarte d. Königreichs Sachsen" (1881). 
Among the Saxon occurrences of Rothliegende that of the Plauenscher Grund near Dresden is of especial interest, on account of the abundance of Stegocephala (Branchiosaurus, Pelosaurus, Archegosaurus, etc.) and of the oldest reptiles yet known in Germany (Palcohatteria), in calcareous beds of Lebach age, near Niederhässlich. Similar Stegocephala have also been found in beds of the same age at Oberhof, Manebach, and Friedrichsroda in the Thüringerwald, and in a boring near Offenbach on the Main.

On the southern slope of the Riesengebirge and in the neighbourhood of Glatz and Waldenburg there is a considerable area of Rothliegende. At the base, resting directly on the crystalline schists of the Riesengebirge, lie coarse conglomerates; above these come red sandstones and shales with interbedded bituminous shales and platy limestones, which at Ruppersdorf, not far from Braunau, and at other places contain the fish fauna of the Lebach beds.' These are followed by thick conglomerates and sandstones of the Upper Rothliegende, which near Radowitz include considerable masses of silicified stems, the so-called fossi] forest.

In Central Bohemia also, on the north-west side of the great Siluro-Devonian trough, and on the Northern slope of the Riesengebirge, in the region of Löwenberg, ${ }^{2}$ the Rothliegende occupies a not inconsiderable space. Here, as in the more restricted area in the Black Forest, the Lebach Fauna serves as an important horizon for comparison.

\section{Zechstein Formation.}

The deposits of the Zechstein, of considerably less thickness than the Rothliegende, form a calcareous-clayey-dolomitic series containing Gypsum and Rocksalt. Like the Rothliegende it is limited to the borders of the old mountain cores, which it surrounds as a narrow fringe. In such a form the Zechstein is found on the northern slopes of the Riesengebirge, at the foot of the Harz, of the Thüringerwald and Frankenwald, on the east side of the Lower Rhine Schiefergebirge, of the Spessart and Odenwald. The most southerly occurrence is that in the Neckar valley near Heidelberg. On the left bank of the Rhine no Zechstein is known with certainty, unless one supposes that it is here represented by some sandy beds hitherto generally referred to the

1 Beyrich, Zeits. d. deutsch. geol. Ges. (1856), p. 14.

2 Ferd. Römer, ibid. (185̄), p. $5 \overline{7}$. 
Bunter Sandstone. This was a favourite idea of E. de Beaumont's, and has recently been supported by Leppla in the Hardtgebirge on the ground of a few bivalves found by him, which are said to agree with some of the Zechstein forms. In several areas, as in the Mansfeld, in the neighbourhood of Eisenach, on the northern slope of the Riesengebirge and elsewhere, the Zechstein is underlaid by the Rothliegende; but in many other places, as near Waldeck and Stadtberge, near Allendorf on the Werra, near Saalfeld, on the western border of the Harz, etc., the Zechstein lies directly on Carboniferous, Devonian or still older rocks. Economically the Zechstein formation is important for two reasons, first, on account of its thick layers of rocksalt and chloride of potash; and, secondly, on account of the amount of copper contained in it, which in the Kupferschiefer is often very considerable. In consequence of the old mines in this latter, there is no other series of rocks in Germany which has been so long known in all the peculiarities of its constitution as the Zechstein. As early as the beginning of this century, Freiesleben gave a perfectly correct description of the composition of these beds in the Harz and in Thuringia. ${ }^{1}$ On the basis of this and of the work carried out by E. Beyrich and others in later times for the Geological Map; ${ }^{2}$ the Zechstein has been divided in this classical area as follows, from above downwards :-

Bunter Sandstone.

Upper Zechstein.

Middle Zechstein.

Lower Zechstein.
Upper Clay with (the newer) gypsum and dolomite intercalations.
Stinkschiefer and Great Dolomite.

(Older) gypsum, rauchwacke and ashes.

Zechstein Limestone.

Kupferschiefer.

Zechstein conglomerate.

The lowest division of the Lower Zechstein, the Zechstein conglomerate of Beyrich, is a pale, grey, calcareous, gravelly conglomerate one or two yards thick. It is typically developed on the

1 "Geogn. Beitr. z. Kenntn. d. Kupferschiefergebirges" (1807 -15).

2 "Erläut. z. d. Blättern Nordhausen, Frankenhausen, etc., der geol. Specialkarte ven Preussen," etc. 
southern border of the Harz, between Lauterberg and Sangerhausen. Its connection with the Zechstein is shown by the fact that in its distribution it follows the Zechstein and not the Rothliegende. In the Mansfeld area it is represented by a sandy or finely conglomeratic bed $\frac{1}{2}-2$ metres thick, the Weissliegende in its restricted sense. ${ }^{1}$ Near Gera Zechstein brachiopods occur in it.

The $\mathrm{Kupferschiefer} \mathrm{is} \mathrm{a} \mathrm{black,} \mathrm{marly} \mathrm{shale,} \mathrm{rather} \mathrm{over}$ half a yard thick, distinguished by containing bitumen and ore, and by its richness in fish remains. The amount of bitumen present is often so great that lighted pieces of shale will burn of themselves. The ore generally occurs as very fine granules, hardly visible to the naked eye, of copper pyrites, copper glance and variegated copper ore, iron pyrites, galena, etc., and usually decreases rapidly as we go upwards. It amounts at the most to 3 per cent; nevertheless this remarkable occurrence of ore has given rise to by far the most important copper mines in Germany. These are now worked only in Mansfeld, where in 1882, 233,827 Centner (about 222,000 cwt.) of copper, and 125,416 Pfund (about 138,200 pounds) of silver were won ; but formerly mines were successfully worked in the Kupferschiefer at Riechelsdorf and Bieber in Hesse, near Saalfeld and at other places. With respect to the fish remains, the most abundant and widespread forms are Palconiscus Freieslebeni (XXXI. 2) and Platysomus gibbosus (XXXI. 1). Besides these, plants-especially twigs and fruits of Ullmannia Bromni-and saurian remains (Proterosaurus Speneri). are met with. That the richness of the shale in ore and fish remains was not, as is often thought, due to springs rich in metallic salts which opened into a flat sea basin and caused the death of its inhabitants, is shown by the circumstance that the English marl-slate, which corresponds exactly with the Kupferschiefer, contains indeed many fish, but no copper ore. That the shale was deposited in a sea, is shown by the occasional occurrence of starfish and brachiopods.

The Zechstein limestone is a thick grey platy limestone, generally some 10 or 11 yards thick. It contains the greater number of the animal remains of the Zechstein: Productus horridus (XXXII. 1), Spirifer undulatus (XXXI. 6), Terebratula ctongata (XXXI. 5), Camarophoria Schlotheimi (XXXI. 7),

1 “Erläut. z. Blatt. Mansfeld," (1884), pp. 27, 37. 
Strophalosia Goldfussi (XXXI. 4), Schizodus obscurus (XXXII. 2), Gervillia ceratophaga (XXXI., 8) ; Avicula speluncaria (XXXI. 9), Fenestella retiformis (XXXI. 3).

The Middle Zechstein consists at the base of the older Gypsum, sometimes accompanied by small veins of rocksalt, or of the so-called "ashes" and "rauchwacke." The two latter, as Beyrich has shown, are only the remains of masses of gypsum which have been dissolved away. The "ashes" occur in loose, friable to powdery, masses; the "rauchwacke" in firm, often breccia-like, masses, which contain numerous fragments of the covering rocks, that is, of the Stinkschiefer. Both have the composition of dolomite. The Stinkschiefer is a thin-bedded, dark greyish brown, very bituminous limestone, which on being broken emits a fetid odour. It is present only in East Harz and Kyffhäuser; but further west is represented by the Great Dolomite, a pale, sometimes thick-bedded, sometimes nearly unbedded, blocky limestone, which reaches a thickness of 150 feet, and not uncommonly (especially at Niedersachswerfen not far from Nordhausen) contains Gervillia ceratophaga, Mytilus (Liebea) Hausmanni, Schizodus obscurus, Terebratula sufflata and other fossils.

Lastly, the Upper Zechstein consists of tough bluish or red shales, in which numerous masses of gypsum, sometimes accompanied by ash-like masses, and also nodules or bed-like layers of dolomitic limestone occur. The gypsum is largely developed in the Kyffhäuser and on the southern and western borders of the Harz, where in the form of a high white wall it winds round the mountains. It everywhere contains numerous holes, the so-called Gypsschlotten, which have been formed by the carrying off of the rock in solution, and which by their downfall have caused superficial landslips. Originally the gypsum (sulphate of lime with water of crystallization) was anhydrite (the same salt without the water); and even yet, as has been proved by mining works, many of the gypsum masses pass down into anhydrite below.

In Thuringia the development of the Zechstein is quite like that in the regions named. In south-eastern Thuringia (e.g. east of Saalfeld) "Bryozoa reefs" occur in the Upper and Middle Zechstein. These are thick unbedded dolomite masses which form high plateau-like hills, and are made up of Acanthocladia, Fenestella, Phyllopora, and other Bryozoa thickly crowded together. These reefs (at Pössneck, etc.) are always extraordinarily rich 
in other forms. Strophalosia Goldfussi, Terebratula elongata, Spiriferina cristata, Avicula (Pseudomonotis) speluncaria, etc., are especially common.

In Hesse also the structure of the Zechstein differs but little from that in the Harz. The Stinkschiefer is unknown, and it is very characteristic of the region in question that the dolomite in the upper division of the series becomes a distinct group 60 feet and more thick, the Plattendolomite. In consequence of this, the Upper Zechstein in the Hessian area falls into three groups, the lower gypsiferous clays, the Plattendolomite, and the upper gypsiferous clays. Near Frankenberg the Zechstein is somewhat different. A lower zone of grey clays, limestones and dolomites,

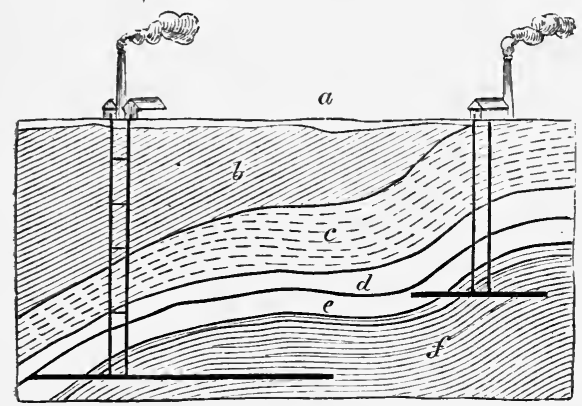

soo ronet:

Fig. 25.-Section through the Salt beds of Stassfurt (Bischof).

a. Drift and Tertiary. b. Bunter sandstone.

c. Gypsum of the Upper Zechstein. d. Salt clay. $e$. Impure salt. $f$. Rock salt. which include remains of plants fossilised in copper glance, ${ }^{1}$ and which represent the Lower Zechstein, is followed by a coarse red conglomerate like the Rothliegende, with interbedded dolomites. ${ }^{2}$ In the Wetterau, the Middle Zechstein according to Bücking is partly represented by salt-bearing clays and marls, in the Spessart by dolomite accompanied by ironstone.

Especial mention should be made of the extraordinary abundance of salts in the German Zechstein. The great salt-beds which occur on the north of the Harz, and are worked at Stassfurt, Egeln, Vienenburg and other places, are the best known. They are especially interesting and important because the mass of rocksalt, which is some 1,200 feet thick, is followed by a zone 150 feet thick of potash and magnesia salts (the so-called Abraumsalze). (Fig. 25.) Moreover, the bed of salt several thousand feet thick, pierced by a boring at Sperenberg (thirty-three miles south of Berlin), and

${ }^{1}$ Among them especially twigs of Ulmannia Bronni, the "Frankenberger Kornähren" (ears of corn) of the old miners.

2 Holzapfel, "Die Zechsteinform. am Ostrande d. rhein. Schiefer-geb." (1879). 
probably stretching under the German metrop,olis, very likely belongs to the Upper Zechstein; and this is also the case with numerous other salt occurrences (Lieth on the Lower Elbe, Lüneburg, Kolberg, Greifswald, Inowrazlaw, etc.), which are scattered over North Germany and are sometimes indicated only by brine springs.

France.-Only the lower division of the Permian, the Rothliegende, is definitely represented. The principal areas, and these are but small, are in Autun and the Department of Herault.

In Autun the Coal Measures pass up quite gradually into the Permian, which is here divided into two stages, the upper of which lies unconformably on the lower.

Upper Stage. Red Sandstone without fossils.

Inconformity.

Lower Stage $\left\{\begin{array}{l}\text { 3. Shaly; often bituminous (boghead). Flora distinctly } \\ \text { Permian. } \\ \text { 2. Bituminous shales at base; shales and sandstone. Vixed } \\ \text { Carboniferous and Permian flora. } \\ \text { 1. Bituminous shales followed by sandstones. Fauna } \\ \text { Permian. Flora contains many Coal Measure plants. }\end{array}\right.$

In Herault on the south of the Central Plateau, Permian rocks, are known at Lodève, where they are grouped as follows:-

Slates of Lodève.

Dolomites.

Conglomerate and Sandstone.

It is in one of the zones of the slates that the well-known Lodève flora is found.

Britain.-In England the Permian is much better developed than in France; and there is represented not merely the German facies, but also, to a certain extent, that of Russia.

In the East of England the succession is closely comparable to that of Germany; and we may take Durham as the type. Here the beds are divisible as follows:-

Zechstein
(Magnesian Limestone
series). $\left\{\begin{array}{l}\text { Red Sandstone and Marl, } 50^{\prime} \\ \text { Magnesian Limestone, } 500^{\prime}-600^{\prime} \\ \text { Marl Slate (bituminous } \\ \text { shales with Palconiscus, } \\ \text { Platysomus, etc.), 10 } 10^{\prime}-60^{\prime}\end{array}\right\}$ Kupferschiefer.

Rothliegende. White or yellow false-bedded sand, $20^{\prime}$

The correspondence with the German succession is very close. The fossils of the Magnesian Limestone are similar to those of G. G. 
the Zechstein Limestone; and the fishes of the Marl Slate resemble those of the Kupferschiefer.

Passing southwards the massive Magnesian Limestone becomes less uniform and is broken up by intercalated beds of marl and sandstone; so that in Yorkshire the succession is-

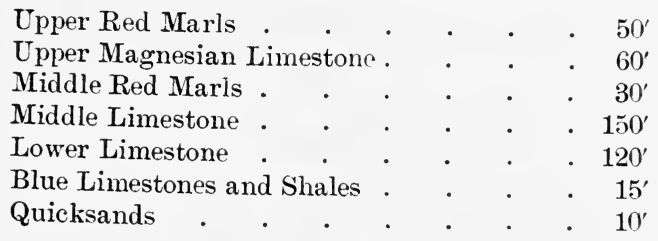

In the West of England the Magnesian Limestone is always very thin, if present at all : the Lower Permian on the other hand is frequently much thicker than in the east. In the Valley of the Eden the series is grouped as follows :-

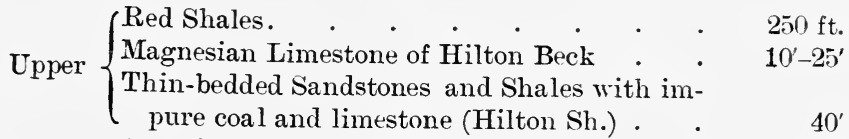

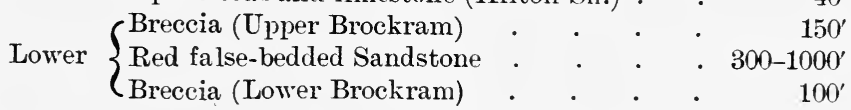

Owing to the rarity of fossils no exact correlation of these beds can be attempted. The Hilton Shales yield Ulmannia, Alethopteris, Odontopteris, etc., and perhaps correspond with the Marl-slate.

According to Professor Hull the Lower Permian of the West of England presents two facies, and was deposited in two areas separated by a ridge of land which crosses the plain of Cheshire.

\section{Russian Facies.}

Russia.-The Russian Permian is distinguished from the German by the absence of the Zechstein limestone. It is true that this limestone with its characteristic fossils is found in the Baltic Provinces ; but in the south-east of the country, the district from which the formation derives its name, the Zechstein is quite differently developed. Here we find a thick series of varied alternations of sandstone, conglomerate, clays, marls, limestones, gypsum, rock-salt and coal. This series lies quite horizontally, sometimes resting directly on Upper Carboniferous rocks, and extends over some thousands of square miles. Near the Ural it is accompanied by sandstone containing copper ore (especially chessylite), 
the so-called Kupfersandstein. It passes upwards into variegated almost unfossiliferous marls. These were referred by Murchison to the Permian; but the presence of Voltzia heterophylla, Equisetum arenaceum, and Estheria minuta indicates their connection with the Trias, into which the Permian is thus seen to pass quite gradually.

The Russian Permian contains partly remains of plants and partly marine mollusca. The former, which agree in the main with those of the German Rothliegende, are confined to the sandy beds; the latter, among which are several species of the German Zechstein, to the limestones. There is, however, no separation of the beds into a lower sandy and an upper calcareous subdivision, as in Germany; bit there is a repeated alternation of plant and mollusc-bearing beds. Productus horridus (XXXII. 1), P. Cancrini, Strophalosia, Camarophoria Schlotheimi (XXXI. 7), Terebratula elongata, Gervillia ceratophaga (XXXI. 8) and others are among the most abundant of this molluscan fauna; which indeed surpasses the German Zechstein fauna in numbers, but like it, bears the stamp of poverty.

According to Nikitin the series may be divided in Sam a ra and Uf a as follows :-

h. Upper Tartarian group. Red argillaceous sandstone.

g. Lower Tartarian group. Pink argillaceous limestone.

f. Grey group. Limestones and marly sandstones with numerous Zechstein fossils.

$e$. Red argillaceous sandstone with Zechstein fauna in its upper beds.

d. Argillaceous limestone without fossils.

c. Gypsum, clays and limestones penetrated by gypsum, without fossils.

b. Dolomite and porous limestone with Permian fauna.

a. Dolomite and porous limestone with Permo-carboniferous fauna.

On the Western slopes of the Urals, the Fusulina limestone is succeeded by a series of sands and marls with coal, which was named by Karpinsky in 1874 the "Artinskische Etage." This series contains numbers of brachiopods, which for the most part are identical with Upper Carboniferous forms ; a few Ammonoidea with strongly differentiated Ammonite-like lobes (Medlicottia Orbignyana, etc., Thallassoceras, etc. [XXXII. 3-6]); ${ }^{1}$ and numerous true reptiles. Altogether 300 species are now known from these passage beds, of which 150 are also found in the

1 Karpinsky, "Ammoneen der Artinsk Stufe Mém. Acad. St. Pétersb." (1889). 
Carboniferous, but only 53 in the true Permian rocks above. ${ }^{1}$ The plant remains on the other hand are chiefly Permian forms. They have been described by Schmalhausen ${ }^{2}$ and include Calamites gigas, Callipteris conferta, several Walchias and Ullmannias, Cardaioxylon, etc.

The Artinsk stage is succeeded by marls and sandstones, and the whole is divided by Krasnopolski ${ }^{3}$ in the middle parts of the Ural range, as follows:-

Red stage. Clays and marls with beds of limestone and sandstone.

Cupriferous Sandstone.

Stage of marls and sands. Marls, sandstones, and conglomerates. Unio umbonatus, etc., Solemya, etc. In places Productus Cancrini, P. Koninckianus, Athyris pectinifera, Spirifer lineatus.

Stage of dolomite and limestone, with gypsum (=upper horizons of the sandstones of Artinsk).

Artinsk stage.

The Permian Rocks known in the South of Europe, Central and Southern Asia, and in North America, are allied to the Uralian or Indo-uralian facies of the system, which is characterized by a rich marine fauna and which stands in the same relation to the German facies as the Russo-Asiatic Upper Carboniferous to the Western European.

Alps -This facies has long been known in the Alps. On both sides of these mountains the Permian is represented mainly by thick red sandstones and conglomerates which pass up imperceptibly into the Triassic Bunter Sandstone. The sandstones are known in the Eastern Alps as the Grödner Sandstone, the conglomerates, which are also found in the Apennines, as the Verrucano Conglomera te, ${ }^{4}$ after the castle Verruco, in the Monte Pisano in Tuscany. In many places these beds include small intercalations of porphyritic rocks, especially of melaphyre; and the thick porphyry masses of Botzen and the similar rocks of I ugano also belong to the time of the Rothliegende. In the Val Trompia in the Brescian Alps and in other places the series in question contains well preserved plants agreeing with those of the German Rothliegende (Walchia piniformis, W. filiciformis, Schiz-

1 Krotow, "Artinsk. Etage." Kazan (1885).-Tschernyschew, "Mém. du Comité géol. russe," iii. no. 4 (1889).

2 "Mém. du Com. géol." (1887).

3 ". Mém. du Com. géol. St. Petersb." xi. no. 1.

4 The Permian age of the Apennine Verrucano has again become very doubtful. 
opteris, Noeggerathia, etc.). ${ }^{1}$ In the Karawanke and the Carinthian chain on the other hand Limestones which contain numerous swollen Fusulinas, Pecten Hauni, Chonetes, Camarophoria aff. Schlotheimi and some species recalling (see page 183) the PermoCarboniferous of Nebraska in North America, follow directly on and are in intimate connection with the marine Carboniferous.2

To a higher horizon, near the German Zechstein, is referred a thick-bedded Dolomite which is interbedded in the upper part of the Grödner Sandstone. In favour of this view we have the plant remains found by Gümbel in the shales of this zone near Neumarkt in the Tyrol, and afterwards proved in the Venetian Alps and at Fünfkirchen in Hungary, which agree in part with the forms of the German Kupferschiefer (Ullmannia Bronni, etc., Toltzia, Schizolepis, Baicra, Araucarites, etc.).

This is followed by the well-known Bellerophon Limestone of the Southern Tyrol. It is a dark-coloured limestone with a rich fauna of Permo-carboniferous type, which has been described by G. Stache, ${ }^{3}$ and which consists of numerous Bellerophons, Nautili, brachiopods (Productus, Strophomena, Spirifer, Athyris, etc.), bivalves (Aviculopecten, Clidophorus, Gervillia cf. ceratophaga) Archaocidaris, etc. Geologists were for a long time in doubt whether this limestone should be referred to the Permian or to the Bunter, but in recent times it has usually been reckoned with the former.

Sicily.-An extremely rich and important fauna, resembling that of the Permian Fusulina limestone of the Alps, has lately been discovered in Sicily in the valley of the Sosio, and has been made the subject of a comprehensive monograph by Gemellaro. ${ }^{4}$ From below Triassic rocks of Alpine facies there rise up grey and white Fusulina limestones which contain an extraordinary number of Ammonoidea with more or less highly developed, and in part completely ammonitic, lobing. Along with Medlicottia, Popanoceras and other forms common to the Artinsk stage (XXXII. 3-6), we find here numerous species of the new genera Waagenoceras, Stacheoceras, Daraelites, Adrianites, in all 17 genera and 54 species. To these are added many Nautili of Carbo-triassic char-

1 Süss, "Ueber d. Aequivalente des Rothlieg. i. d. Südalpen. Sitzungsber. d. Wien. Akad." (1868).

${ }^{2}$ G. Stache, Zeits. d. deutsch. geol.Ges. (1884), p. 367.

3 G. Stache, "Jahrb. d. k. k. geol. Reichs." (1877) p. 271 (1878) p. 94.

4 "Fauna dei calcari con Fusulina del fiume Sosio" (from 1887 onward). 
acter, a whole series of Orthoceratites, a Gyroceras, also a great number of Gasteropods (Bellerophon, Pleurotomaria, Loxonema, Naticopsis, etc.), brachiopods (Richthofenia), trilobites, etc.

Asia.-Passing on to Asia we find a similar rich Permian fauna near $\mathrm{Djulfa}$, in the valley of the Araxes. Along with brachiopods, among which Productidae are very abundant, occur Ammonoids with Ceratite-like lobes.

A similar set of species has also been found in Darwas in Bokhara, and these are considered by Karpinsky the exact equivalent of the Artinsk fauna. But by far the most important of the faunas of this age is that of the Productus Limestone in the Indian Salt Range, which has become well known through the work of W. Waagen. ${ }^{1}$ As remarked earlier, the lower part of this limestone, which is overlaid by Triassic formations, belongs to the Upper Carboniferous; whilst as Tschernyschew has lately shown, according to the brachiopods, the middle part represents the Uralian Artinsk stage. The Ammonoidea, which are of the greatest interest, are few and are first found in the uppermost zone of the limestone; but they show a high development (Medlicottia, Popanoceras, Xenodiscus, Arcestes, etc.) as in the Artinsk Fauna. Along with these appear numerous richly sculptured Nautili, Orthoceras and Gyroceras, many Bellerophons and other shells, various bivalves-among which Lucina, Lima and Myophoria, are unusual appearances in Palæozoic beds-and more than all, a great army of brachiopods. Among these the Productidæ (with Productus, Marginifera, Strophalosia, Aulosteges, and Chonetes) play a chief part; but Orthis, Leptaena, Streptorhynchus, Terebratula, Rhynchonella and others are also common. Common with the Upper Carboniferous are the remarkable corallike genus Richthofenia, Enteletes and a few of the extremely peculiar and aberrant gigantic Thecidæ (Lyttonia, Oldhamina). There aiso occur a few Bryozoa, corals, sponges, Fusulinas, etc. With the Lower Carboniferous but few species are common (Productus cora, $P$. lineatus, etc.), and on the other hand a large number are common with the Zechstein (Streptorhynchus pelargonatus, Camarophoria Humbletonensis, Strophalosia excavata, S. horrescens, Spiriferina cristata, Polypora biarmica).

Lastly we find a similar facies of the Permian in North America. In Virginia and Pennsylvania the Productive

1 "Salt Range fossils. Productus Limestone. Palæontologia Indica." (1879-88). 
Coal Measures are conformably succeeded by the so-called Upper Barren Measures with Callipteris conferta and other true Rothliegende forms along with many Carboniferous types (Sphenophyllum, Annularia longifolia, etc.). In the Southern and Western States on the other hand, in Texas, Nebraska, etc., the marine Upper Carboniferous is immediately succeeded by limestones which along with numerous Carboniferous forms (especially brachiopods) contain many undoubted Permian species (such as Avicula speluncaria, Pecten Hauni, Productus Cancrini, Schizodus aff. obscurus, etc.) and-what is of still greater importance-Ammonoids of the Artinsk group (Medlicottia, Popanocerás, Ptychites), and numerous reptiles long spoken of by Cope as Permian. In spite of the opposition of Meek, those beds should therefore be considered as Permian, in agreement with the views of H. B. Geinitz.

It should still be mentioned that Permian, as well as Upper Carboniferous, fossils are known also from the Far North, from Spitzbergen and New Scotland.

\section{THE PERMO-CARBONIFEROUS GLACIAL EPOCH.}

In the coal-bearing beds of India and Australia (supposed to be of Permian age), certain very remarkable and widely spread conglomeratic deposits have long been known. They have been called in India the Talchir Conglomerate, in the colony of Victoria the Bacchus Marsh Beds.

In a fine sandy or argillaceous base there are found blocks and masses of the most various character and size, sometimes scattered, sometimes in large numbers, without any arrangement. No bedding is to be seen in these deposits, and the blocks often show a polish and striation very like the blocks from glacial formations. It has long been maintained by various geologists that these remarkable deposits are of glacial origin, and this view has gradually gained ground, though it is yet by no means universally accepted.

In more recent times similar formations have been found in Afghanistan and also in South Africa and Brazil. In Africa they are known as the Dwyka Conglomerate, and the important observation has been made that the immediate foundation on which the block-bearing beds lie, is smooth and striated quite like the rocky beds of the glaciers of the present, and of the glacial boulder clays of the North German Drift.

Everywhere this conglomerate appears to have been formed at the end of the Carboniferous or in the Permian period. In South 
Australia the Bacchus Marsh beds-which rest upon Upper Carboniferous beds with marine fossils-are overlaid by the coal-bearing Newcastle beds. These contain a flora which differs widely from the Carboniferous and includes numerous Mesozoic plants (especially Glossopteris [Fig. 26], also Gangamopteris, Phyllotheca, Noeggerathiopsis, etc.); and like the overlying Hawksbury beds, they have lately been regarded as Permian. The Hawksbury beds also commence with a conglomerate supposed to be of glacial origin.

In India, the Talchir conglomerate is followed in the Salt Range by the Productus Limestone, which is in the main Permian; and in the interior of the peninsula by the Karharbairi and Damuda

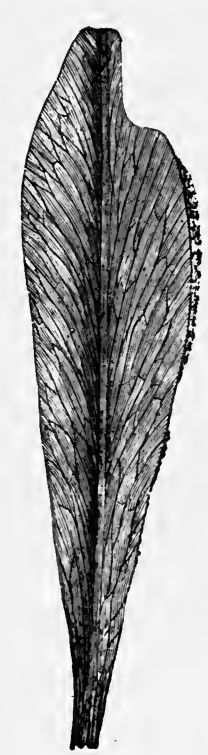

Fig. 26.-Glossopteris Brouniana, Brngn. series of the Gondwana system, the lower part of which is Palæozoic and the upper part Jurassic. Both Karharbải and Damuda beds are characterized by Glossopteris, Gangamopteris, Noeggerathiopsis, Voltzia, Phyllotheca, Vertebraria, etc., like the Australian Newcastle beds. Lastly, in South Africa the above mentioned Dwyka Conglomerate is followed by the coal-bearing Ecca beds with the same Glossopteris flora, here also referred to the Permian. ${ }^{1}$

From the foregoing remarks it follows that throughout the southern hemisphere, and as far north as Southern Asia, there is found at the boundary of the Carboniferous and Permian, a peculiar and extensive deposit of blocks with glacial characters. It is very remarkable that these are everywhere followed, in Africa as well as in Sonth Asia and Australia, by a flora which contains none of the characteristic types of the Carboniferous period, but is made up of quite new and for the most part Mesozoic forms. If now, with Oldham, Blanford, Waagen, Neumayr and others, we believe in a glacial origin of the deposits in question, we arrive at the conclusion that the climate of our planet was then colder, on account of which the Carboniferous flora gradually died away and room was made for the ancestors of the Mesozoic flora. Blanford and

1 It must be noticed that Glossopteris occurs also, but rarely, in the Carboniferous of Australia and South Africa. According to Feistmantel it reaches in India up to the Trias plant beds. But its chief development is in the intervening Permian Period. 
Waagen, indeed, go a step further and would bring the decline of the marine Palæozoic fauna also into connection with the cold period occurring in the southern hemisphere at the end of the Palæozoic Period. ${ }^{1}$ Such far-reaching conclusions, however, ought not to be definitely accepted until the glacial origin of these block-bearing. deposits is placed beyond doubt.

\section{PALAONTOLOGY OF THE PERMIAN.}

As in the Carboniferous so also in the Permian, the remains of plants as well as animals play an important part. The Rothliegende has yielded the chief part of our knowledge of the Permian flora; but the German Kupferschiefer also and the Alpine and Hungarian plant beds of nearly the same age, contain a not inconsiderable flora, which contrasts with that of the Rothliegende in the fact that it is of Mesozoic rather than Palæozoic type. According to E. Weiss this contrast is so great that if we wish to draw the boundary between the Mesozoic and Palæozoic formations according to the flora, we must draw it not at the Upper but at the Lower limit of the Zechstein. It scarcely needs remark that as we now limit the groups and formations, this peculiarity of the Zechstein flora tells in favour of the distinction of the Permian from the Carboniferous system.

The flora of the Rothliegende is essentially like that of the Carboniferous and consists exclusively of land plants. The most abundant forms are Ferns, Calamites, and Conifers,

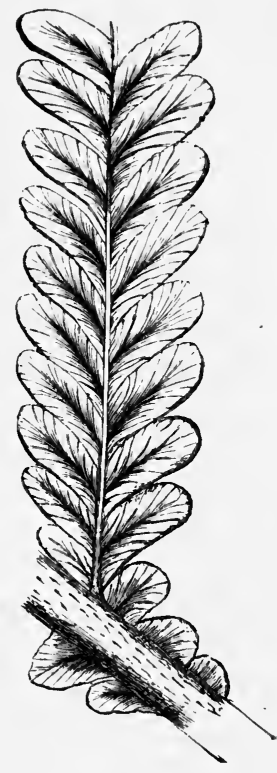

FIs. 27.-Callipteris coufeita, Brngn. while the Sigillarias and Lepidodendra so important in the Carboniferous, and the Stigmaria comnected with them, have almost entirely disappeared. Among the ferns Callipteris (allied to Alethopteris, but the thin middle nerve of the pinnule ends before the point) conferta (Fig. 27) is especially important on account of its extent and abundance; among the Conifers, Walchia pini-

1 Waagen, "Die carbon. Eiszeit. Jahrb. d. Wien. geol. Reichs." (1887). Translated in "Rec. Geol. Surv. of India" (1888)-Feistmantel, "Sitzungsber. d. böhm. Ges. d. Wiss." (1857, 88). Neumayr, "Erdgeschichte" ii. p. 191.-Schenck, "Glacialersch. in Südafrika. Verhandl. d. 8 deutsch. Geogr.-Tages" (1889). 
formis (XXIX. 1), W. filiciformis, and the interesting genus Gingko. The Permian G. primigenia Sap. is very like the modern type G. biloba of China and Japan. The Cycads were represented by Medullosa and Pterophyllum. The not uncommon silicified fragments of stems, formerly known as Araucarites, now as Cordaioxylon, belong to the Cordaites group, intermediate between Cycads and ferns.

In the Zechstein also land plants play the chief part. Neither Sigillarias, Lepidodendra, nor Calamites are known here; but besides a few ferns (Sphenopteris, Alethopteris), we have chiefly Conifera, namely Ullmannia, Voltzia, Schizolepis, Baiera and others, of which the last two are especially characteristic of the Upper Keuper and still newer beds.

In the Permian of Australia, India, and South Africa, Voltzia and Pterophyllum are accompanied by Mesozoic types, such as especially the fern genus Glossopteris (belonging to the Tæniopteridæ), characterized by long, simple, undivided leaves; the Equisetid genera, Phyllotheca and Vertebraria, etc.

As already remarked, we cannot form a complete picture of the F a u na of the Permian epoch from an examination of the impoverished German fauna alone, but we must in the first place, consider the far richer fauna of India, Sicily, and of the Bellerophon Limestone of the Alps.

Of the lowest animals the Foraminifera are almost as important as in the Upper Carboniferous. Of Corals there is, however, in the German Zechstein scarcely any other than the Cyathophyllid Polycoelia, and the finely perforated Stenopora (Geinitzella) with the chief species columnaris. In the Indian Salt Range, on the other hand, Michelinia, Pachypora, Lonsdaleia, and other genera are still present. The Echinodermata are everywhere rather rare. The Bryozoa on the other hand, which, as already noticed, locally form reefs (as at Gera, Pössneck, etc.) everywhere play an important part. Fenestella (XXXI. 3), Polypora, Phyllopora, Acanthocladia, are especially widely distributed genera.

The Brachiopods are of very great importance in the Permian as in all the older Palæozoic formations. In the West European Zechstein scarcely thirty of them are known, in the Indo-Uralian Permian on the other hand, some hundreds. As in the Carboniferous, so here also the Productidæ excel all other families in abundance and variety of form. Productus horridus (XXXII. 1) is 

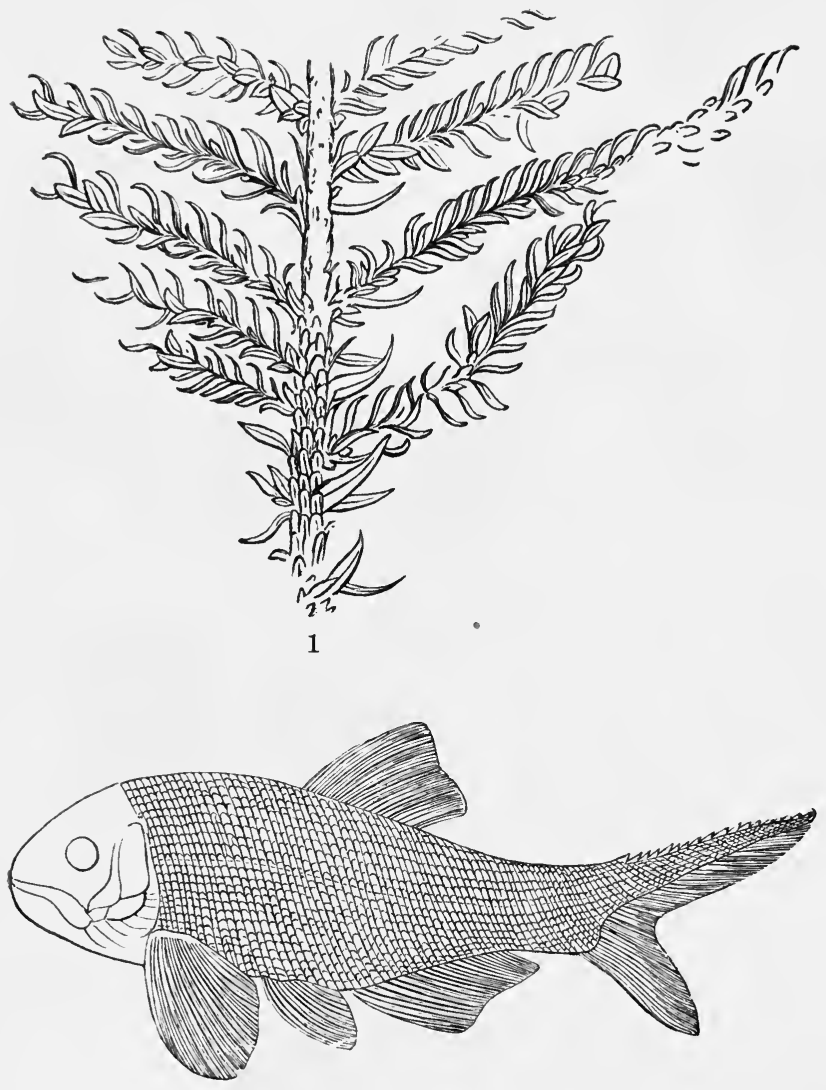

$2\left(\times \frac{1}{3}\right)$

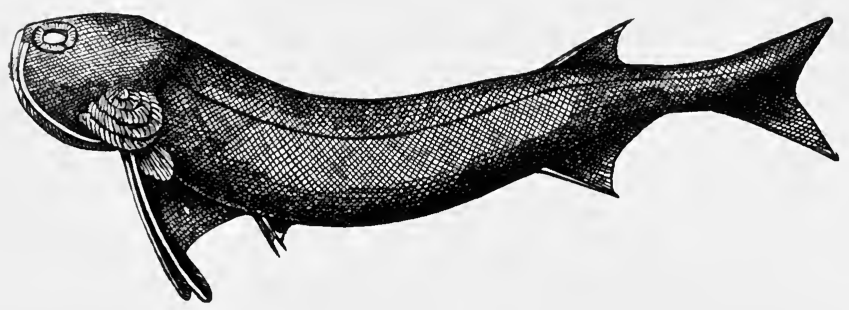

$3\left(\times \frac{1}{3}\right)$

Plate XXIX.-Fossils of the Rothliegende.

1. Walchia piniformis, Sternb. 2. Amblypterus macropterus, Bronn. 3. Acanthodes gracilis, F. Röm. 


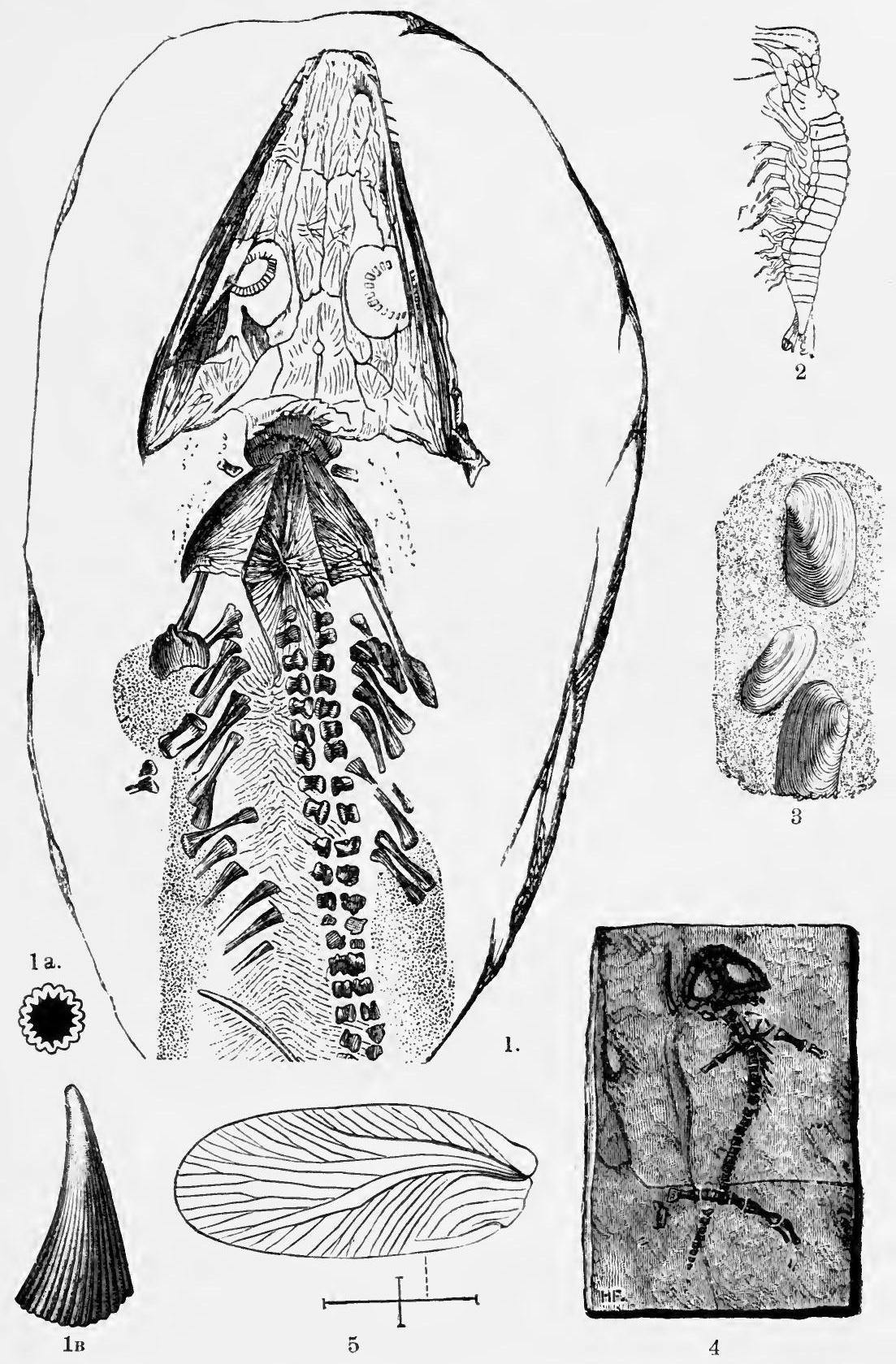

Plate XXX.-Fossils of the Rothliegende.

1. Archegosaurus Decheni, Goldf., young. 1A. Transverse section of tooth. 1B. Sideview of tooth, enlarged. 2. Gampsonyx fimbriatus, Jordan. 3. Anthracosia carbonaria, Goldf. 4. Protiton petrolei, Gaudry. 5. Blattina anthracophila, Germ. 

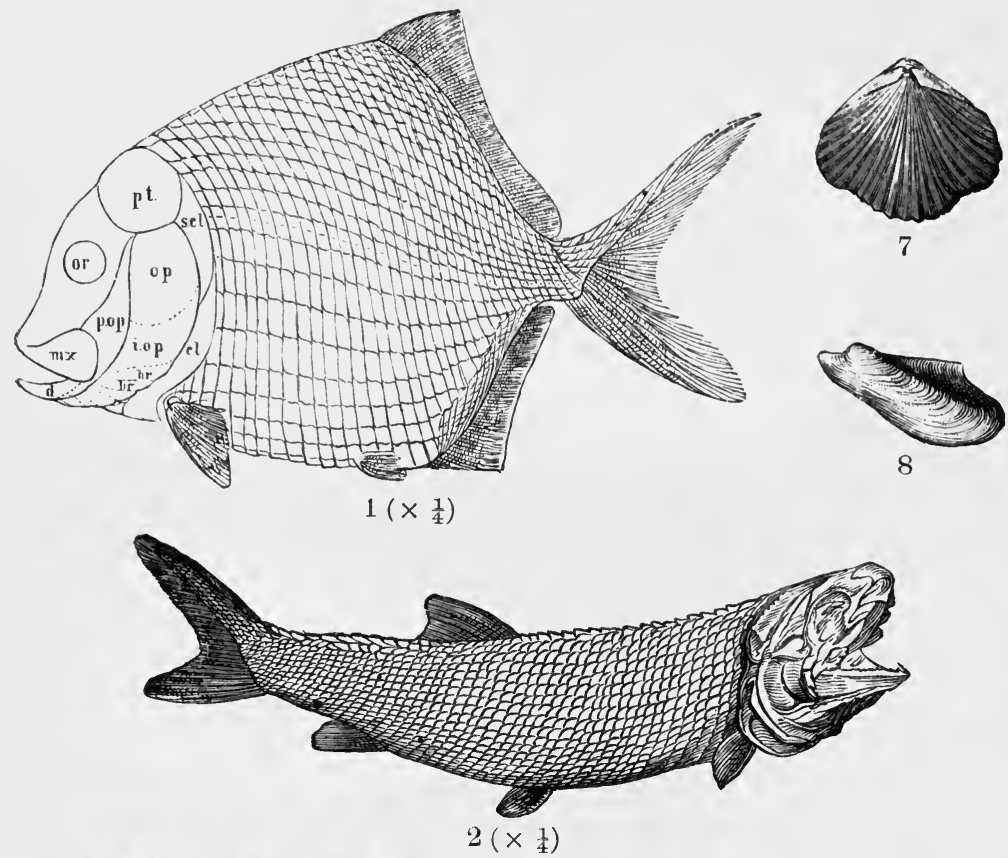

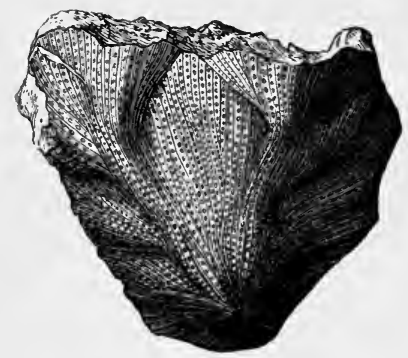

3

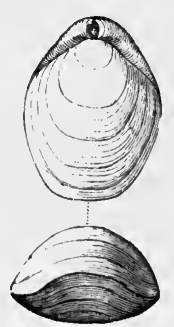

5

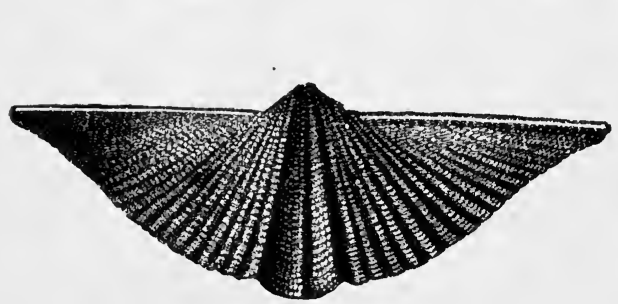

6

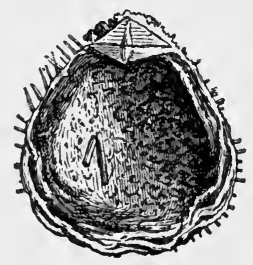

4

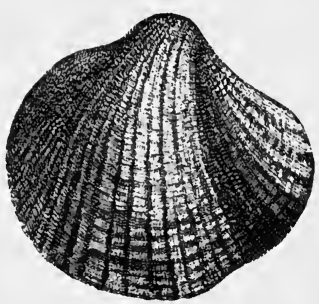

9

PLATE XXXI.-Fossils of the Zechstein.

1. Platysomus gibbosus, Agass. 2. Paloconiscus Fieieslebeni, Agass. 3. Fenestella retiformis, Schloth. 4. Strophalosia Goldfussi, Münst. 5. Terebratula (Dielasina) elongata, Schloth. 6. Spirifer undulatus, Schloth. 7. Camarophoira Schlotheimi, v. Buch. 8. Geivillia ceratophaga, Schloth. 9. Avicula (Pseudomenotis) speluncaria, Schloth. 


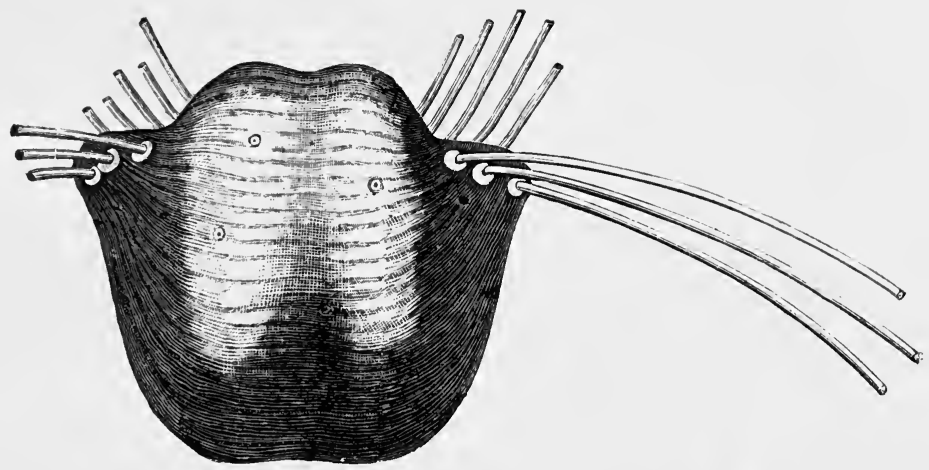

1
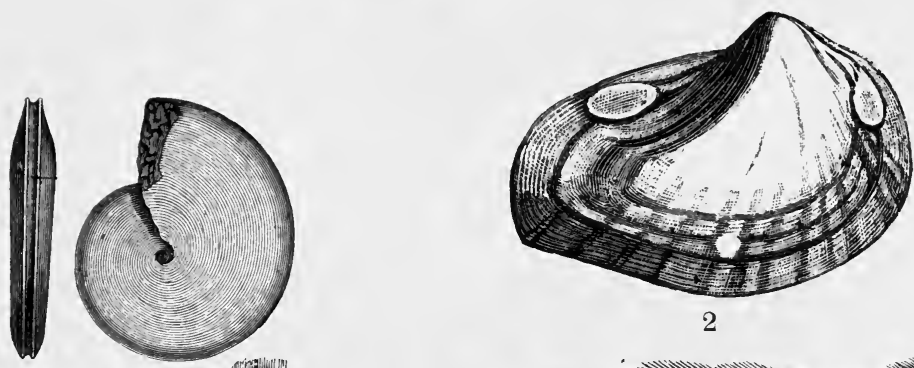

2

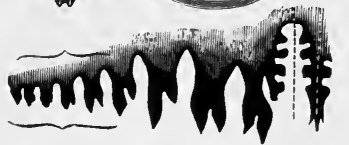

3

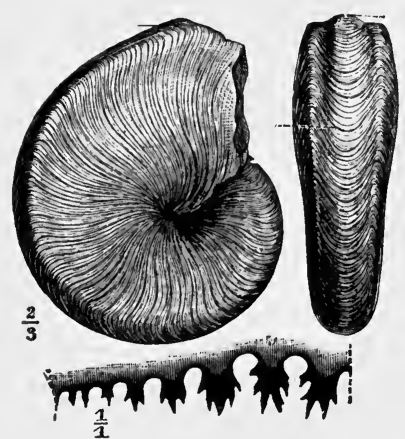

5

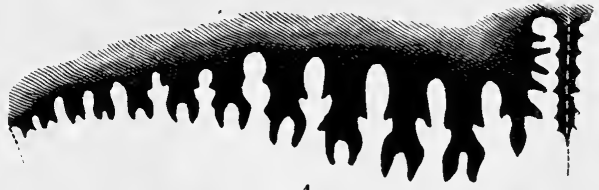

4
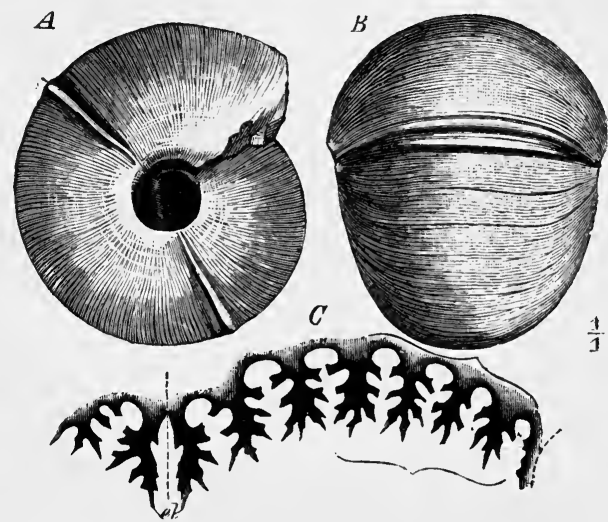

6

Plate XXXII.-Permian Fossils.

1. Productus horidus, Sow. 2. Schizodus obscurus, Sow. 3. Medlicottia Trautscholdi, Gemell. 4. Suture of Medlicottia primas, Waag. 5. Popanoceras multistriatum, Gemell. 6. Cyclolobus Stachei, Gemell. 
one of the characteristic types and reaches from Poland to Spitzbergen. The Productid genera Aulosteges and Strophalosia (XXXI. 4), are important Permian forms, and the same is true of Camarophoria (Schlotheimi [XXXI. 7], a specially widely spread species). The brachiopods of the German, Alpine, and Asiatic Permian have already been noticed above.

In Germany, Lamellibranchiata, with the genera Gervillia (ceratophaga [XXXI. 8]), Pseudomonotis (speluncaria [XXXI. 9]), Arca, Pleurophorus, Allorisma, Schizodus (obscums [XXXII. 2]), etc., form, along with the Brachiopoda, the chief part of the Zechstein fauna. Other striking genera of the Salt Range have already been specially noticed.

The Gasteropoda are tolerably numerous, but, if one excepts the large banks of the genus Bellerophon in the Alps and in India, they offer little worthy of special remark.

The Cephalopoda of the German facies are limited to a few species of Nautilus and Orthoceras. In Southern Europe, Asia, and America, on the other hand, there occur not only both the genera mentioned-the Nautili with strongly sculptured shells recalling the Carboniferous and Triassic species-but also Gyroceras, and more than all, a great number of Ammonoids. It has already been remarked that some of the latter possess undivided goniatitelike sutures, some ceratite-like (zigzag lobes, simple saddles), or even completely divided ammonite-like sutures (cf. Pl. XXXII.); and the most abundant genera have already been mentioned.

Of the Articulata, Ostracoda are tolerably widely spread both in the German Rothliegende and in the Zechstein. Among the Phyllopoda the genus Estheria should be mentioned; while Gampsonyx fimbriatus (XXX. 2), not uncommon near Lebach, has been referred to the Amphipoda. Trilobites, which even in the Carboniferous rocks were approaching extinction, have their last representative in the Russian and North American Permian in a form of the genus Phillipsia. Myriapods and Insects are found in the Kohlenrothliegende in considerable numbers.

Among the most interesting and peculiar members of the Permian fauna are the Vertebrates, which are represented by Fish, Amphibians, and Reptiles. In Germany, the Lebach beds and the Kupferschiefer are the chief beds in which they are found.

The fish are mainly heterocercal Ganoids. They include the herring-like Palconiscus and the rhombic Platysomus (Pal. Freieslebeni and Pl. gibbosus [XXXI. 2 and 1], the two commonest forms 
of the Kupferschiefer); the large, slender, easily recognised genus Acrolepis (Kupferschiefer) with its diagonally grooved scales; Amblypterus (macropterus [XXIX. 2], common in the clay-ironstone nodules of Lebach), etc. The genus Acanthodes (gracilis [XXIX. $3]$, in the Kohlenrothliegende), distinguished by its very small rhombic scales, and by the spines with which its fins are armed, Coelacanthus, and others also belong here. Janassa, the teeth of which, consisting of numerous denticles, are found in the Kupferschiefer, belongs to the Rays; while the genus Xenacanthus or Pleuracanthus (Decheni, a type form of the Rothliegende) with chagrin skin, large neck spines, long fins provided with a bony axis (the so-called Crossopterygian fins), etc., is an interesting synthetic type.

The Amphibians of the Permian period belong to the Stegocephala or Labyrinthodonts, a family reaching from the Carboniferous to the Triassic. They were animals of very various appearance, like salamanders, lizards, crocodiles, or snakes. Their metamorphosis and double occipital condyles show that they were Amphibians. The lower side of the skull is formed as in these; but in the upper side and the scaly covering of the body they are like reptiles. The Stegocephala thus form a characteristic synthetic type and at the same time, as the incomplete ossification of their skeleton shows, an embryonic type. The head and the region of the throat and breast were mailed in all; in many the stomach also. Further peculiarities were the labyrinthine teeth (XXXVI. 2), the bony eye-ring, etc. In the German Kohlenrothliegende, the crocodilelike Archegosaurus (Decheni [XXX. 1], latirostris) is especially important. Other types, occurring in Saxony, Bohemia, and elsewhere, are Branchiosaurus, Pelosaurus, Melanerpeton, Protriton (XXX. 4), etc.

Finally, the Permian Reptiles, the oldest, apparently, of their kind, belong to the two orders of Rhynchocephala and Theromorpha. The former are lizard-like animals, represented in the present world only by the New Zealand genus Hatteria. Palcohatteria, from the Rothliegende of Nieder Hässlich, near Dresden ; Proterosaurus, from the Kupferschiefer, and others belong to this order. The Theromorpha, on the other hand, are limited exclusively to the Permian and Trias, and are remarkable for their relationships not only to other Reptilian and Amphibian orders, but also to the mammalia. Both orders occur in the Rothliegende and Kupferschiefer of Central Europe (Naosaurus, Parasaumus), and still more in the Russian and North American Permian. 


\section{MESOZOIC OR SECONDARY GROUP.}

The deposits of the Mesozoic era, the "Middle Ages of the History of our Earth," form a succession of beds many thousands of feet thick, which is now almost universally divided into three great groups or systems, namely, the Trias, the Jura, and the Cretaceous. From sections such as that in Fig. 28, this sequence of the three formations is visible at once. Few geologists agree with v. Hauer in separating a fourth division, between the Trias and the Jura, namely, the Rhætic System, the uppermost part of the Trias of most geologists; but there is no general agreement yet as to the

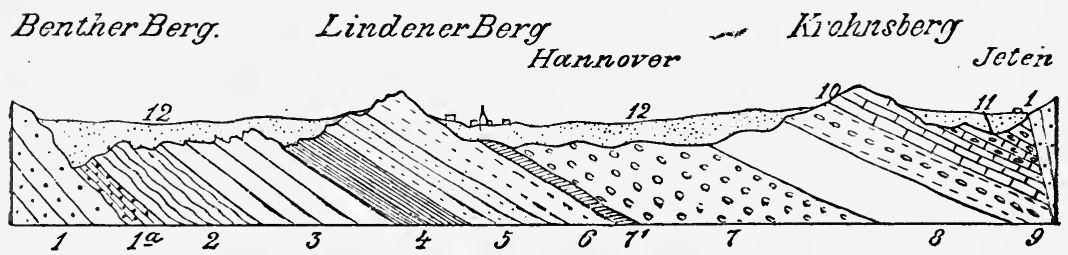

Frg. 28.-Section through the Mesozoic rocks of Hanover (Heinr. Credner).

1. Lower and Middle Bunter sandstone. 1a. Röth. 2. Muschelkalk. 3. Keuper. 4. Lias. 5. Brown Jura. 6. White Jura. 7'. Serpulite. 7. Hils. 8. Gault. 9. Cenomanian. 10. Turorian. 11. Senonian. 12. Drift and Alluvium.

mutual limitations of the three Systems. Thus many observers, especially among the French, reckon the Rhætic with the Jura, while others in England and Germany place it with the Trias. A marine formation moreover, the Tithonian, between the Jurassic and Cretaceous, is united by a number of geologists with the Cretaceous, but by the majority with the Jurassic. The Wealden beds, lying at the base of the Cretaceous, were formerly placed sometimes with the Jurassic, sometimes with the Cretaceous; but are now almost universally united with the last named.

As to the petrographical constitution of the Mesozoic rocks, there is, in comparison with the Palæozoic deposits, a considerable increase of the calcareous rocks, which now, indeed, play the chief part. There is an almost complete absence of the clay-slates, sili-

C. G. 
ceous slates and quartzites so abundant among the Palæozoic rocks, and instead of them we have clays, shales, and sandstones. These together with limestones, marls, dolomites, gypsum and rocksalt, are the predominant rocks of the Mesozoic Systems.

The Mesozoic formations are in general little disturbed, especially in comparison with the Palæozoic deposits. A horizontal disposition of the beds is the exception with these, but the rule with the Mesozoic rocks. It is only in the higher chains of mountains, such as the Jura and the Alps, and in the neighbourhood of great faults, that the beds become strongly folded or steeply inclined.

The eruptive action which in Permian times was still so active, decreased very much with the beginning of the Mesozoic era. Over large areas of Germany, England, France and Russia, not the slightest trace of interbedded eruptive rocks or tuffs is found in the Mesozoic deposits; and where they do occur, as in Southern Tyrol and the North of Scotland, they are limited to a narrow area.

Palæontologically the Mesozoic era is chiefly characterized by the occurrence of the first mammals, birds, bony fishes, and leaved trees. The great development of Saurians, Ammonites, and Belemnites, of the Hexacoralla, etc.; the great reduction of the Brachiopods, so predominant throughout Palæozoic times, in comparison with the Lamellibranchs, and of the Crinoids in comparison with the Echinoids; and lastly the complete absence of mailed fishes and Trilobites, of Cystidea, Rugose and Tabulate corals, Lepidodendra, Calamites, etc., are important characters which distinguish Mesozoic from Palæozoic life.

\section{A. TRIASSIC SYSTEM.}

\section{GENERAL AND HISTORICAL.}

The Triats, the oldest of the Mesozoic systems, owes its name to the circumstance that in Germany, where it first became known in detail, it falls into three divisions sharply separated from one another, namely (from below upwards), the Bunter Sandstone, the Muschelkalk, and the Keuper. Even last century, in the time of Lehmann, Fuchsel, and Werner, the Bunter Sandstone and Muschelkalk were distinguished as important groups of the "Flötzgebirge," but it was not till a much later period (1820-30) that the Keuperthe term originated in the district of Koburg-was separated from 
the Muschelkalk by L. v. Buch, Hausmann and others. It was in 1834 that the three groups were first united under the name "Trias" by the Swabian observer v. Alberti."

In no other country in Europe is the Trias so widely spread as in Germany, where it reaches from Lorraine and Luxemburg to Upper Silesia, and from the Jura far into the North German plain, and occupies a larger area than any of the other formations. The Triassic beds of England also, in spite of the absence of the Muschelkalk, are allied to the German formation; and this is true also of the Trias of the South of Sweden. The German facies of the Trias has consequently a very widedistribution in the centre of Europe. But if we pass to other continents, it is only in a few regions, such as the eastern part of North America and the southern part of Africa, that we find a development of the formation in some degree like the "German." In all other areas in which Triassic rocks are known they belong to a very different facies, namely, that of the Alps. This "Alpine" Trias is met with of great extent throughout the Mediterranean area, in Southern, Eastern and Northern Asia, in Western North America, in Mexico and Peru, and even in New Zealand and others of the Australian islands, so that it forms the normal facies for the whole earth, while the German Trias is relatively a very restricted local facies. The difference between the two modes of development is both petrographical and palæontological. The German Trias is, with the exception of the calcareous Muschelkalk, composed mainly of sandy or argillaceous rocks,-in England indeed these form almost the whole. In the Alps, on the other hand, the sandy rocks are very much reduced in comparison with the massive pure limestones, dolomites and marls. Still more considerable is the difference in fauna. In Germany it is only the Muschelkalk that contains a fauna of any abundance, while the Keuper and still more the Bunter Sandstone are very unfossiliferous. But the fauna even of the Muschelkalk is poor in comparison with that of the deposits of the same age in the Alps. This is especially true of the deep-sea Cephalopoda, which in the German Trias are represented by a few small species, but in the Alpine Trias by a whole series of rich faunas. Thus the German Trias bears the same relation to the Alpine type as the German Zechstein bears to the fossiliferous Indo-uralian Permian. Just as

1 "Beitrag zu einer Monographie des Bunten Sandsteins, Muschelkalkes. und Keupers." The same author afterwards published the "Ueberblick über die Trias" (1864). 
in this case the usual view is that the latter was deposited in the open ocean, and the Zechstein in a brackish inland sea, so we must come to the like conclusion for the two different Trias types: the widespread Alpine Trias is the pelagic facies of the formation, the more restricted German Trias, on the other hand, is a shallow shore, bay or inland sea formation.

Besides the predominant sandy character of the rocks and the poverty of the fauna, numerous other facts tell in favour of such a mode of formation of the German Trias; such as the common discordant or cross bedding, the tracks of animals, impressions of rain drops, sun cracks, and ripple marks on the surface of the Bunter Sandstone, the salt-pseudomorphs found at the most various horizons, and the often very abundant remains of land plants.

In consideration of this it may be questioned whether the Alpine Trias should not be described first, and the German afterwards. But the fact that the knowledge of the formation originated in Germany, and that the English Trias belongs to the German type, leads us to begin with the description of the German facies.

\section{The German Facies of the Trias.}

As above remarked, this falls into a lower clayey and sandy subdivision, the Bunter Sandstone, a middle calcareous, the II uschelkalk, and an upper sandy clayey, the Keuper. ${ }^{1}$ Since these three groups are sharply distinguished from one another, not only petrographically but also in part palæontologically, it will be advisable to describe them separately.

The extraordinary extent of the Trias in Germany has already been referred to. It is the predominant formation everywhere in Central and Southern Germany, in Thuringia, Hesse, Franconia, Swabia and Lorraine. But it also occupies not inconsiderable areas in the southern part of the Eifel, and in the Trier Bay; in Hanover, Brunswick, and Magdeburg, and also in Lower and Upper Silesia. It forms small masses rising up like islands from the Diluvium in Brandenburg (especially near Rüdersdorf not far from Berlin), near Iüneberg, etc., and its presence has been proved by borings near Cottbus, Bromberg, and in the neighbourhood of Stade. The most northerly occurrence of the Trias in Germany is in the island of Heligoland. Beyond the limits of the Empire, deposits of German

1 The terms used in France are "grès bigarrẻ" (=Bunter), muschelkalk, and marnes irisées (=Keuper). 
Trias occur once in Poland, to which place they are continued from Upper Silesia; while in the west they pass beyond the limits of Germany, and reach on the borders of the Rhenish Schiefergebirge from the Trier (Trèves) region to Luxemburg, and on the western slopes of the Vosges into France. Further west, red Triassic sandstone is known also in the neighbourhood of the French Central Plateau. Finally, the coal-bearing Keuper Sandstone of the South of Sweden is an outlier of the German Trias.

As to the literature of the German Trias the original work of v. Alberti has already been mentioned. Since the appearance of this a large number of geologists have occupied themselves with the study of this formation. Among the older we may mention: Quenstedt, ${ }^{1}$ E. E. Schmid, v. Strombeck, Giebel, and Bornemann ; among the later, v. Seebach, Eck, Nies, Sandberger, E. Weiss," Schalch, Benecke, Nötling, Blankenhorn. The researches of Gümbel ${ }^{3}$ in Bavaria, and of F. Römer ${ }^{4}$ in Upper Silesia, and still more, the recent researches of the Geological Survey in Prussia ${ }^{5}$ and Alsace Lorraine, ${ }^{6}$ are of the greatest importance. Thanks to these, our knowledge of the constitution of the Triassic deposits in the most different regions of Germany is more complete than that of any other System.

\section{The Bunter Sandstonc.}

As the name suggests, this group of beds consists mainly of variegated, chiefly red, sandstones, shaly sandstones and shales coloured by oxide of iron, with which there are locally conglomerates and variegated, calcareous clays, containing gypsum and rocksalt, the latter of which however are limited to the upper division of the series. In these latter beds there occur several bivalvebearing beds of limestone or dolomite, which are completely wanting elsewhere in the Bunter Sandstone.

1 "Das Flötzgebirge Württembergs" (1813).

2 "Gliederung der Trias im Saarbrückenschen. Neues Jahrb." (1869), p. 215, and Zeits d. deutsch. geol. Ges. (1869), p. 837.

3 "Die geogn. Verhältn. des fränkischen Triasgebietes." Bıvária IV. 11 (1865). "Geogn. Beschreib. d. Fichtelgebirges" (1879).

4 "Geol. von. Oberschlesien" (1870).

5 See the explanations to the sheets referring to Thuringia, the environs of the Harz, the Saar area, etc., and numerous papers on the Trias in the "Jahrb. der preuss. geol. Landesanstalt."

6 "Erläut. z. geol. Uebersichtskarte von Deutsche-Lothringen; Erläut * Uebersichtskarte der südl. Hälfte des Grossherzogth. Luxemburg." Heraus. geg. von der geol. Landesuntersuchung von Elsass-Lothringen (1887). 
In Northern and Central Germany, in the Harz, Thuringia, Hesse, etc., the Bunter Sandstone everywhere succeeds the Zechstein quite conformably. The connection between the uppermost Zechstein clays and the lowest clayey beds of the Bunter Sandstone is indeed generally so intimate that the separation of the two is very difficult, and is to a certain extent arbitrary. It is different in S.W. and W. Germany, where in the Eifel, the Black Forest and the Odenwald, and in the Vosges, the coming in of the Bunter Sandstone was often accompanied by a clear overlap, in consequence of which it rests locally (as in the Odenwald and Black Forest) directly on crystalline schists. Since this transgression lasted beyond the Bunter Sandstone period, the lower or even the lower and the middle Bunter Sandstone are often absent in these areas.

The Bunter Sandstone throughout Germany is divided, mainly on petrographical grounds, into three groups, namely, in ascending order: 1. the Lower Bunter Sandstone, 2. the Middle or Main Bunter Sandstone, and 3. the Upper Bunter Sandstone or Röth.

The Lower Bunter Sandstone consists of a series, a few hundred feet thick, of red, greenish, yellowish, whitish, or speckled, fine-grained, micaceous, clayey sandstones and shale. Firm sandstones, valuable as building material, occur in this division, in Central Germany quite subordinately, in Southern Germany of considerable thickness. The rounded or angular inclusions of dark red clay, the so-called "clay galls," which are everywhere found in the sandstones of this series, are very characteristic. Other extremely characteristic formations are the Rogensteins, which are peculiar oolitic, more or less dolomitic calcareous sandstones, which occur sometimes in solitary banks, sometimes (as near Bernberg, Artern, Sangerhausen) in thick layers. These are almost limited to the region north, east, and south-east of the Harz, and are found elsewhere only at Rüdersdorf near Berlin. They were the chief occasion of the separation of the Lower and Middle Bunter Sandstone, first adopted in 1860-70 by Beyrich, Eck and others. Ripple marks, sun cracks, and impressions of rain drops are abundant in this division of the Bunter; conglomerates on the other hand are practically absent. In Eastern Hesse, especially in the so-called Riechelsdorf Gebirge and in the Spessart, the lowest zone, resting directly on the Zechstein, consists of dark red crumbly clays, the so-called Bröckelschiefer. 
Fossils are everywhere very rare in the Lower Bunter. In the neighbourhood of Halle and elsewhere, there are certain beds filled with impressions of the small Phyllopod Estheria minuta (the socalled Estheria beds of the upper part of the Lower Bunter); in Hesse, at the upper limit of the series, the small, generally badly preserved Gervillia Murchisoni, which rises also to the Middle Bunter, is locally not uncommon. In Upper Silesia Eck found Lingula tenuissima and Pecten sp.

The Middle or Main Bunter Sandstone is a series, sometimes 1,000 feet thick, of more or less coarsely granular quartzose sandstone, with little or no cement. Conglomerates may occur at any horizon, but usually they are quite subordinate. Shales and shaly sandstones are not wanting between the massive sandstone beds, but on the whole they are very much reduced compared with

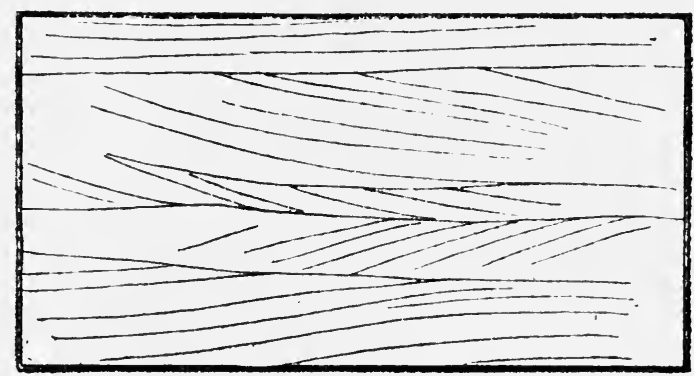

FrG. 29.-False-bedding in the Middle Bunter Sandstone near Marburg.

these. In this division of the Bunter discordant or cross bedding (Fig. 29) is particularly abundant throughout Germany, and ripple marks are not uncommon. In Thuringia, Hesse and Franconia, the Spessart and the Odenwald (especially at Hildburghausen, "Jena, Karlshafen on the Weser, Kissingen, etc.) the upper sandstones, which are mostly pale and fine grained, contain the footprints of Amphibians, especially Stegocephala, known as Cheirotherium. In the Vosges the Main Bunter Sandstone is represented by the thick, pale red sandstones, conglomeratic at the top, which have long been known as Vosges Sandstone.

Except, these tracks the Middle Bunter Sandstone contains hardly any fossils save Labyinthodonts. At Bernburg it includes numerous remains of them, especially a well-preserved skull of Trematosaumus Brauni, Burm.

Lastly, the Upper Bunter Sandstone or Röth consists 
mainly of variegated clays or marls, which, especially in Thuringia, contain numerous masses of gypsum, and in the north of the Harz (at Juliushall [Harzburg], Salzgitter, Schöningen, etc.) beds of salt. Where these beds of salt are not known, salt pseudomorphs are usually not uncommon on the surfaces of the beds. In Hesse and Thuringia the lower part of the Röth commonly contains. thin intermediate beds of pale coloured quartzite sandstone; the upper part, on the other hand, in Thuringia includes dolomite limestone beds, the so-called Rhizocorallium Dolomite, which is of interest on account of the fact that it contains the only Bunter fauna of any importance. Besides the snake-like coiled rolls of the Rhizocorallium jenense, now supposed to be a horny sponge, Myophoria costata (XXXIII. 3), the most characteristic fossil throughout Germany, is found here; and also My. vulgaris, Gervillia socialis, Lingula tenuissima, Myacites mactroides, Myoconcha Thielani, Pecten discites, and other Muschelkalk species. Of especial interest, but only locally abundant (as near Jena), is an Ammonite, Amm. (Bencckeia) tenuis, the predecessor of B. Brichi: of the Lower Muschelkalk.

In Lorraine, the Saar area and the Eifel, the Röth is chiefly composed of fine grained, micaceous clayey sandstones, with numerous plant remains, the so-called Voltzia Sandstone (Fig. 30). The most widely spread plant is the Abietid Voltzia heterophylla (XXXIII. 1), and there also occur Equisetum Mougeoti, species of Anamopteris, and Caulopteris, etc. ${ }^{1}$ In Lorraine, as also in the Haardt, the Vosges, the Black Forest, and the Odenwald, the lowest zone of the Röth, usually only a few meters thick, is characterized by nodules and strings of dolomite and carnelian (Carneol), the so-called Carneol bank.

On the south border of the Ardennes, and near Malmédy, thick coarse conglomerates form one of the remaining facies of the Röth.

The occurrence of galena in grains and small nodules in the Bunter of Mechernich and Commern in the North Eifel and in more restricted masses near St. Avold in Lorraine, should be mentioned as very interesting. At the first-named place this remarkable occurrence (the so-called Knottenerz) has called into existence the most important lead mines in Germany, which were worked even by the Romans.

${ }^{1}$ Schimper and Mougeot, "Monogr. des plantes foss. du grès bigarré des Vosges" (1844). 


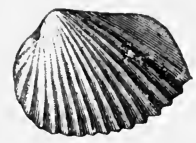

$3 \mathrm{~A}$
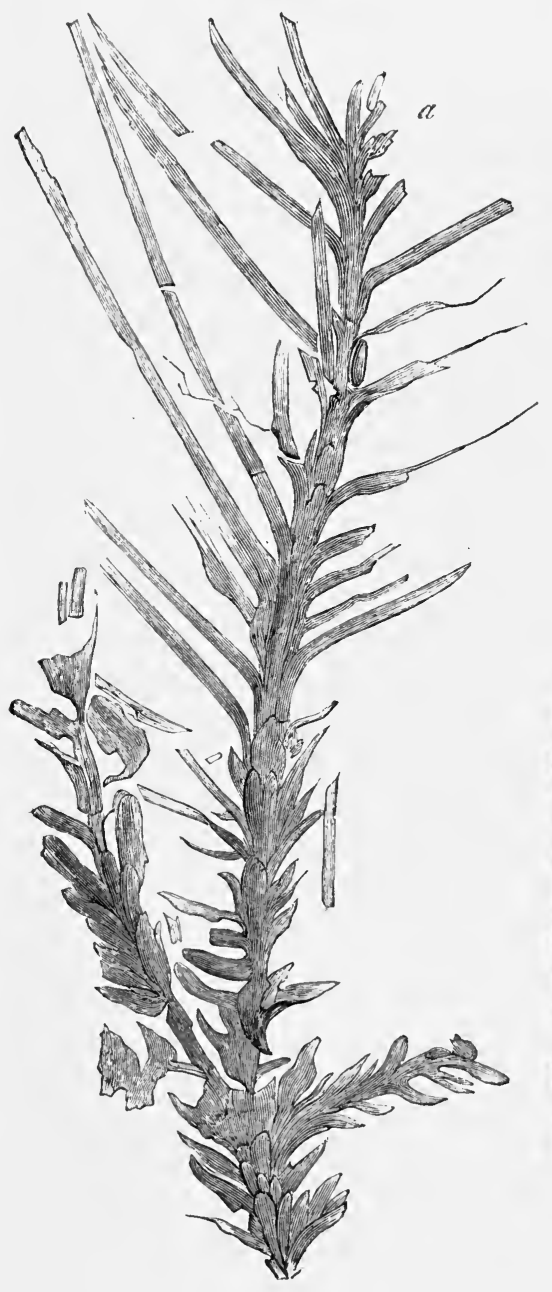

1

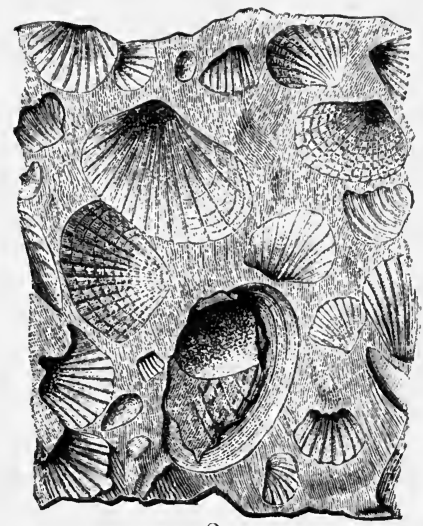

3
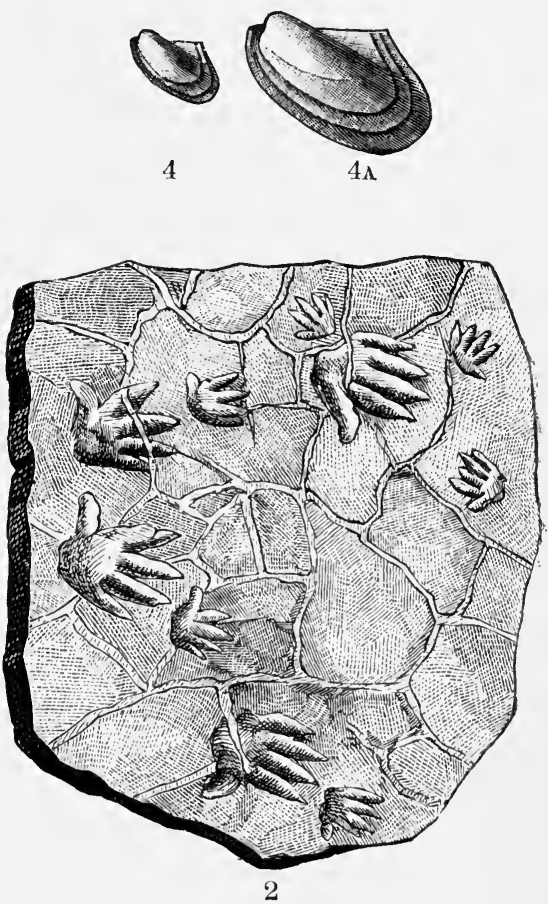

2

Plate XXXIII,-Fossils of the Bunter Sandstone.

1. Voltzia heterophylla, Brongn. 2. Cheirotherium footprints (much reduced). 3. Casts and impressions of Myophoria costata, Zenk. 3A. Shell of the same. 4. Gervillia Murchtsoni, Gein. 4A. The same, enlarged. 


\section{The Muschelkalk.}

Unlike the Bunter Sandstone and the Keuper, the Muschelkalk is in the main a calcareous series. Some 1,000 feet in thickness, it consists in its lower and upper parts of thin-bedded, pale grey limestones, with interbedded greenish grey marls; in the middle, on the other hand, of gypsum and salt-bearing marls and dolomites. Only at the extreme western border, in a zone reaching from the Cologne curve of the Rhine into the Empire, the lower part of the Muschelkalk is represented by sandy rocks, the Muschelsandstein. The fossils of the Muschelkalk are not by any means evenly distributed through the series, but are usually found in certain beds, in which they often occur in such abundance, though yenerally with only a few' species, that the name Muschelkalk appears quite appropriate.

In its extent the Muschelkalk is indeed inferior to the Bunter; but it occupies considerable areas in Thuringia, Franconia, Swabia, and Lorraine, and plays a not inconsiderable part in the north and north-west of the Harz and in Silesia. Its most northerly occurrence is in Heligoland. From Lorraine it stretches to the west and south of the Vosges into the Department of Jura. In the Morvan also, in the north-east of the French Central Platean, it may still be recognised in the form of a few thick grey limestones and dolomites intercalated between the Voltzia Sandstone and the Keuper. Further west it is, at least in its calcareous form, as little known as in England. On the other hand true Muschelkalk occurs in the neighbourhood of Toulon and Montpellier.

Throughout Germany the Muschelkalk falls into three divisions, namely: (1) the Lower Muschelkalk or Wellenkalk; (2) the Middle Muschelkalk or Anhydrite group of v. Alberti; (3) the Upper Muschelkalk (Main Muschelkalk of Quenstedt, Friedrichshall Limestone of v. Alberti). In general the constitution and the organic contents remain strikingly similar everywhere.

The Lower Muschelkalk or Wellenkalk consists of thin and wavy-bedded, somewhat marly limestones, with folded or wrinkled upper surfaces. In the lowest layers there are numerous yellow dolomitic beds, the so-called Wellendolomite. These are followed by the Lower or Main Wellenkalk, with beds full of Natica (Turbo) gregaria and Dentalium torquatum. The Upper Wellenkalk is distinguished by intercalations of 
Schaumkalk, a yellowish grey, porous limestone. This rock, which yields stone as easily worked as it is durable, and therefore very valuable, occurs partly in single strong beds, partly in thick series. In Thuringia two chief Schaumkalk zones may be distinguished, which are separated by 60-80 feet of Wellenkalk. The lower of these zones corresponds with that which E. Schmid in South Thuringia has called the Terebratula Limestone (from the numerous shells of $T$. vulgaris [XXXIV. 7] contained in it). The Lower Muschelkalk ends with the so-called Orbicularis-Platten covered with thousands of examples of Myophoria orbicularis.

The Lower Muschelkalk of Alsace-Lorraine, the Saar and Moselle areas and the North Eifel is, as E. Weiss first showed for the Saar area, not so commonly made of Wellenkalk, but of grey dolomitic marly sandstones, and it is only the beds with Myoph. orbicularis that consist of limestone. The sandstones are often red in colour, and were formerly referred to the Röth, till Weiss, by the discovery of the usual Muschelkalk fossils, proved that they form only an abnormal sandy facies of the Lower Muschelkalk, the so-called Muschelsandstein (Fig. 30). In the neighbourhood of Baireuth also, according to Gümbel, a similar sandy formation of the Lower Wellenkalk is found.

Palæontologically the Lower Wellenkalk is characterized not only by Rhizocorallium jenense, Terebratula vulgaris, Lima lineata, Myophoria cardissoides, Chemnitzia scalata (XXXIV. 8), etc., but also by a few rare Ammonites (A. Strombecki, Buchi, Ottonis, Damesi). The Upper Wellenkalk, with its Schaumkalk, one of the richest horizons of the whole Muschelkalk, contains Myophoria vulyaris (XXXIV. 5), M. cardissoides, and M. elegans, Gervillia costata, Monotis Alberti, Pecten discites (XXXIV. 3), P. lavigatus, Nucula Goldfussi, Spiriferina fragilis, S. hirsuta, Athyris trigonella, Terebratula vulgaris (XXXIV. 7), T. Ecki, T'. angusta, Ammonites (Bencckeia), Buchi, etc., and a few other inportant Ammonitidæ, more or less rare, such as Ptychites dux and Ceratites antecedens and $C$. trinodosus. ${ }^{1}$

The Middle Muschelkalk consists mainly of dolomites, which sometimes bear limestone nodules, sometimes are cellular or cavernous (Zellendolomite), and of yellowish grey, smooth-bedded, dolomite marls and limestones, with anhydrite, gypsum, and rocksalt masses. Beds of salt are found at some points in Thuringia

1 The last, an important species of the Alpine Muschelkalk, has lately been found at Rüdersdorf. 

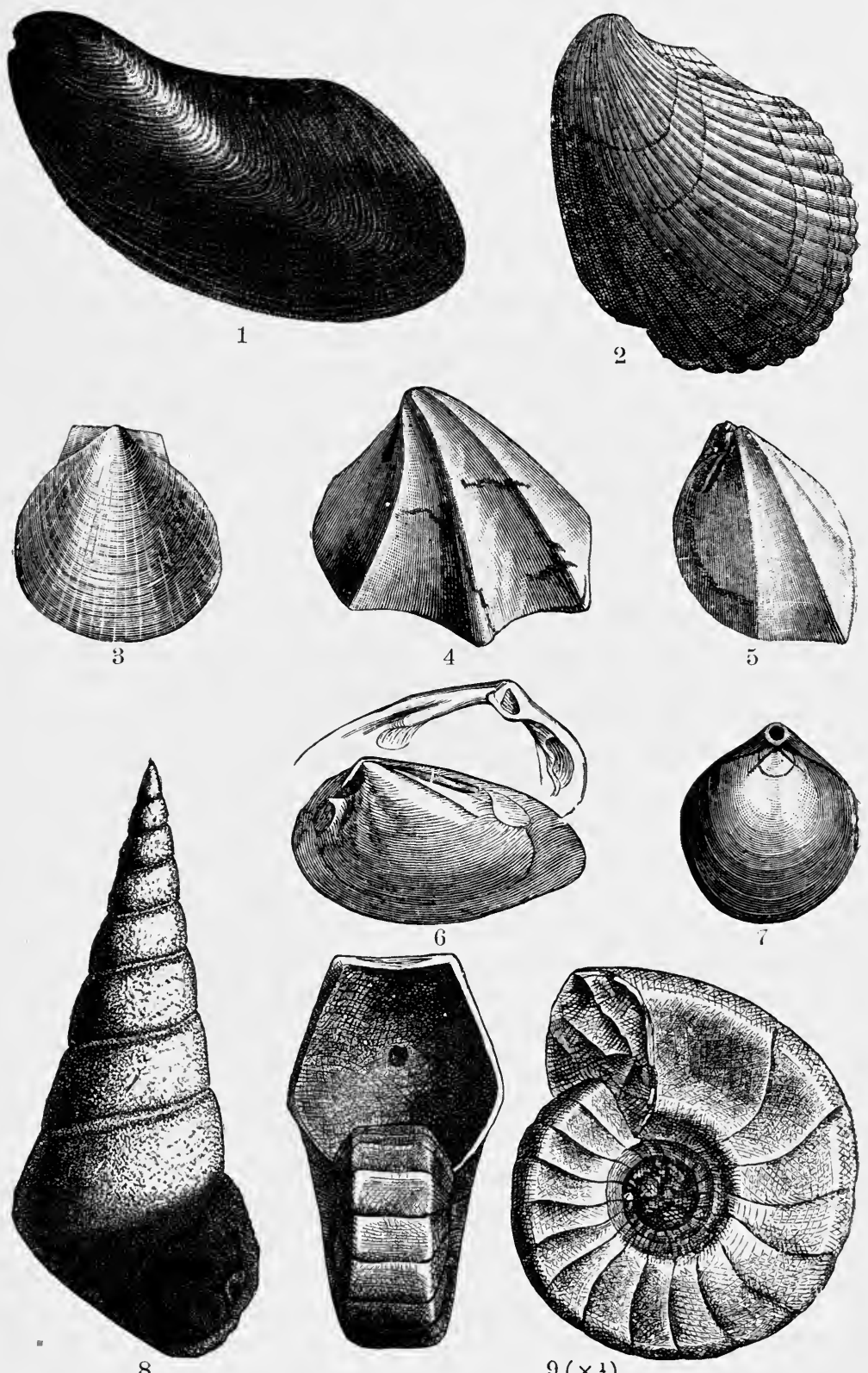

Platr XXXIV.-Muschelkalk Fossils.

1. Gervillia socialis, Schloth. 2. Lima striata, Schl. 3. Pecten discites, Schl. 4. Myophoria pes anseris, Schl. 5. M. vulgaris, Schl. 6. Trigonodus Sandbergeri, v. Alb. 7. Terebratula (Coenothyris) vulgaris, Schl. 8. Chemnitzia scalata, Schl. 9. Nautilus bidorsatus, Schl. 

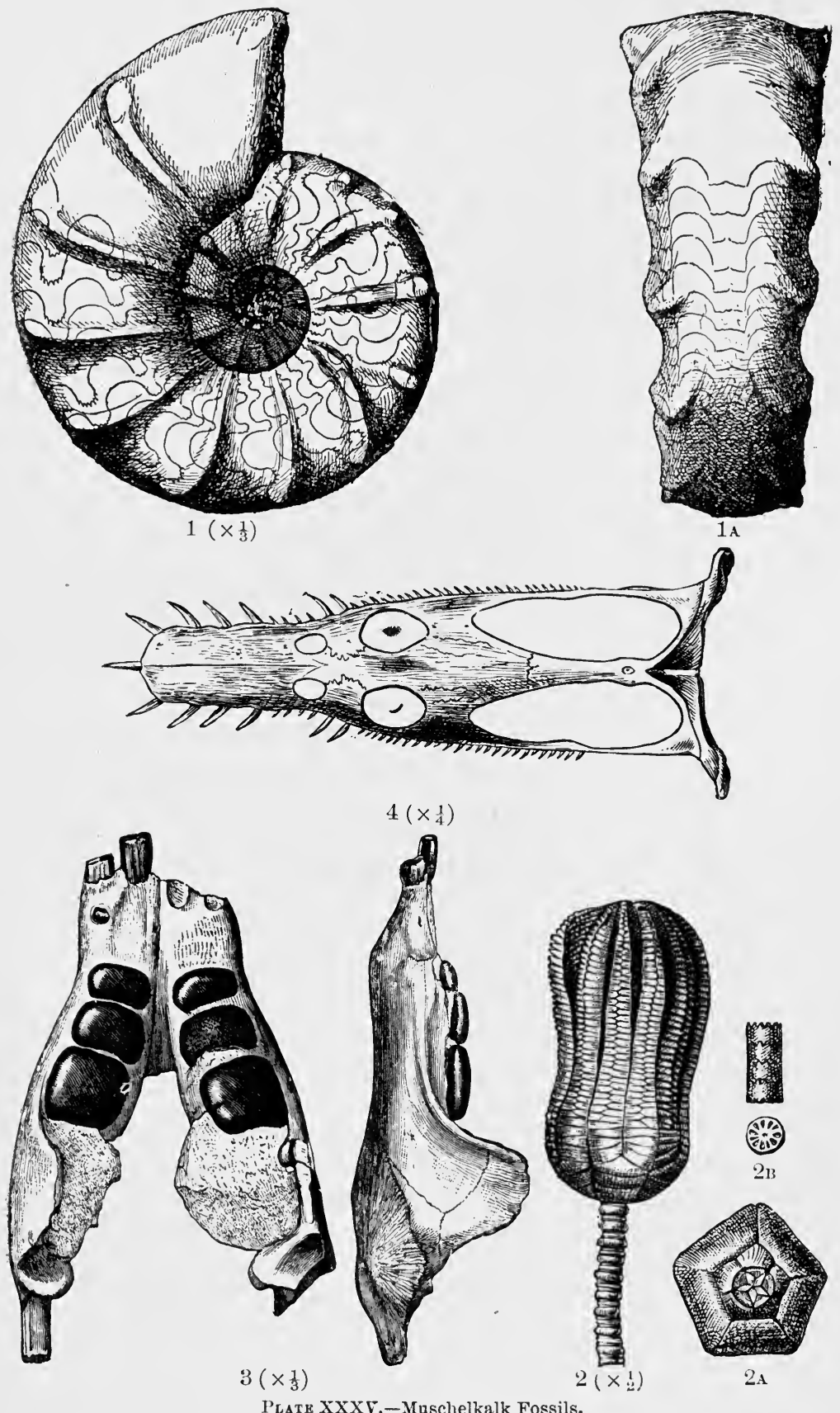

1, 1s. Ceratites nodosus, de Haan. 2. Encrinus liliiformis, Lam. 2A. Calyx from below. 2B Portion of stem. 3. Placodus gigas, Agass. 4. Nothosaurus mirabilis, v. Münst. 
(Erfurt, Gotha, Stotternheim, etc.), and in South Germany (Rappenau near Wimpfen in Baden, where the first South German rocksalt was bored, Friedrichshall in Wurtemberg, Stetten in Hohenzollern, Schweizerhall in Switzerland). In the region of Ettelbrück in Luxemburg, the Middle Muschelkalk, like the Wellenkalk throughout the left bank of the Rhine, is replaced by sandy beds. Fossils are very rare in this division of the Muschelkalk.

The Upper Muschelkalk evorywhere consists of two main divisions: at the base the so-called Trochitenkalk, a very hard limestone consisting almost wholly of stems of Encrinus liliiformis (XXXV.2), and often accompanied by glanconitic limestones; and above, the so-called Nodosus beds, thin bedded limestones alternating with grey clays and shales, which everywhere contain Ceratites nodosus as the most characteristic fossil. In South-west Germany there is added to these an upper, not very thick, series of dolomite and platy limestone with Trigonodus Sandbergeri-the so-called Trigonodus beds.

This is the richest in fossils of all the three subdivisions of the Muschelkalk. Encrinus liliiformis, Lima striata (XXXIV. 2), Gervillia socialis (XXXIV.1), Terebratula vulgaris (XXXIV. 7),T. cycloides, Pecten discites (XXXIV.3), Myophoria vulgaris (XXXIV. 5), often fill whole beds. Especially characteristic, because known only in the Nodosus beds, are Ceratites nodosus (XXXV. 1), with broad back and strong, simple ribs ending at the angle of the back with a knob-like swelling, and the larger, sharp-backed C. semipartitus and the smaller C.cnodis. The large Nautilus bidorsatus (XXXIV.9) has its greatest development in the Upper Muschelkalk.

The Muschelkalk in Upper Silesia and the neighbouring part of Poland is somewhat abnormal owing to the dolomitic character of the whole Upper and Middle and the upper half of the Lower Muschelkalk. The beds corresponding to the latter (the Schaumkalk-bearing division of other regions) are important not only from their richness in ores (brown hæmatite, galena and calamine), but also on account of the occurrence of Gyroporellas, and other interesting fossils common to the Alpine Muschelkalk, especially Athyris trigonella, Spiriferina Mentzeli, Terebratula angusta, and Rhynchonella decurtata (cf. Pl. XXXVIII.), species which are not unknown elsewhere, especially in Franconia.

The remarkable Styloliths, though not uncommon in other limestones, are especially abundant in the Muschelkalk. 
The influence of the Muschelkalk on the physical features is very marked. The large horizontally bedded areas form monotonous dry plateaux with deeply cut narrow valleys, while the smaller masses, on the other hand, form bastion-like hills, with precipitous sides. Where such masses consist of the whole Muschelkalk, the hard Upper division forms a second terrace above the lower Wellenkalk terrace. Lastly, where, as in Fig. 31, the Muschelkalk beds are strongly inclined, the varying hardness and resistance to weather of the different strata is well shown. The relatively firm Wellenkalks (especially the Schaumkalk zone), and the Trochites Limestone of the Upper Muschelkalk sometimes form only slight projections and sometimes higher ridge-shaped elevations, whilst the easily worn rocks of the Middle Muschelkalk, like those of the Röth, allow of the formation of trough-like depressions often coinciding with river valleys.

\section{The tieuper.}

The uppermost group of the Trias, the Keuper (marnes irisées of the French), consists of variegated, chiefly red-coloured, clays (which in the middle of the sories contain great beds of gypsum and less frequently rocksalt), of pale-coloured sandstones, and of impure, generally not very thick, limestones and dolomites, to which are added in the lower division small impure seams of coal. The boundary line between this series and the Muschelkalk is usually not very sharp; that between it and the Lias, on the other hand, is very clear. As the character of the rock, and still more clearly the scanty and monotonous fauna, in which deep-sea Cephalopoda are practically absent, ${ }^{1}$ show, the Keuper in general, like the Bunter, is a shallow water deposit. The main area of the German Keuper lies in Franconia and Swabia ; but it also occupies a considerable extent in Alsace-Lorraine and Luxemburg. Next to these the middle of the Thuringian basin, the hollow between the Teutoburger Wald and the Wesergebirge, and Upper Silesia, are the most important areas. On the whole the limits of the distribution of the German Keuper coincide with those of the German Empire. Beyond this it is only in the southermmost parts of

1 The discovery by Zimmerman (Zeits. d. deutsch. geol. Ges., 1883) of Ceratites Schmidi in the Grenzdolomite of Thuringia is an isolated case. The same observer has also made known from the same horizon ("Jahrb.d. preuss. geol. Landesanst.," 1889) a new Nautilus, N. jugatonodosus, different from $N$. bidorsatus. 


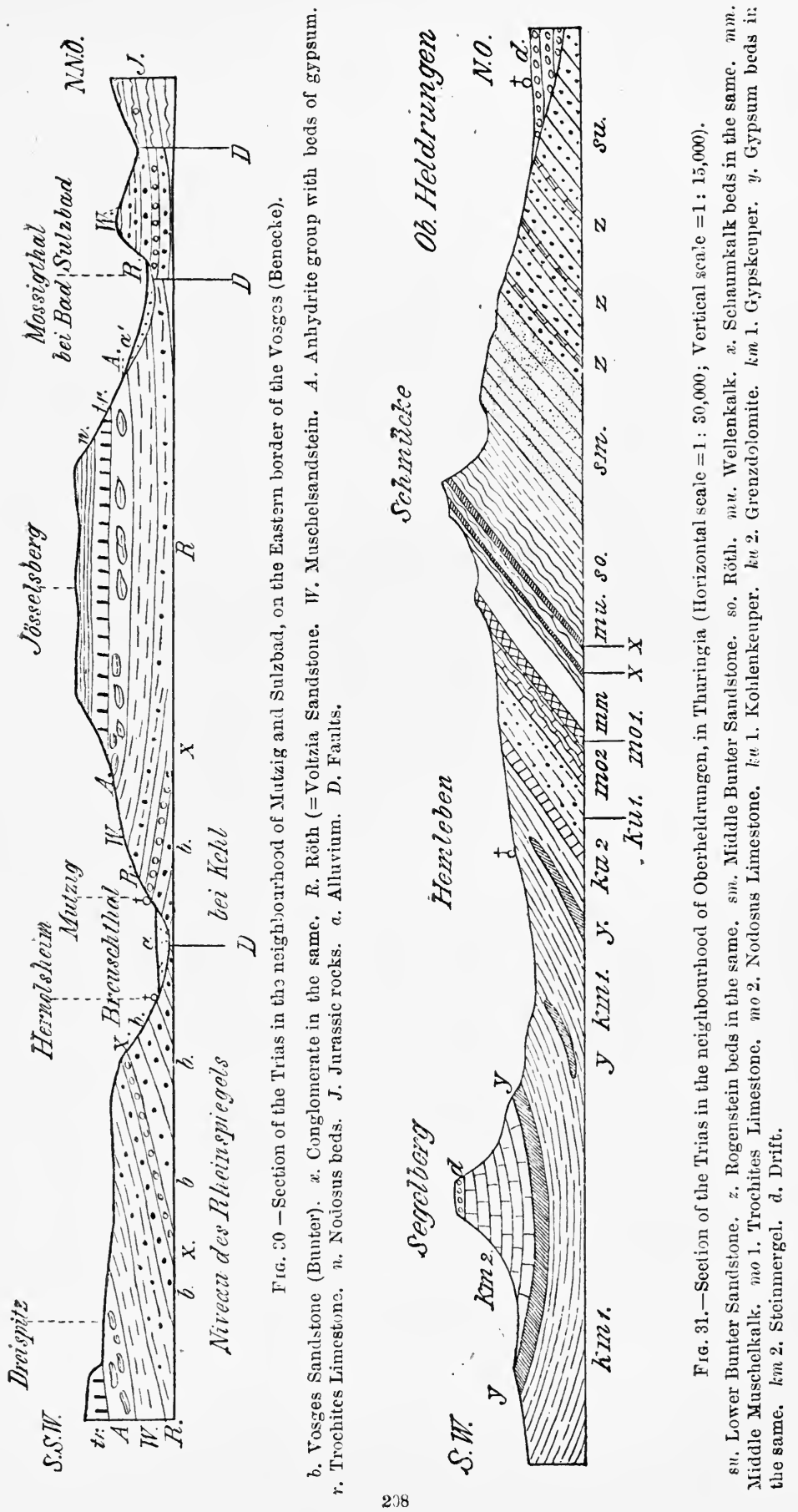


Sweden that we get an area of any size of Upper Keuper, and this is only an extreme outlier of the German facies.

On account of their softness the Keuper rocks everywhere form an undulating country; and it is only the rather harder sandstones that stand out as ridges or terraces.

Like the Bunter Sandstone and Muschelkalk, the Keuper also is divided into three groups, which are everywhere recognisable with great certainty, in spite of numerous local variations, namely, the Lower or Kohlenkeuper, the Middle, Main or Gyps Keuper, and the Upper Keuper, or Rhät.

The Lower or Kohlenkeuper, also called the Lettenkohl group, consists of grey clays and shales, whitish, yellowish, brownish, or greenish grey sandstones and dolomitic limestones. In Thuringia and South-west Germany, weak, scarcely ever workable, seams of an impure shaly coal are found, and these have given to the group in question the name Lettenkohle. At the upper limit there lies a variously formed yellowish dolomitic limestone, sometimes dense, sometimes porous, sometimes also oolitic, the Grenzdolomite, which is found throughout Germany. It contains among other fossils the important type-form Myophoria Goldfussi (XXXVI. 4), like M. costata of the Röth. Of the other fossils of the Kohlenkeuper Estheria minuta (XXXVII. 4) and Lingula tenuissima should be specially mentioned. The former, together with other small ostracods belonging to the genus Bairdia, is often present in the shales in great abundance (Estheria or Bairdia beds). Of Molluses, besides Myophoria Goldfussi, there are usually only M. transversa, Anoplophora lettica, A. donacina, and Gervillia, usually not in very good preservation. Small fish teeth and scales (Acrodus, Hybodus) are more abundant in Thuringia and Swabia, and so are the larger very characteristic teeth of the Dipnoan genus Ceratodus (XXXVI. 3), and remains of Labyrinthodonts and Saurians (Mastodonsaurus [XXXVI. 1], Nothosaurus). Plant remains too are widely spread, but are generally badly preserved. Quenstedt considers the Kohlenkeuper as the uppermost division of the Muschelkalk.

The Middle or Main Keuper, the thickest division of the whole Keuper, consists in North Germany of bright red and green crumbly shales, which in their lower half, the Gypskeuper in its narrower sense, contain beds of gypsum, whilst the upper half, known as the Steinmergel (Stone marl), is free from gypsum. Salt psendomorphs are very widely distributed in the

C. G. 
gypsum-bearing group; rocksalt beds, on the other hand, are well known at this horizon in Lorraine (especially near Dienze) but not in North Germany. In South Germany also the Middle Keuper begins with variegated gypsum-bearing shales. These are succeeded by sandstones with the plant-bearing Schilfsandstein (with Equisetum arenaceum [XXXVII.2], Pterophyllum Jaegeri [XXXVII. 1]) at the base. Higher up, above a new zone of gypsumbearing shales (the Lehrberg or Berggyps beds) we get in Swabia the white Stuben Sandstone, which near Stuttgart has yielded the famous group of Aëtosaurus ferratus, Belodon Kapffi, and other saurian remains which adorn the Stuttgart museum; and in Franconia, the Semionotus Sand s tone, with the ganoid S.Bergeri. Lastly, in Lorraine a considerable zone of variegated gypsumbearing marl lies on the Schilfsandstein.

Fossils are rare in the Middle Keuper, if we except the plants and saurians of the South German sandstones already mentioned. So much the more interesting therefore is the occurrence of a number of bivalves, which are found also in the Raibl beds of the Alps (especially Corbula Rosthorni and Myophoria Kefersteini $[\mathrm{XL} .8]$ ) in a galena-bearing limestone (Corbula bank) in the lower part of the gypsum-bearing shales of Thuringia, Franconia, etc.

The Upper Keuper or the Rhætic (Gümbel) is composed mainly of pale thick sandstones and grey shales. The latter, especially near Baireuth, Culmbach, Bamberg, etc., contain beautifully preserved plant remains (Cycads, Ferns, Equiseta). The sandstones of this series, on the other hand, bear on the surfaces of the beds many examples of Avicula contorta (XXXVI. 5), Protocardium rhaticum, Modiola mimuta, Taniodon Eualdi, T. pracursor, Anodonta (?) postera, Gervillia pracursor, etc. ${ }^{1}$

This Rhætic or Contorta Fauna is indeed not rich; but it is of great importance, because it extends not only throughout Germany, England and Central France, but also through the Alps, and thus fixes a definite horizon of comparison between the Alpine and extra-Alpine Keuper. ${ }^{2}$ The thick coal-bearing sandstones and

1 The paper of Schlönbach in the "Neues Jahrb." (1862), p. 146, is especially important for a knowledge of this fauna in the area of Hanover and Brunswick.

2 Oppel and Süss. "Ueber die muthmasslichen Aequivalente der Kössener Schichten in Schwaben. Sitzungsber. d. Wien. Akad." (1856). 

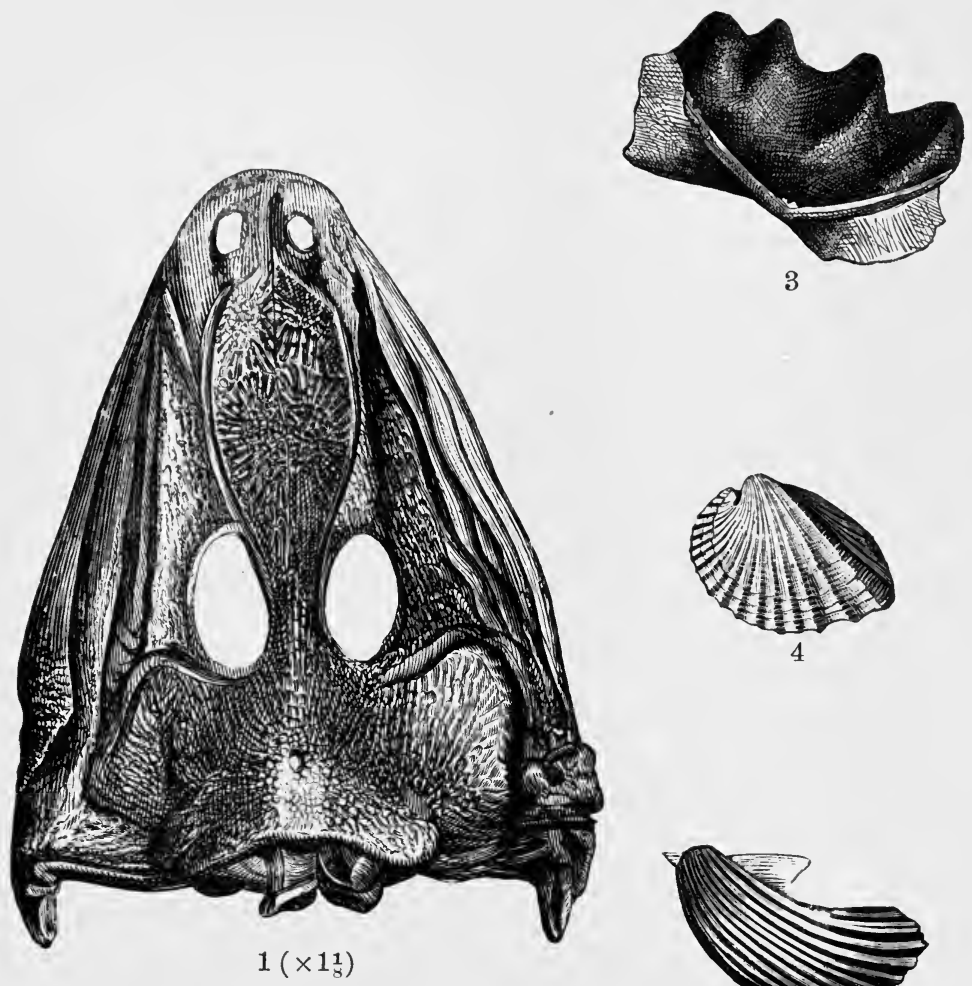

3
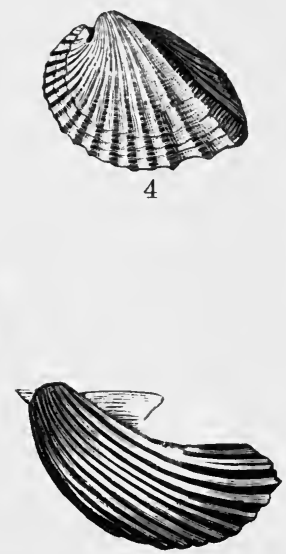

5

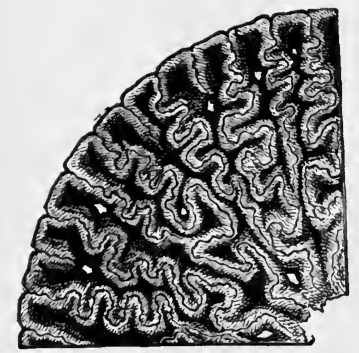

2

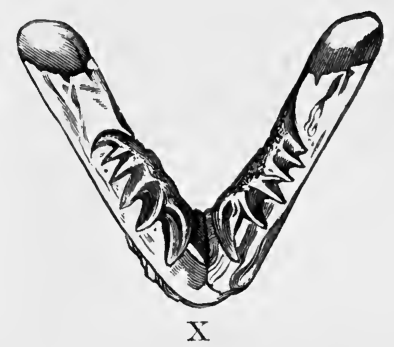

Plate XXXVI.-Keuper Fossils.

1. Skull of Mastodonsaumus giganteus, Jaeg. 2. Part of transverse section of a tooth of Mastodonsaurus. 3. Ceratodus Kaupi, Agass., tooth from the lower jaw. X. Lower jaw of the living Ceratodus Forsteri. 4. Myophoria Goldfussi, v. Alb. 5. Avicula contorta, Portl. 

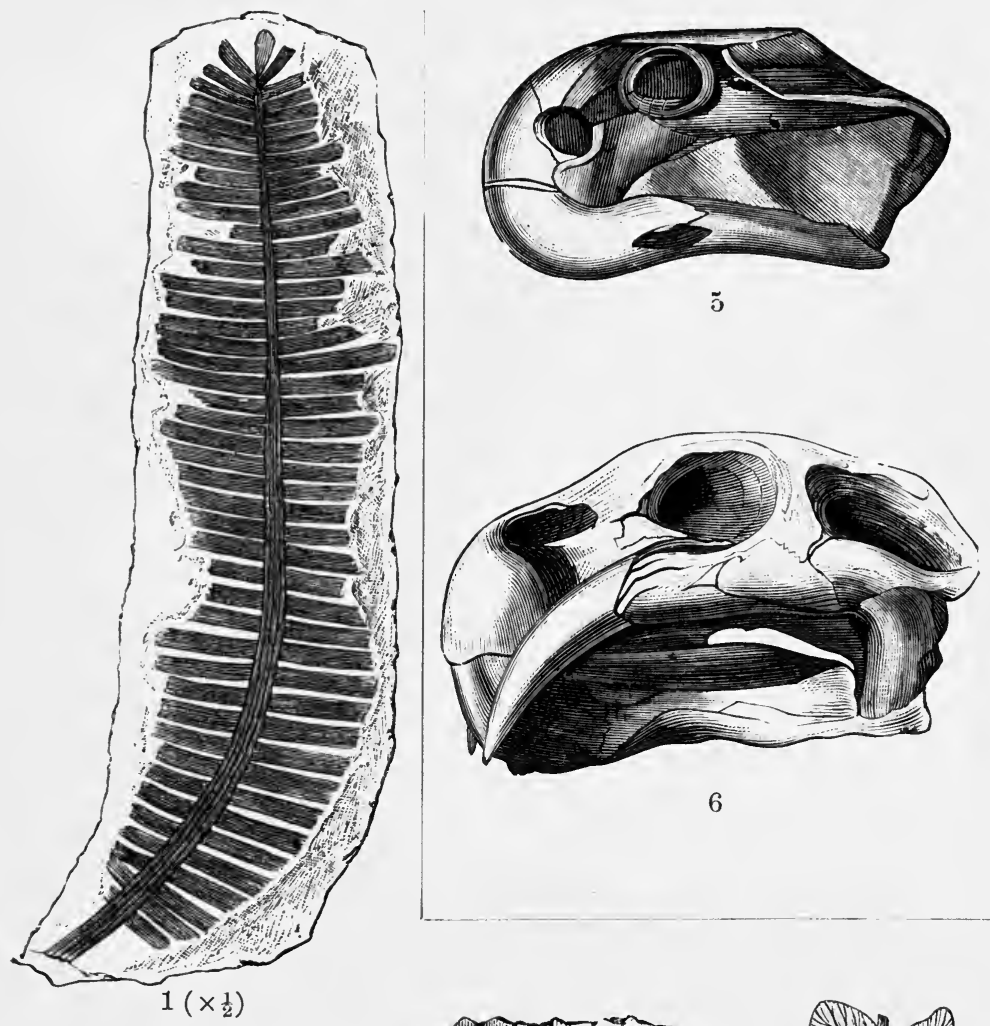

6

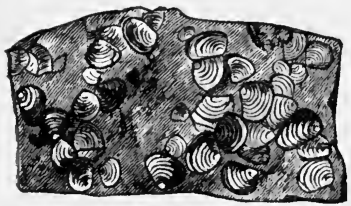

4

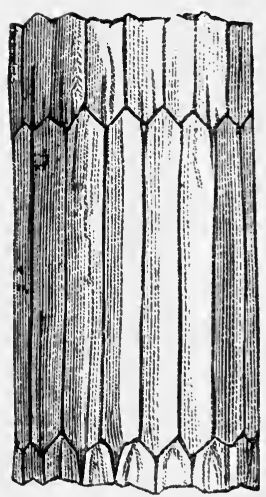

2

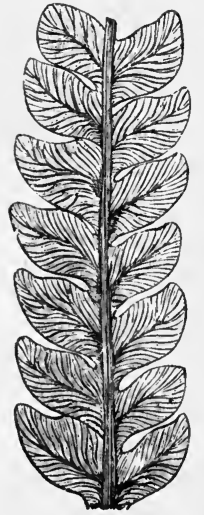

3

Plate XXXVII.-Fossils of the Keuper (1-4) and of the Karoo Series $(5,6)$.

1. Pterophyllum Jaegeri, Brongn. 2. Equisetum arenaceum, Brongn. 3. Neuropteris remota, Presl. 4. Estheria minuta, v. Alb. 5. Oudenodon Baini, Owen. 6. Dicynodon feliceps, Owen. 
shales of Scania also belong to the Rhætic. The series is remarkable for the so-called Bone beds, only a few inches thick, which are made up almost entirely of the teeth and bones of fishes and reptiles. Near Stuttgart small teeth of Microlestes antiquus, the oldest known mammal, have also been found in it.

Some geologists, having regard to the close relationship between the Rhætic and Jurassic Floras, unite the Rhætic formation with the Lias; or-as is often done in France-separate it as a special group, the Infralias. This classification, however, is not supported by the Molluscan fauna of the beds in question, and has therefore not found general acceptance.

British Isles.-The Triassic rocks here closely resemble those of Germany except in the absence of the Muschelkalk. In face of the fact that there is no proof of unconformity between the socalled Bunter and Keuper, it is a question whether the Muschelkalk is not represented (as in Lorraine) by beds resembling the Bunter Sandstone. Since this question, on account of the complete absence of characteristic fossils, must remain open, the Triassic rocks of Britain are universally divided into the two series, the Bunter and the Keuper.

In England they are found in Devon, Somerset and South Wales, but the principal area is that of the Midlands, from which two great arms pass northwards, one on the west of the Pennine Palæozoic rocks into Cheshire and Lancashire, and the other on the east into Nottinghamshire and Yorkshire. Other small patches are found near Carlisle, the Hebrides, the north-east coast of Scotland, and the north-east of Ireland.

The general grouping of the beds in England is as follows :-

Rhætic. $\left\{\begin{array}{l}\text { White Lias, 1-25'. } \\ \text { Black Shales, 8-30'. } \\ \text { Grey Marl, 10-50'. }\end{array}\right.$ Keuper. $\left\{\begin{array}{c}\text { Upper Keuper. Red and variegated marls and sandstones, } \\ 800^{\prime}-3000^{\prime} \text {. } \\ \text { Low er Keuper or Basement Beds. Sandstones, marls, } \\ \text { grits and breccias, } 150^{\prime}-250^{\prime} .\end{array}\right.$

(Upper Mottled Sandstones. Soft red and variegated sand and sandstone.

Bunter. $\left\{\begin{array}{c}\text { Pebble Beds. Harder brownish-red sandstones with } \\ \text { quartzite pebbles, conglomerate. }\end{array}\right.$ Lower Mottled Sandstone. Soft red and variegated sandstone, with breccias. 


\section{The German Trias}

\begin{tabular}{|c|c|c|}
\hline & Thuringia, Harz. & Hesse, Franconia. \\
\hline $\begin{array}{l}\text { Upper Keuper or } \\
\text { Rhætic. }\end{array}$ & $\begin{array}{l}\text { Dark Slates and pale } \\
\text { Quartz Sandstones. }\end{array}$ & The same. \\
\hline $\begin{array}{l}\text { Middle (Gyps.) } \\
\text { Keuper. }\end{array}$ & $\begin{array}{l}\text { Marl without gyp- } \\
\text { sum (Steinmergel). } \\
\text { Variegated gypsife- } \\
\text { rous Marl. }\end{array}$ & $\begin{array}{c}\text { Sandstone. Marl } \\
\text { without Gypsum. } \\
\text { Variegated gypsiferous } \\
\text { Marl. }\end{array}$ \\
\hline $\begin{array}{c}\text { Lower Keuper } \\
\text { (Kohlenkeuper, } \\
\text { Lettenkohl group.) }\end{array}$ & $\begin{array}{c}\text { Grenzdolomit. } \\
\text { Dark Clays, Sand- } \\
\text { stones and impure } \\
\text { Limestones. }\end{array}$ & $\begin{array}{l}\text { Grenzdolomit. } \\
\text { The same. }\end{array}$ \\
\hline Upper Muschelkalk. & $\begin{array}{l}\text { Nodosus beds. } \\
\text { Trochites limestone. }\end{array}$ & $\begin{array}{l}\text { Trigonodus beds. } \\
\text { Nodosus beds. } \\
\text { Trochites Limestone. }\end{array}$ \\
\hline $\begin{array}{l}\text { Middle Muschelkalk } \\
\text { (Anhydrite group). }\end{array}$ & $\begin{array}{l}\text { Dolomitic Marl with } \\
\text { salt and gypsum, } \\
\text { Zellendolomit. }\end{array}$ & The same. \\
\hline $\begin{array}{l}\text { Lower Muschelkalk } \\
\text { (Wellenkalk). }\end{array}$ & $\begin{array}{c}\text { Orbicularis beds. } \\
\text { Wellenkalk with } \\
\text { beds of Schaumkalk. } \\
\text { Wellenkalk without } \\
\text { these. }\end{array}$ & The same. \\
\hline $\begin{array}{c}\text { Upper Bunter } \\
\text { Sandstone (Röth). }\end{array}$ & $\begin{array}{c}\text { Yellow gypsiferous } \\
\text { Marl. }\end{array}$ & The same. \\
\hline $\begin{array}{c}\text { Middle (Haupt) } \\
\text { Bunter Sandstone. }\end{array}$ & $\begin{array}{c}\text { Cheirotherium } \\
\text { Sandstone. } \\
\text { Coarse-grained } \\
\text { Quartz Sandstone. }\end{array}$ & The same. \\
\hline $\begin{array}{l}\text { Lower Bunter } \\
\text { Sandstone. }\end{array}$ & $\begin{array}{l}\text { Fine-grained clayey } \\
\text { Sandstone with } \\
\text { Rogenstein. }\end{array}$ & $\begin{array}{l}\text { Fine-grained clayey } \\
\text { Sandstone. }\end{array}$ \\
\hline
\end{tabular}




\section{in Various Areas.}

\begin{tabular}{c}
\hline Swabia. \\
Clays and Sandstones \\
with Avicula contorta, etc. \\
Bone bed with Micro- \\
lestes, etc. \\
Stube Sandstone. \\
Schilfsandstein. \\
Gypsiferous Shales.
\end{tabular}

Grenzdolomit. Dark Shales, Sandstones

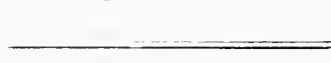

The same.

The same.

Orbicularis beds. Wellenkalk. and impure Limestones.

Sandstones and Clays with Avicula contorta.

Upper variegated Marl. Variegated gypsiferous dstone, with Dolomite nodules below, and Karneol bank at base.

Coarse and fine-grained light red Sandstone.

White fine-grained, clayey Sandstone. Schilfsandstein. Marl.

Grenzdolomit. Variegated Marl, dark Clays, etc.

The same.

The same.

Orbicularis beds. Muschelsandstein.

Voltzia Sandstone.

Lorraine, Saar Area.

$$
\text { | }
$$

\section{Zone of}

Avicula contorta.

Bone bed.

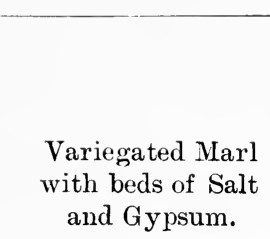

Absent (?).

Vosges Sandstone.

Red Sandstones, Shales and Conglomerates. 
It is possible that in places the system may rest conformably upon the uppermost beds of the Permian, but it overlaps on to, and rests uncomformably upon, the older beds of that and the underlying systems.

The Bunter beds are of nearly the same character throughout the great central area, and offer little of general interest. Footprints and other remains have been recorded; but in some cases, at least, the supposed Bunter beds in which these are found should be referred to the Keuper. The series is apparently absent in S. Wales and the Mendip Hills, and, according to Mr. Ussher, is represented in Devonshire by the "Lower Sandstones and Breccias."

The Keuper often begins with breccias and conglomerates, which seem to point to a certain amount of denudation after the deposition of the Bunter. It contains footprints of Labyrinthodonts (Cheirotherium), and remains of reptiles (Hyperodapedon, etc.), fishes (Palaoniscus, Hybodus, Acrodus), Estheria minuta, etc. In the Mendips it is represented by dolomitic conglomerate and limestone, sandstone and marls.

The Rhætic beds are found above the Keuper from Yorkshire to Devonshire, wherever the contact with the Lias is exposed. The Grey marls have yielded the mammalian Microlestes Rhaticus and a few fish scales. The Black shales are, however, the most characteristic part of the series, and they include the "Bone bed" which, like the similar deposits in Germany, is full of remains of fish (Ceratodus, Acrodus, etc.). The characteristic Rhætic fossils, Avicula contorta, Protocardium Rhaticum and Pecten Valoniensis, are also common in these shales. The White Lias is best developed in Devon and Somerset, and consists chiefly of pale limestones and marls with Protocardium Rhaticum, Lima procursor, Myophoria postera, and other Rhætic forms.

In Devonshire alone contemporaneous lava flows occur in the Trias. They are chiefly mica-traps, and are found in the Lower Sandstone group (Bunter).

France. - The Triassic rocks which surround the Central Plateau of France, also consist mainly of red, often gypsum-bearing sandstone and conglomerate, which are very like the equivalent rocks of the Anglo-German Trias. Except at a few points in the Morvan the Muschelkalk is absent here also, while the Rhætic beds are generally easily recognised at the base of the Lias. 
North America.-In the eastern and central part of North America, on the eastern slope of the Alleghanies, and in the Rocky Mountains, in contrast with California where beds are developed of the Alpine type, Triassic deposits occur which are comparable with those of England and Germany, and are called in America also, the New Red Sandstone. They consist of red sandstones, shaly sandstones and shales, sometimes accompanied by conglomerates, and here and there including impure limestone beds. On the surface of the sandstones, etc., we find ripple marks, raindrop impressions, and footprints. Near Richmond these beds contain valuable seams of coal and sphærosiderite. Still more abundant than these are layers and sheets of dioritic and melaphyre-like rocks, to which belong the famous Palisades of the Hudson River near New York, a thick bed of diorite split up into columns 130 meters high. Organic remains are generally rare. Among the plants are Voltzia heterophylla, Equisetum columnare, and other forms also found in the German Trias. A rich Keuper flora, closely related to that of Lenz in the Austrian Alps has recently become known in Virginia. The beds in the Connecticut Valley and of New Jersey contain not only plant remains, but also a tolerably rich fauna of Ganoid fishes. Along with these are remains of reptiles. Lastly, in North Carolina remains of a Marsupial (Dromatherium) have been found. In other parts of North America the Trias is of the Alpine type (q.v.), and differs greatly from that just described.

In South America, according to Stelzner, Triassic beds of New Red Sandstone type occur in the Argentine Republic; and the thick Karoo Sandstone which is so widely spread in South Africa, and appears to be in great part of Triassic age, bears a similar character. These sandstones are the chief homes of the very remarkable reptiles described by Owen, and known as Anomodontia and Theromorpha.

\section{The Alpine Trias.}

On both sides of the central zone of the Alps there is a broad zone made up chiefly of thick masses of limestone. L. v. Buch and Humboldt, in their earlier journeys, considered these limestone masses, the Kalkalpe, as equivalent with the Zechstein; but thanks to the numerous researches carried out since that time, we now know that they represent very various formations which, however, are all of younger age than that originally ascribed to them. 
The first Triassic fossils were discovered near Recoaro in the Vicentine, and near St. Cassian in the S. Tyrolese Alps. Near Recoaro, where Bunter Sandstone and Muschelkalk are present in a form remarkably like that of Germany, v. Buch had already recognised that the fossils in question belonged to the Muschelkalk. The fauna of St. Cassian, on the other hand, on account of its peculiar constitution, very different from any yet known, could not for a long time be correctly interpreted. Along with Orthoceratites, Murchisonias, Spiriferas, and many other fossils of Palæozoic character, there were found Cephalopoda with Ceratitelike and even Ammonite-like sutures, such as were then known only from the Jurassic and Cretaceous; so that even an authority like Bronn supposed the fauna to be derived. Under these circumstances the discovery of an Ammonite fauna in the Hallstatt Limestone of the Northern Alps was of great importance. This fauna agreed in part specifically with that of St. Cassian, and thus the equivalence in age of these Northern and Southern Alpine deposits was recognised. Both faunas are now referred to the lower horizons of the Keuper; and it was not till much later that true Muschelkalk fossils were found in the Northern Alps (at Reutte not far from the Tyrol-Bavarian frontier). A far more important advance was made when Oppel and Süss, in 1856 , proved beyond doubt the equivalence of the uppermost Keuper beds of Swabia and the Kössen beds so widely spread on both sides of the Alps, and thus fixed an important horizon for the comparison of the Alpine and German Trias. ${ }^{1}$ From that time v. Haner, Escher von der Linth, v. Richthofen, Gümbel and others have devoted themselves to the examination of the Alpine Trias; and our knowledge has consequently made such rapid progress, that as early as 1858 , v. Hauer was able to complete the classification of the Lombardy Trias, and also to correlate individual beds with those of the Southern Tyrol and Carinthia.?

In spite, however, of the restless zeal with which the study of the Alpine Trias has been prosecuted in the last thirty years, it still offers many unsolved problems. These depend in part on the of ten very much disturbed lie, but especially on the very numerous and often very sudden changes of character of the Triassic beds of the Alps. One and the same division of the

1 "Sitzungsber. d. Wien. Akad.," 1855.

2 Erläuter. zu einer geol. Uebersichtskarte der Lombardei. "Jahrb. d. geol. Reichsanst.," ix. p. 445. 
formation may in a short distance be developed as a fossil-bearing shale or marl, as an eruptive tuff, as a bedded Cephalopod limestone, or lastly, as thick almost unbedded limestone and dolomite. V. Mojsisovics has the merit of being the first to remark strongly on the important part which this change of facies plays in the Alpine Trias. ${ }^{1}$ Many things which were formerly very difficult to understand are thus satisfactorily explained. On the other hand, the correlation of the Alpine with the extra-Alpine Trias is even yet very uncertain. As Mojsisovics has rightly remarked, in the Alps we know with certainty the equivalents of only three horizons of the German Trias, namely, the Röth, the Lower Muschelkalk and the Rhætic beds (Contorta zone); whilst we are still in darkness, for example as to where the representative of the Muschelkalk ends in the Alps and that of the Keuper begins. Formerly the Alpine Keuper was tolerably generally supposed to begin with the (S. Tyrol) Buchenstein Limestone, or at least with the succeeding Wengen beds; but lately the attempt has been made, apparently on good grounds, to place the lower limit of the Keuper much higher, so as to include a part at least, if not the whole, of the Norian series of Mojsisovics in the Muschelkalk. ${ }^{2}$ In the face of these uncertainties no definite correlation of the Alpine and German Trias will here be attempted, but the division of the former proposed by Mojsisovics, into five series, namely, the Alpine Bunter Sandstone, the Muschelkalk, the Norian, Carinthian and Rhætic series, will be followed; and it must remain undecided how far the first two series coincide with the similarly named German groups.

It is remarkable that the Trias is much better developed in the Eastern Alps (east of the Rhine Valley) than in the Western Alps where on the other hand the Jurassic and Cretaceous rocks play an important part. Hence it is the Austrian and German geologists who have contributed most to our knowledge of the Alpine Trias. For the Triassic deposits of the Bavarian Alps, ${ }^{3}$ Gümbel's

1 "Ueber d. Gliederung d. ober. Triasbild. i. d. östl. Alpen. Jahrb. d. geol. Reichsanst.," 1869. "Faunen u. Faciesgeb. d. Triasper. i. d. Ostalpen." Ibid. (1874). "Ueber d. heteropischen Verhältnisse d. lombardischen Trias." Ibid. (1880). "Die Dolomitriffe von Südtirol und Venetien,"Wien (1878).

2 v. Wöhrmann, "Jahrb. d. geol. Reichsanst." (1888), p. 69; (1889) p. 180.

3 "Geogn. Beschreib. d. bayer. Alpengeb." (1858-61). See also the "Kurze Anleitung zu geol. Beobachtungen in der Alpen" (from the publications of the German Alpine Club) of the same author. 
works are the most important; for those of the Alps of the Tyrol and Lombardy, the researches of v. Richthofen and Benecke; ${ }^{1}$ and for those of the Austrian Alps, the researches of Bittner, v. Hauer, Pichler, Stache, Stur, Süss, Toula and others, and still more those of Mojsisovics, to whom we owe also the most comprehensive palæontological works on the Alpine Trias. ${ }^{2}$

\section{The Alpine Bunter Sandstone.}

In the Alps certain reddish, sandy, micaceous slates, the so-called Werfen beds (named after Werfen in the Salzburg), have been correlated with the Bunter Sandstone. They often contain gypsum and rocksalt, and in the upper part impure limestone also. The boundary between them and the Grödner sandstone, which belongs to the Permian, is difficult to fix. Among the type fossils are Avicula (Posidonomya) Clarai (recognisable by its thick rings of growth adorned with fine radial striæ), Naticella costata, and Ceratites (Tirolites) cassianus (XXX VIII. 1-3). In the uppermost part of the series numerous calcareous beds occur with Myophoria costata, the type fossil of the German Röth, etc.,-the so-called Myophoria beds. The whole of the Alpine Bunter Sandstone forms one single zone of Mojsisorics, namely, that of Nat. costata and Tir. cassianus.

\section{The Alpine Muschelkalk.}

The calcareous rocks belonging to this group are designated by various names, such as Virgloria Limestone (after the pass of that name in the Rhætic Alps), Recoaro Limestone, Guttenstein and Reiffling Limestone, Mendola Dolomite, etc. Mojsisovics separates firstly a normal, generally clayey, sedimentary series, within which again several Cephalopod, Brachiopod, and Bivalve facies can be distinguished; and secondly, light-coloured limestone and dolomite poor in clay, which forms large massesold coral reefs according to Mojsisovics. He recognises further a Lower Muschelkalk, the zone of Ceratites binodosus; and an.

1 Richthofen: "Geogn. Beschreib. d. Umgebung von Predazzo, etc., in Südtirol "(1860). Benecke: "Trias u. Jura i. d. Südalpen. Geogn. paläontol.," Beitr. I. 1 (1866). "Ueber d. Umgeb. von Esino i. d. Lombardei," Ibid. ii. 3 (1876). See also Lepsius : "Das westl. Südtirol," 1878 , several papers by Gümbel in the "Sitzungsber. d. bayer. Akad." etc.

2 "Das Gebirge um Hallstatt. Abh. d. geol. Reichsanst.," vi. (1875), still incomplete. "Die Cephalopoden der mediterranen Triasprovinz," Ibid. x. (1882). 


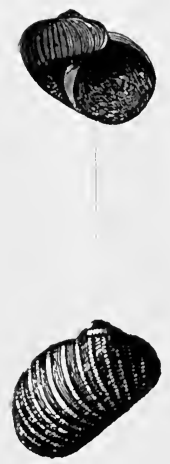

1
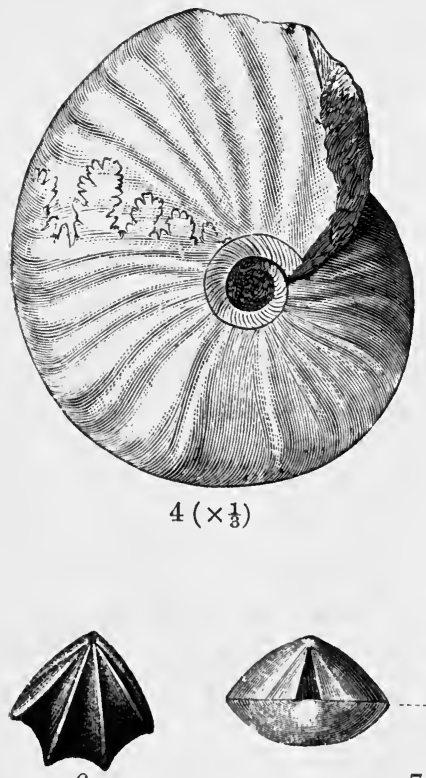

6
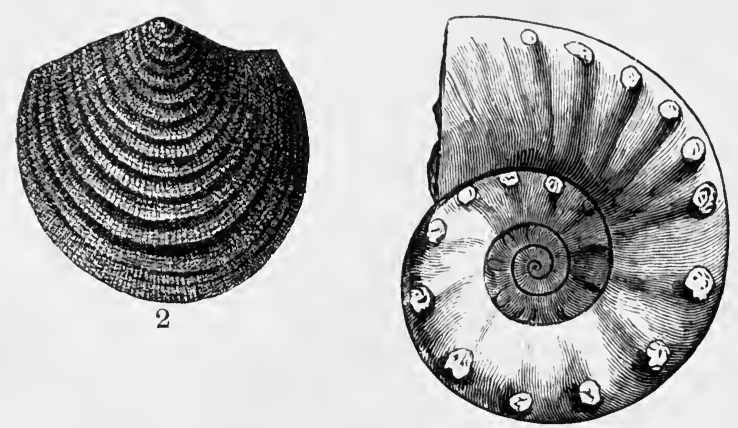

3

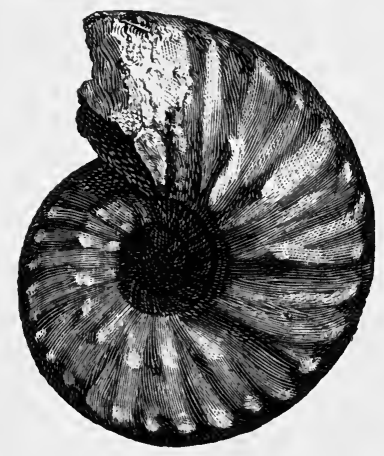

$\tilde{5}$

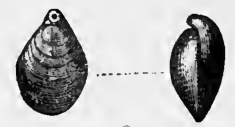

8

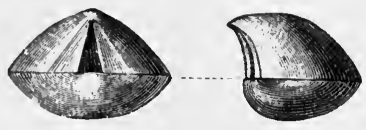

7

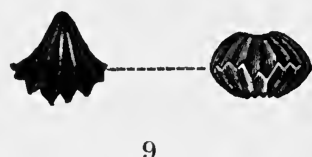

9

Plate XXXVIII.-Fossils of the Bunter Sandstone (1-3), and the Muschelkalk (1-9) of the Alps.

1. Naticclla costata, Münst. 2. Avicula (Posidonomya) Clarai, Emmr. 3. Ceratites (Tirolites) cassianus, Quenst. 4. Ptychites Studeri, v. Hau. 5. Ceratites trinodosus, Mojs. 6. Athyris trigonella, Schloth. 7. Spiriferina Mentzeli, Dunk. 8. Terebratula angusta, Schl. 9. Rhynchonella decurtata, Girard. 

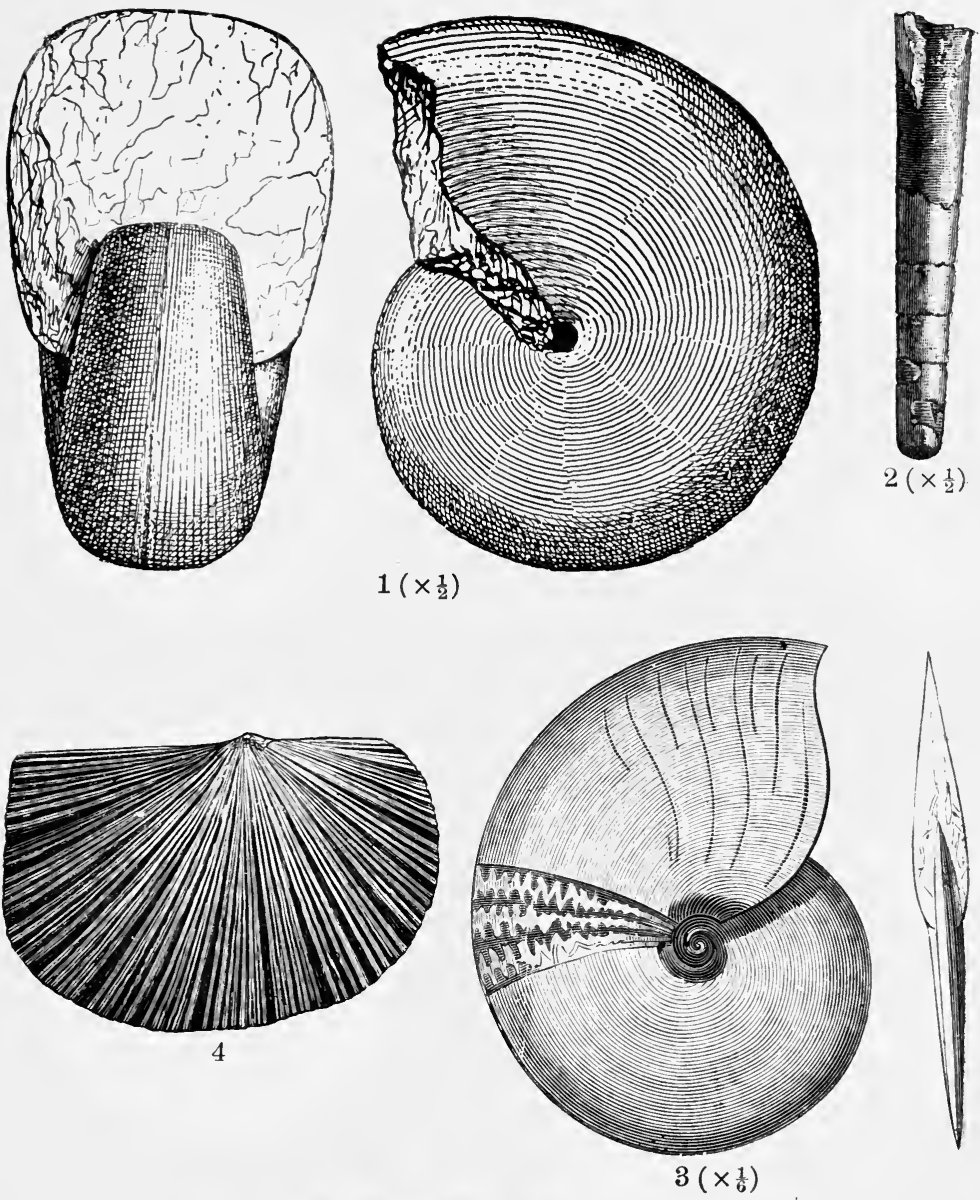

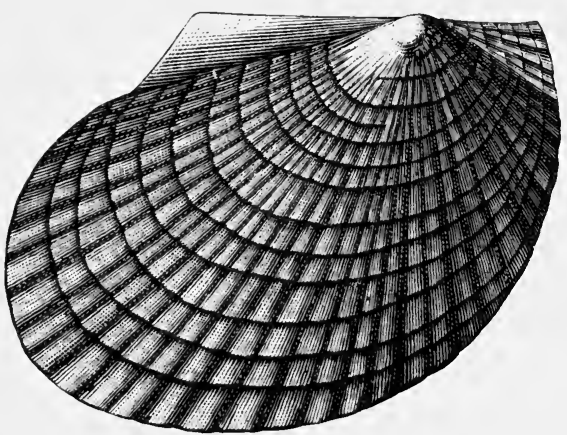

5

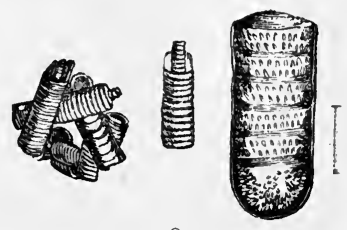

6

Plate XXXIX.-Fossils of the Norian Series of the Alps.

1. Clad iscites tornatus, Bronn. 2. Orthoceras latéseptatum, v. Hau. 3. Pinacoceras Metternichi, v. Hau. 4. Daonella Lomneli, Wissm. 5. Monotis (Pseudomonotis) salinaria, Schloth. 6. Diplopora annulata, Schafh. 


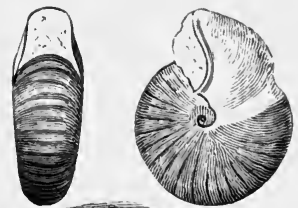

imm

1
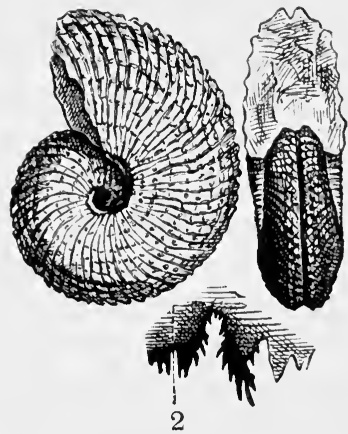
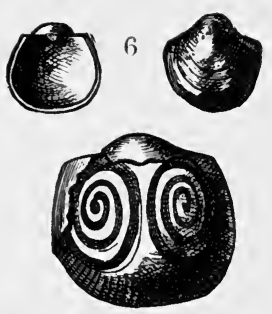

$6 \mathbf{A}$

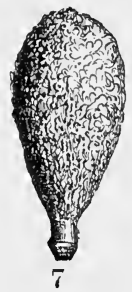

4
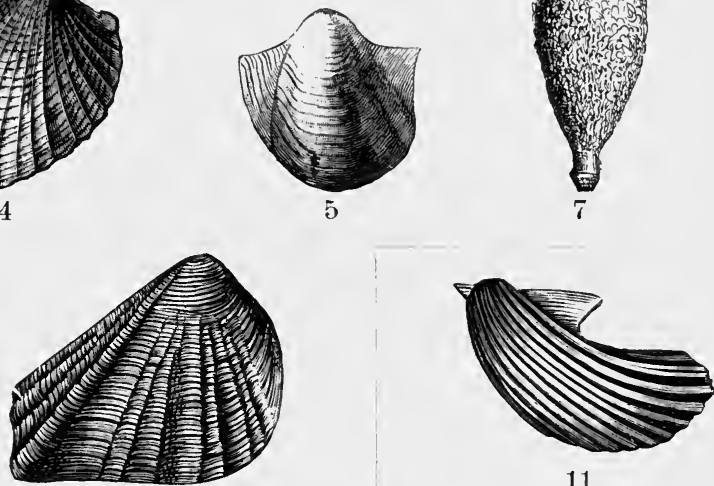

11
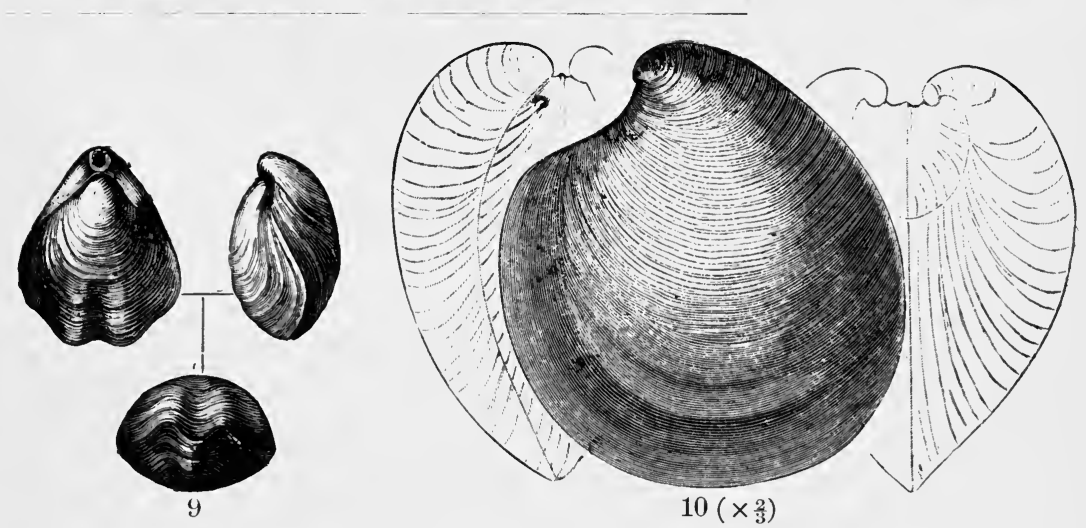

Puate XL.-Fossils of the Carinthian (1-8) and Rhætic (9-11) Series of the Alps.

1. Lobites delphinocephalus, v. Hau. 2. Trachyceras aon, Münst. 3. Murchisonia Blumi, Klipst. 4. Cavdita crenata, Münst. 5. Cassianella gryphaeata, Münst. 6. Koninckina Leonhardi, Wissm. 6A. Large valve of the same enlarged. 7. Spine of Cidaris dorsata, Brann. 8. Myophoria Kefersteini, Münst. 9. Terebratula gregaria, Süss. 10. Megalodon scutatus, Schafh. 11. Avicula contorta, Portl. 
Upper, the zone of Ceratites trinodosus (XXXVIII. 5). To the lower zone belong the well-known Brachiopod Limestone of Recoaro and Reutte with Athyris trigonella, Spiriferina Mentzeli, Terebratula vulgaris, T. angusta, and other species which occur also in the Wellenkalk of Upper Silesia, France, etc. (XXXVIII. 6-9). Of other forms found in the German Muschelkalk there should be mentioned from this zone Gervillia socialis, G. costata, Myophoria vulgaris, Pecten discites, P. lavigatus, Encrinus liliiformis, $E$. gracilis; and the chief type fossil of the upper zone, Cer. trinodosus has also been mentioned as occurring in the Schaumkalk of Rüdersdorf near Berlin. The greater number of the remaining fossils of the Alpine Muschelkalk, among which Ammonites of the genera Ceratites, Trachyceras, Arcestes, Ptychites, Pinacoceras, Megaphyllites, etc., play an important part, are quite unknown in the Muschelkalk of Central Europe, just as the most important and widely distributed Ammonite of the latter, Cer. nodosus, has never yet been found in the Alps.

\section{Norian Series.}

This series is characterized by the fact that during the period of its deposition the E. Alps were divided into two completely separate marine provinces. The one, the Juvavian Province, included the Salzkammergut and the Salzburg region, and reached from there to the Carpathians; the other, or Mediterranean Province, comprised the whole of the rest of the Alpine area. Each of these two provinces had its own peculiar development, each its own peculiar fauna. The very numerous Ammonites of each belonged not only to different species but in part even to different genera.

In the Mediterranean Province Mojsisovics distinguishes-

2. The Wengen beds or zone of Trachyceras Archelaus and Daonella Lommeli ${ }^{1}$ (XXXIX. 4).

1. The Buchenstein beds or zone of Trach. Reitzi.

In their typical development in the Southern Tyrol the latter (1) are grey, nodular or platy limestones with siliceous segregations; the former (named after Wengen in the S. Tyrol) are dark, shaly and marly sandstones, intimately connected with eruptive tuffs. The reef facies plays an important part in both, especially in the

1 D. franconica of the Nodosenkalk of Würzburg is probably only a variety of $D$. Lommeli. 
upper zone. Thus not only the wide-spread and thick dolomite of the Southern Tyrol (Schlern dolomite); but also the Esinokalk of Lombardy (rich in gasteropods) and the Wettersteinkalk of the Bavarian Alps, belong to the Wengen zone. In these reef limestones, and also in the younger Haupt and Dachstein dolomites, the greater part of the rock is formed not by corals but by the rock-building algæ which have been described by Gümbel and others under the names of Gyroporella and Diplopora. The Partnach bods (named after the Partnachklamm) are sandy and clayey cquivalents of the Wengen beds in the Bavarian Alps, and contain plant remains.

In the Juvavian Province the Muschelkalk is succeeded by the marly Zlambach beds (zone of Choristoceras IIaucri). These are followed by the variegated red Cephalopod Limestones, developed as marble or nodular limestone, of Berchtesgaden, Hallein, Hallstatt, Aussee, etc. These are the so-called Hallstatt limestones, the greater part of which belongs to the Norian Series, and they are divided by Mojsisovics in to four palæontological zones (see table on p. 229). Pinacoceras Metternichi, Cladiscites tornatus, Arcestes intuslabiatus, species of Trachyceras, Megaphyllites, etc., Orthoceras dubium and others, Nautili and Halobias-a genus of Wivalves limited, according to Mojsisovics, to the Juvavian Province -Monotis salinaria, etc., are here prominent forms (PI. XXXIX.).

\section{Carinthian Series.}

The separation of the Mediterranean and Juvavian Provinces throughout the Norian period, continued into the oldest phase of the Carinthian period. This phase was represented in the $M e d i$ terranean Province by the berls of St. Cassian, grey or brown calcareous marls, which contain an extremely rich fauna, including over 200 gasteropods, some 80 brachiopods, 70 lamellibranclss, 37 Ainmonites, almost as many Echinoids, corals, etc. ${ }^{1}$ Between the marls there occur here and there at St. Cassian calcareous or dolomitic coral banks which are in part directly connected with the neighbouring equivalent, unbedded reef dolomites (cf. the view in Fig. 32, which clearly shows the lateral passage from the reef to the marl facies). The zone fossil of Mojsisovics for the Cassian beas is Trachyceras aon

1 This fauna, first described by Count Munster ("Beitr. z. Petrifactenkunde" iv., 1841) has since been made the subject of a Monograph by Laube ("Denkschrift. d. Wien. A kad.," 1865-59).

( . G. 
(XL. 2). Other important species are Arcestes Gaytani, Megaphyllites jarbas, Cassianella gryphaata, Cardita crenata, Nucula lineata, Encrinus cassianus, Cidaris dorsata, Koninckina Leonhardi, etc., (see upper part of PI. XL.). All the St. Cassian fossils are dwarfed.

In the Juvavian Province, the uppermost part of the Hallstatt marble, Mojsisovics' zone of Trophites sub-bullatus belongs to the oldest phase of the Carinthian Series. With the succeeding second zone of this series the separation of the two

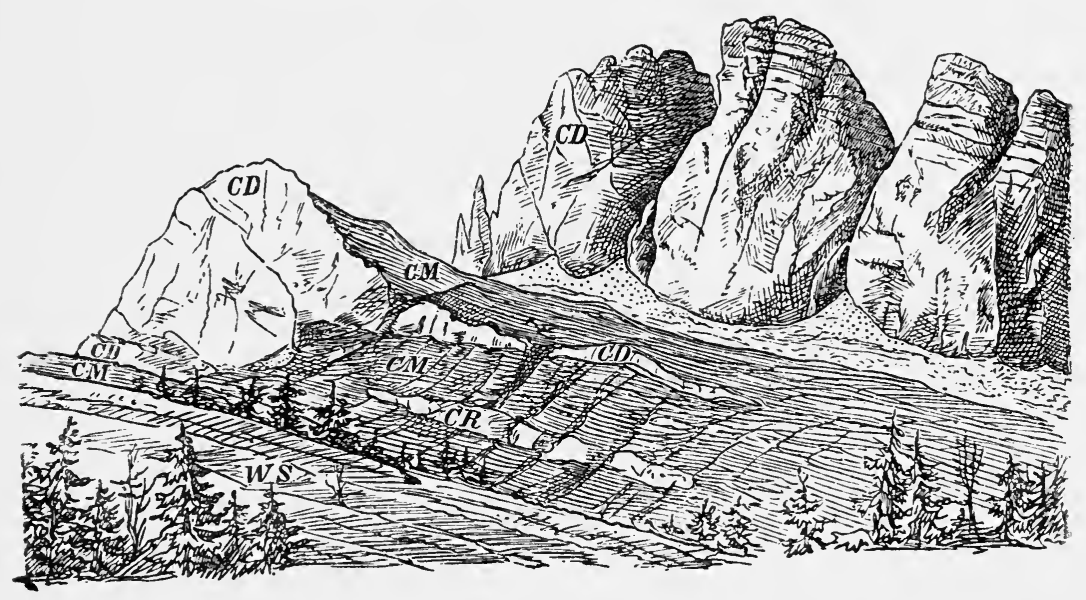

Fra. 32.-The Dolomite Reefs of the Sett Sass in the Southern Tyrol.

WS. Wengen heds. CM. St. Cassian Marl. CR. Cipit Limestone. CD. Unbedded reef Dolomite. On the left is seen the so-called Richthofen Reef with tongue-shaped projections given off' into the equivalent marly beds.

marine provinces came to an end. The deposits of this zone, the Raibl beds (after the town of Raibl in Carinthia), consist of dark bituminous marly shales and limestones. They are widely distributed both in Lombardy, the Southern Tyrol and Carinthia, and also in Northern Tyrol, Vorarlberg, etc., and hence they serve as. a very important horizon for the comparison of the two provinces. The fauna consists chiefly of bivalves and has a marked littoral character; and in many ways it is very like the St. Cassian Fauna. The zone fossil of Mojsisovics is Trachyceras aonoides. Other widely distributed species are Myophoria Kefersteini, MI. Whatleya, Cardita Guembeli (especially in the Bavarian Alps, where these beds are in consequence known as the Cardita 
beds), IIalobia rugosa, Gervillia bipartita, etc., ${ }^{1}$ A few species such as Myoph. Kefersteini and Corbula Rosthani, are, as already mentioned, found also in the German Gypskeuper.

According to the Austrian geologists the Lunz Sandstone (Fig. 33), in the Lower Austrian Alps is to be considered a local coal-bearing sandstone facies of the Raibl beds. It has a rich fauna, which includes many species of the German Kohlenkeuper (Equisetum arenaccum, Pterophyllum Jaegeri). In other places gypsum and Rauchwacke occur at this horizon; and the Swiss Röthidolomite probably belongs here.

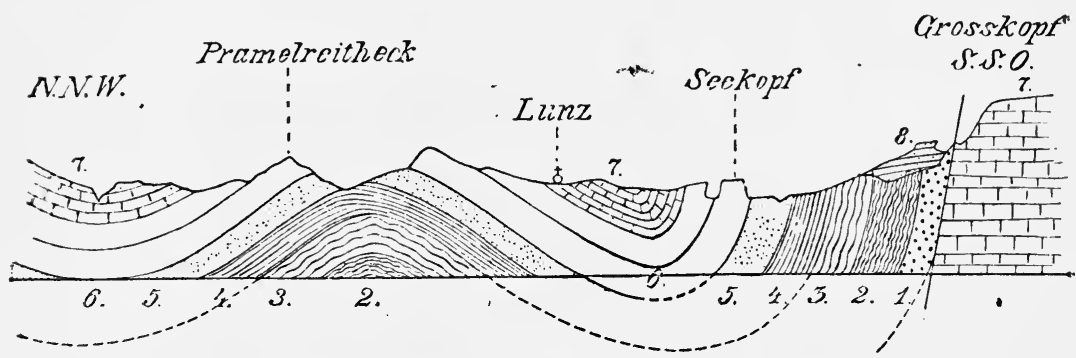

Fig. 33.-Section through the Trias of Lunz in the Lower Austrian Alps (Bittner).

1. Werfen beds. 2. Guttenstein limestone. 3. Reifling limestone. 4. Reingraben beds. 5. Lunz sandstone. 6. Opponitz limestone. $\%$. Great, dolomite and Dachstein limestone. 8. Cretaceous.

Lastly, with the third and last Carinthian zone there begins a series, often several thousand feet thick, of pale, partly thinbedded to platy, partly blocky almost unbedded limestones and dolomites, which are widely spread as the uppermost group of the Trias; and of ten form the main mass of the Limestone Alps. The so-called Great Dolomite or Lower Dachstein Limestone (after the Dachsteingebirge) of this series, Mojsisovics' zone of Avicula exilis and Turlo solitarius, belongs to the Carinthian series. In general fossils are rare in this zone. The most abundant are stonecasts of large Megalodons, M. Guembeli, M. complanatus, etc., generally known under the old collective name M. triqueter (cf. the similar M. scutatus, Pl. XL., Fig. 10), or as." Dachstein bivalves. Gyroporellas also play a large part in many bods.

1 Cf. Deecke, "Neues Jahrb. Beilageband.iii.p. 3 (1885),"-r. Wöhrmann, “Jahrb. d. geol. Reichsanst." (1889), p. 69 ; (1859), p. 180. 


\section{Rhatic Series.}

Into this falls the Upper Dachstein limestone (with Megalodon scutatus [XL. 10] also usually known as triqueter). At a somewhat lower horizon there are usually found grey, of ten brecciated fossiliferous marls, the so-called $\mathrm{K} \ddot{\text { össen }}$ or Contorta beds (after the specially characteristic species Avicula contorta [XL. 11]). These form much the most important member of the Rhætic on account of the fact that they are not limited to the Alpine region but occur throughout W. Europe. The more or less complete separation till then existing between the German basin of deposition and the Triassic Sea of the South of Europe ceased at this time. The conditions became nearly uniform for the whole of Western Europe, and so they remained through the succeeding Jurassic period.

The whole Rhætic Series corresponds with but a single one of Mojsisovics' zones, namely that of Avicula contorta. Besides this, the more abundant forms are Gervillia inflata, Protocardium rhaticum, Modiola minuta, Anatina pracursor, Terebratula gre.Jaria, 'T. norica, Athyris oxycolpos, Choristoceras Marshi, Thamnastrea rhatica, and others. ${ }^{1}$

As already noticed, Triassic formations of the Alpine facies are found over the whole of S. Europe, in the Maritime Alps, the Apennines, in Sicily, the Balearic Isles, Spain, the Balkan Peninsula, in Bakonywald and the Carpathians. "The small masses of limestone of the Bogdoberg (in the Kirghiz steppes of S. Russia) which lie above a thick succession of red sandstones and marls, are portions of Muschelkalk of Alpine facies which lie upon the equivalents of the Bunter Sandstone and have escaped denudation. Moreover the Daonella deposits of Djulfa on the Araxes are of the same type; and all that is known of the Trias in Turkestan, Central Asia and in the Himalayas, shows a remarkable resemblance to the beds of the same age of the E. Alps. In the Himalayas especially, all the chief divisions of the Alpine Trias from the Bunter to the Rhætic, can be recognised, with faunas quite like those of Europe. In spite of this, certain peculiarities of the Indian rocks have led Mojsisovics to distinguish a special Indian Triassic Province, which would probably include all the Central Asian Trias, whilst the

1 Cf. v. Dittmar. "Die Contorta Zone," 1864. 
A.-TRIASSIC SYSTEM.

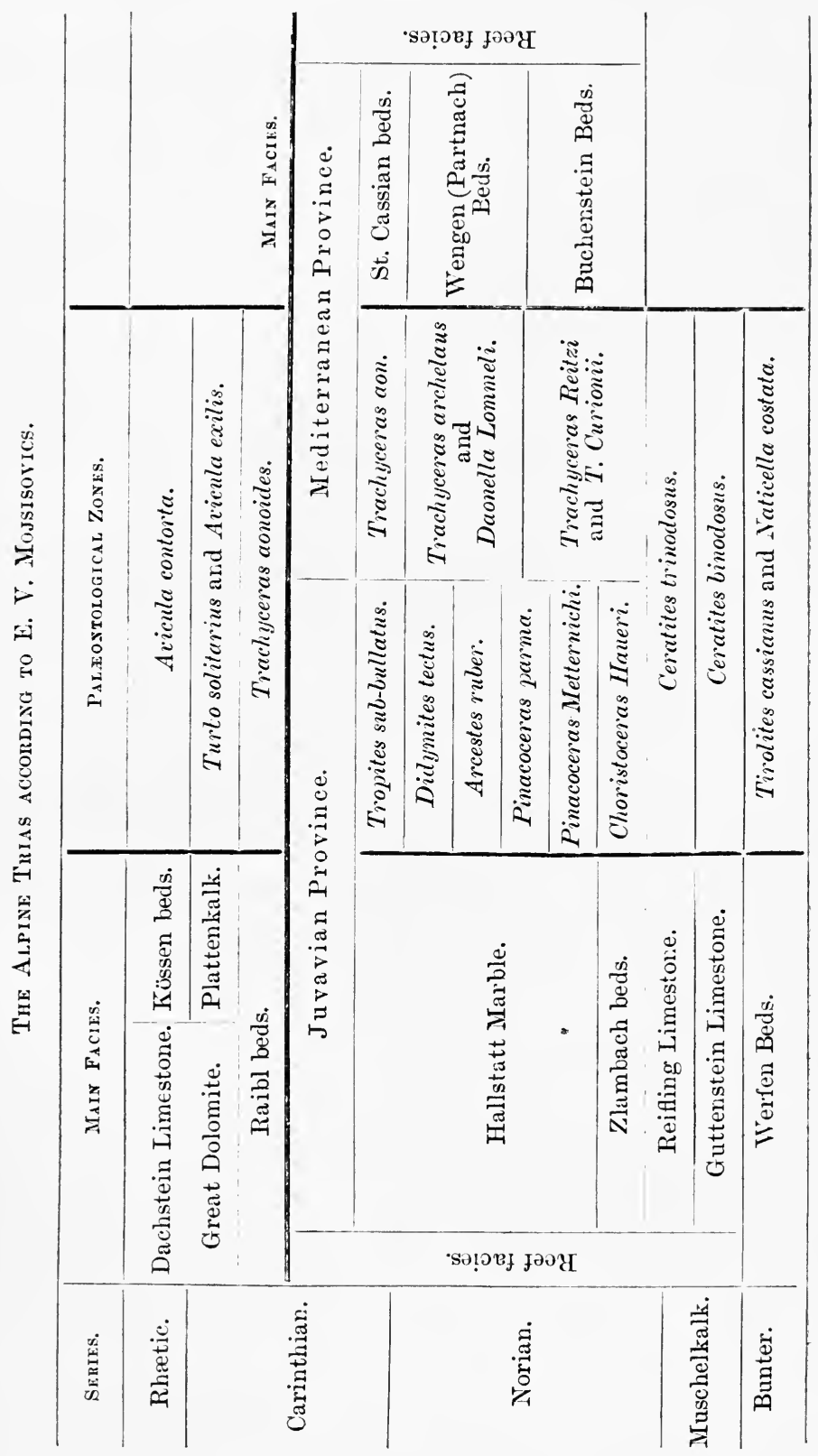


Bogdoberg is considered by him to be the most easterly outlier of the Mediterranean facies.

Triassic formations of similar character occupy a very large area in the North of Asia, in Spitzbergen and in Siberia, and in the neighbouring country of Japan; also in W. North America, in Alaska, British Columbia, California, Nevada and Wyoming; furtherS. in Columbia and Peru; and lastly in $\mathrm{New}$ Zealand, New Caledonia, Timor. In all of these regions large areas are occupied by Upper Triassic Cephalopod limestones with Ceratites, Dinarites, Trachyceras, Hungarites, Meekoceras, Encrinites, Daonella, Halobia, species of Monotis and other characteristic forms of the Alpine Trias. The great abundance and wide distribution of the species of Pseudomonotis, allied to the Alpine Ps. salinaria, in Siberia and in the whole Circumpacific region (Ps. ochotica in Siberia and Japan, Ps. subcircularis in N. and S. America, Ps. Richmondiana, in Australia), is specially remarkable. The close palæontological relationships which all these Triassic deposits show to one another, as well as certain differences from the equivalent formations of India and Europe, with which they have not a single species in common, have led Mojsisovics to distinguish for them a fourth Triassic province, called the Arcto-pacific.

\section{PALEONTOLOGY OF THE TRIAS.}

The Triassic Flora is on the whole nearly allied to that of the Zechstein. It consists mainly of Cycads and Conifers. Of the former the most widely distributed genera are Pterophyllum (XXXVII. 1, with parallel nerves of uniform strength in the pinnules), Nilssonia (with some of the nerves stronger than the rest), Zamites, Dioonites, etc.; amongst the latter the genus Voltzia (with V. heterophylla [XXXIII. 1], the important type form of the Röth). A few ferns also, such as Anomopteris, Caulopteris, Taniopteris, etc., are not unimportant, while of other vascular Cryptogams there are only a few Equisetacex, including Equisetum Mougeoti and E. arenaceum (XXXVII. 2) of the Bunter and Keuper. Sigillaria occurs but very rarely in the Bunter. Lastly among marine plants calcareous algæ (Gyroporella, Diplopora [XXXIX. 6]), are important on account of the part that they take in the formation of the Alpine reef limestones.

Outside the Alpine area the only important Sponge is Rhizocorallium jenense, with its cylindrical serpentine roots covering 
the surfaces of the Muschelkalk beds; whilst in the Alps, especially near St. Cassian, calcareous spongess of the group Pharetrona are not uncommon.

Outside the Alps Corals occur only in the Muschelkalk and even there are rare; in the Alps on the other hand they are much more widely spread and abundant, especially in the reefs of the Upper "Trias (Rhabdophyllia, Calamophyllia, etc.). It appears that they are always allied in their structure to the later Hexacoralla.

Amorg the Crinoids we meet only with articulate forms, whilst the tesselate Palæocrinoids have quite disappeared. The genus Encrinus is the most important (E. gracilis in the Lower, $\boldsymbol{E}$. liliiformis [XXXV.2] in the Upper Muschelkalk, E. cassianus, etc., near St. Cassian).

Among the Echinoids, all of which belong to the regular group, Cidaris (especially rich in species at St. Cassian) should be mentioned.

The reduction of the Brachiopods in comparison with the increase of the now abundant Lamellibranchs is especially worthy of notice. But the Triassic brachiopod fauna still shows many affinities to the Palæozoic. Along with numerous Spiriferina we here find the last survivors of the important Palæozoic genera Cyrtina, Retzia, and Athyris the latter still with some fifteen species; A. trigonella [XXXVIII. 6] in the German and Alpine Muschelkalk, A. oxycolpos in the Rhætic Series). The genus koninckina (XL. 6) now referred to the Spiriferida (formerly placed near Productus) and a few others are peculiar to the Trias. The occurrence in the Alpine Upper Trias of a few species of Thecidium, a genus which first becomes rich in species in later times, is interesting. The most widely spread genera in the "Trias as in all the Mesozoic formations are Terebratula ( $T$. rulgaris [XXXIV. 7], T. angusta, T. gregaria, T. norica, etc.), and Rihynchonella.

The Lamellibranch fauna is rich and varied, especially in comparison with that of the Palæozoic rocks. Among the Monomyaria are Pecten, Hinnites, Lima, Monotis, IIalobia, Daonella, etc.; among the Dimyaria, Gervillia, Myophoria (unusually rich in forms both within and without the Alps) Anoplophora, Cardita, Megalodon (only in the uppermost Alpine Trias; but there very important), etc., are very rich in species and include many characteristic forms. Representatives of the most highly organized division, the Sinupalliata are however still rare. In Germany 
IIomomya (formerly Myacites) musculoides of the Muschelkalk, belongs to this group.

Gasteropods are very abundant, particularly in the Alps (St. Cassian, Esinokalk.) Types such as Murchisonia and Loxonema recall the Palæozoic fauna; while Cerithium, Emarginula and others belong rather to the later univalve faunas.

The Cephalopoda are much more important. In the AlpineKeuper the last species of the important Palæozoic genus Orthoceras (XXXIX. 2) are found. Of the other Nautiloid forms, Nautilus is still important. The genus is represented in Germany only by $N$. jugatonodosus and N. bidorsatus of the Muschelkalk; in the Alps on the other hand, by numerous angular richly ornamented species recalling the Carboniferous and Permian forms. The genera Atractites and Aulacoceras too, are very interesting as forerunners of the true Belemnites, which become so important from the Jurassic onwards. Very much more important however are the Ammonites, which here for the first time are abundantly developed; and, as in the Jura and the Chalk, include the zone fossils.

The most important genus is Ceratites, distinguished by a widely umbilicated shell bearing ribs and knobs, and by its peculiar sutures consisting of simple saddles, and lobes weakly denticulated. In the German Trias this genus is present only in the Muschelkalk (C. antecedens in the Wellenkalk; $C$. nodosus, [XXXV. 1] C. semipartitus, C. enodis in the Upper Muschelkalk), and as a rare occurrence in the Kohlenkeuper; in the Alps on the other hand it is found throughout the Trias (Ceratites [Tirolites] cassianus in the Bunter Sandstone, C.bi-and tri-nodosus [XXXVIII. $5]$ in the Muschelkalk.) The allied genus Trachyceras with deepmouthed shell decorated with numerous rows of knobs (T. aon [XL. 2], ' $T$. aonoides; Norian and Carinthian) is exclusively Alpine. Other important and characteristic genera of the Alpine Trias are Arcestes, with globular, completely involute shell, and strongly divided sutures (A. Gaytani, etc.); Cladiscites, the whorls of which are subquadratic in section and spirally striated (C. tornatus: [XXXIX. 1], etc.); Pinacoceras, disc-shaped with sharp back and very numerous lobes (P. Metternichi [XXXIX. 3], P. parma, etc); Beneckeia Buchi from the German Muschelkalk also is related to this genus. Further there occur Ptychites (P. Studeri [XXXVIII. 4], Alpine; P. dux, German; Muschelkalk), Tropites, Megaplıyllites, Monophyllites and others. The two last named belong to the 
important family of the Phylloceratida, which is first richly developed in the Jura. Another great family, the Lytoceratida, chiefly belonging to the Jura and Chalk, has also its forerunners in the Trias.

The Crustacean fauna of the Trias does not offer much wortly of remark. Of the Ostracoda, Bairdia, of the Phyllopoda Estheria (E. minuta [XXXVII. 4] in the Bunter and Keuper) should be mentioned. Pcmphix (P. Sucurii of the Upper Muschelkalk) is a true macrurous Decapod,

Among the fishes, along with Selachii (IIybodus, Acrodus, etc.), the tecth of which are not uncommon; especially in the Kohlenkeuper, heterocercal Ganoids still predominate. These belong especially to the Lepidosteidæ (Semionotus, Dapedius, Colobodus, Lepidotus, etc.), which are covered with large shining enamel scales and are not known with certainty in the Permian. The important Dipnoan genus Ceratodus is very characteristic. Its peculiar grinding teeth, deeply zigzag at the border and very like those of the living C. Forsteri (XXXVI. x.), are especially abundant in the German Kohlenkeuper (XXXVI. 3). Lastly the genera Saurichthys and Belonorhynchus, although their vertebral column is still incompletely ossified, are probably the oldest representatives of the Bony Fishes or Teleostei, which is now the most. predominant group.

The Amphibia were represented by a special group of Stegocephala, the huge Labyrinthodonts, characterized by the absence of stomach plates and sclerotic ring, by the marked labyrinthine structure of the teeth and other characters. To these belong Trematosaurus from the Bunter (especially from Bernburg); Mastodonsaumus (with brond triangular, flat skull, large eyes, small nostrils [XXXVI. 1]), from the Muschelkalk and Kohlenkeuper; Capitosaumus from the Keuper; and others.

Reptiles were very abundant in the Trias, especially in comparison with the Permian. Almost all the groups characteristic of Mesozoic times had their representatives in the Trias.

The order Ichthyosauria with the chief genus Ichthyosaurus, which becomes so important in the Jura, was already present in the Trias (I. atavus of the S. German Muschelkalk).

The like is true of the Plesiosauria (Sauropterygia). To this group belongs the genus Nothosaurus (XXXV. 4) with its very long, small skull, conspicuous large oval temporal fossæ separated by a very small parietal bone. This form is found chiefly in the 
Muschelkalk of Baireuth. In the English and French Rhætic, traces of Plesiosaurus itself have been found.

The genera Telerpeton and Hyperodapedon from the red Keuper sandstone of Elgin in Scotland are referred to the Rhyncocephala, a group already present in the Permian. The former, so long as the sandstone mentioned was supposed to be Devonian, used to be looked upon as the oldest reptile.

The remarkable Theromorpha, which owe their strikingly mammalian appearance to the height of the skull and the lateral position of the eyes, are remarkable peculiar forms of the Trias. Both the chief groups, the Anomodontia and the Theriodontia, are mainly limited to the S. African Karoo series and the Indian Panchet beds. The first-named group, which is distinguished by its toothless, horny under-jaw, and upper jaw either horny or provided with large cutting edged teeth, includes Dicynodon (said to occur also at Elgin) and Oudenodon (XXXVII. 5, 6). In the second group, the Theriodontia, the differentiation of the teeth into incisors, canines, and grinding-teeth, a differentiation which is quite foreign to reptiles generally, is especially characteristic. It is now usual to refer to the Theromorpha the peculiar genus Placodus (XXXV. 3), the very characteristic, black, enamelcovered, bean-shaped palatal teeth of which are not uncommon in the Muschelkalk. The complete skull of this form has been found in the Muschelkalk of Baireuth.

The Crocodiles were represented by Belodon (Swabian Stubensandstein, also N. Caroina) and others. Iastly to the Dinosaurs are referred the gigantic Zanclodon and the smaller Aëtosaurus (ferratus), both from the Stuttgart Stubensandstein. The orders Pterosauria, Lacertilia and Ophidia were not represented in the Trias.

The oldest known mammals belong to the Keuper. The small cusped teeth described as Microlestes antiquus were first found in the Swabian Bone-bed, and afterwards in equivalent beds in England. Hypsiprymnopsis (England), Dromatherium (N. Carolina), and Tritylodon (S. Africa) are founded on teeth and other remains of similar kind and age. ${ }^{1}$

1 Until recently, all these remains were referred to the Marsupialia. Lately, however, they have been grouped together as a special Order, the Pantotheria, which is united with the Monotremata to form the subclass Prototheria, the primitive mammals. 


\section{B. JURASSIC SYSTEM. ('ENERAL AND HISTORICAL.}

The Jurassic System, the second of the three great Mesozoic divisions, is locally several thousand feet thick. It was for the most part laid down in a deep sea, and is therefore generally more or less calcareous. Sandy and conglomeratic beds, on the other hand, are very much less important than in the Trias, and volcanic tuffs and interbedded eruptive rocks are entirely absent, at least in Central Europe. The succession of the Jurassic deposits is extraordinarily regular over large areas, and the lie of the rocks is generally very slightly disturbed. Over large districts the beds are nearly horizontal and are unaffected by any strong folds or faults. It is only in the younger mountain ranges, such as the Swiss Jura and the Alps that we find the Jurassic beds steeply inclined, folded, reversed and faulted over wide areas.

The name Jura formation was first applied by Al. Brongniart and Humboldt to these deposits, and was borrowed from the Jura Mountains of W. Switzerland. In England, instead of this name, the terms Lias and Oolite were long in use. The former is a local designation for certain calcareous clayey rocks which form the lower part of the system. The term Oolite alludes to the oolitic limestone and ironstone which are very widely spread in England, and which are not rare in France and North Germany.

In England, as well as in France and Germany, the Jurassic System contains, at the most different horizons, an extraordinary number of fossils, in part beautifully preserved. This explains why it is that the series has long been a favouriteamong geologists, and that the vertical distribution of the Jurassic fossils was known before that of many other formations. The knowledge of the Jura of England took its rise when William Smith, the father of English Geology, in the first decade of this century, separated the chief divisions of the system from one another, and correctly determined their chronological sequence; so that his successors, Conybeare and Phillips, were able in $1822^{1}$ to establish a classification of the English Jurassic which is nearly identical with that now in use. A few years later Phillips ${ }^{2}$ published the first descriptions and illustrations of a large number of type fossils of the English Jura. The important part which England has thus played in

1 "Outlines of the Geology of England and Wales."

2 "Illustrations of the Geology of Yorkshire" (1834-36). 
the increase of our knowledge of the Jura explains why the English names of so many of the Jurassic series have come into general use.

In France the examination of the system has gone on since D'Orbigny's time. He divided the Jura into ten subdivisions which he found also in various other countries, and at the same time he illustrated and described a number of Jurassic fossils. ${ }^{1}$

In Germany L. v. Buch was the first to occupy himself with the detailed study of the Jurassic beds, and he proposed the classification still used in Germany, into Lower, Middle and Upper, or (according to the chief colours of the rocks composing these divisions), the Black, Brown, and White Jura. Buch's 'work in this was the foundation for the later works of Friedr. August Quenstedt, who determined the rertical distribution of the included organic remains with a completeness even yet unequalled elsewhere, and divided the formation into eighteen series. The "Flötzgebirge Württembergs," published in 1843, was in great part occupied with the Jurassic rocks, and his "Cephalopoda" 3 (1846-1849) treated chiefly of the Swabian Jurassic Ammonites. In 1850 followed his chief work, appearing afterwards in a second edition, "Der Jura"; and lastly (1883-1888), his great work, "The Ammonites of the Swabian Jura," completed shortly before the death of the author.

A. Oppel's work lay in a somewhat different direction from that of his teacher Quenstedt. With as much sagacity as success, he endeavoured to apply to other countries, especially to England and France, the classification of the Jura founded by Quenstedt and completed by himself, in which he distinguished some thirty palæontological zones.

Since Oppel's early death a great number of geologists, in part his pupils, have worked ceaselessly on the Jurassic rocks, so that their detailed classification and the tracing out of the various horizons, has now been brought to a greater pitch of perfection than in any other system. Among the observers who have helped in this work only the most important, such as Benecke, Neumay. and Waagen, can here be mentioned.

One of the first results of the researches of these observers has been the recognition of the astonishingly wide distribution of many of Oppel's zones. Thus Waagen ${ }^{4}$ has been able to recognise

1 "Paléontologie française. Terrain jurassique" (1840-46).

2 "Ueber den Jura in Deutschland. Abh, d. Berl. Akad.," 1839.

3 In "Petrefactenkunde Deutschlands."

4 "Palæontologia Indica" (1871). 
in the Jura of Kach (Cutch) in India, a whole series occurring in the same order as in Europe; and the detailed classification of Oppel seems to be applicable to South America also. If in other cases no such agreement is shown, one should not forget that it can only be expected in the case of the Anmonite-bearing deposits of the deep sea; whilst in coastal deposits, such as coral limestones, etc., the character of the fauna must depend largely on local conditions.

Another very important result of later observations on the Jura, is the proof of the existence of various Jurassic marine Provinces, distinguished by different faunas. After Marcou had separated a Burgundo-norman from a Hispano-alpine Jurassic Province, Neumayr followed up this result with great sagacity and unusual ingenuity. He distinguished in Europe three large Jurassic Provinces generally stretching from East to West. These are, (1) the Mediterranean Province, which includes the deposits of the Carpathians, the Cevennes, Italy, Spain, and the Balkan Peninsula. "The fauna is characterized by the extraordinary abundance of Ammonites of the genera Phylloceras, Lytoceras and Simoceras. Terebratulas of the group of the remarkable T. diphya are peculiar to this Province. (2) The Middle European Province. This includes the whole extra-Alpine Jurassic of France, Germany, England, and the Baltic Region. Phylloceras and Lytoceras are here much rarer, while Harpoceras, Oppelia, Peltoceras, and Aspidoceras are very abundant. Coral reefs are present of great extent and thickness. (3) The Russian or Boreal Province, includes the Jurassic beds of Central and Northern Russia, of Novaja Semlja, Spitzbergen, and Greenland. Lytoccras, Phylloceras and Haploceras are quite absent here, and so are coral reefs; while Cardioceras, a kind of Ammonite, and the bivalve genus Aucella are very characteristic and widespread. Neumayr seeks for the cause of the differences in the fauna of the three provinces in climatic differcnces, which he supposes to have been already established. In other words, the marine provinces are to him nothing but climatic zones. On account of the interest which this circumstance has, a special section will be devoted to it, after the description of the Jurassic formation of the various regions.

We owe to the same observer an attempt at a cartograpic reconstruction of the oceans and continents of the Jurassic period-the first attempt made for so remote a period and for the whole earth. ${ }^{1}$

1 "Die geograph.Verbreitung der Juraformation. Denkschr. d. Wien. Mkad." (1885). 
The most important result of this work, as interesting as it is bold, has been to show the extraordinary extent of the Upper Jurassic beds compared with those of the Lias. That this was the case in Europe, had already been known for a long time. It was known that the Lias is indeed developed throughout Western Europe, but that even near Regensburg and Passau, Hohnstein in Saxony, throughout (extra-Carpathian) Moravia, in Upper Silesia, near Cracow, and in the Baltic area it is entirely absent. In these places the Jura everywhere begins with deposits of the Middle or Upper divisions of the formation, which rest directly on far older rocks. But according to Neumayr this is also the case further east, throughout European and Asiatic Russia, in N.W. and Arctic N. America, Eastern Greenland and Spitzbergen, and also in Asia Minor, Persia, India, and E. Africa. In all these places the Lias is completely absent, and the Jurassic begins with one or other of the subdivisions of the Middle or Upper part of the System. Evidently all the areas named were land during the whole of the Liassic epoch, and in part also during a part of the Middle Jurassic. The sea gradually, during the progress of the second half of the Middle, or during the Upper, Jurassic period, began to overflow the whole of this large region. This is one of the greatest, probably the greatest, encroachments of the sea which we know of in any period of the history of the earth. The Jurassic sea reached its greatest extent in Oxfordian times. In the later phases of the period the land gradually rose above the sea in Central Europe and other places.

The general classification of the Jurassic formation in Germany and England is shown in the following scheme:-

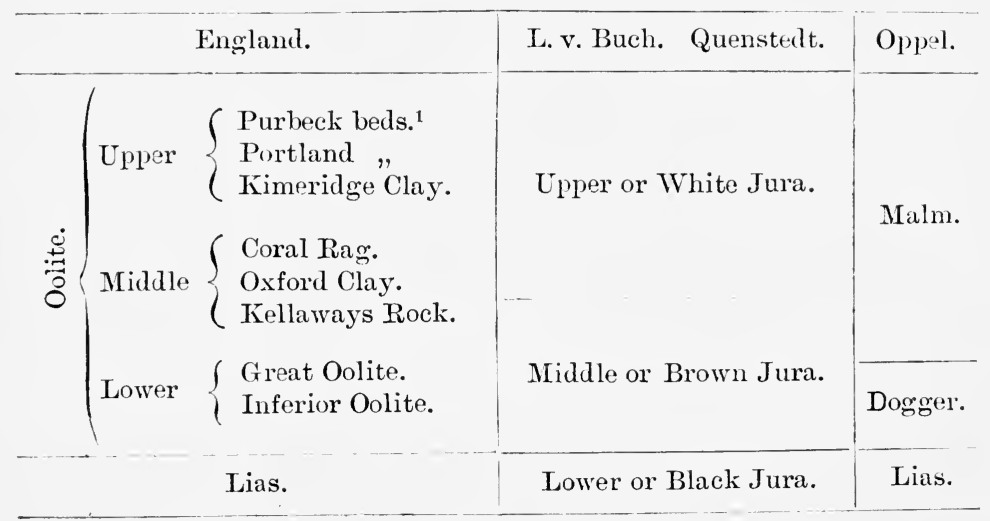

1 Here referred to and described under the head of the Cretaceous. 
While in Germany, since v. Buch's time, three main divisions are recognised, English geologists distinguish two or four. The boundary between the Middle and Upper Jura is placed by v. Buch and Quenstedt between the Kellaways Rock and Oxford Clay, while Oppel, agreeing with the English geologists, draws it between the Great Oolite and the Kellaways Rock. The terms, Dogger and Malm, used by Oppel, are English local names. Lastly, the French agree with the English in recognising only two main divisions, namely, (1) The Liassic system, and (2) The Oolitic system; but, as already noticed, they generally refer the Rhætic Series to the Lias under the name Infra-Lias.

\section{DISTRIBUTION AND DEVELOPIIENT OF THE JURASSIC.}

Jura of Central Europe.

From what has been remarked in the foregoing on the distribution of the Jurassic deposits comprised by Neumayr in the Middle European Province, it is clear that to this belong before all the extra-Alpine parts of Germany, England and France. Since our knowledge of the Jura was originally derived from these countries, it is necessary to describe them first.

In Germany, three great areas of Jurassic rocks can be distinguished: the Franko-Swabian, the N.W. German, and the Upper Silesian.

The Franko-Swabian Jurassic forms a large curve, one arm of which extends with south-easterly strike from the region of Coburg to Regensburg, whilst the other stretches thence in a south-westerly'direction to the foot of the Black Forest. The northern limb forms a large trough the middle of which consists of Upper Jura, whilst towards the borders we get in normal succession, first the Middle, then the Lower Jura, and lastly the Kenper beds. The larger westerly arm is, on the other hand, composed of a series of Jurassic rocks also lying regularly on the Trias, but dipping to the south, and not forming a trough. Here, therefore, the Lias, forming an undulating country, appears only along the northern border of the Jurassic belt. It is succeeded by a narrower zone of Middle Jura, then by the Upper Jurassic Limestone, the gently inclined layers of which, near the Danube, form the platean of the Swabian Alps (Fig. 34).

The Jurassic of N.W. Germany includes a zone reaching from the neighbourhood of Helmstedt and Quedlinburg in a west- 
erly direction to the Teutoburger Wald. It does not form a continuous belt like the S. German Jura, but a series of small bands or closed elliptic rings, anticlinals and synclinals, striking north-westerly, in the composition of which the Trias, and sometimes also the Cretaceous, rocks take part. The most considerable of these Jurassic masses forms the Weser range, which, where it is

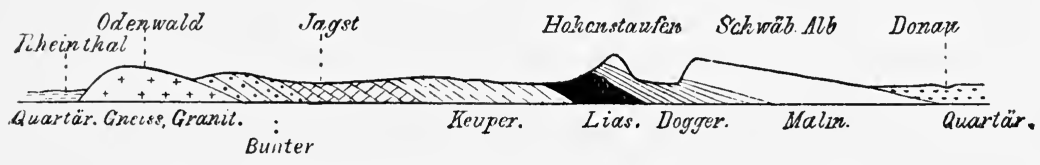

FIG. 34.-Section through the Triassic and Jurassic beds of Swabia.

crossed by the Weser, at the Porta Westfalica, shows the grandest section of the Jura in North Germany.

The Upper Silesian Jura region, which, unlike the two areas already mentioned, contains only Middle and Upper Jurassic rocks, forms a belt some thirty miles long, reaching from Krakau (Cracow) to Kalisch, which in the N. appears only here and there

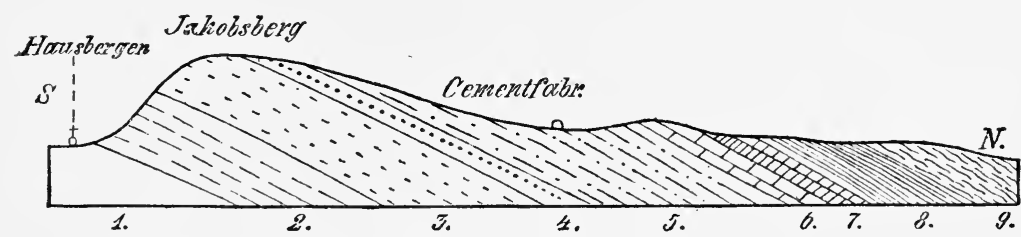

Fig. 35.-Section through the Upper Jurassic of the Porta Westfalica (Heinr. Creduer).

1. Buth heds. 2. Kellaways. 3. Oxfordian. 4. Coral oolite. 5. Kimeridge. 6. Lower Portland. 7. Upper Portland (Eimbeckhäuser Plattenkalk). 8, 9. Wealden.

through the Diluvium, and in the S.W. rests against the Jurassic of Upper Silesia.

Besides these larger areas there are in Germany a number of smaller occurrences of Jurassic rocks. Thus Middle and Upper Jura occur at the mouth of the Oder, in the neighbourhood of Kammin and Kolberg. Also near Thorn and Inowrazlaw there are found detached patches of Upper Jura rising through the Diluvium, and at Dobbertin in Mecklenburg a similar patch of Lias. To the Lias belong also a row of smaller patches of Jura in Central Germany, namely at Gotha, Eisenach, Göttingen, Wabern, etc., which have been sunk between large faults to the level of the 
older formations, and have thus escaped denudation. Near Hohnstein in Saxony, and at a few places in Bohemia, there occur along the great thrust-plane which separates the Lausitz granite mountains from the Bohemian chalk area to the S., a few reversed masses of Jura. All these occurrences are of great interest, as evidences of a former much wider extension of the Jurassic beds in these regions. Lastly, along the sides of the Valley of the Upper Rhine there are various remnants of this formation, which point to a former connection between the Swabian and the Lorraine Jura.

The Swiss Jura Mountains, stretching from Basel to Geneva, are only an extension of the Swabian Jura beyond the Rhine into the Swiss area. Unlike the Jurassic rocks of Swabia, however, they are here strongly folded, and form a chain of mountains, the complicated structure of which was long ago described and explained in the beantiful works of Thurmann.

In France the Jurassic rocks surround the great Central Plateau in a tolerably complete ring. Resting in part directly on crystalline rocks, they dip away on all sides from the older mountain core, so that the innermost zone of Lias, lying on the primitive rocks, is succeeded by a second zone of Middle, and this by a third of Upper, Jura. There are also two other Jurassic belts, which, together with the band on the N. of the Central Plateau, form a rim to the great Cretaceous and Tertiary basin of $\mathrm{N}$. France. The eastern belt, starting from the north-east corner of the Central Plateau, runs through Burgundy, Lorraine, and Luxemburg, and after a long interruption reappears once more at Boulogne-sur-Mer; while the western arm begins at the north-west corner of the Plateau, and runs along the eastern border of the old Breton massif to the English CChannel.

Lastly, in England the Jura forms a broad zone striking N.N.E., underlaid on the W. by Keuper, and overlaid on the E. by the Cretaceous rocks. This zone (a continuation of the Breto-norman belt) stretches from Lyme Regis and Portland in the Channel, throngh Bath and Oxford to Whitby on the coast of the North Sea. All three divisions of the system are here clearly developed.

Since in all the regions mentioned, so far as the Jurassic formation is present, a classification into Lower, Middle, and Upper Jurassic is clearly recognisable, these three divisions will here be described separately, and according to the limitations which L. v. Buch and Quenstedt have ascribed to them.

C. $G$. 


\section{The Lias or Lover (Black) Jura.}

Following the grouping of v. Buch and Quenstedt, this is now usually separated into Lower, Middle, and Upper stages. d'Orbigny proposed for them the names Sinémurien, Liasien, and Toarcien, but these terms are not generally used except in France. Basing his classification on petrographical characters, Quenstedt has divided each of these three stages into two smaller zones. He thus obtains for the whole Lias, six zones, which he denotes by the Greek letters $\alpha, \beta, \gamma, \delta, \epsilon, \zeta$. In later times Oppel proposed a still more detailed classification into fourteen zones. $\mathrm{He}$ chooses as zone fossils, forms of the widest possible distribution and relative abundance. Oppel's classification is now everywhere accepted; but the latest writers have chosen Ammonites as zone fossils, even in those cases where they had not yet been given by Oppel. This has happened because any classification, to have a universal application, must be based on pelagic deposits; and in such deposits, in all Mesozoic periods, Ammonites are the most important form.

In Swabia, ${ }^{1}$ according to Quenstedt, the Lias is developed as follows :-

3. Upper Lias. 10 metres thick.

Lias $\zeta$. Jurensis Marls. Grey calcareous marls, with Amm. (Harpoceras) radians (XLIII. 3), and $A$. (Lytoceras) jurensis.

Oppel. Zone of A. jurensis.

Lias $\epsilon$. Posidonia Shales, Very bituminous, laminated shales, full of Posidonomya Bromi (XLIII. 5), Belemnites acuarius, Amm. communis, A. bollensis, etc., Pentacrinus briareus, remains of Saurians (Ichthyosaurus, Plesiosaurus, Teleosaurus), Fish (Dapedius), and naked Cephalopoda, of which both the pen and inkbag, with dried ink, are often preserved (XLIII. 4). Holzmaden, in Württemberg, and Banz, not far from Koburg, are famous localities for Saurian remains.

Oppel. Zone of Posidonomya Bronni.

2. Middle Lias. 15 - 30 metres thick.

Lias $\delta$. Amaltheus Clays. Unctuous clays, with Amm. (Amaltheus) margaritatus, Montf.=amaltheus Schl. (XLII. 3); also Pentacrinus basaltiformis, Belemnites paxillosus (XLII. 4), etc.; then limestones with Amm. (Analtheus) spinatus, Brug.=costatus Schl.

Oppel. 2. Zone of Amm. spinatus.

" $1 . \quad$ Amm. nargaritatus.

1 Besides the works already quoted of Quenstedt and Oppel, see Waagen, "Der Jura in Franken, Schwaben und der Schweiz" (1864); Fraas, "Geogn. Beschr. v. Württemberg, Baden und Hohenzollern" (1882); Engel, "Geogn. Wegweiser durch Württemberg" (1883). 
Lias $\gamma$. Numismalis Marl. Hard, grey, stony marl, with Terebratula numismalis (XLII. 7). Also Amm. (Agoceras) Jasoni, A. Ibex, etc.

Oppel. 3. Zone of Anm. Davoei.

$\begin{array}{llll}, & 2 . & & \text { Amm. ibex. } \\ , & 1 . & \text { 1. Anm. Jamesoni. }\end{array}$

1. Lower Lias. 30-35 metres thick.

Lias $\beta$. Turneri Clays. Below, tough, unfossiliferous clays; above, limestones, with Amm. obtusus, Sow.=Turneri Ziet, and clays with Amm. o.re? not us.

$$
\begin{array}{clll}
\text { Oppel. } & \text { 3. Zone of } & \text { Amm. raricostatus. } \\
, " & 2 . & \text { A } & \text { Amm. oxynotus. } \\
\text { " } & 1 . & " & \text { Amm. obtusus. }
\end{array}
$$

Lias a. c. Arietes Beds. Beginning with the Arietes or Gryphæa Limestone, dark limestones full of Grypleca arcuata (XLI. 4), and many Arietes Ammonites (especially Amm. [Arietites] Bucklandi [XLI. 2], A. Conybeari, and spiratissimus), Lima gigantea (XLI. 3), Avicula inaquivalvis, Nautilus aratus, Spiriferina Walcotti (XLI. 7), etc.; closing with the Pentacrinus beds (with Pentacrinus tuberculatus [XLI. 6]) and the so-called Oil shales.

b. Angulatus Sandstone. At the base the Cardinia (Thalassites) zone, with numerous Cardinias (Cardinia Listeri and others [XLI. 5]); above, the Angulatus Sandstone, with Amm. angulatus (XLI. 1).

a. Psilonotus Limestone. With Amm. planorbis Sow.=psilonotus Quenst.

$\begin{array}{cccc}\text { Oppel. } & \text { 4. } & \text { Zone of Pentacrinus tuberculatus. } \\ \text { " } & 3 . & \text { 3. } & \text { Amm. Bucklandi. } \\ " & 2 . & " & \text { Amm. angulatus. } \\ \text { " } & 1 . & \text { 1. } & \text { Amm. planorbis. }\end{array}$

The development of the Lias in Franconia, the Swiss Jura, in the Reichsland and in Luxemburg, is in general very similar to that in Swabia. The white conglomeratic Luxemburg Sandstone, reaching 100 metres in thickness, is a peculiar formation found in Luxemburg and the neighbouring parts of Lorraine. It is a coast deposit, corresponding in the main with the Angulatus beds, but in part reaching to a higher horizon in Quenstedt's $\alpha$.

The Lias of N. W. Germany is also very like that of S. Germany. v. Seebach distinguishes nine zones, the names of which and their relations to Quenstedt's series are shown in the table on page 248. It differs from the S. German type in the occurrence of oolitic ironstone in the horizon of the Brevispina beds at Schöppenstedt, Harzburg, Salzgitter, Markoldendorf, and other places. Similar ironstones occur locally in N. Germany, in both lower and higher horizons, as for example at Harzburg in the Arietes beds. The S. German stone marl, Quenstedt's $\gamma$, is absent in N. Germany; but the Amaltheus Clays and the Posidonia beds, 
which from their petrographical character afford an important horizon easily and universally recognisable, are developed just as in S. Germany. The Dörnten shales, lying on the Jurensis beds, and hitherto known only from the regions of N. Goslar, are distinguished by their great richness in Ammonites (especially species of Harpoceras).

In N. Germany a very interesting outcrop of Upper Lias, with numerous insect remains, is known at Dobbertin in Mecklenburg. The most easterly occurrence of Lias known in Germany is at Kammin, and has been discovered by a deep boring.

The Lias of England is very similar to that of Northern Germany. It forms a belt extending from Dorsetshire to the coast of Yorkshire, and is also found on the coasts of Scotland and in the north-east of Ireland. It is everywhere divisible into zones, closely corresponding with those of Oppel; and these were originally determined in England by Dr. Oppel himself, but have since been more closely examined by Wright, Judd, Tate, Blake, and others. On the whole it is a clay formation, with beds of limestone. It is divided as follows:-

Upper Lias.-Blue or grey shales and clays below, with nodules of limestone; Midford Sands above.

Middle Lias. - Micaceous sands, marls and clays below; tough ferruginous marlstones above.

Lower Lias.-The lower part consists of blue clayey limestones with beds of clay; the upper part chiefly of marls and clays.

The zones into which these are divided and their correlation with the German deposits are given in the table on page 248. The line between the Lower and the Middle Lias is not marked by any change in lithological character, and is sometimes drawn below the zone of Amm. margaritatus instead of below that of Amm. Jamesoni. The Midford Sands (zone of Amm. jurensis) are not uncommonly placed in the succeeding Oolitic Series.

The most important peculiarity of the English Lias is the occurrence of deposits of carbonate of iron-the famous Cleveland iron ore-in the zone of Amm. spinatus in the north of Yorkshire. Ferruginous deposits of less importance are found at this and other horizons in the Lias of other areas. The Alum Shales of Whitby with their numerous remains of fish and saurians belong to the zone of Posidonomya Bronni. Another locality famous for its fish and large saurians is Lyme Regis in Dorsetshire.

The Lias of France differs but little from the types already 

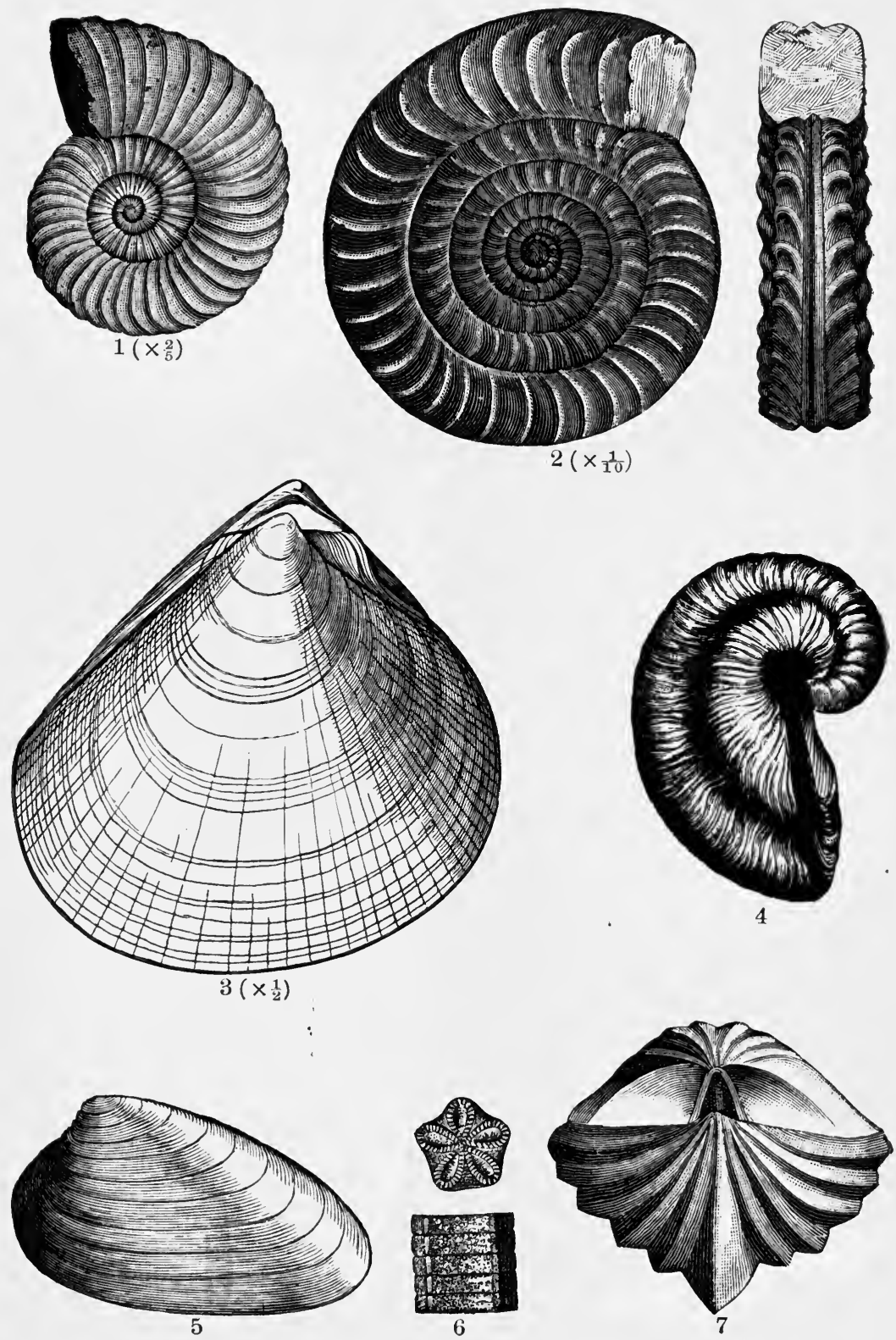

Platn XLI.-Fossils of the Lower Lias.

1. Schlotheimia angulata, Schloth. 2. Arietites Bucklandi, Sow. 3. Lima gigantea. 4. Gryphaea arcuata, Lam. 5. Cardinia hybrida, Sow. 6. Pentacrinus tuberculatus, Mill., portion of the stem seen from the side and from above. 7. Spiriferina Walcotti, Sow. 

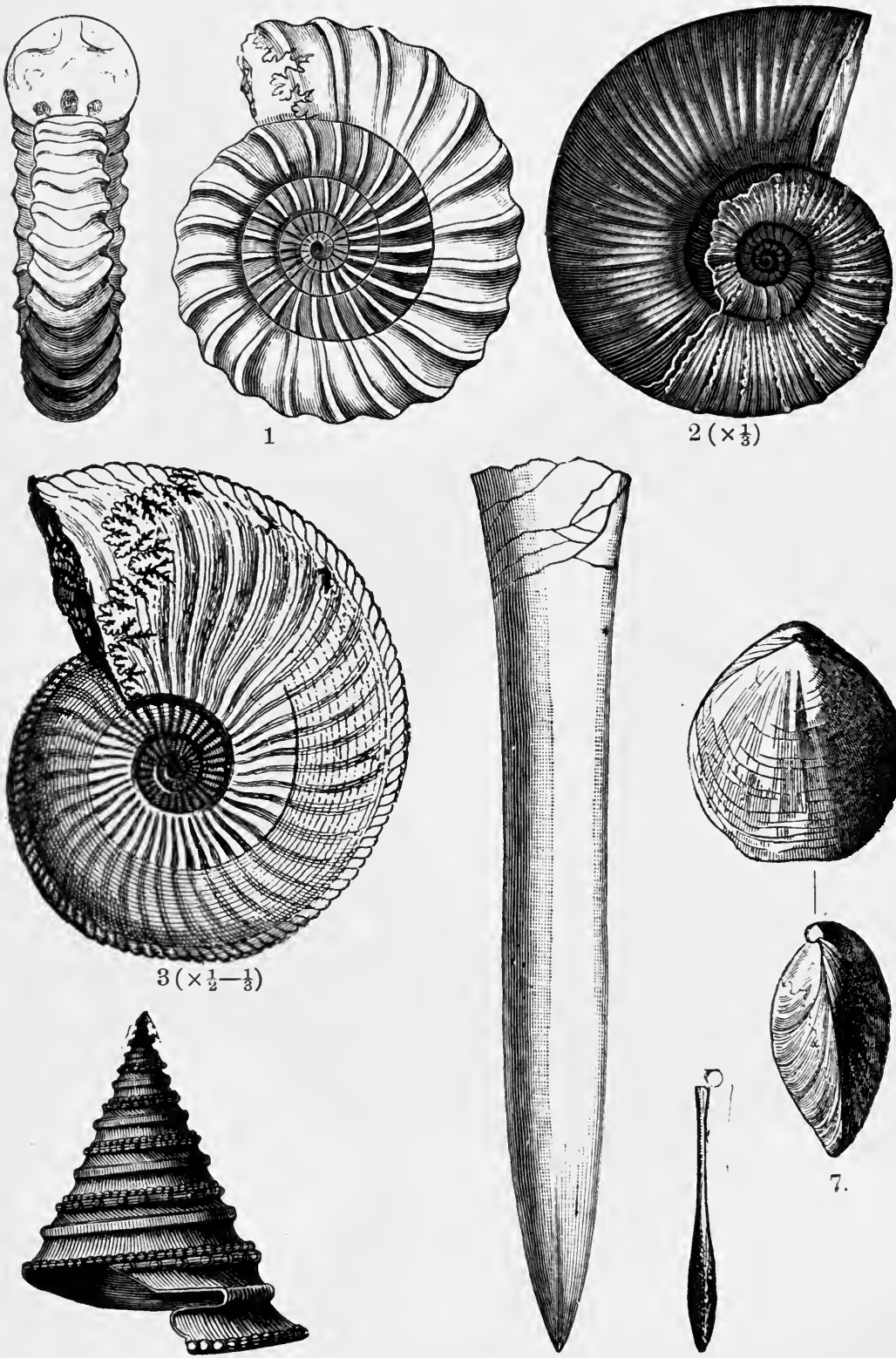

6
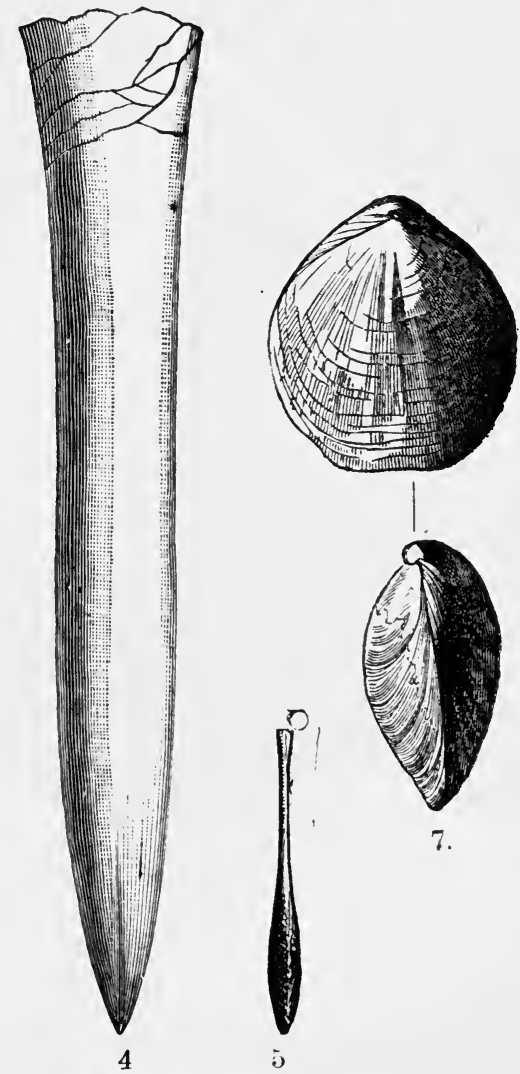

PLATE XLII.-Fossils of the Middle Lias.

1. Aegoceras capricornum, Schl. 2. Lytoceras fimbriatum, Sow. 3. Amaltheus margaritatus, Montf. 4. Belemnites paxillosus, Schl. 5. Bel. clavatus, Blainv. 6. Plewrotomaria bitorquata, Deslongch. 7. Terebratula numismalis, Lam. 

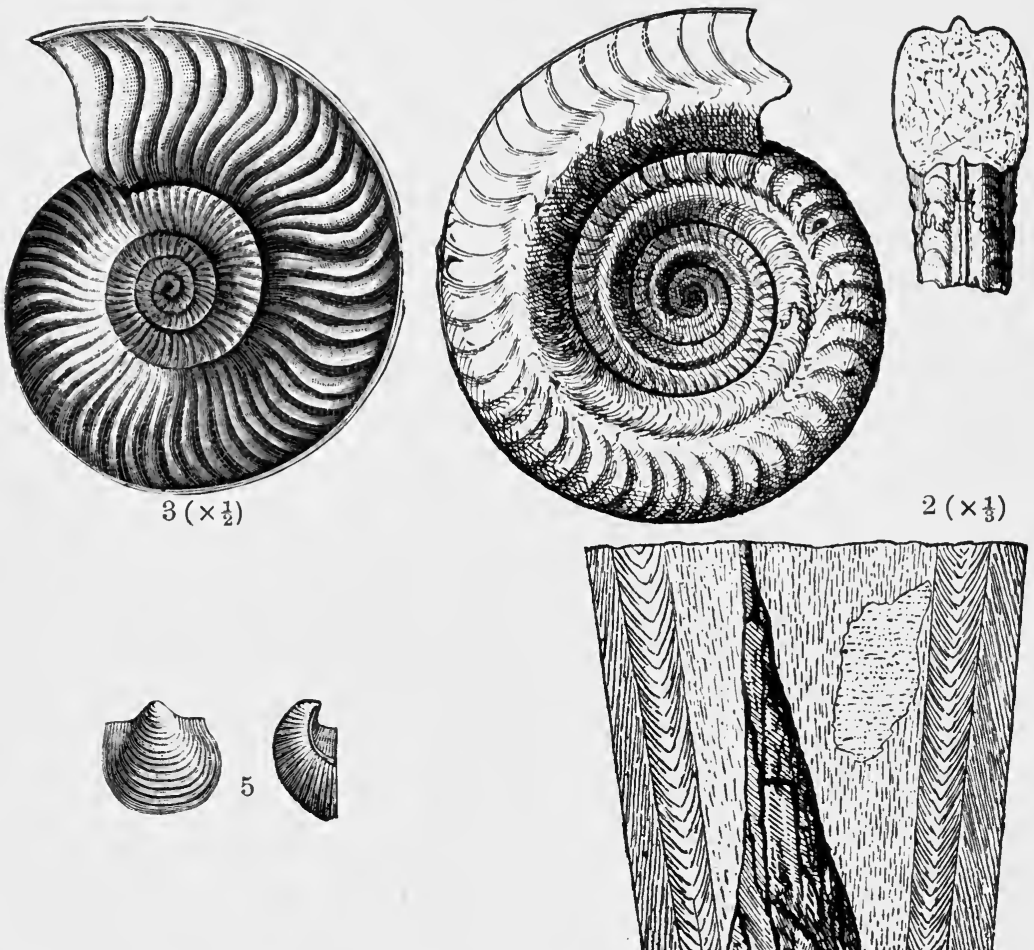

$2\left(\times \frac{1}{3}\right)$

$1\left(\times \frac{1}{4}\right)$

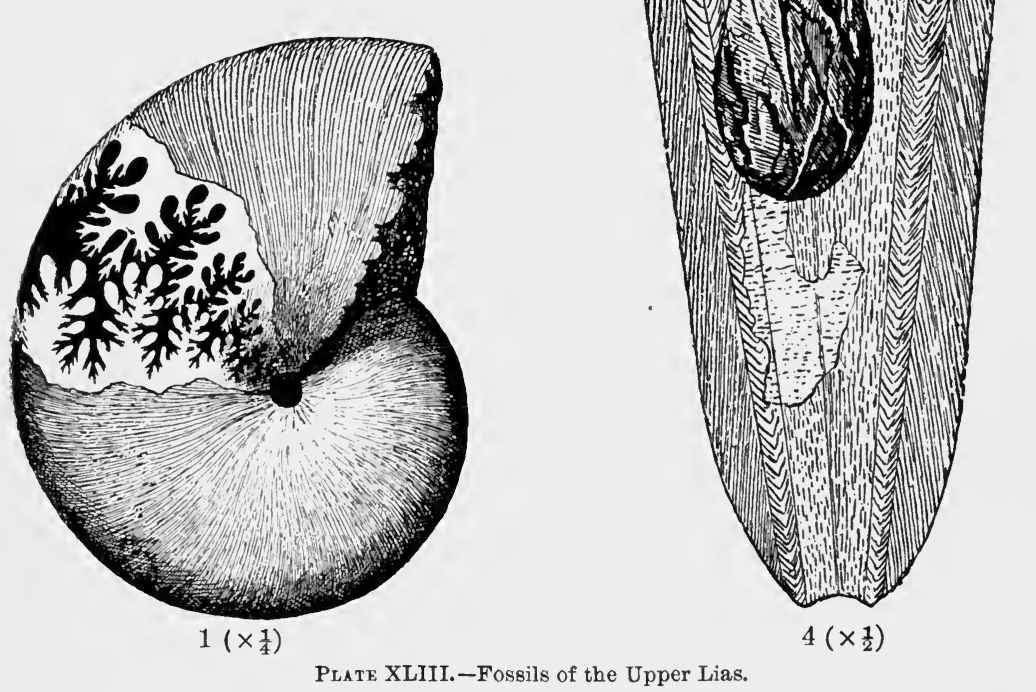

1. Phylloceras heterophyllum, Sow. 2. Harpoceras (Hildoceras) bifrons, Brug. 3. Harpoceras radians, Rein. 4. Geoteuthis bollensis Ziet. 5. Posidonomya Bronni, Voltz. 


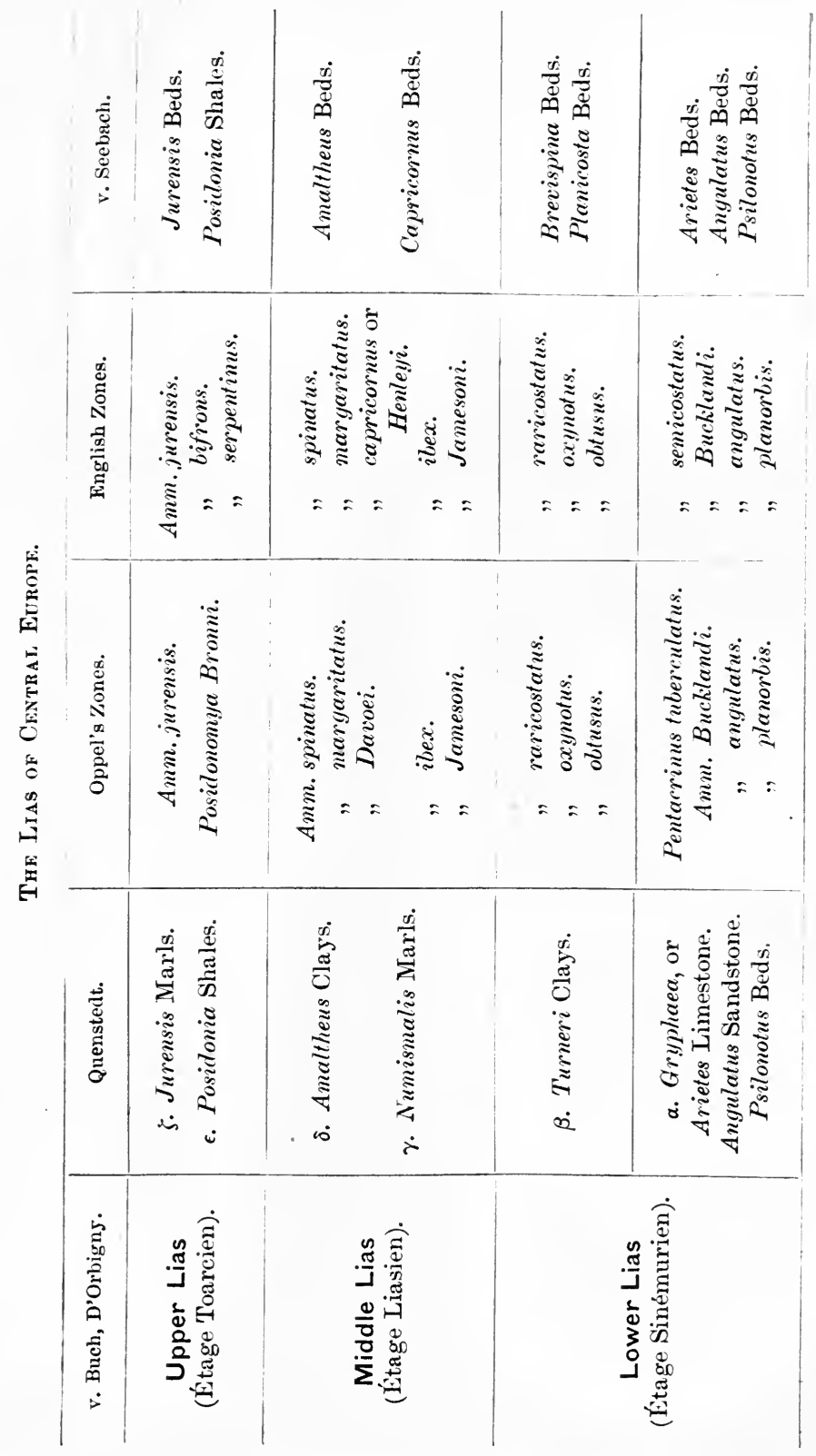


described, and consists chiefly of clays, marls and limestones. In the Moselle area the deposits are more sandy, and near Luxemburg the greater part assumes the form of sand and sandstone. In the French Ardennes the zone of Amm. planorbis is absent or rudimentary, and the zone of Amm. angulatus begins with a conglomerate of Devonian pebbles. As in England, ferruginous deposits are found at various horizons, and the oolitic ironstone of la Verpillière (near Lyons) has long been famous for its beautifully preserved fossils of the Amm. bifrons zone.

It should be noticed that French geologists usually include the Opalinus beds, here placed in the next series, with the Lias.

\section{The Middle or Broun Jura (Dogger).}

In Württemberg Quenstedt divides this group also in to six stages $(\alpha-\zeta)$. Oppel recognises for it eleven zones, to which has now been added a further zone of Amm. Sowerbyi. Oppel draws the upper boundary of the Middle Jura somewhat differently from Quenstedt. He concludes his Dogger with the zone of Terebratula lagenalis, and refers the overlying beds to the Upper Jura. This corresponds with the English and French classifications. Thus in England one of the chief boundaries, namely that between the Lower and Middle Oolite, is drawn between the Great Oolite and the Kellaways Rock. It has already been mentioned that the French, and some English, geologists begin the Middle Jurassic (Lower Oolitic) with the Murchisonce zone. Another grouping has been proposed by Taček, ${ }^{1}$ who bases his view on a denudation unconformity observed in many places between the Soverbyi zone and the lower beds of the Jura. This points to a continental period preceding the deposition of that zone, and Vaček therefore would draw the lower boundary of the Oolitic Series between the Murchisona and Soverbyi zones. Here, however, the grouping adopted by Quenstedt and Neumayr is followed.

In Swabia the Middle Jura is classified by Quenstedt as follows :-

\section{Upper Brown Jura.}

5. Ornatus Clays. Dark unctuous clays with numerous Ammonites (replaced by iron pyrites): Amm. Jason, A. anceps, A. lecticus, A. ornatus (XLVI. 8), A. athleta, etc.

\section{Oppel. Zone of Amm. athleta.} $"$, Amm. anceps.

1 "Fauna der Oolithe vom Cap San Vigilio. Abh. d. geol. Reichsanst." (1886). 
є. Clays and ferruginous Oolite. Below, zone of Amm. (Parkinsonia) Parkinsoni (XLV. 4); above this, limestone with Rhynchonella varians (XLVI. 2); at top, zone of Amm. (Macrocephalites) macrocephalus (XLVI. 7).

Oppel. Zone of Amm. macrocephalus.

$$
\begin{aligned}
& \text { " "Terebratula lagenalis. } \\
& " \quad \text { "T. digona (XLVI. 3). } \\
& \text { " Amm. Parkinsoni. }
\end{aligned}
$$

\section{Middle Brown Jura.}

ס. Fossiliferous Clays, Limestones, ferruginous Oolite. At the base, Giganteus clays, with the large Beleminites giganteus (XLV. 5). Then Ostrea Limestone with the plaited Ostrea Marshi (XLIV.5), and the smooth O. eduliformis, Trigonia costata (XLIV. 3), etc. These are followed by Coronatus Beds with Amm. (Stephanoceras) Humphriesianus, A. Blagdeni (XLV. 3), and A. Braikenridgi. Above, Bifurcatus Beds with Amm. bifurcatus, etc. The commoner fossils of this stage include (besides those mentioned) Pholadomya Murchisoni (XiIV. 6), Lima proboscidea, Modiola modiolata, Terebratula perovalis.

\section{Oppel. Zone of Amm. Humphiesianus.}

$\gamma$. Blue Limestone, poor in fossils. Near the middle of the stage are beds with Amm. (Hammatoceras) Sowerbyi.

Oppel. Zone of Amm. Sauzei.

\section{Lower Brown Jura.}

B. Yellowish Sandstone and oolitic Ironstone (of Aalen). Chief fossils: Amm. (Harpoceras) Murchisone and Pecten personatus.

Oppel. Zone of Amm. Murchisonce.

a. Opalinus Clays. Dark clays with Amm. (Harpoceras) opalinus (XLIV. 1). At the base, zones with Amm. torulosus and A. opalinus, Nucula Hammeri, etc.; in the middle, limestones with Lucina plana, Astarte opalina, Pentacrinus opalinus; at the top, Trigonia navis (XLIV. 2) and Amm. opalinus in calcareous nodules.

$$
\begin{aligned}
& \text { Oppel. 2. Zone of Trigonia navis. } \\
& \text { 1. " "Amm. torulosus. }
\end{aligned}
$$

In Franconia, the Middle Jura is almost exactly like that of Swabia.

In Lorraine and Luxemburg, Steinmann and Van Werweke classify as follows :- 1

\section{b. Bathian.}

\section{Upper Dogger.}

8. Clays and marly limestones with Ostrea Knorri and Rhynchonella varians.

$$
\text { a. Vesullian. }{ }^{2}
$$

7. Marl oolite of Gravelotte with Amm. Parkinsoni.

6. Oolitic limestone of Jaumont.

5. Marl of Longwy.

1 See also Branco, "Der untere Dogger Deutsch-Lothringens" (1879).

2 "Neues Jahrb." (1880), ii. p. 251, 367. 


\section{Middle Dogger.}

4. Limestones, rich in corals, with Amm. Humphriesianus.

3. Sand marls with Amm. Sowerbyi.

\section{Lower Dogger.}

2. Argillaceous sandy beds with Trigonia navis and Anm. Murchisona.

1. Clayey beds with Astarte Voltzi and Amm. striatulus.

Of these 1 and $2=a-\beta$ of Quenstedt, $3=\gamma, 4=\hat{o}, \bar{\partial}-7=$ lower part of $\epsilon, 8=$ middle part of $\epsilon$.

In the North-west of Germany, v. Seebach distinguishes the following subdivisions of the Dogger :-

8. Ornatus clays.

7. Macrocephalus beds.

6. Solid ferruginous limestone beds with Monotis (Pseudo-monotis) echinata (XLVI. 1). (Also called Cornbrash.)

5. Beds with Ostrea Knorri.

4. Parkinsoni beds.

3. Coronatus beds.

2. Beds with Inoceramus polyplocus.

1. " "Amm. opalinus.

v. Seebach's 1=Quenstedt's $a$. The beds equivalent with the S. German Murchisonce beds are not developed as such in the Weser range. Cephalopoda are here almost entirely absent, so that v. Seebach was forced to make an Inoceramus the type form. Seebach's $2=\beta+\gamma ; 3=\delta ; 4=$ Parkinsoni zone (lower $\epsilon$ ) $; 5+6=$ Bath (middle $\epsilon$ ) $; 7=$ Macrocephalus zone (Upper $\epsilon$ ); and $8=\zeta$. The two last series are placed by Seebach as by Oppel, in the Upper Jura.

In Eastern Germany, as already remarked, the Lias and the lower part of the Middle Jura are absent. In Silesia the lowest Jurassic beds belong to the Parkinsoni horizon. On the Baltic also, near Kammin, etc., the oldest Jura beds which come to the surface belong to the zone of Ostrea Knorri (the English Bath Oolite). ${ }^{1}$

In England the Middle Jurassic (Lower Oolite) is variously developed in different parts of the country. Its upper boundary is most naturally drawn below the Kellaways Rock or Callovian, i.e. below the zone of Amm. macrocephalus.

In the South-west of England the series is divided as follows :-

\section{Great Oolite Series.}

Corn brash. Earthy or rubbly limestones, sometimes shelly, sometimes marly. Numerous fossils, including Terebratula lagenalis.

1 A deep boring near Kammin has proved the presence of coal-bearing Lower Lias quite like that of Bornholm and Scania; but the higher beds of the Lias are absent, and also the whole of the lower part of the Dogger. 
Forest Marble and Bradford Clay. Clay, shale, sand, and flaggy, shelly and oolitic limestones; variable. Ostrea Souerbyi, Pecten vagans, Rhynchonella varians, etc. The Bradford Clay at the base, contains Terebratula digona and $T$. coarctata.

Great or Bath Oolite. Shelly limestones and fine-grained oolites, with partings of sandy marl. Gasteropods very abundant (Nerincea, etc.), also bivalves and corals. Rhynchonella concinna, Terebratula digona, etc. The Stonesfield Slate with its mammalian remains occurs at the base of this stage.

Fuller's Earth. Grey clay and marl with nodules of earthy limestone. Ostrea acuminata, Terebratula ornithocephala, Rhynchonella varians.

\section{Inferior Oolite Series.}

Inferior Oolite. Brownish oolitic limestone with layers of sand and marl. Divided into four zones:-

$$
\begin{gathered}
\text { Zone of Amm. Parkinsoni. } \\
\text { " } \quad \text { "Amm. Humphriesianus. } \\
\text { " } \quad \text { Amm. Sowerbyi. } \\
\text { " Amm. Murchisona. }
\end{gathered}
$$

Midford Sands. ${ }^{1}$ Micaceous yellow sands, occasionally calcareous, capped by brown marly limestone. The latter is the zone of Amm. opalimus and according to the classification adopted here should be referred to the Middle Jurassic; while the former is the Amm.jurensis zone and belongs to the Lias.

The Cornbrash forms a constant horizon almost throughout England; but the other deposits vary. The limestones are more or less local and thin out irregularly. Passing towards the northeast the whole becomes more sandy. In Northamptonshire the Inferior Oolite Series is represented by the Northampton sands In Lincolnshire the beds are grouped as follows :-

Cornbrash.

Great Oolite Clay.

Great Oolite Limestone.

Upper Estuarine Series.

Lincolnshire Limestone.

Collyweston Slate.

Northampton Sands. $\left\{\begin{array}{l}\text { Lower Estuarine Series. } \\ \text { Ferruginous beds. }\end{array}\right.$

The Northampton Sands consist of beds of ferruginous sand, with ironstone at the base; and near Northampton they include the zones of Amm. Murchisona and Amm. opalinus. The Collyweston Slate and Lincolnshire Limestone are by no means universally found in the Midlands. They form the Amm. Sowerbyi zone.

1 This term is objected to by Buckman (Quart. Journ. Geol. Soc., xlv. p. 440) on the ground that it has been applied to sands not all on the same horizon. 
The Upper Estuarine Series consists of clays, marls, etc., and often rests directly on the Lower Estuarine.

In Yorkshire the whole of the Lower Oolite has become an estuarine series, divided up by beds of limestone, and is grouped as follows :-

Cornbrash. Probably lies at a lower horizon than that of the south, and represents the Great Oolite Series in part.

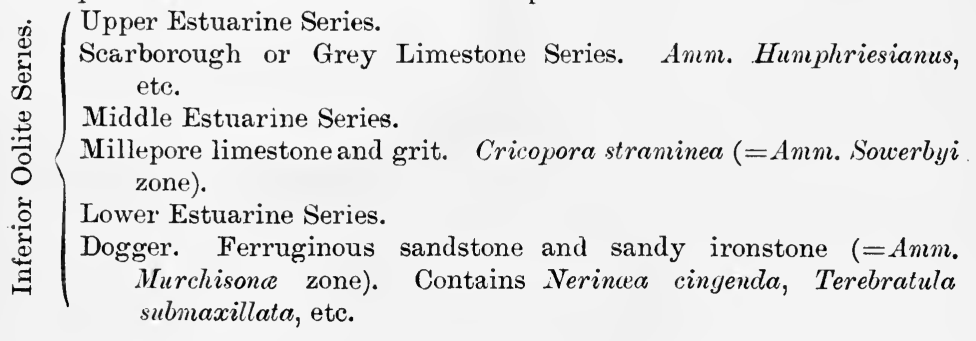

In France the Middle Jurassic or Lower Oolite is divided into two series, the Bajocien (named from Bayeux, near Caen) and Bathonien. In Normandy we have-

Bathonien.= Great Oolite Series.

Bradfordien. "Oolithe miliaire" below, with few fossils; Bryozoa limestone above, with Terebratula digona, etc.

Vesulien. Two facies: the marly limestone of Port-en-Bessin, and the limestone of Caen.

Bajocien.=Inferior Oolite Series.

White oolite with Amm. Parkinsoni, and other fossils in abundance.

Ferruginous oolite. Amm. Parkinsoni, A. Humphriesianus, A. Sowerbyi, Belemnites giganteus, etc.

Limestone with Lima heteromorpha=zone of Anım. Murchisona.

Proceeding eastwards along the circle of Jurassic rocks; in the French Ardennes the Bajocien consists at the base of marly limestone, above of limestone with Amm. Blagdeni; the Bathonian is fully developed as a series of limestones. In Burgundy the Bajocien is mainly formed of the "calcaire à entroques" (a crinoidal limestone) with Amm. Parkinsoni, etc.; and the Bathonian (Côte d'Or) consists chiefly of limestones and marls.

\section{The Upper or White Jura (Malm).}

The Upper division of the Jura in Central Europe is composed mainly of thick, pale-coloured, often oolitic limestones. Shallowwater and coast formations occur at many piaces, especially in the Coral Rag, along with deep-sea deposits, and hence the palæonto- 

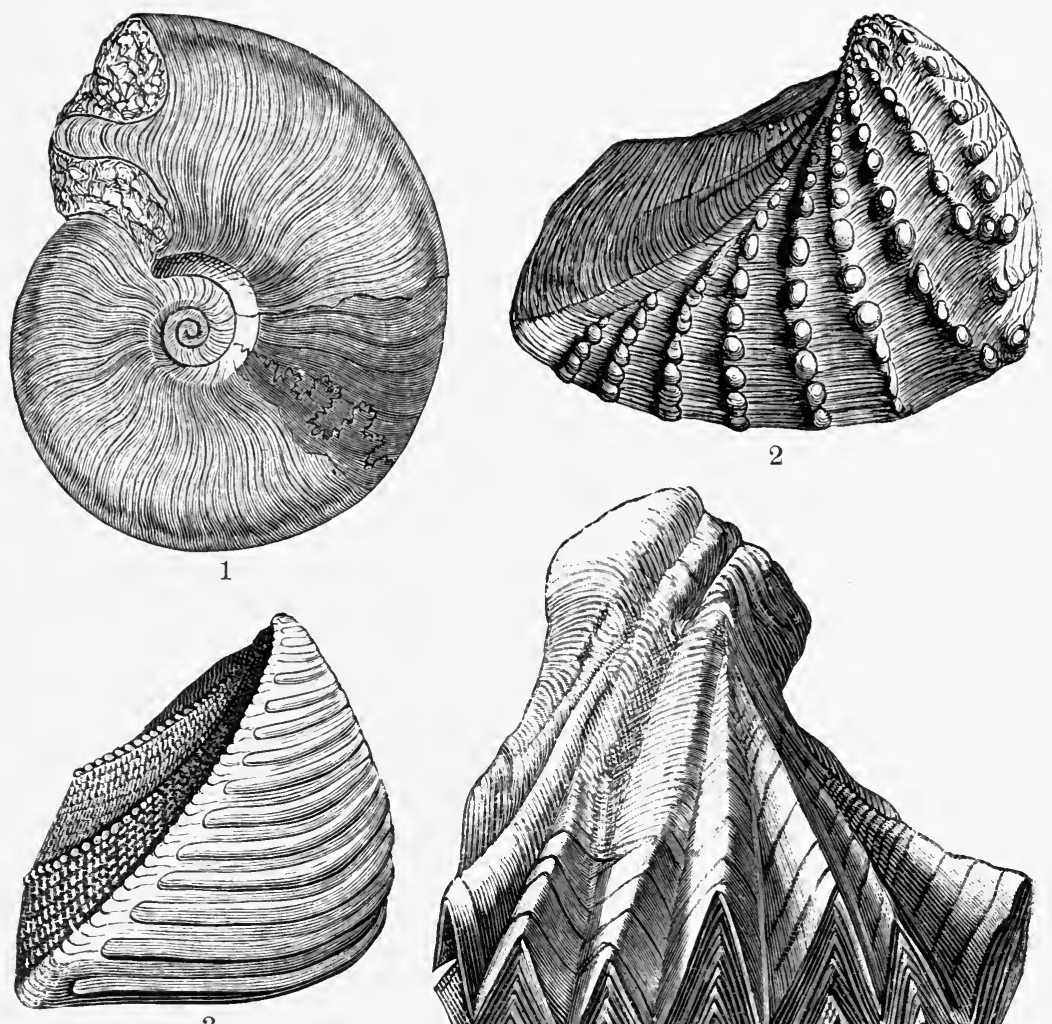

3

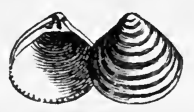

4

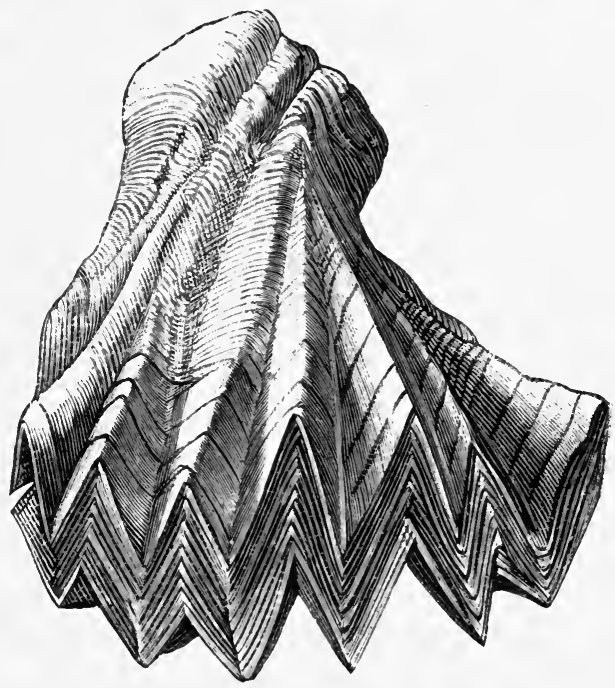

$5\left(\times \frac{1}{4}\right)$
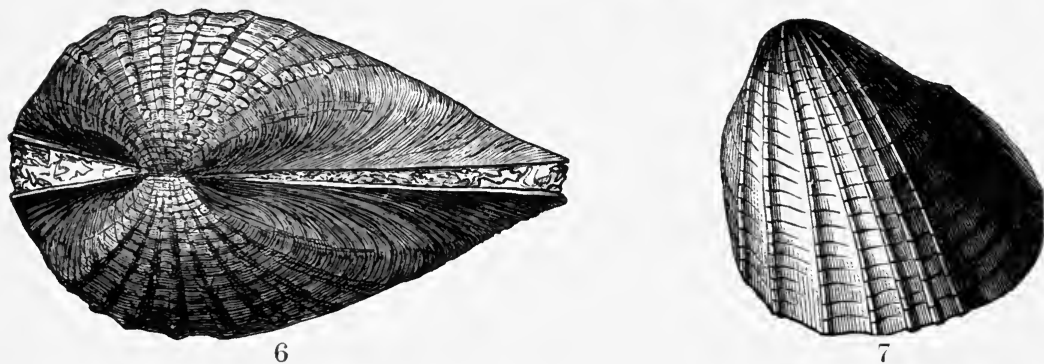

Plate XLIV.-Fossils of the Lower Oolite.

1. Harpoceras opalinum, Rein. 2. Trigonia navis, Lam. 3. Tr. costata, Park. 4. Astarte Voltzi, Ziet. 5. Ostrea Marshi, Sew. 6. Pholadomya. Murchisoni, Sow. 7. Phol. deltoidea, Agas:. 

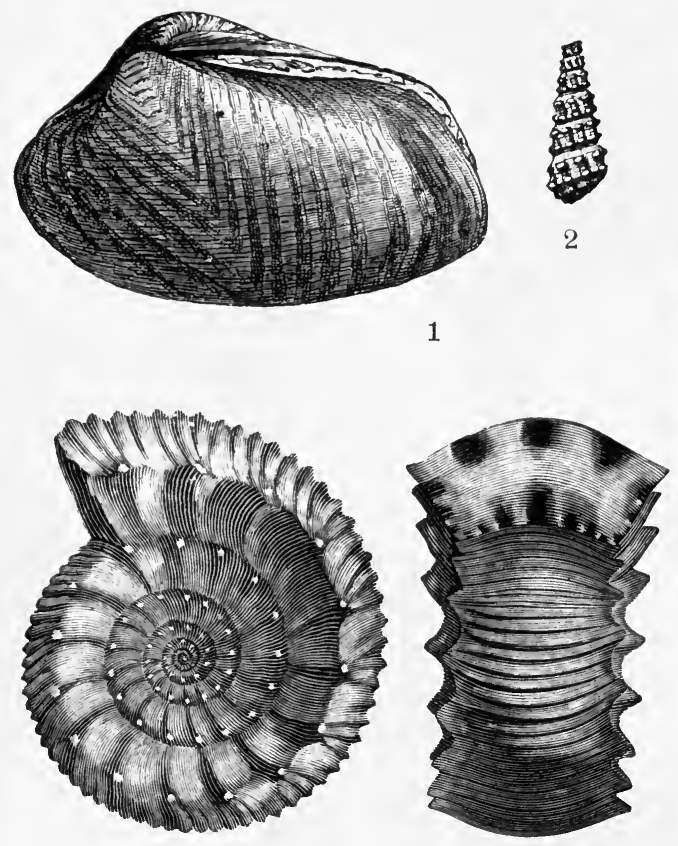

$3\left(\times \frac{1}{3}\right)$

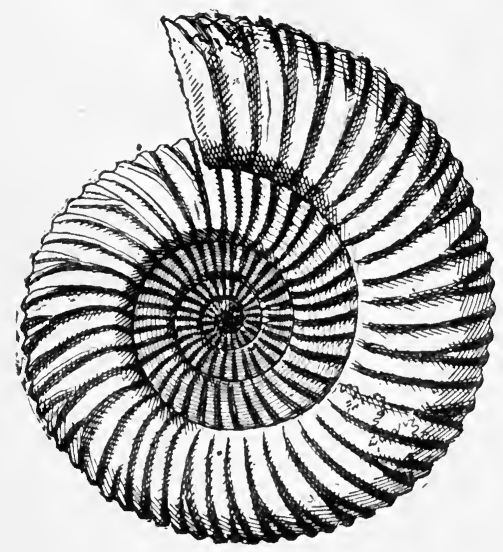

$4\left(\times \frac{1}{2}\right)$

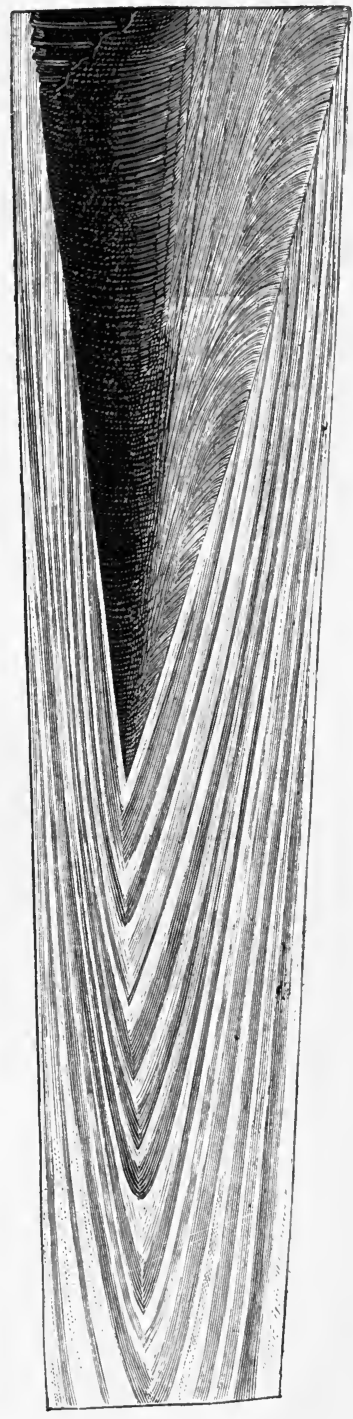

5

Plate XLV.-Fossils of the Lower Oolite.

1. Goniomya Duboisi, Agass. 2. Cerithium armatum, Gf. 3. Stephanoceras Blagdeni, Sow. 4. Parkinsonia Parkinsoni, Sow. 5. Belemnites, giganteus, Schloth, median section through the upper part of the guard, with complete alveolus 

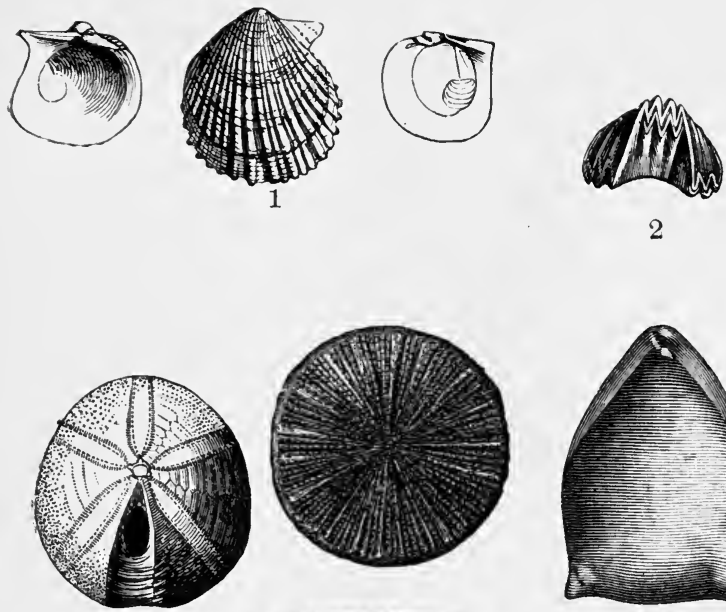
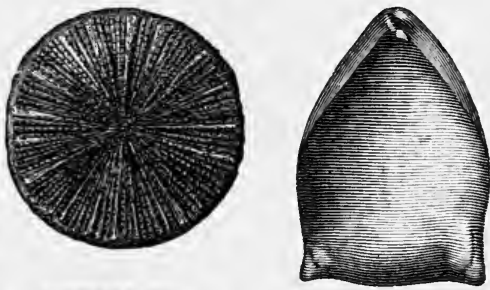

3

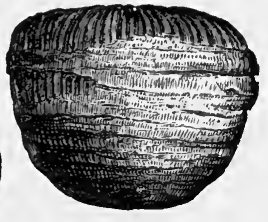

6

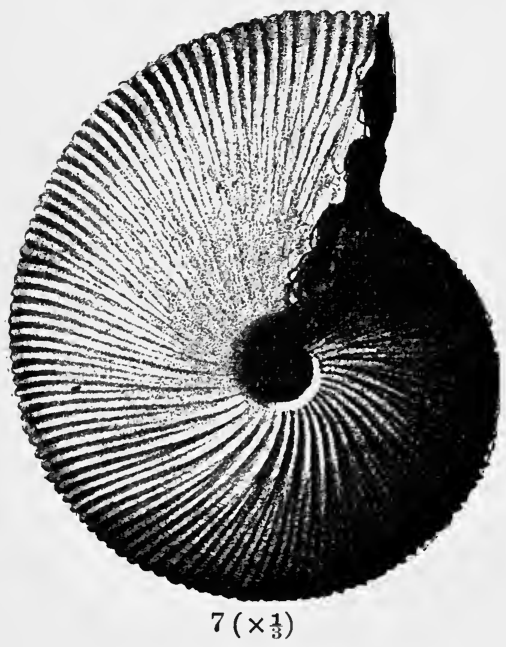

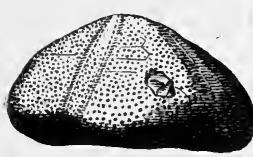

5

PLATe XLVI.-Fossils of the Great Oolite (1-6) and of the Kellaways Rock (7-9).

1. Pseudomonotis echinata, Sow. 2. Rhynchonella varians, Schl. 3. Terebratula digona, Sow. 4. T. lagenalis, Schl. 5. Echinobrissus clunicularis, Lwyd. 6. Montlivaltia caryophyllata, Lamx. 7. Macrocephalites macrocephalus, Schloth. 8. Cosmoceras ornatum, Schl. 9. Cardioceras cordatum, Sow. 


$$
\text { B.-JURASSIC SYSTEN. }
$$

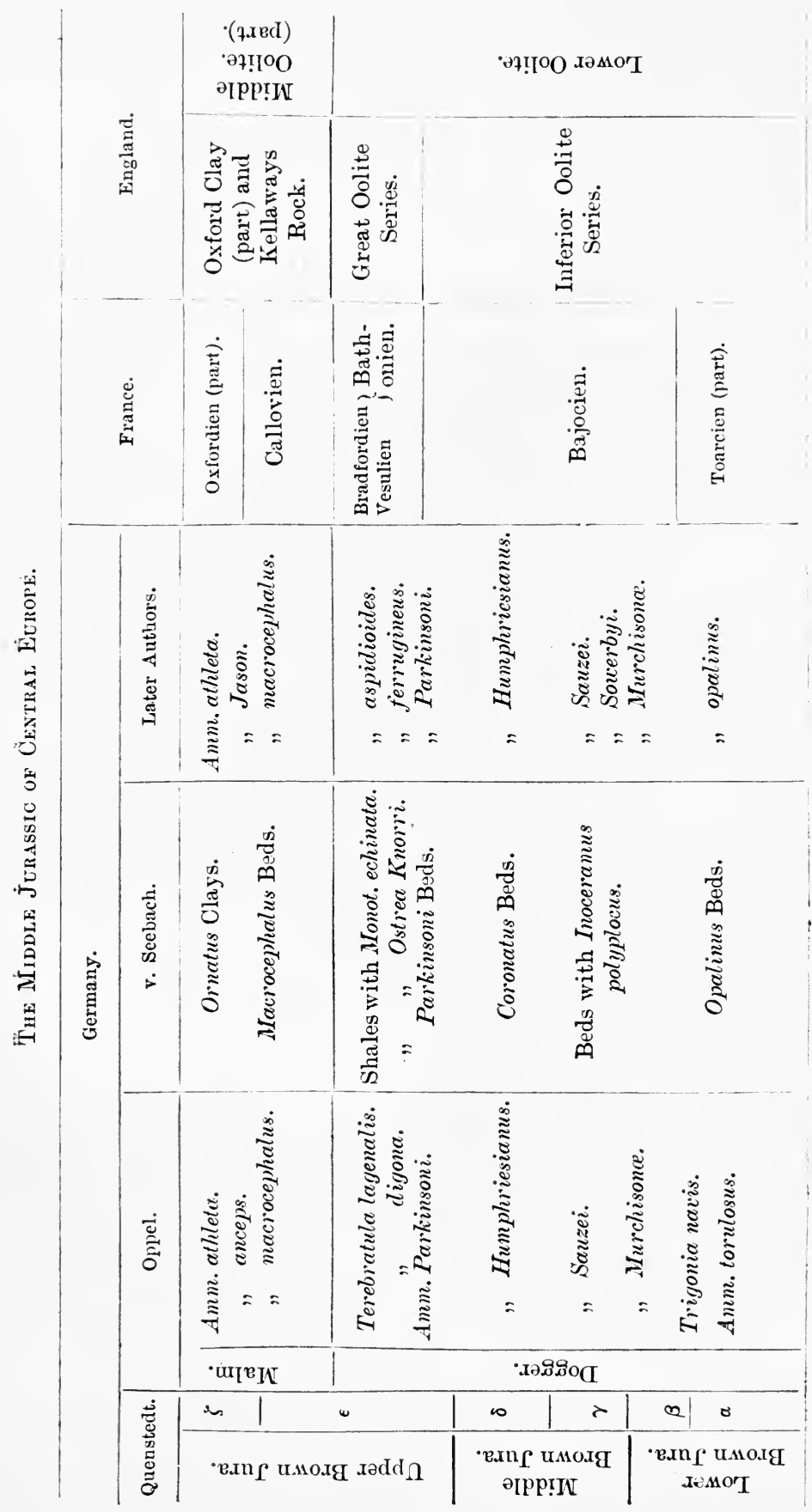

s. G. 
logical character of the Upper Jurassic limestones commonly changes much more frequently and more considerably than that of the older Jurassic deposits of Central Europe. In the deposits. formed in the deep sen, ammonites, and not uncommonly sponges also, play the chief part; in the intercalated shallow-sea deposits sometimes reef-building corals, crinoids, and sea urchins. predominate, sometimes thick-shelled bivalves and gasteropods. The famous Lithographic Limestones of Solenhofen and Pappenheim in Franconia, and of Cirin, in the S.E. of France, are peculiar formations evidently laid down in a deep quiet arm of the sea. They are very fine and crenly grained, platy to schistoselimestones, which contain an abundance of various crustacea, stalkless crinoids, worms, and naked pen-bearing cephalopods, a few Ammonites and Belemnites, as well as remains of terrestrial saurians, birds and insects, in part in an unsurpassably finestate of preservation. Among other peculiar deposits, most common at the uppermost limit of the Jura, are the brackish formations containing fresh-water along with marine bivalves.

For the various groups of the Upper Jura still more than for those of the older Jurassic, the English names are used. It was. formerly usual to distinguish from below upwards, Oxfordian, Coral Rag (Corallien), Kimeridge, Portland, and Purbeck. Since, however, Oppel, Mösch, and especially Waagen, ${ }^{1}$ have shown that the Upper Jurassic coral limestones, all of which used to be referred to the Coral Rag, occupy very different horizons in different regions, inany authors have given up the distinction of the Corallian as a special group. The Purbeck, a fresh-water formation found between the Portland and the Wealden in S. England and N.W. Germany, has usually been referred in England to the Jurassic. Here, however, on account of its close connection with the Wealden, we follow Beyrich, Struckmann, and others, and place it in the Cretaceous.

In S. Germany Quenstedt has divided the White Jura also. into six series $(\alpha-\zeta)$, but more in order to agree with the classification of the Brown and Black Jura than because this sixfold division is natural. The dark Kellaways clays (Brown $\zeta$ Quenst.) are followed in Swabia by thick, light, loose marls. These: are the Impressa marìs, Quenst.'s a, with Terebratula impressa

1 "Versuch einer allgemeinen Classification der Schichten des oberen. Jura" (1805). 
as the type fossil and with the Transversarius horizon (Amm. transversarius) at the base. Quenstedt's $\zeta$ on the other hand includes the Lithographic Limestone and the platy "Krebscheeren kalke" (Crab's claw limestones) of Nusplingen, which is its equivalent in Swabia. The compact limestones and dolomites lying between $\alpha$ and $\zeta$ are divided into four other zones, not. always easily separated from one another. The chief support. which they receive, is from the occurrence of large accumulations of sponges at some distance above the upper boundary of $\alpha$. These Sponge and Scyphia limestones were called $\gamma$, the bedded limestones between them and $\alpha, \beta$; the bedded limestones overlying $\gamma$ were called $\delta$; and, lastly, the still higher coral limestones, especially well developed near Nattheim, were designated as $\epsilon$.

- In the N.W. of Germany, where the Upper Jurassic formations agree rather with those of the Anglo-Parisian area than with those of S. Germany, Karl v. Seebach, Heinr. Credner, ${ }^{1}$ and Struckmann a classify them, in agrecment with the English grouping, as follows :-

\section{Portland group.}

(b) Eimbeckhäuser Plattenkalk. Platy limestone with C'orlula inflexa, C. alata and others, Modiola lithodomus, Palndina, C'yrena, etc.

(a) Oolite limestone and marly clays with Ammonitas giyas, A. portlandicus, and other species.

3 Kimeridge Limestone.

(c) Beds with Exogyra virgula (XLIX. 3), (a small oyster filling the oolitic beds in thousands), Ostrea multiformis, Terebratula subsella, etc.

(b) Pteroceras beds. Pteroceras Oceani (XLIX., 1), C'ymina Brongniarti, Pholadomya multicostata, etc.

(a) Nerinrea beds. Including the zone of Terebratula lumeralis.

2. Coral Oolite (Corallian). Coral-bearing limestones divided into-

(b) Beds with Nerincea visuryis.

(a) " " Ostrea rastellaris.

1. Oxford Group.=Hersumer beds of Seebach. Dark, calcareous sandy beds, with Amm. perarmatus (XLVII. 2), A. cordatus (XLVI. 9), etc., Gripluce lilatata, etc.

['The Oruatus and Macrocephalus beds are referred in Germany to the Midd!e Jurassic.]

The classification of the Upper Jurassics adopted in Germany

1 "Ueber d. Glieder. d. ober Juraform. ". d. Wealdbildung i. nordwestl. Deutschl." (1863).

2 "Der obere Jura der Umgegend von Hannover" (1878); also Zeits. d. deutsch. geol. Ges. (1887), p. 32. 
(as given above) and in France, originally came from England, where we get the following succession :-

Portland Beds. Sands, marls, calcareous sandstone (Portland Sand) below; white shelly and oolitic limestone with nodules of chert (Portland Stone) above. Amm. gigas, A. biplex, A. boloniensis ; Trigonia gibbosa, Cerithium portlandicum, etc.

Kimeridge Clay. Dark bluish-grey clay, containing crystals of selenite, septaria, etc:

Corallian. Very variable; calcareous sandstones, coral rags, and coralline oolite, all of which are frequently replaced by clay. The lower beds contain Gryphcea dilatata, and pass down into the Oxford clay; the upper contain Ostrea deltoidea, and pass up into the Kimeridge.

Oxford Clay. Dark blue or yellowish clay; frequently with selenite, septaria, and iron pyrites. Brown calcareous sandstone (Kellaways Rock) forms the base in many places.

The Oxford Clay is tolerably uniform in character throughout the country; but the Kellaways Rock at its base is variable, and is found chiefly in Berkshire, Wiltshire, and in Yorkshire and Lincolnshire, etc. Elsewhere it is commonly replaced by clay, undistinguishable from the Oxford Clay. The whole group is divided into three zones:-

Cordatus beds. Amm. cordatus, A. Lamberti, etc.

Ornatus beds. Amm. ornatus, A. Jason, etc.

Macrocephalus beds (Kellaways Rock). Amm. macrocephalus, A. Calloviensis, A. Koenigi, etc.; Gryphwa bilobata, etc.

The Corallian group is the most variable of the whole series. In Yorkshire, where it is best developed, Blake and Hudleston divide it into :-

$$
\begin{aligned}
& \begin{array}{l}
\text { Zone of } \\
\text { m. plicatilis. }
\end{array} \quad\left\{\begin{array}{l}
\text { Upper Calcareous Grit (Supracoralline). } \\
\text { Coral Rag. Sub-zone of Cidaris jlorigemma. } \\
\text { Coralline Oolite. } \\
\text { Middle Calcareous Grit. }
\end{array}\right. \\
& \text { Zone of Jlower Limestone. }
\end{aligned}
$$

It contains numerous fossils; and, among these, corals (Thecosmilia annularis, Thamnastraa arachnoides, $T$. concinna, Isastraca, Stylina, etc.) are especially important and frequently form reefs. But the calcareous form of the deposit is local, and is chiefly found in Yorkshire; in Wiltshire and Dorsetshire; and, imperfectly, in Cambridgeshire, etc. Elsewhere the Kimeridge and Oxford Clays seem to be in contact, wiich probably means that the Corallian is represented by portions of these clays. Thus it 
has been shown that the Ampthill Clay of Cambridgeshire, which has been mapped as Oxfordian, is the equivalent of the Corallian. ${ }^{1}$

The Kimeridge Clay is fairly constant in lithological character ; but palæontologically it varies considerably. Exogyra virgula, which gives its name to the Upper division abroad, is found in England throughout the series, except the uppermost part; though locally it forms banks in the Upper division. Blake recognises the Virgulian and Astartian of the Continent, but has not found the intervening Pterocerian definitely represented in England. In Dorsetshire he divides the group into:-

Upper Kimeridge. Lucina mimuscula, L. lineata, Discina latissima, Amm. biplex.

Lower Kimeridge. Rhynchonella inconstans, Astarte supracorallina, Exogyra virgula. Passage beds at base with Ostrea deltcidea, etc.

In Cambridgeshire, T. Roberts distinguishes five zones :-

$$
\begin{gathered}
\text { Zone of Discina latissima. } \\
\quad, \quad \text { Exog!rra virgula. } \\
\text { " Ammonites alternans. } \\
\text { " Astarte supracorallina. } \\
\text { Ostrea deltoidea. }
\end{gathered}
$$

It is in the Kimeridge Clay that the great saurians of the Oolites are principally found (Cetosaurus, Pterodactylus, Plesiosaurus, Ichthyosaurus, etc.); and fishes also are not uncommon.

The Portland group as developed at Portland does not extend further north than the neighbourhood of Leighton Buzzard (Beds.); and even in Buckinghamshire the Sands appear to have thinned out. In the central part of the oolitic band the group is entirely unknown; but towards the north it appears to be represented by a part of the Belemnites lateralis division of the Speeton Clay in Yorkshire.2 A serpulite bed with Serpula gordialis, at Portland, is worthy of notice.

The succeeding Purbeck group is usually referred to the Oolites, but is here described with the Lower Cretaceous.

The Upper Jurassic rocks of the Parisian basin closely resemble those of England, and they are classified in nearly the same way. In Normandy the Oxford Clay is some 300 feet thick, and is characterized by the same fossils as in England. It is succeeded by the Coral Rag (of Trouville), which consists

1 T. Roberts. "The Jurassic rocks of the neighbourhood of Cambridge," 1892.

2 See footnote on page 291. 
of oolites and marls, and contains the characteristic Cidaris florigemma and other English forms. The Kimeridgien is divided into Sequanien, Pterocerien, and Virgulien, which consist of marls, clays and siliceous limestones.

On the north-east side of the basin the same beds are well developed, and the general succession is as follows:-

\section{Portlandien.}

Calcareous sandstones and oolites. Trigonia giblosa, etc.

\section{Kimeridgien.}

Bolonien. Amm. gigas, A. suprajurensis, etc.

Virgulien. Exogyra virgula, etc.

Pterocerien. Passes into compact limestone towards the south. Pteroceras oceani, Waldheimia humeralis, etc.

Sequanien (Astartien). Chiefly oolitic in the east of France; chalky in Burgundy. Astarte minima, Diceras arietinum, etc.

\section{Corallien.}

Coral reefs, etc., 400 feet thick in the Ardennes, thinning towards the south. Cidaris florigemma, Thecosmilia, and other corals, etc. A lower zone with Glypticus hieroglyphicus; and an upper with Diceras arietinum.

\section{Oxfordien.}

Oxfordien proper. In the Ardennes consists of clays with soft sandstones; further north is more calcareous, and contains bands of oolitic iron ore. Amm. cordatus, A. macrocephalus, Gryphaca dilatata, etc.

Callovien. Clays, limestone, sometimes with iron ore. Not always easy to separate from the Oxfordien.

\section{The Alpine Jura.}

The difference between the Alpine and extra-Alpine Trias is repeated in the Jurassic deposits, though not quite so strikingly. From a palæontological point of view this difference, according to Neumayr, is due chiefly to the great development of the Ammonite genera, Phylloceras, Lytoceras, Haploceras, and Simoceras throughout the Alpine area. These genera are found in great abundance in all the Ammonite beds of the Alps quite independently of their facies, while in Central Europe they are represented by only a few scattered species.

There are also great differences in the mode of derelopment of the rocks in the Alpine and extra-Alpine areas. Thus the red Ammonite-bearing marbles, which are very like the Triassic Hallstatt limestone, are quite unknown outside the Alpine region, but are found at various horizons in the Alpine Jura. This form of development is well named the Adneth Facies after one of its chief occurrences in the Lias of Adneth not far from Salzburg. 

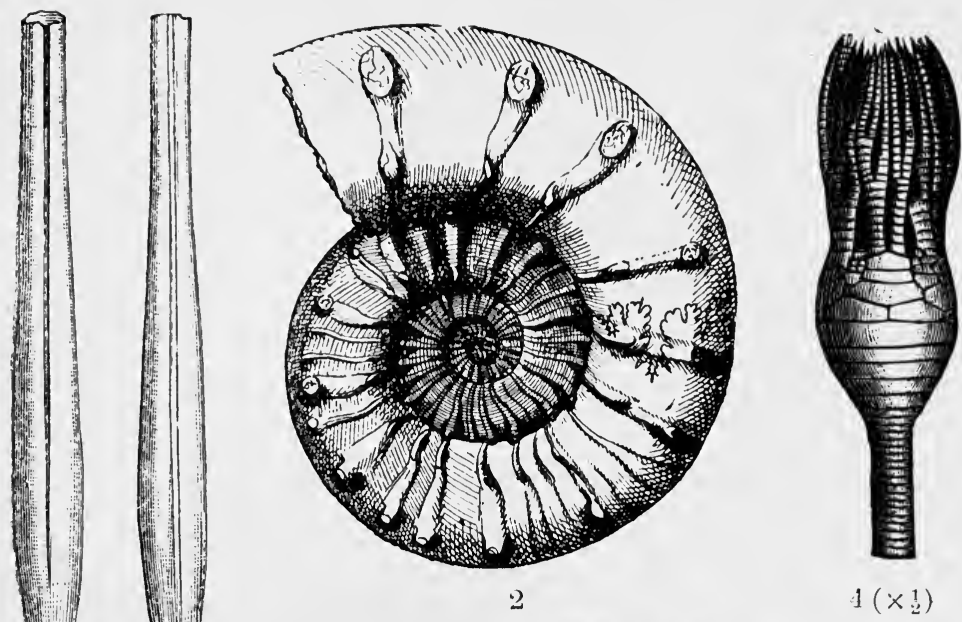

2
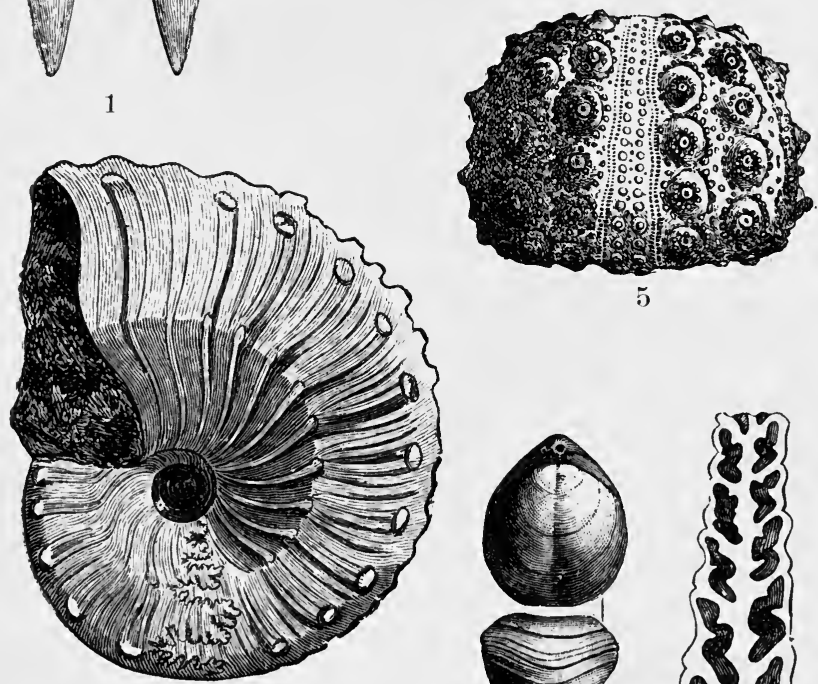

3
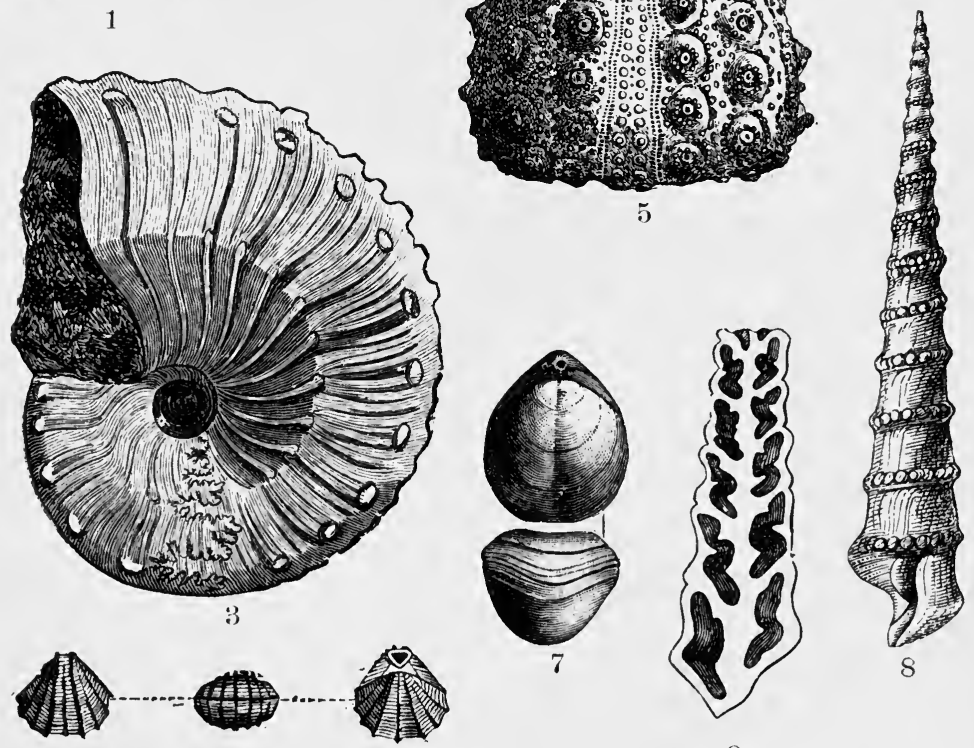

6

$8 \mathbf{A}$

Plate XLVII.-Fossils of the Oxfordian and Corallian.

1. Bclennites lastatus, Blainv. 2. Aspidoceras pciarmatum, Sow. 3. Oppelia flexuosa, v. Buch. 4. Apiocinus Roissianus, d’Orb. 5. Hemicidaris cienularis, Lam. G. Megerlea pectunculus, Schl. 7. Terebratula impressa, Bronn. 8. Nerinea tuberculosa, A. Röm. 8A. The same, longitudinal section. 

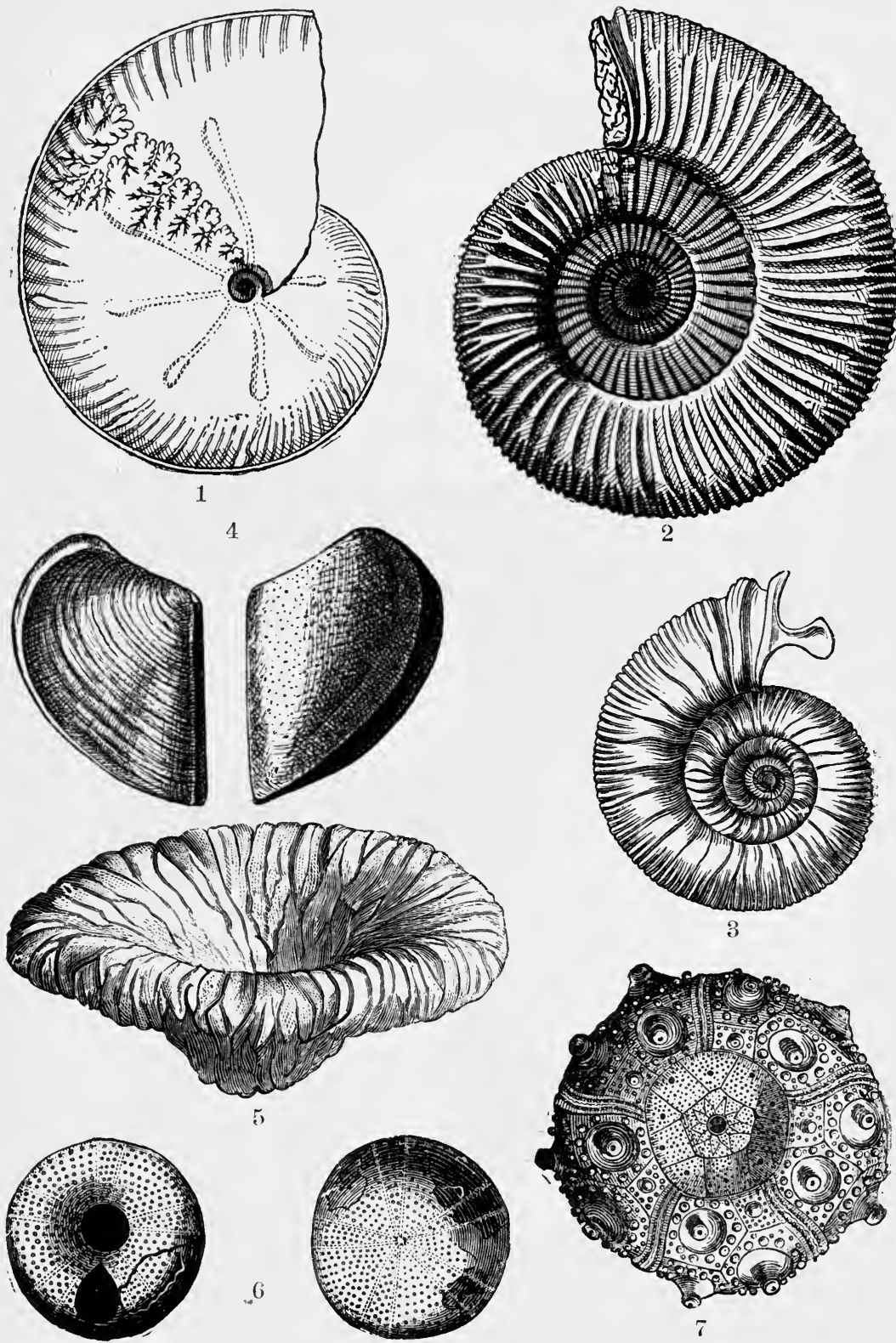

Plate XLVIII.-Fossils of the Kimeridgian.

1. Oppelia tenuilobata, Oppel. 2. Perisphinctes Tiziani, Opp. 3. Per. polyplocus, Rein. 4. Aptychus lovis, v. Mey. 5. Cnemidiastrum rimulosum, Gf. 6. Holectypus orificatus, Schl. 7. Cidaris coronata, Gf. 

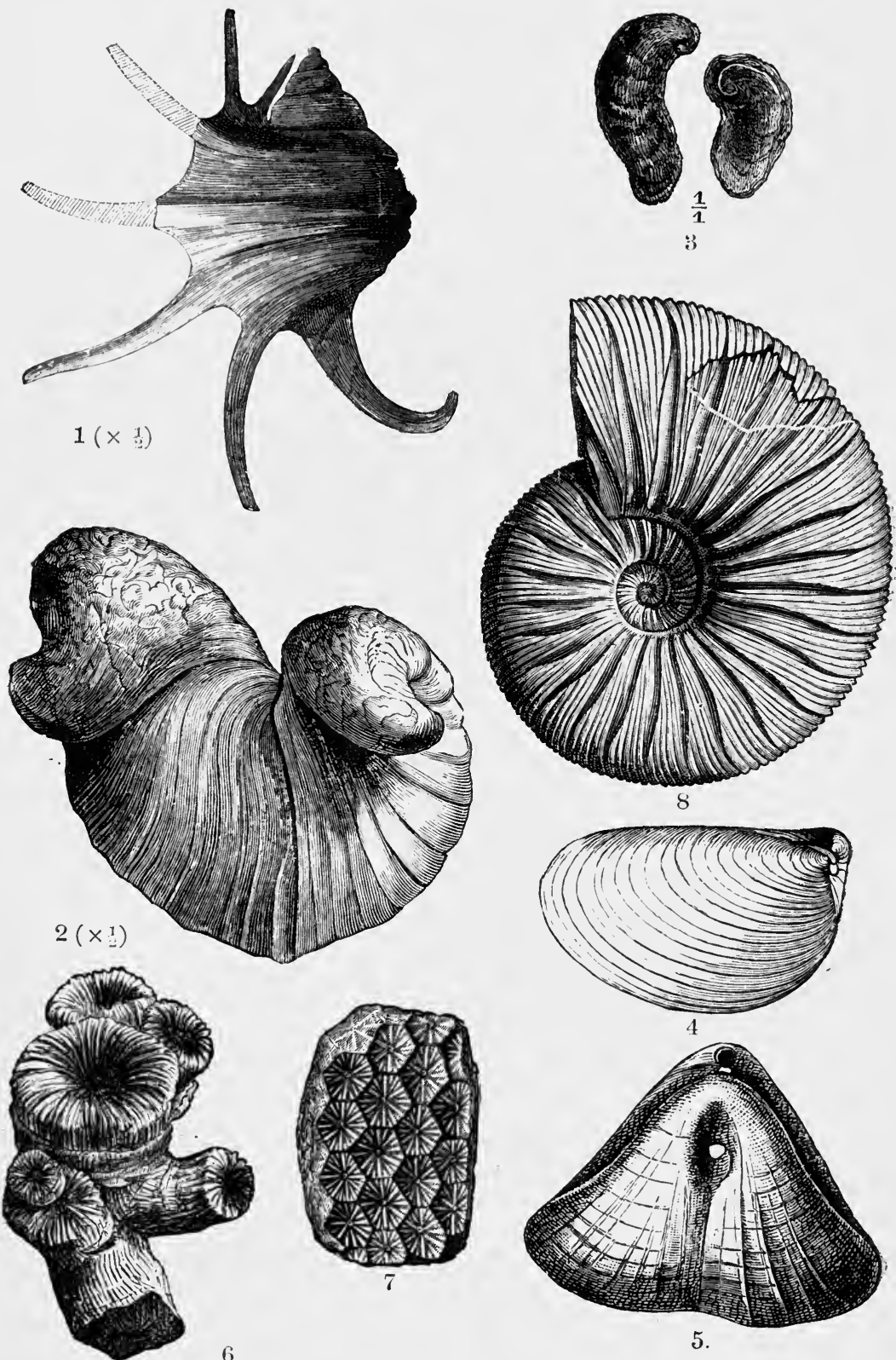

5.

Plate XLIX.-Fossils of the Kimeridgian and Portlandian, also Tithonian.

1. Pteroceras Occani, Brngn. 2. Diceras arietinum, Lam. 3. Exogyra virgula, Sow. 4. Aucella mosquensis, v. Buch. 5. Terebratula diphya, Colonna. 6. Thecosmilia trichotoma, Cif. 7. Isastraea helianthoides, Gf. 8. Perisphinctes virgatus, v. Buch. 


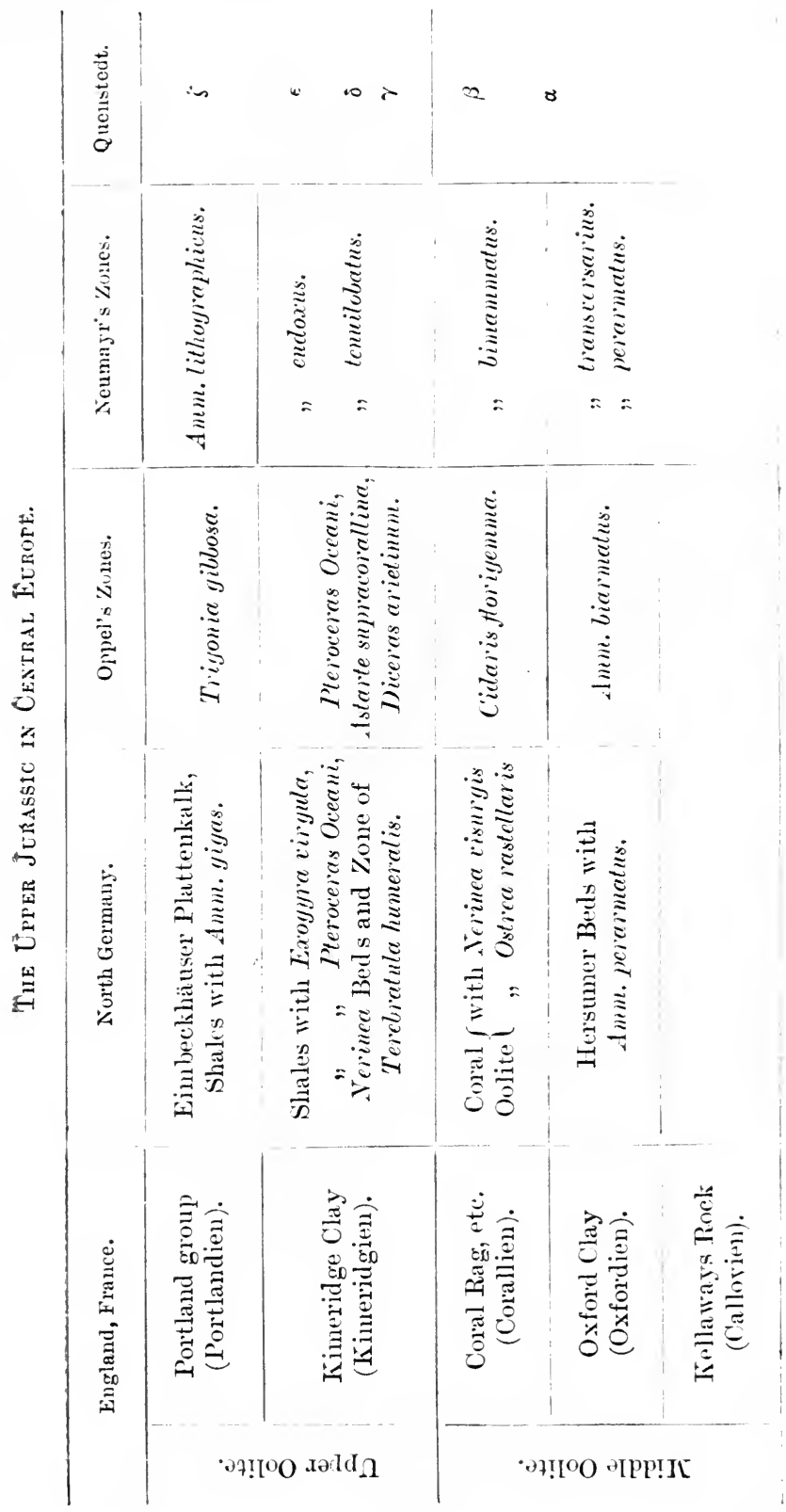


Another peculiar Alpine form of deposit is the so-called Hierlatz Facies (after the Hierlatz Mis. in the Salzkammergut). This is formed by thick white or reddish limestones of ten accompanied by breccias, and it often includes extraordinary masses of Brachiopod and Crinoid remains. A third remarkable facies is known as the Aptychus Shales. These are very uniform, thin-bedded, wrey or variegated calcareous shales, which include hardly any fossils but the well known two-valved bodies (supposed to be organs of Ammonites) known as Aptycluts (XLVIII. 4): and they often represent the whole of the upper half of the Jura together with the Lower Cretaceous.

The classification of the Alpine Jura in general agrees very well with that of Central Europe; in the Lias and Lower Oolite especially, the succession of the zones is quite the same as in Germany and England. It must, however, be mentioned, that in the Middle and Upper Jura there are everywhere great gaps in the succession. Thus it happens that except a few universally distributed zones, the most are known only at a few, or, it may be, only at one solitary point.

The Lias is well developed throughout the greater part of the Alpine region. It occurs especially as red Ammonite limestone with Arictites, Egoceras, Amaltheus, etc. The so called Fleckenmergel, grey spotted platy marly limestones with numerous included Ammonites, are also very widely spread. The Lower and Middle Lias are also represented in many places by the Hierlatz Limestone. Lastly, there is a sandy and marly coastal formation known as the Gresten beds, which are locally coal-bearing (especially at Fünfkirchen in Hungary).

The Middle Jura in the Alpine area is very badly dereloped and is very poor in fossils. To the zone of Amm. Murchisonce belong the fossiliferous oolitic Garda limestones (chief locality Cap San Vigilio in the Garda See) $;^{2}$ the Bath series is represented hy the Klaus beds with the wide-spread Posidonomya alpina; and the brachiopod-bearing Vils Limestone (of Vils near Fiissen) is to be considered as a representative of the Kellaways Rock.

1 Neumayr, "Zur Kenntniss d. Fauna d. unterst. Lias in d. Nordalpen. Abh. d. geol. Reichs." (1879). Rothpletz, "Monograp. der Vilser Alpen. Palæontographica." (1886).

${ }^{2}$ Vaček, "Die Fauna der Oolithe von Cap S. Vigilio. Abh. d. geol. Reichsanst." (1886). 
The lower part of the Upper Jura also is poorly represented in the Alps. It is only the later deposits that in the North, and still more in the South Alps, attain a great development. They occur mostly as Ammonite and Aptychus limestones, but sometimes also as Coral reefs or in still other forms. In the S. Tyrolese and Venetian Alps these have been made sufficiently known by the works of Benecke, who was the first to distinguish here at the base of the limestone in question an almost universally developed Horizon with Amm. (Aspidoceras) acanthicus; and as many of the species are identical with forms from the Central European zone of Amm. (Oppelia) tenuilobatus (XLVIII. 1), he correlates it with the Kimeridge. ${ }^{1}$ This group, which has since been traced over large areas from the Tatra and the Balkans to Sicily and Algeria, is followed by white or reddish marble limestones, also of very great horizontal extent, which are distinguished by numerous Ammonites (A. ptychoicus, A. lithographicus, etc.), and the peculiar perforated Terebratula diphya (XLIX. 5). It is these Diphya Limestones and also the Ammonite and Nerineabearing Stramberg Limestones (the organic contents of which have been described by Zittel), 2 which together form the Tithonian of Oppel. ${ }^{3}$ This is an unbroken succession of ammonite-bearing deposits which imperceptibly lead from the Upper Jura into the Lower Cretaceous, and completely bridge over the sharp boundary that exists between the two formations in Central Europe. The Tithonian rocks are now correlated with the Lithographic Limestone of S. Germany (with which they have Ammonites lithographicus and A. steraspis in common) together with the Portland, and are divided into two series, namely, a lower, the Diphya Limestone with Terebr. diphya, Amm. lithographicus, A. cyclotus, etc.; and an upper, the Stramberg Limestone with Amm. transitorius, Terebr. janitor, Diceras Laci, etc. The lastnamed beds, best developed at Stramberg and in the Porte de France near Grenoble, contain about a dozen species in common with the Cretaceous.

1 Benecke, "Trias u. Jura in der Südalpen." (1866). See also Neumayr, "Die Fauna der Schichten mit Aspidoceras acanthicum. Abh. d. geol. Reichsanst." (1873). Favre, "Monogr.d. 1. Zone à Ammonites acanthicus des Alpes suisses. Abh. d. schweiz. pal. Ges." (1877).-C. Mösch, "Der Jura in den Alpen der Ostschweiz." (1872).

2 "Cephalopoden und Gasteropoden der Stramberger Schichten. Mittheil. a. d. Museum d. bayer. Staates." $(1868,1873)$. "Fauna der älteren Tithonbildungen." Ibid. (1870).

3 Keits. d. deutsch. geol. Ges. (1865), p. 535. 
III. The Russian Jura.

After L. v. Buch in 1840 had described from the region of Moscow the first Russian Jurassic fossils, this formation was very soon shown by the works of Murchison ${ }^{1}$ and Count Keyserling 2 to occupy a very large area in the central and northern parts of European Russia. As already remarked, the Lias and all the lower beds of the Middle Jura are absent throughout this region. "The oldest known Jurassic deposits belong to the zone of $A \mathrm{~mm}$. macrocephalus, or, locally, to the Ornatus clays. While, however, these beds, as well as the succeeding representatives of the Oxford Clay (with Ammonites [Cardioceras] cordatus and $A$. alternans) still show a great resemblance in famna to the equivalent deposits of Central Europe, the agrcement becomes less and less in the higher beds, so that it was not till recently that the exact correlation of the latest Russian Jurassic deposits was made clear. According to Nikitin and Pavlow, to whom we nwe this correlation, the Oxford beds are succeeded by Ammonite beds in which, near Ssimbirsk (on the Lower Volga), the characteristic Kimeridge fosssils, Amm. eudoxus and Exogyra virgula, have been found. These are succeeded by the Volga beds of Nikitin. "The lower part of these, the so-called Virgatus beds, are characterized especially by Amm. (Perisphinctes) virgatus (XLIX. 8), a form with very peculiar fasciculate ribs, and by various species of the genus Aucella (A. Pallasi, A. mosquensis [XIIX. 4], etc.) remarkable on account of the great inequality of its two valves. In the Upper Volga beds also, which contain numerous peculiar Ammonites and Belemnites, the large number of species of Aucella (A. Fischeriana, etc.) is striking. Since the two Russian paiæontologists have proved the occurrence of various characteristic species of the Volga beds (Amm. catenulatus, Bclemm. Iateralis Phill. = corpulentus Nikit., Aucella Pallasi, etc.) in the English Portland, the whole of the Lower and a part also of the Upper Volga beds must correspond with that division of the English Jura, whilst the overlying part of the Volga beds corresponds with the Neocomian."

According to Neumayr the palæontological peculiarities of the

1 Murchison, de Verneuil u. Tieyserling, "Russia and the Ural Trountains" (1845).

2."Wissenchafti. Beobacht. auf einer Reise in das Petschoraland" (1848).

$\therefore$ The Upper Volga beds are held to be the equivalent of the Belemnites iateralis zone of the Speton Clay. (See footnote, p. 291.) 
Russian Jura consist in the rarity of the Ammonite genera. Phylloceras, Lytoceras, IIaploceras, and Simoceras, so abundant in the Alpine area, and the complete absence of canaliculate Belemnites and reef-building corals; further in the sparing occurrence of the forms Oppelia and Aspidoceras, and on the other hand the very great development of the Ammonite-like Cardioceras, the group of Belemnites excentricus and absolutus, and more than all of the bivalve Aucella.

The extraordinarily wide distribution of Jurassic formations of the Russian type throughout the northern parts of Europe, Asia, and North America is very remarkable. Similar Jurassic rocks, especially recognisable by the abundance of Aucella, are found in Novaja Semlja, Spitzbergen, throughout Siberia, Kamtschatka, the Aleutian Islands, and Alaska, in Dakota in the United States, on Patrick's Island in the Arctic Archipelago of North America ; and on the East Coast of Greenland.

\section{CLIMATIC ZONES OF JURASSIC TIMES.}

That Jurassic rocks of the Central Russian type are developed all round the North Pole, is a point of great importance; and its significance is increased by the fact that the two other facies which have been described in the preceding pages, namely the Central European and the Alpine, are similarly widely distributed. The Central European facies includes the Jurassic deposits of England, of X. W. Spain and Portugal, the whole of extraAlpine France and Germany, the parts of Hungary and Russian Poland that lie north of the Alps and the Carpathians, the north border of the Caucasus, and, after a great break, the Jurassic: rocks known in Japan and California. In the Alpine facies are included not only the Jurassic beds of the Alpine and Carpathian areas, of Italy, the Iberian and Balkan peninsulas, but also all that is known of the Jura in the Crimea, in the Inner Cancasus, Asia Minor and Further India, Central Africa (Mombasa) and Madagascar, and in Mexico, Guatemala, Peru, ete. All three facies, as will be seen if we cast a glance at their distribution, occupy wide belts passing round the whole earth in the direction of the parallels of latitude. The zone of the Alpine facies reaches from some $30^{\circ}$ north to the same number of degrees south latitude, and has a breadth of fully $60^{\circ}$. Since there were in the Jurassic period three such zones, following on one another from north to south, and reaching round the whole 
oarth, and since each of these zones possessed its own type of fauna, Nenmayr's conclusion follows-that these three homo-nzoic zones are due to the development of climatic differences; or, in other words, that each of the three zones coincides very nearly with a climatic zone. The absence of reef-building corals during these early times, in the whole of the Northern or Boreal zone, is in this connection an important hint, inasmuch as all the reefbuilding corals of the present day require for their prosperity a high tropical temperature. What tells most, however, in favour of Neumayr's theory, is the fact that all the Jurassic rocks known to the south of the equatorial zone, i.e. beyond $30^{\circ}$ south latituder bear, not the character of the Alpine, but that of the Central European zone, or as it is otherwise expressed, the temperate Jurassic zone. The Jurassic deposits found hitherto in South Australia and New Zealand, and also those in Cape Colony, and in Chili, Bolivia, and the Argentine Republic, differ in fauna entirely from the Alpine or Equatorial type, but recall in a striking way the Jurassic development of Swabia, Franconia, and England. If Neumayr's views are correct, such a zone would in fact lie to the south of the Tropical zone, forming a Southern Temperate zone; so that it appears impossible to doubt the correctness of Neumayr's views. We must in fact conclude that climatic zones had been established on our earth in Jurassic times.

\section{P.1L.EONTOLOCY OF THE JURASSIC SYSTEMT.}

The Jurassic Flora, like the Triassic, consists mainly of Cycads and Conifers, Ferns and Equisetacex. Among the Conifers, Baicra, Araucaria, Gingko and others are the most abundant; among the Cycads, Zamites, Podozamites, Diomites, etc.

In the uncommonly rich Fauna, sponges are very much developed; in the Upper Jura especially, they often occur as rockbuilders. Of the Lithistidæ we need only mention here the genera Chemidiastrum (XLVIII. 5), IIyalotragos and Cylindroplyyma ; of the Hexactinellidx Tremadictyon and Craticularia.

Corals also occur in great abundance, especially in the Upper Jura. The commonest are the composite reef-building forms (such as Thammastrace, Isastraca [XLIX. 7], Latimaandra [XLIX. 6], Thecosmilia, Calamophyllia, etc.) which, however, were limited to the warmer seas; while of the solitary corals Montlivaltia (XLVI. 6) deserves mention. 
Echinoderms are very richly developed; and the sudden increase of Echinoids by the side of the hitherto predominant Crinoids is remarkable. Among the latter the genus Pentacrinus (XLI. 6) (with pentafoliate ornamentation of the stalk joints and an extraordinarily richly branched crown) deserves the first place. Next come the genera, especially abundant in the Upper Jura, Eugeniacrinus, Apiocrinus (XLVII. 4) and the stalkless Antedon (Comatula). Among the Echinoids the genera Cidaris (C. coronata [XLVIII. 7], C. florigemma, etc.) Acrosalenia and Hemicidaris (XLVII. 5) belonging to the group of Regular Echinoids; and Echinobrissus (XLVI.5), Holectypus (XLVIII. 6), Collyrites, etc., belonging to the Irregular group, are specially important.

The Brachiopods have decreased in variety ever since Triassic times, and only two families are left which are rich in species or in individuals, namely the Terebratulidæ (with the chief genera 'Terebratula and Waldheimia; also Megerlea [XLVII. 6] in the Upper Jura) and the Rhynchonellidæ. As the last survivors from the Palæozoic period we find in the Lias still a few Spiriferidæ (Spiriferina Walcotti [XLI. 7] and others.)

The Lamellibranchs are of greater importance. Among the Monomyaria the large true Oysters (Ostrea, Gryphaca, Exogyra) for the first time become abundant and often form beds. Several, such as $G$. arcuata (XLI. 4), Ex. virgula, etc. are important type forms. Lima (XLI. 3) also and Pecten as :well as, among the Heteromyaria, Avicula, Pseudomonotis (XLVI. 2), Aucella (XLIX. 4), Posidlonomya (XLIII. 5), Gervillia and others are very widely spread. Among the Homomyaria Trigonia (T. navis [XLIV. 2], T. costata [XLIV. 3], T. clavellata, etc.) is specially important; of the Dimyaria only Astarte (XLIV. 4), Diceras (XLIX. 2), Cyprina and Isocardia are represented; of the Sinupalliata, which are still but sparingly developed, Pholadomya (XLIV. 6, 7), Goniomya (XLV. 1), and Pleuromya.

The Gasteropoda, although richly represented, show few peculiarities. Pleurotomaria (XLII. 6) is especially rich in species. - In the Upper Jura the turreted genus Nerinea (XLVII. 8), characterized by numerous internal spiral folds, plays a prominent part. In the Kimeridge of Central Europe the genus Pteroceras, with the type Pt. oceani (XLIX. 1), is important.

Far the most important of the Mollusca are the Cephalopods: and among them the Ammonites, which everywhere afford the most important type and zone fossils. Of the chief Triassic 
families of Ammonites only the Phylloceratidæ and Lytoceratidæ with the two type genera Phylloceras (XLIII. 1) (=Group of IIeterophylli, L. v. Buch, with involute shell and very characteristic leaf-like widened saddles to the sutures) and Lytoceras (XLII. 2) (=Fimbriati, d'Orbigny, evolute shell with a fimbriate cross striation of the shell and large symmetrically divided lateral lobe) reach to the Jura. All the remaining families and genera are new. For the Lias the important genera are Arietites (XLI. 2) (= Arietes, v. Buch, only in the Lower Lias; more or less evolute, with simple straight ribs not continued to the back; back with a middle keel bordered by two channels), Egoceras (XLII. 1) (=Capricorni, v. B., evolute, with simple ribs flattened on the back), Amaltheus (XLII. 3), (Amalthei, v. B., mostly disc-shaped, tolerably strongly involute, with notched keel), and Harpoceras (XLIII. 2, 3 ; XLIV. 1), (Falciferi, v. B., flat, high mouthed, keeled shell with sickle-shaped ribs or stripes). Amaltheus reaches from the Lias to the Cretaceous, Harpoceras to the Upper Jura. In the Middle Jura the specially important fossils are Stephanoceras (XLV. 3) $f=$ Coronati, v. B., thick, broad-backed shell with ribs beginning simply but further on forming knobs and then dividing), Macrocephalites (XLVI. 7) (=Macrocephali, v. B., very thick swollen shell), Parkinsonia (XLV. 4), (flat, widely umbilicated shell, ribs ending at a smooth groove on the back), Cosmoceras (XLVI. 8) (=Ornati, v. B., shell ornamented with knobs and spines). In the Upper Jura the chief forms are Perisphinctes (XLVIII. 2, 3 ; XLIX. 8) (=Planulati, v. B., flat, widely umbilicated, slightly involute shell with ribs forking beyond the middle of the side), Oppelia (XLVII. 3; XLVIII. 1) (=Flexuosi, v. B., Denticulati Quenst., flat, high-mouthed, strongly involute, mostly very slightly sculptured, forms), Aspidoceras (XLVII. 2) (=Armati, v. B., thick, round backed, generally smooth forms with several rows of knobs).

In comparison with these and the numerous other genera of Ammonites separated in later times, the Nautili are very much reduced in number. Unlike many of those of the Trias, the .Jurassic forms are of normal, rounded, more or less involute shape. On the other hand the Belemnites, which are represented in the Trias only by a few forms, are richly developed in the Jura. The genus Belemnites itself in particular extends through all the groups of the system with numerous species, which are sometimes very large (reaching a yard in length). Among the most important are B. paxillosus (XLII. 4), (Middle Jura) $B$. c. G. 
acuarius, B. clavatus (XLII. 5) (Lias), B. giganteus (XLV. 5), B. canaliculatus (Middle Jura), B. hastatus (XLVII. 1) (Upper Jura). Lastly the occurrence of naked ink-sac bearing Cephalopoda allied to the Loligidæ of the present day, in the Posidonia shales of the Lias and in the Lithographic Limestone (Geoteuthis: [XLIII. 4]) is of great interest.

The Lithographic Limestone contains a rich Crustacean and Insect Fauna. Among the former the long-tailed Decapods (Pencus, Liger, Eryon, etc.) are richly developed, whilst the short-tailed are represented by the small genus Prosopon and its allics. The Liassic beds of Schambelen in Switzerland and

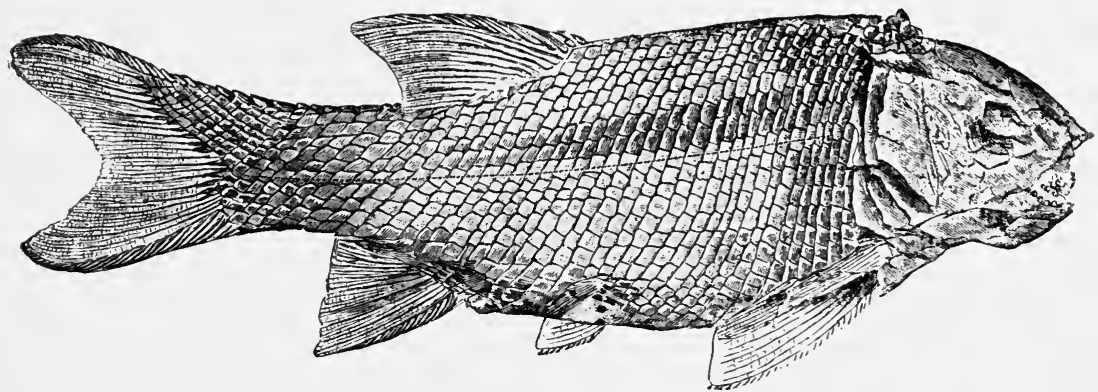

Fig. 36.-Lcpidotus notopterus, Agass. $\left({ }_{6}^{1}-\frac{1}{d}\right.$ nat. size)

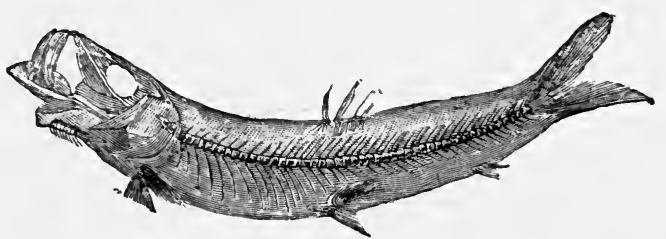

Frg. 37.-Leptolepis sprattiformis, Agass.

Dobbertin in Mecklenburg are important localities for insects, which were very numerous in Jurassic times.

The Vertebrate fauna is also of great importance. Among the fishes the heterocercal Ganoids have almost disappeared. Among the homocercal Ganoids the most wide-spread are the remarkable rhombic Pycnodonts (Gyrodus, Microdon), and the Lepidosteidæ (the large Lepidotus [Fig. 36], Dapedius, the elongated Aspidor.hynchus, striking on account of its very prominent upper jaw). Of the Selachii, Iybodus and Acrodus should be mentioned. The Bony Fishes, which appear for the first time in the Trias, show in the Jura no great increase. The small herring-like genus Leptolepis (Fig. 37) is referred to this group. 
The most important of all the Vertebrates are the Reptiles, which were at no time before or afterwards so richly developed as in the Jurassic period, which is therefore fitly called the age of Reptiles.

The Palæozoic and Triassic Stegocephala, which stand near the boundary between Amphibians and Reptiles, were much reduced. On the other hand both the Ichthyosauria and Plesiosauria, which had already appeared in the Trias, now reach their highest development. The best known and most important genera of these large marine saurians (which do not reach beyond the Mesozoic period), are Plesiosaumus and Ichthyosaurus (Figs 39 and 38). The former is characterized by its remarkable long snake-like neck and small head; the latter by its large pointed head, short neck, thick tail, and a ring of bony plates, the sclerotic ring, surrounding the eye. Plesiosaurus reached 30, Ichthyosaurus 40 feet in length. Both were naked; in both the extremities were changed'into paddles; and both possessed biconcave vertebræ, numerous abdominal ribs, and large conical grooved teeth.

Another very remarkable order of Saurians limited to the Jurassic and Cretaceous is that of the Pterosauria or winged saurians. They possessed pneumatic bones like birds, a long neck, and, as in birds, a keeled breast-bone, whilst their structure is otherwise like that of reptiles. The jaws of the Jurassic forms are always toothed, the toes armed with claws. But the chief peculiarity of these strange creatures lies in the extreme elongation of the outer finger of the front limb. This served for the extension of a flying membrane attached behind to the hind foot, which may itself be observed in impression in some specially well-preserved examples from the Solenhofen limestone-the chief locality for these Jurassic winged saurians. ${ }^{1}$ The two chief genera are Pterodactylus with short and pointed tail (Fig. 40) and Rhamphorhynchus with a long tail flattened at the end (Fig. 41).

A further remarkable circumstance is the great development of Chelonians, which were still rare in the Trias. These occur in tolerable abundance in the Upper Jura of Solothurn, Solenhofen, and Hanover. Crocodiles also were fairly widely distributed and include the Gavial-like genera Mystriosaurus and Teleosaurus, which differ however from the living forms in possessing the embryonic character of biconcave vertebræ.

Lastly, the Dinosaurs were fairly abundant. To this group belong 1 Zittel, "Palæontographica" (1882). 
the long-necked Compsognathus of the Solenhofen limestone, with short anterior and unusually long posterior limbs, and a bird-like

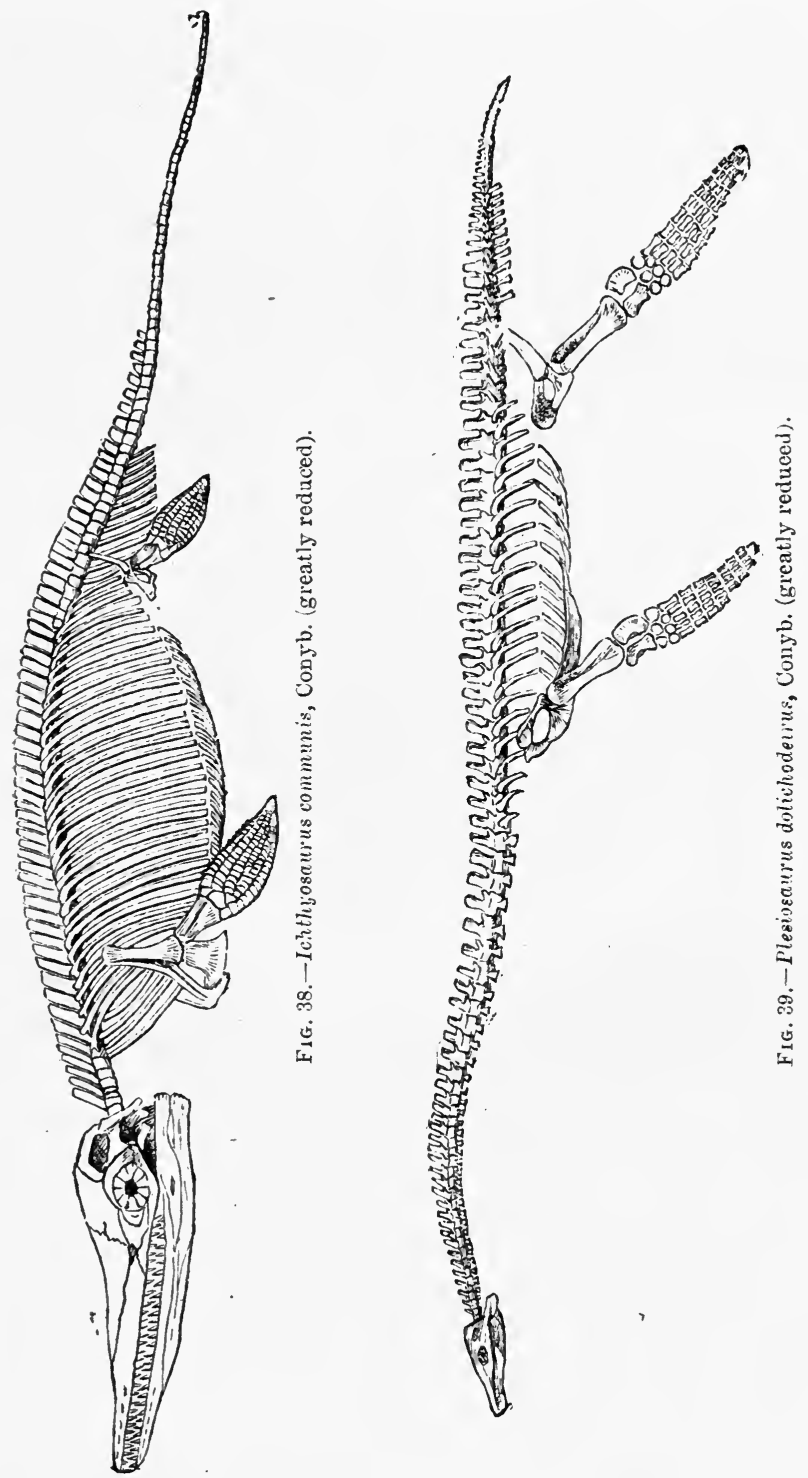

pelvis; also the American Brontosaurus, Atlantosaurus (over 100 ft. long), and others. It is still uncertain, however, whether 


$$
\text { B.-JURASSIC SYSTEM. }
$$

the latter does not belong to the Cretaceous rather than to the Juiassic.

The occurrence of the oldest known bird, the genus Archacopteryx $x$, in the Solenhofen Limestone is of special interest (Fig. 42).

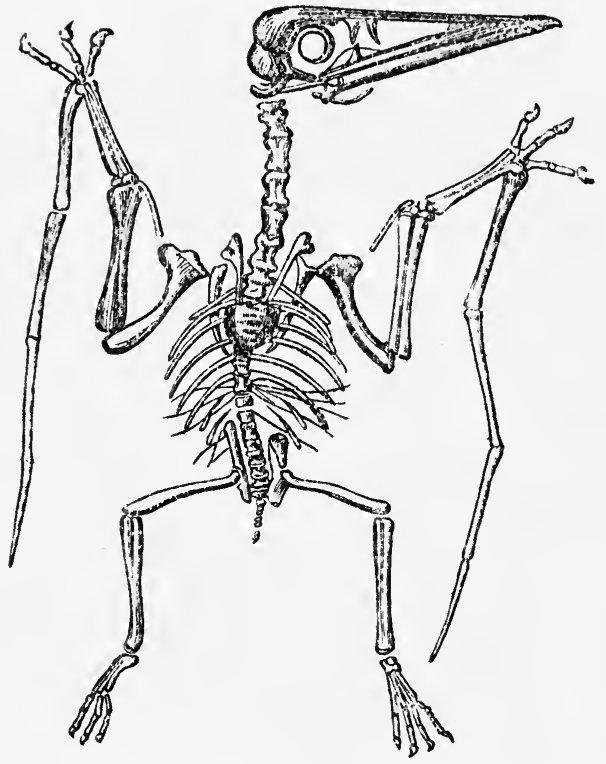

Fia. 40.-Pterodactylus spectabilis, H. v. Mej., somewhat reduced.

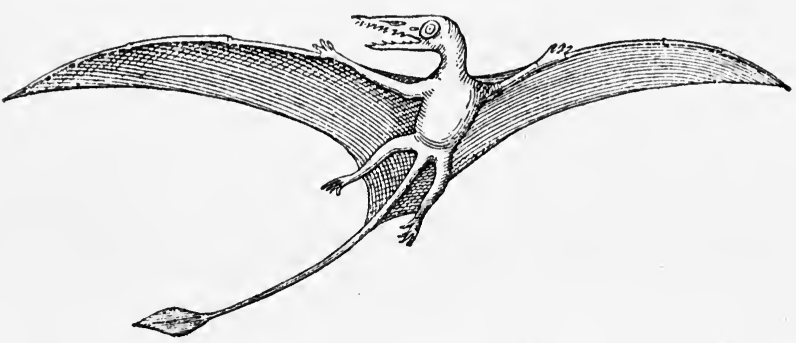

F1G. 41.-Restoration of Ramphorhynchus phyllurus, Marsh. Reduced (after Marsh!. 
As the examples hitherto discovered show, ${ }^{1}$ this creature may be spoken of as a true bird; the feathers, the closed skull and the

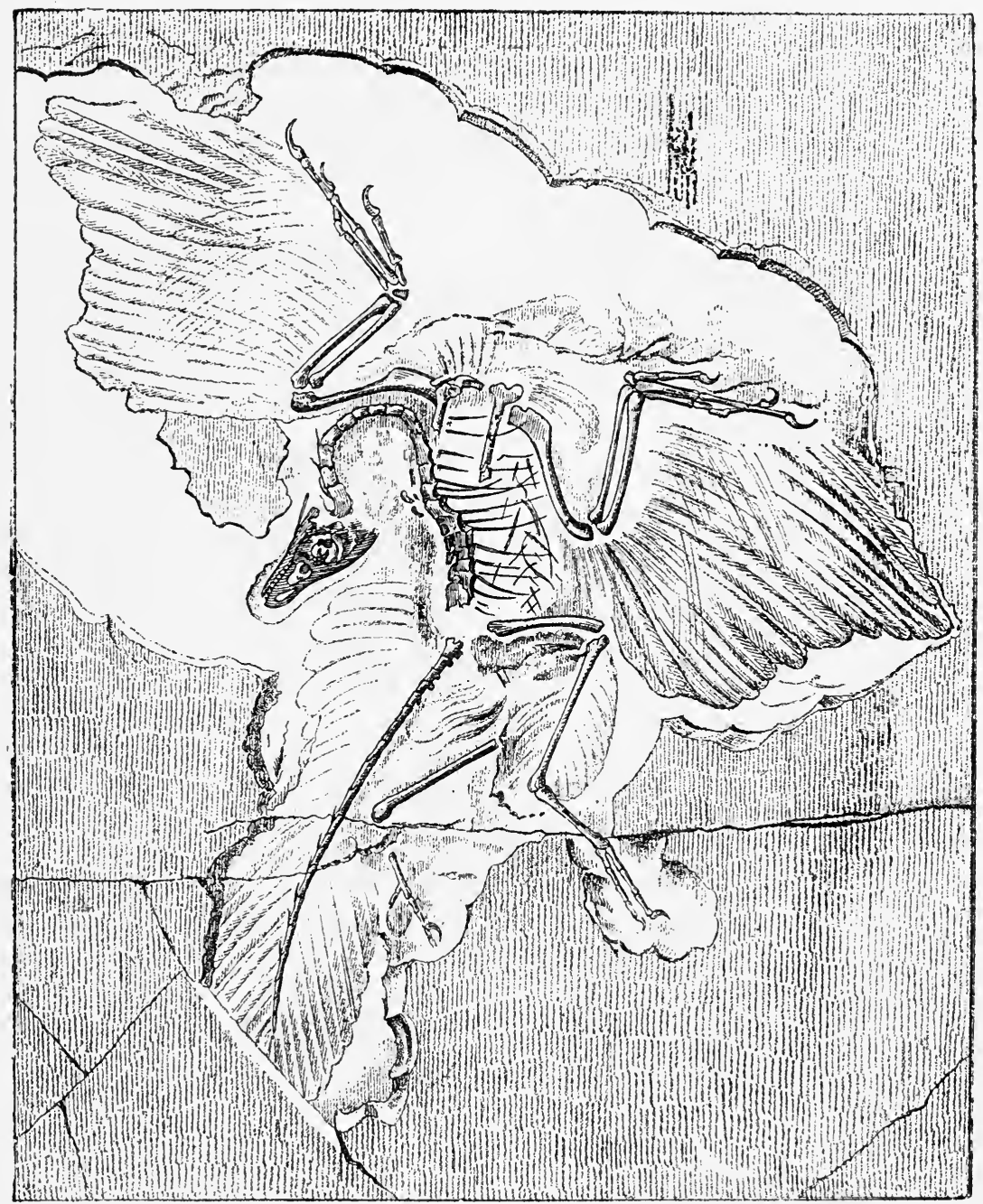

FIG. 42.-Aichooptrvyx macrura, Owen.

Specimen in the Berlin Museum, about $\frac{1}{3}$ rd natural size.

1 One is preserved in London, a second, more complete, in the Berlin Museum. The latter has been made the subject of a monograph by W. Dames (Dames u. Kayser, "Paläontol. Abhandl.," 1884). 
structure of the foot are sufficient proof of this. The biconcave vertebræ, however, the sclerotic ring of the eye, the teeth, the long lizard-like tail, the very thin ribs pointed at the end, the presence of 12-13 pairs of abdominal ribs, the three free claw-bearing fingers of the anterior limb, etc., are characters which are partly of an embryonic nature, partly characteristic of reptiles, so that this remarkable animal bridges over in great measure the large gap existing at present between birds and reptiles.

Finally, the Jurassic mammals, like those of the Trias, all belong to the Pantotheria, and their remains have been found in the English Jura (Stonesfield Slate).

\section{CRETACEOUS SYSTEM.}

\section{GENERAL AND HISTORICAL.}

The Chalk or Cretaceous System, the youngest of the three great Mesozoic systems, is widely spread over the whole earth; but is very differently formed in different areas. The name originated in England where, as also in N. France and in the Baltic area, the white writing chalk plays an important part in the upper division of the system. Even in these regions, however, various other calcareous, clayey and sandy deposits take part in the constitution of the system; and in other regions, such as Saxony and Bohemia, the Alps, etc., the white chalk is entirely absent, so that the term Chalk, which has become naturalised among the geologists of all countries, is by no means happily chosen for the System in question.

Like the Jura the Cretaceous was first accurately described in England. W. Smith and his immediate successors there distinguished (about the year 1820) a lower glauconitic sandy series, the Greensand, from the true chalk and its accompanying marls, the Chalk, and also separated a clayey formation interbedded in the Greensand, as the Gault. The upper part of the Greensand lying on this was called the Upper, that found below, the Lower Greensand. Lastly, even at that time the name Wealden beds was applied to a thick, fresh-water formation which was however developed only in the S. of England.

The Cretaceous System is developed very characteristically in France, where it occurs both in the north and south of the 
country, very differently constituted in the two areas. It was first comprehensively studied by d'Orbigny. ${ }^{1} \quad \mathrm{He}$ originally distinguished (towards the beginning of the fifth decade of this century) in the Lower division of the system three groups,namely, the Neocomian, the Aptian, and the Albian; and in the Upper division, four groups, - the Cenomanian, Turonian, Senonian and Danian. Later (1850) he added the Urgonian, to include beds which he had formerly classified as Upper Neocomian; so that now each of the two main divisions of the Cretaceous was divided into four groups.

In Germany single groups of the Cretaceous System, such as. the Quader Sandstone, the Plänerkalk, and the Hils, have long been distinguished by special names: but owing to the changes. of facies proper to the North German Cretaceous and the generally imperfect character of the exposures, it is only recently that we have attained to a correct comprehension and classification of these deposits.

Among the first who occupied themselves with the detailed study of the Cretaceous in Germany and described its fossils, were: H. Br. Geinitz, ${ }^{2}$ F. A. Römer, ${ }^{3}$ and Reuss. ${ }^{1}$

The so-called Wälderthongebirge of N.W. Germany, a brackish. and fresh-water formation corresponding with the English Wealden, ${ }^{5}$ lying at the base of the Cretaceous, found about the same time an exponent in W. Dunker. ${ }^{6}$ The further examination of the $\mathrm{N}$. German rocks has been carried out by Beyrich, Ewald, F. Römer, v. Strombeck, Heinr. Credner and others, and in the most recent times by Schlüter. In general the classification adopted in Germany is that of d'Orbigny, with, however, the difference that the term Neocomian is used in d'Orbigny's older and wider sense, and that instead of the names Aptian and Albian, the term Gault is employed in a wider sense than in England, and that the Danian is united with the Senonian. Thus we get the following general classification of the Cretaceous in England, France and Germany.

1 "Paléontologie française. Terrain crétacé" (1840-46).

— "Characteristik d. Schichten und Petrefacten d. Sächs. Böhm. Kreidegebirges" (1839-43). "Das Quadersandsteingebirge oder Kreidegebirge in Dentschland" (1849-50).

3 "Die Versteinerungen d. norddeutsch. Kreidegebirges" (1840-41).

4 "Die Versteinerungen d. böhm. Kreideform." (1845-46).

' See note on p. 287.

6 "Monographie der norddeutschen Wealdenbildung " (1846). 


\begin{tabular}{|c|c|c|c|}
\hline England. & France. & Gerinany. & \\
\hline Chalk $\left\{\begin{array}{l}\text { Upper. } \\
\text { Middle. } \\
\text { Lower. } \\
\text { Upper Greensand.j }\end{array}\right.$ & $\begin{array}{l}\text { Danien. } \\
\text { Senonien. } \\
\text { Turonien. } \\
\text { Cenonamien. }\end{array}$ & $\begin{array}{l}\text { Senon. } \\
\text { Turon. } \\
\text { Cenoman. }\end{array}$ & 岀 \\
\hline $\begin{array}{l}\text { Gault. } \\
\text { Lower Greensand. } \\
\text { Wealden. }\end{array}$ & $\begin{array}{l}\text { Albien. } \\
\text { Aptien. } \\
\text { Neocomien. }\end{array}$ & $\begin{array}{l}\text { Gault. } \\
\text { Neocom. }\{\text { Hils and } \\
\int \text { Wealden. }\end{array}$ & 苟 \\
\hline
\end{tabular}

In England the above grouping is still followed. In France and Switzerland, on the other hand, the classification of the Cretaceous has been made much more detailed since d'Orbigny's time. However, the various French authors agree but little in the grouping and many have retained the old classification to the present. day. In Germany a palæontological division into zones has become usual by the side of d'Orbigny's classification. This was first made by the work of v. Strombeck, and has been more strictly established for the Upper Cretaceous by Schlüter. ${ }^{1}$ Similar attempts have been made within the last ten years in France, Switzerland and England, and have shown that Schlüter's classification is in the main applicable to other countries; and there is no doubt that in time we shall attain to a general classification into zones of the chalk formation like that which has long been established for the Jurassic.

The boundary between the Cretaceous and Tertiary beds is very sharp throughout Central and Northern Europe. The separation from the Jura also is generally very clear. Connected with this is the fact that in the greater part of Europe the deepest beds found do not reach down to the Lowest Cretaceous or Neocomian, and the system rather begins with younger Neocomian beds lying on and overlapping the older deposits. It is only in the Alpine area and in a part of N.W. Germany and S. England that there is a complete passage from the Jura to the Cretaceous - a passage which in the first named region is formed by marine, and in the two latter by brackish water deposits,-and here the connection between the older and newer formation is so intimate that as yet 
there is no universal agreement as to the mutual limits of the systems.

The Cretaceous System is universally divided into a Lower and an Upper division. Many geologists consider the two as distinct systems and limit the name of Cretaceous to the Upper, while they distinguish the Lower as sub-Cretaceous (or infra-Cretaceous). The Joundary between the two is indistinct only in a few areas in England, where the Gault passes up quite gradually into the Greensand. Throughout the rest of Europe the distinction between Lower and Upper Cretaceous is very sharp. This is the result of a great transgression beginning at the commencement of the Upper Cretaceous. The circumstance that this transgression is observable not only throughout Europe but also in other quarters of the globe, shows that here we have to do with one of the greatest changes in the distribution of land and water over almost the whole earth, that is known in Geological history. Extensive areas which had for long periods been continents, were now overflowed by the sea and covered with Cretaceous deposits. As an example of this great event we may mention the occurrence of Cenomanian at Essen and Namur lying directly on Archæan rocks. In the S.IV. of England also, on the borders of the French Central Plateau, in Asia Minor, Persia, etc., in Hindostan and E. Asia, almost throughout N. America,' in Brazil, W. Australia, and E. Africa, the same thing may be observed: everywhere in these regions deposits of Upper Cretaceous occur immediately above much older rocks.

Moreover, this great transgression was by no means sudden; but even in the older Cretaceous periods similar, though slighter, fluctuations of the sea took place. Thus a large area of Central Europe which during the first phase of the Neocomian was still land, and bore the great Anglo-German Wealden lake, was in the Middle Neocomian period, changed into a sea bed. This circumstance accounts for the above mentioned absence of the lowest marine Neocomian beds in N. France, Germany and England; and it also determined the overlap, in some areas of England, of the Gault over the Lower Greensand on to the region of older rocks. In a similar way many movements of the earth took place in postCenomanian times and caused smaller overlaps, as the occurrence at Aix-la-Chapelle and other places of Senonian deposits on much older beds, shows.

Another, not less significant feature of the Cretaceous System, 
is the striking difference between the Northern and Southern facies. The Northern Cretaceous, which in Europe includes the whole of N. France, England, extra-Alpine Germany, Denmark, S. Scandinavia, and Russia, is distinguished palæontologically by the almost complete absence of the remarkable Lamellibranch families of Caprotina and Rudistes, which attain so extraordinary a development in the S. European Cretaceous; by the absence of reef-building corals; by the rarity of the Ammonite grenera Lytoceras, Phylloceras, and Haploceras; by the great abundance of Belemnitella and Inocerami, and by other characters. The S. European facies on the other hand, which includes the whole of the S. European deposits except those of the Alps and Carpathians, is marked by the occurrence of Rudistes and Caprotina, by the abundance of the above named genera of Ammonites, by the so-called Chalk Ceratite (genus Buchiceras), by the peculiar group of swollen Belemnites (genus Duvalia), by the Gasteropod genera Actaconclla, Nerinea, and others, by the coral genus Cyclolites, etc. The circumstance that the contrast between the Northern and Southern facies of the Chalk is repeated in a similar way in $\mathrm{N}$. America, where the Cretaceous of New Jersey, Tennessee, Kansas, Dakota and California represents the North European formation, and that of Texas and Alabama, of Mexico, the West Indies and Columbia (with Rudistes, Actaoonella, Buchiceras, etc.), the South European; led Römer as far back as the middle of the century to consider these differences due to differences of climate. ${ }^{1}$ Since we have seen above that climatic zones probably existed in Jurassic times, their re-appearance in the Cretaceous period can in no way seem strange but must rather be expected.

The lie of the Cretaceous beds, like that of the Jurassic deposits, is in general simple and undisturbed throughout Northern and Central Europe. Only in a few restricted areas, such as the North of the Harz and in the Teutoburger Wald, do steep dips and reversals occur. Similar disturbances in connection with strong foldings are repeated over much larger areas in the Cretaceous formations of the Alps and other high mountain ranges. Volcanic action in the Cretaceous period, as in the Jurassic, was also very slight. In Europe eruptions of this period have practically not ween discovered; on the other hand in India and Chili ex- 
tensive basaltic and porphyritic flows of late Cretaceous age are known.

\section{DISTRIBLTION AND DEVELOPMENT OF THE CRETACEOUS.}

On account of the independence of the two divisions, as shown by their distribution, it seems advisable to describe the Lower and Upper Cretaceous apart from one another. It will also be necessary to treat of the Northern and Southern facies of the System separately.

\section{Lower Cretaceous.}

Louer Cretaceous of Germany, Northern France, and England.

The extent of the Lower Cretaceous in Germany is rather limited. It occurs only in the $\mathrm{N}$. of the Harz, in Brunswick and Hanover, as far as the north border of the Wesergebirge, and in the Teutoburger Wald. In continuation of the latter, older Cretaceous rocks rise above the alluvium in the region of Bentheim (not far from the Dutch border).

In the North of France the Cretaceous formation occupies a large part of the plain between the old mountain cores of the Ardennes, the Central Massif, and Brittany. Lying directly on the Upper Jurassic, the Cretaceous beds dip gently towards the middle of the basin, to be there overlaid by Tertiary deposits.

The English Cretaceous region is only a continuation of this Cretaceous area of Northern France. It occupies, though indeed of ten covered by overlying Tertiary and even younger beds, the whole space east of the Jurassic belt already described, which stretches in a northerly direction from the Channel to the East Coast of the Island; and the Cretaceous rocks lie upon the youngest beds of this belt with a gentle easterly dip. It follows that within this great Anglo-Gallic Cretaceous basin the Lower Cretaceous beds must in the main be limited to the outer borders. However in the S.E. of England, in consequence of an anticlinal here present, a large area of Lower Cretaceous crops out in the middle of the basin; and it is just in this part that the peculiar facies of the Wealden is developed -a facies which is not elsewhere found of any extent except in the N.W. of Germany. Since these brackish and shore deposits, at least in their lowest parts, represent the oldest Cretaceous formations of Central Europe, they will be first described here.

Wealden.-The Wealden, or Weald Clay, stretches in Ger- 


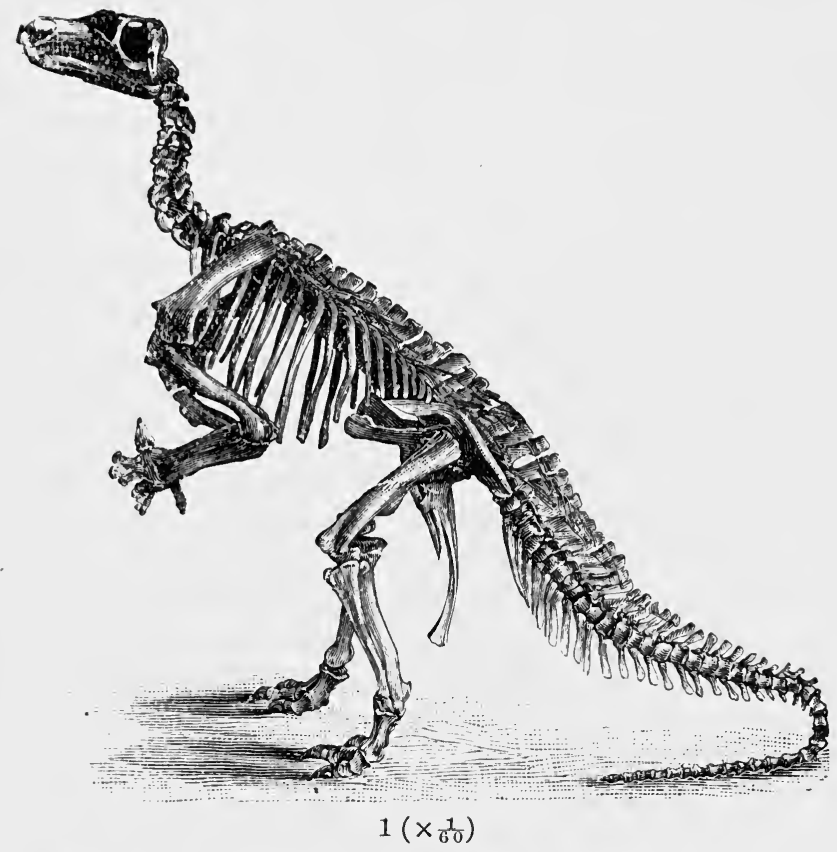

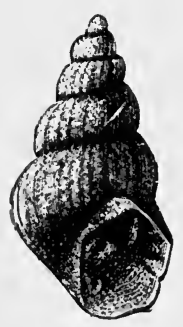

()

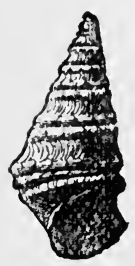

(3)

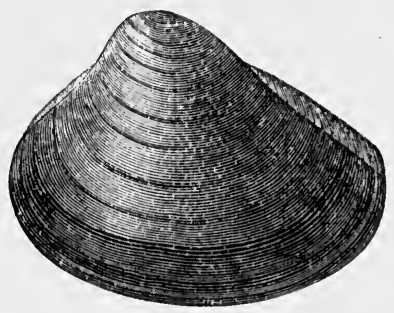

ј

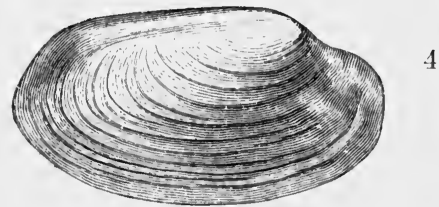

4

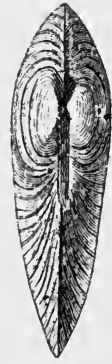

Plate L.-Fossils of the Wealden.

1. Iguanodon bernissartensis, Boulgr., restored by Dollo. 2. Paludina fluviorum, Sor. 3 Melania strombiformis, Schloth. 1. Unio planus, A. Röm. 5. Cyrena Bronni, Dunk 
many from Brunswick to Bentheim not far from the Dutch border, and is at the same time developed in the Deister, Osterwald, Süntel, the Bückeburg Mountains, and in the Teutoburger Wald. ${ }^{1}$ As the oldest fresh-water formation of so great extent and thickness, it is of quite special interest. Its fresh-water character is quite free from doubt; in England, Unios, and Paludinas, in Germany, Cyrenas and Melanias fill whole banks.

In Exgland the marine Portland beds of Portland are followed quite conformably by the Purbeck beds, calcareous deposits gradually becoming more and more fresh-water in character. These are usually included with the Jurassic rocks; but Topley considers that they cannot justly be separated from the Wealden, and must therefore be referred to the Cretaceous. They consist of an aiternating series of limestones, clays, and marls, and, especially. in the upper parts, contain true fresh-water shells (Unio, Cyclas, Cyrena, Paludina, Planorbis, Limnaa); but they also contain marine beds, among which is the "Cinder bed," which is made up of the shells of Ostrea distorta. The most striking of the Purbeck deposits, however, are the "Dirt-beds," which consist of sandy clay with carbonaceous matter. These are terrestrial soils and (at the base of the Middle Purbeck) have yielded many remains of marsupial mammals (Spalacotherium, Amphitherium, Plagiaulax, Stylodon, etc.); and one especially is full of the stools and trunks of trees (cycads and conifers).

The succeeding beds form the Wealden Series, as the term is usually employed in England. They consist of clays, sands, sandstone and shelly limestones, all of which are of lacustrine or estuarine origin; and they are found principally in the Weald of Kent, Surrey, and Sussex; but occur also in Dorsetshire and the Isle of Wight. The fossils include plant remains (Pecoptcris, Sphenopteris, etc.), ostracods (Cypridea Valdensis, etc.), freshwater shells (Cyrena, Unic Valdensis, Paludina, etc.), fishes and reptiles. The best known of the latter is the Iguanodon (L. 1), but Megalosaurus, Hylaeosaurus, etc., are also found.

In the Weald they are divided into

$$
\text { Weald Clay. } \begin{aligned}
& \text { Tunbridge Wells Sands. } \\
& \text { Hastings Beds }\left\{\begin{array}{l}
\text { Wadhurst Clay. } \\
\text { Ashdown Sand. }
\end{array}\right.
\end{aligned}
$$

1 See the Monograph of Dunker already mentioned, and also Struckmann's " Die Wealdenbildungen der Umgegend von Hannover" (1880). The English Wealden was first made known by Mantell and Fitton (1822-24). 
The Hastings Beds are generally sandy and with local beds of clay; while the Weald Clay is chiefly clay with layers of shelly limestone.

In Lincolnshire (according to Pavlow ${ }^{1}$ ) the Wealden is represented by the lower part of the Tealby Clay and the upper part of the ferruginous rock of Claxby. In Yorkshire its marine representative is the lower portion of the Belemnites jaculum beds of the Speeton Clay.

In Germany the Purbeck is represented by: (1) the $M \ddot{u} n d e r$ Marl, 300-400 ft. thick, a variegated, Keuper-like marl containing gypsum and salt and very few fossils. (2) The so-called Serpulite, a limestone from a few feet to 60 feet thick, penetrated by innumerable winding tubes of a marine Serpula (Serpula coacervata). Besides this it contains only Corbula inflexa (a form which occurs in the Jurassic Plattenkalk of Eimbeckhaus, and is present also in the Münder Marl), Cyrena, Melania, and a few other fossils. The Hastings Sand ${ }^{2}$ is represented by the Deister Sandstone,-a pale-coloured sandstone 150 feet thick, which yields a well-known building stone. Palæontologically it is interesting on account of the Cheirotherium-like footprints of Iguanodon and allied Dinosaurs, and the remains of the skeletons of Iguanodon, Crocodiles and Chelonians; and economically it is important for its valuable coal seams (worked particularly in the neighbourhood of Obernkirchen). The clays accompanying the coal contain the remains of a rich flora described by Schenk, ${ }^{3}$ which is composed especially of Cycads, Conifers, and Ferns, and still shows quite a Jurassic character. The coal-bearing beds also contain large ganoid fish (Lepidotus) and Iguanodon remains.

Lastly, the English Weald Clay is represented by the German Wälderthon, dark grey shales, 70-100 feet thick, with interbedded limestones which are filled with examples of Cyrena (L. 5), Cyclas, Paludina (L. 2), and especially Melania strombiformis (L. 3), whilst the clays are full of innumerable shells of $C y p r i s$.

Hence we get the following classification of the German and English Wealden:-

1 Pavlow and Lamplugh, "Argiles de Speeton et leurs équivalents." Moscow (1892).

2 Ácc. to Pavlow, loc. cit., the German "Wealden" represents the upper part of the English Purbeck; while the English Wealden corresponds with a part of the German "Hils."

3 "Die fossile Flora der nordwestdeutschen Wealdenformation. Palæontographica" (1871). 


\begin{tabular}{|c|c|c} 
& Germany. & England. \\
\hline Upper. & Wälderthon. & Weald Clay. \\
\hline Middle. & $\begin{array}{c}\text { Deister Sandstone } \\
\text { (w.coal seams). }\end{array}$ & Hastings Sands. \\
\hline Lower. & $\begin{array}{c}\text { Serpulite. } \\
\text { Münder Mergel. }\end{array}$ & Purbeck. \\
\hline
\end{tabular}

As already pointed out, the views concerning the most natural elassification of the Wealden still differ from one another:v. Dechen, Struckmann and others refer it to the Jura ; v. Strombeck, Beyrich and others to the Cretaceous. Struckmann argues for his views from the great number of species common to the Wealden and the uppermost beds of the Jura. Beyrich, however, lays stress nn the fact that-as was first shown by Strombeck,- - wherever the Wealden is developed in N. Germany the marine Neocomian, begins with newer beds than where no Wealden is present. From this it follows directly that the Wealden and the Lower Neocomian are equivalent formations; and this is confirmed by the occasional occurrence-observed both in Germany and in England - of beds with marine Neocomian fossils in the midale of the fresh-water deposits.

Some authors indeed place the Upper Wealden beds in the Cretaceous but leave the Münder Marl and Serpulite in the Jura. These beds, however, are intimately connected, palæontologically, with the overlying Wealden, and in Germany their distribution coincides with that of the latter and not with that of the Jura. Pavlow ${ }^{1}$ in a recent work correlates the Münder Marl, Serpulite and German "Wealden" with the English Purbeckian; while he places the Weald Clay and Hastings Sands, the Wealden of England, at a higher horizon (= the greater part of the German Hils.)

It should be noticed here that a weak development of Purbeck deposits (with Corbula inflexa) is found in the neighbourhood of Neuchatel, and that similar old Cretaceous fresh-water deposits are found in Portugal and the Peruvian Andes.

Neocomian. - The Neocomian (so called in 1832 by Thurmann, after Neocomum, the Latin name of Neuchatel), has long

1 Pavlow and Lamplugh, "Argiles de Speeton et leurs equivalents." Moscow (1892). 
been known in northern Germany under the local name of Hils. We owe our detailed knowledge and classification of this formation to v. Strombeck. ${ }^{1}$

The North German Hils begins with a calcareous conglomerate, which includes numerous nodules of sphæro-siderite, the so-called Hils Conglomerate, and this is succeeded by the Hils Clay. These series are subdivided as follows :-

IIils Clay.

(3) Clays with Crioceras Emerici (LIII. 3)-also Toxaster complanatus Anım. astierianus, A. noricus.

(2) Clays with Exogyra Couloni (LI. 3).

(1) Elligser Brinks Clay with Belemnites sub-quadratus, B. pistilliformis, Amm. (Hoplites) noricus (LI. 1), Thracia Phillipsi, etc.

Hils Conglomerate.

(3) Unfossiliferous Clays.

(2) Beds with Toxaster conıplanatus (LI. 4), Amm.(Olcostephanus) astierianus (LI. 2), Amm. (Hoplites) radiatus, Ostrea macroptera, and numerous brachiopors.

(1) Beds without these fossils.

This succession, however, is applicable only to the Brunswick area. Further west, Wealden is developed instead of the Hils Conglomerate, and a sandstone, which contains numerous interbedded layers of granular red ironstone, instead of the Hils Clay. This is especially the case at Salzgitter, where this ironstone contains a rich Ammonite fauna." Here, as in the Hils Sandstone, the large Pccten crassitesta is, along with the Ammonites, a characteristic fossil. On the other hand, as we go from Brunswick to the east, the Hils conglomerate and clay pass into sandstone, so that the development of the Hils in N. Germany is as shown in the following table:-

IVEST.

EAST.

\begin{tabular}{c|c|c|c}
\hline $\begin{array}{c}\text { Upper } \\
\text { Hils. }\end{array}$ & $\begin{array}{c}\text { Teutoburger Wald, } \\
\text { Deister, Süntel. } \\
\text { Sandstone, in part } \\
\text { with Ironstone. }\end{array}$ & $\begin{array}{c}\text { Goslar, } \\
\text { Brunswick Area. }\end{array}$ & $\begin{array}{c}\text { Quedlinburk, } \\
\text { Halberstadt. }\end{array}$ \\
\hline $\begin{array}{c}\text { Lower } \\
\text { Hils. }\end{array}$ & Healds Clay. & Sandstone. \\
\hline
\end{tabular}

1 "Neues Jahrb." (1857), p. 639, and Zeits. d. deutsch. geol. Ges. (1861), p. 20. Sre also G. Bühm, Ibid. (1877), p. 215.

"Neumayr and Uhlig, "Palæontographica" (1881). Sze also Weerth,

"Fauna d. Neocomsandst. d. Teutoburg. Waldes. Paläont. Abh." (18\&4).

c. G. 

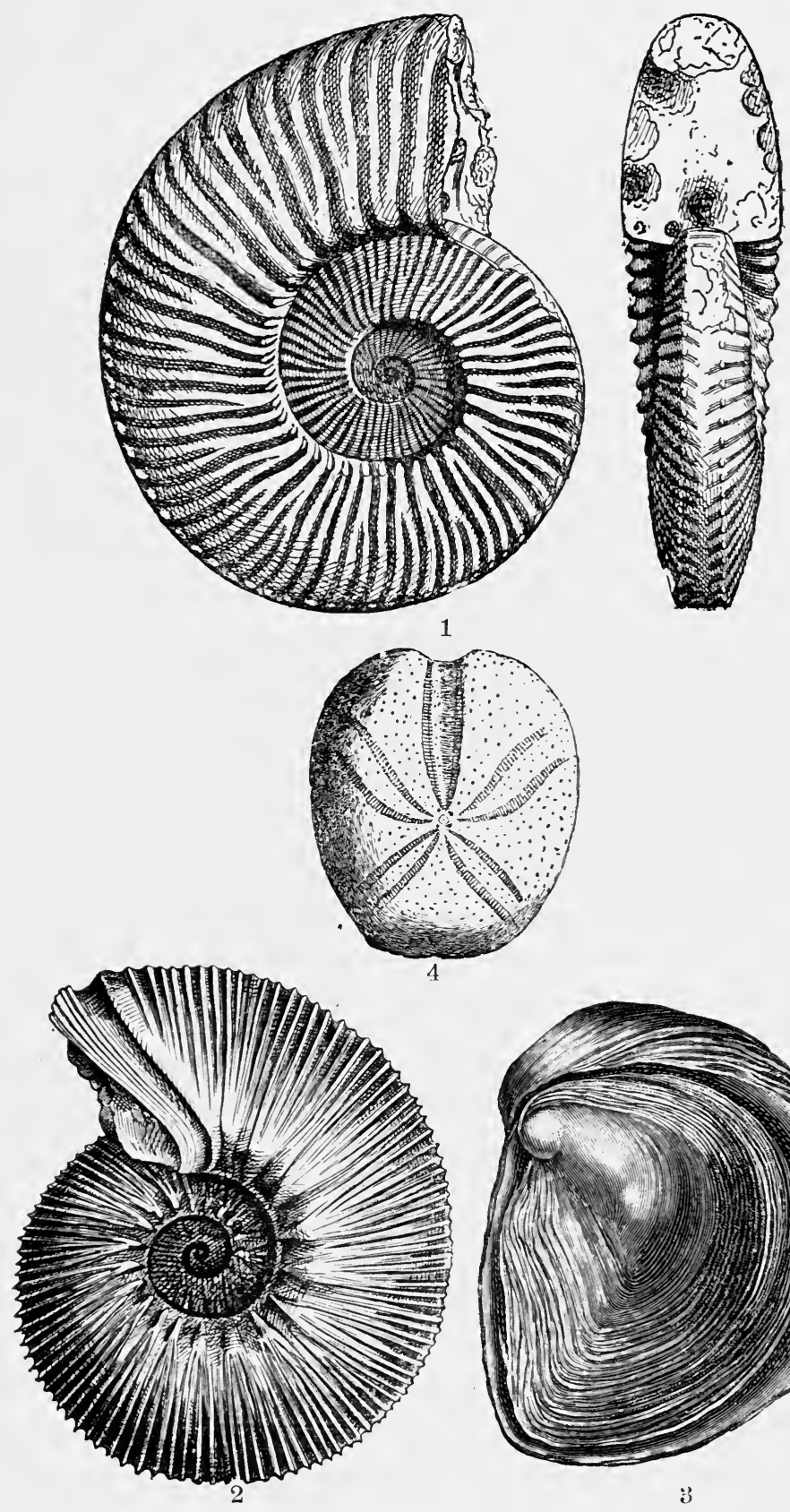

1

Plate LI.-Fossils of the Neocomian.

1. Floplites noricus, Schloth. 2. Olcostephanus astierianus, d'Orb. 3. Faogyra Couloni, d'Orb. 4. Toxaster complanatus, Agass. 
In ENGland the Neocomian is similarly formed. Here also in the area of the Wealden development, in the south of the country, the Wealden is overlaid only by uppermost Neocomian, the socalled Punfield beds (with Exogyra Couloni and other fossils), and the Atherfield beds (with Exogyra Couloni, Terebratula sella, etc.), forming the base of the Lower Greensand. In the N. of England on the other hand, in Yorkshire, Lincolnshire, etc., where the typical Wealden is absent, we find, besides the higher Neocomian beds, others equivalent to the German Hils Conglomcrate. A large part of those beds which are known as the Speeton. Clay, represents the Neocomian. The lowest beds, as in $\mathrm{N}$. Germany, contain Amm. astierianus and Toxaster complanatus, the higher Amm. noricus, and still higher we get Crioceras Emerici. ${ }^{1}$

Moreover, in the N. of France and in the Swiss Jura, in spite of some Alpine influences in the latter area, the Neocomian development is in the main similar. Especially widely spread here are those beds which in Switzerland are called the Hauterive stage, and contain as type fossils Belemnites dilatatus (LIII. 6), Amm. astierianus, A. radiatus, and Toxaster complanatus. Below these, near Neuchatel and other places, the lowest Neocomian beds found are the so-called Valenginien, with Belemnites dilatatus, B. pistilliformis, Ostrea macroptera, and others, in part species found also in the German Hils Conglomerate.

As already mentioned and as the word gap in the above table of the development of the German Hils shows, the marine Neocomian throughout Central Europe is incompletely developed, since the lowest horizon of it, the true Lower Neocomian, is nowhere reached. In order to learn to know the group we must go somewhat further S., to the region of Grenoble. As Lory, Hébert and. others have shown, the Valenginien here reaches into the area of

1 The Speeton Clay is divided by Lamplugh (Quart. Journ. Geol. Soc., XLV. p. 575) as follows :-
A. Zone of Belemnites minimus.
B. $\quad " \quad B e l$. semicanaliculatus? (=brunsvicensis).
C. . $"$ Bel.jaculum.
D. " Bel.lateralis.
E. Coprolitic seam.
F. Shales with Bel. Oxenii.

$\mathrm{F} .=$ Upper Kimeridge; D.=Passage beds from Jurassic to Lower Cretaceous; A. = probably Lower Gault; B. and C.=Intermediate beds. The zones referred to in the text are those of Judd; the first=D., the other two occur in $\mathrm{C}$. 
the Alpine facies. It does not, however, follow directly on the uppermost Jura (Tithonian), but is separated from it by the zone of Belemnites latus and the still deeper zones of Terebratula diphyoides and of Hoplites occitanicus, the so-called Berrias beds. If these two lowest zones of the Cretaceous are classified as Low er Neocomian, the Hauterive series together with the allied Valenginien would be Middle Neocomian; and therefore the Hils Conglomerate standing parallel with it and the equivalent so-called Lower Neocomian of England, must be classified as Middle Neocomian, whilst the Hils clay and equivalent deposits in England and France would be Upper Neocomian. ${ }^{1}$

Thus the development of the Neocomian in the areas described would be as follows :-

\begin{tabular}{|c|c|c|c|}
\hline & $\begin{array}{l}\text { North France, } \\
\text { England, } \\
\text { North Germans. }\end{array}$ & $\begin{array}{l}\text { Region of } \\
\text { Neuchatel, etc. }\end{array}$ & $\begin{array}{l}\text { Reginn of } \\
\text { Grenoble, etc. }\end{array}$ \\
\hline $\begin{array}{c}\text { Upper } \\
\text { Neocomian }\end{array}$ & $\begin{array}{l}\text { Beds with } \\
\text { Crioceras Emerici } \\
\text { (Hilsthon). }\end{array}$ & $\begin{array}{l}\text { Limestonfs with } \\
\text { Rermenia and } \\
\text { Radiolites. }\end{array}$ & $\begin{array}{l}\text { Barreme Series } \\
=\text { Wernsdorf beds } \\
\text { with Hacro- } \\
\text { scaphites Itanii. }\end{array}$ \\
\hline $\begin{array}{c}\text { Middle } \\
\text { Neocomian. }\end{array}$ & $\begin{array}{c}\text { Beds with Amm. } \\
\text { astierianus, A. radi- } \\
\text { atus, Toxaster com- } \\
\text { planatus, Ostrea } \\
\text { macroptera, etc. } \\
\text { (Hilsconglomerate.) }\end{array}$ & $\begin{array}{c}\text { Hauterive } \\
\text { Series with Be- } \\
\text { lemnites dilatatus, } \\
\text { Amm. astierianus, } \\
\text { Toxaster compla- } \\
\text { natus, etc. } \\
\text { Valenginien, } \\
\text { with Bel. dilatatus, } \\
\text { Ostrea nacroptera. }\end{array}$ & $\begin{array}{l}\text { Beds with Be- } \\
\text { lemnites dilatatus, } \\
\text { Amm. astierianus } \\
\text { Amm. radiatus, } \\
\text { Toxaster compia- } \\
\text { natus, etc. }\end{array}$ \\
\hline $\begin{array}{c}\text { Lower } \\
\text { Neocomian. }\end{array}$ & Absent. & Absent. & $\begin{array}{c}\text { Zone of Belemnites } \\
\text { latus. } \\
\text { Berrias Series } \\
\text { with Amm. occitani- } \\
\text { cus and Terebratula } \\
\text { diphyoides. }\end{array}$ \\
\hline
\end{tabular}

1 Most of the French writers classify the beds with Belennites dilatatus, and also the Valenginien and Hauterivien as Upper Neocomian; while following the example of Coquand and Leymerie, they unite the beds with Urioceras Emerici (U. Neoc. of the Germans, Urgonien of d'Orbigny) with the Aptien under the name Urgo-Aptien, and place it as a special division of the Lower Cretaceous, between Neocomian and Albian. 
Albian and Aptian.-The beds which succeed the Neocomian are known in Germany as the Gault, under which term however they include not only the English Gault, the Albian of French geologists; but also the Aptian. In Germany, England and France these beds (Albian and Aptian), consist mainly of clays and marls, with, in many places, sandstones also. The group is characterized by the great number of richly decorated Ammonites, the hook-shaped IIamites and Belemnites, whilst of the other classes of animals only Gasteropods and Lamellibranchs are abundantly represented.

As with the classification of the Hils, so also that of the $\mathrm{N}$. Germax "Gault" rasts entirely on the works of v. Strombeck." $\mathrm{He}$ distinguishes for the region N. of the West Harz and Brunswick from above downwards:-

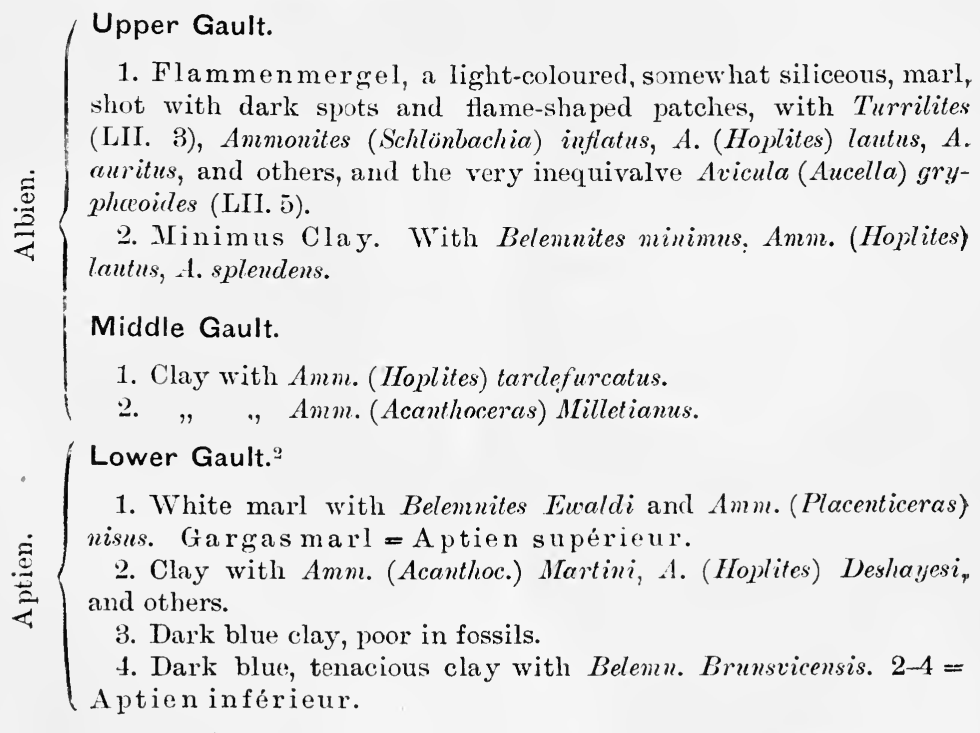

This classification however is applicable only to the abovementioned area. In the west, in the Deister and Teutoburger Wald, as also in the east, in the region of Quedlinburg and Halberstadt, a light Sandstone is developed instead of the Clay, and like many other similar sandstones so widely spread in the German Cretaceous, is known as Quader and indeed as Gault.

1 "Nenes Jahrb." (1857), p. 639. Zeits. d. deutsch. geol. Ges. (1861), p. 20.

2 Cf. Ewald. "Ueber die foss. Faun. d. unt. Gaults bəi Ahaus. Monatsberichte d. Berl. Akad." (1860), p. 332. 

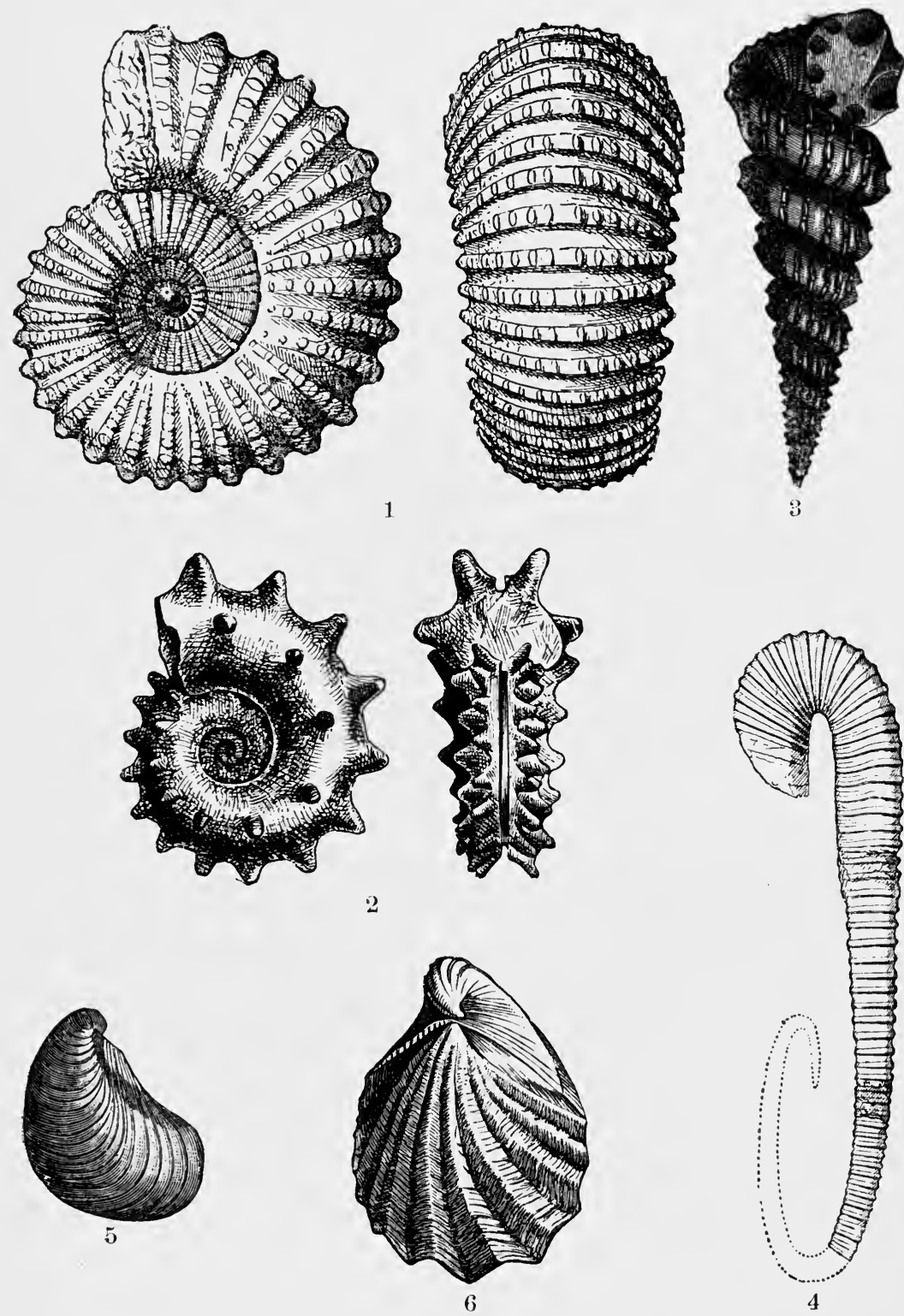

Plate LII.-Fossils of the Albian and Aptian.

1. Acanthoceras mammillare, Schl. 2. Hoplites tuberculatus, Sow. 3. Turrilites catenatus, d’Orb. 4. Hamites rotundus, Sow. 5. Avicula (Aucella) gryphaeoides, Sow. 6. Inocerainus sulcatus, Park. 
Quader. The development of the "Gault" in N. Germany may therefore be represented as in the following table:-

wEST.

EAST.

\section{Teutoburger Wald, Deister, etc.}

Sandstone.
Brunswick Area.

Flammenmergel Clay.
Region of Halberstadt

Sandstone.

In ENGLAND what is known to the Germans as Ganit is reprcsented by the twodivisions, Lower Greensand below and Gault above.

In the Wealden area the Lower Greensand is divided into

Folkestone Beds. Sand and Carstone.

Sandgate Beds. Dark clayey sand and clay

Hythe Beds. Limestones, sandstones, sand.

Atherfield Clay. Clay.

The Atherfield Clay has already been referred to the Neocomian (Urgonian) of the French. The Beds of Hythe and Sandgate, with Gervillia anceps, etc., are the representatives of the Aptian of the French, while the Folkestone Beds with Arca Raulini, Pecten (Janira) quinquecostata, etc., and the zone of Amm. mammillaris, belong to the Albian.

In the south-west of England the Punfield beds with Exogyra sinucata, Corbula striatula, etc., appear to belong to the Urgonian, and the beds overlying these to the Albian.

In the Midlands the Lower Greensand is represented chiefly by sravels and sands, which include the Faringdon beds with their numerous sponges, the Shotover and the Woburn Sands. In Lin.colnshire the group is represented by the Tealby series, and in Yorkshire by marine beds in the Speeton Clay.

The Gault is a stiff blue clay, sometimes calcareous or sandy, and contains numerous fossils. At Folkestone it has been divided into the following zones:-

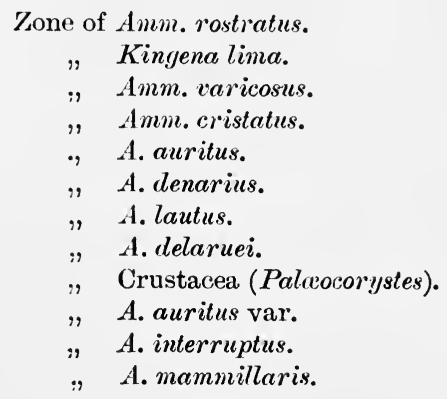


In FrANCE the upper part of the Lower Cretaceous is, ast already mentioned, divided into two stages, the Aptien below and the Albien above. The former is typically developed at Apt in Vaucluse, and there consists of a group of blue marls with Plicatula placunea, Amm. Nisus, etc., succeeded by a limestone with Ancyloceras renauxianus, Ostrea aquila. In the north of France. the series is mainly clay. The special characteristic of the group is the abundance of Ancyloceras (Crioceras). The Albien is composed in the Paris basin of greensand below and clay above. At the base is the zone of Amm. mammillaris (Folkestone beds of England), and above, the zones of Amm. lautus and Amm. inflatus.

\begin{tabular}{|c|c|c|}
\hline England. & s. France. & Germany \\
\hline $\begin{array}{l}\text { Gault proper with Amm. inflatus, A. auritus, } \\
\text { A. lautus, A. interruptus. } \\
\text { Folkestone Beds with Amm. mammillaris (LII. 1). }\end{array}$ & Albien. & \pm \\
\hline $\begin{array}{l}\text { Sandgate Beds with Conchifera, brachiopods, ete. } \\
\text { Hythe Beds with Amm. Martini, A. Deshayesi, etc. } \\
\text { Exogyra Couloni, brachiopods. }\end{array}$ & Aptien. & J \\
\hline
\end{tabular}

\section{Louer Cretaceous of S. Europe.}

The S. European facies is developed in the Alps and Carpathians, S. France, Italy, Spain, and the whole Mediterranean basin. The most characteristic features of the older Cretaceous. of these areas are the occurrence of the peculiar Requienia (LIII. 2) (with their large valves shaped like the horn of a ram and their small ones like a lid) and of the oldest liudistes; and in the second place the development of large Ammonitidæ with freewhorls (Crioceras [LIII. 3] Ancyloceras, Macroscaphites [LIII. 4], IIamites [LIII. 5], etc.), and of the genera Phylloceras, Lytoceras, etc.

The Lowest Neocomian of the S. European Cretaceous consists of the above-mentioned Berrias beds with the perforated Terebratula diphyoides-a variety of the Tithonian T. diphyaHoplites, Olcostephanus, Perisphinctes, etc.; and these beds are overlain by the zone of Belemnites latus. The two together form the Lower Neocomian. The Middle Neocomian, or the zone of Belemnites dilatatus, is formed throughout the W. Alps of the Talenginien, which overlaps the Jura in this area, and contains Pygurus rostratus and Vola atava; as well as the Spatanguse 

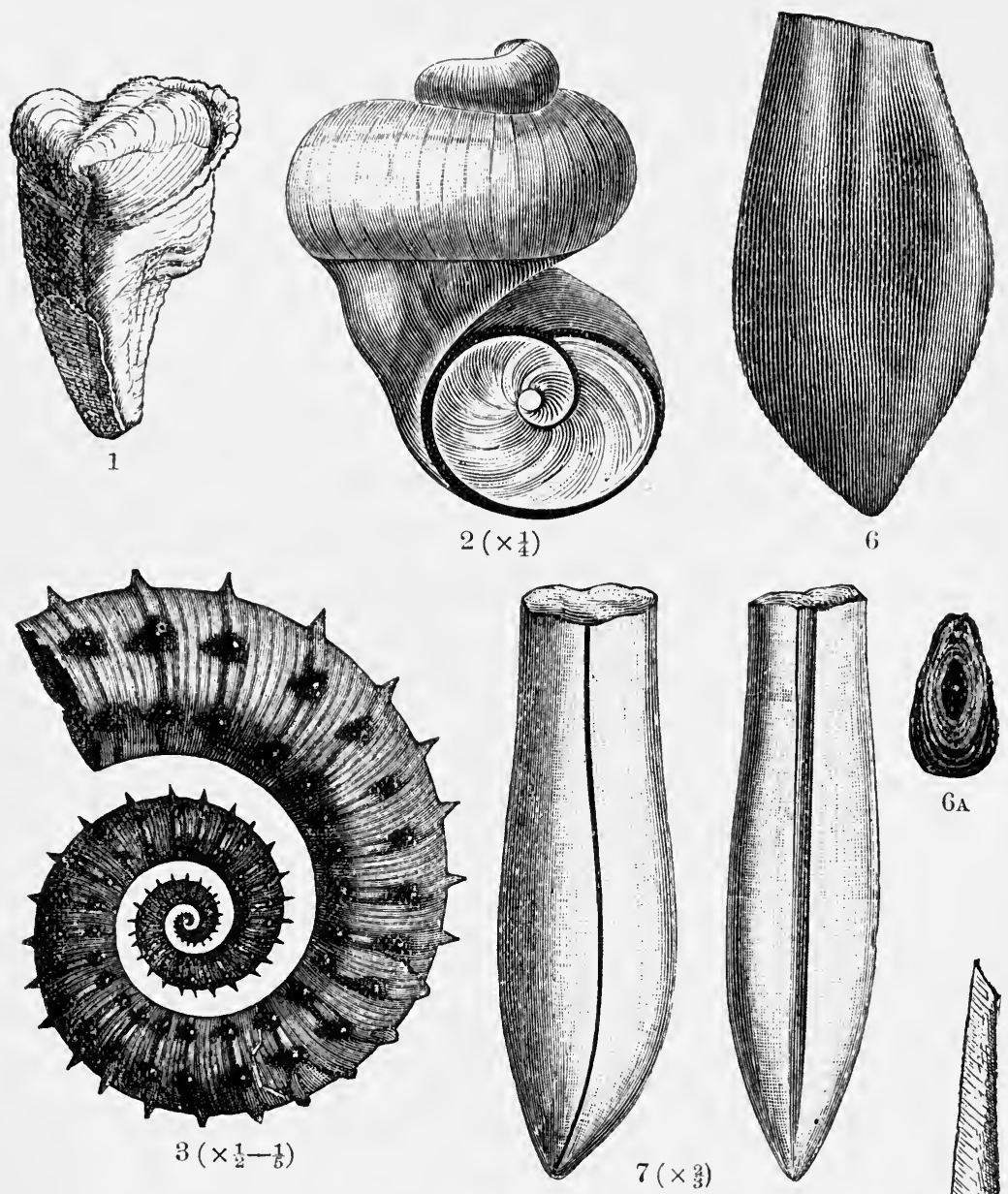

GA

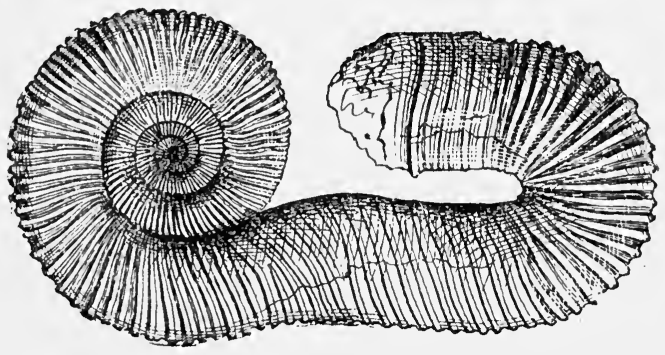

4

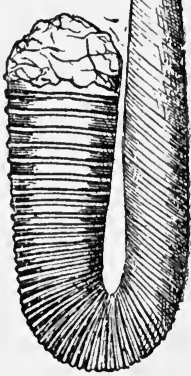

5

Puatr LIIT.-Fossils of the Alpine Lower Cretaceous

1. Monopleura trilobata, d'Orl, 2. Requienia ammonia, Gf. 3. Crioceras Emerici, Lév. 4. Macroscaphites Ivanii, d'Orb. 5. Hamulina subcylindrica, d’Orb. 6. Belemnites (Duvalia) dilatatus, Blainv 6... 'Iransverse section of the same. 7. Bel.latus, Blainv. 297 
Limestone, the cquivalent of the Swiss Hauterivien, with I'oxaster cordiformis, Olcostephanus astierianus (LI. 2), Hoplites neocomiensis, Belemnites pistilliformis, and other Central European fossils. Lastly, the Upper Neocomian appears sometimes in the form of limestones with Macroscapleites Ivanii (LIII. 4) and Crioceras Emerici (LIII. 3)-the latter also occurring in the Upper Neocomian of Central Europe-numerous species of PhylIoceras and Lytoceras, Haploceras, Aspidoceras, Acanthoceras, etc., and this development is known as Barrêmien after one of the chief localities in S. France, or as the Wernsdorf beds 1 after another in the Silesian Carpathians. In the Swiss Jura also, which in Upper Neocomian times was a bay of the Southern European sea, and also in the Algäu, in Vorarlberg, and other parts of the Alps, white limestone, often forming rugged hills, occurs. This is the massive Caprotina or Schratten Limestone, which extends throughout the whole of S. Europe and N. Africa (Algeria, Morocco, etc.), and the upper part of which sverywhere belongs to the Newer Cretaceous. In the lowest parts of this limestone, referred to the Neocomian, the type fossil Requienia (Caprotina) ammonia is not present. This first appears a little higher up; and the main mass of the Caprotina Limestone, which includes besides this fossil Requ. gryphacoides and others, Spharulites Blumenbachi, Monopleura trilobata (LIII. 1), etc., corresponds with what the French geologists now generally designate as Aptien or Urgoaptien, while d'Orbigny applied the name Urgonien to the whole of the Caprotina Limestone.2

But the Caprotina Limestone is only one facies of the Aptien. Another facies is that of the S. French Gargas marl with Ancyloceras Matheronianum, Acanthoc. Martini, Plicatula placunea, Exogyra Couloni, etc.; another is the Orbitolina Limestone, filled with millions of shells of a large lens-shaped Foraminifer, Orbitolina 7enticularis. Lastly the Albien occur's in the Alpine area chiefly as green sandstone with the charac-

${ }^{1}$ Uhlig, "Die Cephalopodenfauna d. Wernsdorf. Schicht. Denkschr. d. Wien. Akad." (1883).

2 Vaček, "Jahrb. d. Wien. Reichsanst." (1879), p. 659. See also his "Neocomstudie." Ibirl.(1880), p. 493. Of other papers on the Lower Cretaceous of S. Europe and especially S. France, those of Coquand, Hébert, Torcapel, Carez, Toucas, etc., are specially important-almost all have appeared in the Bull. Soc. Geol. de France. For the palæontology of these deposits, see the papers of Coquand, Loriol, and Pictet. 
teristic fossils of the English Gault. It has indeed been traced from the S. of France through Switzerland to the Carpathians and to Greece, but is nowhere so fossiliferous or so fully developed as in Central Europe.

Lastly, a white, thin-bedded limestone, very poor in fossils, and known as the Biancone Limestone, should be mentioned as a tolerably widely-spread facies of the Lower Cretaceous in the S. Alps.

\section{Upper Cretaceous.}

Upper Cretaceous of Germany, England, and N. Hrance.

In Germany the following areas of Upper Cretaceous rocks may be distinguished:-

1. The small area of Aix-la-Chapelle and Maestricht, consisting exclusively of Senonian.

2. The area of N.W. Germany, a region lying north of the Lower Rhenish Schiefergebirge and of the Harz, and stretching from the Rhine nearly to the Elbe; also the so-called Westphalian Cretaceous basin, the Teutoburger Wald and Wesergebirge, and the region of Hanover, Brunswick, Goslar and Halberstadt. The small scattered Cretaceous masses of the Ohmgebirge, not far from the town of Worbis, ${ }^{1}$ may be reckoned in this area.

3. The Saxo-Bohemian area. This includes the great Cretaceous area of North Bohemia, with its prolongation into Saxony, and also the Cretaceous outcrops of Löwenberg and other points in Lower Silesia, of Regensburg ${ }^{2}$ and Passan on the Danube.

4. The Upper Silesian Cretaceous area with the outcrops rising from the diluvium in the region of Oppeln and Leobschütz.?

5. The Baltic Cretaceous area. Besides the smaller Cretaceous patches of Rügen at the mouth of the Oder, in Pomerania, Mecklenburg, Holstein, ${ }^{3}$ near Lüneburg, ${ }^{4}$ etc., this includes the extensive outcrops on the Danish Islands and in S. Sweden.

In the N.W. German area the two lower divisions of the Upper Cretaceous, the Cenomanian and Turonian, consist of white, thin-bedded, marly, and in part somewhat siliceous limestone, the Pläner; and this is the case also throughout the area

1 v. Seebach, "Erläuter. z. Blatte Worbis d. geol. Specialkarte v. I'reussen.",

2 Beyrich, Zeits. d. deutsch. geol. Ges. (1849), p. 411; (1850), p. 103.

3 F. Römer, "Geol. v. Oberschlesien," 1870.

${ }^{4}$ v. Strombeck, Keits. d. deutsch. geol. Ges. (1863), p. 97. 
between the Tentoburger Wald and the Harz. The Senonian, on the other hand, consists mainly of light sandstones, the Quader Sandstone. True writing chalk is absent here; yet a rock at least approaching chalk in character occurs ncar Peine, Lehrte, etc.

For the detailed knowledge of the younger Cretaceous rocks of this region, just as for the older, the works of v. Strombeck are specially important; as also are the later beautiful researches of Schlüter for the Westphalian area. ${ }^{1}$

Lower Pläner or Cenomanian. This usually begins with sands and marls, often conglomeratic and glauconitic, which contain Pecten asper (LV. 2), Catopygus carinatus, Ostrea diluviana, etc. This is the so-called Tourtia, a Belgian term used for deposits of this age in the neighbourhood of Namur. In the succeeding marly limestones there are two important Ammonites: in the lower marl, the widespread Amm. (Schlönbachia) varians (LIV. 2) (occurring also in N. Africa, India, and S. America), with keeled back and divided ribs tuberculate at the ends; in the upper marl, the large thick Amm. (Acanthoceras) rotomagensis (LIV. 1), with tuberculate back and ribs slightly divided, but also frequently tuberculate. Moreover, throughout the Cenomanian Amm. (Acanthoc.) Mantelli is not rare. The gasteropod-like richly ornamented Ammonite genus Turrilites ( $T$. costatus, 'T'. tuberculatus, etc.) is also very widely spread.

Upper Pläner or Turonian. v. Strombeck distinguishes here:-(1) Beds with Inoceramus mytiloides=labiatus (LV. 4) (small, longitudinally striated), the so-called Mytiloidespläner, generally more or less brilliantly red coloured, with relatively poor fauna. (2) Beds with Inoceramus Brongniarti (LVI. 5) (large, very thick shelled, with strong concentric lines of growth),Brongniartipläner. (3) Beds with Galerites (=Echinoconus) albogalemus (LVI. 7), Micraster breviporus, Holaster planus, and other sea-urchins, and Terebratula Becksi,-Galeritespläner. (4) Beds with Scaphites Geinitzi (LVI. 2),-Scaphitespläner. In the last horizon, which extends from Westphalia to Silesia, there are also numerous Spondylus spinosus (LVI. 4), the large Amm. (Pachydiscus) peramplus (LVI. 1), Micraster cor testudinarium (LVIII. 2), Tcrebratula semiglobosa, Rhynchonella pli-

1 v. Strombeck, "Glieder. d. Pläners im nordw. Deutschland. Neues Jahrb." (1857), p. 785._-_ Beitr. z. Kennt. d. Pläners üb. d. westfäl. Steinkohlenf." Zeits. d. deutsch. geol. Ges. (185̃), p. 27. Schlüter, "Verbreit. d. Cephalop. i. d. ob. Kreide Norddeutschl," Ilid. (1876), p. 457. 

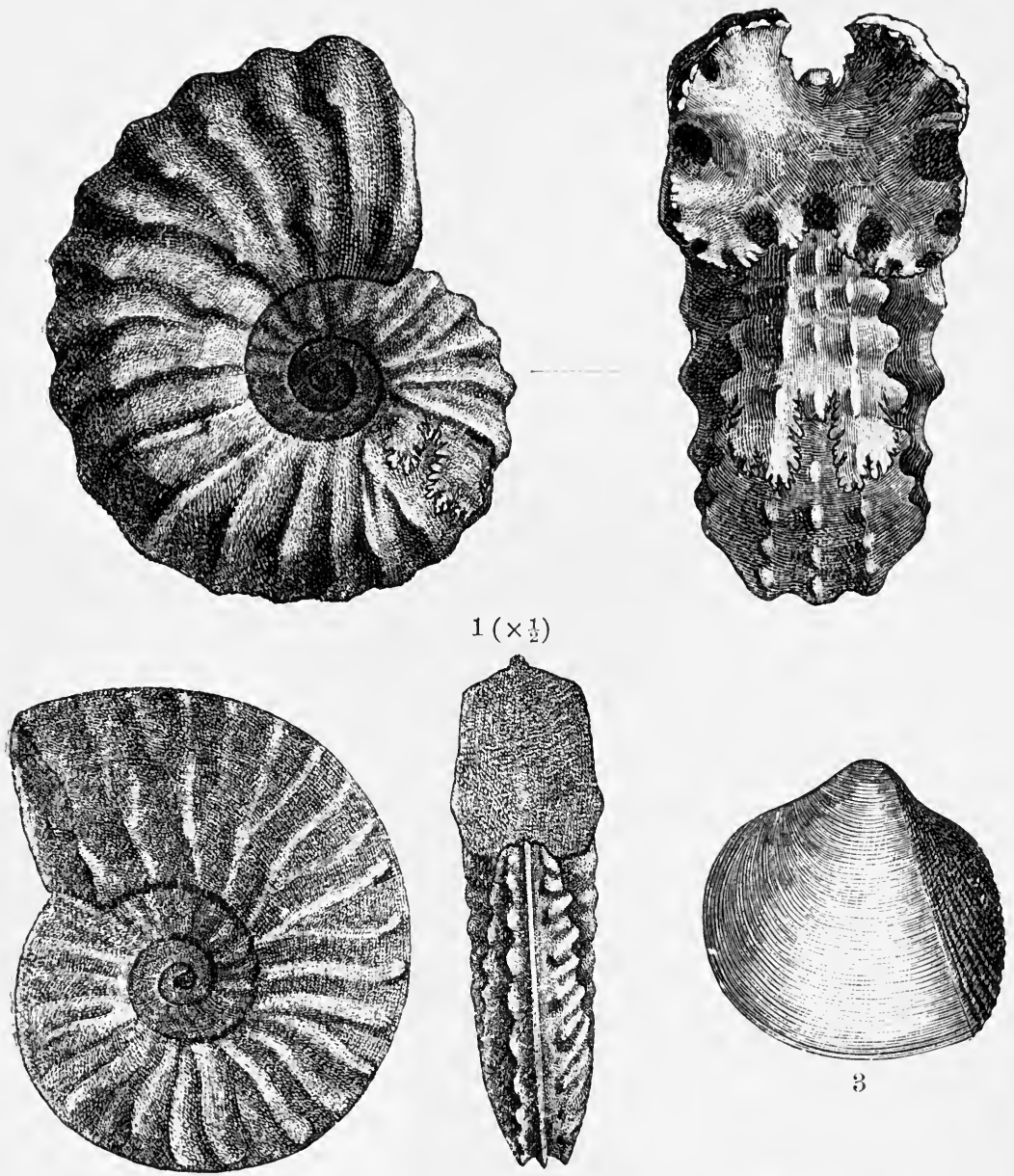

2

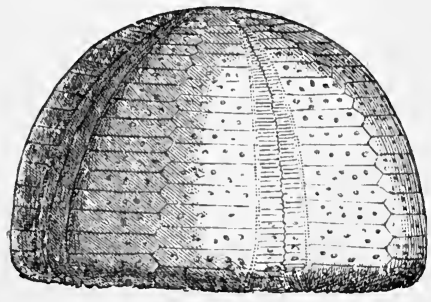

4

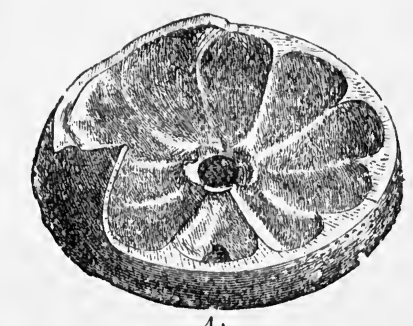

$4 \mathrm{~A}$

Puatr L.IV.-Fossils of the Cenomanian.

1. Acanthoceras rotomagense, Defr. 2. Schlönbachia varians, Sow. 3. Protocardium hillanum, Sow. 4. Discoidea cylindrica, Agass. 4s. The same broken open, showing the characteristic interior ridges. 

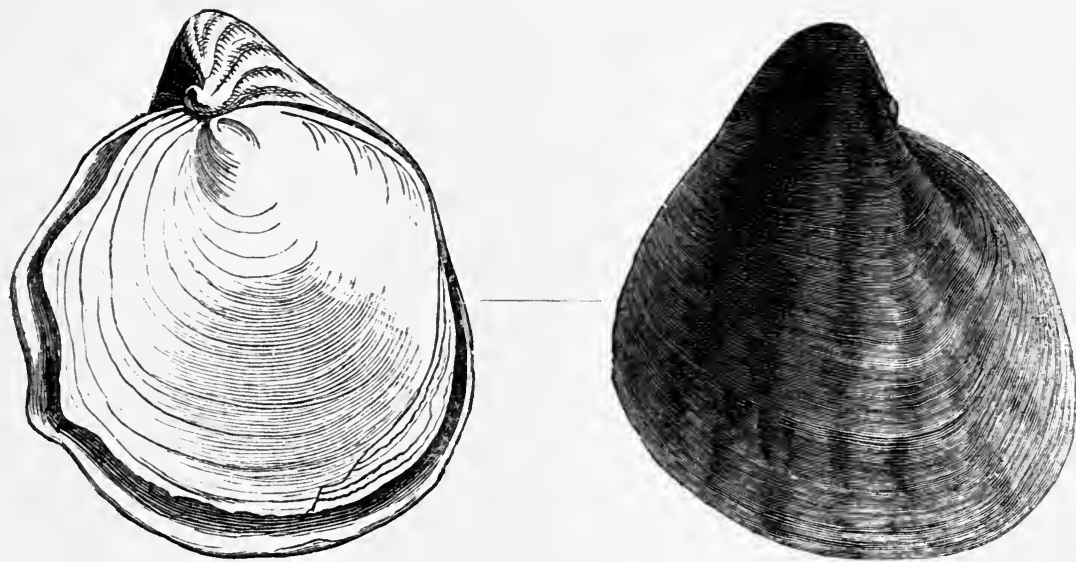

$1\left(\times \frac{1}{2}\right)$
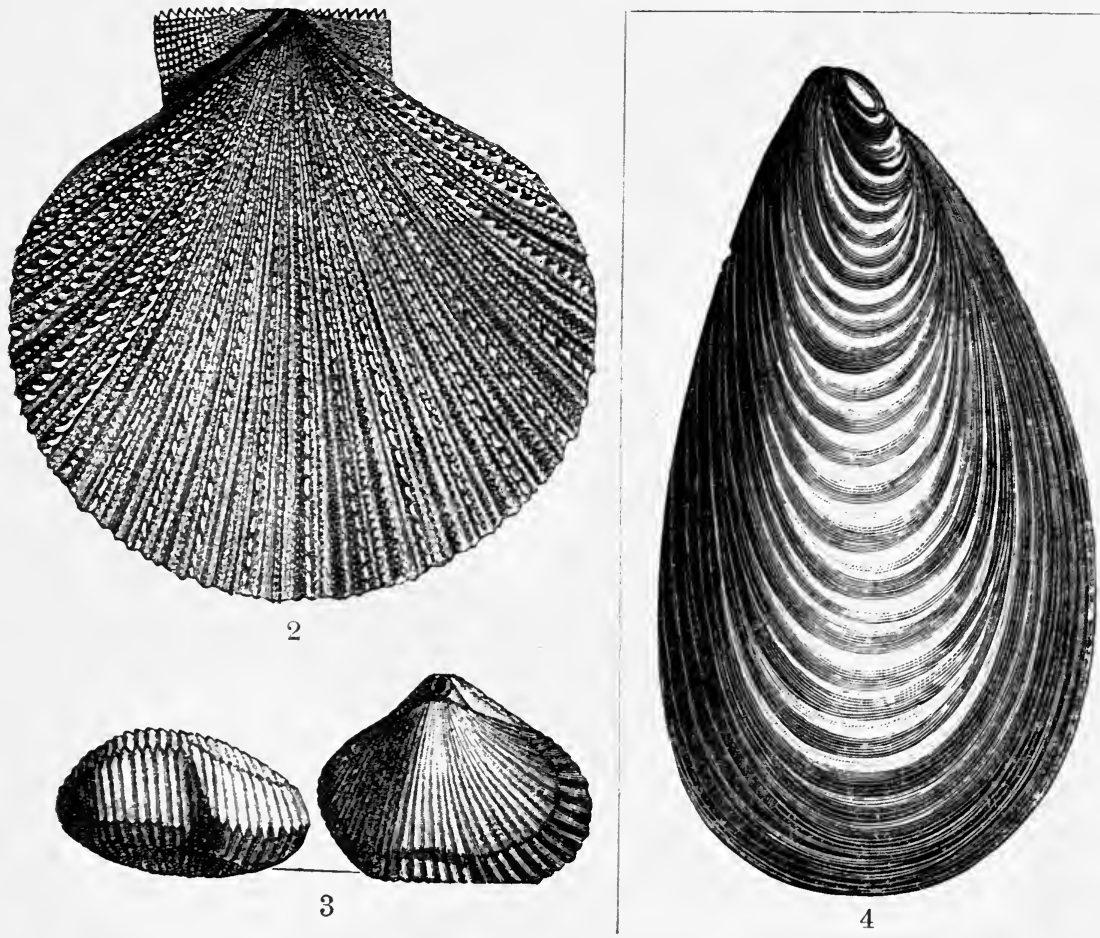

Plate LY.-Fossils of the Cenomanian (1-3) and Turonian (1).

1. Exogy:a columba, Desh. 2. Pecten asper, Lam. 3. Rhynchonella compressa, Lam. 4. Inoceramus labiatus, Schl. (=mytiloides, Mant.). 

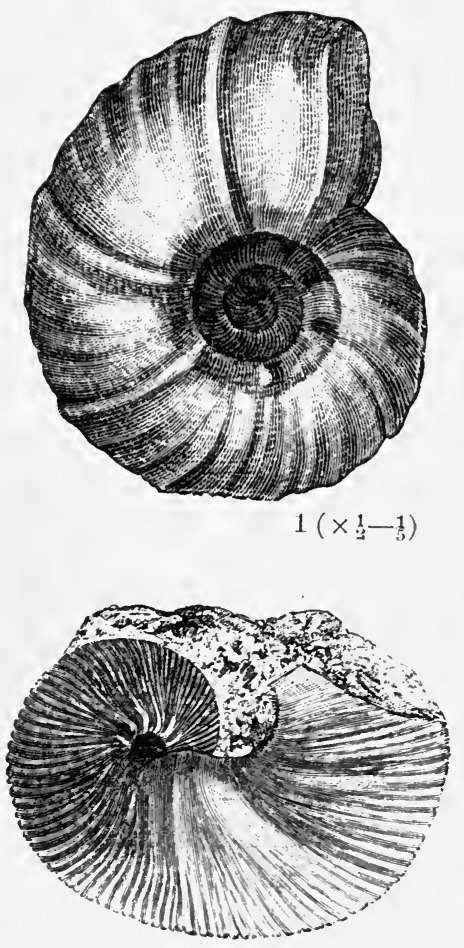

2

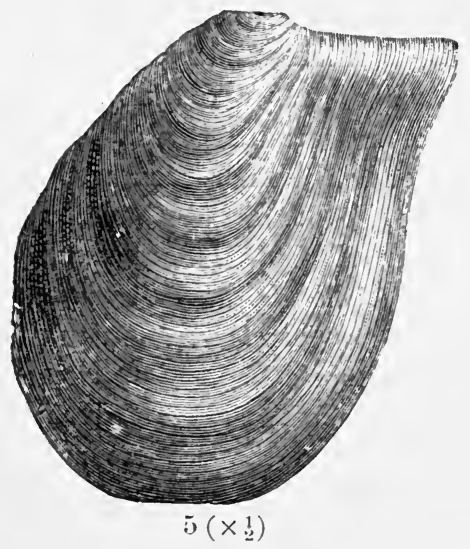

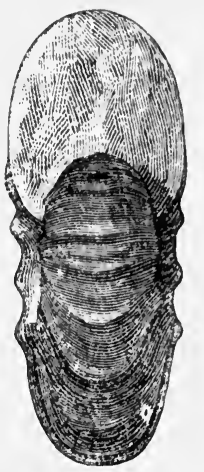
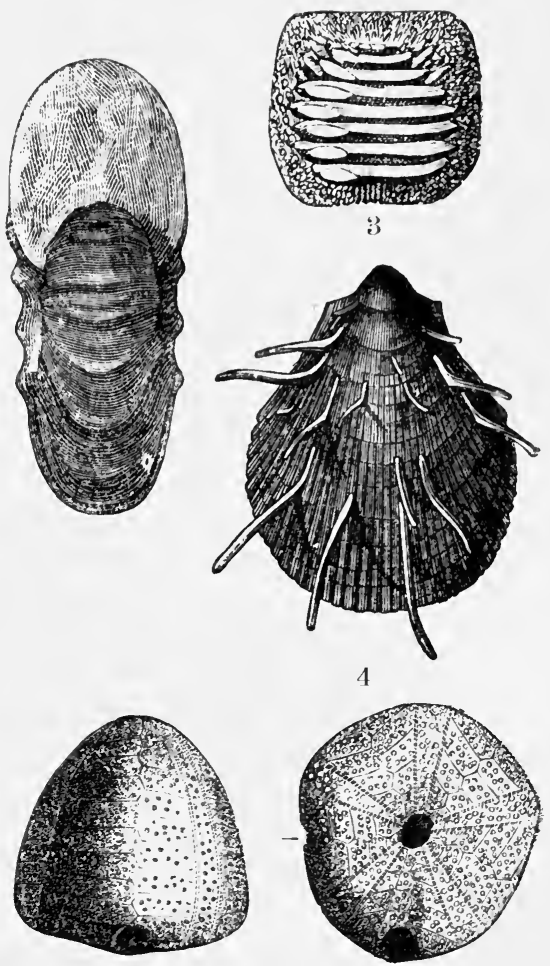

7

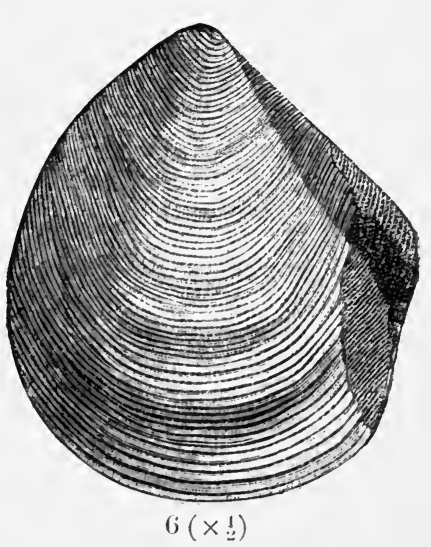

$6(\times \stackrel{1}{2})$

Plate LVI.-Fossils of the Turonian.

1. Pachydiscus peramplus, Mant. 2. Scaphites Geinitzi, d'Orb. 3. Tooth of Plychodus latissimus, Agass. 4. Spondylus spinosus, Sow. 5. Inoceramus Brongniarti, Sow. 6. Inocer. Cuvieri, Sow. 7. Galerites (Echinoconus) albogalerus, Klein, from the side and from below (occurs also in the Senonian;. 
catilis, etc. (5) Beds with Inoceramus Cuvicri (LTI. 6) (broad, of rounded quadratic outline, with short wings), Epiaster brevis, etc.,-Cuvieripläner.

Schlüter divides these series into the following zones :-

Turonian.

5. Zone of Inoceramus Cuvieri and Epiaster brevis.

4. " Heteroceras Reussianum and Spondylus spinosus.

3. ". Inoc. Brongniarti and Amm. Woollgari.

2. " Inoc. labiatus and Amm. nodosuides.

1. " Actinocamax plenus (only found in Westphalia).

Cenomanian.

3. Zone of Amm. rotomagensis and Holaster subglobosus.

2. . Antm. rarians and Hemiaster Griepenkerli.

1. "Pecten asper and Catopygus carinatus.

That Schlüter does not separate a special Galerites stage is explained by the fact that this seems to be only a peculiar facies of the Brongniartipläner. ${ }^{1}$

Senonian. This is a thick fossiliferous series of many divisions and of very various development. Formerly in Germany two series only were usually distinguished:-(1) The Lower Senonian with Belemnitella (At tinocamax) quadrata (LIIII. 1) (with rough granulated surface wind short alveolus), - the Quadrata Chalk; and (2) the Upper Senonian with Belemnitella mucronata (LIX.1) (with branching vascular impressions and long alveolus), - the Mucronata Chalk. The classification of Schlüter is much more detailed. He separates from the Senonian the lowest grey marly beds (shown by numerous bore-holes and pits in Westphalia to be more than 1,500 feet thick), under the name of Emscher Mergel (or shortly "Emscher"), as a distinct, and indeed the thickest, group of the North German Chalk. The chief fossils of this series, which is present on the northern border of the Harz, in Silesia, Bohemia, France, England and the Alps, probably also in North America (Texas) and East Asia, are Amm. (Schlönbachia) Marge (LVII. 1), .1mm. (Schlönbachia) Texanus, Amm. Emscheris, etc., Nautilus neubergicus, and N. leiotropis, Inoceramus digitatus, cliaracterized by its size and the strong ribs which run out from the middle line to both sides (LVII. 2), etc. ${ }^{2}$ Most geologists classify the Emscher as the deepest zone of the Senonian.

${ }^{1}$ U. Schlönbach, "Ueber d. nordd. Galeritenschichten u. ihre Brachiopodenfauna. Sitzungsber. d. Wien. Akad." (1863).

2 Zeits. d. deutsch. geol. Ges. (1874), p. 775.-Compare also Müller, "Bitr. 7. Kennt. d. ob. Kreide a. nördl. Harzrande. Jahrb. d. preuss. geol. Landesanst." (188i ), p. 372. 

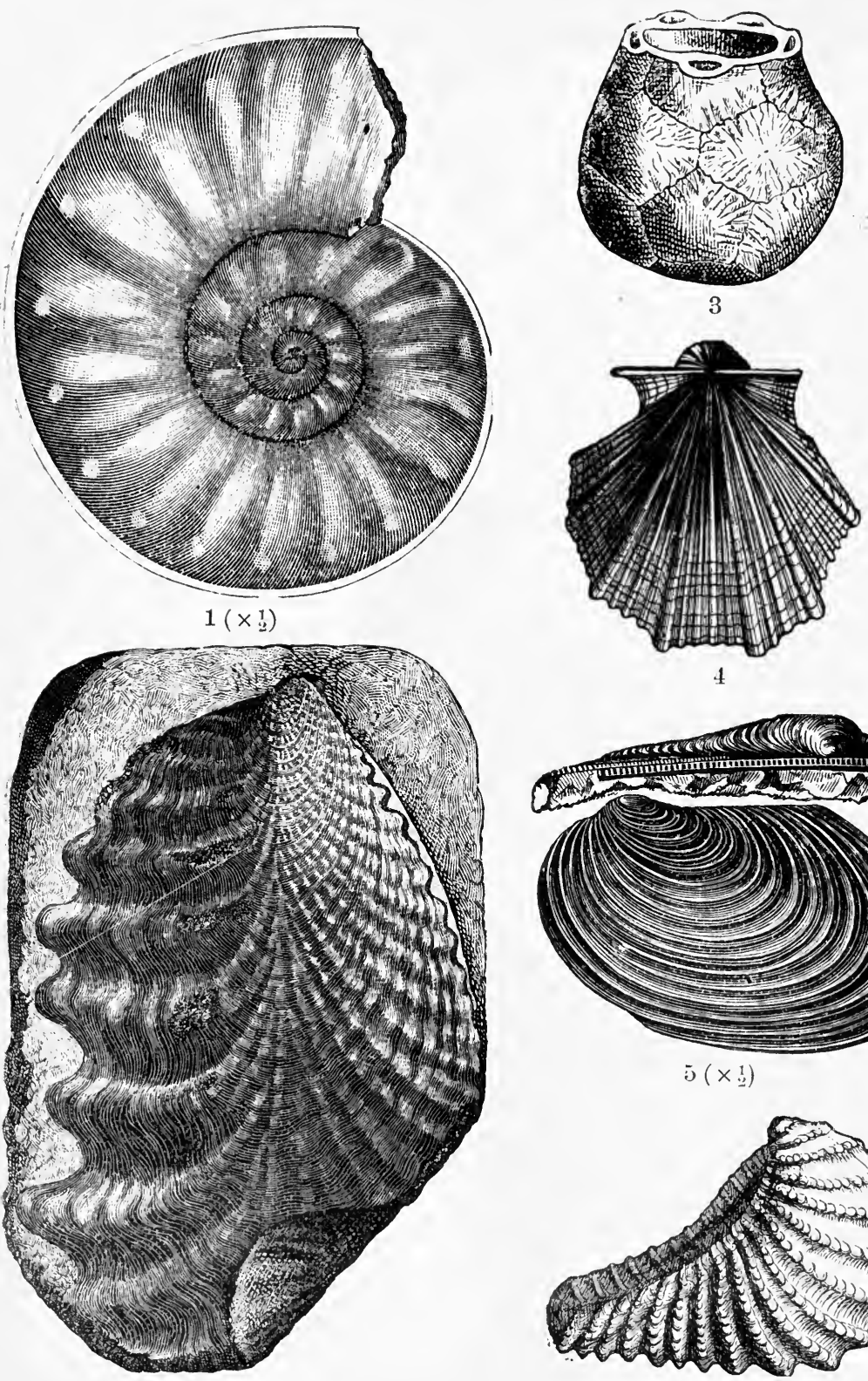

$2\left(\times \frac{1}{3}\right)$
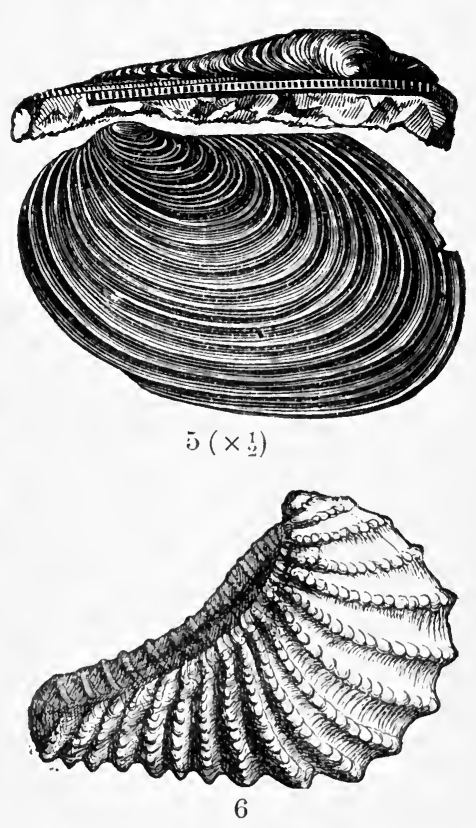

Plate LVII.-Fossils of the Senonian.

1. Schlönachia Margx, Schlït. 2. Inocesamus dijitatus, Sow. 3. Marsupites oinatus, Sow. 4. Pecten (Vola) uninquecostatus, Sow. 5. Inoceramus Cripsi, Mant. 6. Trigonia aliforitis, Park.

C. G. 


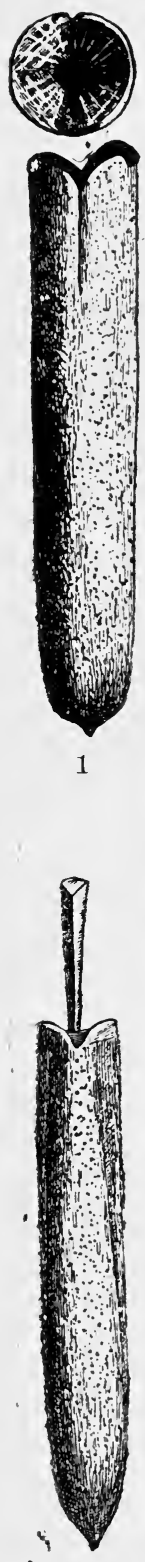

1 ..

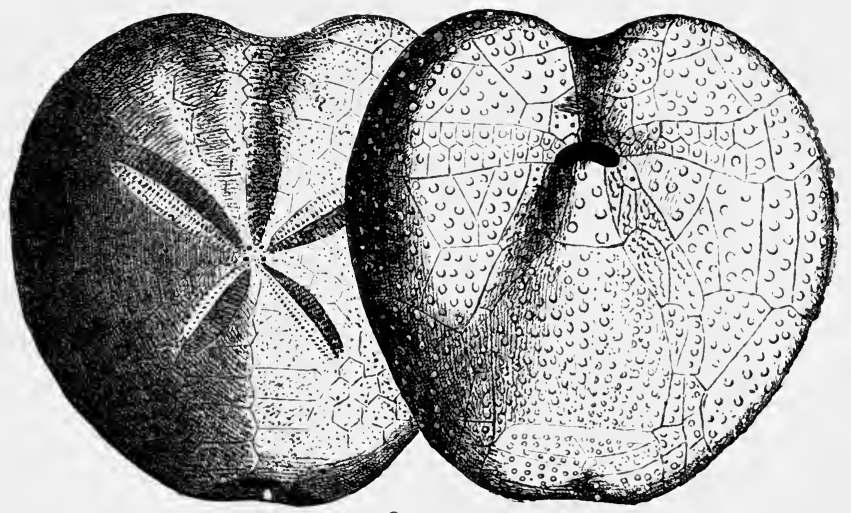

2
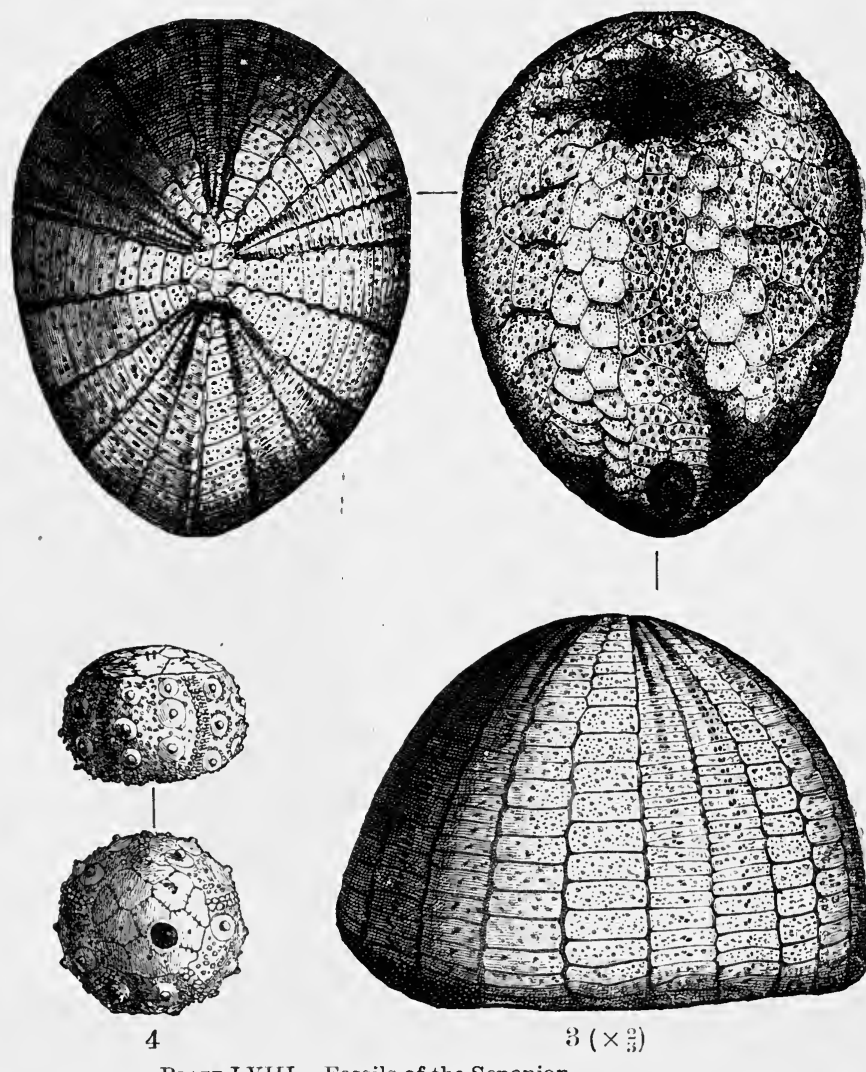

Plate LVIII.-Fossils of the Senonian.

1. Actinocamax quadratus, Blainv. 1s. The same, with alveolus projecting beyond the guard. 2. Miciaster cor testudinarium, Goldf. 3. Echinocorys (=Ananchytes) orata, Leske. 4. Salenia scutigera, Gras. 
C.- CRETACEOUS SYSTEM.
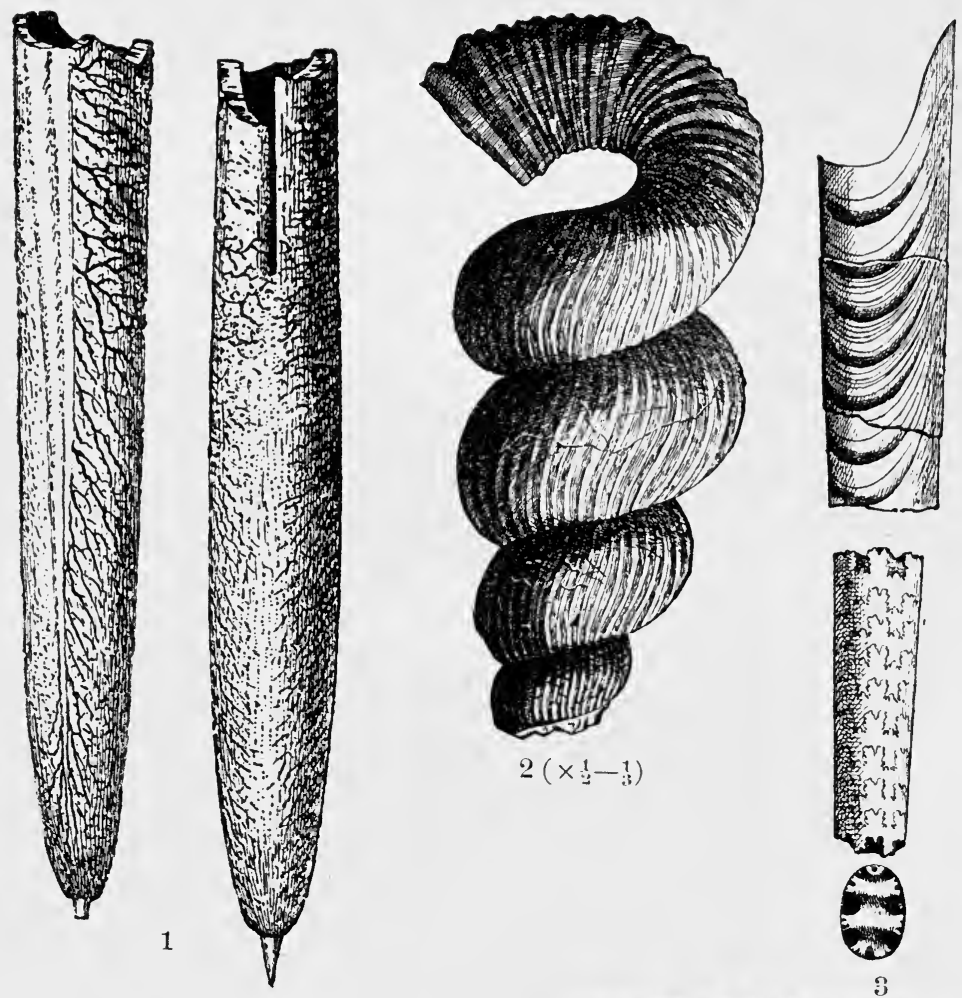

$2\left(\times \frac{1}{3}-1\right)$
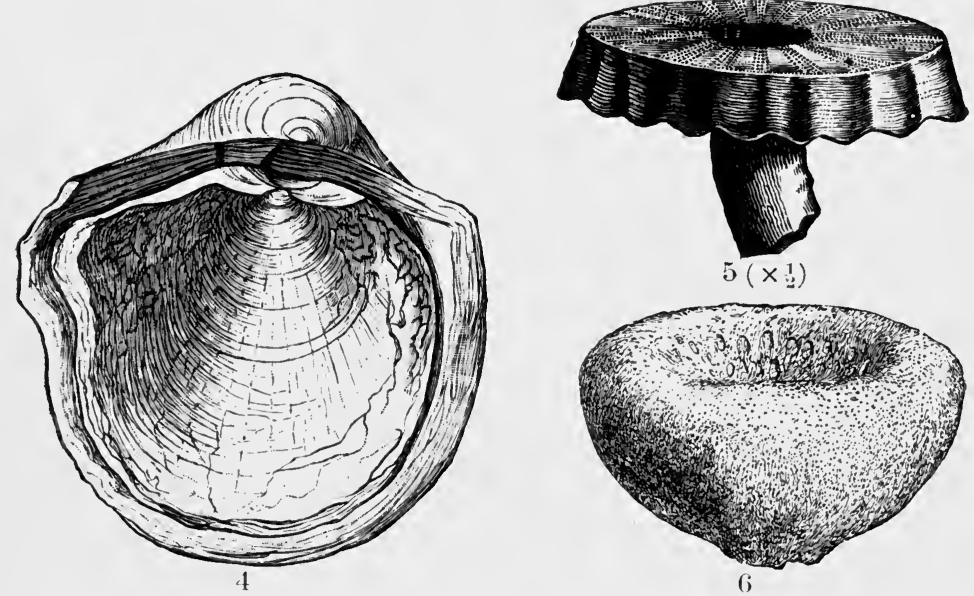

Plate IIX.-Fossils of the Senonian.

1. Belemenitella mucionatr, Schloth. 2. Heteroceras polyplocum, A. Röm. 3. Baculites (anceps, Lam. 4. Gryphea vesicularis, Lam. 5. Celoptychium agaricoides, Gf. 6. Calloegma acaule, Zitt. 


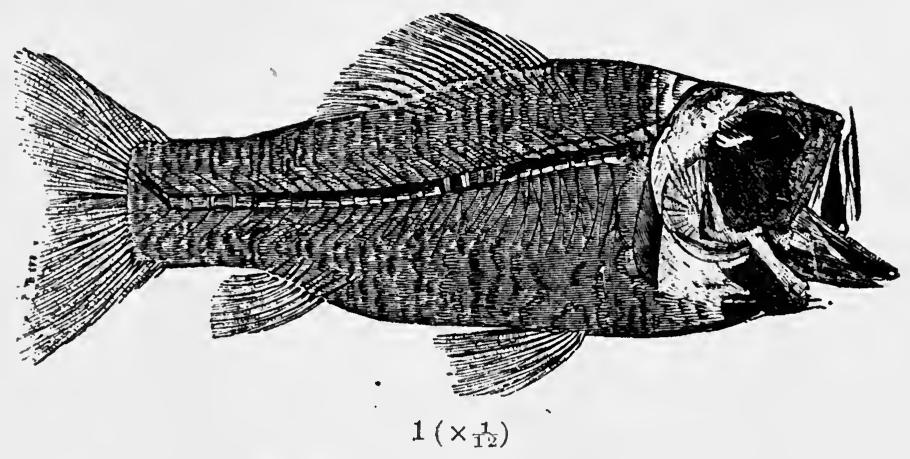

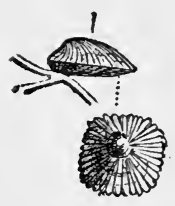

2

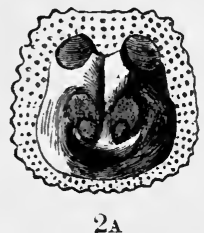

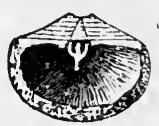

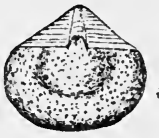

3

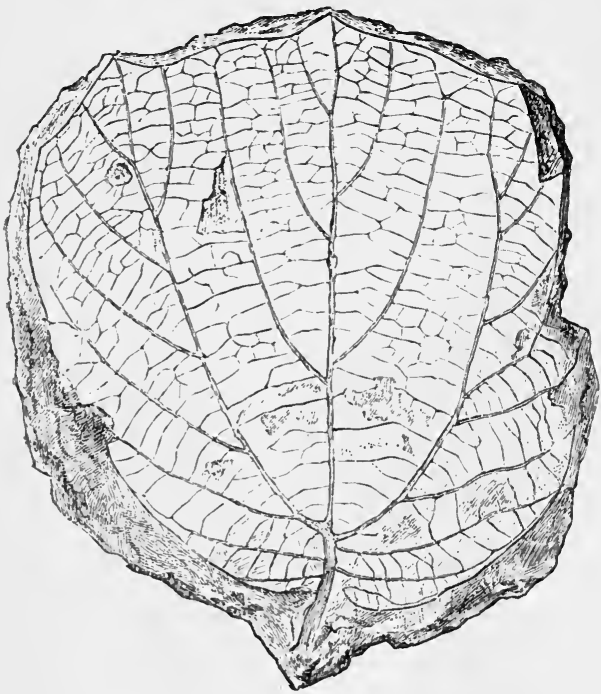

4

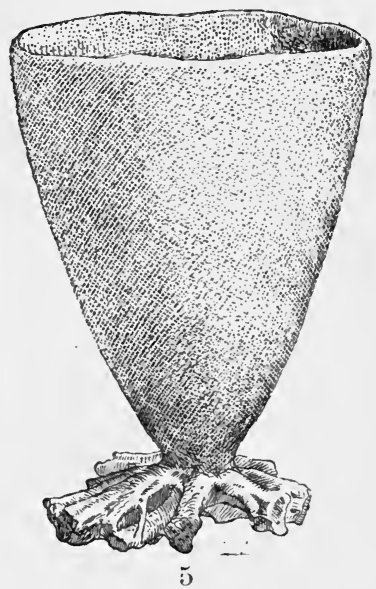

Puate LX.-Fossils of the Senonian.

1. Sardinioides Monasteri, Marck. 2. Crania ignabergensis, Retz. 2A. Interior of lower valve, enlarged. 3. Thecidium digitatum, Gf. 4. Ciedneria triacuminata, Hampe. 5. Coscinopora infundibuliform is, Gf. 
The succeeding series are subdivided by Schlüter as follows:-

\section{Upper Senonian. = Coloptychium Chalk (=Campanien).}

'The remarkable mushroom-shaped sponge genus C'aloptychium (of the Hexactinellidæ) is entirely limited to this uppermost subdivision of the Chalk; and is spread from Ireland to the south-east of Russia.

3. Zone of Heteroceras polyplocum (LIX. 2). (formed like Turrilites but the last whorl free; a large, longitudinally ribbed species) and Siaphites pulcherrimus, $=\mathrm{U}$ p per Mucronata Chalk. Belemnitella mucronata, Aum. Wittekindi, Baculites anceps (LIX. 3), Ananchyles ovata (LVIII.3), numerous fish, crabs and plants (the Plattenkalke of the Baumberg and of sendenhorst are famous for fish and plants). Includes the soft yellow sandstones and marls of Haldem and Lemförde in Westphalia, Aliten near Hanover, etc. Reaches $100 \mathrm{ft}$. in thickness. Contains the latest of the German Ammonoidea.

2. Zone of Amm. C'oesfeldensis and Micraster glyphus =Lower Mucronata $\mathrm{Chalk}$. Includes the marls, limestones, and mariy sandstones of Kösfeld, Darup, Borup, etc., some $200 \mathrm{ft}$. thick. Ananchytes vulyaris, Vola quinquecostata, Crryphaca vesicularis, Pholadomya Esmarli, Terebratula obesa, Belemitella mucronata, etc.

1. Zone of Becksia Sokelandi (a Hexactinellid sponge) $=\mathrm{Cpper}$ Quadrata Chalk. Actinocamax quadratus, Inoceramus Cripsi (IVII. i) (a flat, broad-winged species, very much extended laterally, which is found throughout the Senonian), Vola quinquecostata (LVII. 4), Gryphace vesicularis (LIX. 4), C'oloptychinm agaricoides (LIX. 5), Ananchytes (Echinororys) vulgaris, etc.

Lower Senonian.= Lower Quadrata Chalk (=Santonien).

3. Zone of Scaphites binodosus, with Lxog!lra laciniata, Inoceramus lingna, Scaph. iuflatus, etc. Typical occurrence is the sandy limestone of Dülmen in Westphalia.

2. Zone of Pecten muricatus. Fola quadricostata, Inoceramus lobatus, Trigonia aliformis (IVII. 6), Pimna quadrangularis, leaves of C'redneria (LX. 4), etc. Here belong the beds of Haltern in Westphalia, etc.

1. Zone of Marsupites ornatus (IVII. 3) (a stalkless crinoid, easily recognised by the characteristic markings on its calyx). Here belong the sandmarls of Recklingshausen (Westphalia), and probably also the unfossiliferous marl of the Salzberg near Quedlinburg. ${ }^{1}$

In Eastern Germany the Saxon Cretaceous area is of special importance for the knowledge of the formation, on account of the researches through a lnng series of years of $\mathrm{H}$. Br. Geinitz. The Cenomanian begins here at Platen, Tharandt, etc., with true "Tourtia," a conglomeratic formation or shell breccia, which lies directly, in part in pockets, on the Syenite of the

1 D. Brauns, "Der senon. Mergel d. Salzberges," Zeits. f. ges. Naturw. (1576), p. 325. An approximately equivalent shore fauna as well as it small but interesting fresh-water fauna (including Cyrena and Paludina) has been described by Frech from the same area. Zeits. d. deutsch. geol. (ies. (1887), p. 141. 
Planenscher Grund. The higher beds, on the other hand, are developed mainly in a sandy form as Quader Sandstone (Lower Quader, Geinitz). According to the latest researches of the Geological Survey the Saxon Cretaceous may be classified as follows:-

10. Upper Quader (Upper Turonian, Emscher or Lower Senonian; position still uncertain). Quader sandstone, forming steep isolated hills above the scaphites horizon.

\section{Turonian.}

e. Stage of Scaphites Cieinitzi.

9. Marl and clay of the Copitzer Ebenheil, of Zaltzschke and Oberposta, with sc. Geinitzi, Sc. auritus, Inoceramus latus and Baculites.

d. Stage of Inoceramus Biongniarti.

8. Brongniarti Quader, Upper Quader, Iser sandstone, with In. Brongniarti, Lima canalifera, Vola quadricostata, Exogyra columba, Rhynclionella plicatilis. 'The Elbe Valley is cut in this group, and it also forms the summit beds of the Hoher Schneeberg.

7. Marl of the upper part of the valley of the Gottleuba, unfossiliferous.

6 and 4. Glauconits sandstone with Rhynchonella bohemi:a, Schlönb. (Pirna, Cotter Berg, Rosenthal, Hoher Schneeberg). Between these is intercalated:-

5. Pläner with In. Brongniarti and Spondylus spinosus (Hoher Schneeberg, Krietzschwitz, Cotta'er Berg, Copitz.)

c. Stage of Inoceramus labiatus.

3. Labiatus Quader, Middle Quader, Bildhau sandstone, with Inoceramus labiatus, Pinna decussata. Often marly at the base, and towards the N.W. becomes calcareous and passes into

\section{Cenomanian.}

Labiatus Pläner (Middle Pläner).

b. Stage of Ostrea carinata.

2. Carinata Quader, Lower Quader with Ostrea carinata, O. hippopodium, O. diluviana, Exogyra columba, E. haliotoidea, Inoceramus striatus, Trigonia sulcataria, Protocardia Hillana, Radiolites. At the summit locally hornstone or Pläner sandstone with C'idaris sorigneti. Sometimes with banks of coarse conglomerate. Conglomerates and shell breccias fill local clefts and hollows of the subsoil. The Carinata Quader may be wholly or partially replaced by the

Carinata Pläner or Lower Pläne'1.

a. Stage of Credueria.

1. Dark, thin-bedded sandstones and shales with leaves and carbonaceous stains. (Plant-bearing beds of Niederschöna, Paulshain.) Accompanied by basal conglomerate and gravel.

In Lower Silesia the Cenomanian and Senonian consist of sandstones; the Turonian, on the other hand, as in W. Germany, of Pläner. The coal-bearing character of the uppermost Senonian beds (the Upper Quader) in the region of Löwenberg is remarkable. Accompanying the coal there are numerous remains of land 
plants-Kieslingswald in the county of Glatz is especially famous for these-and some brackish-water bivalves (Cyrena cretacer, etc.) occur along with marine forms. The plastic clays, from which the well-known Bunzlau vessels are prepared, belong to this horizon, and are of economic importance. ${ }^{1}$

In Upper. Silesia the Cenomanian is also composed of sandstones with Amm. rotomayenesis, Exogyra columba, etc., the 'Turonian and Senonian, on the other hand, mainly of calcareous marls with the characteristic fossils.'

Thus the general development of the Cretaceous in the preceding areas of Germany may be shown as in the following table:-

\begin{tabular}{|c|c|c|c|c|}
\hline & $\begin{array}{c}\text { Westphalia } \\
\text { Hanover } \\
\text { Harz Border. }\end{array}$ & Saxony. & Lower Silesia. & Upper Silesia. \\
\hline Senonian. & Sardstone & Quader. & Sandstone. & Calc. marl. \\
\hline Turonian. & Pläner & Pläner $\quad$ Quader. & Pläner. & Calc. marl. \\
\hline Cenomanian. & $\begin{array}{l}\text { Pläner. } \\
\text { Tol }\end{array}$ & $\begin{array}{l}\text { Quader. } \\
\text { urtia. }\end{array}$ & Sandstone. & Sandstone. \\
\hline
\end{tabular}

The small Cretaceous area of Aix-la-Chapelle and Maestricht consists exclusively of Senonian, which shows in its lower parts all the characteristics of a shore or dune formation. Holzapfel, ${ }^{3}$ to whom we owe a new comprehensive description of the rich Molluscan fauna of the Aix-la-Chapelle Chalk, classifies it as follows :-

\section{Upper Senonian (with Belemu. meronatus).}

2. Maestricht Beds, soft yellowish so-called tuffchalk. At Aixla-Chapelle itself only in small remnants; well developed at Maestricht, where the very fossiliferous rock (with numerous Bryozoa, Hemipnenstes and other sea urchins, gasteropods, mussels, brachiopods, foraminifer's) has been worked from very ancient times in the Peters berg. The famous Mosasaurus also was found here.

1. Chalk Marl; at the top with firestone. Gryphece vesicularis, (iania ignabergensis (LX. 2) and other brachiopods, Nantilus, etc.

1 "Erläut. z. geogn. Karte v. Niederschlesien" (1867). Williger. Die löwenberg. Kreidemulde. "Jahrb. d. preuss. geol. Landesanst." (1881).

2 F. Römer, "Geologie von Oberschlesien" (1870).

s "Paläontogr:" (1887-89). 
Lower Senonian (with Actinoc. quadratus).

2. Greensand with rich fauna (Vola quadricostata, Baculites incurvatus, Pectunculus dux, etc.).

1. Aix-la-Chapelle Sand, with numerous plant remains, ${ }^{1}$ Inoc. loluatus. Actoonclla, Pyrgulifera, etc.

The Baltic Cretaceous area is before all characterized by the white writing chalk, the most southerly outcrop of which lies near Lüneburg. This is an earthy material like the Globigerina ooze of the deep sea of the present day, consisting partly of amorphour particles of limestone, partly of innumerable minute shells of Foraminifers (especially Globigerina), and powdered remains of Bryozoa, Mollusca, Corals, etc. A specially well known and characteristic occurrence is that on the N.E. coast of Rügen. Herc, as is so common in the true chalk, there are numerous nodules of flint arranged in layers, which owe their origin to the concentration of the silica contained in the calcareous rock in the form of remains of Radiolaria, sponges and diatoms. The chalk of Rügen, with Ananchytes ovata, Micraster Leskei, Galerites vulgaris, Cidaris resieulosa, various species of Cyphosoma, Gryphara vesicularis, spondylus fimbriatus, Terebratula carnea, Belemnit. mucronata, numerous Bryozoa, etc., belongs to the Senonian; " but the Turonian and Cenomanian, and also the Gault (with B. minimus have been proved below it by borings at Greifswald (Zeits. $d$. deutsch. genl. Ges., 1874, p. 974). The small outcrops of chalk at Mecklenburg also belong chiefly to the Senonian ; but in part also to the Turonian and Cenomanian," whilst at Wollin only Turonian (Inoc. Brongniarti) is developed.

The Senonian rocks of Denmark and the S. of Sweden are much more extensive. Lundgren ${ }^{4}$ distinguishes from above. downwards :-

1. Youngest Chalk (Danian). Flint-bearing Saltholm limestone (near Malmö), and the succeeding Faxe limestone, with Dromia ruyose, Ananchytes sulcatus, Cidaris Forchlummeri, Nantilus danicus, Cyprea, and

1 A list of these, after Debey and $\mathrm{r}$. Ettingshausen, is to be found in $\mathrm{v}$. Dechen, " Erläut. z. geol. Karte d. Rheinprov.," etc. ii., p. 427.

" v. Hagenow. "Monogr. d. Rügen'schen Vesteinerungen. Nenes Jahrb." (1839, 40, 42). Marsson, "Die Bryozoen d. weiss. Schreibkr. d. Ins. Rügen. Palïont. Abh.," 1887.

3 F. Geinitz, "Lbers. ü. d. Geol. v. Mecklenb." (1885), and "9. Beitr. z. (ifol. Mecklenb." (1887).

4 "Öfversigt af Sveriges mesoz. bildningar" (1888). See also Zeits. d. cleutsch. geol. Ges. (1888), p. 725. 
others, which are unusual in Mesozoic formations-except in the youngest ('ialk-and first become abundant in the 'Yertiary.

2. Beds with Belemitella mucromata. Köping Greensand, etc.

3. Beds with Actinoc. subrentricosus. Fragmental chalk of Ignaberga, 'losterup, etc.

1. Beds with Actinoc. quadratus.

5. Beds with Actinoc. verus and A. westfalicus, according to Schlüter= Emscher Mergel.

Lastly, it is to be remarked that the innumerable flints and fragments of chalk scattered throughout the diluvium of $\mathrm{N}$. Germany are derived from the extensive destruction of the Northern Chalk; some of them very probably from outcrops formerly present in N. Germany itself. ${ }^{1}$

In England ${ }^{2}$ the Upper Cretaceous includes the Upper Greensand and the Chalk; and differs from the ordinary German type in the great development of true chalk, which in fact forms by far the greater part of the series.

The Upper Greensand consists of soft light-coloured sand and sandstones, sometimes calcareous, and generally bearing grains. of glauconite. It contains fossils, especially Echinoderms (Discoidec subuculus, Salenia, etc.) and molluses (Pecten asper, Exogyra columba, Grypheace resiculosa, etc.), and is sometimes divided into the following zones:-

2. Zone of Pecten asper.

1. "Exogyra conica.

In Devonshire Meyer has distinguished some dozen zones, which have not, however, been traced over the country. The group is. clearly the equivalent of a part of the Cenomanian.

The Chalk is divisible broadly into-

White Chalk with flints.

White Chalk without flints.

Chalk Marl.

Chloritic Marl.

These divisions can generally be made out; but the lower part of the chalk itself frequently contains flints, and the upper part in some cases does not.

1 Dames, Zeits. d. deutsch. geol. (res. (1874), 1. 761. Schrüder, ibid. (1882), 1. 213. Nötling. "Paläont. Abh." (1885̃).

2 The most important work for comparative purposes, on the Cpper Cretaceous of England, is that of C. Barrois, "Recherches s. 1. terr. crétacé supér. d'Angleterre et de l'Irlande" (1876). 
On the coast of Kent the Chalk is divided into the following zones :-

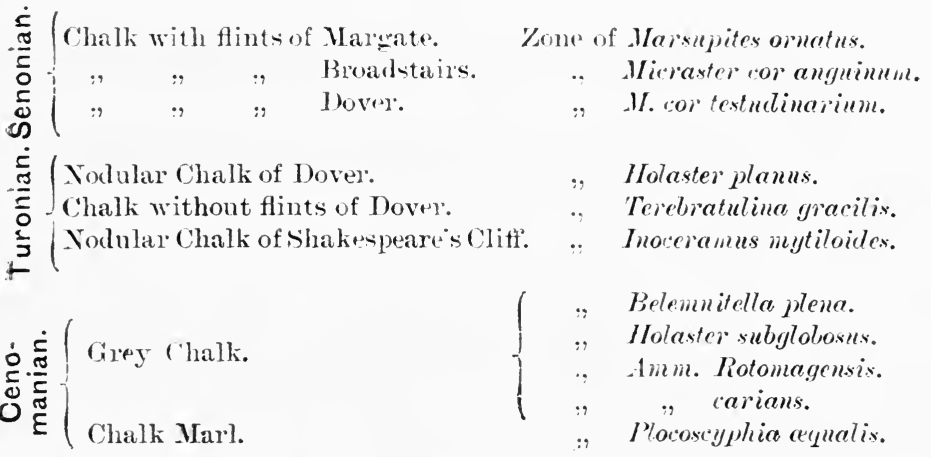

The same zones can be recognised more or less exactly throughont England; and frequently there is a higher zone still, the zone of Belemitella mucronata, which includes the uppermost part of the chalk in the Isle of Wight, Norwich, Yorkshire, ete.

In the Isle of Wight Barrois recognises :-

\begin{tabular}{|c|c|c|c|}
\hline White & Chalk w & with & Belemnitella mucronata. \\
\hline & & & Micraster cor anguimun. \\
\hline & & , & M. cor testudinarium. \\
\hline & & & Holaster planns. \\
\hline Chalk & Marl & $\therefore$ & Terebratulina gracilis. \\
\hline & & "? & Inoceramus labiatus. \\
\hline Glanes & mitic Chalk & k , & Turrilites and sopplites aqualis. \\
\hline Chlori & ic Marl & 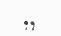 & Amm. latirlavins. \\
\hline Epper & Cireensand & & Amm. inflatus. \\
\hline
\end{tabular}

In the North of France the succession of the Upper Cretaceons rocks closely resembles that of England; but still higher zones are represented, and these are united under the term Danian. The whole series may be divided as follows:-

Danian. Locally developed.

Pisolitic Limestone of Meudon. A yellowish coneretionary rock with Vautilus danicus, C'idaris Forchhammeri, etc. Zone of Nautilus danicus.

Baculite Limestone of the Cotentin, resting on a greensand with Orbitolina. Zone of Baculites anceps.

Senonian. Very homogeneous throughout the Paris basin; formed of white chalk. Divided into-

Campanien. Zone of Belemnitella mucronata.

$\begin{array}{lll}\text { Santonien. } & " \quad \text { B. (Actinocamax) quadrata. } \\ & " \quad \text { Micraster coranguinum. } \\ & & \text { M. cor testudinarium. }\end{array}$


Turonian. Marly Chalk.

Angoumien. Zone of Microster breviporus.

"Terelsatulina gracilis.

Contains also Amm. peramplus, Scaplites Cieinitzi, Spondylus spinosus, Inoceramus Brongniarti.

l.igérien. Zone of Inoceramus labiatus.

Cenomanian. Mlauconitic Chalk.

Carentonien. Calcareous marls with Belemnitella plena.

Grey chalk with Holaster subglobosus.

Glauconitic chalk with Turrilites tuberculatus.

Rotomagien. Glauconitic sands, ete, with Yerten asper and Ammonites inflatus.

It should be remarked that Hébert considers that the Cenomanian and Turonian of the North of France represent only the lower portions of these stages. He supposes the marine sandstone of the province of Maine with Anorthopygus orbicularis, and Errogyre columba to represent the Upper Cenomanian (absent further north); and he does not suppose the Angoumien substage of the Turonian to be represented in the North at all.

The Cenomanian is somewhat variable, but generally in the Paris basin it consists of marls, sands, and chalk, of ten glauconitic. In Flandres and Hainault it assumes the form of a glauconitic conglomerate of quartz pebbles resting directly on Palæozoic rocks, and this is what is known as the Tourtia.

The Turonian also is somewhat variable; but is chiefly formed of chalk marl. The zones established in Normandy, viz.:-

\section{Zone of Terebiatulina gracilis. \\ , Rhyuchonella C'uvieri. \\ "Inoceranus labiatus.}

are precisely the same as are found in Buckinghamshire and Cambridgeshire.

The Senonian is well developed throughout the Paris basin, and consists of white chalk like that of England; while the Danian is found only at one or two places.

\section{Upper Cretaceous of $S$. Europe.}

The most characteristic feature of the Upper Cretaceous of the South of Europe is the extraordinary development of Rudistes. Its thick, heavy shells occur in the shallow-water formations through out the Equatorial zone in S. Europe, and also in N. Africa, Asia Minor, India, Mexico, in great numbers often forming large rock masses. The genus Spharulites (LXI. 4), which alone is present in 
the Lower Cretaceons, is here accompanied by Radiolites and Hippurites (LXI. 3). Other characteristic forms of the Southern Upper Cretaceous are the bivalve genus Caprotina (C.adversa [LXI. 2], U. Cenomanian), the Ammonite genus Buchiceras(LXI. 1), the gasteropods Actreonella (LXI. 5), Glauconia (LXI. 6), and Nerinea, and the peculiar coral Cyclolites (LXI. 8).

In the W. Alps, an important division of the Upper Cretaceous is formed by the Seewen Beds, limestones and marls, poor in fossils, belonging to the Cenomanian and Turonian, probably also to the Senonian (Amm. rotomagensis, etc., characteristic Inocerami, etc.). The Hippurite Limestone also, which often forms by itself the whole of the Upper Cretaceous, plays an important part. Further there belong here the calcareous marly Gosau beds. (named after Gosau near Hallstatt) with numerous Hippurites ( $H$. organisans, H. cormu vaccinum), Nerinea, Actaronella, Cyclolites, etc. About a fourth of the rich fauna occurs also beyond the Alps. The lower beds belong to the Turonian, the higher to the Senonian; Amm. Ifarge and A. texanus, and some other species also point to a relationship with the Emscher marl. ${ }^{1}$ The well known fine marble of the Untersberg near Salzburg also is only a special facies of the Hippurites Limestone. In the Bavarian Alps, moreover, Orbitolina beds (with $O$. concava) occur in the horizon of the Turonian and Senonian, as also in the lower division of the Southern Cretaceous. At some places, $e . g$. near Berchtesgaden, late Senonian deposits with Belemn. mucronata have been proved.

In the S. Alps the so-called Scaglia, white and reddish limestones with Inoceramus Cuvieri, Ananchytes ovata, Cardiaster. Italicis, etc., along with Hippurite Limestones, possess a wido distribution, especially in the Lombardo-Tenetian Alps. Certain very interesting late Cretaceous brackish and fresh-water deposits, in part coal bearing, which lie directly on the Rudistes Limestone in Istria, Carinthia and Dalmatia (with Cyrena, the Melanid genus Stomatopsis, remains of Characeæ) are known as the Cosina beds, or Liburnian series of Stache. ${ }^{2}$ Similar fresh-water deposit. with Unio, Melania, Helix, Auricula, etc., also occur interbedded in the Upper marine Chalk at Ajka in the Bakony and in Provence.

A peculiar facies of the South European Cretaceous is formed by

1 The Cephalopods of the Gosau beds have been described by v. Hauer and Redtenbacher, the Gasteropods by Zekeli, and the Lamellibranchs by Zittel, and the Reptiles by Seeley.

2 "Die liburnische Stufe. Abh. d. geol. Reichsanst." (1889). 

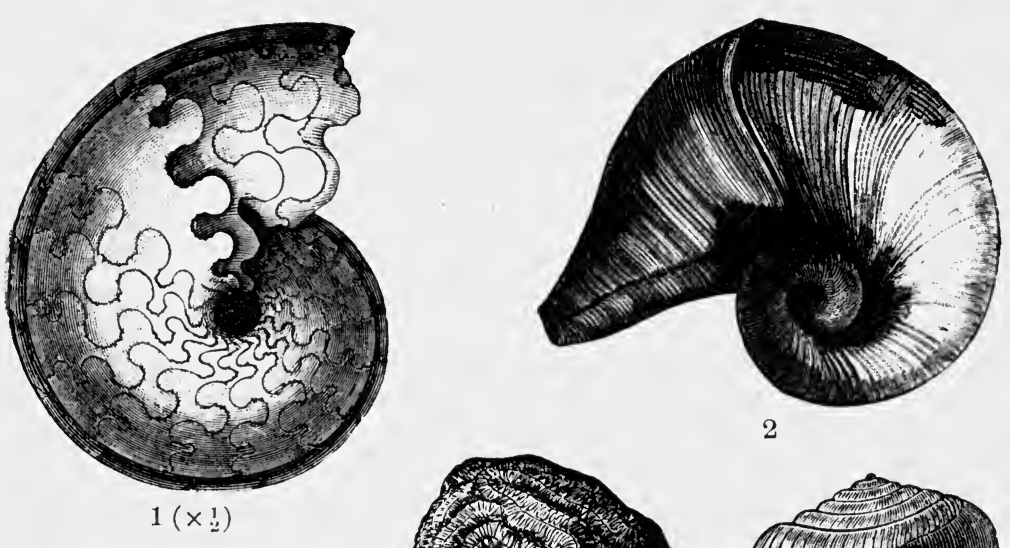

2
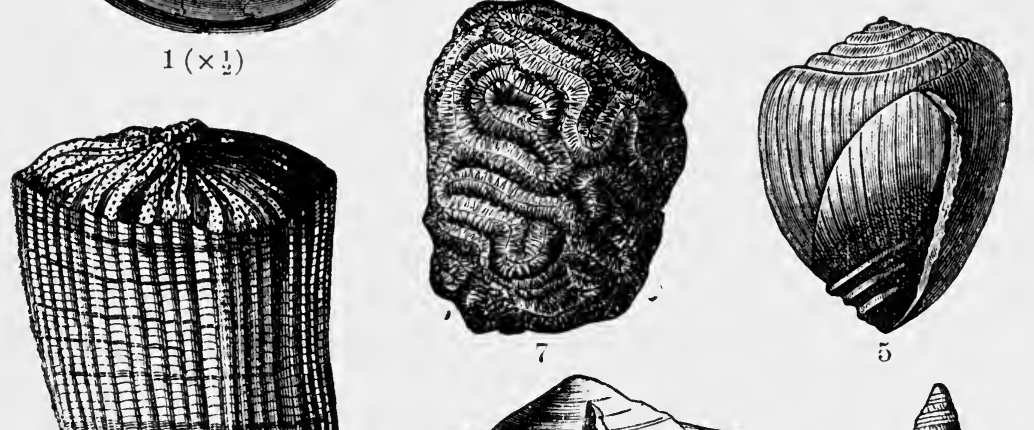

in

$1+12+$

$12+10$

$17+1$

1127

217

H)
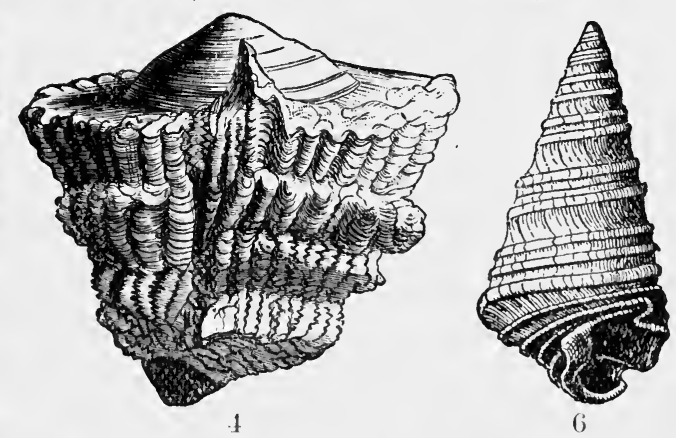

$3\left(\begin{array}{lll}\times & 1 & 1 \\ 2 & 3\end{array}\right)$

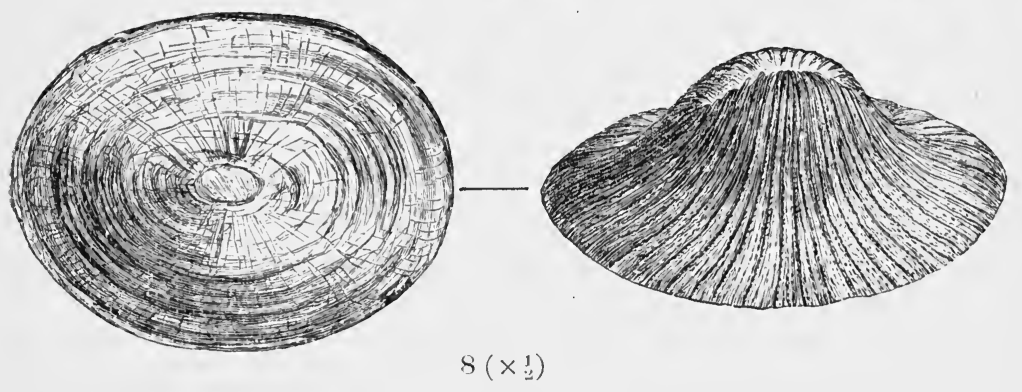

Platr LXI.-Fossils of the Alpine Upper Cretaceous.

1. Buchiceras Eraldi, v. Buch. 2. Caprina adversa, d'Orb. 3. Hippurites cornu vaccinum,

Ff. 4. Sphwrulites angeiodes, Lam. 5. Actoonclla gigantox, Sow. 6. Glauconia Kefersteini,

Gf. 7. Leptoria Konincki, Reuss. 8. Cyclolites undulata, Lam. 
the Vienna or Carpathian Sandstone, a very thick unfossiliferous sandstone like the Tertiary "Flysch," which is very widely spread in Lower Austria, the Carpathians and Bosnia, and according to the views of the Tienna geologists represents the whole of the Cretaceous.

\section{Extra-European Cretaceous.}

A few remarks on the Cretaceous of other areas must here be made. The Cretaceous is rery widely spread in the North of Africa. In the Atlas it shows quite the Mediterranean faciesRudistes Limestones are there very widely spread. In the Lybian Desert, on the other hand, according to Zittel, ${ }^{1}$ the youngest. deposit directly below the Eocene, is writing-chalk, which besides many peculiar fossils contains also Ananchytcs ovata; the oldest. deposit, on the other hand, is a grey or reddish sandstone containing only silicified wood, the so-called Nubian Sandstone, which is of Cenomanian or Lower Turonian age and extends east into Syria and Arabia. In Syria, Palestine, Persia, Arabia, the Caucasus, etc.r U. Cretaceous beds with Rudistes, Nerinea, Buchicercts, etc., are very widely spread. The fish-bearing Senonian beds of Sâhel Alma and Hakel in Lebanon are very famous.

Cretaceous Rocks are also found at many points in S. and E. Asia. In India especially, the very fossiliferous Upper Cretaceous of Pondicherry (in the S. part of the E. Coast) has become famous through the work of Stoliczka and others. These deposits together with the Cretaceous outcrops on the east of the continent, (the Japanese Island of Yesso, Saghalien, etc.), and on the Aleutians, Vancouver I., etc., belong to the Indo-pacific Cretaceous area, and show several peculiarities.

In North America, there !is a contrast between the $\mathrm{N}$. and S. facies of the Cretaceous just as in Europe. In Jamaica, Mexico, Texas, and California, Rudistes, Nerinea, Buchicerds and other characteristic forms of the Cretaceous Equatorial Region occur, while further north a facies corresponding with that of Central Europe, predominates. The Cenomanian (Dakota group), and younger Cretaceous deposits especially are widely spread here, whilst Lower Cretaceons deposits are particularly developed in the extreme W. (Shasta group in California). The thick fresh-water formation of the Rocky Mountain region, known as

1 "Beitr. z. Geol. u. Paläont. d. lib. W'üste. Paläontogr." (1883). 
the Isaramie Croup, belongs rather to the oldest Tertiary than to the Cretaceous.

The Lower Cretaceons is well developed on the W. coast of Sonth America, especially in Columbia, while in Brazil the Upper Cretaceons (here also with Buchiceras) is very widely spread.

In S. Africa the Uitenlage beds belong to the Neocomian, and approximately the same age may be ascribed to the deposits with Criocercs custrale which cover so large an area in $\mathrm{New}$ Zealand.

\section{PALAONTOLOLY OF THE ('RETALEOUS.}

The Flora of the Lower Cretaceons consists chiefly, like the very similar Jurassic flora, of Cycads, Conifers and Ferns, whilstas the rich collections of plants in the Wealden and in the Wernsdorf beds, etc., show-Angiospermous dicotyledons were at that time almost absent in Europe. It was in the Upper Cretaceous period that there began a complete revolution, and dicotyledonous trees suddenly appeared in abundance throughout Europe. Near Aix-la-Chapelle, Haldem (Westphalia), Blankenburo, Niederschöna (Saxony), Moletein (Moravia), they are everywhere the predominating element of the flora, and in comparison with them the Cycads, hitherto so important, are much reduced. Along with several extinct genera of Angiosperms, such as Credneria (IX. 4), we meet with many still living forms, such as Salix, Populus, Aralia, Ficus, etc.

The view, till lately quite universal, that leaf-bearing trees were quite absent in the Lower Cretaceous, has now been shown to be mistaken, since in recent times along with ferns and fir-trees awhole series of Angiosperms has been found in the North American States of Maryland and Virginia, in the so-called Potomac Formation, which is considered equivalent to our Wealden. Only a few of them can be referred to existing genera (Hymencer, Ficus); the greater number belong to extinet forms of an older type, which, however, recall living genera (Salix, Platamus, Populus, Llmus, Aralia, IIedera, etc. $)^{1}$ From these highly interesting discoveries it appears that the leaf-bearing trees spread outwards from the North American region, in which they were present at the beginning of the Cretaceous period. As some of the earlier observations show, even in the time of the older Cretaceons they had set foot in other areas, such as Greenland and Portugal; but it

1 W. M. Fontaine. "The Potomac or Younger Mesozoic Flora. Monogr. of the United States Geol. Surrey, xv." (1889). 
was not till later Cretaceous times that they formed the predominating element of the flora throughout the world.

Turning to the Fanna, we must first notice the large part which the Foraminifera took in the formation of the chalk; and of these Globigerina and others are the most important in the true chalk of North-Western Europe, and Orbitolina in the Alpine Orbitolina Limestone.

The Cretaceous Sponge-fauna is richer then almost any other. This is true of the Calcareous Sponges, but still more so of the Siliceous Sponges, of which the Hexactinellidæ and Lithistidæe reach their greatest development in the Upper Cretaceous. The Hexactinellid genus Cooloptychium may be mentioned as a specially characteristic form of the Upper (Coloptychium) chalk.

The corals in general show little that is peculiar. Great collections of composite reef-building forms are found only in the Equatorial zone (e.g. in the Gosau beds); whilst outside this zone, especially in the deposits formed in the greater depths of the sea, only solitary forms-such as Caryoplyyllia of the chalk-are usually to be observed.

Among the Echinoderms, the Crinoids-one of the most important types of which is the stalkless genus Marsupites (LVII. 3),-and Asteroids were of little importance in Cretaceons times in comparison with the numerous and varied Echinoids.

Among the Regular Sea-urchins the genera Cidaris, Acrocidaris and others are important forms which reach from the Jurassic to the Cretaceous. In the latter, these forms, like the small genus Salenia (LVIII. 4), which now appears for the first time, are especially widely spread in the true chalk. The Irregular, or symmetrical Sea-urchins are still more important on account of their great abundance, and among them especially the Spatangidæ, characterized by their more or less heart-shaped outline. This group includes in the Lower Cretaceons, the genus Toxaster (T. complanatus [LI. 4], Neocomian); in the Upper, IIolaster, Ananchytes $=$ Echinocorys (A. ovata [LVIII. 3], very common in the Senonian), IIemipneustes, Cardiaster, Infulaster, Epiaster and especially Micraster (M. cor anguinum, .M. cor testitudinarium [LVIII. 2], M. glyphus, etc., in the Turonian and Senonian). Of other Irregular forms, Galerites=Echinocomus, $(G$. albogalerus [LVI. 7], G. vulgaris, etc., abundant in the Turonian and Senonian), and Discoidea (D. cylindirica [LIV. 4] in the Cenomanian), should be mentioned as especially important. 
The Bryozoa are very richly developed, especially in the true chalk, but also near Maestricht, in the Essener Greensand and elsewhere.

The Brachiopoda are on the whole like those of the younger Jurassic. Tevebratula and Rhynchonella are here also the most important genera. The ancient genus Crania (LX. 2) is distinguished in the latest chalk deposits by greater richness in species than in any other formation. Argiope and Thecidium (LX. 3) are also relatively abundant; and the extremely long-beaked genus Lyra, the Orthis-like Trigonosemus, etc., are peculiar to the Cretaceous.

Annong the Lamellibranchs there should be mentioned as characteristic of the Chalk, large oysters, especially Gryphace (G. vesiculcris [LIX. 4] Senonian), and Exogyra (E. couloni [LI. 3] Neocomian, E. columba [LV. 1] Cenomanian); among the Pectinidæ, the senera Vola and Neithea (quinquecostata [LVII. 4] Upper Cretaceous) characterized by great inequality of the valves and by radial ribbing; and the widespread genus Inoceramus with many type species (LII. 6 ; LVI. 5,6 ; LVII. 2 and 5 ) is also an important form. But the most remarkable Cretaceous forms are the peculiar Rudistes, limited entirely to the Cretaceous (Hippurites [LXI.3] Radiolites, Spherulites [LXI.4]-the first two only in the Upler, the latter in the Lower Cretaceous), with shells like thick funnels with lids. The remarkable horn-shaped Requienia (R. ammonia [LIII. 2], and others in the Lower Cretaceous), Caprina (LXI. 2) Monopleura (LIII. 1), and other genera of the family Chamidæ, belong exclusively to the Cretaceous.

Among the Gasteropods the genera Actaonella (LXI. 5)-thick forms like Conus but provided with columellar folds-and Glauconia or Omphatia (LXI. 6) should be mentioned as characteristio of the Equatorial Region; but like the Rudistidae, they are represented only by scattered forms in Central Europe. In the newest Cretaceous beds a number of genera such as Cypraa, Conus, Voluta, F'usus, Mitra, Murex and others occur, which give to these deposits a tertiary character.

The Cephalopoda are much more important than the Gasteropods. We find here the last Ammonites and Belemnites. The former are characterized especially by the great number of forms with free whorls (Crioceras [LIII. 3]) or with hooked, staff-shaped, or turreted shell (Hamites [LII. 4], Baculites [LIX. 3] Turrilites [LII. 3], and allied forms), or shell of some other form (Scaphites [LVI. 2]). Among the regularly formed genera are Hoplites ([LI. 1; C. G. 
LII. 2], L. Cret., richly ornamented, tolerably strongly involute shell with forked ribs and distinct dorsal grooves), Haploceras and Desmoceras (L. Cretaceous, smooth shells with rounded whorls), Acanthoceras ([LII. 1; LIV. 1], L. and U. Cret., angular thick shell with stiff, often tuberculate ribs), Schlönbachia ([LIV. 2], L. and U. Cret., with sharp keel and strong forked and tuberculate ribs), Buchiceras ([LXI. 1], only U. Cret. of the Equatorial Region; disc-like form with Ceratite-like sutures), Pachydiscus ([LNI. 1], Turonian, Senonian, very large swollen shells), are the most important. In the Lower Cretaceous of the Southern Province, the remarkably long-lived genera Phylloceras and Lytoceras are still found in tolerable abundance.

Among the Belemnites the laterally compressed flat forms (Duvalia [LIII. 6]) are characteristic of the L. Cretaceous of the South; the forms of the group Absoluti (distingnished by their siphonal canal) and Exccntrici (with very excentric alveolus) for the Northern Cretaceous. In the U. Cretaceous, instead of the true Belemites, the genus Belemnitella (B. mucronata (LIX. 1], a widely spread type fossil of the youngest Cretaceous) occurs, and its sub-genus Actinocamax (A. quadratus [LVIII. 1] in the Senonian Quadratus Chalk).

The genus Nautilus is represented in part by numerous, often very large, species, especially in the U. Cretaceous.

Among the Crustacea the strong development of the Brachyurous Decapods (Dromiopsis, etc.) in comparison with the Macrurous forms (amnng which Calianassa is specially abundant) is noticeable.

Passing on to the Vertebrata we see that among the fish the Teleostei (bony fishes), which are still scarce in the Jura, for the first time become abundant and various, especially in the Upper Cretaceous. Some specially important localities in Westphalia and Lebanon have already been mentioned.

Among the Reptiles we meet in the Cretaceous with the last Ichthyosaurs, Plesiosaurs and Pterosaurs, the latter of which were represented in the Cretaceous of Kansas in North America by a large toothless form with a span of ten feet (Pteranodon). Chelonians and Crocodiles-among which Goniopholis is a characteristic form-were richly represented, and in part by peculiar forms. ${ }^{1}$ Among the most peculiar of the Cretaceous reptiles were

1 Koken, "Dinosa urier, Crocodiliden u. Sa uropterygier d. nordd. Wealden. Paliiont. Abh." (188T). 
the gigantic snake-like Pythonomorpha. Their remains are especially numerons in the Cretaceous of Kansas. Of European forms the well-known gigantic Mosasaurus from the Tuff Chalk of Maestricht belongs to this group. North American species of this genus reach 70 feet in length. A not less interesting and also completely extinct reptilian order, the Dinosauria, reaches its greatest
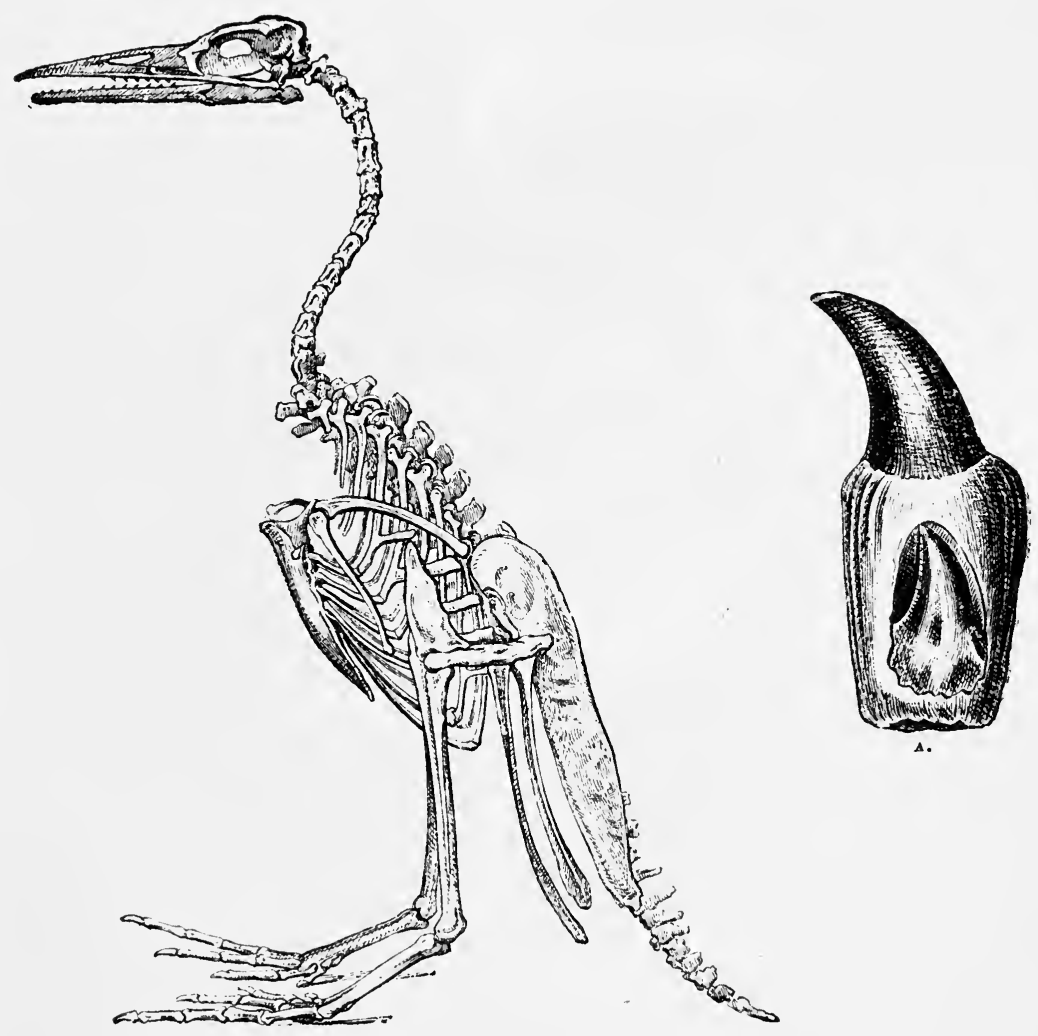

FIg. 43,..-Hesperomis regalis, Marsh. restored, ${ }_{4}^{1}$ nat. size (after Marsh).

Fig. 13.1. Tooth of the same with germ of steceeding touth. Enlarged about 5 times.

development in the Cretaceous, and was represented especially by the gemus Iguanodon (L. 1). Formerly this group was known only from incomplete remains from the English (and German) Wealden; but not long ago a number of complete skeletons, now preserved in the Brussels Museum, were found in one of the Cretaceous Masses, sunk in the Carboniferous rocks, near Bernissart."

1 Doilo, "Bull. Musée roy. d'hist. nat. de Belgique," 1882, 1883. 
Reaching more than 30 feet in length, these mighty animals were characterized by the enormous strength of their hinder extremities and of the long tail, and by the very bird-like appearance of the pelvis. The spoon-shaped, two-edged teeth with oblique grinding surface and zig-zag borders are very characteristic of this genus.

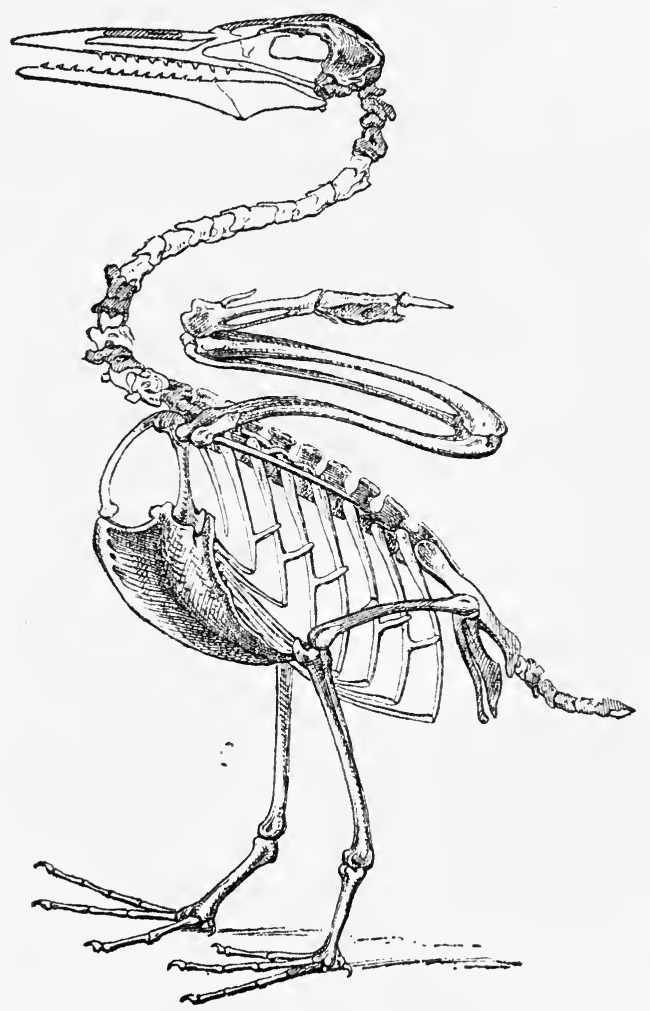

FI6. 41.-Ichthyomis victor, Marsh, "restored, not yuite? nat. size (after Marsh).

A remarkable feature of the higher Cretaceous fauna is the occurrence of toothed birds in the Cretaceous of Kansas, described by Marsh ${ }^{1}$ as Odontornithes. It is of special interest that these forms, though they share with Archapoptery $x$ the archaic toothed jaw and biconcave vertebra, may be separated, perfectly clearly,

${ }^{1}$ Odontornithes, a monograph on the extinct toothed birds of North America. "Report geol. explorat. of the 40th parallel," vii. (1880). 
into two groups-the same as those of the present day-viz, the running and the flying birds. To the former belong Hesperornis (Fig. 43) about the size of a stork, with unkeeled breast-bone, rudimentary anterior extremity consisting only of a stump of a humerus, massive bones, and no pygostyle (ploughshare bone). To the flying birds belonged the Ichthyornis (Fig. 44), about the size of a sea-gull, with large keeled breast bone, pneumatic bones, well developed anterior extremity and pygostyle. 


\section{NEOZOIC GROUP.}

The Neozoic or Kainozoic group of systems includes all those formations which, beginning after the deposition of the chalk, belong to the youngest age of the earth's history, the recent period. The deposits of this long period of time are divided into two great systems, namely an older, or Tertiary, and a newer or Quaternary.

The boundary between the Neozoic and Mesozoic groups is almost everywhere very sharp. Indeed, there is searcely any other division in the history of the earth which is so important and so natural as that between the Chalk and the Tertiary. This is connected with the fact that at the close of the chalk age a ehange took place both in the distribution of land and water and also in the development of organic life, so great and universal, that it has scarcely been equalled at any other period of the earth's geological history. Hand in hand with great earth morements, there took place rast eruptions of igneous rock, the great abundance and extent of which in the Tertiary beds stands in striking contrast with their almost complete absence in the Cretaceous deposits. Like those of the present time, these eruptive rocks, with the tuffs accompanying them, have in most cases originated from volcanoes and craters, and consist of Trachytes, Rhyolites, Andesites, Basalts, and others, differing in no way from those of the present day.

The sedimentary deposits of the Neozoic period are distinguished from those of the older formations by their usually loose and unconsolidated character. It is only in the Lower Tertiary that there are found in some areas hard limestones, quartzitic rocks and slates like those of the older periods; but usually soft crumbly limestones, marls, clays, sands and conglomerates are the predominating rocks. It is also to be remarked that, among the marine deposits, deep-sea formations comparable with the chalk or the Glo bigerina ooze of our present oceans, are practically unknown among the Neozoic rocks. They are, on the other hand, more 
generally shallow-sea or coastal formations. Along with these marine deposits, however, from the beginning of the Tertiary period, estuarine, fluviatile, and even æolian or other terrestrial formations (such as the moraine deposits of the drift) play a considerable part.

The lie of the Neozoic beds is in general undisturbed, like that of the Mesozoic rocks. As a rule they are still nearly horizontal. Only the beds taking part in the formation of the great mountain chains form exceptions to this. Palæontologically the deposits of the last great geological periods are characterized by the more or less complete absence of the large marine saurians, Dinosaurs and Pterosaurs, etc., so abundant in the Cretaceous; of Ammonites and Belemuites, Rudistes, Inocerami, Trigonias, etc.; by the marked reduction in the Brachiopods compared with the now richly developed Gasteropods and sinupallia te Lamellibranchs ; by the abundance of short-tailed Decapods and bony fishes; by the development of snakes and normal birds; before all by the sudden (so far as our present knowledge goes) appearance of placental mammals, and lastly, in the drift, of man.

The Neozoic flora consists mainly of Angiospermous Dicotyledons and Monocotyledons, and belongs to the third and last Vegetation age of $\mathrm{Ad}$. Brongniart, the age of Angiosperms.

\section{A. TERTIARY SYSTEM.}

\section{(GENERAL AND HISTORICAL.}

"The Tertiary System is widely spread over all parts of the earth, but petrographically and palæontologically it is very variously developed. That among the deposits belonging to it, true deep-sea formations are as good as absent, and that the great mass of the beds consists of coastal or shallow-water deposits, has already been mentioned. Also the manifold alternations of marine with brackish and fresh-water deposits to be observed in all the large Tertiary areas have already been noticed. This very characteristic appearance is certainly explained in many cases by the great number of earth movements during the Tertiary period. One and the same part of the earth's surface was during one phase of this period the floor of the sea, and was then covered by marine sediments; during the next phase it was again land, 
and then was covered by the brackish and shore deposits of lagoons, fresh-water lakes and marshes formed on this new land; whilst at a still later period, in consequence of another invasion of the sea, marine sediments were again laid down on the last. In other cases, this manifold alternation of marine and terrestrial deposits is connected with the fact that, as already noticed, much of the Tertiary was formed in basins near the sea coast, where even without any great vertical oscillation, changes in the mutual relations of the land and sea would easily occur, and the latter could for a time invade an area which it might not be able to master permanently.

The very numerous changes of facies among the Tertiary deposits, reflecting similar variations in the local conditions, are in the most intimate connection with these circumstances. It is these also that have brought about the relatively restricted distribution of most of the Tertiary deposits, which no longer extend unaltered over whole countries like those of older Systems, but generally occupy only smaller basin or bay-like areas-filled up inland seas or shallow gulfs.

The restricted extent of the Tertiary deposits explains the great difficulty which accompanies attempts at the exact correlation of the beds of the various basins. The method which has so far been used with great success for the determination of the age of separated deposits, namely the observation of their stratigraphical relations, is usually not applicable. We are therefore forced to make use of another, indirect, method, and that is the comparison of the marine shell fauna with that of the neighbouring seas of the present day.

Our knowledge of the Tertiary formation is relatively new. Until the beginning of this century geologists had united the loose sands, marls and plastic clays of which the Tertiary of so many areas is composed, and which were scarcely considered worthy of observation, with the alluvial and other deposits of recent times. It was in the first two decades of our century that the researches of G. Cuvier and Alex. Brongniart ${ }^{1}$ on the environs of Paris, showed the existence of a considerable and very fossiliferous series of deposits which are proved by their fa una, now extinct, to be equally distinct from the underlying Cretaceous and the overlying drift and alluvial formations. The numerous remains of mammals, in-

1 "Essai s. l. Géographie minéralogique des environs de Paris," 181011. 2nd ed. 1822, 3rd ed. 1835. 
cluding some forty distinct species, of the series, to which these two savants gave the name of Tertiary, were deseribed by Cuvier in his famous work, bearing the title "Recherches sur les ossements fossiles de quadrupèdes." 1 The beautifully preserved. shell fauna, including several thousand species, was worked out by Lamarck" and later by Deshayes." Among the Lamellibranchs searcely a single living species is found, and their nearest living: allies live in tropical seas.

After the Parisian deposits the very similar Tertiary rocks of the S. E. of England were next studied, then those of Italy and S. France, both of which also include a very rich marine Lamellibranch fauna, which howerer is much more nearly allied to the living. This is true especially of the so-called Sub-A pennine, so widely spread in Italy on the borders of the Apennines from the Po to Calabria, the molluscan fauna of which, consisting mainly of recent species, was made known by Brocchi. ${ }^{4}$ The fauna of the region of Bordeaux and Dax stands, according to the number of still living species, between the Parisian and the Sub-Appennineformation, and has been described by Basterot.j Al. Brongniart ${ }^{6}$ in the meanwhile had occupied himself with other older Italian Tertiary deposits, which also included an abundance of organic remains, and recognised them as the nearest to the well known Parisian beds.

By a comparison of all these faunas with one another and with the famnas of the present sea, Deshayes arrived at a general elassification of the Tertiary formation. ${ }^{7} \mathrm{He}$ established the position that the age of a Tertiary deposit can be decided by the percentage of living species occurring in it. The older a fauna is, the smaller is the number of recent species in it; and the newer the fauna the greater the number. Following out this idea, Sir C. Lyell proposed a division of the Tertiary deposits into three groups, the names of which he based on the number of recent species. occurring in these groups. ${ }^{8}$ They are from above downwards:-

1 Eds. 1812, 1821-25, 1836.

2 " Mém. s. 1. fossils d. envir. d. Paris," 1818-22.

3 "Descr. des coquilles foss. d. environs de Paris," 3 vols. (1821-3ī).

4 "Conchiliologia fossile subapennina," 1814.

" "Descr. d. coqu. foss. d. envir. d. Bordeaux," 1825.

" "Mém. s. l. terr. de sédim. supér. calcaréo-trappéen du Vicentin," 1823.

7 "Bull. Soc. geol. d. France," 1830.

s App. to vol. ii. of the "Principles of Geolog 5 ", 1st ed. 1832 
1. Pliocene ${ }^{1}=$ Sub-Apennine deposits and English Crag with $35-50$ p.c. of living species.

2. Miocene ${ }^{1}=$ Deposits of the Loire and Gironde aren (Bordeaux, etc.) with 17 p.c. of living species.

3. Eocene ${ }^{1}=$ Anglo-Parisian basin and Vicentine region, with only $3 \frac{1}{2}$ p.c. of living species.

For the sake of completeness, it has already been remarked that a fourth, the Pleistocene, ${ }^{1}$ division has been added to these three for the still younger deposits of the Quaternary System. This should contain 90-95 p.c. of living shells and also a fauna almost agreeing with that of the present day. Although the principle underlying this classification has in progress of time proved in the main accurate, the percentages of living species originally adopted by Lyell for the various groups have not remained firm. Thus for the Pliocene we must take $40-90$ instead of $35-50$, and for the Miocene 10-40 instead of 17 .

The researches carried out about the middle of the century by E. Beyrich on the N. German Tertiary, and the comparison of these deposits with the French and Belgian Tertiaries, finally showed the necessity of intercalating a fourth division for a series of formations developed in Brandenburg, between the Eocene and Miocene." This division bear's the name of Oligocene, and is now generally looked upon as a fourth group of the Tertiary System. If like II. Hörnes we unite the two upper divisions, which resemble one another in faunas, as Neogene, and the two older as Palæogene (or Eogene), we get for the whole Tertiary the following classification:-

B. Newer Tertiary or Neogene $\left\{\begin{array}{l}2 . \text { Pliocene } \\ 1 \text {. Liocene }\end{array}\right.$

A. Older " " Palæogene $\left\{\begin{array}{l}2 . \text { Oligocene } \\ 1 . \text { Eocene }\end{array}\right.$

Mayer-Eimar has recently attempted a much more detailed division ; but the groups proposed by him (Garumnien, Suessonien, Londinien, etc.) have found so little acceptance that they will not be considered here.

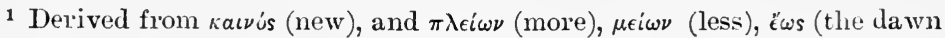
- of the new era). Oligocene from kalvós and oxiros (few); Pleistocene from кauvós and $\pi \lambda \epsilon i \sigma \tau o \nu$ (the most).

${ }^{2}$ Ueber d. Stellung der hessischen Tertiärbildungen. "Monatsber. !. Berl. Akad." (1854), p. 640. See also Beyrich, "Ueber d. Abgrenzung d. oligocän. Tertiärzeit." 1bid. (1858), p. ó1. 
The distribution of land and water in Tertiary times was very different from what it is to-day. This is shown at once by the fact that during the first section of the period a large ocean stretched from the Atlantic over the present Mediterranean into the Himalayan region, and that probably during the whole Tertiary period there was a land connection between North America and the Old World, through Iceland and the Faroes with North West Europe, and across the present Behring's Straits with North-East Asia. A number of facts also tell in favour of a former connection between India and Africa, probably also between the latter and South America, and very probably there was also one during the older Tertiary periods between Australia and South-East Asia. A map of the Tertiary continents and oceans would thus present a very different appearance from that of the present time. Moreover, it will be shown below that the distribution of land and water during the progress of the period changed repeatedly and gradually became more like that of tho present.

It should further be mentioned that the Tertiary period was the epoch of the most considerable mountain making on our earth. The piling up of the Alps, the Carpathians, Apennines, the Cancasus, Atlas, Himalayas, the Cordilleras of North and South America and many other of our highest mountains took place to a large extent in Tertiary times. How great in many cases the amount of the elevation has been since the beginning of the Tertiary period-or perhaps, more correctly, the amount of the general sinking of the sea since that time-is shown by the fact that the old Tertiary Nummulitic beds have been raised in the West Alps to a height of 11,000 , in the Himalayas to 16,000 feet above the sea.

Finally, as for the climatic conditions of the Tertiary period, these also have undergone great change during its progress. We have already learnt in the account of the Jurassic and Cretaceous that climatic zones were not, as was often supposed, first formed in the present period of the earth's history, but were much earlier developed. In the Older Tertiary, as is shown by both the Lamellibranch famna and the flora, the climate of Central Europe was decidedly tropical. Later there was a gradual decrease in temperature, so that at the close of the Tertiary period in our area it was only a little warmer than at present. 


\section{OLDER TERTIARY OR PALAOGENE.}

1. Eocene.

As already noticed, the conclusion of the Cretaceous period was. succeeded almost all over the world by a retreat of the sea. In consequence of this the deposits of the oldest Tertiary and Eocene everywhere occupy a considerably smaller area than the Chalk. In Europe two great Eocene regions may be distinguished. The first includes the marine deposits in South England, North France and Belgium, and is known as the Anglo-Gallic Eocene area. That these deposits were formerly of a greater extent, is shown by the isolated masses of marine Eocene in Brittany and near Copenhagen, and by the Eocene fragments occasionally found in the drift of South Sweden, Bornholm and North Germany. The second, the South European or Alpine Eocene area, is much more extensive. It takes in the whole of South Europe, including. the South and South-West of France, the Alps and Carpathians, and stretches to the south far into North Africa, into the Sahara, Lybian Desert and Egypt, while it reaches to the east over the Caucasus, Asia Minor, Arabia and Persia, in to the region of the Tianshan, Himalayas, and further through Java and Sumatra to Borneo and the Philippines. Thus there existed in the Eocene period a wide sea connection between the Atlantic and Pacific Oceans, the "Mittelmeer," or Central Sea of Neumayr, of which the present Mediterranean appears to be the last remnant. Still the whole of this area was not open ocean; the Alps, part of the Carpathians and Apennines, etc., rose as more or less extensive islands above it.

The Parisian Tertiary basin, ${ }^{1}$ where, as already mentioned, the study of the Tertiary rocks commenced, is formed by a thick series which is by no means marine throughout, but contains numerous intercalated brackish and freshwater deposits. Only the lower part of this belongs to the Eocene, the upper on the other hand to the Oligocene. Of the abundant gasteropods and bivalves, the total number of which may be estimated at two and a half thousand, the genera Cerithium, Pleurotoma and Fusus predominate in richness of species. Cerithium giganteum, nearly half a yard in length, is one of the largest known gasteropods. The whole series may be classified as follows :-

1 Lavolle, "Guide du géologue dans le tertiaire Parisien," Paris, 1890. 

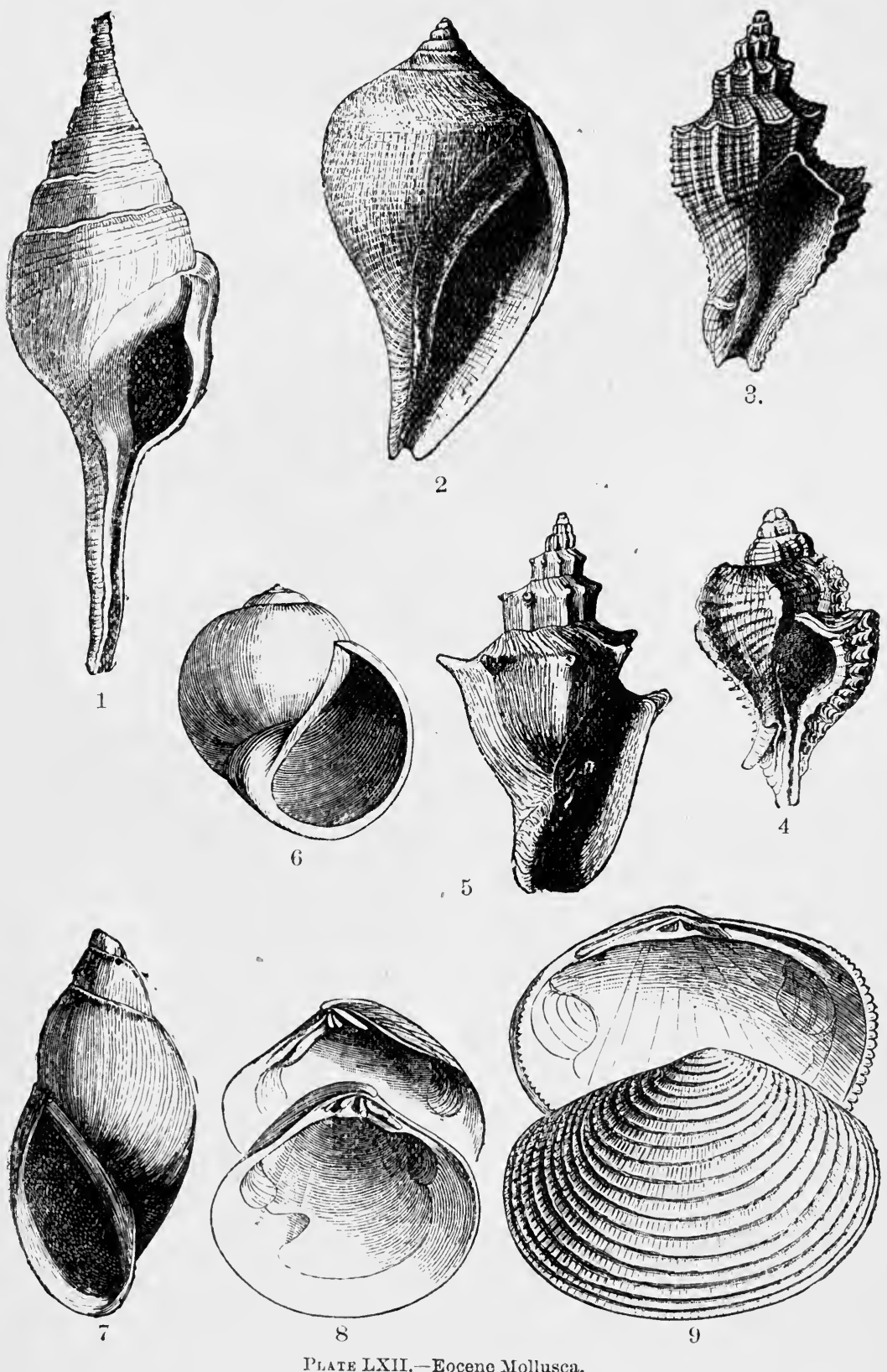

1. F'usus longovus, Lam. 2. Fusus bulbiformis, La. 3. Fusus subcarinatus, La. 4. Murex icarinatus, La. 5. Voluta muricina, La. 6 Natica patula, La. 7. Physa gigantea, Mich. 8. Cytherea scmisulcata, La. 9. Corbis (=Fimbria) lamellosa, La. 

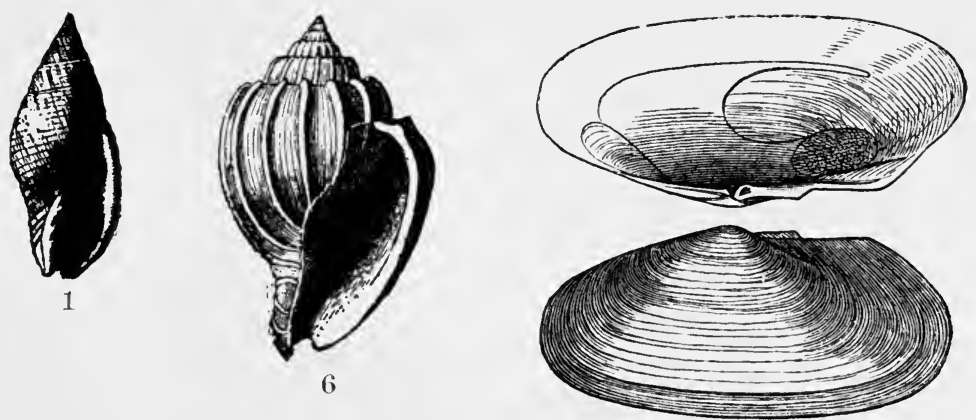

8

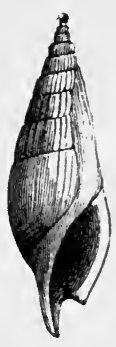

2

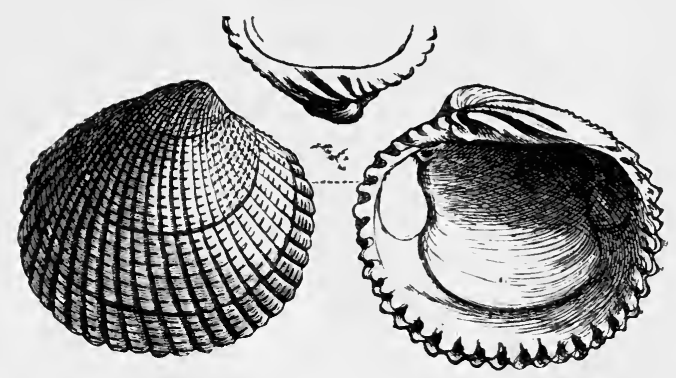

7

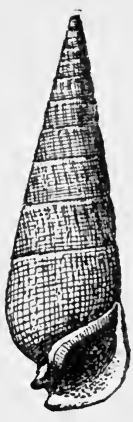

3

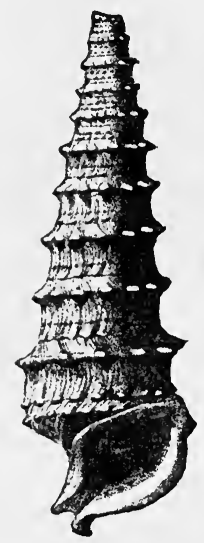

4

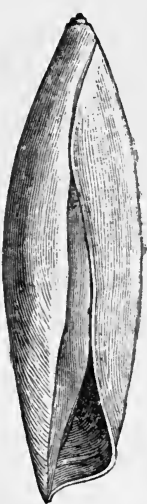

ธ

Plate LXIII.-Eocene Mollusca.

1. Mitra labiatula, Lam. 2. Rostellaria fissurella, La. 3. Cerithium nudum, La. 4. C. serratum, Brngn. 5. Terebellum sopitum, Brander. 6. Harpa mutica, La. 8. Psammobic effusa, Desh. 


\section{Upper Eocene.}

Sand of Beauchamp or Sable moyen. A marine sand 15, theters thick, very rich in fossils. Even here Nummulites are not absent. Freshwater limestones occur locally (Calcaire de St. Ouen) with Limnere longiscate. At the top is the horizon of Cerithium. roncarm.

\section{Middle Eocene.}

Coarse limestone (Calcaire grossier). This, the best known and most fossiliferous group of the Paris Eocene, is a limestone, some 30 $\mathrm{m}$. in thickness, sometimes sandy, sometimes marly; sometimes glaulconitic, filled with marine shells. It is the stone of which Paris is built. The lowest beds are full of Nummulites (levigatus [LXIV. 6], s:aber) oystr's, Echinoder'ms, ('erithium giyantenm; the middle contain numerous foraminifera of the group Miliolidæ, Turritella imbricataria, F'usus bulbiformis (LXII. 2), F. Now, Conus deperditus, C'assis cancellata, Corbis lamellosa (LXII. (1), Cardium porulosum, Cardite planicosta, Crassatella ponderosa, and many others; in the uppermost beds are numerous Cerithia (Pl. LXIII.), ete. Grignon is one of the chief localities.

Sand of Cuise, up to $50 \mathrm{~m}$. thick, fossiliferous marine sands. Along with Nevita conoider, Thritella hybirida, and others, Nummulites planulatus is especially noticuable.

\section{Lower Eocene.}

Plastic Clay (argile plastique) and Brown coal (lignite) of Soissons with freshwater shells.

sand of Braehenx. At the base, freshwater shells (Plysa gigantea [LXII. 7]), and the oldest remains of mammals (.1 retocyon, ete.)-Beds of Rilly; above, marine forms (Ostrea lellovacina, etc.).

Marl of Meudon. A very restricted freshwater formation lying dirretly on the Senonian I'isolitic Limestonr.

The Belgian Eocene shows a similar development. Its composition at its chief localities las been described by A. Dumont. The names, Systeme Heersien, Landenien, etc., for the various aroups originated with him. 'The lowest group of the whole series is the Montien, the "calcaire grossier" of Mons, which rests directly on the newest Senonian, contains some Cretaceous sea-urchins (Cidaris Tombccli and others), and numerous Tertiary fossils. It is equivalent to the Marl of Meudon in the Paris, basin.

In the London Basin, the continuation beyond the Channel of the Paris Basin, the equivalents of the limestone of Mons are absent. The oldest Tertiary beds, the Thanet sands, lie directly on the strongly denuded chalk, and are of much the same age as the sands of Bracheux.

In detail the classification of the Eocene part of the series is as follows :-

1 See Mourlon, "Géol. de la Belgique" (1880). 


\section{Upper Eocene.}

Lower Headon Hill beds with Cerithium concavum.

Barton Clay. A clay up to $100 \mathrm{~m}$. in thickness, with Nummulites (variolarius, etc.) and lother marine remains, corresponding with the Sand of Beauchamp.

\section{Middle Eocene.}

Bagshot and Bracklesham beds. The former consists of some $200 \mathrm{~m}$. of almost unfossiliferous sands lying on the London Clay; the latter of clays and sands developed only in Hampshire, which contain a marine fauna (Cerithium giyanteum, Turitella imlricataria, Conus aleperditus, Cardita planicosta, Nummulites lavigatus [LXIV. 6], ete:), agreeing with that of the calcaire grossier.

London Clay. This well known group of the English Eocene consists of a fine clay, sometimes $200 \mathrm{~m}$. thick, which contains accumulated remains of plants, reptiles, etc., and especially a rich gasteropod fauna (species of Pleurotoma, Fusus, Conus, etc.), and like other similar Pleurotoma clays has been formed at a depth of some $200 \mathrm{~m}$.

\section{Lower Eocene.}

Woolwich and Reading beds. Brackish estuarine sands and clays with Melania inquinata, C'yrena cuneiformis, Cerithium, etc.

Thanet sands. Marine sand with Cyprina Morrisii, etc.

It should be remarked, that in recent times v. Koenen, following the lead of Schimper, has proposed to separate the beds lying below the London Clay and the French Sands of Cuise with their .equivalents, and all the depcsits classified above as L. Eocene, under the designation Palæocene as a special group of the Tertiary System distinct from the Eocene. ${ }^{1}$

In conclusion we give a comparative table of the development of the Eocene in the chief areas of the Anglo-Gallic basin :-

\begin{tabular}{|c|c|c|c|}
\hline & Paris Basin. & $\begin{array}{l}\text { Belgian } \\
\text { Gulf }\end{array}$ & London Basin. \\
\hline Upper Eocene. & $\begin{array}{c}\text { Sand of Beauchamp } \\
\text { and Limestone of } \\
\text { St. Ouen. }\end{array}$ & $\begin{array}{l}\text { Wemmelien. } \\
\text { C }\end{array}$ & $\begin{array}{l}\text { L. Headon Hill beds. } \\
\text { Barton Clay. }\end{array}$ \\
\hline Middle Eocene. & $\begin{array}{c}\text { Calcaire } \\
\text { grossier. } \\
\text { Sand of Cuise. }\end{array}$ & $\begin{array}{c}\text { Laekenien. } \\
\text { Bruxellien. } \\
\text { Paniselien. } \\
\text { Ypresien. }\end{array}$ & $\begin{array}{c}\text { Bagshot and } \\
\text { Brackleshan beds. } \\
\text { London Clay. }\end{array}$ \\
\hline Lower Eocene. & $\begin{array}{c}\text { Plastic Clay and } \\
\text { Lignite of Soissons. } \\
\text { Sand of Bracheux. } \\
\text { Marl of Meudon. }\end{array}$ & $\begin{array}{l}\text { Landenien. } \\
\text { Heersien. } \\
\text { Montien. }\end{array}$ & $\begin{array}{l}\text { Woolwich and } \\
\text { Reading beds. } \\
\text { Thanet sand. } \\
\text { - }\end{array}$ \\
\hline
\end{tabular}

1 "Ueber eine paleocäne Fauna von Kopenhagen" (1886). 
The development of the Eocene in Southern Europe is very different from that in the Anglo-Gallic Basin, and this difference is expressed in the rocks themselves. They are not, as in North Europe, loose in texture; but-clearly on account of the strong dislocations to which the beds in question have been subjected in the mountain chains of South Europe-are hard, compact limestones, sandstones, and slates such as in North Europe are usually met with only in the older formations. Palæontologically the South Eocene beds are in the first place characterised by the abundance of Nummulites, gigantic disc-shaped Foraminifera chambered internally in a complicated fashion (LXIV. 4-7). Appearing in older formations, these forms suddenly attain a very great development in the beginning of the Eocene period, so that they form massive systems of limestone; but in the Oligocene period they again become reduced in numbers. The marine fauna of the South Eocene area is also distinguished by the relatively large size of its shells, by the presence of reef-building corals, and by the great abundance of sea urchins. In France, especially at Biarritz at the foot of the Pyrenees, and near Nizza, very fossiliferous Nummulitic beds are known; and in Switzerland, at Appenzell and in the neighbourhood of Einsiedeln. In the Bavarian Alps the oolitic red ironstone of the Kressenberg near Traunstein has long been famous for its fossils, including numerous Nummulites (N. complanatus, N. perforatus, etc.), Conoclypus conoideus (LXIV. 1), Cerithium giganteum, Nerita conoidea, Ostrea flabellata and other species of the Parisian Calcaire grossier. The limestones and basalt tuffs of Ronca and other places in the Vicento-Veronese Alps are still richer in well-preserved shells, sea urchins, crabs and corals. The calcareous schist of Monte Bolca also, famous for its rich fish fauna, belongs to the same series.

The Nummulitic formations of North Africa and India are characterised by still greater richness in fossils. In Egypt, where the Nummulitic Limestone has yielded the chief building material for the pyramids, the Mokattam, near Cairo, is especially well known as a locality for well preserved sea urchins and crabs; and the abundance of fossils in the Libyan Desert, studied by Zittel, must be very astonishing. These latter are of special interest from the fact that, according to this observer, there is a perfectly gradual petrographical and palæontological passage, undisturbed by any uncomformity, from the uppermost marine Chalk into the old Tertiary beds in question. ${ }^{1}$

1 "Beiträge z. Geol. u. Paläont. d. libysch. Wüste," 1883.

C. G. 


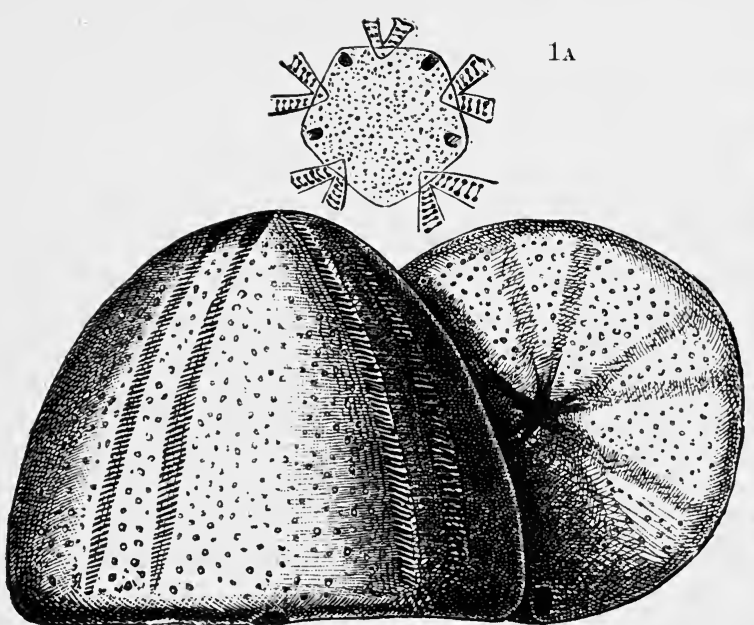

$1\left(\times \frac{1}{2}\right)$
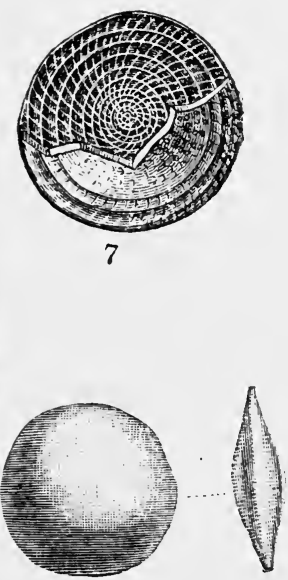

6

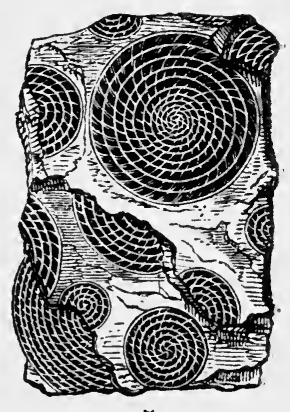

5

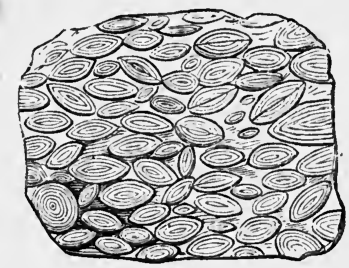

4

3

Platr LXIV.-Fossils of the Nummulitic Beds.

1. Conoclypus conoideus, Gf. 1s. Apical disc, enlarged. 2. Linthia Heberti, Cott. 3. Serpula spirulaea, Lam. 4. Stone with transverse sections of Nummulites Lucasanus; Defr. 5. Stone with longitudinal sections of Nummulites distans, Pusch. 6. Nummulites lavigatus, Lam. 7. Nummulites (Assilina) exponens, Sow. 
This calcareous development is accompanied in the South Eocene region by a very different facies, sandy and shaly in characterthe so-called Flysch of the Swiss Alps or Macigno of the Maritime Alps and Apennines. This consists of extraordinarily thick and uniform grey sandstones and shales, which contain scarcely any organic remains except fucoids. These rocks occur in intimate connection with Nummulitic beds throughout the Alps and in the Apennines; and they are largely developed in the Carpathians, in Istria, Dalmatia, Bosnia, Greece, Asia Minor, the Cancasus, and further east throughout South Asia to California and the West Indies. They represent not only the Eocene, but also, without however showing any definite separation into two series, the Oligocene. As already noticed in the account of the Uppermost Chalk of the South, the Flysch sandstone of the Lower Austrian Alps, Carpathians, and other areas, appears to represent not only the Older Tertiary, but also the greater part, or it may be the whole, of the Cretaceous Formation.

In North America also, the Eocene series is very widely spread. Its marine development is represented by the so-called A labama beds, which are of great extent, especially in the state of that name and in the states bordering it on the east. Still more interesting, however, is the great lignite bearing fresh and brackish water formation known by the name of the Laramie beds, which has been traced up to 4,000 feet in thickness on both slopes of the Rocky Mountains from Mexico to British Columbia. Among the most characteristic fossils of these deposits, which are supposed to be in part of Cretaceous age, are the Gasteropod genera Pyrguliferca and Physa (the latter occurs in the Paris Eocene), also Melania, species of Melanopsis, Paludina, Planorbis, Unio, Cyrena, and other freshwater forms, Ostrea glabra, etc. Between the Rockies and the Wahsatch Mountains, in the waste known as the Bad Lands, similar, but, as it seems, somewhat newer, Eocene marine deposits contain numerous remains of mammals, especially of Dinoceras (see p. 352).

\section{Oligocene.}

Germany, with the single exception of the part included in the Alps, was land during the Eocene period, but with the beginning of the Oligocene a great part of the north of the country was overflowed by the sea. From the shores of the present Baltic and 
North Seas it stretched at least to the neighbourhood of Stargard, Frankfort on the Oder, Cottbus, Leipzig and Aschersleben; and round the Harz in a deep gulf to beyond Cassel; thence it spread beyond Lemgo, Osnabrück and Düsseldorf, and over the Netherlands and Belgium into connection with the Anglo-Gallic marine basin. The sea which extended over South Europe during the Eocene period, continued also during the Oligocene; indeed from North Switzerland it invaded the plain already existing at that time on the Upper Rhine, and filled this to the neighbourhood of Frankfurt and Wiesbaden. In the period of the greatest extent of the ocean, during the Middle Oligocene, there was very probably a direct connection between the north and south seas in the form of a narrow arm reaching from Cassel past Ziegenhain, Marburg and the region of the present Vogelsberg, to Frankfurt.

The study of the Oligocene commenced in the neighbourhood of Berlin, where in 1847 a clay very rich in marine fossils, especially species of Pleurotoma, was discovered at Hermsdorf. This Septaria Clay (so called from the numerous septaria in it,large calcareous concretions with internal radiating cracks), together with the corresponding Belgian deposits (the Rupelien supérieur of Dumont), was made by E. Beyrich the central division of the Oligocene, the Middle Oligocene. To the Lower Oligocene were referred the Clays of Latdorf, not far from Bernburg, and of Egeln near Magdeburg with a marine fauna which resembles in general character that of Hermsdorf, but consists in great part of other species, and corresponds exactly with that of the Belgian Tongrien inférieur (chief locality KleinSpauwen). Lastly the Upper Oligocene includes the marine sands of Neuss, Krefeld and other places in the Rhine area, also those of the Doberg near Bünde (not far from Herford) in Westphalia, of Cassel and the so-called Sternberg Kuchen. The last are calcareous sandy, ironshot concretions filled with shells, which are very abundant as diluvial fragments, especially in the neighbourhood of Sternberg in Mecklenburg, and have long been known there, whilst the original rock was first discovered in situ a short time ago in the neighbourhood of Parchim. In Belgium the Upper Oligocene is not represented.

Thus the Oligocene deposits of North Germany and Belgium may be classified as follows :- 


\begin{tabular}{l|c|c}
\hline & North Germany. & Belgium. \\
\hline U. Oligocene. & $\begin{array}{c}\text { Sternberg Rock. } \\
\text { Sands of Cassel, Bünde, etc. }\end{array}$ \\
\hline M. Oligocene. & $\begin{array}{c}\text { Septaria (Rupel) Clay } \\
\text { and Stettin Sand. }\end{array}$ & $\begin{array}{c}\text { Clay of the Rupeiien, sup. } \\
\text { Sand " } " \text { inf: } \\
\text { Tongrien supérieur. }\end{array}$ \\
\hline L. Oligocene. & Clays of Egeln-Latdorf. & Tongrien inférieur. \\
\hline
\end{tabular}

With respect to this table it is to be remarked that the Stettin Sand is a local sandy equivalent of the Septaria Clay, occurring also at Magdeburg and Söllingen in the Brunswick area. The term $R$ upelthon is equivalent with Septaria Clay and was formed by A. v. Koenen in imitation of the name Rupelien of Dumont.

The Belgian Oligocene, which is in general very similar to that of North Germany, is distinguished from the latter by the fact that instead of being exclusively marine, it is formed of an alternation of marine and freshwater formations. Another difference is that the Belgian Oligocene is intercalated between the marine Eocene and Miocene, a circumstance which is of the greatest importance for a complete comprehension of the stratigraphical position of the Oligocene and its relations to the older and newer Tertiary deposits.

In Germany the series is nowhere so directly underlaid and overlaid by marine beds. The Oligocene is here the oldest known Tertiary and the great denudation of the generally very restricted Tertiary outcrops, which only rise up here and there through the thick covering of drift, makes the determination of their connection and mutual stratigraphical relations very difficult. In most places only a single horizon is represented. The Doberg area is an exception, for there Lower, Middle and Upper Oligocene are present; and recently deep borings carried out in the March have sunk through all these series.

The following ideal section (Fig. 45), based mainly on the results of the deep borings, gives an idea of the lie and composition of the Oligocene beds in the March of Brandenburg. ${ }^{1}$

1 See G. Berendt, "D. Tertiär i. Bereiche d. M. Brandenburg." Sitzungsber. d. Berl. Akad. (1885).-—"Die bisher. Aufschlüsse d. märk.-pommer'schen Tert. Abh. d. preuss. geol. Landesanst." (1886). 
In the March and throughout North Germany, the Septaria Clay is the most widely spread of these deposits (Hermsdorf, Buckow, Freienwalde, and Joachimsthal are well-known fossil localities). One of the most important type fossils, which occurs in Belgium, Hesse, and in the Mainz basin, is Leda Deshayesiana (LXV. 6); besides this, Nucula Chasteli, Axinus obtusus, A. unicarinatus, Pleurotoma Selysii, P. scabra, P. turbida, P. regularis and others, Fusus Konincki, $F$. multisulcatus, $F$. elongatus and Dentalizm Kickxii are to be mentioned. Almost everywhere the Septaria Clay includes remains of Foraminifera. The Lower Oligocene is known in the March only by deep borings and contains but few fossils (only Ostrea ventilabrum). On the other hand the equivalent outcrops of Latdorf and Egeln contain a large number of well preserved

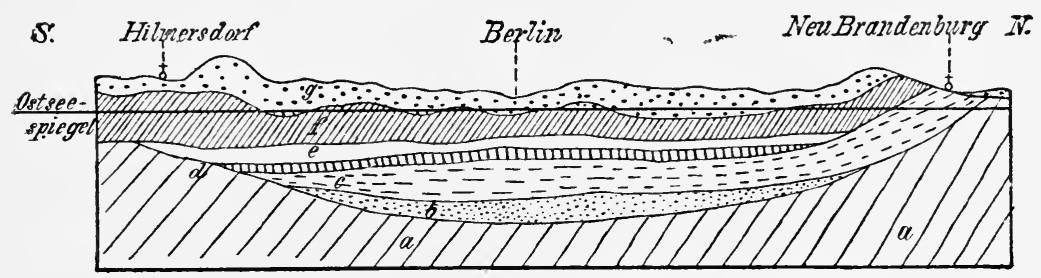

Fig. 45.-Section of the Tertiary Beds of Brandenburg (G. Berendt).

a. Ancient, rocks. ''. Lower Oligocene Glauconite Sand. c. Middle Oligocene Septaria Clay. d. II. Olig. Stettin Sand. e. U. Olig. Sand. $f$. Mioce Le Lignite deposits. $g$. Drift.

shells, among which Ostrea ventilabrum, Pecten bellicostatus, Spondylus Buchi, Cardita Dunkeri, Leda perovalis, Astarte Bosqueti, Arca appendiculata, Buccinum bullatum, Toluta decora, Pleurotoma Bosqueti, P. Beyrichi and others may be mentioned. Solitary corals, Nummulites, fish remains, etc., also occur. Lastly, in the March, the Upper Oligocene only rises to the surface in a limited way; while on the other hand it is present in a very characteristic and fossiliferous form in the Doberg at Bünde, and in the region of Cassel (Wilhelmshöhe, Hohenkirchen, Kaufungen, etc.). In the Doberg, fine sea urchins (Echinolampas Kleinii [LXVI. 3], Spatangus [Maretia] IIoffmanni), Pectunculus obovatus (LXV. 8) and P. Philippii and the large Terebratula grandis (LXVI. 2), are especially abundant; ${ }^{1}$ at Cassel besides these there are Cyprina rotundata, Pecten janus, P. Muensteri and P. suldecussatus, Cardium ungulatum, Pleurotoma subdenticulata, $P$. Duchastelii, etc.

1 See E. Lilienklaus, Jahresber. d. naturw. Ver. zu Osnabrück, 1891. 


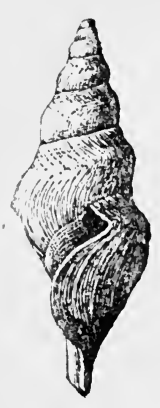

1

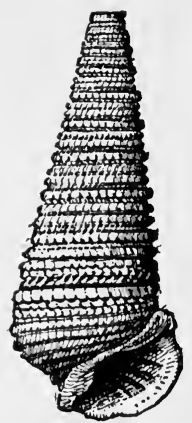

2

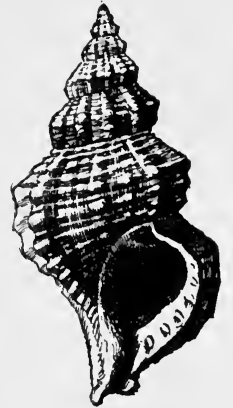

3

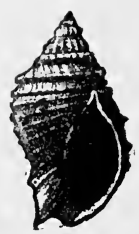

4

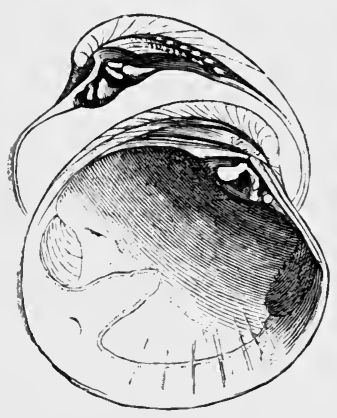

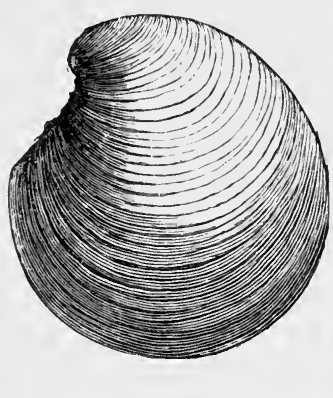

5

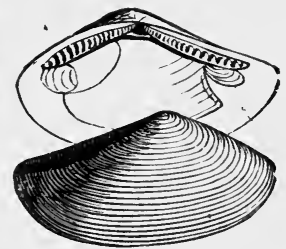

6

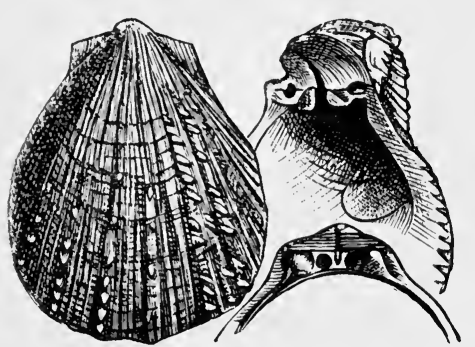

7

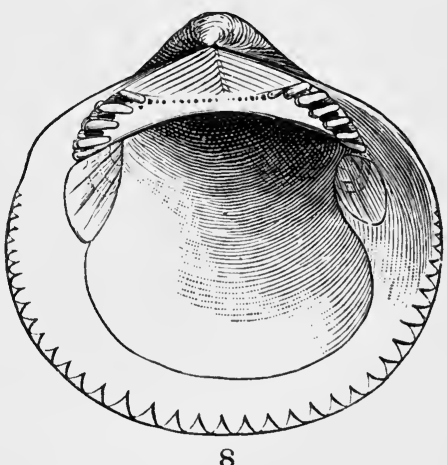

Plate LXV.-Oligocene Mollusca:

1. Pleurotoma belgica, Nyst. 2. Cerithium margavitaceum, Brocchi. 3. Tritoruum 'flandrieum, de Kon. 4. Buccinum cassidaria, A. Braun. 5. Cytherea incrassata, Sow. 6. Leda Deshayesiana, Duch. 7. Spondylus tennispina, Sandb. 8. Pectunculus obovatus, Lam. 

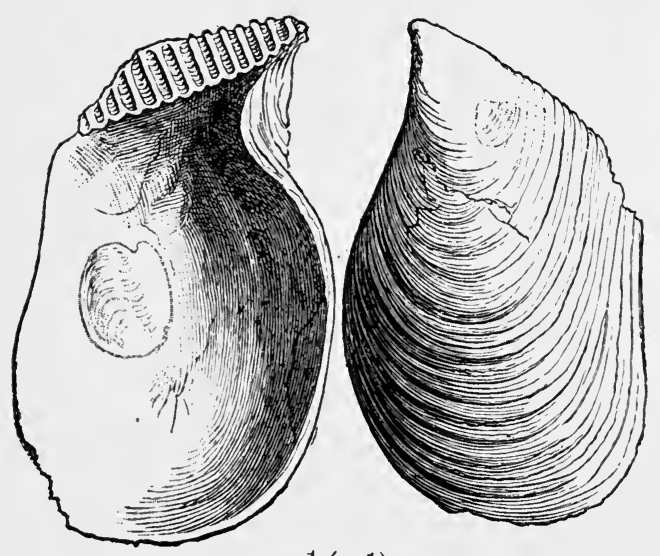

$1\left(\times \frac{1}{3}\right)$
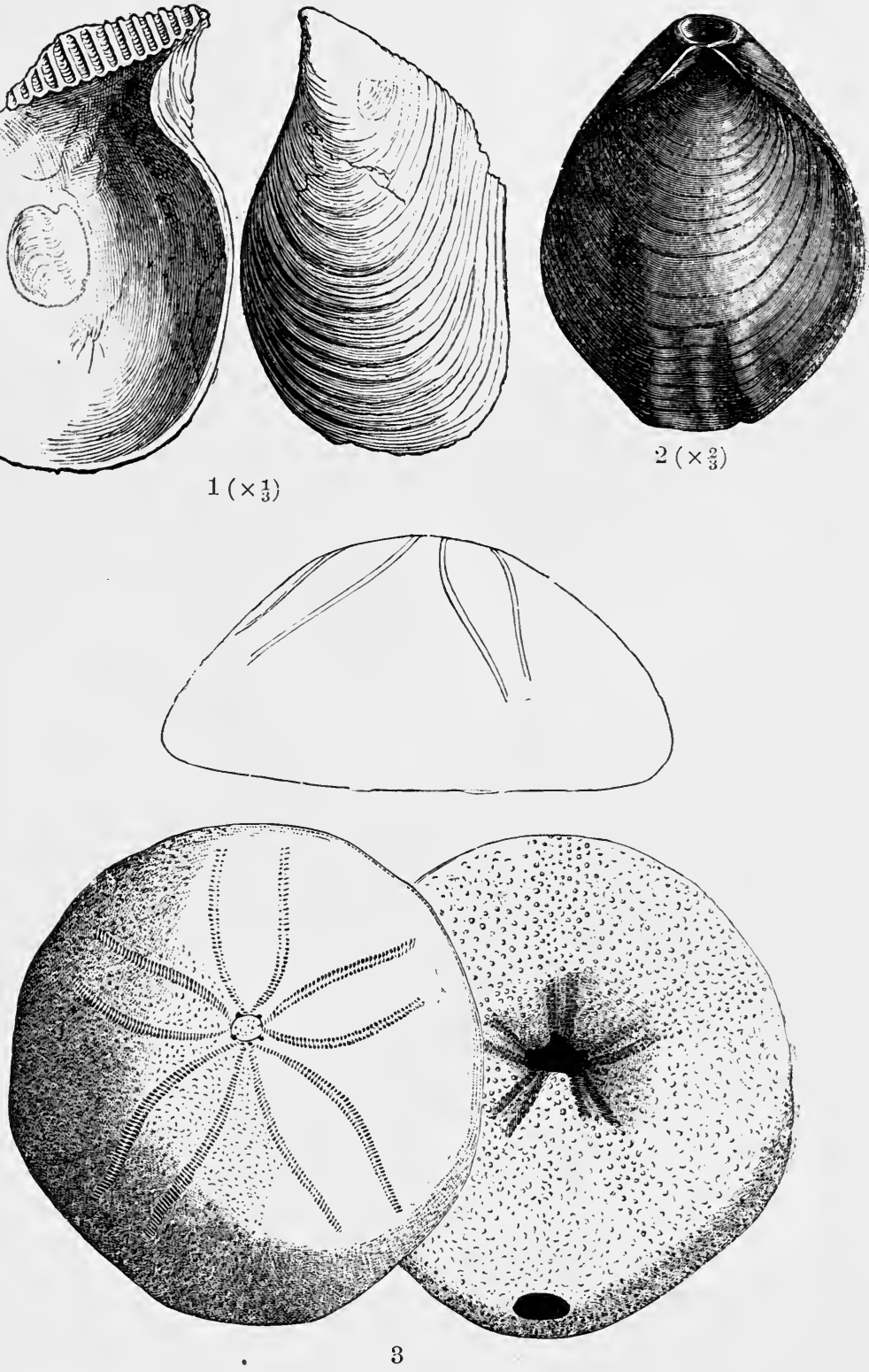

Plate LXVI.-Oligocene Fossils.

1. Perna Soldani, Desh. 2. Terebratula grandis, Blumenb. 3. Echinolampas Kleinii, Goldf 
The Lignite beds of the March, Priegnitz, and Mecklenburg, formerly supposed to be Lower Oligocene, have in more recent times proved to belong to the Miocene. ${ }^{1}$ On the other hand the (so-called sub-Hercynian) lignites of the Halle gulf ${ }^{2}$ and of the north border of the Harz belong to the Lower Oligocene, as is shown in section (Fig. 46).

In the neighbourhood of Leipzig both the older beds, below the Oligocene, and the newer, above it, are known. This also appears to be the case in Hesse. ${ }^{3}$ Here, according to v. Koenen, the greater part of the lignite-bearing beds belongs to the Miocene, but certain lignite outcrops (at Kaufungen, Lichtenau, etc.), as shown by Beyrich, lie below the Septaria Clay.

The age of the lignites of the Cologne bay is the most uncertain. These include the well-known occurrence of laminated coal (Dysodil),

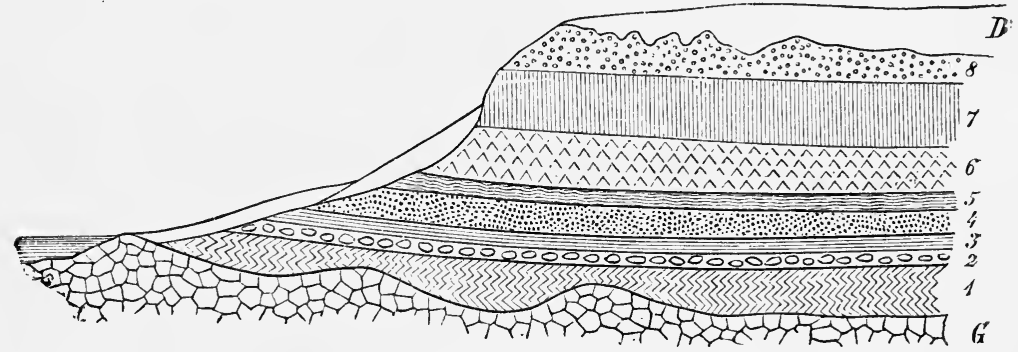

Frg. 46.-Section of the Oligoccne Lignite deposits of the neighbourhood of Halle on the Saal (H. Laspeyres).

G. Ancient Rocks (porphyry). 1-5. Lower Oligocene Lignite deposits: 1. Sagger clay. 2. Lignite. 3. Lower seam. 4. Quartz sand. 5. Upper seam. 6. Middle Oligocene sand. 7. Septaria clay. 8. Moulding or mica sand. $D$. Drift.

accompanied by opal, of Rott not far from Bonn. Like the laminated coal of the Habichtswald near Cassel they contain Leuciscus papyraceus and many other fish (in all more than 100 species), besides insects, crustaceans, and remains of a flora of Upper Oligocene character.

The famous amber-bearing deposits of the Samland near Königsberg are also Oligocene, of very peculiar character. The lower part is composed of marine glauconite sands with a rich

1 Berendt.

2 The rich fossil flora of these lignites has been described by Friedrich, "Beitr. z. Kenntn. d. Tertiär-flora d. Prov. Sachsen. Abh. d. preuss. geol. Landesanst." (1883).

s Credner, "Das Oligoc. d. Leipziger Kreises." Zeits. d. deutsch. geol. Ges. (1878). 
fauna consisting mainly of sea urchins, crustaceans, and remains of sharks, but containing also molluses; the upper part, on the other hand, is made of lignite-bearing beds. The whole, according to Nötling, ${ }^{1}$ the latest worker at the fauna, is of Lower Oligocene Age. The home of the amber, which is the fossil resin of various pines (especially of Pinus succinifera), is the "Blue Earth" Jying not far from the base of Glauconite sand. The great scientific interest of the amber depends on the extraordinary number of insects, spiders and plant remains, inclosed in it and preserved in unexampled perfection. The number of insects is estimated at some 2,000 ; of plants, Conwentz ${ }^{2}$ has described of late over 100 Dicotyledons alone. The occurrence of four species of palm (among them a Phonix), of Magnolias, Cinnamomum, etc., along with Quercus, Acer, etc., allows us to infer that the climate of those regions was somewhat warmer than at present.

In the Paris Basin only the Middle Oligocene consists of marine deposits; the Lower and Upper are brackish and freshwater in character. The constitution is as follows:-

\section{Upper Oligocene.}

Uppermost part of the Fontainebleau Sandstone, and Upper Freshwatel formation (Millstone of Montmorency, and freshwater limestone of Beauce), with Limncea, Planorbis, Paludina; at the top with numerous species of Helix.

\section{Middle Oligocene.}

Sandstone of Fontainebleau, with a fauna corresponding with that of the marine sand of Stettin and Alzey.

\section{Lower Oligocene.}

Gypsum and Marl of Montmartre with rare marine shells, but with the famous mammalian remains described by Cuvier (Palceotherium, Anoplotherium, Xiphodon, etc.

Marl, with Limncea strigosa.

The English Oligocene deposits consist almost exclusively of brackish limestone and marls, and are almost entirely limited to the Isle of Wight, and the county of Hampshire. We distinguish here :-

\section{Upper Oligocene.}

Not recognised with certainty.

\section{Middle Oligocene.}

Hampstead beds, with Cyrena semistriata, Cerithium plicatum, Melania, etc.

1 "Fauna d. samländ. Tert. Abh. d. preuss. geol. Landesanst." (1885-88).

2 "Die Flora d. Bernsteins," etc. (Vol. i. Conifera, by Göppert and Menge; vol. ii. Angiosperms, by H. Conwentz). 


\section{Lower Oligocene.}

Osborne and Bembridge beds, with Cyrenas (C . semistriata), C'ytherea incrassata (LXV. 5), C'erithium, Melania, etc.

Middle and Upper Headon beds, with Cytherea incrassata, Natica, Buccinum, Cerithium, etc.

The Mainz Basin occupies a kind of middle position between the Northern and Southern Oligocene areas. This basin was at first purely marine, and gradually became freshwater, and it is only tise lower beds that belong to the Oligocene, while the higher beds reach up to the Miocene, and even in part to the Pliocene. The classification of the series is, in descending order :-

\section{Upper Oligocene.}

Cerithium Beds. Brackish, sometimes more sandy, sometimes more calcareous, formations with numerous Cerithium plicatum, $C$. submargaritaceum, and others, Mytilus Faujasi, Perna Soldani (LXVI.1), etc. The land-shell limestone of Hoch heim, with numerous species of Helix, is a local deposit of this stage.

\section{Middle Oligocene.}

Cyrena Marl and Sand. In part lignite-bearing, already somewhat brackish. Cyrena semistriata $=$ subarata, Cerithium plicatum, $C$. nargaritaceum (LXV. 2), Perna Śandbergeri, Buccinum cassidaria (LXV. 4).

Septaria Clay (Flörsheim on the Main, etc.), with Leda Deshayesiana (LXV. 6), etc.

Marine Sand, very fossiliferous (at Weinheim, not far from Alzey in Rhenish Hesse, and at Waldböckelheim on the Nahe) becoming conglomeratic at the borders of the basin. Ostrea callifera, Pectunculus obovatus (LXV. 8), Cytherea incrassata (LXV. 5), Natica crassatina, Spondylus tenuispina (LXV.7), etc. Remains of the Sirenian Halitherium Schinzi.

The Oligocene beds extend from the true Mainz basin of the Rhine Valley into the South of Baden and Alsace; and here, below the marine sand, there are found still deeper beds, of Lower Oligocene age (Petroleum sand of Pechelbronn, Hirzbach, etc., with Anodonta; Melania limestone of Brunnstadt), and probably also of Eocene age (Buchsweiler limestone, with Propalcotherium Lophiodon, etc. $)^{1}$

The greater number of the South German, Swiss, and French pisolitic iron ore deposits ${ }^{2}$ seem to belong to the Oligocene. 'These are collections of impure brown ironstone grains which, along with clays and sands, fill up depressions in the Upper Jura lime-

1 Andreæ, "Beitr. z. Kenntn. d. elsäss. Tert. Abh. z. geol. Specialkarte von Elsass-Dothringen " (1883-81).

2 Bohn-erz of the Germans; terrain sidérolithique of the French. 
stone, and are supposed to be deposits from springs. In South Germany, Frohnstätten and Tuttlingen in Vürtemberg, and Kandern in Baden, are the chief localities for these deposits. They contain numerous remains of Palcotherium, Anoplotherium, Lophiodon and others, with forms common to the gypsum of Nontmartre; and thus they show themselves to be Oligocene, while. the remains of some other similar deposits point to a later age.

Further south, in the region of the Alps, Apennines, Carpathians, etc., the Oligocene is represented chiefly by the Flysch sandstone, which, together with the so-called Molasse, forms in a tolerably unbroken chain the range in front of the Limestone Alps. The slate-like fish shales of Glarus and other points form an interesting local facies of the Flysch. These were formerly referred to the Eocene, but are now correlated with the middle Oligocene Amphysile beds of Alsace and other similar formations. (Meletta beds, Lepidopides beds) of Upper Bavaria and the Carpathians.

The Swiss and South German Molasse consists of thick, soft, conglomeratic sandstones, or coarse conglomerates, the so-called Nagelfuh of the Rigi and many other hills. Only its lower part. the Older Molasse, belongs to the Oligocene, whilst the youngeris of Miocene age. The Older Molasse again divides into a Low er marine division, the fossils of which (Ostrea callifera, Cyprina rotundata, Cytherea incrassata, Natica crassatina, Pleurotoma Selysii, etc.) prove it to be of Middle Oligocene age; and an Upper division of estuarine character, including many layers of lignite-especially at Miesbach in the Bavarian Alps-which is probably, as Cyrena semistriata, Cerithium margaritaceum, C. plicatum, and other species (in part common with the Mainz basin) show, of Upper Oligocene age.

Very fossiliferous Oligocene beds, containing numerous corals, sea urchins, and molluscs (Natica crassatina, etc.) occur in Vicenza at Castel Gomberto, Crosara, and other localities.

\section{PALAONTOLOGY OF THE OLDER TERTIARY.}

The chief distinctions between the Fauna and Flora of the Tertiary and those of the Cretaceous have already been briefly pointed out. So far as concerns the Older Tertiary in particular, the most important palæontological characters are as follows :-

The Old Tertiary Flor a consists mainly of Dicotyledons, Monocotyledons, and a number of Conifera. Among the Dicotyledons 
we find many tropical forms, such as Proteaceæ, Araliaceæ, Cinnamomum, etc.; various sub-tropical genera, Ficus, Laurus, Magnolia, Juglans, etc., and a crowd of forms of our present European forests, Quercus, Acer, Platanus, Ulmus, Carpinus, Salix, etc. Among the Monocotyledons the Palms, which at that time spread throughout Northern Europe (Sabal, Flabellaria, Phanix, Chamarops [Fig. 47]), are of interest. Of the Conifers the genus Sequoia (with the wide-spread $S$. Langsdorfi, which reaches into the Neogene) deserves special mention.

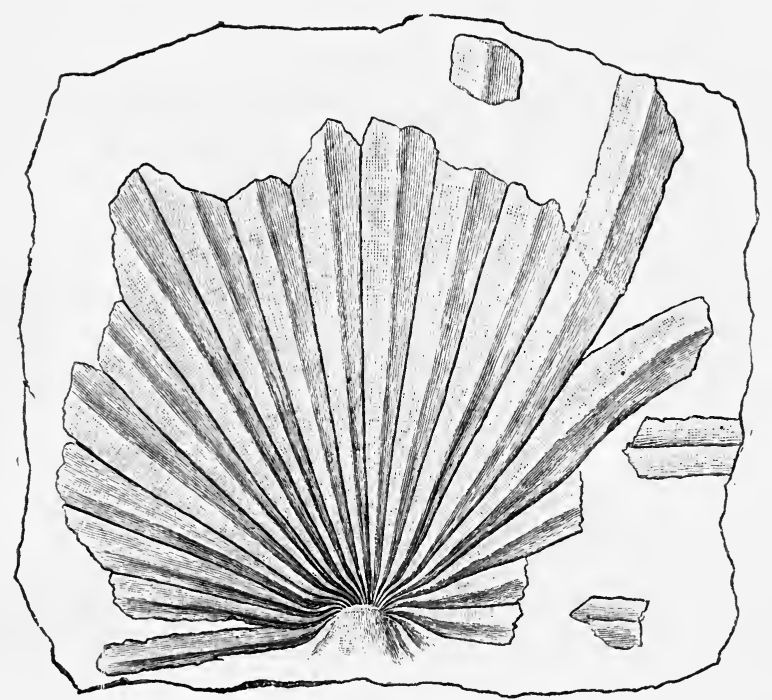
FIG. 47.-Chamaerops helvetica, Heer. Lower Oligocene of Nachterstädt, near Halle on

In the Fauna the lowest animals attain a special importance from the extracrdinary development of Nummulites, and to a less extent of some other Foraminifers, such as Orbitoides, Miliola, Alveolina, and others.

Among the Coelenterata, the reef-building corals, as noticed above, are important only in the Southern European Seas.

Of the Echinodermata by far the most important are the Echinoids, which are still very abundant and various in the Mediterranean area. The regular forms are even more reduced than in the chalk in comparison with the bilaterally symmetrical. Among the latter the family of the Spatangidæ still plays the chief part. To it belong the genera Spatangus, Linthia (LXIV. 2), Maretia, 
Brissus, Schizaster, Macropmeustes, and others, whilst of other symmetrical forms Conoclypus (LXIV. 1), and Echinolampas are to be noticed. E. Kleinii (LXVI. 3), from the Upper Oligocene is the commonest German fossil sea urchin.

In the Mollusca the Sinupalliata among the Lamellibranchs, such as Venus, Cytherea, Tellina, Corbula, etc. (Pls. LXII., LXIII., LXV.), are more important than hitherto. Of other bivalves, Ostrea, Pecten, Arca, Pectunculus, Leda, Cardita, Lucina, Cardium, Cyrena, etc., are very rich in species. Among the Gasteropods the Siphonostomata now play the chief part. To this group belong Pleurotoma, Fusus, Voluta, Conus, Pyriula, Murex, Strombus, Nitra, Cyprea, Borsonia, Cerithium, and others;

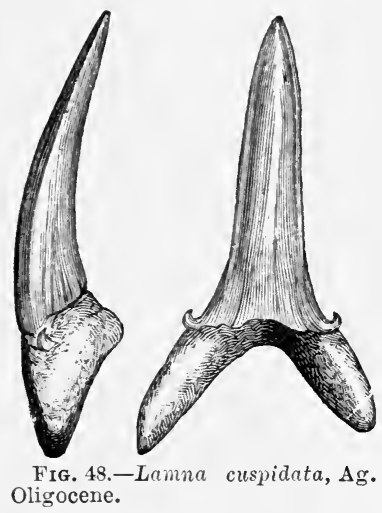

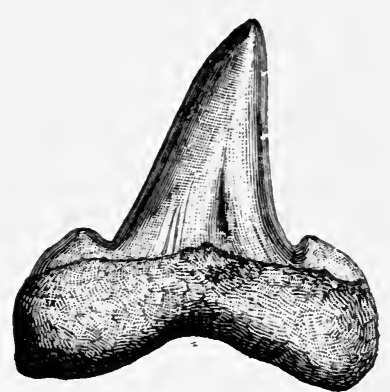

Fig. 49.-Otodus obliquus, Ag. Eocene.

while of the other gasteropods, Turritella, Natica, Nerita, Melania, and others are especially widely spread (Pls. LXII.-LXV.).

Among the Crustacea the great development of Brachyurous Decapods, or Crabs (Ranina, Caloma, Lobocarcinus, Psammocarcinus, etc.), requires special mention; among the fish the continually increasing development of the sharks-of which numerous isolated teeth belonging to the genera Lamna, Otodus, Carcharodon, etc., are found-and still more of the bony fishes or Teleostei (Leuciscus, Meletta, Amphisyle, Semiphorus, Calamostoma, Palceorliynchus, etc.).

Far the most important character, however, of the whole Tertiary, as well as of the Older Tertiary, is the first and quite sudden appearance of a rich fauna of placental mammals.

Aplacental mammals, which first appeared, so far as is known, in the Trias, were, in opposition to their present limitation to 
Australia and South America, present throughout the whole world (Didelphys in the Gypsum of Montmartre, Proviverra, in the phosphorites of Quercy, etc.), but were much reduced in importance compared with the placental mammals. ${ }^{1}$ In consequence of the very sudden development of the latter during the Tertiary: period their remains are of the greatest value for the determination of the age of the Tertiary deposits.

The chief localities are the Gypsum of Montmartre, the Phosphorites of Quercy in the South of France, and the pisolitic deposits of Frohnstetten, and other points in the Swabian Alps. All the forms belonging here are synthetic types, and many show also embryonic characters.

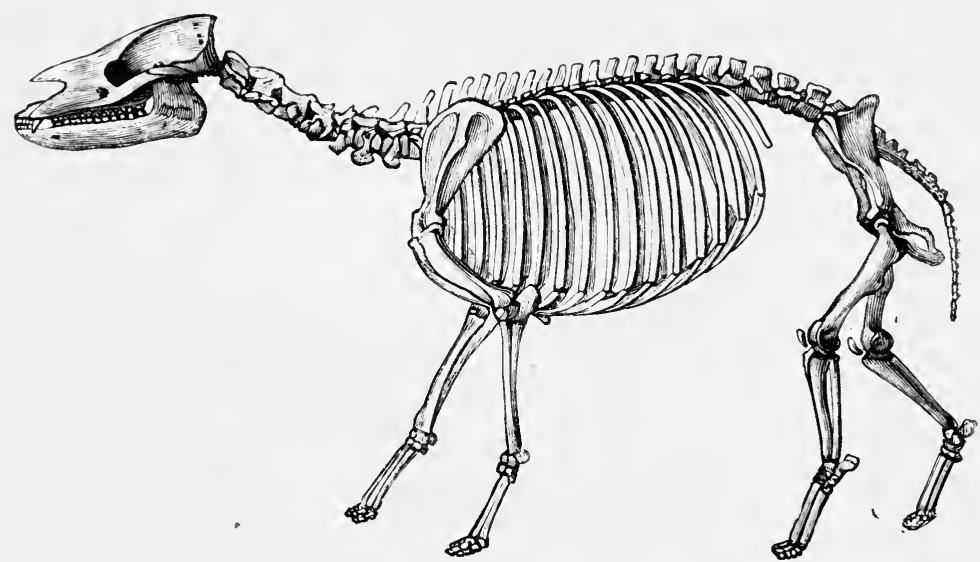

Fig. 50.-Palootherium magnum, Cuvier. Oligocene, Montmartre, near Paris.

The chief part among the older Tertiary mammals is played by the hoofed beasts, or Ungulates. As at the present day, they were already divided into two great groups, with paired and with unpaired hoofs-one of the circumstances which shows that the oldest known mammals in question cannot really be the oldest, but must rather have possessed pre-Tertiary ancestors, in which this distinction had not yet been developed.

Of the Imparidigitata, or Perissodactyla, to which the living Tapir, Rhinoceros, and Horse belong, the most important is the Palcotherium (Fig. 50), of the size of a horse or under, with tapir-

' See Gaudry. "Les Enchaînements du Monde Animal. Mammifères trartiaires" (1878). 
like snout, three-toed front and hind feet, and rhinoceros-like teeth. Another form, Lophiodon, is allied to the Tapirs.

To the Paridigitata, or Artiodactyla, belong Anoplotherium, with horse-like head, long neck and tail, 44 teeth of ruminant structure, and two-toed feet; also Xiphodon, of delicate gazellelike build; Anthracotherium, swine-like, with strong incisors and canines, and four-toed foot; Hyopotamus, similar, but with differently formed molars, etc.

A special group of Ungulates is formed by the remarkable gigantic Dinocerata (Marsh) from the Eocene of the Rocky Mountains. In their general form, in the structure of the pelvis, and in the possession of five-toed extremities, they resembled the Pro-

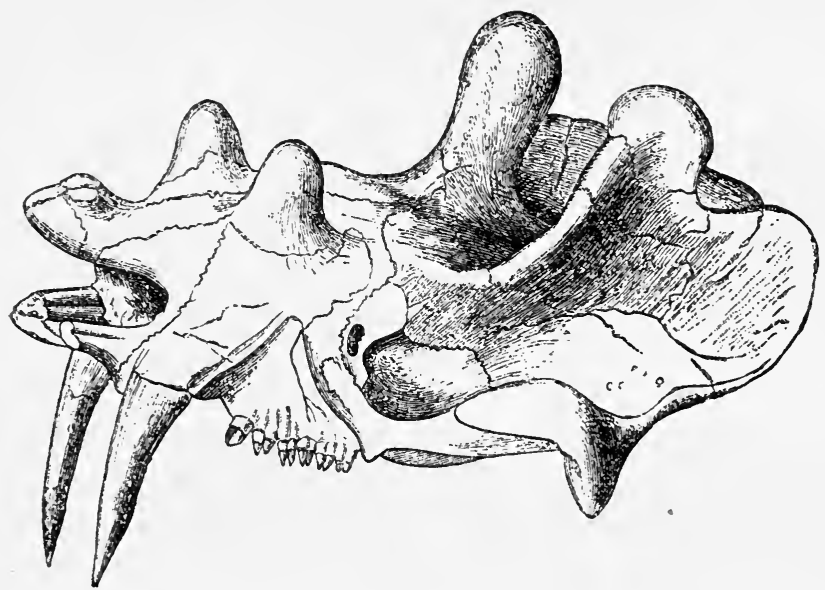

Fig. 51.-Skull of Loxolophodon (Dinoceras) mirabilis, MIarsh. Eocene of Wyoming (after Narsh).

boscideans, but they' bore three pairs of horns, and were armed with long sabre-like upper canines. The chief representative of the group is Loxolophodon (Dinoceras) mirabilis (Fig. 51). Like their companions, the Coryphodontidæ and Brontotheriidæ, the Dinocerata are characterised by a brain very diminutive in comparison with the skull.

Along with the Ungulates Carnivora occur in tolerable variety. Protoviverra and Iyanodon show certain relationships with the Hyænidæ and Viverridæ; Amphicyon, Cynodon, etc., with the Ursidæ. The name Creodonta has been applied to these most ancient Carnivora, which differ from the true Carnivora in the 
slighter development of the brain, in the absence of a distinctly differentiated carnassial, in the generally small number of incisors, and in other characters.

The Lemuridæ also were widely distributed, and numerous remains of them are found, especially at Quercy and in North America. Some of them, for example Adapis (referred by Cuvier to the Pachyderms), Coenopithecus, etc., show decided ungulate affinities. C'ebochwrus, from Quercy, referred to the Simiæ, shows, as its name implies, a remarkable mixture of pig-like and ape-like characters. True apes do not occur till Neogene times. Remains of Rodents, Insectivores, and bats are known from the Older Tertiary.

\section{NEWER TERTIARY OR NEOGENE.}

\section{Miocene.}

The distribution of the sea during the Miocene period was very "lifferent from that in Older Tertiary times. In Europe it had retreated in the north; in the south, on the other hand, it had sained in extent. In North Germany at that time only SchleswigHolstein and Friesland were covered by sea, which stretched west over Holland and a part of Belgium. In England and North France marine Miocene deposits are absent; and this area was then dry land. The Mainz basin also, which even in Upper Oligocene times had begun to become freshwater, was now entirely an inland sea.

The main area of the marine Miocene of Europe lies on the Atlantic coast and in the Mediterranean region. The Loire and Garonne plains were gulfs of the Atlantic Ocean, which during the Miocene period overflowed great stretches of the present Portuguese and Spanish coasts. From the Mediterranean, which still covered large areas in the north-west of Africa, the Miocene Sea extended through the Rhone Valley to the level part of Switzerland, and thence through Upper Swabia and Upper Bavaria to Vienna. An arm of the sea stretched north of the Carpathians to Moravia, probably even to Galicia, while a second formed the connection with the great "Pannonian basin" which extended over Hungary and a part of Steiermark, Carniola, Kroatia, and Bosnia, and reached east beyond the present Black and Caspian Seas, which are only the last remains of that great Miocene Ocean. The Alps, like the Carpathians, were still islands in the Mediterranean, while the greater part of Sicily, Malta, etc.

c. G. 
- islands formed chiefly of marine Miocene beds-was at that time under the sea. In the eastern part of the Mediterranean, Miocene marine deposits possess a considerable extension, but not in Egypt, Syria, Asia Minor, Persia, Arabia, etc., where indeed Old Tertiary heds, but not Miocene, are to be observed everywhere-a proof that the connection between the Mediterranean and the Indian Ocean existing throughout the Old Tertiary period had ceased to exist now-that, in other words, the Mediterranean from an intracontinental, had now become an inland sea.

The palms, magnolias, myrtles, and other evergreen trees, still present, at least in our area, at the beginning of the Miocene period, and the southern character of the insects and molluses, allow of a lefinite conclusion as to the climate of the Miocene period: that at the beginning of the period the climate in Central Europe was still subtropical; but, as follows from the absence of palms in the newer Miocene, it gradually became cooler.

The southern character of the Tertiary floras of Iceland, Greenland, Spitzbergen, and Grinell-land (the last in Arctic North America under $81^{\circ}$ N. Lat.), which are nsually referred to the Miocene, is very evident. According to the numerous works of $\mathrm{O}$. Heer, they consist of beeclies, poplars, elms, oaks, even Taxodia, Planes, Magnolias, whilst the limit of trees (at a mean temperature of $10^{\circ} \mathrm{C}$. for the warmest months) is now some degrees south of Greenland. In the regions in question therefore, in, geologically speaking, a comparatively recent period an abnormally warm climate prevailed. This circumstance appears so much the more strange since the Tertiary floras of the north-east of Asia-the floras of Kamtschatka, Amurland, and Saghalien, described by Heer, and that of Japan, shortly described by Nathorst-show no signs of a similar warmth, but rather point to a climate colder than that of the present day.

Since Greenland lies on the one side of the pole, and NorthEastem Asia on the opposite side, the difference in character of the floras might well be explained by a shifting of the pole, according to the bold hypothesis of Neumayr and Nathorst. Certainly if, with Nathorst, we place the pole in North-East Asia in $70^{\circ}$ N. Lat. and $120^{\circ}$ E. Long., no Tertiary flora with evergreen plants would lie within the polar circle, and thus most of our difficulties would be explained.

Palæontologically the chief characteristic of the Miocene consists in the appearance of gigantic Proboscideans-Dinotherium (Fig. 54) and Mastodon (angustidens, Fig. 50), whilst Elephas is 
still absent; of Rhinocerotide instead of the extinct Paloeotheridae and Anthracotherilie: of the genus of horses Anchitherium; of horned ruminants, and the oldest Felidx (Macharrodus, Fig. 67. The marine Mollusca are no longer tropical in character, but approach the living fauna of the Mediterranean. The number of still living species is also very much higher than in the Old Tertiary.

As alrearly mentioned, our knowledge of the Miocene took its rise in the region of Bordeaux. Here, as also in Touraine, the Oligocene is overlaid by loose, sandy shell beds, the so-called Faluns, which contain a great number of well-preserved fossils. Léognan, Mérignac, Saucats and Salles, near Bordeaux; Pontlevoy and Manthelau in Tonraine are the chief localities for these. Especially important forms are the narrow Ostrea crassissime (=longirostris [LXVIII. 4]), which reaches a length of half a yard, the fine Pecten (Vola) solarium, Cardita Jouanneti, Toluter Lamberti, V.miocenica, Cassis saburom (LXVII. 5), Arca turonica, Cytherea eryeinoides, and numerous sea urchins, among which the genus scutclla (LXIX. 1) is distinguished by its unusually flat shell.

In Belgium there belong to the Miocene:- A. Dumont's Système Bolderien (named after the Bolderberg, near Hasselt) and Diestien (after the city Diest). In character and fauna these beds are very similar to the French Faluns.

Characteristic marine Miocene is also found in the North West of Germany, in Schleswig Holstein, Lauenburg, Mecklenburs, North Hanover, and Oldenburg as far as the neighbourhood of the Dutch border at Wesel and Xanten. The most important localities for fossils are the Island of Sylt, Glückstadt, Lüneburg, Dömitz in Mecklenburg. Dingden in Westphalia, and Rothenburg near Diisseldorf. The two formations formerly distinguished as differcnt stages, the dark-coloured micaceous clay and the sandy $\mathrm{Hol}$ stein rock are, according to v. Koenen, merely different facies of. the same group. Among the most abundant species are Arer, dilurii, Pectunculus pilosus, Limopsis aurita, Astarte concentrica, Isocardia cor, l'ems Brocchii, Conus antediluvianus, C. Dujardini, Fusus tricinctus, $\mathbf{r}$. festirus, etc., Ientalium elephantinum, etc. ${ }^{1}$

1 T. Koenen, "Das Miocïn Norddeutschlands und soine Molluskenfauna I." (1572) (Shrift. d. (ies. z. Bef: d. ges. Naturu. su Marburg) and II. (Neues Jalirb. Beilageb. II.p.223).- "Gottsche. Mioe. von Reinbeck" (Verh.d Ver.t. noturu. Cnterh. Hambury, Vol. iii. (1878).--"Die Molluskenfauna d. Holst. (Gest." (Festschrift. d. naturu. Ver. z. Hamburg, 1887). 
In the rest of North Germany, and throughout Central Germany, marine Miocene is unknown, while Miocene freshwater deposits are widely spread in both these areas. According to Berendt and others the Lignite deposits of Brandenburg, Pomerania, and Mecklenburg are Miocene; and, sccording to v. Koenen, the greater part of the lignite beds of Hesse, the Wetteran, Westerwald, and the Lower Rhine, are of the same age. The last-named observer distinguishes a Lower Lignite formation, to which he refers the Melania Clays of Ludwig (Gross-Almerode, etc.) with Melania horrida and other freshwater shells, and an Upper Lignite formation which is often accompanied by polishing slates and basalt tuffs. The two lignite horizons are separated from each other by basalt flows (the Lower basalt) and the upper was in its turn again covered by a basalt sheet (the Upper basalt of the Rhön, Habichtswald, Vogelsberg, Westerwald, etc.). Similar lignite bear-

iv.

Meissner

U.

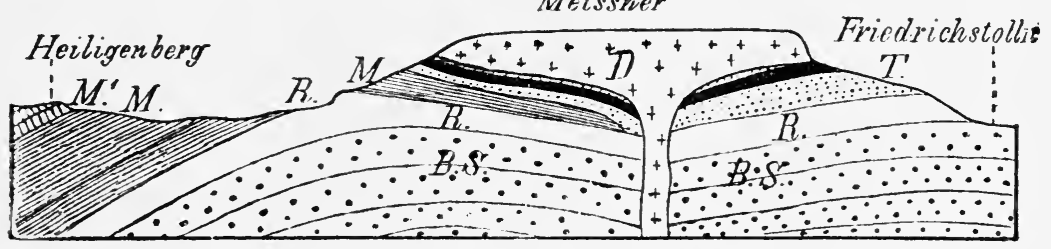

Fig. 52.-Section through the Meissner, near Cassel (Fr. Moesta).

B.S. Bunter Sandstone. R. Röth. M. Lower and Middle Muschelkalk. M'. Upper Muschelkalk. L. Lignite-bearing Tertiary. D. Dolerite.

ing Miocene formations intimately connected with basalts are also developed in Bohemia.

In the Mainz Basin the Oligocene Cerithium Limestone is followed by Miocene beds, which are divided into the Corbicula beds below and the Litorinella beds above :-

Miocene.

Litorinella beds. Calcareous clayey marsh deposits with innumerable specimens of Litorinella acuta (LXVIII. 7), Dieissena Brardi (LXVIII. 6), Helix moyuntina, Planorbis, etc.

Corbicula beds. Calcareous, somewhat brackish water formations with Corbicula Faujasi, thousands of Hydrobia (Litorinella) inflata, H. acuta, C'erithium plicatum, etc.

In Southern Germany the greater part of the marine Tertiary belongs to the Miocene. The newest Oligocene beds are usually followed by the oldest Miccene deposits, the so-called Blätter- 


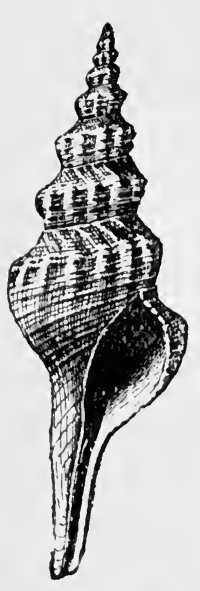

1
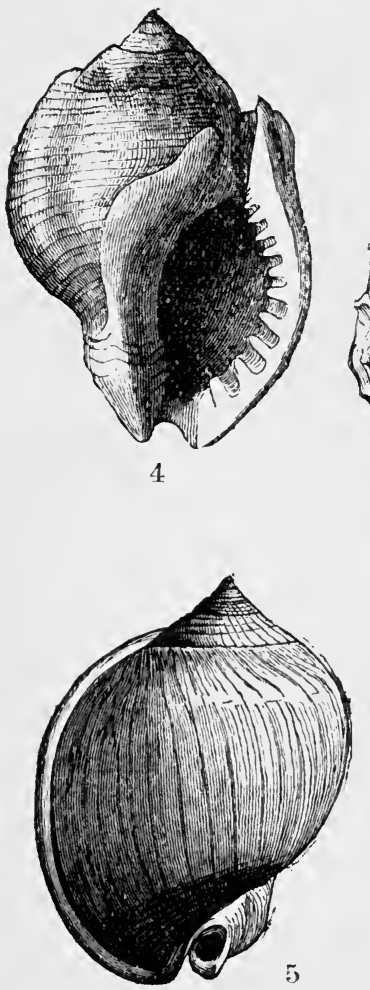

PLATE LXVII.-Miocene Gasteropoda.

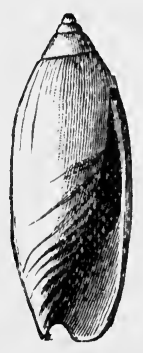

9
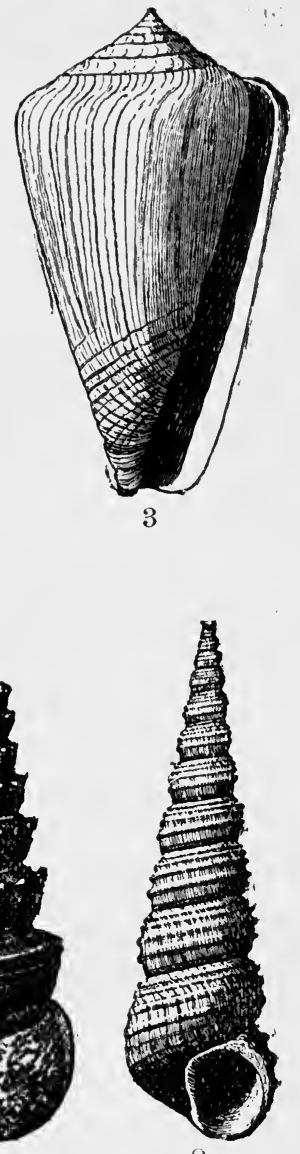

8

1. Fusus longirostris, Brocchi. 2. Pyiula vusticula, Bast. 3. Conus ponderosus, Broc.

4. Ranella maiginata, Broc. 5. Cassis saburon, Lam. 6. Pleurotoma asperulata, Lam.

7. Melania Escheri, Beng. 8. Tumitella turis, Bast. 9. Olira clavula, La. 10. Ancillavin, glandiformis, La. 


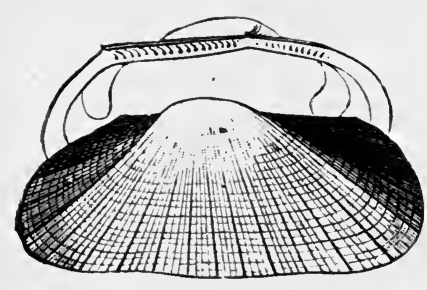

1

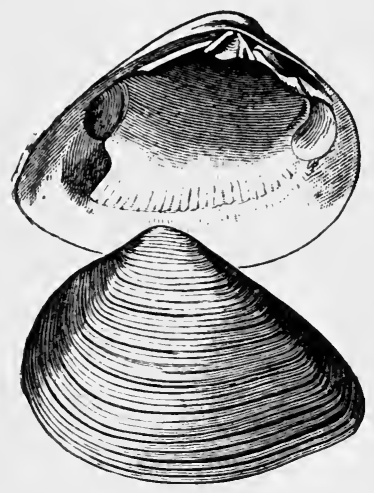

3

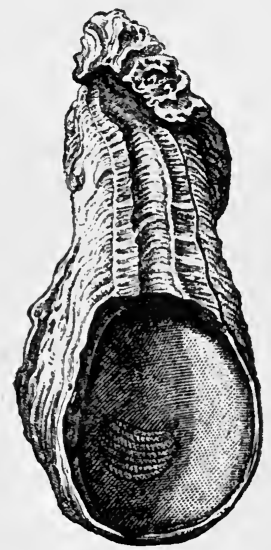

$4\left(\times \frac{1}{2}\right)$
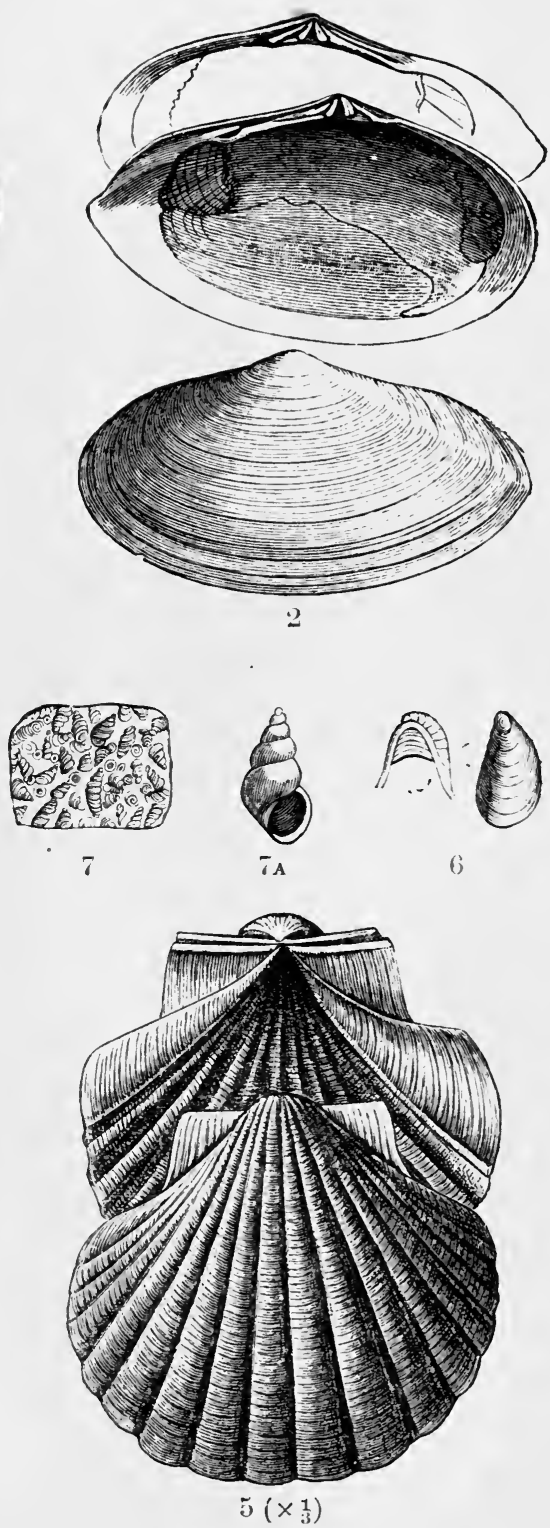

Puate LXVIII.-Mioceno Mollusca.

1. Aica baibata, Lin. 2. Tellina planata, Lam. 3. Mactia podolica, Eichr. 4. Ostiea frassissima=longirostris, La., joung. 5. Pecten (Vola) aduncus, Eichw. 6. Dreissentu Brardi, Fanj. 7. Hydrobia (=Litorinella) acuta, A. Braun. 7A. The same enlarged. 


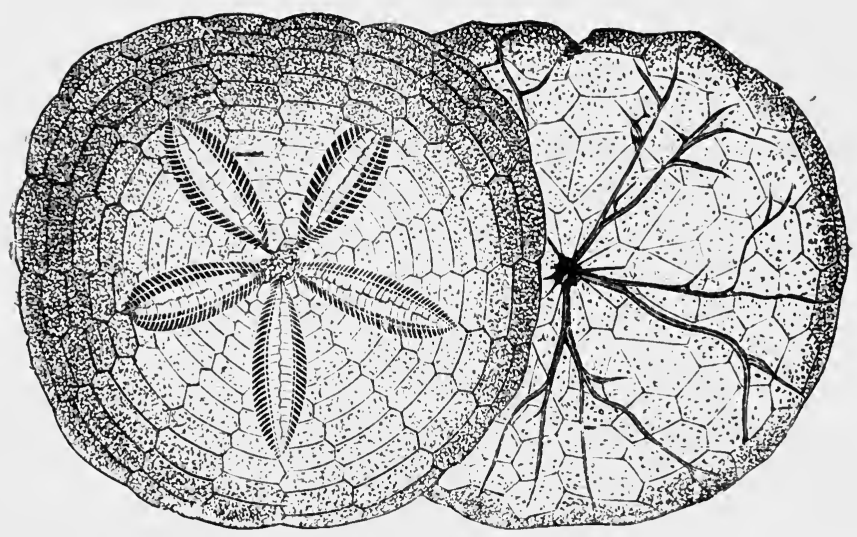

1

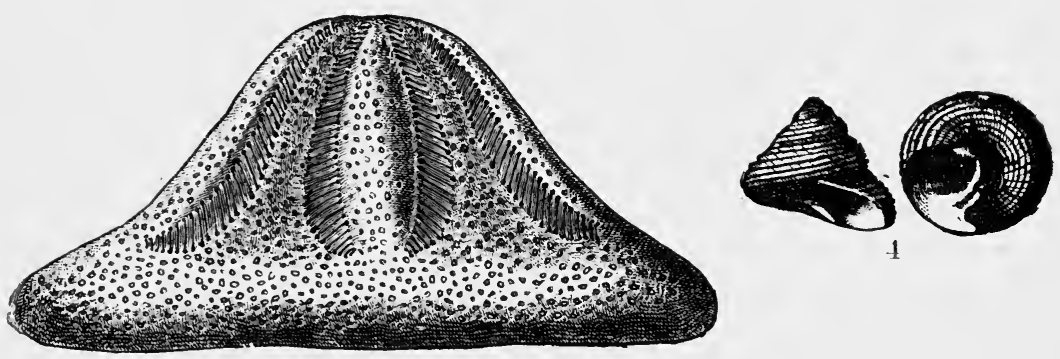

$2\left(\times \frac{1}{2}\right)$
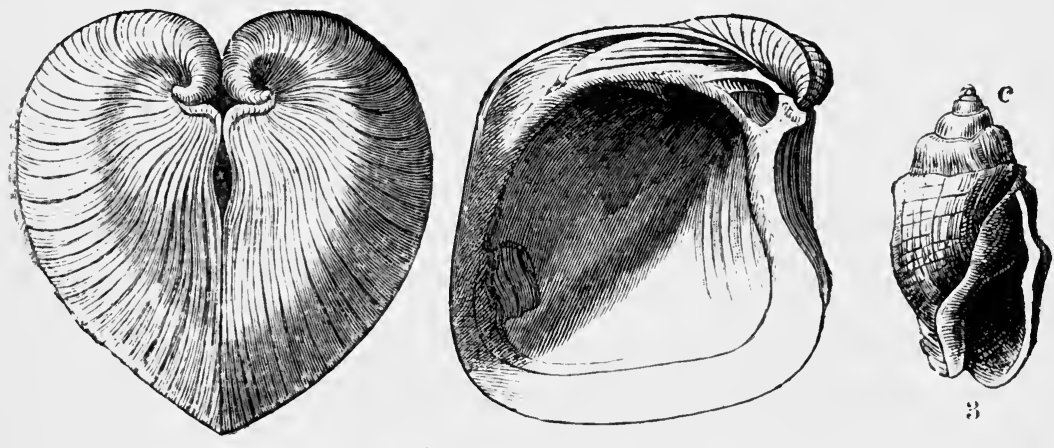

5)

Peate LXIX.-Miocere Fossils.

1. Sutella subiotundata, Lam. 2. Clypeasteraltecostatus, Mich. 3. Mclanopsis Martinicma, Fér. 4. Trochus patulus, Brocchi. 5. Dreissena (=Congeria) conglobata., Partsch. 
molasse (Leaf-MIolasse of Kiempten, etc.), which consists of sandstones and marls with impressions of leaves and land and freshwater shells. These are succeeded by the Marine Molasse with Ostrea crassissima (LXVIII. 4), Cardita Jouameti, Pectunculus pilosus, Turritclla cathedralis, T. tercbralis and others, Panopere. Menardi, etc. - the equivalent of the Faluns of Bordeanx. The succeeding Freshwater Molasse, which is sometimes coal bearing, and contains Mclania Escheri (LXVII. 7), Unio, Planorbis, etc., forms the uppermost division of the South German Miocene: for the overlying Bone-sands of Ulm, Ingolstadt, etc., with Mastodon, etc., probably belong to the Pliocene.

The small isolated Basin of Steinheim (west of Heidenheim) deserves special mention on account of the occurrence of Planorbis multiformis, so famous for its great variability.

The Swiss Molasse is most closely connected with the South German. It occupies the whole of the space between the Alps and the Jura, and near the former consists of coarse conglomerates of Alpine origin, which have been raised with very disturbed lie to a height of 6,000 feet above the sea ; whilst with increasing distancefrom the Alps these pass gradually into fine sandy and clayey sediments which, towards the north, gradually become horizontal. In Switzerland also, the lowest Miocene stage, the sc-called Grey Molasse, lying directly on the Oligocene, begins as a rule with a freshwater deposit rich in leaf impressions, which is succeeded very soon by thick marine deposits with Ostrea crassissima and other species of the French Faluns. This Grey Molasse is followed by the true or St. Gallen Marine Molasse, with a rich shell fauna consisting of some 400 species, almost one-third of which are living. forms; and the uppermost part of the Miocene is here formed of a freshwater deposit, the Upper Freshwater Molasse, with Irelania Escheri (LXVII. 7) Unio flabellatus, ete. To this group is also referred the platy and marly limestone of Oeningen on Lalke Constance, which has yielded many insect and plant impressions and also the famous fossil (preserved in the Zurich Museum) which was described by Schenchzer as the skeleton of a man, but which is the remains of a large salamander allied to the living Andrias Joponicus.

The Miocene group is characteristically developed in the Vienna Basin, which through the researches of Hörner, Süss, Fuchs, etc., las become one of the best known tertiary areas. Like the Mainz Basin, it affords a fine example of a series which at the base is 
purely marine, but gradually becomes freshwater. The following groups are distinguished :-

\section{Miocene.}

4. Congeria or Pontian series. Tegel (marl) of Inzersdorf; brackish water deposits with Lnio, C'ongeria subglobosa, ('. conglobata (LXIX. 5), Cardium, Melanopsis, (Martiniana [LXIX.3]), etc. Forms the foundation on which Vienna is built.

3. Sarmatian series. Brackish inland sea deposits whth C'erithiun pictum, C. rubiginosum and numerous species of Tapes, Cardium, Iactra, (pololica [LXVIII. 3]), ete., allied not to those of the Mediterranean, but to those of the Black Sea. The deposits of this series extend eastwards as the so-called older Steppe limestone beyond the Caspian and Aral Seas.

2. Second, or younger Mediterranean series, consisting partly of coastal formations, - the fragmental conglomeratic Leitha-

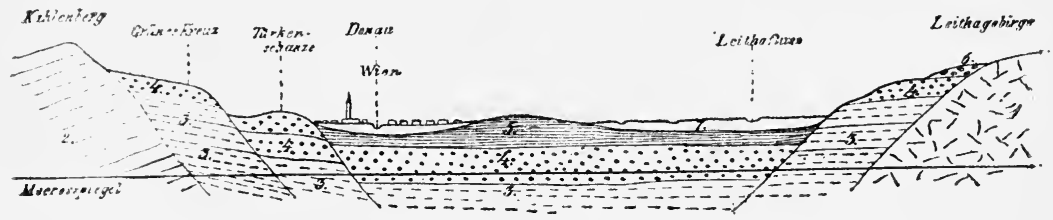

FrG. 53.-Diagrammatic Section through the Vienna Tertiary- Basin (Karrer). 1. Crystalline rocks of the Leithagebirge. 2. Flysch of the Vienna Hills. 3. Marine Jiocene (Merliterranean Series). 4. Brackish Upper Miocene (Sarmatian Series). 5. Congeria beds. "Belvedere gravels. $\%$. Drift and alluvium.

kalk; partly of clays deposited in a deep sea-the Baden Tegel; and partly of marls,-the so-called Schlier. Calcareous algæe (Lithothamium ramosissimum) take the chief part in the formation of the Leithakalk, the building stone of the city of Vienna. 'This series extends on the one side to the Sea of Azof, and on the other to Cyprus and North Africa. C'assis saburon (LXVII. 5), Ranella marginata (LXVII. 4), Comus Mercati, Conus antediluviamus, etc., Ancillavia glandiformis (LXVII. 10), Turritella turris (LXVII. 8), Plenrotona asperulata (LXVII b), Pecten adumens (LXVIII. 5), Arca turonica, Cardita Jouameti, Ostrea. collear, lenus clathrata, and a number of other species.

1. First, or older, Mediterranean series, =Horner beds. Sands, clays and marls of Loibersdorf, Horn, Molt, Gauderndorf, etc., with Ostiea crassissima (LXVIII. 4), Pecten solarium, Turritella cathedralis, ('erithium plicatum, C. margaritareum (LXY. 2), Pyrula rustirule (LXII. 2), etc.

The Tertiary beds of Galicia, which reach to Upper Silesia, are also commected with the Vienna Basin, and include at Vieliczka the well-known beds of salt. The salt outcrops of Kalusz, which contain potassium chloride, are probably also of the same age.

Throughout Italy, and as far as Sicily and Malta, and also in the 
East Mediterranean region, Miocene deposits are very widely sprearl. A characteristic type form of this area is the large bellshaper sea urchin, Clypeaster altus (like LXIX. 2).

\section{Pliocene.}

At the conclusion of the Nincene perind the sea retreated throughout Europe. In Northern Europe only the South of England, Belgium, and a small part of the North of France was covered by it; while Germany was quite chy. It was only in the South of Europe that the area covered was of any considerable width, as may be seen from the great extent of marine Pliocene deposits throughout Italy, Spain, Algeria, Greece, etc. The great SarmatioCaspian area on the other hand had become a continent with numerous, somewhat brackish inland seas, in which lived a shell fauna nearly allied to that of the present Caspian.

Palæontologically the Pliocene is characterised by the occurrence of large Proboscideans, especially of Dinotherium (Fig. 54) and Mastodon (Figs. 5(j-58) (type form M. longimstris), of the horse-like genus Hippotherium (Fig. 59), and of numerous Rhinocerotidæ (Aceratherium incisirm, Rh. Schleicmacheri, Figs. 4;3 and 64); stags, antelopes, wiraffes, etc. It was towards the conclusion of the epoch that there appeared, as characteristic forms, Elephas meridionalis, E. antiquus, Mastodom arrernensis, Equus Stenonis, IIippopotamus major, Rhinoceros Ieptorhinus R. meyarhinus and Macharodus pliocenicus.

The Pliocene shell fauna of South Europe approaches rery near to that still living in the Mediterranean, while already more northem forms (especially numerous species of Astarte [LXX. 3]) had established themselves in North Europe. The appearance of a number of Arctic types, such as Cyprina islandica, Panopera norregica, etc., in the newer Pliocene not only in England, but eren in Italy, is very remarkable.

The Pliocene flora in South Europe is nearly related to that now living in the Sonthern Mediterranean countries; but the palms, which were still tolerably abundant in the Miocene period, had almost entirely died out. It is only near Marseilles that a Chamcerops has been found in Pliocene deposits.

There is no general agreement as to the limitation of the Pliocene above and below, or as to the way in which it should be divided. Formerly all the marine Pliocene deposits of Southern Europe 
were known simply as Subapennine (d'Orbigny); in later times however there have been distinguished, in Italy, (1) the Z $\mathrm{Z}$ a e le a no, (2) the Piacentine Stage of Mayer, and (3) the Arno Stage. In Belgium these formations are represented by Dumont's A nver*ien and Scaldisien; in England by the so-called Crag.

The Italian Pliocene formation is typically developed on the north side of the Apennines as far as Piedmont; but also extends on the south of these mountains over the whole of Central and southern Italy. It consists of more than 1,000 ft. of clays, marls and sands, in which deep valleys have been cut. Castel Arquato (near Parma) and Asti (near Turin) have long been famous as the chief localities for the extremely rich and well preserver shell fauna. The marine beds of Monte Mario and of the Tatican in Rome are referred to the Lower Pliocene; those of Asti and Castel Arquato to the Middle Pliocene; and certain fluriatile sravels and sands occurring especially in the Arno ralley, with Equus Stenonis, Elephas antiquus, E. meridionalis, Mastodon arremensis, Irippopotamus major, etc., to the Upper Pliocene.

The English Pliocene deposits, included under the name of Crag, differ greatly from those of Italy. They are divided as follows :-

4. Chillesford Beds. Sands and clays with coaly layrers and a molluscan fauna, about two thirds of the species being norther'n forms.

3. Norwich Crag. Sand, gravel, and loam, 93 per cent. of the shells are living forms, and 1.6 per cent. are northern species.

2. Red Crag. Iron-shot sands, 93 per cent. of living species, $10.7 \mathrm{per}$. (ent. northern.

1. White (Coralline) Crag. Sands and clays full of bivalues ant Bryozoa, 54 per cent. living, only 5 per cent. northern species.

The most interesting feature here is the gradual increase in the number of living and of northern species (Astarto borecalis, I'anopea norecgica, Cyprina islandica, Scalaria groulandica, etc.).

The Belgian Pliocene deposits are very similar to these.

In Germany there is no marine Pliocene present, but fluriatile deposits of this age, rich in mammalian remains, are found. One of the best known of these occurrences is that of Eppelsheim in Rhenish Hesse, where the Miocene Litorinella Limestone is succeeded by bedded sands with Dinotherium gigartcum, Mrsstodon longirostris, Accratherium incisivum, IIippotherium gracile, stags, etc. Similar deposits are repeated in the Rhine valley at Dürkheim, Hanau, Fulda, in the valley of the Saale, 

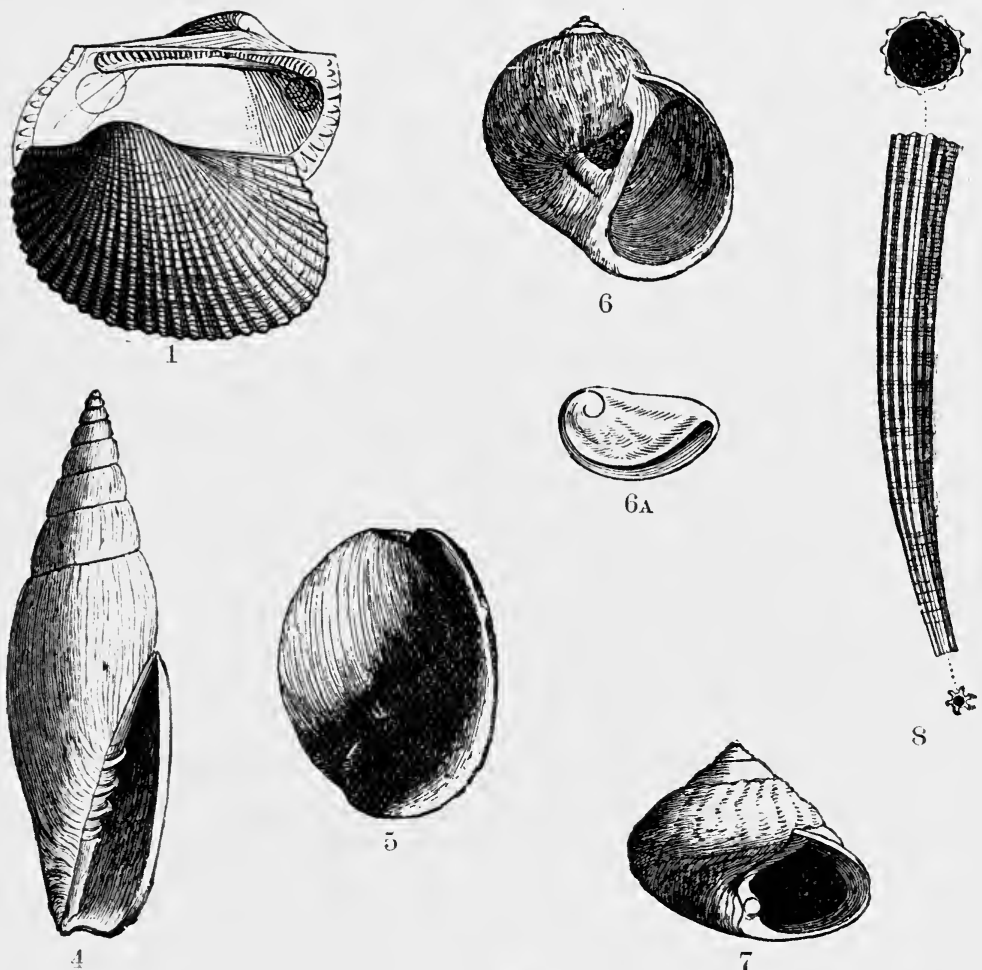

$6 \mathrm{~A}$
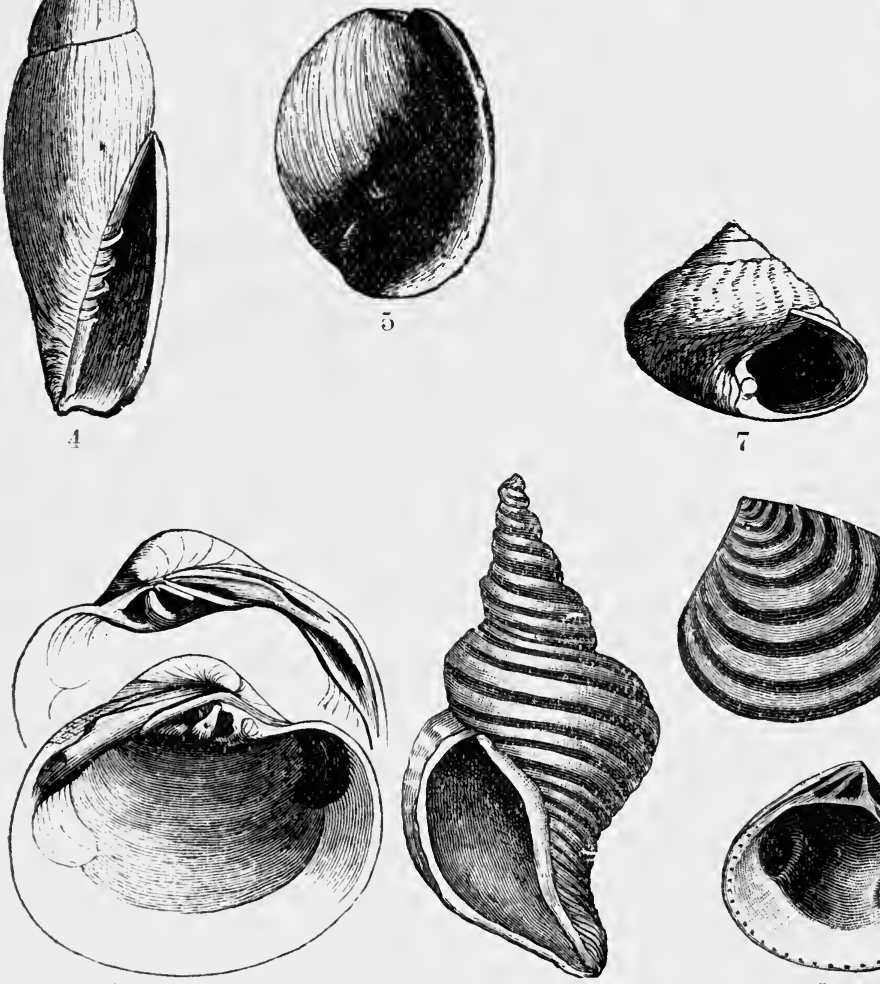

9

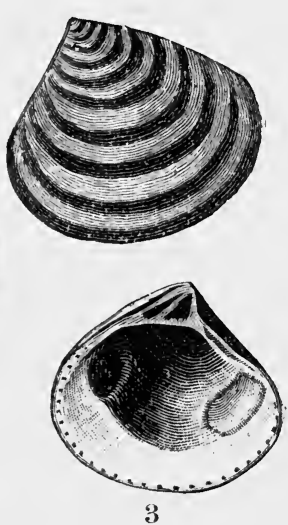

Plite LXX.-Pliocene Mollusca.

1. Area diluvii, Lam. 2. Cyprina tumidn, Nyst. 3. Astarte Omali, Lajonk. 4. Mitra fusiformis, Broc. 5. Bulla ampulla, Lin. 6. Natica millepunctata, Lam. 6s. Operculum of the same. 7. Trochus Brocchii, K. Mayer. 8. Dentalium sexangulare, La. 9. Fusus antiquus, Müll., var. st:iatus, Sow. 
Gera, Ilm, etc., and at many points in South Germany and Austria (Bone-sands of Ulm, Ingolstadt, etc.).

The bone loam of Mont Luberon in the South of France, and the red clay of Pikermi in Attica are famous for a similar rich mammalian fauna (at the former locality Dinotherium, Hippotherium, Rhinoceros, Macharodus [Fig. 67]; at the latter numerous antelopes, apes, the giraffe-like Helladotherium, ${ }^{1}$ etc.).

In the Vienna basin the Pliocene is represented by the Belvelere beds, which consist of sands and gravels containing remains of Dinotherium, Mastodon, Rhinoceros and Itippotherium. They are approximately equivalent to the similar Eppelsheim beds of the Mainz basin.

Of another kind are the Levantine deposits developed orer wirle areas in the South-East of Europe-in the same areas in which the Miocene Congeria beds are so widely spread. They are inland sea formations, which, in the west part of the area, especially in West Slavonia, contain innumerable Paludinas, Unios, Melanias, Valvatas, Bithynias, Hydrobias, Neritinas, etc. ; ${ }^{2}$ but further east, in the Aralo-Caspian district, besides numerous Congerias and true Cardiums, they contain the remains of an earlier marine fauna.

of the extra-European Pliocene formations, the deposits of the Sivalik Hills at the foot of the Himalayas require special mention. These are sands and conglomerates, with remains of Steyodon (a passage form between Mastodon and Elephas), soveral Mastodons, Apes (Semnopithecus), Hippotherium, Chalicotherium (also found at Pikermi), Sivatherium, the gigantic chelonian Colossochelys, etc. Similar Pliocene forms, especially distinguished by Stegodont Elephants, are also known from the bone caves of China and from Japan.

Lastly, according to the views of Gaudry, Cope, Ameghino, and nthers, the clayey loess-like Pampas formations of the South American plains, occupying large areas in the State of La Plata, belong to the Pliocene; but, according to Burmeister, they should be referred to the Drift. These deposits contain Mastodon giganteus, Equus, Macrauchenia, and (according to Ameghino) probably also remains of men, and are specially distinguished by the remains of gigantic Edentates (Megatherium, Glyptodon, Mylodon, and others).

1 Gaudry, "Animaux fossiles de l'Attique" (1862-68).

2 Neumayr and Paul, "Fauna d. Congerien- u. Paludinen-Schichten Slavoniens. Abh. d. geol. Reichsanst." (1875). 


\section{PALAONTOLOCY OF' THE NEUER TERTIARY.}

Some remarks have already been made concerning the Neogene Flora, and the chief peculiarities of the lower divisions of the animal kingdom have also been mentioned in the preceding pages, so that only the Mammalian Fauna remains to be described.

Throughout the Newer Tertiary times the Proboscidians, with the three chief genera Dinotherium, Mastodon, and Elephas, play

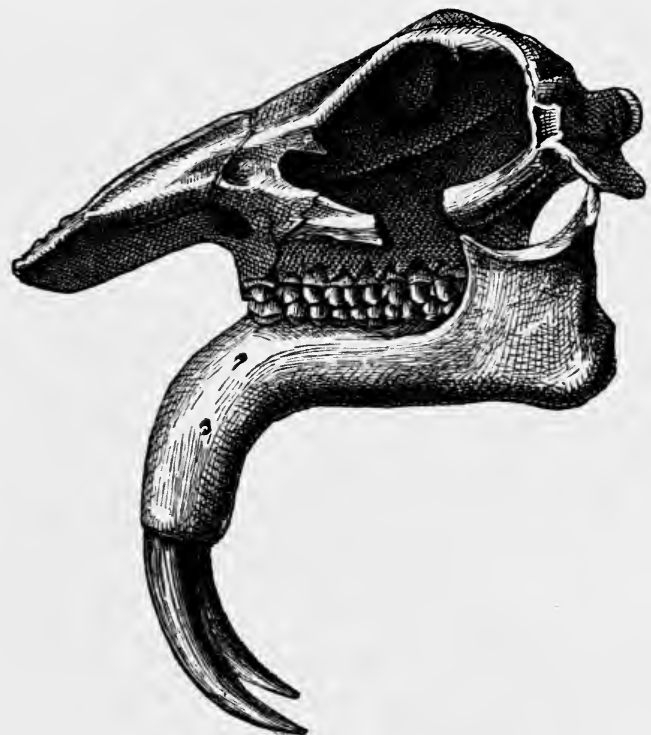

FIG. 54.-Dinotheriuin gigantcum, Kaup. Pliocene of Eppelsheim $\left(x_{i s}{ }_{1}\right)$.

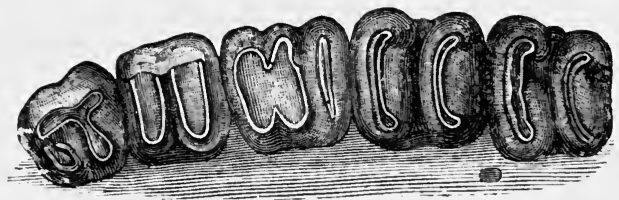

FIG. 55.-Upper molar teeth of the same $\left(\times_{6}^{1}\right)$.

an important part. Dinotherium and Mastodon occur already in the Miocene, but Elephas does not appear till towards the end of the Pliocene. Dinotherium does not pass beyond the Tertiary; Mrastodon does so only in America; while Elephas reaches its. chief development in the Drift. The huge Dinotherium (Fig. 54) was distinguished by simply formed teeth (Fig. 55) and sabreshaped lower incisors curved dornwards. The chief locality in 
Germany for the best known species, D. giganteum, is Eppelsheim. In appearance IIastodon was elephant-like, but was often provided

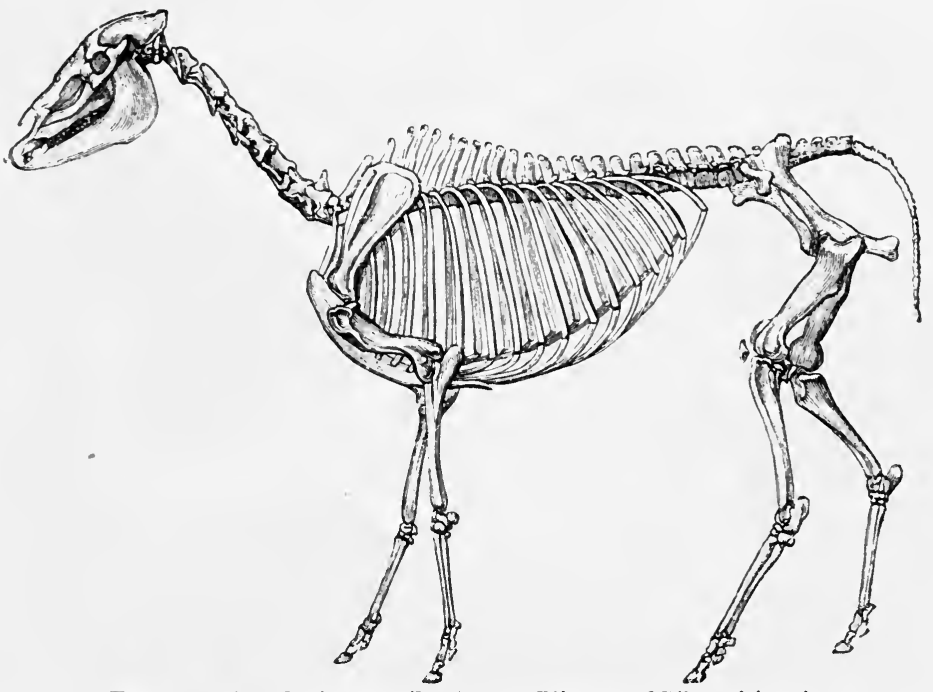

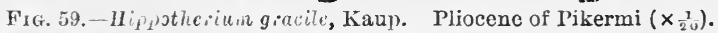
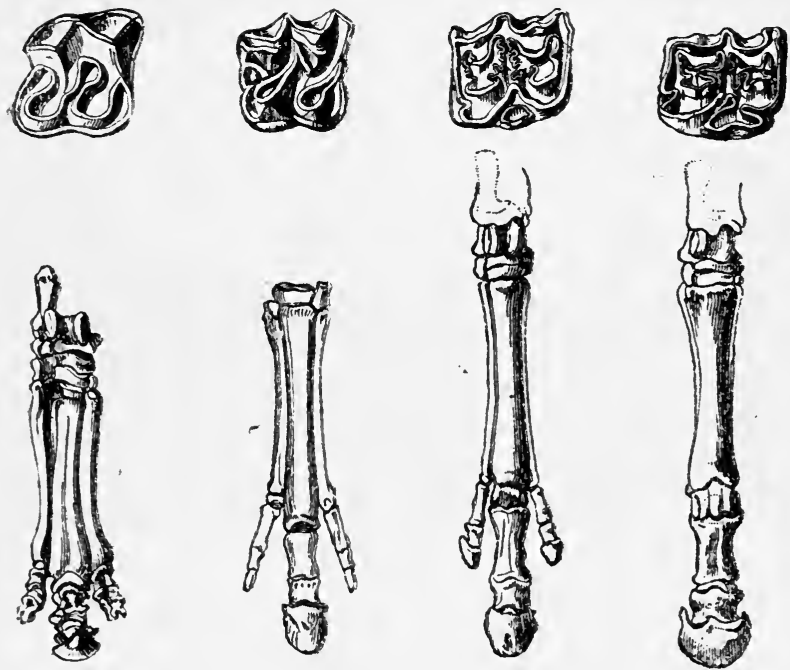

$b$

$c$

d

TIG. 60.-Upper molars and hind feet of (a) Palaotherium; (b) Anchitheitum; (c) Hippotheriun; (d) Equus.

with tusks in its lower jaw also, and the molars are tuberculate. M. angustidens and M. turicensis are Miocene; M. longirostris and 
M. arvernensis, Pliocene. Finally, Elephas is distinguished by its lamellar back teeth (LXXI. 2). E. meridionalis is Upper Plio.cene, especially in Europe.

Among the Imparidigitate Ungulates the Equidæ require notice. The two most important types of the Newer Tertiary are the Miocene Anchitherium and the Pliocene IIippotherium (=IHipparions). These include a beautiful series (Fig. 60) leading from the old Tertiary three-toed Palaotherium to the genus Equus (which just appears in the Uppermost Pliocene). The end of the series is reached by the disappearance of the side toes and the change of the originally short-fanged teeth (Fig. 61A) into long prismatic teeth (Fig. 61B). The chief species are Anch. aurelianense and Ilipp. gracile (Fig. 59). The Rhinocerotidæ also, which first appeared in the Upper Oligocene, are of importance in the Newer Tertiary. The small hornless $R h$. (Aceratherium) incisivum (Fig. (i3) and the larger two-horned Rh. Schlcicrmacheri (Fig. 64) (sometimes, as at Eppelsheim, the two occur together) were specially widely spread; Rh. leptorhinus, Rh. minutus, and others should also be mentioned. Of other perissodactyle ungulates Tapirs (Protapirus and Tapirus) were still present.

Among the Paridigitates the Hippopotami were remarkable for their wide distribution, in striking contrast with their present limitation to the single continent of Africa. In Newer Tertiary and older Drift times they spread over the whole of South A sia and South Europe, and as far north as England. The oldest (from the Sivalik Hills) possessed three upper and three lower incisors (Hexaprotodon), the later forms only two (Tetraprotodon). To the latter group belongs the Upper Pliocene and lower Drift form, II. major, scarcely distinguishable from the living $H$. amphibius.

Since Miocene times true Pigs have been present in Europe, and in the Pliocene, especially in the Sivalik Hills, they were very abundant. Sus antiquus occurs in the Miocene; S. erymanthus is a gigantic Pliocene form.

Passing on to the highest Paridigitates, the Ruminants, we see the Camelidæ playing a not inconsiderable part. The genus Camelus itself is only known from the Uppermost Pliocene of the Sivalik Hills, while allied genera (Auchenia, the llama; Protauchenia) are present also in the younger Pliocene of South and North America, and their predecessors (Procamelus, Protolabis, etc.) reach back in the last-named region to the older Neogene and probably even further.

C. G. 


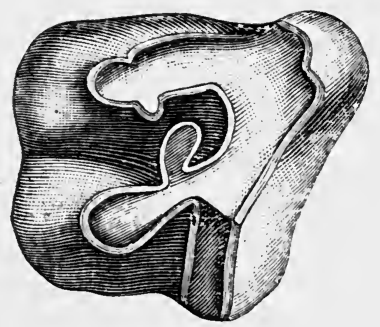

FIG. 62.- Upper molar of Aceratherium incisivum $\left(\times \frac{2}{3}\right.$.

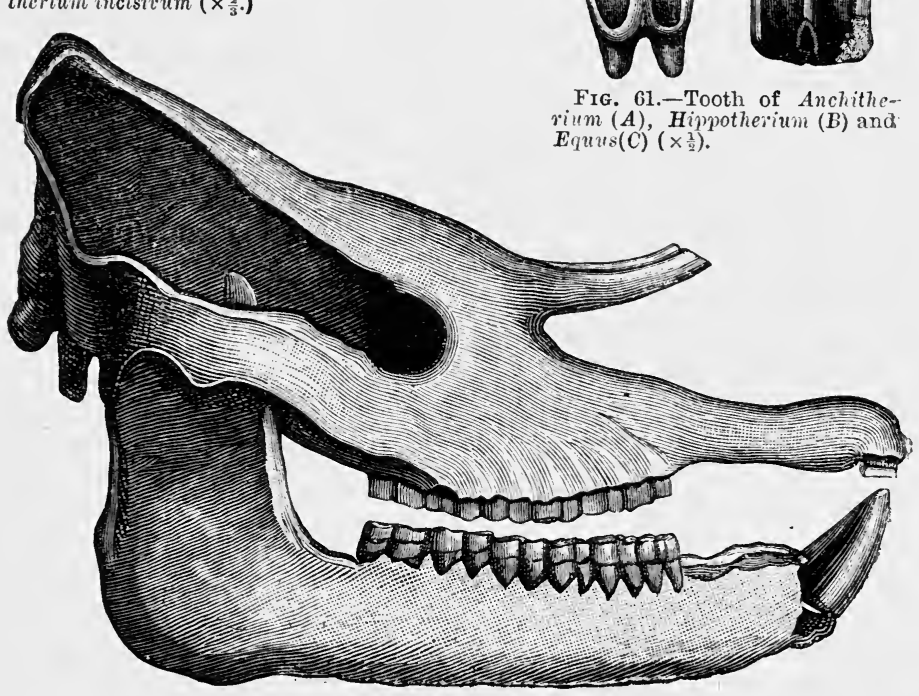

Frg. 63.-Rhinoceros (Aceratherium) incisivus, Cuv. $\left(\times \frac{1}{6}\right)$.

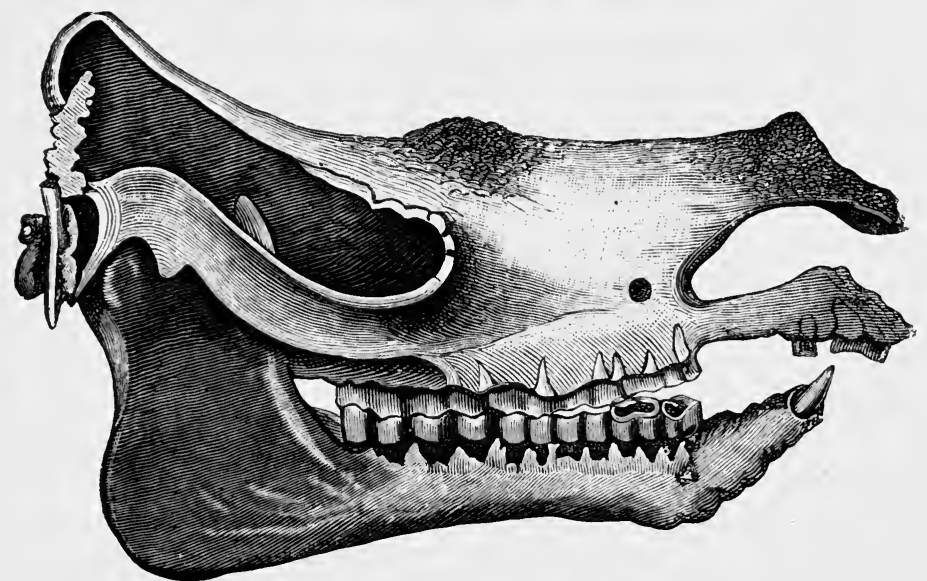

Fra. 64. - Rhinoccros (Dihoplus) Schleiermacheri, Kaup. $\left(\times \frac{1}{7}\right)$. 
The Deer are much more important. The oldest, among which, for example, is the Lower (?) Miocene Procervulus, according to Gaudry, did not cast their horns; but, like antelopes, sheep, etc., bore permanent antlers, and thus bridged over the gap which exists now between antler and horn-bearing ruminants. The older deer are distinguished by a long pedicle and deeply-forked, two-pointed antlers (Sub-genus, Palcomeryx or Dicrocerus [Fig. 6כa and r] from Steinheim, Sansan, Pikermi, etc.). Later there appeared forms with short pedicle and three-pointed antlers (Cervus Motheronis and ('.martialis), and from the Uppermost Pliocene we get the first with richly branched antlers (C. Sedguricki), Fig. 66.

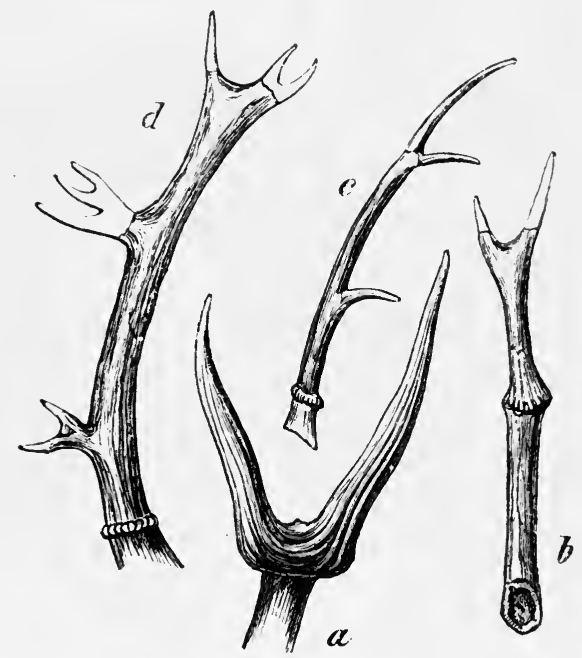

Frg. 65.-Antler's of : a. Cervus (Paloomeryx) elegans, Lartet=furcatus, Hens.; Miocene, Sansan. b. C. (Pal.) anocerus, Kaup.; Pliocene, Eppelsheim. c. C. Matheronis, Gaudr., Pliocene, M. Luberon. d. C. martialis, Croiz. and Job.; Pliocene, St. Martial (all about $\frac{1}{7}$ nat. size).

The Antelopes also are of great importance. They are most abundant in the Older Pliocene (Mt. Luberon, etc.), while in the Older Miocene (Sansan, etc.), they are still rare. The Giraffes of Pikermi and the Sivalik Hills (Helladotherium, Camelopardalis, Siratherium, etc.) also require mention.

The genus Tragoceros from Pikermi is an interesting form intermediate between antelopes and goats; while true goats, sheep, and also cattle are not greatly developed till the beginning of the Drift. Of the latter only the late Pliocene Bos ctruscus (Val d'Arno, etc.) was represented in the European Neogene, whilst at 
the same time they were already well developed in India (B. planifrons, B. namadicus, Bison sivalensis).

The Carnivora attained a full development in Neogene times.

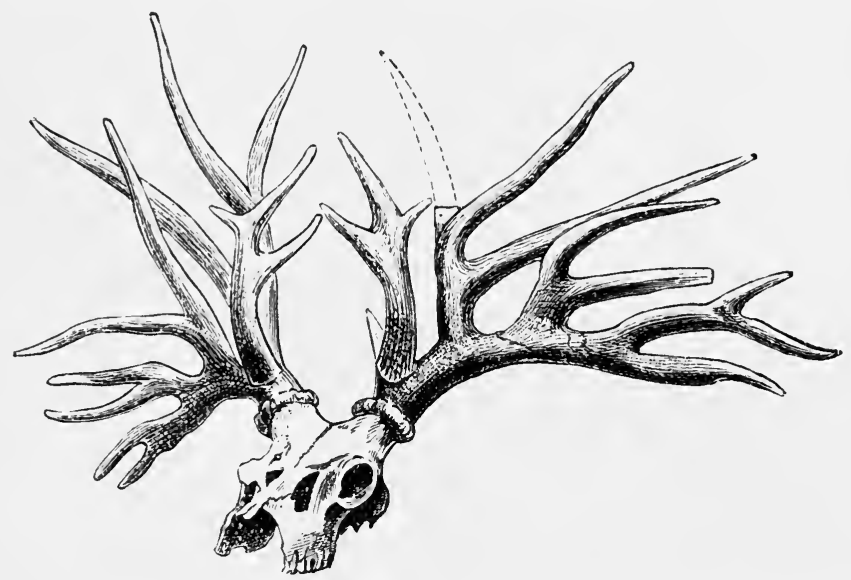

Fra. 66.-Cervus Sedguichi, Falc. Upper Miocene, Val d'Arno $\left(\times_{\frac{1}{20}}^{\frac{1}{0}}\right)$.

They were in part, e.g. Hyanarctos (Sivaliks, South of France), Ictitherium, and Hyanictis (Pikermi), synthetic types of Hyænidae, Viverridæ, and Ursidæ; but the Pliocene has also yielded true hyænas, cats (Felis attica, Pikermi), dogs (Canis etruscus,

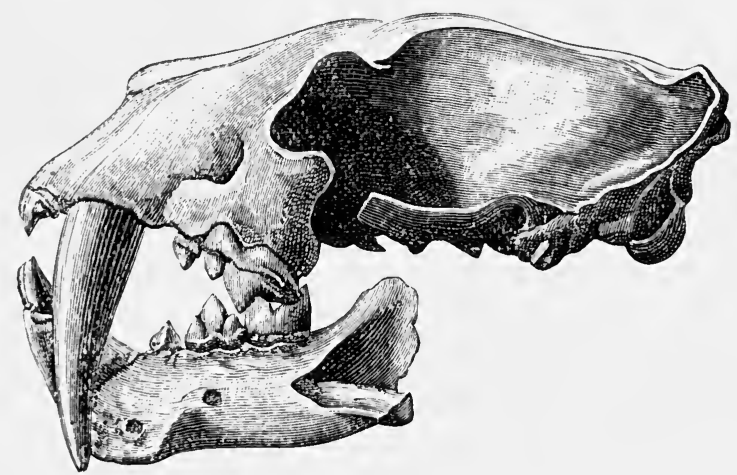

Fig. 67.-Macharodus meganthereon, Croiz. and Job. Pliocene of S. France $\left(\times \frac{1}{3}\right)$.

Val d'Arno), and bears (South of France). One of the most characteristic forms was Machcerodus, the sabre-toothed tiger, which spread over almost the whole world in Pliocene times, and reached also into the Drift. This was probably the most terrible carnivore 
that ever lived, and bore large, strongly compressed, sabre-shaped upper canines, toothed on the edge.

The Apes, Rodents, Insectivores, etc., were of less importance. Apes were still spread over the whole of South and Central Europe (Pikermi, Southern France, Eppelsheim) in younger Tertiary times. Of the Rodents, the genera Castor, Sciurus and others were already present. The Edentates, as at present, had their home in Neogene times principally in South and North America. Burmeister has described a whole series of forms, some of gigantic size, from the

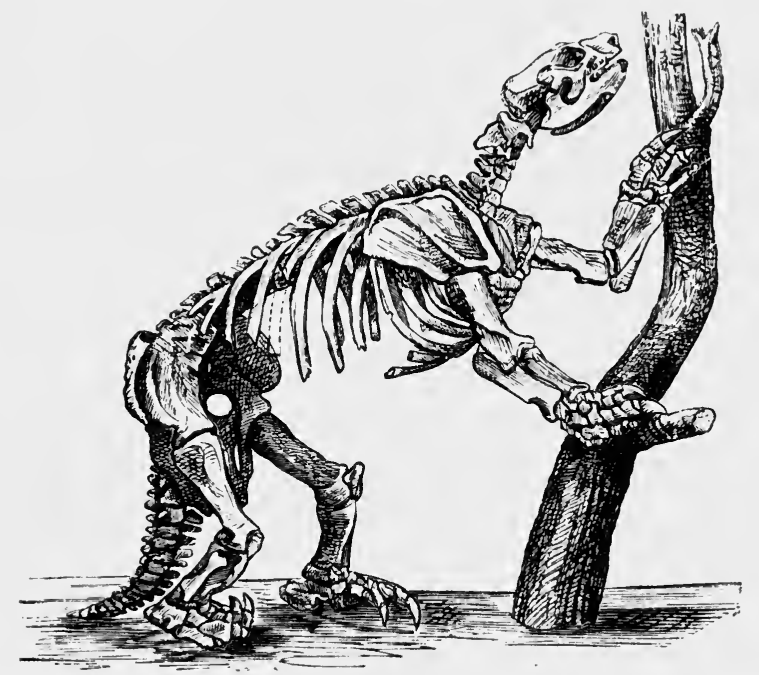

FIG. 68.-Mylodon robustus, Owen. Argentine Pampas formation $\left(\mathrm{x}_{3 \mathrm{i}}^{\frac{2}{30}}\right)$.

younger Pliocene Pampas formation of the Argentine Republic. Among the best known of these were the Glyptodon, which reached the size of a rhinoceros, and was provided with tortoise-like immovable armour, composed of numerous polygonal bony plates, and bore also a long armoured tail; and Megatherium, the giant sloth, an animal of the size of an elephant, with enormously large bones long heavy tail, and relatively small head. An allied form, smaller in size but still clumsier in build, is known as Mylodon (Fig. 68).

\section{B. QUATERNARY SYSTEM.}

The Quaternary system represents the latest period of the history of the earth, the period in which we are now living. It 
includes the whole of the loose pebbly, sandy, loamy, clayey and other deposits of post-Tertiary age--deposits which were known by the geologists of the Wernerian School as "aufgeschwemmtes Land." At present the deposits in question are divided into two chief divisions: an older, the Drift, or Pleistocene (after the analogy of the terms Miocene, Pliocene, etc., from $\pi \lambda \epsilon i \sigma \tau o r$, the most, and кauvós, new;, and a newer, the Alluvium or Recent deposits.

The Quaternary is inferior to the older systems in thickness, but not in extent, in which it at least equals any of the older Formations. The floors of almost all low-lying regions are formerl of Quaternary deposits, which often, for example in the North of Germany, almost entirely cover up the older rocks. Owing to the circumstance that the Quaternary, and especially the Alluvial, leposits everywhere afford the soil best fitted for cultivation, they are economically of the greatest importance.

It has already been remarked of the Tertiary deposits, that the rapid changes in facies and the very limited extent of single berls make the accurate correlation of the deposits of different regions very difficult; and this is true in a still higher degree of the Quaternary beds, the difficulty of the determination of the age of which is often increased by the complete absence of fossils.

\section{DRIFT OR DILUVILII.}

General and Historical.

The Drift or Diluvial Epoch, following directly on the Tertiary, was the period of the gradual formation of the present geographical, climatic, and biological conditions. The distribution of the sea at the beginning of the Drift epoch was not very different from the present; nevertheless the Europe of that time differerl in many ways from that of to-day. Thus, for example, the British Isles were still united with the main land. Whether the Baltic Sea Basin was already present, is not yet certain; but Neumayr and Süss have made it probable that the Adriatic and Egean Seas were first formed in this period.

The marine fauna of the Drift was very similar to that of the present day, while the land animals still showed great differences. Numerous still living forms were present and a number of extinct animals, such as the Mammoth, the Cave bear, etc.; and in consequence of the coldness of the climate of Europe during the greater part of the Drift period, animals and plants which are now 
sentirely restricted to the Arctic Regions, then extended much farther to the south.

Unlike the rocks of the older systems, the main mass of the Drift consists not so much of deposits formed in the ocean or in large inland seas, as of deposits from running waters. The wravels, sand, clay, loam, calcareous sinter, and peat formations in question are therefore in the main contained in the present river valleys, the greater number of which were already present in the time of the Drift, although not as yet cut down to their present level. Along with these formations, laid down from running water, Eolian loams-i.e., loams borne by wind and rain,-play a considerable part. These often pass beyond the limits of the present valleys, and this is true to a still greater extent of the remarkable Glacial deposits, which were formed by the agency of ice, and which both in Europe and other parts of the earth form a. more or less continuous covering over very large areas.

The most important characteristics of the Drift are due to the great reluction in temperature which took place at the time of its formation throughout the Northern Hemisphere, and probably throughnut the whole earth. That this remarkable period of intense cold, the so-called Glacial epoch, did not appear quite without warning, is proved by the gradual increase of northern species of shells in the Tertiary deposits of many regions. At the beginning of the Drift epoch, however, the temperature had sunk so low that extensive glaciers were developed in Europe, especially in the mountains of Scandinavia. Like the present ice sheet of Greenland, they covered the whole of the north of our continent with a thick, almost unbroken, covering of ice. These mighty diluvial wlaciers carried an extraordinary amount of both coarse and fine materials, which on the melting of the ice remained behind and formed the Erratic, or rather Glacial, deposits of North Europe. (tlacial polishings and scratches, roches moutonnées, moraines and other appearances to be mentioned further, have remained in North Europe, in the mountains of Central and Southern Europe, in N. America and other areas, as witnesses of this mighty glaciation; snd along with the above-rnentioned northern animals and plants, aifford indubitable proof of the extreme cold of the Ice Age.

In spite of the clearness of this evidence it was long before the correct view on the morle of formation of these extensive glacial גeposits of Europe and America gained acceptance. As early as the beginning of this century Playfair asserted that the great 
erratic blocks of the Swiss platean had reached their present positions by the agency of glaciers; and independently of him, the Swiss engineer Venetz had spoken in the same sense. But this explanation found little credit; and in spite of the approval given to it by Charpentier, L. Agassiz and others, it conld not keep its ground against the "Drift theory" proposed by Ch. Lyell. According to this theory the erratic deposits were not formed by glaciers, but by floating icebergs. Like the ice masses laden with moraine material which are derived from the Greenland glaciers and are strander yearly on the bank of Newfoundland, those icebergs would be driven by ocean currents from Scandinavia to the south. Over the plain of North Germany, which according to Lyell's views was at that time covered by the sea, they melted and dropped their burdens, and thus yielded the material of the boulder clays, sands, etc., of the Drift.

For nearly thirty years the Drift theory of Lyell held its ground almost undisputed, in spite of many facts telling against it, such as the complete absence of marine shells over great areas; till at length (1870-80) it was displaced by the Glacial theory. This was the fruit of the long continued observations of the English and Scandinavian Geologists, and especially of the extensive comparative researches of the Swedish savant, Otto Torell. From his researches it gradually became clear that the Scandinavian and North German Glacial deposits were of the same constitution and origin. In consequence of this the Drift theory could no longer be held: for the researches carried ont in Scandinavia had proved with the greatest certainty that the erratic deposits in that country had been formed by glaciers. ${ }^{1}$

In England, in the mountainous parts of which the traces of the Ice period are everywhere clearly present, the new theory, chiefly in consequence of the beautiful works of Ramsay, the brothers Geikie, ${ }^{2}$ and others, has long been universally received. In Germany, thanks to the continuous researches in North Germany during the last fifteen years of the German and Scandinavian Geologists, especially of Berendt, H. Credner, de Geer, Helland, Jentzsch, Keilhack, Laufer, Penck and Wahnschaffe, and the fulness of the evidence thus gained of the former glaciation of this area, the Glacial theory has now found almost universal acceptance. The

1 Berendt, Zeits, d. deutsch gecl Ges. (1879), p. 1.

2 James Geikie, "The Great Ice Age," 2nd ed. (1877); and "PrehistoricEurope" (1881). 
North American Geologists also, who have lately occupied themselves with the similar deposits of their country, have without exception adopted the Glacial theory, for the further support of which they have brought together a number of decisive proofs.

The extreme cold and great glaciation did not last through the whole of the Drift period. In the second half, more favourable climatic conditions stepped in, in consequence of which the icemasses gradually melted away. In correspondence with this, one can distinguish an older Glacial period and a newer post-Glacial, and also separate the oldest relatively warm phase of the Drift as pre-Glacial. Moreover within this Glacial period there were repeated fluctuations in temperature, and, with them, alterations in the extent of the glaciers. Recent researches have shown that not only in Europe, but also in North America, the first chief glaciation was followed by a decided retreat of the ice-sheet, and again by a second, though weaker glaciation. The period between the two glaciations, the climatic conditions of which nearly corresponded with those of the present day, is called the Interglacial period; so that we now distinguish in all :-

\section{Post-glacial. \\ Newer Glacial. \\ Interglacial. \\ Older Glacial. \\ Preglacial.}

The very characteristic mammalian fauna of the Drift may be divided into: (1) Forms since completely lost, e.g., the Mammoth, Cave-bear, etc. (2) Beasts which became extinct or were exterminated by man in historical times, such as Bos primigenius, Bison priscus, Cervus alces, etc., and lastly, (3) Northern animals which in consequence of the climatic conditions of that time invaded the south, such as the Musk Ox, Arctic Fox, Lemming and many others.

In general one may' distinguish, according to these mammals, three divisions of the Drift period, namely (1) The period of the predominance of Elephas antiquus, Macharodus, and Hyana spelcea. (2) That of the predominance of Elephas primigenius (the Mammoth) and Rhinoccros antiquitatis=tichorhinus, with which Crsus spelaus, Bos primigenius, Bison priscus and various other northern animals were associated; and lastly, (3) The period of the greatest abundance of the reindeer, Rangifer tarandus. The 
Mammoth and Rhinoceros were indeed present to the end, but were rarer than before. As will be shown more clearly below, during the last phase of the second and the first half of the third period, numerous northern steppe animals lived in Central Europe, and these afterwards made way for a forest fauna.

Lastly, it is in the Drift deposits that we find the first certain proof of the appearance of man. As a rule it is not so much the remains of the men themselves that we find, as the remains of their arts, especially more or less rude implements of stone. The olclest period cluring which man was present on the earth, is called the Palrolithic or Older Stone Age.

\section{Distribetion and Developient of the Drift.}

We begin with the description of the Drift deposits of the Alpine area, since this is the region from which the knowledge of the slacial formations of our part of the earth took its rise. Not only were the Alps themselves covered by huge ice-masses which left nnly the highest points free; but the country at their feet was also buried in ice. Especially on the northern side of the mountains the glaciers crowding together from all the large valleys filled the whole of the level part of Switzerland. They reached to the foot of the Jura, whilst eastwardly they stretched into Swabia, Bavaria, and Austria, and to the west they invaded the valley of the Rhone as far as the neighbourhood of Lyons. Everywhere they have left evidences of this wide extension, in the form of huge terminal moraines which sometimes lie one behind the other in concentric hows, and which have often, as in the valley of the Garda See, helped in the formation of lakes.

Erratics of gigantic size, brought from the interior of the Alps, have been borne to considerable heights on the slopes of the Jura, and thus afford evidence as to the thickness of the ice-sheet. One of the most remarkable of these erratics is the Pierre $\dot{a}$ Bot, a granite block some 15,000 tons in weight, which lies almost 1,000 feet above the level of the Lake of Neuchatel. The weight of such erratics shows that they conld not have reached their present positions by the action of floods of water or mud ; and the glacia! polishings and scratches which are to be observed in the Alpine valleys at a considerable height above the highest of the present shlaciers, the roches moutonnées, and the pot holes (hollowed out in solid rock by glacial streams) found far outside the mountains (for example in the well-known "glacial garden" near Lucerne), 
are other evidences of former glacial activity in the Alpine valleys.

The Alpine glacial deposits consist chiefly of sand, gravels, and boulder clay, and in general commence with a gravel zone (to which belong the coarse conglomerates known as Newer or Diluvial Nagelfluh). This is overlaid by a zone of pebble or boulder clay, and this by an upper gravel zone. The bedded Lower Gravels have been laid down by the melting water, which flowed from the glaciers on their first advance at the beginning of the Ice Age. The completely unstratified Boulder Clay consists of a loamy marly groundmass, full of fragments of rock of all sizes and of all sorts, which are sometimes scratched and polished, and are scattered through the clay without any arrangement. In all these characters the Boulder Clay agrees precisely in appearance with the ground moraines of the present glaciers, and it is in fact only the ground moraine, locally some hundred feet thick, of the great diluvial ice-sheet. The bedded Upper Gravels, like the Lower, have been laid down by the water derived from the glaciers on their retreat.

In the Alps we can also distingnish an older and a newer period of glaciation separated by an interglacial period. To this interglacial period belong the lignites of Utznach, Dürnten, etc., in Switzerland, the flora of which has been described by Heer and consists of beeches, birches, maples, larches, firs, etc., while the fauna of the period included Elephas antiquus, Rhinoceros Merckii, Bos primigenius, the cave bear, various deer, etc. Heer reckoned the mean temperature of this region at that time to hare been $6-9^{\circ} \mathrm{C}$, as compared with $8.7^{\circ} \mathrm{C}$. at present. At some other places, such as Höttingen, not far from Innsbruck, Sonthofen in Bavaria, etc., similar interglacial deposits have been found.

Very different from this was the true glacial flora, as it was found by Nathorst at Schwarzenbach, not far from Zurich, in a shaly layer under the old ground moraine. It consists of purely northern forms, such as Salix polaris, Betula nana, Polygonum riviparum, Hypnum Wilsoni, etc.

Sweden and Norway almost everywhere show the clearest evidences of diluvial glaciation, such as polished and scratched rock surfaces, roches montonnées, "giant kettles," moraine walls, etc. According to Erdmaun, Kjerulf, Torell, Nathorst, Helland, de Geer and others, the following general classification may be established for the glacial drift of Scandinavia :- 
Postglacial. Bædded sands of the retreat (Rullstensgrus).

Newer Glacial. Upper (mainly yellow) Boulder clay (Krosstenslera).

Interglacial. Bedded sands and clays (with remains of the dwarf birch, etc.). Chiefly in South Sweden (Scania).

Older Glacial. Lower (blue) Boulder clay (Krosstenslera).

The so-called Asar are peculiar deposits which are found chiefly in Scandinavia, but also in the North of Germany. They form. wall-like ridges of sand and pebbles, which are sometimes $100 \mathrm{ft}$. in height and often wind for many miles across the country. Their origin is not yet satisfactorily explained; but probably they were formed by the filling up of channels which the melting. water had hollowed out in the ice-covering.

The thickness of the Scandinarian land ice must be estimated at least at 1,000 metres, for it passed orer mountains more than 1,800 metres high.

From Scandinavia this mighty ice-sheet spread not only to Finland and the Russian Baltic Provinces, but also far to the southeast and south, into North West Russia and North Germany; so that the Baltic basin, if indeed it existed, was no hindrance to its progress: Up to the region where the Petschora opens into the Arctic Ocean, and far beyond Moscow and Kiew, the ground moraine of this gigantic ice-sheet may be followed, whilst its south border runs to the west somewhat beyond Lemberg and Cracow, along the north border of the Riesengebirge to Dresden and Chemnitz, and along the north border of the Harz, beyond Hildstein, Dortmund and Essen, to Groningen in Holland ; from thence in the south-east of England to the neighbourhood of London. The erratics of Scandinavian granites, gneisses, etc., which reach up to a height of 1,200 to almost 1,500 feet on the slopes of the Harz and Riesengebirge, allow us to form some idea as to the depth of the ice in these areas.

The thickness of the glacial deposits spread orer this great area is variable and decreases in general from the north to the south. On Seeland borings have given a total thickness of 126 metres, at Hamburg and Berlin they have reached more than 100 metres; while in the neighbourhood of Halle on the Saale on the other hand they are only 15-20 metres thick.

The constitution of the North German glacial drift is quite like that of Sweden. We distinguish :- 
Postglacial. Upper or covering sand.

Newer Glacial. Upper (yellow) Boulder clay.

Interglacial. Middle Diluvial sand (with mammalian remains), occasionally with intercalated beds of calcareous tuff.

Older Glacial. Lower (blue) Boulder clay.

Pre-glacial. Bedded sands and clays.

From this agreement in constitution alone we could infer an

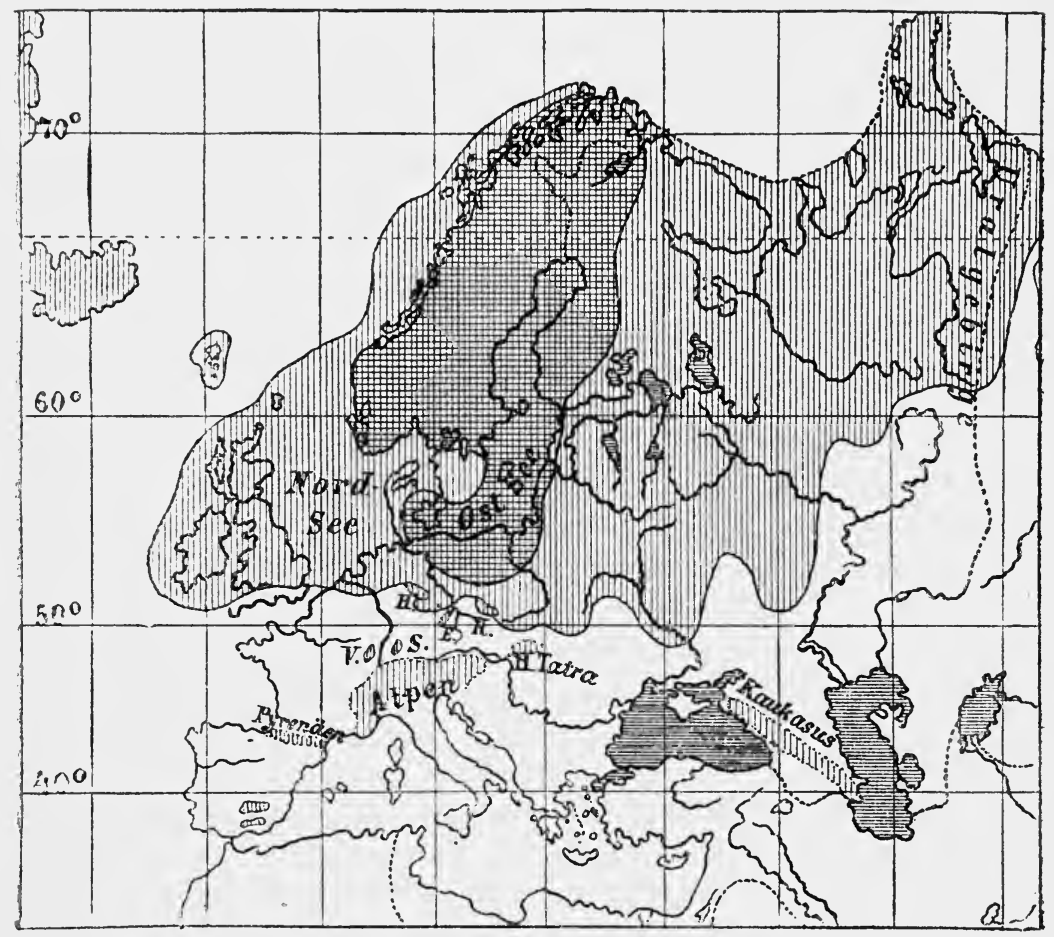

iㅔㅐㅐ Area of the first glaciation.

Area of the second glaciation.

Fig. 69.-Extent of the ice-sheet and glaciers during the Ice Age in Europe.

agreement in origin, which certainly no one can doubt who knows the deposits in question in both countries. Whilst the two unbedded Boulder Clays filled with scratched blocks of Scandinavian crigin, like the Scandinavian Krosstenslera and the similar Boulder Clays of the Alpine region, are to be considered as the ground moraine of the Scandinavian land-ice, the intermediate middle 
sands, and also the covering sand and the lowest (pre-glacial) sands: are deposits from running water which flowed from the ice on its. retreat, or on its first advance. That the Diluvial Sand of North Germany consists mainly of Scandinavian 'material is proved by its richness in red felspar grains derived from the destruction of massive rocks (Granite, Gneiss, etc.), whence it has been called by the name of Spathsand.

Remains of the Pre-glacial fauna and flora have been described by Keilhack from the region of Belzig and Uelzen. Among the plants are the maple, alder, lime, willow, pine, and others of our present forest trees, whence we may infer a climate corresponding fairly well with the present. Paludina diluviana (LXXIII. 4) the most important type fossil of the North German Diluvium (proved by Neumayr to be living in the Dobrudscha) is also of Preglacial age, Its original position was in the Preglacial gravels and sands; and from there it has been transported into the lower Boulder Clay and the Middle Diluvial Sand. Together with Paludina diluviana occur more rarely some other shells, such asDreissena polymorpha, Lithoglyphus naticoides, Cyrena fluminalis-all four are now living in the Lower Danube, or in the Caspian area.

During the Interglacial period also the climate of North Grermany was probably not very different from that of the present time. In the sands belonging to this period at Rixdorf near Berlin we find numerous remains of Mammoth (Elephas primigenius), Elephas antiquus, and also Rhinoceros antiquitatis, the giant elk (Cervus megaceros), the Greenland reindeer (Rangifer grœnlandicus), Bos priscus, Ovibos moschatus, Ursus, etc.

The beds with marine shells in the N. German Diluvium are only of limited extent and occur in E. and W. Russia, Holstein and Schleswig, and in Denmark. Here belong the W. Prussian Cyprina and Yoldia clays with Cyprina islandica, Yoldia (Leda) arctica, Tellina solidula, Corbula gibba, etc. According to Torell both are of Preglacial age, but the Cyprina clay was formed during an older warmer period of the Preglacial epoch, for in it we find Ostrea edulis and other North Sea forms. The Yoldia clay on the other hand contains a completely Arctic fauna, including remains of Narwhals as well as the Yoldia. One can scarcely but believe that an arm of the Arctic Sea must have reached at that time beyond the Ladoga and Onega Seas into the regions in question. In Jutland, Sweden, and England, Yoldia clays occur 
also at higher horizons, up to the C. Dilurium.-The Sands of Elbing, on the other hand, with Cardium edule, Mactra solida, Tellina baltica, Nassa reticulata, etc., are, according to Jentzsch, of interglacial age. This is true also of the similar outcrops which may be followed in a W. direction into Holstein, Schleswig and Denmark, and which no longer contain Arctic forms, but mainly those of the North Sea, and thus afford evidence that the earlier connection with the Arctic Sea ceased in the Interglacial period, and instead the area in question was directly connected with the North Sea.

The difference in the extent of the two glaciations is a point of great importance. The southern limit of the Glacial deposits in $\Lambda$. Germany and Russia as given above shows the S. limit of the first or Older glaciation. The second glaciation did not extend so. far to the south, and in the west of Germany did not reach beyond the Elbe. The direction of movement of the ice was also quite different in the two cases. The motion of the older land-ice-as shown both by the glacial striæ on the rocks and by the direction in which the Scandinavian blocks have been carried-was in the main from N. to S.; while that of the younger was chiefly from $\mathrm{E}$. to W., from Finland and the Russian Baltic Provinces over the bed of the Baltic to S. Sweden, Denmark, and N. Germany. That during the first glaciation there was a partial transport from $\mathrm{E}$. to W., was first shown by Nathorst for Sweden and was confirmed by the discovery of the Finnish Rapakivi granite and Esthoniar Silurian limestone with Pentamerus borcalis in the Lower Boulder Clay near Groningen in Holland and Jever in Oldenburg.

That the North German Boulder Clay, like the bedded diluvial sand, was formed by glacial action and not by transport on icebergs, is shown by the following facts:-

1. The character of the Boulder Clay, which in the absence of bedding and the quite irregular distribution of the blocks, mostly only slightly rounded, and often polished and scratched, bears all the characters of the ground moraine of the present glaciers.

2. The roches moutonneés, polished surfaces and scratches on the exposed rocks, such as those observed on the Quartz porphyry mountains of Taucha and Lommatzsch in the kingdom of Saxony and near Halle on the Saale, on the Muschelkalk of Rüdersdorf near Berlin, the Keuper sandstone of Velpke not far from Magdcburg, and other places. 
3. The large wall-like collections of blocks which often form parallel ridges many miles long, present exactly the appearanee of old terminal moraines. A specially fine example of such a wal\} is afforded by the so-called S. Baltic End Moraine, lately described by Berendt and Wahnschaffe, which stretches from the neighbourhood of Neustrelitz in a south-easterly direction beyond Templin, Joachimsthal, Chorin and Oderberg, and has been traced over a length of almost 100 kilometres and probably reaches still farther. ${ }^{1}$

4. The Giant potholes, which have been found in great abunslance in the limestone of Rïdersdorf, the gypsum of Wapno, the diluvial clay of Uelzen, and the Jurassic of the mouths of the Oder, etc.

5 . The distribution of the varions kinds of boulders in the older Boulder Clay, which shows that the lines of transport radiated from a centre in Scandinavia and Finland. This mode of distribution has brought it to pass that in England we find chiefly such rocks as the Rhombic porphyry and Zinkon syenite from the Christiania area; near Kiew, on the other hand, mainly the Finnish Rapakivi granite; and in the central drift region of $\mathbf{N}$. Germany we find blocks of which the home lies in central and southern Sweden, and on the islands of Oeland and Gotland. Also where the land ice has passed orer exposed surfaces of rock in the N. German plain (such as the limestone of Rüdersdorf, the porphyry of Halle, and the much more extensive chalk outcrops of the Baltic coast), the fragments of these rocks torn off by the ice (the so-called local ground moraine) are always carried in the direction of movement of the ice, i.c. in the main from N. to S., a circumstance which cannot well be explained by the Drift theory.

Whether the numerous disturbances and small foldings which are perceived in the beds forming the immediate foundation upon which the Boulder Clay lies are in all cases to: be referred to the pressure exerted by the ice on the earth below it, still appears doubtful, They may in part be due to internal dislocations such as in loose rocks might easily result under the influence of gravity, and in part also to earth-movements.

The Glacial deposits of England are in general very like those

1 "Jahrb. d. preuss. geol. Landesanst." (1888), p. 110.-Keilhack has traced another still larger terminal moraine along the whole of the southern border of the Pomeranian plain, from West Prussia into Neumark. "Jahrb. d. preuss. geol. Landesanst." (1889), p. 142. 
of Scandinavia and the Continent. Here also along with unbedded Boulder Clays or Till, the bedded sands and gravels play an important part. The Preglacial Forest beds of Cromer in Norfolk lying on the Pliocene Crag are of peculiar interest. They contain remains of the oak, alder, hazel, pine, etc., and of some fifty great mammals, among which are Elephas meridionalis, $\boldsymbol{E}$. antiquus, E. primigenius, Hippopotamus, Rhinoceros, Equus, Macharodus, and Ursus spelceus. In all, about one-third of the species (including the two first-named species of elephants) are common to the Crag. In the Freshwater beds which follow the Forest bed, the number of Tertiary species diminishes; and in the still higher Myalis beds with Yoldia arctica, which lie immediately below the oldest Boulder Clay, the influence of the cold shows itself in the clearest manner. ${ }^{1}$

Although England was completely covered by ice in the Ice Age, yet, with the exception of the S.E. part, which was overridden by the Scandinavian ice, it was covered by its own glaciers radiating from the centre of the country. The ice scratches are everywhere directed from the centre of the island to the coasts, and allow of no doubt on this point. Similarly Helland has shown that the Farōes had their own proper glaciers; whilst the Shetland Islands, lying between Scotland and Norway, lay within the influence of the Scandinavian sheet. ${ }^{2}$

Compared with their great development throughout the $\mathrm{N}$. of Europe and in the Alpine area, the glacial deposits of the other mountains of Europe are of little importance. Yet more or less distinct traces of glacial activity are found on the Vosges, in the Black Forest, in the Riesengebirge, and in the Harz; ${ }^{3}$ and the High Tatra, the Pyrenees, and the Caucasus, also carried glaciers of considerable size during the Drift period. The Ural also was glaciated almost as far south as N. Latitude $61^{\circ}$.

Among the Drift Deposits which were formed in the parts of Europe untouched by the glaciation, the most important are the gravel and pebble terraces which are observed in almost all the valleys, both of the mountains and the plains. These are

1 Sandberger, Palaontographica, 1880.

2 See the maps of Helland, Zeits. d. deutsch. geol. Ges. (1879), pl. 21; and of De Geer, Ibid. (1885), pl. 13.

3 Partsch, "Die Gletscher der Vorzeit in den Karpathen und den Mittelgebirgen Deutschlands" (1882).

C. G. 
the remains of old valley floors, which originated at a time when the rivers had not yet hollowed out their channels to their present level. The lowest terraces, which lie but little above the present floor of the valleys, in many cases belong to the older Alluvial period; but the higher terraces, of which there are two or three one above another, were formed in the Drift period. Not only their position, but also the remains of the extinct Drift animals found in the gravels and sands covering them allow of no doubt on this point.

Another Drift formation which spreads over extensive areas of Europe from the Channel to Galicia and Hungary, but the origin of which is still doubtful, is the Loess. It is a fine, powdery, yellowish, calcareous, unbedded loam, which is perforated by innumerable little vertical tubes, and is distinguished by a marked tendency to vertical cleavage, and thus to the formation of vertical walls. The calcareous matter often forms concretions, which, on account of their remarkable shapes, are known as Lössmänchen (Loess-mannikins) and Lösspuppen (Loess-dolls). Only three shells occur so widely and abundantly as to play the part of type fossils, namely: Helix hispida, Succinea oblonga, and the small Pupa muscorum (LXXIII. 5-7). These and the greater number of the other less common shells of the loess, are all land shells, whilst freshwater forms are unknown in the true loess. ${ }^{1}$ Remains of land mammals are not uncommon, especially of the Mammoth (LXXI.1,2) and Rhinoceros (LXXIII. 1). The deposit occurs both in the depths of the valleys and also on the higher parts of the slopes and on the plateaux, where under certain circumstances it reaches to a height of 1,000-1,500 feet. The higher loess is distinguished from the typical low-lying form by its comparative impurity, the smaller amount or complete absence of carbonate of lime, and by the rarity or absence of shells. The two, however, are often so closely connected that the frequently attempted separation into Valley and Hill loess cannot be practically carried out. It is noticeable that the Valley loess as a rule occurs only on one side of the valleys (as the so-called Flankenlehm or flanking loam), and indeed on that side which is protected from the prevailing winds, while the opposite side is free from loam. When the loess, as is so often the case, occurs in company with diluvial gravels, it covers them, and

1 The so-called Sandlöss of the S. German geologists is a bedded impure loess-like deposit, containing fresh water shells, and strictly speaking ought not to be called "loess." 
must therefore be younger than they; but it usually overlaps them so as to lie in part directly on older rocks.

The earlier view on the origin of the loess was, that wherever it is typically developed-as especially in the Rhine valley between Basel and Bonn-it is the silt deposited by the waters which on the melting of the great ice sheet filled the valleys of that time to a considerable height. This view was upheld by Lyell, Ramsay, J. Geikie, and others for the Rhenish loess, and is still held by some geologists, e.g. by Wahnschaffe, for the loess lying north of the Harz, and for the Bördelöss of the Magdeburg district, which is coloured dark by superficial mixture with humus. According to Sandberger, on the other hand, who has occupied himself with the Main valley, the loess is a product of the high floods of that river; and a similar view has been proposed by Gümbel and others for the loess of the Rhine.

The absence of freshwater shells, the usually complete absence of bedding, the capillary structure, and above all the great variations in the height of the loess within a short distance, prevent these explanations from being in any way satisfactory. If in fact in late diluvial times an extensive area had been covered by water to the height of the highest occurrence of loess, one would have expected to find other evidence of this, and such evidence is not known.

Under these circumstances it can easily be understood that many geologists have recently been led to believe that the loess is not always a water-deposit, but, as Richthofen has taught, an æolian formation, i.e. a deposit formed by wind. It was for the loess of China that Richthofen first proposed this new view,-a deposit which resembles the European in all essential points, but reaches a thickness of 1,000 feet and a height above the sea of 7,000 feet. ${ }^{1}$ Afterwards he applied the same explanation to the loess of Europe and other areas. According to him loess is formed in regions where, as in a large part of Central Asia, the dryness of the climate allows the products of weathering of the rocks to collect in extraordinary amount and so causes the terrible dust storms which are described by all travellers in those regions. Where the dust falls on a naked rock floor, it may remain only till

1 Richthofen, "China," vol. i. (1877), pp. 56, 152. "Verh. d. Ges. f. Erdkunde zu Berlin "(1873).-See also Tietze, "Jahrb. d. geol. Reichsanst." (1882), p. 105, and Wahnschaffe, "Die Quartärbild. d. Umg. v. Magdeburg. Abh. d. preuss. geol. Landesanst.," vii. p. 1 (1885). 
it is again whirled away by the next gust of wind. When it falls on a grass-grown steppe and the grass stems lend it support, it will be otherwise. From the fallen dust-bed a new grass covering always springs, and thus are afforded all the conditions necessary for the formation of a thick deposit of dust. ${ }^{1}$ On this view the origin of the capillary structure, which was formerly inexplicable, is easily understood, for it has been caused by the dead roots of the grasses. The absence of bedding, the practically complete absence of freshwater shells, but presence of land snails and higher terrestrial animals, appear to be necessary consequences of such a mode of formation, and the variable and sometimes very great height is also easily understood.

Soon after it was proposed, this Eolian theory received unexpected support from the extremely important discoveries made by Nehring at Thiede in Brunswick, and at Westeregeln. In the loess of those places he found a rich fauna very closely resembling that of the steppes. Along with the usual large plant-eaters of the Drift, the Mammoth and Rhinoceros, there occur a number of animals of which some, such as Cervus tarandus, Ovibos moschatus, Lepus glacialis, etc., now live in the North, and others, such as Antilope saiga, Myodes torquatus, M. obensis, Arctomys bobac, Lagomys pusillus, Alactaga jaculus, Spermophilus, etc., dwell in the Siberian tundras. ${ }^{2}$ More recently similar faunas have been found at many other points (by Liebe in the Lindenthal cave at Gera; by Sandberger in the Main valley; by Woldrich at Zuslawitz in Moravia; also at Steetin on the Lahn, at Nussdorf near Vienna, etc.), and we may therefore conclude that in the later glacial period the climatic conditions prevailing in Central Europe were similar to those of to-day in the so-called steppe regions. According to later researches it appears indeed as if the steppe character of Germany was not quite simple, but rather that the steppe was here and there interrupted by extensive forests. All the circumstances, however, seem to show that at that time a cold dry climate, favouring the formation of æolian loess, prevailed in general in the N. of Europe. ${ }^{3}$ Afterwards the

1 It should be noticed that, according to recent observations in Saxony, collections of dust are formed by the wind in winter, which closely resemble the true Loess of the Drift. Zeits. d. deutsch. geol. Ges. (1888), p. 575.

2 " Archiv. f. Anthropol.," vols. x. and xi. (1878).

${ }^{3}$ Sandberger, judging frorn the fauna, reckons the mean annual temperature of the valley of the Main during the Loess period at $4 \cdot 4^{\circ} \mathrm{C}=$ that of St. Petersburg at the present time. 
climate gradually grew moister, so that forest vegetation could develop more quickly, and a new fauna, including large forest animals, could exist. Woldrich, therefore, divides the Diluvial and Post-diluvial period of Central Europe into four different phases-1. Glacial, 2. Steppe, 3. Pasture, 4. Forest.

The most important of the remaining formations of the Drift period are the deposits of the bone caves and the deposits of peat and travertine. Extensive deposits of travertine are found in Germany, for instance, at Cannstatt near Stuttgart, at Weimar, Burgtonna, Mühlhausen, and Greussen in Thuringia, etc. Diluvial peat-beds, on the other hand, occur especially at Enkheim near Frankfort on the Main, Rosenheim in Bavaria, and other places; while of the extra-German occurrences, the extensive Irish peat-bogs are the most remarkable (as the chief locality for the gigantic extinct elk, Cervus megaceros=hibernicus [LXXII. 2]).

The caves in which the bone deposits are found occur mostly in limestone, dolomite, and gypsum rocks, as the result of the denuding action of water on these comparatively easily soluble rocks. The floor of the caves is usually formed by a reddish-brown ferruginous sandy or stony loam, the so-called cave earth, which is covered above by a layer of stalagmite, and often contains an abundance of bones of the most various sorts. Well known examples of such bone caves in Germany are the Gailenrenth and Muggendorf caves of the Franconian Jura, the Baumann, Biel and Hermann caves at Rübeland in the Harz, the Decher cave not far from Iserlohn in Westphalia, and others. In Belgium, England, France, and the Mediterranean countries, they are not rare in the limestone rocks. One of the characteristic animals of the bone caves is the Cave bear, Ursus spelaus (LXXI. 3), of which the remains of some 800 individuals have been found in the Gailenreuth cave. Another abundant form is the Cave hyæna, Hyana spelaus, which occurs in great numbers, especially in England. The remains of the Cave lion, the reindeer and other deer, of the elephant, rhinoceros, horse, ox, various rodents, etc., are also common.

The only important marine formations of the Drift period are the highlying old coastal terraces with marine shells. They afford evidence of a higher shore line at that time, and are met with especially on the coasts of Norway and Scotland, where they are clearly marked and are of great extent. The highest Swedish 
shell banks lie almost 200 metres above the present sea level, and the best known is that at Uddevalla, not far from Gothenburg. These contain Pecten islandicus, Yoldia arctica, Saxicava arctica, Buccinum gronlandicum, and other forms of high latitudes; whilst in the lower terraces, a fauna like that of the present North Sea gradually makes its appearance. In Scotland the oldest terraces lie at a height of about 100 , the newer at $50-45$, and the latest at 30-25, feet above the level of the North Sea. On the French, Spanish and Italian coasts, such old terraces, with collections of shells, are by no means absent. Here also the highest contain a series of Northern forms, such as Cyprina islandica, Buccinum grœenlandicum, etc., which are found at Palermo and on Rhodes Island.

Passing to other parts of the earth, several of the high mountain chains, such as the Himalayas and the Tianshan, show traces of a former considerable glaciation. In Northern Asia there are Drift deposits of great extent in the N. of Siberia. Elephas primigenius was there present; and its remains occur locally in such numbers that a very considerable part of the ivory of commerce is derived from the tusks of the mammoths found in Siberia. Still more striking is the fact that in the permanently frozen soil of that region corpses of the mammoth and of Rhinoceros Merckii have been repeatedly found with even the skin and hair preserved. Another very remarkable formation is the diluvial ice which occurs at some places in N. Siberia (as on the New Siberia Islands), and still more in Eschscholtz Bay on the coast of Alaska. It is from fifty to some hundreds of feet thick, and is interrupted by layers of coastal deposits, and covered by loam deposits with remains of mammoths and freshwater shells.

Glacial deposits are developed on a very large scale in $\mathbf{N}$. America, where they cover a still larger area than in $\mathrm{N}$. Europe. Moreover in N. America the ice-sheet reached considerably farther south than in Europe, viz. to about $40^{\circ}$ north latitude, about the latitude of Naples and Madrid. The character of the N. American glacial deposits agrees very closely with that of N. Europe. This is true especially of the true moraine deposits, the Boulder Clay. In N. America also there were two glaciations, separated by an Interglacial period, and here also the later glaciation was not of so great extent as the older. To the first 
belongs the gigantic end moraine, which has been traced from the Atlantic coast over a length of more than 450 miles into Dakota. The thickness of the ice-sheet is estimated at 3,000-5,000 feet, and here also gigantic erratic blocks have been carried nearly 1,000 miles. Thus, for example, pieces of native copper from the Lake Superior have been found in the middle of the States of Indiana and Illinois.

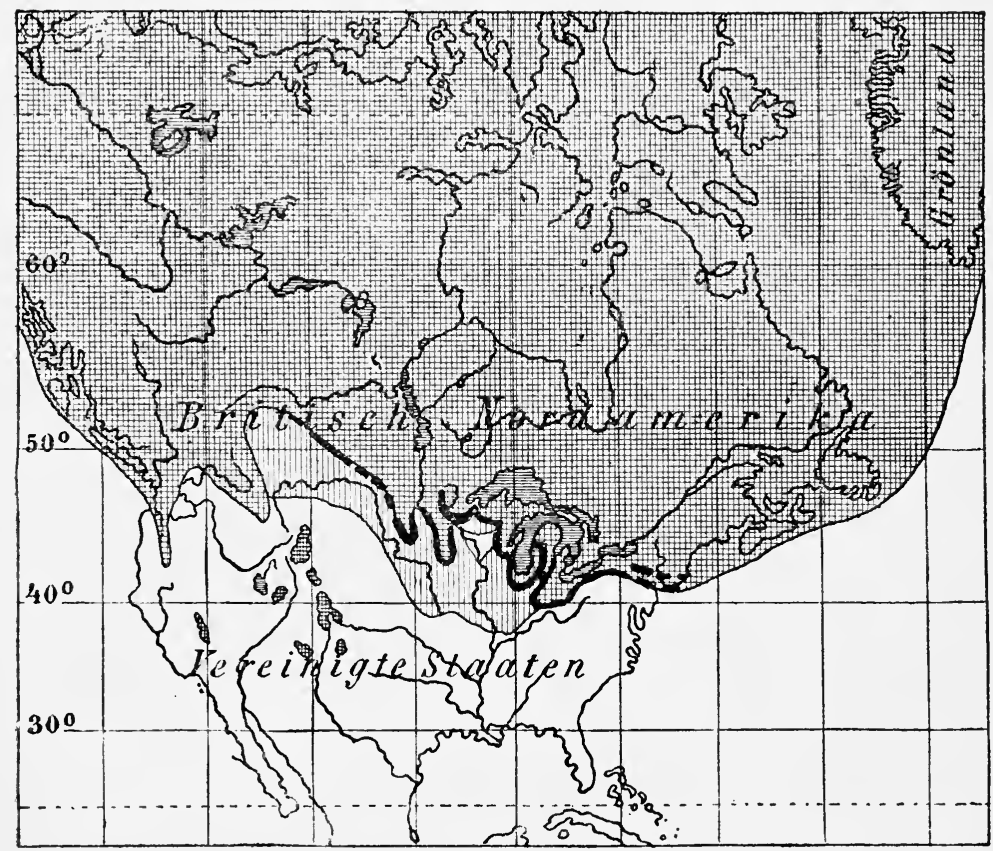

VIIII Area of the first glaciation.

Area of the second glaciation.

- The great Terminal Moraine.

Fig. 70.-Map of the Ice Sheet and Glaciers in North America.

A remarkable feature of that time was the presence of great lakes in the western part of the country, especially in the region of the Great Basin, which have been made known to us by the works of C. King, Gilbert, Russel and others. The most important was the so-called Lahonta Lake, a water basin which stretched 
to the foot of the Wahsatch Mountains. The last remains of this now form the Great Salt Lake of Utah, which even now is over 11,000 square miles in area. Another, the Bonneville Lake, lay on the west side of the Great Basin. Its banks are marked by uncommonly sharply defined terraces, the highest of which lies more than 1,000 feet above the present level of the Great Salt Lake.

The so-called Driftless a rea of the Upper Mississippi is very striking. It is a strip of land, some 10,000 square miles in extent, in the midst of the glaciated area ; and, in spite of its low-lying position, has remained unglaciated. ${ }^{1}$ According to the views of Chamberlain and Salisbury this is to be explained by the topographical features. The high land on the north and the valleys of Lakes Michigan and Superior directed the ice to the right and left of this area in such a manner that it retained its direction for a great distance, and consequently the intermediate area was untouched by the ice.

Loess-like deposits occupy a large area, especially in the Mississippi region. They are considered by some of the American geologists as fluviatile, by others as æolian deposits.

The mammoth, Elephas primigenius, lived only in the most westerly parts of N. America near Behrings Straits. In the south of the United States its place was taken by a local American form, $\boldsymbol{E}$. americanus. Throughout the rest of the country the chief part was played by the giant Mastodon giganteus or M. ohioticus, the "American mammoth" (LXXII. 1). Another characteristic form of the N. American Drift is Hippotherium, a form which, like Mastodon, there lived into the Drift period, while in Europe neither reached beyond the Tertiary. The genera Rhinoceros, Hippopotamus, and Hycena, so important in the Emropean Drift, are entirely absent in N. America.

In S. America, as Darwin long ago showed, glacial deposits are very widely spread, especially in Patagonia, Tierra del Fuego, and Chili. Within the tropics, on the other hand, traces of former extensive glaciation have been found only in the Sierra de Santa Marte (11 ${ }^{\circ}$ north latitude), in North Columbia and in Venezuela. Penck considers this to be evidence that the glaciation of the Drift period did not affect the two hemispheres one after the other as had been supposed, but together.

1 In the map this is left white. 
New Zealand also, as has been shown by v. Hochstetter and others, bore large glaciers during the Glacial period.

The last deposit that requires notice is the "Laterite," which is so widely spread in moist tropical areas (India, Africa, South America), and probably belongs chiefly to the Drift period. It is a red or brown ferruginous rock, which has been formed by the decomposition of various rocks containing iron, and generally presents a scoriaceous appearance owing to the manner in which the iron has segregated.

\section{Mammalia of the Drift.}

After the observations already made on the flora and molluscan fauna of the Drift, it will only be necessary to give here a short general description of the most important element of the Drift fauna-the mammals.

Starting with the Old World, the genus Elephas everywhere played the chief part. The most widely spread form was $E$. primigenius, the Mammoth (LXXI. 1) which is found in extraordinary numbers, especially in Siberia. The well-preserved bodies found in the frozen soil of Siberia show that, thanks to its thick coat of woolly hair, this species was adapted to life in a cold climate. In S. Europe there were two other large species of Elephant, $\boldsymbol{E}$. antiquus and $\boldsymbol{E}$. meridionalis (the latter occurring also in the Upper Pliocene); while in the Island of Malta, which was then connected with the African continent, there lived a dwarf form, $\boldsymbol{E}$. melitensis. Other species still have been described from the East and India.

Among the Imparidigitate Ungulates the genus Rhinoceros is of special importance, with the chief species-Rh. antiquitatis = tichorhinus (LXXIII. 1)-distinguished by its ossified nasal partition. This was the companion of the mammoth, and like it was protected from the cold by a coat of woolly hair. Whilst this species has two horns, the Siberian Rh. Merckii and the $R h$. leptorhinus of the south were hornless. To the horned forms was allied the giant Elasmotherium of Siberia, with very weak, probably hornless, nasal region, but with a large swelling on the forehead, which no doubt bore a horn. Among the Hippopotami the Hippopotamus major, a form scarcely distinguishable from the living $H$. amphibius, was not rare in the older Drift period. The Horse also (Equus fossilis) was widely spread. 


$$
394 \text { IV.-NEOZOIC GROUP. }
$$
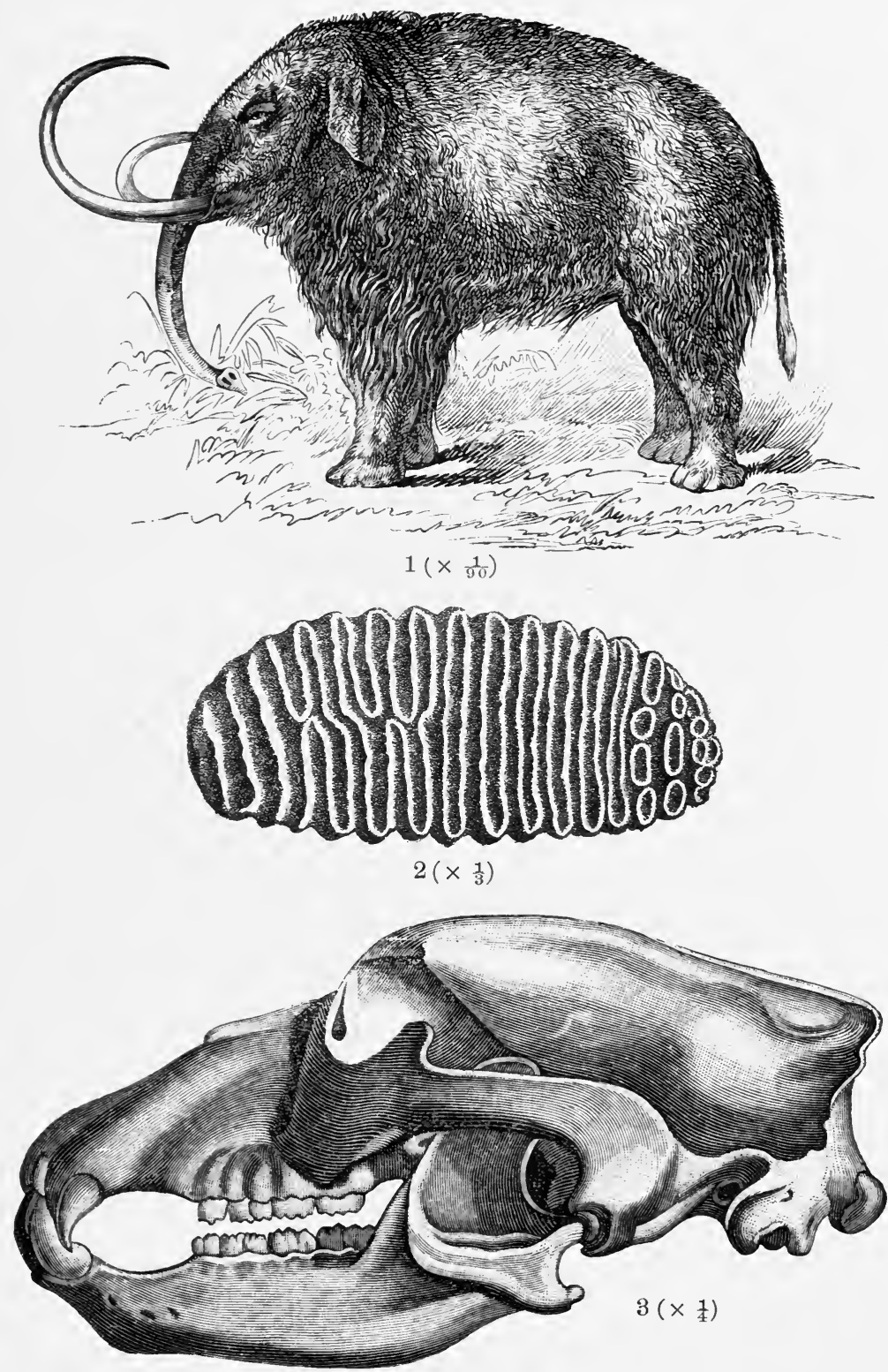

PLATE LXXI. - Mammals of the Drift.

1. Elephas primigenius, Blum., restored according to the Siberian finds. 2. Molar of the same, seen from the grinding surface. 3. Skull of Ursus spelceus, Rosenm. 
B.-QUATERNARY SYSTEM.

395

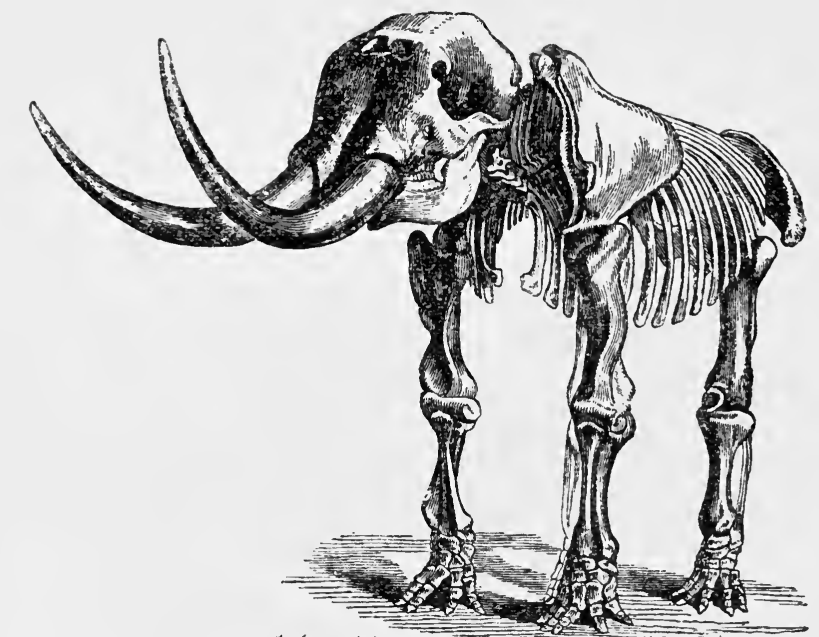

$1\left(\times \frac{1}{60}\right)$
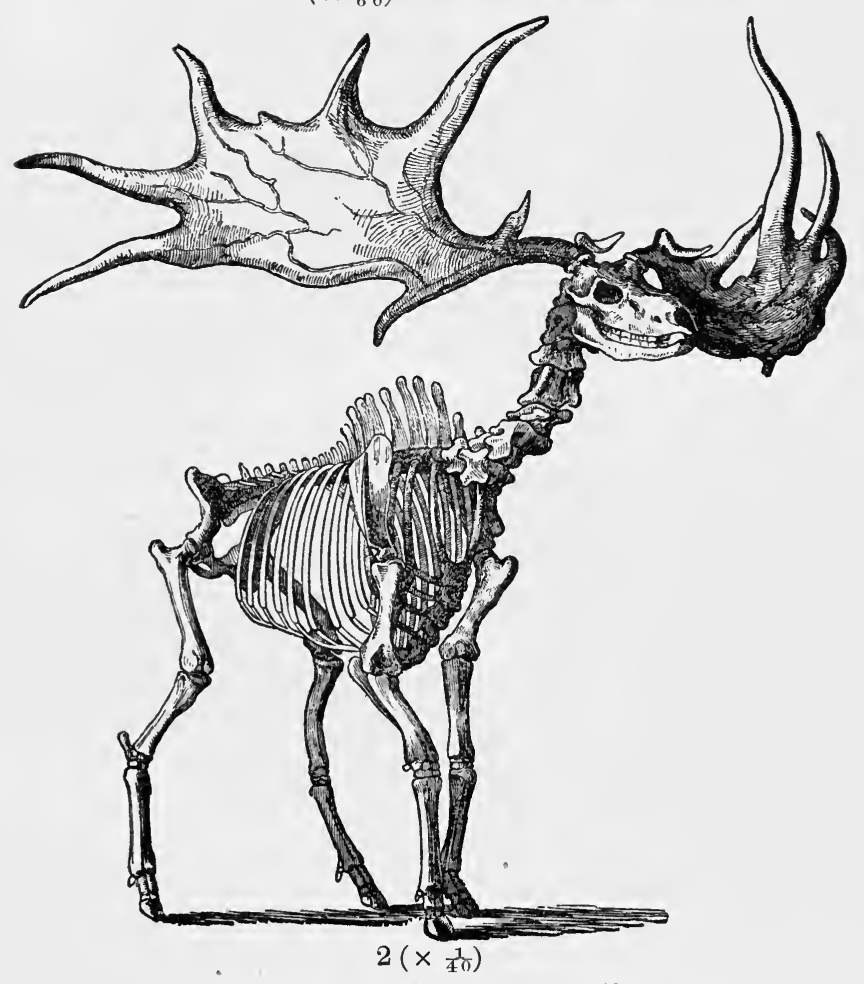

Plate LXXII.-Mammals of the Drift.

1. Skeleton of Mastodon ohioticus Blum. = giganteus, Cuv. 2. Skeleton of Cervus megaceros, Hart = Megaceros hibernicus, Desmar.=euryceros, Aldr.= jiganteus, Blum. 


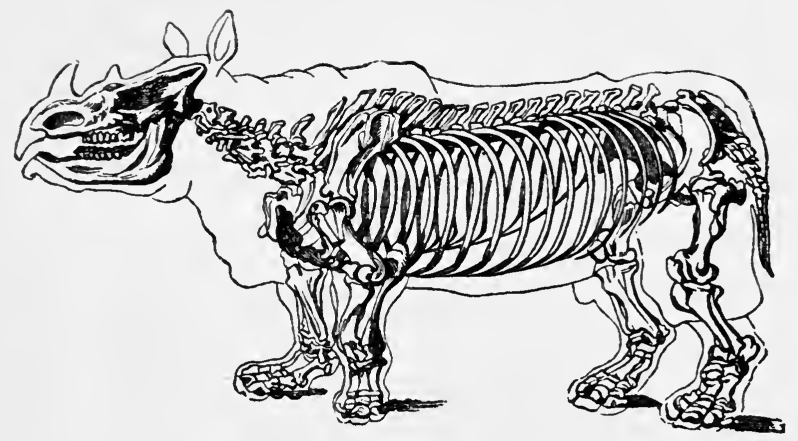

$1\left(\times \frac{1}{40}\right)$
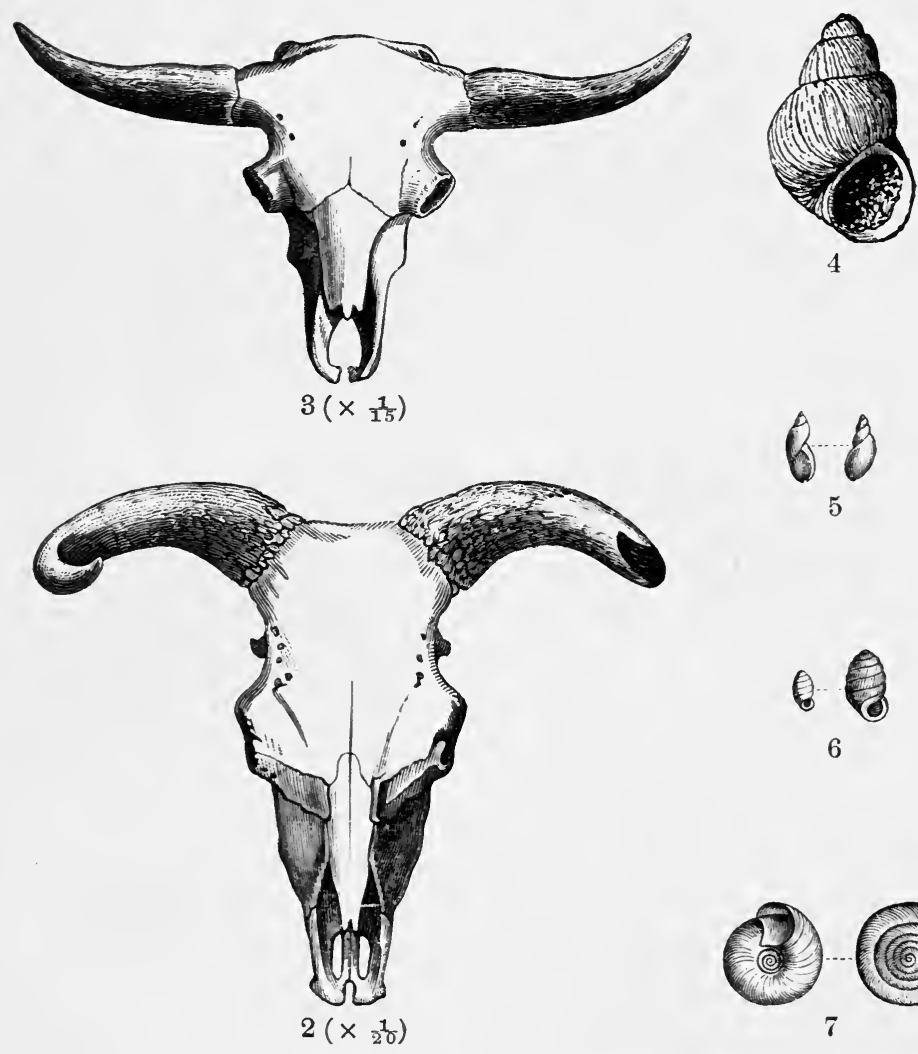

6

PLATE LXXIII.-Mammals and Molluses of the Drift.

1. Rhinoceros antiquilatis, Blum.=tichorhinus, Cuv. 2. Skull of Bos primigenius, Cuv. 3. Skull of Bos priscus, Boj. 4. Paludina diluviana, Kunth. 5. Succinea oblonga, Drap. 6. Pupa muscorum, Lin. 7. Helix hispida, Lin. 
Among the Paridigitate Ungulates the ruminants were the most important in the Drift period. There was in the first place the giant Irish elk with flattened horns, Cervus (Megaceros) giganteus =hibernicus (LXXII. 2), which was especially abundant in the Irish peat-bogs, but was also scattered over the whole of Europe. Of other species of deer there were $C$. alces, the elk, and $C$. elaphus, the stag, while one of the most widely spread of the Drift animals was the reindeer, with the two species $C$. (Rangifer) tarandus and $C$. groenlandicus (the latter in the Interglacial deposits).

Of the Antelopes there were several species. The chamois at that time dwelt not only on the hills but also in the low country. Antilope saiga, which was then widely distributed, now lives in the Central Asiatic steppes. Remains of the sheep and goat are comparatively rare in the diluvium. Of the latter the Steinbock, Capra ibex, is specially interesting, because it is now found only on the hills, like the chamois, but at that time lived in the low country also. Allied to the sheep was the Musk-ox, Ovibos moschatus, which now occurs only in the far north of N. America.

Of the oxen, Bos primigenius (LXXIII. 2), the last descendants of which are now preserved in England at Chillingham Park, etc., and Bos (Bison) priscus, the Auroch, which still lives in the forests of Lithuania, are specially interesting; while the buffalo also, Bos (Bubalus) Pallasi, was found in North Europe, but somewhat less commonly.

Among the Carnivora Felis spelcea was closely allied to, or probably identical with, the African lion of the present day, and Macharodus leoninus was a form very like the sabre-toothed tiger of the Tertiary. The Cave hyæna, Hyona spelcea, probably identical with the S. African $H$. crocuta, was very widely spread in Italy, France and England. Among the dogs, the wolf (Canislupus) was not uncommon in the Drift. One of the most important and widely-spread of the Drift forms, especially in the German caves, was the Cave bear, Ursus spelaus (LXXI. 3), the largest species of the genus that ever lived. It differs from the present species in its sloping forehead and in the absence of premolars in the adult. Among the smaller Carnivora, the marten, badger, weasel and ermine require notice, and, of the northern forms, the glutton (Gulo borealis), which at that time spread as far south as Dalmatia.

The Rodents were very richly represented, and among them we 
observe numerous Steppe forms, along with many northern species. Of the latter, we must notice the Arctic hare (Lepus glacialis); of the dwellers in the steppes, the Lemming (Myodes obensis), the Souslik (Spermophilus), Alactaga, the Pika (Lagomys), etc. The beaver also, which since historical times has gradually become extinct in Europe, was then widely distributed.

In $N$. America, as already noticed, one most important Drift form, the Mammoth, was present only in the westernmost parts near Behring's Straits, while another elephant (Elephas americanus) lived in the S. of the United States. One of the most important forms of the N. American Drift, the so-called American Mammoth, belongs not to the genus Elephas but to Mastodon, a genus which in Europe does not pass up beyond the Tertiary. This is the huge M. giganteus or ohioticus (LXXII. 1). Like the Mastodon, the genus Hippotherium or Hipparion also survived till the Drift period in America, but not in Europe, and during that period it was contemporaneous with the horse. Yet afterwards the latter became quite extinct in America, and was again introduced from Europe. A further peculiarity of the N. American Drift was the presence of large Edentates (Megatherium in S. Carolina, Megalonyx, etc.), which immigrated from S. America.

In $\mathbf{S}$. America the large Edentates which are met with in the Tertiary, in part survived until the period of the Drift as ancestors of the sloths, armadilloes and ant-bears which form so peculiar a feature of the present fauna. Other characteristic S. American mammals, such as the llama, tapir and sea-hog were already present in the Drift period. In S. America the Mastodon lived on into the Diluvial epoch.

In Australia the Drift contains many marsupials, the order so characteristic of that region at the present time. Many of the forms greatly exceed the living in size; for example, Thylacoleo, as large as a lion; the genus Diprotodon, etc. The remarkable Australian Monotremes also had much larger ancestors in the Drift, e.g. Echidna Ramsayi; and the same was the case with the birds. Thus the ancestors of the present wingless Ratitæ (Emu [Dromaus] and Kiwi [Apteryx]) were gigantic forms, such as the New Zealand Moa (Dinornis).

Hence we recognise everywhere a more or less in timate connection between the Drift fauna and that of to-day, or, in other words, the present geographical distribution of animals was, in the main, established in the Drift period. 


\section{ALLUVIUM.}

The Alluvium is the latest division of the Quaternary System, and includes the whole of the geological deposits since the formation of which no marked change in climate, or in the general distribution of the seas and rivers, or in the character of the fauna and flora of the globe, has taken place.

Here belong the pebbles, gravels, sands and loams in the depths of the valleys, the deltas, the large masses of peat, and travertine deposits, the various shore, dune, and marsh formations, the collections of guano, coral reefs, etc. Palæontologically, the flora and fauna of the alluvial deposits present no noticeable difference from the fauna and flora of the same areas at the present day. However, in the older alluvial epoch there lived with us a number of animals which have since been exterminated or driven away, such as elks, aurochs, beavers, peat-hogs, etc. The alluvial fauna is distinguished from that of the Drift chiefly by the absence of a number of animals which, like the Mammoth, Rhinoceros antiquitatis, the Cave bear, Cave lion, and Cave hyæna are now quite extinct, or, like the reindeer, the musk-ox, steinbock, marmot, etc., have retreated to the far north or to the higher parts of our mountains.

The remains of man's activity from the Older alluvium show a great advance on the similar remains of the Drift. The implements, though made of stone like those of the Drift, are of finer workmanship, and this period is known as the Neolithic or Later Stone Age.

The Neolithic Age of prehistoric man was followed by the Metal Age, in which men had learned the use of metals. Accordingly, in the deposits of this age, we find not only weapons and tools of stone, bone, and wood, but also similar implements of metal. The Metal Age can generally be divided into an older, Bronze, and a newer, Iron, Age. 


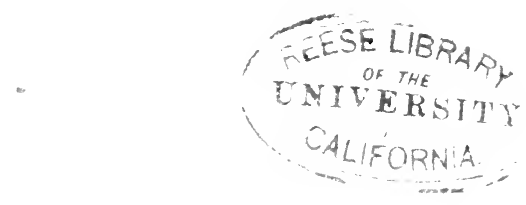




\section{INDEX.}

An asterisk denotes that the form is figured on the page indicated.

PAGE

Abraumsalze . . . . . . 176

Acanthoceras (v. Ammonites). 322

Acanthocladia . . . . . 175

Acanthodes . . . . . . 170

" gracilis. . . . . *187

Acaste Downingiæ . . . . 65, 67

Acer . . . . . . . . . 346

Aceratherium incisivim $362^{\circ}$,

Acerocare, v. Olenus.

$363,369, * 370$

Acervularia luxurians

Acidaspis . . . 51, 71, 85, 101, 102 , Buchii .. . 59,61 , Dufrenoyi . . . . $\$ 80$ " erinaceus. . . . . 66 Acrocidaris. . . . . . . 320 Acroculia neritoides . . . . $* 152$ Acrodus . . . . . . . . 209,216 Acrolepis . . . . . . . . 192 Acrosalenia . . . . . . . 272 Acrothele . . . . . . . 43,49 Acrotreta . . . . . . . 43,49 Actaeonella. . . . . 283, 312, 321 " gigantea . . .316,317 Actinocamax, v. Belemnitella.

Actinocrinus pulcher . . . . 65

Adavis" pyriformis . . .*154

Adneth facies (Alpine Jura) $\quad 262$

Adorf limestone . . . . . . 97

Adrianites . . . . . . . 181

Aeger. . . . . . . . . . 274

Aeglina . . . . . . 51, 59, 75

" prisca . . . . . *76

" rediviva $. \quad . \quad . \quad .59$

Aegoceras (v. Ammonites) .267, 273

Aëtosaurus ferratus . . . 210

Agathioceras . . . . . . . 145 Agnostus, 33, 34, 39, 40, 43, 48,

$51,55,56,60$

, atavus . . . . 37

C.G.
PAGB

Agnostus fallax . . . . . . 36 intermedius . . . 36 laevigatus . . . 36 Lundgreni . . . . 36 pisiformis . . $34,36, * 46$ rex. . . . . 36 tardus. . . . . 59

Aix-la-Chapelle sand . . . . 313 Alabama beds. . . . . . . 339 Alactaga jaculus. . . . . . 388,398 Albian . . . . . . . 293 Alethopteris . . . . . $.160,178$ Algonk̈ian Serli • • • • • Alluvium . . . . . . . 399 Alpine Trias . . . . . .195, 217 Alum shales of Scandinavia . 35 " " Whitby . . . 244 Alum sla"tes of Thuringia . $\quad 71$ Alveolina . . . . . . . 349 Alveolites . . . . . . . 88 suborbicularis. . . 95 Amälthei (Ammonites) . . . 273 Amaltheus (v. Ammonites) .267, 273 Amaltheus clay . . . . . 242 Amblypterus . . . . . . 170 macropterus . . $* 187$ Ammonites acanthicus . . . 268 alternans . . .261, 269 amaltheus. . . 242 anceps . . . 249 angulatus .243, *245, 249 aspidoides. . • 257 astierianus, 289 , $* 290,291,292,298$

athleta . . . . 249 auritus . . . .295, 296

biarmatus. . . 266

bifrons . . $\$ 247,249$ bifurcatus. . . 250

D D 
Ammonites bimamimatus PAfE biplex Blagdeni .250, 253, *255 bollensis . . . 242 boloniensis . . 260 Braikenridgi. . . 250 Buchi . . . . 203 Bucklandi. . 243, *245 calloviensis . . 260 capricornus . . $\$ 246$ catenulatus . . . 269 coesfeldensis . . . 309 communis. . . . 242 Conybeari. . . . 243 cordatus, $* 256,259$,

$260,262,269$

. . . 242

cristatus . . . 295

cyclotus . . . 268

Damesi. . . . 203

Davoei . . . . 243

delaruei . . . 295

denarius . . . 295

Deshayesi . . .293, 296

Emscheris. . . 304

eudoxus . . . . 269

ferrugineus . . 257

fimbriatus . $\$ 246$

flexuosus . . . . *263

gigas . . 259, 260, 262

hecticus . . . 249

Henleyi . . . . 248

heterophyllus . . *247

$\mathrm{Hum}$ phriesianus $250,251,252,253$

ibex . . . . . 243

inflatus, 293, 296, 314, 315

interruptus . .295, 296

Jamesoni . . .243, 244

Jason . . 243, 249, 260

jurensis. . 242, 244, 252

Koenigi • . . 260

Lamberti . . . 260

laticlavius. . . 314

lautus . . 293, 295, 296

lithographicus . . 268

macrocephalus, 250 ,

$251, * 256,260,262,269$

mammillaris, 294

295,296

Mantelli . . 300

Margae $.304, * 305,316$ margaritatus, 242 , $244, * 246$

Martini. . 293, 296, 298

Milletianus . . 293

Murchisonae 250 , $251,252,253,267$

neocomiensis. . . 298 nisus. . . . .293, 296
Ammonites nodosoides noricus. 289 \% 290,291

obtusus. . . 243

occitanicus . . . 292

opalinus 250,251 ,

ornatus . .249, *256, 260

Ottonis . . . 203

oxynotus . . . 243

Parkinsoni, 250,252,

$253, * 255$

peramplus $300, * 303,315$

perarmatus, 259 ,

$260, \approx 263$

planorbis . . .243, 249

plicatilis . . . 260

polyplocus. . . . $* 264$

portlandicus . . . 259

psilonotus. . . 243

ptychoicus . . 268

radians . . 212, \$247

radiatus . 289, 291, 292

raricostatus . . 243

rostratus . . . 295

rotomagensis, 300 , *301, 301, 311, 314, 316

Sauzei . . . 250

semicostatus . . 248

serpentinus . . . 248

Sowerbyi, 249, 250,

sulendens. $251,252,253$

spinatus . . 242

spiratissimus. . . 243

steraspis . . . 268

striatulus . . . 251

Strombecki . . . 203

suprajurensis. . 262

tardefurcatus . . 293

tenuilobatus . 264,268

tenuis . . . . 200

Texanus . . . 4,316

Tiziani. . . . 264

torulosus . . . . 250

transitorius . . 268

transversarius . . 259

tuberculatus . . . $\$ 294$

Turneri. . . . 243

varians, $300, * 301$, 304,314

varicosus . . . 295

virgatus . *26ว. 269

Wittekindi . . 309

Woollgari. . . 304

Amphicyon . . . . . . 352

Amphion . . . . . . . 55,60

Amphisyle . . . . . . . 348

Amphitherium . . . . . . 286

Amplexus . . . . . . . . 162

Ampthill Clay . . . . . . 261 
PAGE

Ampyx . . . . . . 51, 56, 85

" alariensis . . . . . 66

" Portlocki. . . . . . 59

Ananchytes . . . . . . 320 " ovata $* 306,309,312$,

316,318

sulcata . . . 312

" vulgaris . . . 309

Auarcestes . . . . . . . . 102

Anatina praecursor.

Anchitherium . . 355, *368, *370 aurelianense . 369

Ancilläria glandiformis . *357, 361

Ancyloceras . . . . . . . 296

" Matheronianum . 298 renauxianus . . 296

Andrias Scheuchzeri . . . . 360

Angers, slates of . . . . . . 61

Angoumien . . . . . . . 315

Angulatus sandstone . . . . 243

Anhydrite group. . . . . . 202

Annelidian. . . . . . . . 44

Annularia . . . . . . 161

longifolia . . . 140, 183

sphenophylloides *156

Anorlon Jukesii . . . . . . 107

Anodonta . . . . . . . . 317

" postera . . . . . 210

Anomopteris . . . . . . . 200

Anoplophora . - . . . . . 231

$"$ donacina. . . . 209

lettica. . . . 209

Anoplotherium · · . $346,348,352$

Anor, sandstone of . . . . . . 99

Anorthopygus orbicularis . . 315

Antedon. . . . . . . . . 272

Anthracomya. . . . . 132, 170

Anthracosia . . . . 132, 136, 143 carbonaria . . 188

" Lottneri . . . *158

Anthracotherium . . . . . 352

Anthrapalaemon. . . . . . 163

Antilope saiga . . . . 388, 397

Anversien . . . . . . . 363

Aphyllites . . . . . . . . 102

Apiocrinus. . . . . . . 272

Aptian Roissianus . . *263

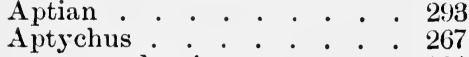

" laevis. . . . . . 264

Aptychus shales . . . . . . 267

Aralia . . . . . . . . . 319

Araucaria . . . . . . . 271

Araucarioxylon . . . . . . 161

Araucarites . . . . 161, 181

Arca appendiculata . . . 342

barbata. . . . . ${ }^{*} 358$

diluvii . . . . 355, *364

oreliana.
Arca Raulini.

PAGE

"turonica . . . . 355,361

Arcestes. . . . . 182, 224, 232

" Gaytani. . . . . 226

" intuslabiatus. . . . 225

" ruber. . . . . . . 229

Archaean Rocks. : . . : . 12

Archaeocalamites radiatus, v. Calamites transitionis.

Archaeocidaris . . . . 147, 181 rossica. . . 145

Archae"ocyathus . . . . : 41, 43 " minganensis . *47

Alchaeopteryx macrura . . *278

Archegosaurus . . . 170, 172

" Decheni - *188, 192

. latirostris . . 192

Archimedes (=Archimedipora)

" Wortheni. . . *159

Arctic Fox. . . . . . . . 377

Arctocyon . . . . . . . . 335

Arctomys bobac . . . . . 388

Arctopacific 'Triassic province. 230

Ardmillan series. . . . . . 53

Ardwick series . . . . . . 132

Arenig beds . . . . . . . 51

Arethusina. . . . . . . . $8 \tilde{3}$

" Haueri. . . . . 72

Arietes (Ammonites) . . . . 273

Arietes beds . . . . . . . 243

Arietites (v. Ammonites). 267, 273

Arionellus . . . . . 33, 39, 41, 43

Armati (Ammonites) . . . 273

Armorican grit . . . . . . 61

Arno stage. . . . . . . 363

Artinsk stage. . . . . 179, 180

Arvonian . . . . . . . . 22

Asaphus . . 59, 60, 61, 62, 72, 75

, armoricanus. . . 61

$"$ expansus. . . . $55, * 76$

" Homfrayi. . . . . 51

$"$ ingens. . . . . . 59

$"$ platyurus. . . . . 55

" Powisii . . . . . 51

" tyrannus. . . . . 51

Àsar", Scandinavian. . . . . 380

Ashdown sand . . . . . . 286

"Ashes" of the Zechstein . . 175

Ashgill group. . . . . . . 52

Aspidoceras (v. Ammonites)

Aspidorhynchus . . . . . 274

Astarte . . . . . . . . . 362

borealis. . . . . 363

Bosqueti. . . . . 342

concentrica . . . . 355

minima. . . . . 262

Omalii . . . . . *364

opalina . . . . 250 
Astarte supracorallina PAGB ". Voltzi . . . 251 254 Astartien . . . . . . . . 262 Asterophyllites . . . . . . 161 equisetiformis. $* 156$

Astylospongia præmorsa. . . *79 Atherfield beds . . . . . . 291 Athyris . . . . 104, *116, 181 concentrica . . . 94 " lamellosa . . . . . * * 153 " oxycolpos . . . . . 228 " pectinifera. . . . 180 "trigonella $203,206, * 221,224$ Atlantosaurus. . . . . . 276 Atrypa prunum . . . . . . 70 reticularis. $61,65,70$,

$* 83,94,100$

Aucella . . . . . . 237, 270

" Fischeriana . . . 269

" gryphaeoides. . 293, *294

", mosquensis. . . *265, 269

Auchenia Pallasi . • . • • • 269

Aufgeschwernmtes Gebirge. . 7

Aulacoceras . . . . . . 232

Aulocopium . . . . . . 88

Aulopora tubaeformis. . . * *118

Aulosteges . . . . . . . . 182

Auricula . . . . . . . 316

Avalon group. . . . . . . 42

Avicula (Posidonomya) Clarai

$220, * 221$

, contorta 210, *211.

"216, *223, 228

" damnoniense. . . 106

$"$ exilis. . . . . . 227

" gryphaeoides. : 293, $* 294$

" inaequiralvis. . . . 243

" (Pseudomonotis) speluncaria $175,176,183$,

, (Posidonomya) ven-

$* 189$

97,106

Aviculopecten. . . . . . . . 181

$$
\text { " } \quad \text { papyraceus } 130,145
$$

Axinus obtusus . . . . . . 342

unicarinatus . . . 342

Aymestry limestone . . . . 61

Azoic group . . . . . . . 13

B.

Bacchus Marsh beds . . . . 183

Bactrites . . . . . . . 123

" carinatus. . . . 96

$"$ elegans . . . . *119

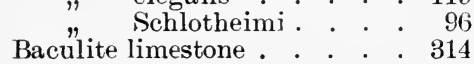

PAGE

Baculites . . . . . . . 310

$"$ anceps. . . 307,314

Baden Tegel incurvatus . . . 312

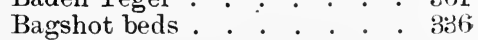

Baiera . . . . . . . 181

Bairdia . . . . . . . 209

Bairdia beds (Kohlenkeuper) . 209

Bajocien. . . . . . . . 253

Bala rocks . . . . . . . 51

Ballantrae rocks. . . . . . 53

Ballymoney series : . . . . 54

Bannisdale slates : . . . 67

Barr series. . . . . . . . 53

Barrême series : . . . 292, 298

Barton clay . . . . . . . 336

Bathian. . . . . . . 250

Bathonien . . . . . . . 253

Bath Oolite. . . . . . . . 252

Bathynotus . . . . . . . 43

Bathyuriscus. . . . . . 43

Bathyurus. . . . . . . . 62

Beauce, freshwater limestone of 346

Beauchamp, sand of . . . . 335

Becksia Soekelandi . . . . . 309

Belemnitella . . . . . . . 283

mucronata 304 , *307, 309, 311, 312,

, (Actinoca max) $313,314,316$

(Actinocamax) quadrata 304 , $* 306,309,312$.

(Actinocamax) subventricosa . 313 (Actinocamax)

vera . . . 313

(Actinocamax) westfalica . 313

Belemnitıs (absoluti) . . . 322 absolutus . . . 270 acuarius . . . 242 brunsvicensis 291, 293 canaliculatus . . 274 clavatus . . . . 246 corpulentus . . 269 (Duvalia) dilatatus 291, 292, 296, *297

Ewaldi. . . . 293 (excentrici) . . . 322 excentricus . . 270 giganteus 250,253 , *25 hastatus . . . 263 jaculum : . 287, 291 lateralis $\quad 261,269,291$ latus. - 292, 296, 297 minimus $291,293,312$ Owenii . . . 291 
Belemuites paxillosus PagF

Bradford clay . . . . . . 252

Bradfordien . . . . . . . 253

, pistilliformis 289

291,298

, subquadratus . . 289

Braintree group . . . . . . 42

Branchiosaurus . . . . . . 172

Brancoceras (v. Goniatites)*152, 163

Brathay flags. . . . . . . 67

Brevispina beds . . . . . . 243

Brissus . . . . . . . . 350

Bröckelschief $\bullet$ r . . . . . 198

Bellerophon limestone. • . 18

Bell Isle group .

Beloceras . . . . . . . 97, 123

Belodon . . . . . . . . 234

" Kapffi . . . . . . 210

Brockram . . . . . . . . 178

Brongniartipläner. . . . 300

Brongniartiquader. . . . 310

Bronteus . . . . . . . 85, 101

Belonorhynchus. . . . . . 233

Belvedere gravels . . . . . 365

Bembridge Beds . . . . . . 347

Beneckeia (v. Ammonites) . . 232

Berggyps beds . . . . . 210

Bernician series. . . . . . 130

Berrias beds . . . . . .292, 296

Betula nana . . . . . . . 379

Beyrichia . . . . . . . 85

" Klodeni . . . . 67,69

tuberculata . . $70,{ }^{*} 80$

Beyrichia limestone . . . . 55

Biancone limestone . . . . 299

Bierlé, quartzite of . . . . . 99

Bifurcatus beds . . . . . . 250

Bilobites . . . . . . . . 61

Birdseye group . . . . . . 62

Birkhill shales . . . . . . 68

Bison priscus . . . . . . . 377

" sivalensis . . . . . . 372

Bjerojölagård Öveds beds $\quad . \quad$. 69

Black River group . . . . . 62

Blätter molasse of Kempten 356

Blattina anthracophila . . . ${ }^{*} 188$

Blue Clay (Baltic Provinces) . 37

Blue Earth of the Samland. . 316

Bohn-erz deposits . . . . . 347

Bojian gneiss . . . . . . . 22

Bolderien . . . . . . . 355

Bolonien . . . . . . 262

Bone bed of the Rhaetic .215, 216

".,$\quad$ Silurian . . 65

Borealis bed". . . . . . . 69

Borkholm beds . . . . . . 57

Borrowdale series . . . . . 52

Bos etruseus . . . . . . . 371

" namadicus . . . . . . 372

" Pallasi. . . . . . . . 397

" planifrons . . . . . . 372

$"$ primigenius . $377,379, * 396,397$

" priscus : . . . 382, *396, 397

Botriocidaris . . . . . 87

Boulder Clay : $\quad 380,381,384,385$

Bracheux, sand of . . . . 335

Brachiopod limestone. . . . 96

Brachiopod schists . . . . 55

Bracklesham beds . . . . . 336

peltis 96, 101, 102, 104, *121
Brontosaurus .

Bronze age . . . . . . . . 399

Browgill beds . . . . . . . 66

Bruxellien . . . . . . . 336

Bryograptus Kjerulfi . . . . 36

Bryozoa reefs (Zechstein) . . 175

Bubalus Pallasi, v. Bos.

Buccinum ballatum . . . . 342

$" \quad$ cassidaria . . * 343,347

Buchenstein beds . . . . . 224

Buchiceras . . 283, 318, 319, 322

Ewaldi . . 316, 317

Buchsweiler limestone . . . 347

Bulla ampulla . . . . . . 364

Bunter, Alpine facies . . . . 220

, German facies. . . $.197,216$

Burnot, conglomerate of . . . 94

\section{C.}

Cabo Busto, sandstone of . . 61

Cærfai group . . . . . . . 33

Calamite and Fern stage . . 128

Calamites . . . . . ${ }^{*} 156,161$

$" \quad$ arenosus . . . . 140

$"$ Cisti . . . . 140

" gigas . . . 170, 171, 180

" Suckovi . . . . 143

". transitionis (Archaeo-

calamitesradiatus) 134 , $139,140,144,{ }^{*} 151$

Calamophyllia . . . . 231, 271

Calamostachys . . . . . . 161

Calamostoma . . . . . . . 350

Calcaire grossier . . . . . 335

Calcareous division . . . . 130

Calcareous grit . . . . . . 260

Calceola. . . . . . . . . 113

$"$ sandalina $95,100,104$,

$105, * 118$

Calceola beds. . . . . . . 94

Calciferous sandstone . . 62, 130

Calianassa. . . . . . 322 
Callipteris conferta 170,171 PAGE $180,183 .{ }^{*} 185$

Callopegma acaule. . . . . *307

Callovian . . . . . . . 262

Calymene . . 60, 62, 72, 75, 102, 104 " Blumenbachii, 56, 59, 64, $65,70,71,{ }^{*} 80$

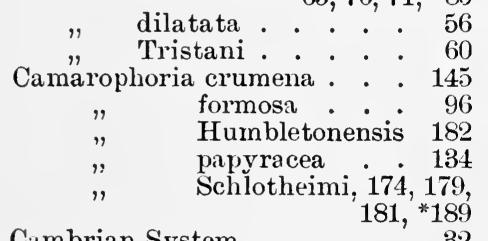

Cambrian System . . . . . 32

Cambro-Silurian rocks . . . 28

Camelopardalis . . . . . 371

Camelus . . . . . . . . 369

Campanien . . . . . . 314

Canis etruscus . . . . . . 372

" lupus . . . . . . . 397

Cañons, limestone of the $\quad . \quad 143$

Capitosaurus . . . . . . . 233

Capra ibex. . . . . . . . 397

Capricorni (Ammonites). . . 273

Capricornus beds . . . . 248

Caprina . . . . . . . . 321

" adversa . . . . 316, ${ }^{*} 317$

Caprotina . . . . . . . 283

" ammonia . . . . 298

Caprotina limestone . . . 298

Capulus. . . . . . . . 71

Caradoc beds, v. Bala.

Caradocien. . . . . . 60

Carbonaceous division . . 130

Carboniferous limestone. . . 130

" $\quad$ slate . . . 131

Cardiaster . . . . . . . 320 italicus . . . . 316

Cardinia hybrida. . . . . ${ }^{*} 245$

. Listeri . . . . . 243

Cardinia beds . . . . . 243

Cardioceras (v. Ammonites) 237,270

Cardiola fibrosa. . . . . 67

$$
\begin{aligned}
& " \quad \text { interrupta, } 66,67,69,71, \\
& " \quad \text { retrostriata, } 95,97,100,
\end{aligned}
$$

$$
106,110,{ }^{*} 119
$$

Cardiola shales - 69

Cardita crenata. . . . *223, 226

Dunkeri . . . . 342

Gümbeli . . . . . 226

imbricata. : . * *334

" Jouanneti. 355, 360, 361

" planicosta . . . 335, 336

Cardita beds . . . . . . 226

Cardium . . . . . . . 361

" cingulatum . . . 342
PAGE

383

143

335

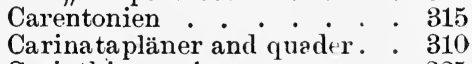

Carinthian series . . . . . 225

Carneol bank. . . . . . . 200

Carpinus . . . . . . . . 349

Caryocrinus ornatus . . . . $\$ 78$

Caryophyllia . . . . . . 320

Cassel, Marine sand of . . . 340

Cassianella gryphæata . *2:3, 226

Cassian beds... . . . . 225

Ce ssis cancellata . . . . . 335

" saburon . . 355, $\$ 357,361$

Castor . . . . . . . . 373

Catopygus carinatus . . . .300, 304

Catskill group . . . . . . 110

Cauda galli grit . . . . . . 110

Caulopteris . . . . . . 200

Cebochoerus . . . . . . 353

Cenomanian, 300, 304, 310, 314,

$315,316,318$

Cephalaspis . . . . . 66, 107

Cephalograptus cometa, v. Diplograptus.

Ceratiocaris . . . . . 68,72

Ceratites . $.5 . \quad . \quad .230,232$

, antecedens . . . . 203

" binodosus. . . 220

$"$ cassianus. . . 220, *221

., enodis . . . . . 206

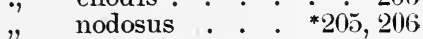

" Schmidi . . . . . 207

" semipartitus. . . . 206

$"$ trinodosus .203, *221, 224

Ceratodus . . . . . .£09, 216

, Forsteri . . . . *211

Ceratopyge $\quad . \quad . \quad . \quad . \quad . \quad . \quad 36$

Ceratopyge limestone . . . 55

Cerithium . . . . . . . 232

$"$ armatum . . . . ${ }^{*} 255$

" concavum . 335,336

" giganteum, 332, 335 ,

336,337 margaritaceum $* 343$, 347,348

Cerithium nudum . . . . 334

$"$ pictum . . 361

$" \quad$ plicatum, $346,347^{\circ}$,

348, 356, 361

portlandicum . . . 260

rubiginosum . . 361

serratum . . . . *334 submargaritaceum,

347,361

Cerithium beds . . . . . 347

Cervus . . . . . . . . 371

, alces. . . . . . 377, 397 


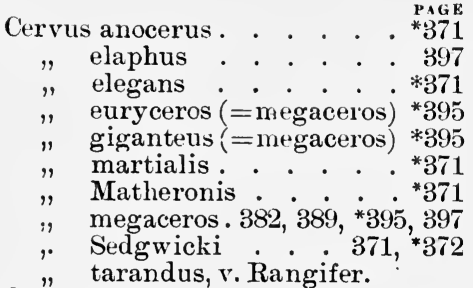
Cetosaurus.

Chaetetis radians . . . 145, *159 Chalk $312,313,315$ Chalk Marl. . . . . .311, 313 Chamærops . . . . . . . 862 " helvetica . . . 349 Chasmops . . . . . . 62,75 " bucculentus . . . 58 " conicophthalmus. 52,56 , macrourus . . 52, 56,58 " Odini . . . . 58, *76 " Wesenbergensis . . 58 Chasmops limestone . . . . 55 Chazy group . . . . . . . 62 Cheirotherium . . . . 199, 216 Cheirotherium footprints . . $* 201$ Cheirurus $51,52,55,58,59$, $60,62,75,101$

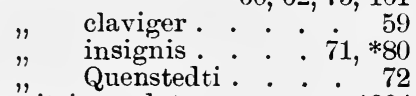
Chemnitzia scalata. . . . . *204 Chemung group . . . . . 110 Chillesford beds . . . . . 363 Chiton priscus . . . . . . $* 152$ Chloritic marl . . . . . . 313 Chonetes . . . . 134, 181, 182 " comoides . . . . 133 " dilatata . . . . 94 " plebeja. . . . 92, *114 " sarcinulata. . . 92 " striatella . . 55, 70, *82 uralica. . . . 145, 146

Choristoceras Haueri . . . . 225 $\begin{array}{lll} & \text { Marshi . . . . } 228 \\ \text { Cidaris . . . . . . . } 272\end{array}$ coronata. . . . *264 dorsata . . . *223, 226 florigemma. . . 260,262 Forchhammeri . 312,314 sorigneti . . . . 310 Tombecki . . . . . 335 vesiculosa . . . . . 312 Cincinnati group . . . . . 62 Cinder bed . . . . . . . . 286 Cinnamomum. . . . . . . 346 Cipit limestone . . . . . . . 226 Cladiscites . . . . . . . . 232 ,$\quad$ tornatus . . $* 222,225$
Cleveland ironstone

Clidophorus

Climacograptus : $43, \dot{5} 5,62,72$ bicornis.. 52 rugosus . . . 56 scalaris . . . 56 styloideus . . 56 Vasæ . . . 56 Clinton" group Wilsoni . . 53 Clunian. . . . . . . . . 64 Clymenia . . . . . . . 106 " lævigata. . . . . 97

"neapolitana. . . . 110

" striata . . . . 97

" undulata. . . 97, *119

Clymenia limestone . . . . 97

Clymenia series . . . . . 98, 103

Clypeaster altecostatus . . . *359

" altus. . . . . 362

Cnemidiastrum . . . . . 271 rimulosum . $* 264$

Coal, formation of . . . . . 148

Coal measures . . . . . . 131

Coblenz beds . . . . . . . 93

Coblenz quartzite . . . . . 93

Coblenzian . . . . . . . . 99

Coccosteus . . . . . . 106, 107

Cochliodus . . . . . . . . 163

Coelacanthus . . . . . . 192

Coloma . . . . . . . . . 350

Colloptychium . . . . 309, 320 agaricoides ${ }^{*} 307,309$

Coloptychium chalk . . . . 309

Coenograptus . . . . . . 88

" gracilis . . . 56, *79

Conopithecus . . . . . 353

Conothyris vulgaris . . . . 204

Coldwell beds. . . . . . . 67

Collyrites . . . . . . . . 272

Colobodus . . . . . . . . . 233

Colonies of Barrande . . . . 59

Colossochelys . . . . . . . 365

Comatula . . . . . . . . 272

Comley sandstone . . . . . 32

Compsognathus . . . . . . 276

Condroz, psammites of . . . 98

Congeria conglobata . . *359, 361 $"$ subglobosa . . . . 361

Congeria series . . . . . . 361

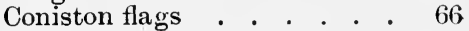

Coniston limestone. . . . . 52

Conocardium . . . . . 62, 110 aliforme . . . ${ }^{*} 153$

Conocephalites, v. Conocoryphe.

Conocoryphe . $33,34,39,41,43,48$ equale exsulans . . 37

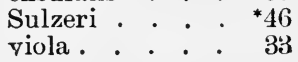




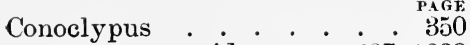
Conoideus. . 337, *338 Contorta beds, v. Rhætic.

Conularia

Conus

antediluvianus deperditus . . . Dujardini . . . . 350 Mercati . . . . . 361 ponderosus . . . . $\quad * 357$

Corallian . . . . 259, 260, 262

Coralline Oolite . . . . . . 260

Coral Rag . . . . . . . . 260

Corbicula Faujasi . . . . . . 356

Corbicula beds . . . . . . 3506

Corbis (Fimbria) lamellosa *333, 335

Corbula alata. . . . . . . 259 gibba. . . . . . 382 inflexa . . 259, 287, 288 Rosthorni . . 210, 227 striatula . . . . 295

Corbula bank. . . . . . . 210

Cordaioxylon. . . . . . 180

Cordaites . . . . . . . . 146

Cornbrash . . . . . . . . 251

Corniferous limestone. . . . 110

Corona beds . . . . . . . 52

Coronatus beds . . . . . . 251

Coronati (Ammonites) . . . 273

Coscinopora infundibuliformis ${ }^{*} 308$

Cosina beds . . . . . . . 316

Cosmoceras . . . . . . 273

Crag . . . . . . . . . 363

Crangopsis. . . . . . . 163

Crania . . . . . . . 321 ignabergensis . . *308, 311

Crassatella ponderosa. . . . 335

Craticularia . . . . . . 271

Credneria . . . . . . . . 310 $"$ triacuminata . ${ }^{*} 308,309$

Cretaceous System . . . . . 279

Cricopora straminea . . . . 253

Crinoid beds (Middle Devonian) 95

Crioceras . . . . . . . 296 " australe . .319 " Emerici 289, 291, 292,

Crocodiles . . . . . . . . 234 298
234
275

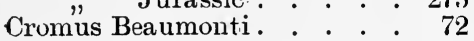

Crotalocrinus. . . . . . . 87

$" \quad$ rugosus $. \quad . \quad . \quad 65$

Cruziana . . . . $35,37,48$

Cryphæus . . . . 93, 101, 123

" calliteles. · $\cdot 94^{*} 110$

" laciniatus . . 94, ${ }^{*} 115$

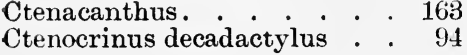

Ctenocrinus typus

Ctenodus . . . . . . . . . 163

Cuboides beds . . . . . . 97

Cucullæa Hardingii . . . . 98

" trapezium . . . . 106

Cucullella solenoides . . . . *115

Cuise, sand of . . . . . . . 335

Culm. . . . . . . . . 126, 134

Culm measures . . . . . 131

Cupressocrinus . . . . . . 95

" crassus . . . ${ }^{*} 118$

Cusel beds . . . . . . . 170

Cuvieripläner . . . . . . 304

Cyathocrinus . . . . . . 87

" longimanus . . ${ }^{*} 84$

Cyathophyllum cæspitosum $\quad{ }^{*} 118$

" ceratites. • $\cdot 34$

" helianthoides . 94

Cyclas". . hexagonum $286,{ }^{*} 118$

Cyclognathus, vi Olenus.

Cyclolites . . . . . . . 283

Cyclolobus Stachei . • . 316, ${ }^{*} 317$

Cylindrophyma . . . . . . 271

Cynodon . . . . . . . . 352

Cyphaspis . . . . . . . 85

Cyphosoma . . . . . . . 312

Cypraea . . . . . . . . 312

Cypridina, v. Entomis.
Cypridina slates . . . . 97, 105

Cyprina . . . . . . . . . . 272

" Brongniarti. . . 259

$" \quad$ islandica $362,363,382,390$

" Morrisii . . . 336

" rotundata. . . 342,348

" tumida . . . . . *364

Cyprina clay . . . . . . . 382

Cypris . . · · . 287

" (Cypridea) valdensis : 286

Cyrena . . 259, 286, 287, 316, 339

" Bronni .. . . . *285

" cuneiformis. . . . . 336

" cretacea. . . . . . 311

" fluminalis . . . 382

" semistriata . . $346,347,348$

" subarata. . . . . 347

Cyrena marl . . . . . . . 347

Cyrtina heteroclita. . 94, *116

Cyrtoceras . . . . . 57, 71, 86

"Murchisoni. . . *81

Cyrtograptus. . • • • . 71

\begin{tabular}{|c|c|c|}
\hline & & \\
\hline & Carruthersi & · 69 \\
\hline & trayae & $, 68,69$ \\
\hline & Murchisoni. & \\
\hline & rigidus . & .6 \\
\hline & spiralis. & \\
\hline
\end{tabular}


Cyrtograptus shales . . $\quad 67,69$

Cystidean limestone . . . . 55

Cystiphyllum vesiculosum .94,*118

Cytherea erycinoides . . . . 355 incrassata *343, 347, 348

". semisulcata.. . *333

\section{D.}

Dachstein limestone . . . 2227, 228

Dactylodus . . . . . .145, 147

Dakota group. . . . . . 318

Dailly series . . . . . . . 67

Dala sandstone . . . . . . 36

Dalila . . . . . . . . . 108

Dalmanites $51,59,75,93,104$,

" caudatus: . . . 65

" Downingiae, v. Acaste.

Hausmanni, v. Odontochile.

" Phillipsi. rugosa, v. Odontochile.

socialis . . . $59, * 76$

Damuda beds. . . . . . 184

Danian . . . . . . . 312, 314

Daonella. . . . . . . 228, 230

" $\quad$ Lommeli . . . $\quad 222,224$

Dapedius . . . . . . . . 242

Daraelites . . . . . . . . 181

Davidsonia . . . . . . . 122

Dechenella. . . . . . . . 123

Deister sandstone . . . . . 287

Delthyris limestone . . . . 111

Dendrerpeton. . . . . . . 163

Dendrograptus . . . . . . 51

Dentalium elephantinum . . 355

" Kickxii . . . . 342

$" \quad$ sexangulare . . . $* 364$

" torquatum . . . 202

Denticulati (Ammonites) . . 273

Desmoceras . . . . . 322

Devillo-Revinien . . . . . 41

Devonian System . . . . . 89

Diagenesis, hy pothesis of . . 25

Dicellocephalus . . . 34, 44, 48, 55, 62

Dicellograptus minnesotensis. *46

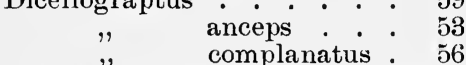

Diceras". . . . . . 272

$" \quad$ arietinum . . 262, 265

"Luci . . . . . . . 268

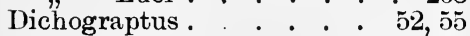

Dicranograptus . . . . . 51,62

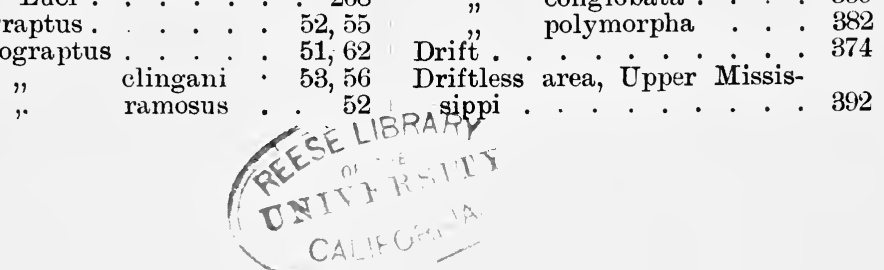

Dictyograptus . . . . . 40,41 (=socialis) $\quad \cdot 34,36,38, * 47$

Dictyograptus shales . . 34, 36, 38 Dictyonema, v. Dictyograptus

Dictyopteris sub-Brongniarti . 143

Dicrocerus . . . . . . . 371

Dicynodon . . . . . . . . 231

Didelphys feliceps. . . . . . . . $\begin{gathered}* 212 \\ \text {. }\end{gathered}$

Didymites tectus . . . . . 229

Didymograptus . $51,52,55,59,63$

" $\quad$ Murchisoni $51,56,{ }^{*} 79$

Diestien. . . . . . . 35๊

Diluvium . . . . . . . . 374

Dimetian . . . . . . 22

Dimorphograptus confertus . $\quad 66$

Dinarites . . . . . . 230

Dinichthys . . . . . . . 124

Dinoceras . . . . . . . . 339

. mirabile. . . . 352

Dinornis . . . . . . . 398

Dinosaurs . . . . . . . . 234

Jurassic . . . 275

Dinotherium . . . 354, 362, 365

" giganteum $363,{ }^{*} 366$

Dioonites . . . . . 230, 271

Diphya limestone . . . . 268

Diplograptus . . . . 43, $51,55,59$ acuminatus $66,68,69$ cometa . . 68,69 foliaceus . . 51

palmeus . . * *79

pristis . . . 56

putillus. . . . 56 quadrimucronatus 56

Diplopora . . . . . . . . 225

" annulata . . . ${ }^{*} 222$

Dipnoi, Devonian . . . . . 124

Diprotodon. . . . . . . . 398

Dipterus . . . . . . . 107

Discoidea cylindrica . . . . ${ }^{*} 301$

subuculus . . . . 313

Doberg, marine sand of . . . 340

Dörnten beds. . . . . . . 244

Dogger . . . . . . . . 249, 250

Dolgelly beds. . . . . . . 34

Domanik slates . . . . . . 109

Downton sandstone . . . 65

Downtonian . . . . . . 64

Dreissena Brardi . . . 356, * 358

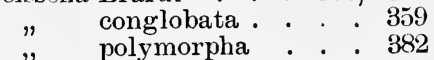

Drift". . . . . . . . . 374 392
" Cretaceous . . . . 323

Discina latissima . . . . . 261 
Dromatherium . . . 217,234

Dromia rugosa . . . . . . 312

Dromiopsis . . . . . . . 322

Dualina . . . . . . . 71,72

Dürness limestone . . . . . 54

Durnten lignites. . . . . . 379

Duvalia . . . . . . . . 283

Dwyka conglomerate . . . 183

Dyas . . . . . . . . . 164

Dysodil . . . . . . . 345

E.

Ecca beds . . . . . . . . 184

Echidna Ramsayi . . . . 398

Echinobrissus . . . . . 272

Echinoconus, v. Galerites.

272
$* 256$

Echinocorys . . . . . . 320

320

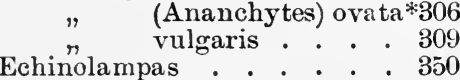

Kleini . : "342, 344

Echinosphaerites aurantium 56,*78

Echinosphaerites limestone. 56,57

Edestus . . . . . . 145, 147

Eifelian . . . . . . . 99

Eimbeckhäuser Plattenkalk . 259

Elasmotherium . . . . . 393

Elbingerode grauwacke . . 100

Elephas . . . . . 365, 366

$"$ americanus 392,398

" antiquus, $36 \dot{2}, 363,377$,

" $379,382,385,393$

" melitensis. . . 393

" meridionalis, $362,36 \dot{3}$,

$369,385,393$

" primigenius, $37 \overline{7}, 382$, $385,390,392,393$, *394

El Horno, slates of . . . . . 61

Elligser Brinks Clay . . . . 289

Ellipsocephalus . . . . 39,41

Emarginula . . . . . . . 232

Emscher mergel . . . . . . 304

Encrinurus . . . . . 64, 85

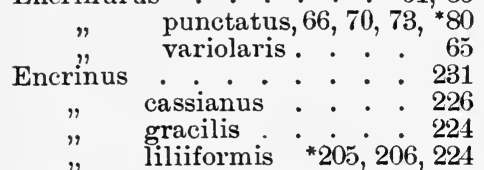

Endoceras . . . . . 57,86

$"$ commune . . . 55

" duplex . . . $\quad 55,61$

" longissimum . . . * *77

$"$ vaginatum . . 55

Enteletes . • • • . 147,182

L Lamarcki. . . .145, 146

Entomis (Cypridina) serrato-

striata, $97,106, * 119$

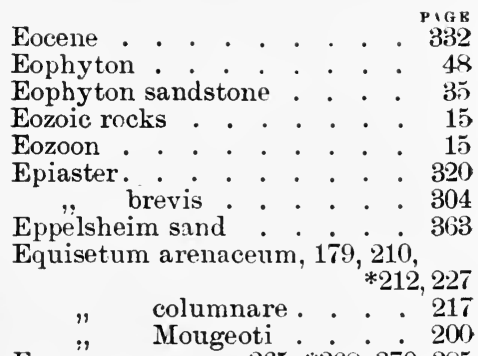

Equus . . . 365, *368, 370, 385

" fossilis. . . . . 393

$"$ Stenonis . . . . .362.363

Erbray, limestone of . . . . 104

Erratic blocks . . . . . 378

Erratic deposits . . . . . . 376

Eryon . . . . . . . . 274

Esino limestone . . . . . . 225

Estheria . . . . . . . 191

$"$ minuta $179,199,209$,

beds. . . . . . 212,216

Estonus bed . . . . . . . 69

Estuarine series (Oolitic) . . 252

Etoblattina manebachensis. . *158

Etroeungt, limestone of . . . 98

Eugeniacrinus . . . . . 272

Euomphalus qualteriatus, v.

Pleurotomaria.

$"$ pentangulatus. * *152

Whitneyi . . 145

Eurycare latum . . . . . 36

camuricorne. . . 36

Eurypterus . . 64, 66, 70, 106, 107

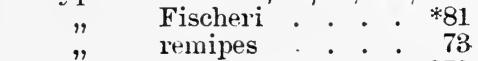

Exogyra $\cdot \cdot \cdot \cdot 272$

$"$ columba, ${ }^{*} 302,310,311$,

313,315
.$\quad$ conica . . . 313

" Couloni $289, * 290,291,298$

" haliotoidea . . . 310

laciniata . . . 309

sinuata. . . . 295

virgula, 259, 261, 262,

$* 265,269$

F.

Facies . . . . . . . . . 5

Falciferi (Ammonites) . . 273

Faluns . . . . . . . 35ว

Famenne, slates of . . . . 98

Famennien. . . . . . . 99

Faringdon beds . . . . . 295

Favosites . . . . 95

$" \quad$ gotlandica $\cdot 6 \dot{5}, 73, * 83$ 
INDEX.

Faxe limestone PAGE

Felis attica

" spelaea . . . . . . 397

Felltop division . . . . . . 130

Fenestella . . . . . . . . 186 retiformis . . $175, * 189$

Ffestiniog group. . . . . . 34

Ficus. . . . . . . .319, 349

Fimbria, v. Corbis.

Fimbriati (Ammonites) . . . 273

Fintona beds . . . . . . . 107

Flabellaria. . . . . . . . 349

Flammenmergel . . . . . . 293

Fleckenmergel . . . . . . 267

Flexuosi (Ammonites) . . . 273

Flinz. . . . . . . . . 96

Flötzgebirge . . . . . . . 7

Flötzleerer sandstein . . . . 135

Flysch . . . . . • . . . 339

Flysch sandstone (Oligocene) . 348

Fontainebleau sandstone . . 346

Fordilla. . . . . . . . . 43

Forest beds of Dromer . . . 385

Forest marble . . . . . . 252

Frasne, limestone of . . . . 97

Frasnien . . . . . . . . 99

Fucoid beds (Scotland) • . . 34

Fucoid sandstone (Scandinavia) 35

Fucoides cauda galli . . . . 111

Fuller's earth . . . . . . . 252

Fusus . . . . . . . . . 332,336

" antiquus . . . . . .*364

$"$ bulbiformis . . . * 3333,335

". elongatus . . . . . . 342

" festivus . . . . . 355

Konincki . . . . 342

longaevus. . . . . . *333

longirostris . . . . . 357

multisulcatus . . . . 312

Noae . . . . . . 335

subcarinatus . . . . *333

tricinctus. . . . . . 35ّ

Fusulina . . . . . 127, 146, 147

" carinthiaca . . . 144

$" \quad$ cylindrica $14 \dot{2}, 144,14 \dot{6}, * 159$

" robusta . . . 144

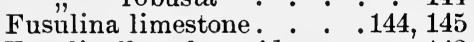

Fusulinella sphaeroidea . . . 143

G.

Gailthal slates . . . . . 143

Galerites . . . . . 320

$"$ albogalerus : $500,{ }^{*} 303$

" vulgaris . . . . . 312

Gampsonyx fimbriatus . . . *188

Gangamopteris . . . . . 184

Ganister series . . . . . . 132

Garda limestone . . . . . . 267

Gargas marl . . . . . 293, 298

Gault. 293 PAG

" quader . . . . . . 295

Gedinnien . . . . . . . 92,99

Genessee slates . . . . . 110

Georgia group . . . . . . 43

Geoteuthis . . . . . . . 274

" bollensis . . . . ${ }^{*} 247$

Gephyroceras . . . . . 97

German Trias. . . . 167, 195, 196

Gervillia . . . . . . . 209

" anceps. . . . . . 295

" bipartita. . . 227

" ceratophaga . 175, 179,

$181,{ }^{*} 189$

costata. . . . . 224

" inflata. . . . . 228

" Murchisoni : . 199, ${ }^{*} 201$

" praecursor . . . . 210

$"$ socialis $200, * 204,206,224$

Giganteus clay . . . . . 250

Girvan area . . . . . 533, 67

Givet, limestone of . . . . . 99

Givetien . . . . . . . . 99

Glacial deposits . . . . . 379

$"$ flora . . . . . . . 379

Glarus, fish shales of : . . 348

Glauconia . . . . . 316,321

Kefersteini . . . *317

Glaüconite limestone . . . . 57

Glauconite sand, L. Oligocene. 342

$\begin{array}{rr} & 57 \\ \text { Glengariff grits L. Silurian • } & 107\end{array}$

Glenkiln shales . . . . . 53

Globigerina . . . . . . 312

Glossograptus Hincksii . . . 56

Glossopteris . . . . . . 186

Glyphiocer Browniana . . * *184

Glypticus hieroglyphicus : 262

Glyptodon . . . . . . .36う, 373

Gneiss . . . . . . . . . 14

Gomphoceras b. ·. · · 71

Goniätites . . . . $93,106,136$

ammon . . . 108

Bronni . . . . 97

compressus. . . . 96

crenistria . . 143, *151

cyclolobus . . . . *152

Dannenbergi . . . 96

diadema. . . . 135

expansus . . . 110

gracilis . . . 96, 100

intumescens $96,97,100$,

$104,108,{ }^{*} 119$

Jugleri . . . . 96

lateseptatus . .96, ${ }^{*} 121$

Listeri . . . 130, 132

lunulicosta . . . ${ }^{*} 119$

mixolobus . 131, 134, 139 
Goniatites multilobatus PAGE occultus . . .96, ${ }^{*} 121$ Patersoni . . . 110 rotatorius . . . . ${ }^{*} 152$ simplex . . 96, 97, *119 sphaericus $131,134,139$,

" sphaericus 131, 134, 139 ,

." subnautilinus. . . 96

Goniomya · • • • • · 272

Goniopholis . . . .

Goniophyllum pyramidale . . ${ }^{*} 84$

Gosau beds. . . . . . . . 316

Goslar slates . . . . . . . 100

Gosseletia . . . . . . . 104

Gotland limestone . . . . . 68

Grammysia cingulata. . . 69

" hamiltonensis .92, *115

Granatocrinus . . . . . . 162

Graptolite shales . . . . 55,69

Great Oolite . . . . . . 251

Greensand, Lower . . . . . 295

" Upper . . . . . 313

Greifenstein limestone . . . 102

Grenz dolomite . . . . . . 209

Grès à anthracite . . . . . 143

Grès anthracifère . . . . . 142

Grès bigarré . . . . . . . 196

Gresten beds . . . . . . 267

Grey molasse . . . . . . 360

Griffelschiefer . . . . . 60

Grödner sandstone . . . . . 180

Grundgebirge . . . . . . 6

Gryphaea . . . . . . 272

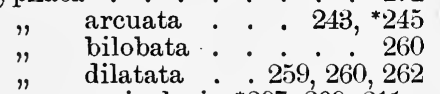

", vesicularis * $307,309,311$,

" vesiculosa . . . . 313

Gryphaea limestone . . . . 243

Gshelien, étage . . . . . . 145

Guano deposits . . . . . . 399

Gulo borealis . . . . . . . 397

Guttenstein limestone · · . 220

Gymnograptus Linnarssoni 56

Gypskeuper . . . . . . 209

Gyracanthus . . . . . . 163

Gyroceras . . . . . . . . 182

Gyrodus nodosum . . . . . ${ }^{*} 117$

Gyroporella $: . \quad \cdot \quad \cdot \quad 206,225$

\section{H.}

Hainichen Chemnitz beds . . 140

Haliserites Dechenianus. . . 124

Halitherium Schinzi . . . . 347

Halobia . . . . . 225, 230

" rugosa . . . . . 227

Halstatt limestone

Halysites catenularia $52,64,65,2$

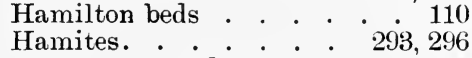
$"$ rotundus. . . . . 291

Hammatoceras Sowerbyi, v. Ammonites.

Hampstead beds. . . . . 346

Hamulina subcylindrica. . . *297

Haploceras (v. Ammonites)

Harlech grits $237,262,270,283,322$

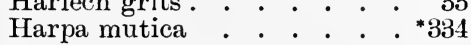

Harpes . . . . . . 71, 85, 102

$"$ ungula . . . . . $* 80$

Harpoceras (v. Ammonites) 237,

Hartfell shales . . . . . . 53

Hastings beds . . . . . . 286

Hauptkieselschiefer (Devonian) 100

Hauptquartzite (Devonian) . 100

Hauterive stage. . . . . . 291

Hawksbury beds . . . . . 184

Headon beds . . . . 336, 347

Hedera . . . . . . . . 319

Heersien . . . . . . . . 336

Helderberg group . . . 110, 111

Heliolites interstincta . . 64, 65, 73

Helix porosa. . . 94, ${ }^{*} 118$

Helix
" hispida :

Helladotherium . $\quad . \quad \cdot \quad \cdot \quad \cdot 365,371$

Hemiaspis . . . . . . . . 85

Hemiaster Griepenkerli . . 304

Hemicidaris . . . . . 272

" crenularis . . . *263

Hemipneustes . . . . 311

Hercoceras subtuberculatum $96,{ }^{*} 121$

Hercynella . . . . . . 108

Hercynian . . . . . . . 101

Hersumer beds . .
Heiss

Hesperornis . . . . . . 325

Heteroceras regalis. . . . * *323

" polyplocum . * 307,309

$" \quad$ Reussianum . . 304

Heterophylli (Ammonites) . . 273

Hexaprotodon . . . . . 369

Hierges, grauwacke of . . . 99

Hierlatz limestone . . . . . 267

Hils . . . . . . . . . 289

Hilton shales . . . . . . . 178

Hinnites . . . . . . . . 231

Hipparian, v. Hippotherium.

Hippopotamus . . . . : 385

$$
\begin{array}{r}
\text { major } \begin{array}{r}
362,363, \\
369,392,393
\end{array}
\end{array}
$$


Hippotherium (= Hipparion)

$362,365,{ }^{*} 368$, *370, 392, 398

Hippotherium gracile 363 , $\$ 338,369$

Hippurite limestone . . . . 316

Hippurites. . . . . . . 321

$" \quad$ cornu vaccinum $316,{ }^{*} 317$

Hochheim, limestone of : : 316

Holaster . . . . . . . . 320 $"$ planus . . . 300,314

Holectypus . • . . . . . 272

" orificatus. . . . \$264

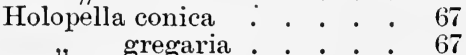

Holoptychius . . . . . $10 \bar{\tau}, 110$ nobilissimus . . *120

Homalonotus . . . . $7 \tilde{5}, 10 \tilde{5}, 110$ armatus . . 105 $\begin{array}{ll}\text { crassicauda } & .93, * 114 \\ \text { Dekayi . . . } 110\end{array}$ lævicauda . . 94 ornatus. . . . 93

Homomya (Myacites) muscul-

oldes . . . . . . . . 232

Hoplites (v. Ammonites) . 296, 321

Horner beds . . . . . . 361

Hudson River group . . . . 62

Hungarites . . . . . . 230

Hunsrück slates . . . . . 93

Huronian . . . . . . . . 22

Hyaenarctos . . . . . . . 372

Hyaena spelaeus . . 377, 389, 397

Hyaenictis. . . . . . . 372

Hyaenodon . . . . . . . 352

Hyalotragos . . . . . . 271

Hybodus . . . . . 209, 216

Hydrobia acuta . . . . . 356

" inflata . . . . . 356

Hylaeosaurus . . . . . . 286

Hymenocaris vermicauda $.34, * 47$

Hyolithellus . . . . . . 43,49

Hyolithes . . . . . 33, 39, 43

" parens. . . . . . 47

Hyopotamus . . . . . . . 352

Hyperodapedon . . . . 216, 234

Hypnum Wilsoni . . . . . 379

Hy psiprymnopsis . . . . 231

Hythe beds . . . . . . 295

\section{I.}

Iberg limestone . . . . . . 97

Ichthyocrinus $. \quad . \quad . \quad . \quad . \quad .87$

Ichthyornis . . . . . . 325

" victor . . . . . . $\$ 324$

Ichthyosaurus $\quad \cdot \quad \cdot \quad \cdot \quad \cdot 242,261$

" $\quad$ atavus . $\quad . \quad . \quad 233$

Ictitherium . . . . . . . 372
Iguanodon . . . . . 286, 287, 323 bernissartensis . . 285

Illaenus. . . . . 52, 59, 62, 75

$"$ Barriensis. . . . 73

" Bowmanni. . . . . 51

$"$ chiron . . . . . . 55

" crassicanda . . . . 55

$"$ oblongatus . . . 55, *76

" giganteus . . . . 61

Impressa marls . . . . . . 258

Indian Triassic province . . 228

Indo-pacific Cretaceous pro-

vince . . . . . . . 318

Indo-uralian Permian . . . 180

Inferior Oolite . . . . . . 252

Infracretaceous beds . . . . 282

Infralias (=Rhaetic) . . . .

Inoceramus $\cdot \cdot \cdot \cdot \cdot \cdot \cdot 320$

" Brongniarti $300^{\circ}$ *303, 304, 310, 312, 315

Cripsi . . . *305, 309

Cuvieri. **303, 301,316

digitatus . . 304, ${ }^{*} 305$

labiatus $300, * 302$,

$304,310,314,315$

latus . . . 310

lingua . . . . 309

lobatus : . .309, 312

mytiloides . . .300, 314

polyplocus . . 251

striatus . . . 310

sulcatus . . . . ${ }^{*} 294$

Insects, Carboniferous . . . 163

Jurassic . . . . . . 274

Permian (Rothliegende) 191

Silurian. . . . . 75

Interglacial deposits . . . .380, 381

$"$ fauna . . . . .379, 382

$"$ flora . . . . . 379

" period. . . . 379,382

Intumescens series . . . . . 97

Isastraea . . . . . . . 260

" helianthoides . . . *265

Isocardia . . . . . . . 272

" cor . . . . . . . 355

J.

Janassa . . . . . . . . . 192

Janira, v. Vola.

Jewe beds . . . . . . . . 57

Jinetz beds . . . . . . . 39

Jörden beds . . . . . . . 69

Juglans . . . . . . . . . 349

Jura, Alpine . . . . . . . 262

" Black. . . . . . . 242

" Brown . . . . . . . 249

", Central European . . . 239 
PAFH

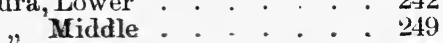

"Russian. . . . . . 269

"Upper . . . . . . . 253

$"$ White . . . . . . . . 253

Jurassic System . . . . . 235

Jurensis marls . . . . . . 242

Juvavian Triassic province . 224

K.

Kainozoic group . . . . . 326

Karharbàri beds . . . . . 181

Karoo sandstone. . . . . . 217

Kellaways rock . . . . . . 260

Keraterpeton . . . . . . . 163

Keuper . . . . . . . .207, 216

Kiltorcan beds . . . . . . 107

Kimeridge clay . . • . .260, 261

Kimeridgian . . •

Kingena lima . . . . . . 295

Kirkby Moor flags . . . . . 67

Klaus beds . . . . . . . 267

Knorria . . . . . . . 107

, imbricata . . . 133, ${ }^{*} 151$

Knottenerz . . . . . . 200

Knox group . . . . . . . 42

Kochia capuliformis . . . . 93

Köping greensand . . . . . 313

Kössen beds . . . . . . 228

Kohlenkeuper . . . . . . 209

Kohlenrothliegende . . . . 167

Koninckina Leonhardi . *223, 226

Konjeprus, limestone of . . . 101

Krebsscheerenkalk . . . . . 259

Kressenberg haematite . . . 337

Kreuznach beds. . . . . . 170

Krosstenslera. . . . . . . 380

Kucker beds . . . . . . . 57

Kupfersandstein . . . . . 179

Kupferschiefer . . . . . . 174

Kutorgina . . . . . 33, 43,49

\section{L.}

Labiatuspläner . . . . . . 310

Labiatusquader . . . . . 310

Laekenien . . . . . . . . 336

Lagomys pusillus . . . . . 388

Lamna . . . . . . . 350

" cuspidata . . . . * 350

Landenien . . . . . . . 336

L'Anse a loup group. . . . 43

Laramie beds . . . . . . . 339

Latdorf, clay of . . . . . . 340

Laterite . . . . . . . . 393

Latimaeandra . . . . . . 271

Laurentian gneiss . . . . . 22

Laurus . . . . . . . . 349
Lebach beds 167 PAGK

Lebach ore. . . . . . . . 170

Leda aretica : . . . . . . . 382

"Deshayesiana . . 342, 343, 347

$"$ perovalis . . . . . . 342

Ledbury shales . . . . . . 65

Lederschiefer . . . . . . . 60

Lehesten slates . . . . . . 138

Lehrberg beds . . . . . . 210

Leithakalk . . . . . . 361

Lena beds . . . . . . . . 143

Lenne slates . . . . . . . 95

Leperditia . . . . 33, 36, 43, 73, 85

Hisingeri . . . ${ }^{*} 80$

Lepidodendron . . $7 \dot{5}, 106,128,161$

$" \quad$ dichotomum $: 157$

$" \quad$ elegans $\cdot *{ }^{*} 157$

$"$ tetragonum . . 139

" Veltheimianum

134, 139. 140 ,

Lepidostrobus . . .

Lepidotus . . . . . . . . 287

$"$ notopterus . . . . ${ }^{*} 274$

Leptaena . . . . . . 62, 182

$" \quad$ sericea. . . . . 51

$"$ transversalis . . $65,{ }^{*} 82$

Leptaena limestone . . . . 69

Leptolepis . . . . . . . . 274

Leptoplattiformis . , . ${ }^{*} 274$

Leptorja Konincki . . . . . . ${ }^{*} 317$

Lepus glacialis . . . . . 388, 398

Lettenkohl group . . . . . $20 \%$

Leuciscus . . . . . . . 350

Levantine deposits . . . . . 365

Lewisian gneiss . . . . . . 22

Lias . . . . . . . . 242

Liasien . . . . . . . . 242

Liburnian series . . . . . 316

Lichas . . . . .52, 58, 60, 71, 85

, anglicus . . . . . 65

"Haueri . . . . . . 102

Ligérien. . . . . . . . . 315

Lignite deposits, Miocene . . 356

" Oligocene . . . . . 345

Lima . . . . . . . . . 182

$"$ gigantea . . . . 243, $\cdot 245$

" heteromorpha. . . . 253

" lineata . . . . . . 203

" praecursor. . . . . . 216

", proboscidea . . . . 250

"striata . . . . *204, 206

Limnaea . . . . . . . 286

" longiscata . . . 335

" strigosa . . . . . 346

Limopsis aurita . . . . . . 355

Lingula . . . 41, 49, 51, 60,61 
PAG K

Lingula Davisii . . . . . $34,^{*} 47$

$"$ squamiformis . . . 106

"tenuissima - 199, 200, 203

Lingula flags . . . . . . . 33

Lingulella . . . . . . 43, 49, 57

" Davisii . . . $34, * 47$

$"$ ferruginea $=$ primaeva

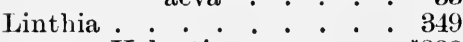
Heberti. . . . . . 338

Lithoglyphus naticoides . . 382

Lithographic slate or limestone of Solenhofen . . . . . 258, 259

Lithostrotion . . . . . 162 basaltiforme . . ${ }^{*} 154$

Litorinella acuta . • . 350 , *35 8 inflata . . . . . 356

Litorinella beds . • • • • • • 356

Lituites . . . . . . . . 86 $"$ antiquissimus . . . 55 lituus . . . . 55, $* 77$

Llanberis slates . . . . . . 33

Llandeilien . . . . . . . 60

Llandeilo flags . . . . . . 51

Llandovery beds. . . . . . 64

Llanvirn beds . . . . . . 51

Lobites delphinocephalus . . *223

Lobocarcinus . . . . . . 350

Lodève, slates of . . . . . . . 177

Loess . . . . . . . . . 386

London Tertiary basin . . . 335

London clay . . . . . . . 336

Longmynd beds . . . . . . 32

Lonsdaleia . . . . . . 186

Lophiodon . . . . . 347, 348, 352

Lower Helderberg group . . 111

Loxolophodon mirabilis . . . 352

Loxonema . . . . . . . 182

Lucina . . . . . . . 18\%

" lineata . . . . . 261

" minuscula . . . . . 261

" plana . . . . . 250

Lud̂low beds . . . . . . . 6 . 65

Lunz sandstone . . . . . . . 227

Lyckholm beds . . . . . . 57

Lynton slates. . . . . . . 106

Lyra . . . . . . . . . 321

Lytoceras (v. Ammonites) 237,

262, 270, 273, 283, 296, 298

M.

Machaerodus . . . 355, 365, 377 " leoninus . . 397 n meganthereon . 372 " pliocenicus . 362

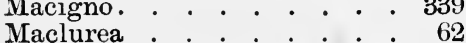
" Logani. . . . 53,77
Macrauchenia . . . . . $\begin{array}{r}\text { PAGE } \\ 365\end{array}$

Macrocephalus beds . . .251, 257

Macrocephali (Ammonites) . . 273

Macrocephalites (v. Ammonites) 273

Macrochilus arculatum 95, 103, *117

Macropneustes . . . . . . 350

Macroscaphites . . . . . . 296

Ivanii $292, * 297,298$

Macrostachya . . . . . 161

Mactra podolica . . . . $\$ 358,361$

" solida. . . . . . 383

Maentwrog group . . . . . 34

Maestricht beds . . . . . . 311

Magnesian limestone . . . . 177

Magnolia . . . . . . 346, 349

Main Bunter Sandstone . . . 199

Mainz (Tertiary) basin . . . 347

Malm. . . . . . . . . 253

Mammoth $=$ Elephas primigenius

Manticoceras, v. Gephyroceras.

Marbre griotle . . . . 142, 143

Marcellus beds . . . . . . 110

Maretia . . . . . . . . 349

Hoffmanni . . . . 342

Marginifera . . . . . .147, 182

"uralica . . . . 145

Marlslate . . . . . . . . 177

Marnes irisées . . . . . . 196

Marsupites . . . . . . 320

ornatus . $\% 305,309,314$

Mastodon . . . . . 360, 365, 366 americanus, v. giganteus. angustidens $354,368, * 367$ arvernensis $362,363,369$ giganteus $365,392, * 395,398$ longirostris $362,363,368$ ohioticus, v. giganteus. turicensis . . * 367,368

Mastodonsaurus . . . . . 209

Matagne, slates of giganteus . . *211

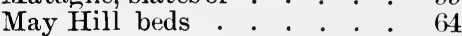

May, sandstone of . . . . . 61

Medina sandstone . . . . . 73

Mediterranean Jurassic province . . . . . . . 237

Mediterranean Triassic province. . . . . . . 224

Mediterranean sories . . . 361

Medlicottia . . . 181, 182, 183 , Orbignyana. . . 179 primas. . . . . $* 190$ 'Trautscholdi . . *190

ullosa . . . . . . . 186

Medusæ . . . . . . . . 37

Meekella, v. Streptorhynchus eximius . . . . . . 147

Meekoceras . . . . . . 230

Megaceros hibernicus, v. Cervus megaceros. 
Megalaspis . . . . . . $\frac{}{\mathbf{P A G} B}$

" limbata. . . . . 55

" planilimbata. . 55,58

Megalodon complanatum : . 227

" cucullatum $95,106, * 116$

", Gümbeli . . . . 227

" scutatum . . \$223, 228

Megalonyx triqueter . . . 227

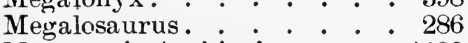

Meganteris Archiaci . . . . *122

Megaphyllites . • . . 224, 225

Megatherium jarbas . . 365, 373, 398

Megerlea . . . . . . . 272

" pectunculus . . . $\$ 263$

Melanerpeton . . . . . . 192

Melania . . . $316,339,346,347$

$$
\text { " Escheri . . * *357, } 360
$$

$"$ horrida $. . \div \quad . \quad 356$

" inquinata. . . . 336

"strombiformis . $\$ 285,287$

Melania limestone of Brunn-

stadt . . . . . . . . 347

Melanopsis . . . . . . . 339

Martiniana . *359, 361

Meletta . • . . . . . . 350

Meletta beds . . . . . . . 348

Melonites . . . . . . . . 162

Mendola dolomite . . . . $2 \approx 0$

Menevian series . . . . . 33

Merista passer . . . . . 102

$$
\text { , plebeja. . . . . . } 94
$$

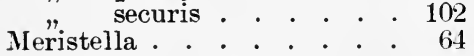

" angustifrons . . . 67

" crassa . • . . 66

$"$ tumida . . . . $65, * 83$

Mesozoic group . . . . . . 193

Meudon, limestone of . . . . 314 marl of . . . . 335

Michelinia . . . . . . 162,186

" favosa . . . . ${ }^{*} 154$

Mickwitzia . . . . . . . 33

Micraster monilifera $. . \quad . \quad . \quad 35$

$"$ breviporus . . .300, 3I5

$" \quad$ cor anguinum . . . 314

$" \quad$ cor testudinarium, 300 ,

" glyphus . . . . . 306,314

$" \quad$ Leskei . .

Microdiscus . . . . . . 43

$$
\text { scanicus . . . } 36
$$

Microdon . . . . . . . . 274

Microlestes antiquus . . .213, 234

Midford sands

Miliola . . . . . . . . 349
Millstone grit

Mimstone grit. . • . • . . 131

Mimoceras, v. Goniatites.

Minimus clay . . . . . 293

Miocene . . . . . . . 353

Mitra . . . . . . . . 321

" fusiformis. . . . . . 364

labratula . . . . . *334

Modiola lithodomus . . . . 259

" minuta. . . . .210, 228

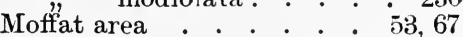

Molasse . . . . . . . . 348, 360

Monograptus . . . . . . 64,72

acus .. . . . 67

argenteus . . 66

Becki. . . . 71

Clingani . . 66

colonus . . 71, 72, *79

convulutus. . . 66

crispus . . . 66

cyphus . . . 69

exiguus . . . . 67

fimbriatus. . 66

gregarius - $66,68,69$

Halli . . . . 71

leptotheca . . 69

Nilssoni . . . . $* 79$

priodon $67,68,72, * 79$

Riccartonensis . 69

runcinatus ... 69

Sedgwickii . .67, 68

spinigerus . 66,68

turriculatus $66,71, * 79$

vomerinus. . 67

Monophyllites . . . . . 232

Monopleura . . . . . . 321

trilobata . . ${ }^{*} 297,298$

" Alberti . . . . . . . 230

" echinata, v. Pseudomonotis.

" salinaria . . . . 225

Monte Bolca, fish beds of, . . 337

Monticulipora . . . . . 87

Montien . petropolitana $* 79$

Montigny, grauwacke of $\quad . \quad \cdot 335,336$

Montlivaltia ... . . . . 271

" caryophyllata * *256

Mont Luberon, bone earth of . 362

Montmartre, gypsum of . . . 346

Montmorency, millstone of . . 346

Monzig beds . . . . . . 170

Moraine. . . . . . . . .. 384

Morte slates . . . . . . 106

Mosasaurus . . . . . . . 311

Moscovien, étage . . . . . 145

Mountain limestone . . . . 126

Mucronata chalk . . . . 301,309

Münder marl . . . . . . . 287

Murchisonia bilineata . .95,*117 
Murchisonia Blumi

Nurex

tricarinatus. . . . *333

Muschelkalk, Alpine . . . . 220

Muschelsandstein - ' 202

Myacites mactroides . . . . . 200

Myalina. . . . . . . . 106

Myalis beds . . . . . . 385

Mylodon . . . . . . . 365

robustus . . . . . ${ }^{*} 373$

Myoconcha Thilaui. . . . . 200

Myodes obensis . . . . 388, 398

Myophoria . : . . . . . . . 388

$" \quad$ cardissoides $* 201,203$

" costata $200, \quad * 201$,

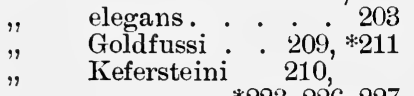

" orbicularis . . 203

" pes anseris . . . *204

" postera . . . . 216

" transversa . . . 209

" vulgaris 200,203 ,

*204, 206, 224

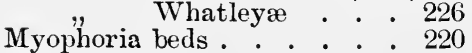

Mystriosaurus . . . . . 275

Mytiloidespläner . . . . . 300

Mytilus Faujasi : . . . . . 347

" Hausmanni . . . 175

N.

Nagelfluh, Diluvial . . . 379

" Oligocene, Miocene. 348

Naosaurus . . . . . . . 192

Naples beds . . . . . . . 110

Nassa reticulata . . . . . 383

Natica crassatina . . . 347,348

" (Turbo) gregaria . . . 202

" millepunctata . . . .*364

, patula . . . . . *333

Naticella costata . . . 220,*221

Naticopsis . . . . . . . . 182

Nautilus . . . . . 110, 144, 225

$"$ aratus . . . . 243

" bidorsatus . . . 204,206

bilobatus . . . * *151

danicus . . . 312,314

jugatonodosus. . . 207

leiotropis . . . . 304

neubergicus . . . 304

Nehden Goniatite slates . . 97

Neithea . . . . . 321

Neocomian . . . . . . . 288

Neogene. . . . . . . 3\%3
Neolimulus

Neolithic period

Neozoic . . . . . . 326

Nereites beds . . . . . . . 103

Nerinea . . . 252, 283, 316, 318

" cingenda . . . . 253

" tuberculosa . . . . *263

" visurgis . . . . . 259

Nerinea beds (Jurassic) . . . 259

Nerita conoidea . . . 335, 337

Neuropteris . . . . . . 160

" flexuosa. . . . \$155

remota . . . . 212

Newcastle beds . . . . . . 184

Newlands series . . . . . 67

New Red Sandstone . . . . 166

Niagara limestone . . . . . 73

Nilssonia . . . . . . 230

Niobe. . . . . . . 55,60

lata . . . . . . 56

Nodosus beds . . . . . . 206

Noeggerathia. . . . . . 181 tenuistriata . 146

Noeggerathiopsis . . . . . 184

Norian series . . . . . . . 224

Northampton sands . . . . 252

Norwich crag. . . . . . . 363

Nothosaurus . . . . . . 209

mirabilis . . . 205

Nubian sandstone . . . . 318

Nucula . . . . . . . . 59

"Chasteli . . . . . 342

" Goldfussi . . . . . 203

". Hammeri . . . . 250

, lineata . . . . . 226

Numismalis marl . . . . . 243

Nummulite limestone . . . . 337

Nummulites complanatus . . 337

" distans . . . . 338

" exponeus. . . . \$338

" laevigatus 335 , 336 ,

*338

Lucasanus . . *338

perforatus . . 337

planulatus . . 335

scaber. . . . 33a

variolaris . . 336

Nyrschan gas coal . . . . . 140

O.

Obolella . . . . . . . 33, 43, 49

Obolus . . . . . $39,49,55,57$

" Apollinis . . . . 38, *47

Ockerkalk . . . . . . . 71

Odontochile : . 10i, 103, 110, 111

Hausmanni . . 101

$" \quad$ rugosa. . . $: * 120$

Odontopteris . . . . 160,178

" obtusa. . . . $* 155$

E E 
Oesel group . . . . . . ${ }_{70}^{\text {PAGE }}$

Ogygia . . . . .59,60,61, 75

"Buchi . . . . . 51

"glabrata . . . . . 61

scutatrix .... 51

Olcostephanus (v. Ammonites) 296

Oldhamia . . . . . 34,40,48

Oldhamina . . . . . . . 182

Old Red Sandstone. . . . . 106

Olenellus . . . . . 32, 34, 43, 48 Kjerulfi . . . 35, 37, *46 Mickwitzi . . 37

Olenellus beds . . . . 32, 36, 43

Olenoides . . . . . 43

Olenus . . . . . $34,48,51,60$ $"$ (Protopeltura) acanthu-

rus . . . . 36

cataractes. . . . . 34

(Acerocare) ecornis . . 36

gibbosus . . . . . . 34

(Cyclognathus) miciopygus . . . . 36

micrurus . . . . . 34

(Peltura) scarabaeoides 34, 36

(Parabolina) spinulosus 34,36

truncatus. : $34,35,36, * 46$

Olenus beds . . . . 32, 36, 42

Oligocene . . . . . . . 339

Oliva clavula. . . . . . . *357

Omphalia . . . . . . . 321

Omphyma subturbinatum . . *84

Onchus . . . . . . . . 70

Oneida conglomerate . . . : 73

Onondaga limestone . . . . 110

Oolite salt group . . . . 73

limestone of Jaumont : 250

Opalinus clays . . . . . 250

Oppelia (v. Ammonites) . 237, 270

Opponitz limestone. . . . . 227

Orbicularis platten . . . . . 203

Orbitoides . . . . . . . . 349

Orbitolina . . . . . . . 320

" concava. . . . 316

" lenticularis . . . 298

Arbitolina beds . . . . . . 316

Ordovician System . • • . 298

Oriskany sandstone : . . 73, 111

Ornatus clays . . . . . . 249

Ornati (Ammonites) . . . . 273

Orodus . . . . . . . 163

Orthis. $33,39,43,49,58,59,60,182$

"Actoniae . . . . 51,61

" arcuata. . . . . . 106

" biforata (v. Platystrophia lynx) . . . . 51

" calligramma $51,56,61,72, * 78$

"circularis... . . 93
Orthis elegantula . $52,65,73, \stackrel{\text { PAG }}{* 82}$

" eximia . . . . . . .*159

$"$ hysterita =vulvaria $.92, * 114$

"Lamarcki . . . . . .*159

" lenticularis : . . $34,36, * 47$

". Michelini . . . . .*1う3

"Pecosii . . . . . . . 146

" resupinata. . . . . . 144

" striatula . . . .94, ${ }^{*} 116$

" testudinaria . . . . 61, 62

" vespertilio. . . . . $* 78$

Orthisina . . . $4 \dot{3}, 51,56,58,62$

$"$ adscendens , . . * *78

Orthoceras 51, 61, 62, $72,86,108,182$

$"$ annulatum . . 65, $* 81$

" bohemicum . . . 71

" dubium . . . . . 225

" giganteum. . 143,144

" lateseptatum . . . *222

" scalare . . . . . 134

" striolatum . . 131,134

" timidum . . . . *81

$" \quad$ triangulare $96,101,104$

Orthoceras limestone . . . 55, 72 slates . . . . 96

Osborne beds . . . . . . . 347

Ostrau beds . . . . . . . 140

Ostrea. . . . . . . . . 272

acuminata . . . . 252

aquila . . . . . . 296

bellovacina . . . . 33 כ̃

callifera . . . . 347,348

carinata . . . . . 310

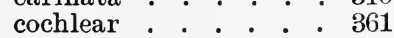

crassissima 355 , *3อั8, 360, 361

deltoidea . . . 260, 261

diluviana . . . 300,310

distorta . . . . . . 286

eduliformis . . . . 250

edulis . . . . . . 382

flabellata . . . . 337

glabra . . . . . . . 339

hippopodium . . . 310

knorri . . . . 250, 251

longirostris . . . $355, * 358$

macroptera . . 289, 291, 292

Marshi . . . . 250, *254

multiformis . . . . 259

rastellaris . . . . . 259

Sowerbyi . . . . . 252

ventilabrum . . . . 342

Ostrea limestone. . . . . . 250

Otodus . . . . . . . . . 350

$"$ obliquus . . . . . *350

Ottweiler beds . . . . . . 138

Oudenodon. . . . . . . . 234

"Baini . . . . . *212

Ovibos moschatus . . 382, 388, 397

Oxfordian . . . . . 259, 262

Oxford clay . . . . . . 260 
P.

Pachydiscus . . . . . . 322

Pachylepis peramplus . . . ${ }^{*} 303$

Palaechinus . . . . . . . 162

Palæoblattinagans . . . . . ${ }^{*} 154$

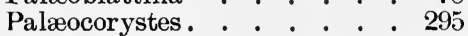

Palæocyclus porpita . . . . ${ }^{*} 84$

Palæogene . . . . . . . 332

Palæohatteria . . . . . 172

Palæolithic period . . . . . 378

Palæomeryx . . . . . . 371

Palæoniscus . . . . . 177, 216

Freieslebeni . 174, ${ }^{*} 189$

Palæorhynchus . . . . . 350

Palæotherium . 346, 348, *368, 369 magnum . . . *351

Palæozoic Group. • • . . . 27

Paleocene . . . . . . 336

Paludina . . . 286, 287, 339, 346 " diluviana. . . 382, *396

" fluviorum . . . . . *285

Pampas formation . . . . 365

Panchet beds . . . . . . 234

Panisélien . . . . . . . 336

Panopæa Menardi . . . . 360 norvegica . . . .362, 363

Parabolina (v. Olenus)

Paradoxides . . . . . 41, 48

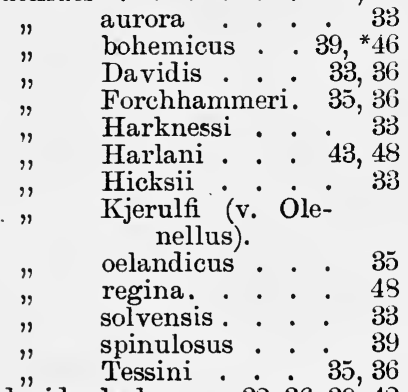

Paradoxides beds . . 32, 36, 39, 42

Parasaurus. . . . . . . . 192

Paris ('Tertiary) Basin . . . 332

Parkinsonia (v. Ammonites) $\quad 273$

Parkinsoni beds . . . . . 251

Partnach beds . . . . . 225

Pebidian . . . . . . . 22

Pecopteris . . . . . 160, 286

" arborescens . . 140

dentata . . . . *155

elegans . . . . 140

Pluckeneti . . . . 143

" Serli... . . . 140

Pecten . . . , . . . . 199

" (Vola) aduncus. * *358, 361
Pecten asper, 300, *302, 304, 313 PAG bellicostatus crassitesta . . . . . 289 discites . 203, ${ }^{*} 204,206,224$ Hawni . . . . 181, 183 islandicus . . . . 390 janus . . . . . . . 342 laevigatus . . . .203, 224 Münsteri . . . . 342 muricatus . . . . 309 personatus . . . . 250 (Vola) quadricostatus, $309,310,312$ "quinquecostatus, $295, * 305,309$ sub̈dec solarium . 355, 361 ssatus . . . 342 valoniens. * * 252

" valoniensis . . . . 216

Pectunculus dux. . . . . . 312 obovatus . $342,343,347$ Philippii. . . 342 Pe pilosus . . . . 355, 360 Pelosaurus . . . . . . . . 192 Peltoceras . . . . . . . 237 Peltura (v. Olenus).

Pemphix Sueurii. . . . . 233

Penaeus. . . . . . . . . 274

Pennant grit . . . . . . . 131

Pentacrinus . . . . . . 272

" basaltiformis . . 242

" briareus . . . . 242

$" \quad$ opalinus . . . . 250

$"$ tuberculatus $243, * 245$

Pentacrinus beds . . . . 243

Pentamerus baschkiricus . . 109 $"$ borealis . . . 69,383 " estonus . . . . 69 $"$ galeatus . $65,94, * 116$ $" \quad$ Knighti . . . 66, ${ }^{*} 83$ $" \quad$ lens . . . 64,67,68 $" \quad$ oblongus . . 64, 67.73

Pentamerus beds . . . 69,73

Pentremites florealis . . . . *154

Pericyclus . . . . . . . 163 Perisphinctes (v. Ammonites)

Permian System _. . . . . $\quad \begin{array}{r}273,296 \\ \hline\end{array}$

Perna Sandbergeri . . . . 317 Soldani . . . . .344, 347

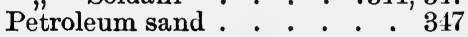

Phacops . • . : . . . . 85, 101

Brongniarti . . . . 51

bufo. . . . . . 110 cephalotes . . 102, *121 cryptophthalmus .97, *119 fecundus . 96, 101, 102, 104 Ferdinandi . . . 93 glaber . . . . . 66 latifrons . . . 98, 106 


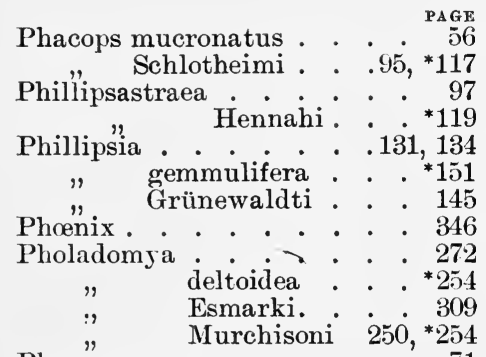

Phragmoceras Broderipi . : . ${ }^{* 82}$ $\begin{array}{ll}\text { Broderipi... . } & { }^{*} 82 \\ \text { ventricosum }\end{array}$

Phycodes . . . . . 40

Phylloceras (v. Ammonites) 237, $262,270,273,283,296,298$

Phyllograptus . . . 52, 55, 63

" typus . .53, 56, *79

Phyllograptus shales . . . 55

Phyllopora . . . . . . . 175

Phyllotheca . . . . . . . 184

Physa . . . . . . . . 339

" gigantea . . . . *333, 335

Piacentine stage . . . . . 363

Pickwell Down beds . . . . 106

Pilton beds . . . . . . . 106

Pinacites . . . . . . . . 102

Pinacoceras . . . . 224: 232

$$
\begin{aligned}
& " \quad \text { Metternichi, *222, } 225,229 \\
& \text { " parma. . . . } 229
\end{aligned}
$$

Pinna decussata. . . . . 310

quadrangularis . . 309

Pinus succinifera. . . . .

Placentia group . . . . . . 43

Placenticeras nisum (v. Ammonites.)

Placodus . . . . . . . *234 " gigas . . . . . ${ }^{*} 205$

Placoparia. . . . . 51, 59, 75

" Tourneminei. . 61

" Zippei . . . . . 59

Plagiaulax. • • • • • • . 286

Pläner . . . . . . . . 299

Planicosta beds . . . . . 248

Planorbis . . . 286, 339, 346, 356 multiformis . . 360

Planschwitz Tuff . . . . . 103

Planulati (Ammonites) . . . 273

Plastic clay . . . . . . 335

Platanus . . . . . . . 319,349

Plattendolomite . . . . . 176

Platyceras . . . . . . . 43

$"$ hercynicum . . . ${ }^{*} 121$

Platycrinus trigintidactylus . ${ }^{*} 154$

Platyschisma helicoides . . . 68

Platysomus uchtensis . . . 109 " gibbosus : . $17 \dot{4},{ }^{*} 189$
Platystrophia lynx (=Orthis PAGB biforata), $51,56,62,{ }^{*} 78$

Pleistocene. . . . . . 374

Plesiosaurus : . 234, 242, 261 dolichodeirus . . ${ }^{*} 276$

Pleuracanthus (v. Xenacanthus)

Pleurodictyum . . . . . . 113 $"$ problematicum, $92,101,105, * 114$

Pleuromya. . . . . . 272

Pleurophorus . . . . . . 191

Pleurotoma . . . 332, 336, 340

asperulata . ${ }^{*} 357,361$

belgica . . . . ${ }^{*} 343$

Beyrichi . . . 342

Bosqueti . . . 342

Duchasteli . . . 342

regularis . . . 342

scabra . . . . 342

Selysi . . . 342, 348

subdenticulata . 342

turbida . . . 342

Pleưrotomaria . . . . . 182

bitorquata . . ${ }^{*} 246$

delphinuloides, $95,{ }^{*} 117$

qualteriata . $55,{ }^{*} 77$

Plicatüla placuna . . . 296, 298

Pliocene . . . . . . . 362

Plocoscyphia æqualis . . . 314

Podozamites . . . . . . . 271

Pön sandstone . . . . . . 98

Poikilitic . . . . . . . 166

Polycoelia . . . . . . . . 186

Polygonum viviparum . . . 379

Polypora . . . . . . 186

" biarmica . . . . 182

Pontian series . . . . . . 361

Popanoceras . : . . 181, 182, 183

$"$ multistriatum . . ${ }^{*} 190$

Populus . . . . . . . . . 319

Porambonites . . . . $51,56,58,72$

" æquirostris . . ${ }^{*} 77$

Portage group . . . . . . 110

Portland group . . . 259, 260, 261

Portlandien . . . . . . 262

Posidonia (v. Posidonomya).

Posidonia (Posidonomya) shales of the Culm, 134 Posidonomya . . . . . . . . . 272

Poteriocrinus . 95,143

Potomac formation . . . . . 319

Potsdam beds. . . . . . . 42

Potsdam sandstone. . . . . 43 
Precambrian ....... 13

Preglacial deposits . . . . . 381

Preglacial fauna and Hora . . 382

Prestwichia . . . . . . 163

Primary Group . . . . . . 27

Primordial fauna (Barrande) . 29

Procamelus . . . . . . . 369

Procervulus . . . . . . . 371

Productus . . . . 134, 144, 181 Cancrini. . 179, 180, 183 carbonarius . . 135 cora, 133, 144, 145, 146, 182 giganteus, 128, 133,

$142,143,144,145,146$, *153 horridus . 175, 179, *190 Koninckianus . . 180 lineatus . . . . . 182 longispinus . . .*153 mesolobus . . . . 146 mexicanus . . . 146 semireticulatus, 142 ,

$144,145,146$ striatus . . . . 146

subaculeatus, $96,106,110$ timanicus ... . 144 tuberculatus . . . 145 undatus . . . . . 133

Productus limestone $: \cdot . \quad \cdot \quad . \quad 182$ Proctus . . . . . . . 85, 101 " concinnus . . . . 70 " eremita. . . . . 102 " orbitatus . . . . 102 "Stokesi . . . . . . 65 Prolecanites . . . *119, 123, 163 Pronorites . . . . . . *152, 163 Propalæotherium . . . . . 347 Prosopon . . . . . . . . 274 Prospect Mountain group . 43 Protapirus . . . . . . . 369 Protaster . . . . . . . . 87 Protauchenia . . . . . . . 369 Proterosaurus . . . . . . 192 , Speneri . . . 174

Protocardium hillanum . *301, 310 " rhaeticum, 210,

Protocaris . . . . . . 43

Protolabis . . . . . . . . 369

Protolycosa anthracophila . . " 158 Protopeltura (v. Olenus).

Protospongia . . . . . . 33 Protoviverra . . . . . . 351,352

Protriton petrolei . . . . . ${ }^{*} 188$

Przibram grauwacke . . . . 39 schists . . . . 39

Psammobia effusa . . . . . ${ }^{*} 334$

Psammocarcinus. . . . . . 350

Psammodus . . . . . . . 163

Pseudomonotis echinata . 251, *256 ochotica. . 230
Pseudomonotis Richmondiana PAG

Pseudomonotis Richmondiana. 230 salinaria : $* 2 \cdot 22,230$ speluncaria

Avicula)

subcircularis . 230

Psilonotus limestone . . . 243

Psilophyton . . . . . . 125

Pteranodon . . . . . . . 322

Pteraspis . . . . . . . . 66

Pterichthys . . . . . . . 106

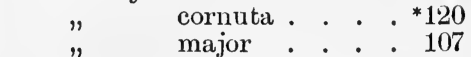

Pterinea costata . . . 92

$"$ lineata . . . . *115

" retroflexa. . . . . 70

Pteroceras . . . . . . . 272

Oceani . . 262, *265

Pteroceras beds . . . . . . 262

Pterodactylus . . . . . . 261

" spectabilis . . . . . 277

Pterophyllum . . . 186, 230

" Jaegeri 210, *212, 227

Pterygotus. . . . . 66,70, 107

Ptychites anglicus . . · 186

" dux.

$" \quad$ Studeri.. $.0^{*} \cdot{ }^{*} 221$

Ptychodus latissimus. $. . \quad . \quad * 303$

Ptychoparia . . . . . . . 43

Punfield beds . . . . . . . 291

Pupa. . . . . . . . . 163

" muscorum . . . . 386, ${ }^{*} 396$

Pürbeck beds . . . . . . . 286

Pygurus rostratus . . . . . 296

Pyrgulifera . . . . . 312, 339

Pyrula rusticula . . . . .357,361

\section{Q.}

Quader sandstone 293, 300,310, 311

Quadrata chalk . . . 301, 309

Quaternary System . . . 373

Quebec group . . . . . 63

Quercy, phosphorite of . .351, 353

Quercus . . . . . 346, 349

R.

Radiolites . . . . 292,310,316

Radowenz beds . . . . . . 140

Raibl beds. . . . . . . . 226

Raiküll bed . . . . . . . 69

Ramphorhynchus phyllurus : *277

Ranella marginata. . . *357, 361

Rangifer grönlandicus : $\quad 382,397$

". . tarandus . . 377, 388, 397

Ranina . . . . . . . 350

Rapakivi granite . . . . 384

Rastrites . . . . . . 64,71

$" \quad$ Linnaei . . . . . *79

" maximus . . 66,67,68 
Rastrites peregrinus . . . . ${ }^{P}$

Rastrites shales . . . . . . 69

Rauchwacke . . . . . . . 175

Reading beds. . . . . . . 336

Rebeiria . . . . . . . . 59

Recklingshausen, sandmarl of. 309

Recoaro limestone . . . . 220

Red crag . . . . . . . . 363

Reef limestones and dolomites

Reifling limestone . 225, 226, 229

Reingraben beds . . . . . 227

Remopleurides . . . . 59,75

Rensselaeria . . . . . . 111

" crassicosta . . . 93

" $\quad \begin{aligned} & \text { ovoides } \\ & \text { strigiceps }\end{aligned} \cdot .98, * 114$

Reptiles, oldest . . . . . . 192

Requienia . . . . . . 292, 296

" ammonia : *297, 298

Retiolites gryphaeoides . • • 298 Geinitzianus . $71, * 79$

Rhabdophyllia . . . . . 231

Rhaetic series . . 210, 216, 228

Rhinoceros. . . . . 365, 385, 392

$" \quad$ antiquitatis 377,382 ,

393,396
incisivus . . $369, * 370$

" leptorhinus $362,369,393$

" megarhinus.. . 362

$" \quad$ Merckii 379, 390, *393

" minutus . . . 369

" Schleiormacheri362, $369,{ }^{*} 370$

tichorhinus $377,393,396$

Rhizocorallium dolomite . . 200

Rhizocorallium jenense . 200, 203 Rhodocrinus crenatus . $95,{ }^{*} 117$

Rhynchonella. . . . . . 67, 182

\begin{tabular}{|c|c|}
\hline & acuminata \\
\hline & bohemica. \\
\hline & borealis . \\
\hline & compressa \\
\hline & concinna. \\
\hline & $\begin{array}{r}\text { cuboides } 96 \\
100,106,\end{array}$ \\
\hline & cuneata - \\
\hline & Cuvieri • \\
\hline & decurtata. \\
\hline & Henrici. \\
\hline & $\begin{array}{l}\text { inconstans } \\
\text { Meyendorfi }\end{array}$ \\
\hline & navicula. \\
\hline & nucula \\
\hline & Orbignyana . . \\
\hline & parallelepipeda. \\
\hline & Pengelliana. \\
\hline & plicatilis . . \\
\hline & pugnus \\
\hline
\end{tabular}

Rhynchonella varians $250,252, \begin{array}{r}\text { PAGR } \\ *^{*} 256\end{array}$ venustula. . 110

Riccarton beds Wilsoni • . 65, 82

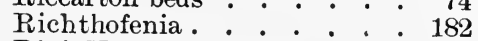

Rigi, Nagelfluh of the : . 348

Rivadeo, slates of . . . . . 41

Rosan, limestone of . . . . 61

Röth . . . . . . . . . . 199

Röthidolomite . . . . . . 227

Rogenstein. . . . . . . . 198

Rostellaria fissurella . . . . *334

Rothliegende. . . . . . 167

Rotomagien . . . . . . 315

Rudistes . . . 283, 296, 315, 318

Rullstensgrus. . . . . . . 380

Rupel clay. . . . . . . . 341

Rupelien . . . . . . . . 340, 341

Russian or boreal Jurassic province . .

237

\section{S.}

Saarbrück beds . . . . . . 138

Sagenaria stage . . . . . 140

Salenia . . . . . . . 313

." scutigera . . . . . *306

Salix . $. . \quad . \quad . \quad .319,349$

" polaris . . . . . . 379

Salmien. . . . . . . . . 41

Salopian . . . . . . . 64

Salt of the Muschelkalk . . . 205

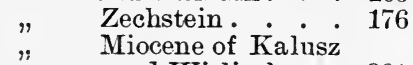

and Wieliczka. . 361

Salzberg marl. . . . . . 309

Sama, slates of . . . . . . 143

Samland, lignites and amber . 345

Sandgate beds . . . . . 295

Santonien . . . . . . . 315

Sardinioides Monasteri . . *308

Sarmatian series . . . . . 361

Saurichthys . . . . . . 233

Saxica va arctica. . . . . . 390

Scaglia . . . . . . . 316

Scalaria groenlandica. . . . 363

Scaldisien . . . . . . . 363

Scaphaspis . . . . . . 66

Scaphites aequalis . . . . 314

" auritus . . . . 310

$"$ binodosus : . . 309

" Geinitzi $300, * 303,310,315$

$" \quad$ inflatus . . . . 309

pulcherrimus . • . 309
Scaphitespläner

Scenella . . . . . . . 37, 43

Schadowitz beds. . . . . 140

Schalstein of the Devonian 96, 98, 99

Schatzlar beds . . . . . 140

Schaumkalk . . . . . 203 
Schilfsandstein

Schizaster . . . . . . . 350

Schizodus . . . . . . . . 145

$" \quad$ obscurus . $175,183, * 190$

Schizolepis

Schizopteris . . . . . . . 180

Schlern dolomite . . . . . 225

Schlier . . . . . . . . . 361

Schlönbachia (v. Ammonites). 322

Schlotheimia angulata . . . *245

Schoharie grit . . . . . . 110

Schratten limestone . . . . 298

Schwagerina . . . . . . . 145

Sciurus . . . . . . . . 373

Scolithes . . . . . . . . 61

Scutella . . . . . . . . 355

subrotundata. . . . *359

Scyphia limestones. . . . . 259

Seewen beds . . . . . . . 316

Semionotus . . . . . . . 233

Bergeri . . . . 210

Semionotus sandstone . . . . 210

Semiophorus . . . . . . . 350

Semnopithecus . . . . . 365

Senonian 304, 309, 311, 312, 314, 315

Septaria clay . . . 340, 342, 347

Sequanien . . . . . . . 262

Sequoia Langsdorfi . . . . 349

Serpula . . . . . . . . 107

" coacervata. . . . . 287

$"$ gordialis . . . . . 261

" spirulæa. . . . . . *338

Serpulite . . . . . . 287

Serpulite grit. . . . . . . 34

Shasta group . . . . . . . 318

Siegen grauwacke . . . . . 93

Sigillaria . . . . . . 75, 161

$" \quad$ alternans . . 140, $* 157$

" hexagona . . . . *157

" oculata . . . . . 140

Sigillaria stage . . . . . . 128

Silurian System . . . . . . 64

Simoceras . . . . . . .237, 270

Sinémurien . . . . . . . 242

Sivalik beds . . . . . . . 365

Sivatherium . . . . . .365, 371

Skellgill beds. . . . . . . 66

Skiddaw slates . . . . . . 52

Sleddale group . . . . . . . 52

Soișsons, plastic clay and lignite of

335

Solemya. . . . . . . . 180

Solva group . . . . . . . 33

Sötern beds . . . . . . . 170

South Baltic End Moraine . . 384

Spalacotherium . . . . . 286

Sparagmite . . . . . . . 36

Spatangus Hofmanni . . . . 342
Spatangus limestone ${ }^{-}$

Spathsand .

Speeton clay : . . . . . . . 291

Spermophilus . . . . 388,398

Sphærexochus mirus . . . 65, 71

Sphærophthalmus alatus . . 36

flagellifer . 36

Sphaerulites . . . . . . 315

$" \quad$ angeioides . . * *317

$" \quad$ Blumenbachi . 298

Sphenophyllum . . . . . 75, 183

$" \quad$ Schlotheimi .*156

tenerrimum . 140

Sphenopteris . . 106, 107, 160, 186

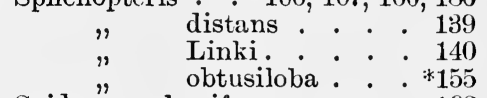

Spiders, carboniferous : . . 163

Spirifer . . . . . . . . 181

aculeatus . . . . . 94

acuminatus . . . 110

Anossofi . . 108, 110

Archiaci . . . . 108

arenosus. . . . . 111

auriculatus . 94,100, 105

cinctus . . . . . . 133

cultrijugatus . . . 95,104

curvatus . . . . . 94

cuspidatus . . . . . 133

dunensis . . . .93,*114

elegans . . . . . . 94

elevatus. . . . 65,70

exporrectus : . . . $\% 83$

fasciger . . . . . 145

glaber . . . . . 143

gregarius . . . . . 110

hystericus $=$ micropterus

intermedius $=$ speciosus

93,104

$94,105, * 116$

Kleini . . . . . 145

lineatus . . . 144, 180

mosquensis $145,146, * 159$

ostiolatus . . . . 94, *116

paradoxus $=$ macropterus 94

pinguis . . . . * *153

plicatellus . $65,70,73, * 83$

primaevus . . 93, 105, *115

striatus . . . . 144, 145

tornacensis . . . . 133

trigonalis . . . 144

undulatus . . 174,*189

Verneuili 96, 97, 98, 104.

$$
108,110 .{ }^{*} 120
$$

Spiriferina cristata . . .176, 182

fragilis. . . . 203

hirsuta. . . . 203

Mentzeli '206, *221, 224

Saranæ . . . 145

Walcotti . . 243, *245 
Spirorbis . . . . . . . . 132

Spirorbis limestone . . . . 132

Spondylus Buchi . . . . . 342

" fimbriatus . 312

, spinosus $300, * 303,304$, 310,315 tenuispina . . . $* 343$

Sporadoceras . . . . . . 97,123

Stacheoceras . . . . . . 181

Stassfurt salt deposits . . . 176

Stauria astraeiformis . . . . *84

Staurocephalus clavifrons . . 56

" globiceps · ·

Stegodon . . . . . 365

Steinheim (Tertiary) basin . . 360

Steinmergel . . . . . . 209

Stenopora columnaris. . . 186

Stenotheca . . . . . . . . 43

Stephanoceras (v. Ammonites) 273

Steppe fauna . . . . . . . 388

Sternberg Kuchen . . . . . 349

Stettin sand . . . . . . . 341

St. Gallen marine molasse . . 360

Stigmaria . . . . . 145, $* 158$

$"$ ficoides . . . . .*158

" inæqualis . . . 139

Stinkschiefer. . . . . . . 175

Stiperstones . . . . . . . 51

St. John beds. . . . . . . 42

Stockdale shales. . . . . . 66

Stomatopsis . . . . . . 316

Stone age, older . . . . . . 378

" " later . . . . . . 398

St." Ouen, limestone of . . . . 335, 336

Stramberg limestone . . . . 268

Streptorhynchus . . . . . 106

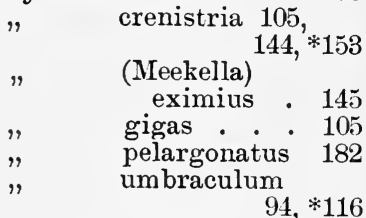

Stricklandinia (v. Pentamerus lens).

Stringocephalus . • . . . . 102

$$
\text { " Burtini } 95,100,
$$

Stringocephalus limestone

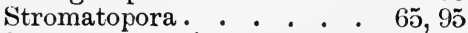

Stromatopora limestone . . . 111

Strophalosia . . . . . . . 179

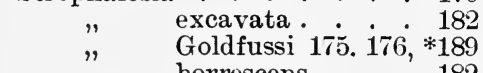

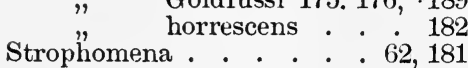

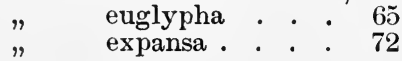

Strophomena laticosta 93,105, PAGE rhomboidalis. $* 82$

Stubensandstein . . . . . . 210

Stylina . . . . . . . . 260

Stylodon . . . . . . . . 286

Styloliths . . . . . . . . 206

Subapennine formation . . . 363

Subcretaceous system . . . 282

Subhercynian lignite. . . . 345

Succinea oblonga . . . 386*396

Sus antiquus . . . . . . . 369

" erymanthus . . . . . 369

Symphysurus . . . . . . 55,60

Syringopora . . . . . . . 162 " parallela. . . 145

T.

Taconic . . . . . . . . . 29

Taeniodon Ewaldi . . . . . 210

" præcursor . . . . 210

Taeniopteris . . . . . . . 230

Talchir conglomerate . . . . 183

Tanner grauwacke . . . . . 100

Tapes. . . . . . . . . 361

Tapirus . . . . . . . . . 369

Tarannon shales . . . . . 64

Tartarian group . . . . . 179

Taunus quartzite . . . . . 93

Taxocrinus . . . . . . . 87

Taxodium . . . . . . . . 354

Tealby beds . . . . . .287, 295

Tegel, Baden . . . . . . . 361

Teleosaurus . . . . . . . 242

Telerpeton . . . . . . . . 234

Tellina baltica . . . . . . 383

$"$ planata . . . . . $* 358$

" solidula . . . . . 382

Tentaculite limestone. . . . 103 slates . . . . 101

Tentaculites . . . . $68,70,73$ $\begin{array}{ll}" . & \text { acuarius . . } 100,102 \\ \text { scalaris . . . } * 115\end{array}$

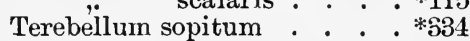

Terebratula . . . . . . 182

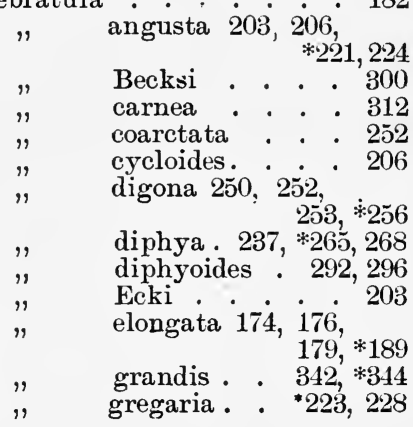


INDEX.

Tertbratula hastata humeralis . . 259 impressa . . 258, ${ }^{*} 263$ janitor . . . 268 lagenalis, 249, 250,

$$
251, * 256
$$

norica . . . . 228 numismalis. $243,{ }^{*} 246$ obesa . . . . 309 ornithocephala . 252 perovalis . . 250 sella . . . 291 semiglobosa. . . 300 submaxillata . 253 subsella . . . 259 sufflata . . . 175 vulgaris, $203, * 204$, 206,224

Terebratula limestone (Wellenkalk), 203

Terebratulina gracilis . . .314, 315 Tertiary System . . . . . . 327 Tetragraptus . . . . . 56 " bryonoides. . . 53

Tetraprotodon . . . . . 369

Thalassoceras. . . . . . 179

Thamnastraea . . . . . 271

" arachnoides. . 260 concinna . . 260 rhaetica . . 228

Thanet sands . . . . . . . 336 Theca (v. Hyolithes).

Thecidium . . . . . .231, 321

" digitatum . . . . *308

Thecosmilia . . . . . . 262

$"$ annularis. . . . 260

Thracia Phillipsi . . . : ${ }^{*} 265$

Thuringite zone . . . . . . 60

Thyestes . . . . . . . 70

Thylacoleo . . . . . . . . 398

Thysanopeltis $96,102,104,{ }^{*} 121,123$ Tichogonia Brardi (v. Dreissena).

Till 385

Tineo, conglomerates of . . 143 Tirolites (v. Ceratites cassianus).

Tithonian . . . . . . . 268

Toarcien . . . . . . . 242

Tongrien : . . . . . 340

Tonto group . . . . . . . 42

Tornoceras . . . . . . . 103

Torridon sandstone . . . . 34

Tournai stage . . . . . . 133

Tourtia . . . . . . . . 300

Toxaster complanatus, $289,{ }^{*} 290$, 291, 292 cordiformis . . . . 298

Trachyceras . . . . .230, 232 " aon $\quad$ aonoides. $\quad{ }^{*} 223,225$
Trachyceras archolaus . PAGE

Curionii . . . . 229

Reitzi . . . 224

Tragoceros . . . . . . . 371

Transversarius horizon . . . 259

Tremadictyon . . . . . . 271

Tremadoc beds . . . . 31, 51

Trematis corona . . . . . . 52

Tremataspis . . . . . . 70

Trematosaurus . . . . . 233

"Trentoni • • • 199

Triassic System . . . . . . .

Trigonia . . . . . . . 272

$"$ aliformis . . . *305, 309

$"$ clavellata . . . 272

$"$ costata . . 250,254

" gibbosa . . 260, 262

$"$ navis . . . 250, 251, *254

". sulcataria . . . 310

Trigonocarpus Noeggerathi ${ }^{*} 158$

Trigonodus Sand bergeri . *204, 206

Trigonodus beds. . . . . 206

Trigonosemus . . . . . . 321

Trinucleus . . . . . 56,61,75

$"$ concentricus . . 53, 62

" coscinorhinus . 56

" Goldfussi . . 59, 61, *77

$"$ ornatus. . . . 59

$"$ seticornis . . . . 51

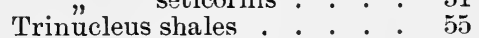

'Tritonium flandricum . . . *343

Tritylodon. . . . . . . . 234

Trochites limestone . . . . 206

Trochus Brocchii . . . . . *364

". patulụs. . . . . . *3599

Tropites . b - . . . . . 232

Tuedian series . . . . . . 130

Tully limestone . . . . . . 110

Tunbridge Wells sands . . . 286

Turbo gregarius (v. Natica gregaria).

solitarius. . . . . 227

Tüneri clays. . . . . . 243

Turonian - . 300, 310, 314, 315

'Turrilites . . . . . 293, 314 catenatus . . . *294 costatus . . . . 300 polyplocus . . *307, 309

Turritella cathedralis. . .360,361 hybrida . . 335

" imbricataria . . $335 \overline{5}, 336$

" terebralis . . . 360

$"$ turris. . . * 357,361

U.

Uebergangsgebirge. . . . . 7

Ullmannia. . . . . . . 178

$"$ Bronni . . . 174, 181 
Ulmus

Uncites gryphus $: \cdot . \quad . \quad .95,{ }^{*} 116$

Ungulite sandstone . . . . 37

Unio . . . . 316, 340, 361 "flabellatus . . . . . 360

" planus . . . . . . . *285

" umbonatus. . . . . . 180

" Valdensis . . . . . . 286

Uralian Permian . . . . . 180

Urgebirge . . . . . . . . 7

Urgo-Aptien . . . . . . . 292

Urgonian .' . . . . . . . 280

Ursus . . . . . . . . . 382

H. spelaeus . 355, 389, *394, 397

Utica group . . . . . . . 62

\section{V.}

Vaginatus limestone . . . . 57

Valenginien . . . . .291, 296

Valentian . . . . . . . . 64

Vega, limestones and slates of the 41

Venus Brocchii . . . . . 355

" clathrata. . . . . 361

Vertebraria . . . . . . 181

Verrucano . . . . . . . 180

Vesulien . . . . . . . 253

Vesullian . . . . . . . 250

Vichter beds . . . . . . 136

Vienna basin . . . . . . 360

Vienna sandstone . . . . . 316

Vils limestone . . . . . . 267

Vireux, grauwacke of . . . 99

Virgatus beds. . . . . . . 269

Virgloria limestone . . . . 220

Visé stage . . . . . . . 133

Vlasta . . . . . . . 108

Vola . . . . . . . . . 321

" atava : • . • . . 296

" quadricostata (v. Pecten).

"quinquecostata (v. Pecten).

Volga beds. . . . . . . . 209

Voltzia . . . . 181, 184

$"$ heterophylla, 179, 200,

Voltzia sandstone . . . . . 200

Voluta . . . . . . . 5321

$"$ decora. . . . . . 342

" Lamberti. . . . . . 35̃

" miocenica . . . . . 355

" muricina. . . . . . *333

Vosges sandstone . . . . . 199

W.
Waagenoceras
Wadern shales
.
PAGE

Wadhurst clay . . . . . . 286

Wälder Thon . . . . . . . 287

Walchia filiciformis . . . 180

$"$ piniformis, 143,171 ,

180. * 187

Waldenburg beds . . . . 140

Waldheimia . . . . . . 272

Wate"lime humeralis • . . 262

Waulsort stage . $\quad . \quad \cdot \quad \cdot \quad \cdot \quad \cdot \quad \cdot 133$

Weald clay. . . . . . . 286

Wealden. . . . . . . . 284

Weissliegende . . . . . . 174

Wellendolomite . . . . . 202

Wemmelien . . . . . . 336

Wengen beds . . . . . . 224

Wenlock limestone. . . . . 64

Werfen beds. . . . . . 220

Wernsdorf beds . . . . . 298

Wesenberg beds . . . . . . 57

Wettersteinkalk . . . . . . 225

Whitby, alum shales of . . . 244

White (coralline) Crag . . . 363

White lias . . . . . . . . 213

Wieda slates . . . . . . 100

Wildungen, limestone of . . . 102

Wissenbach slates . . . . . 96

Woburn sands . . . . . 295

Woolwich and Reading beds . 336

\section{$\mathrm{X}$.}

Xenacanthus Decheni. . . . 192

Xenodiscus. . . . . . . 182

Xiphodon . . . . . . .346, 352

$$
Y \text {. }
$$

Yoldia arctica . . 382, 385, 390

Yoldia clays . . . . . . . 382

Yoredale series . . . . . . 130

Ypresien. . . . . . . 336

\section{Z.}

Zamites . . . . . . . . 230, 271

Zancleano . . . . . . . . 363

Zanclodon . . . . . . . 234

Zaphrentis . . . . . . . 162

" cornicula. . . . ${ }^{*} 154$

Zechstein . . . . . . . 172

Zechstein conglomerate . . . 173

Zechstein gypsum . . . . 175

Zechstein limestone . . . . 174

Zellendolomite . . . . . . 203

Zlambach beds . . . . . . 225

Zonites . . . . . . . 163

Zorge slates . . . . . 100

Butler \& Tanner, The Selwood Printing Works, Frome, and London. 



THIS BOOK IS DUE ON THE IAST DATE STAMPED BELOW

AN INITIS FINE OF 25 CENTS WILL BE ASSESSED POM FAILURE TO RETURN THIS BOOK ON THE DATE DNE. THE PENALTY WILL INCREASE TO 50 CENTS ON MHE FOURTH DAY AND TO \$1.00 ON THE SEVENTH DAY OVERDUE.

OCT 181935

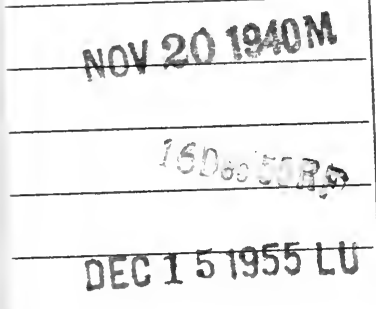

LD 21-100m-7, 

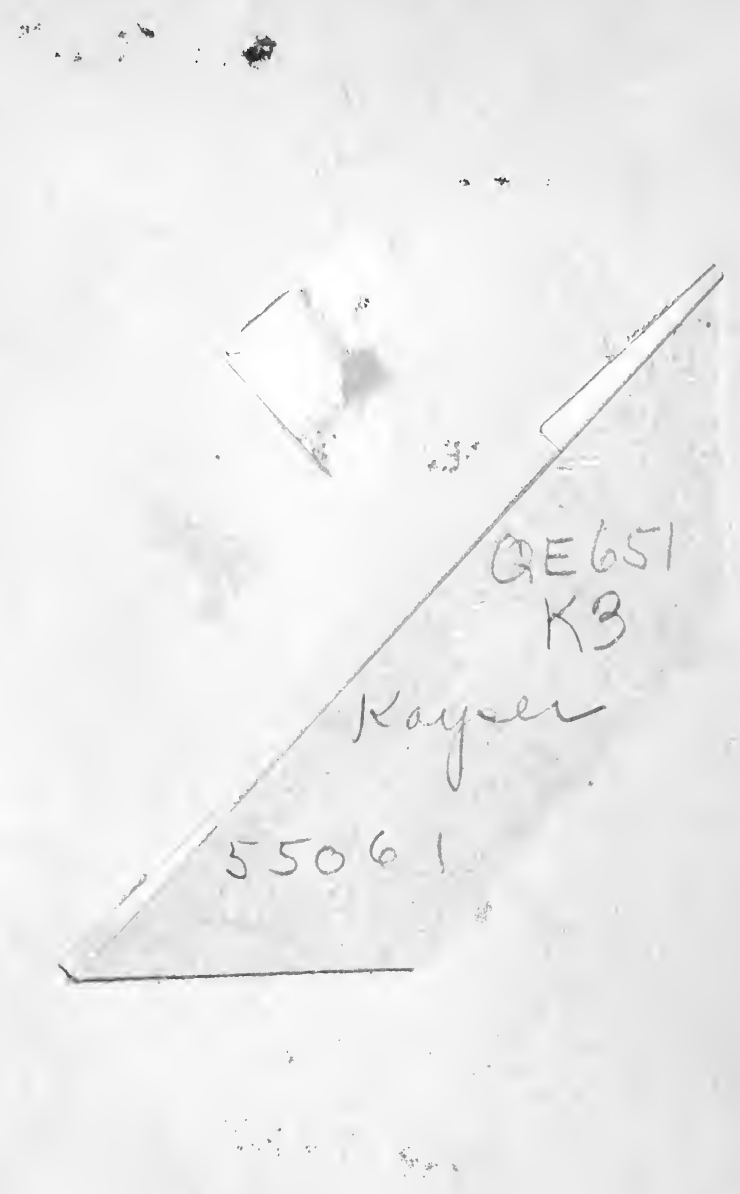


\section{- $\quad$ -}

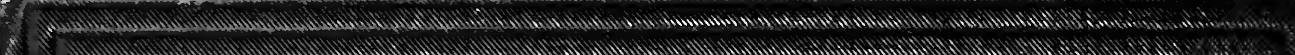
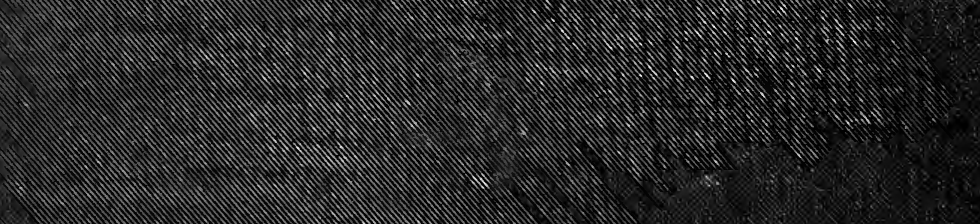

.
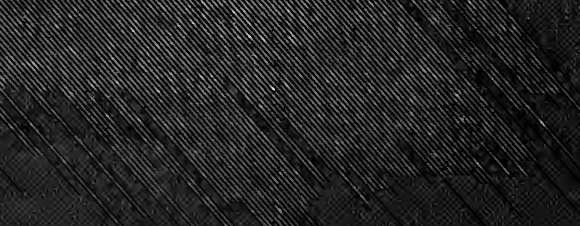